\author{
UNIVERSIDADE DE BRASÍLIA \\ FACULDADE DE DIREITO \\ PROGRAMA DE PÓS-GRADUAÇÃO EM DIREITO \\ CURSO DE DOUTORADO EM DIREITO, ESTADO E CONSTITUIÇÃO
}

DIREITO, POLÍTICA ECONÔMICA E GLOBALIZAÇÃO: FORMAÇÃO DE UM DEBATE

Hugo Luís Pena Ferreira 
Ficha catalográfica elaborada automaticamente, com dados fornecidos pelo(a) autor(a)

FF383d

Ferreira, Hugo Luís Pena

Direito, política econômica e globalização: formação de um debate / Hugo Luís Pena Ferreira; orientador Marcus Faro de Castro. - Brasília, 2016. $475 \mathrm{p}$.

Tese (Doutorado - Doutorado em Direito) -Universidade de Brasília, 2016.

1. cooperação econômica internacional. 2. direito e desenvolvimento; 3. Análise Econômica do Direito. 4. Novo Direito e Desenvolvimento. 5. Análise Jurídica da Política Econômica. I. Castro, Marcus Faro de, orient. II. Título. 
UNIVERSIDADE DE BRASÍLIA

FACULDADE DE DIREITO

PROGRAMA DE PÓS-GRADUAÇÃO EM DIREITO

CURSO DE DOUTORADO EM DIREITO, ESTADO E CONSTITUIÇÃO

\title{
DIREITO, POLÍTICA ECONÔMICA E GLOBALIZAÇÃO: FORMAÇÃO DE UM DEBATE
}

\begin{abstract}
Tese apresentada ao Curso de Doutorado em Direito da FD/UnB, área de concentração "Direito, Estado e Constituição" e linha de pesquisa "Globalização, Transformações do Direito e Ordem Econômica", como requisito parcial para o título de doutor em Direito.
\end{abstract}

Orientador: Prof. Dr. Marcus Faro de Castro

Hugo Luís Pena Ferreira

Brasília 


\title{
Direito, política econômica e globalização: formação de um debate
}

\author{
Tese apresentada ao Curso de Doutorado em \\ Direito da FD/UnB, área de concentração "Direito, \\ Estado e Constituição" e linha de pesquisa \\ "Globalização, Transformações do Direito e \\ Ordem Econômica", como requisito parcial para o \\ título de doutor em Direito.
}

Data de defesa: 18 de março de 2016

\section{Banca examinadora:}

Prof. Dr. Marcus Faro de Castro - FD/UnB

Prof. Dr. George Rodrigo Bandeira Galindo - FD/UnB

Prof. Dr. Eiiti Sato - IREL/UnB

Prof. ${ }^{\text {a }}$ Dr. ${ }^{\text {a }}$ Michelle Ratton Sanchez Badin - FGV/SP

Prof. ${ }^{\text {a }}$ Dr. ${ }^{\text {a }}$ Clarissa Franzoi Dri - UFSC 
“[...] da mesma forma que as ideias não pairam no vácuo social e econômico, também os acontecimentos militares, políticos e econômicos não o fazem. As consequências todas dos acontecimentos fluem das percepções dos acontecimentos tanto quanto dos próprios acontecimentos, e nossas percepções são por sua vez influenciadas pelas ideias que escolhemos ou rejeitamos."

Robert Nisbet (1985, p. 300)

"[...] é imperativo que os defensores de políticas econômicas alternativas não encarem as regras atuais do ambiente global como fixas. Sempre é possível, e certamente é necessário, reescrever as regras globais."

Ha-Joon Chang e Illene Grabel (2004, p. 203) 


\section{RESUMO}

Diferentes ordens econômicas internacionais tomaram forma desde o século XIX até o presente, sendo impulsionadas, justificadas e contestadas por materiais intelectuais diversos. A discussão sobre os referenciais construídos com base nesses materiais e usados para estruturar práticas de cooperação econômica internacional constitui o principal foco desta tese. Recentemente, a ocorrência da crise global de 2007-8, e os protestos sociais daí resultantes, deixaram patentes inadequações e insatisfações com o referencial econômico ortodoxo. Durante as três décadas em que esse referencial foi prestigiado, ele foi usado para sustentar um modelo de cooperação internacional baseado na expansão global de mercados financeiros e na adoção de instituições domésticas orientadas para fomentar o dinamismo e o crescimento destes mesmos mercados. A conjuntura crítica hoje existente desperta o interesse por concepções alternativas e pelo debate em torno das ordens possíveis, o que remete ao objetivo da presente tese: identificar e descrever os principais contornos de ideias jurídicas e econômicas que, permeadas por diferentes concepções de desenvolvimento, formaram quadros de referência para a estruturação da cooperação econômica internacional, até finais da primeira década do século XXI, quando passam a ser debatidos projetos de cooperação com características novas. Assim, no que diz respeito a ideias jurídicas sobre as relações internacionais, são abordados os referenciais correspondentes (i) ao direito internacional clássico; (ii) à fragmentação do direito internacional e (iii) à governança global. Quanto às ideias econômicas, a abordagem compreende (i) o liberalismo econômico clássico; (ii) o liberalismo assistido (embedded liberalism), (iii) o neoliberalismo e (iv) novas perspectivas heterodoxas da economia do desenvolvimento. No contexto definido por esses referenciais a tese aborda o debate interdisciplinar sobre direito e desenvolvimento hoje existente, que apresenta visões contrastantes com o discurso jurídico padrão no Brasil, o qual, permanecendo ainda preso a categorias do século XIX, mostra-se incapaz de orientar de modo adequado a formação, implementação e reforma de políticas públicas. Este debate reúne perspectivas com projetos diversos para padrões regulatórios e de cooperação econômica internacional: a Análise Econômica do Direito (AED), o movimento Law \& Finance, o Novo Direito e Desenvolvimento (NDD) e a Análise Jurídica da Política Econômica (AJPE). Baseada na premissa de que as ideias importam para a formação, perpetuação e contestação dos diferentes padrões regulatórios correspondentes a "momentos" da cooperação econômica internacional, a tese propõe, primeiramente, que as vertentes do debate acima referido modulam diversamente elementos ligados aos referenciais jurídicos e econômicos das relações internacionais, bem como a concepções distintas de desenvolvimento, resultando em dois projetos contrapostos. De um lado, há o projeto, hoje questionado, de universalismo institucional global, correspondente às chamadas "tese da convergência" ou da "harmonização institucional global", e favorecido por materiais intelectuais produzidos pela AED e o Law \& Finance. De outro, há o projeto alternativo, favorecido pelo NDD e pela AJPE, de pluralismo institucional global. Uma segunda proposição da tese consiste na avaliação de que, embora a interdisciplinaridade seja uma marca desse debate, os usos da interdisciplinaridade não são uniformes, havendo perspectivas que atribuem ao direito papéis instrumentais em relação a objetivos definidos a partir de referenciais econômicos (AED, Law \& Finance), e outras que, para além de funcionalidades instrumentais, identificam o direito como fonte de referenciais para a estruturação da ordem econômica, abrindo espaço - com maior ou menor ênfase - para que esta seja pautada por objetivos jurídicos (NDD, AJPE).

Palavras-chave: cooperação econômica internacional; direito e desenvolvimento; Análise Econômica do Direito; Law \& Finance; Novo Direito e Desenvolvimento, Análise Jurídica da Política Econômica. 


\begin{abstract}
Several international economic orders have existed from the 19th century to the present moment. They have been promoted, justified and challenged by multiple intellectual materials. The main focus of the present doctoral dissertation is the discussion of the frames of reference built upon these materials and used to shape practices of international economic cooperation. Recently, the 2007-8 global crisis and ensuing mass protests have stirred discontent with - and brought to light inadequacies in - the orthodox economic conceptual system. During the three decades in which it enjoyed lofty prestige, this set of ideas backed up a model of international cooperation oriented to foster global expansion of financial markets and widespread adoption of domestic institutions amenable to market growth and dynamism. Yet, the critical juncture formed by recent events has rekindled interest in alternative conceptions and aroused a debate on possible orders. Hence the objective of the present work: to identify and describe the main legal and economic ideas linked to varied conceptions of development, which have formed frames of reference used to structure practices of international economic cooperation, up to the end of first decade of the 21 st century, when different kinds of cooperation projects started to be discussed. Thus, regarding legal ideas about international relations, the work covers the frames of reference comprised by (i) classic international law; (ii) fragmented international law and (iii) global governance. With respect to economic ideas, the discussion encompasses (i) classic economic liberalism; (ii) embedded liberalism; (iii) neoliberalism and (iv) new heterodox perspectives on development economics. Given this intellectual background of legal and economic ideas, the doctoral dissertation explores the extant interdisciplinary debate on law and development, comprised by approaches markedly different from standard legal discourse in Brazil, which still relies on 19th-century legal categories thereby hampering the ability of legal analysis to provide guidance to policy formation, implementation and reform. Such more recent debate is comprised of perspectives with different projects of regulatory and international economic cooperation: Economic Analysis of Law (EAL); Law \& Finance; New Law and Development (NLD) and Legal Analysis of Economic Policy (LAEP). Based on the premise that ideas matter for the formation, duration and overturn of the various regulatory standards amounting to "moments" of international economic cooperation, the work advances two central propositions. The first is that the strains of the abovementioned debate modulate, in different ways, elements of the legal and economic frames of reference of international relations, together with different conceptions of development, resulting in two contrasting broader projects. On the one hand there is the currently challenged project of global institutional universalism, related to so-called "convergence thesis" or "global institutional harmonization", and pushed forward by interdisciplinary endeavors corresponding to to the EAL and to Law \& Finance lines of legal argument. On the other hand, there is an alternative project, favored by the NLD and the LAEP perspectives, of global institutional pluralism. The second central proposition put forward in the present dissertation consists in the argument that, notwithstanding their interdisciplinary character, the strains in the law and development debate do not structure in the same way each of their interdisciplinary constructions. In fact, some perspectives regard law as having an instrumental role with respect to goals defined through economic frames of reference (EAL, Law \& Finance), while others identify law as a frame of reference to be used in shaping the economic order, thereby offering grounds - in a lesser or greater degree - for such order to be structured in light of legal objectives (NLD, LAEP).
\end{abstract}

Keywords: international economic cooperation; law and development; Economic Analysis of Law; Law \& Finance; New Law and Development; Legal Analysis of Economic Policy. 


\section{LISTA DE SIGLAS}

AED Análise Econômica do Direito

AJPE Análise Jurídica da Política Econômica

AOD Assistência Oficial ao Desenvolvimento

APEC Asia-Pacific Economic Cooperation

BIRD Banco Internacional para Reconstrução e Desenvolvimento

CDO Collateralized Debt Obligation

CDS Credit Default Swap

CECA Comunidade Europeia do Carvão e do Aço

CEE Comunidade Econômica Europeia

CEPAL Comissão Econômica para a América Latina e o Caribe

CIJ Corte Internacional de Justiça

CPJI Corte Permanente de Justiça Internacional

ECOSOC United Nations Economic and Social Council

Euratom European Atomic Energy Community

FMI Fundo Monetário Internacional

GATS General Agreement on Trade in Services

GATT General Agreement on Tariffs and Trade

ICANN Internet Corporation for Assigned Names and Numbers

IDI Institut de Droit International

ISO International Organization for Standardization

LLSV Rafael La Porta, Florencio Lopez-deSilanez, Andrei Shleifer e Robert Vishny

MAD Mutual Assured Destruction

MPS Mont-Pèlerin Society

NAFTA North American Free Trade Agreement

NDD Novo Direito e Desenvolvimento 
NEI Nova Economia Institucional

NMF Nação Mais Favorecida

OCDE Organização para Cooperação e Desenvolvimento Econômico

OECE Organização Europeia de Cooperação Econômica

OIC Organização Internacional do Comércio

OIT Organização Internacional do Trabalho

OMC Organização Mundial do Comércio

ONG Organização Não Governamental

ONU Organização das Nações Unidas

OPEP Organização dos Países Exportadores de Petróleo

OTAN Organização do Tratado do Atlântico Norte

POI Padrão-Ouro Internacional

TPII Tribunal Penal Internacional para a ExIugoslávia

TRI Teoria das Relações Internacionais

TRIMS Agreement on Trade-Related Investment Measures

TRIPS Agreement on Trade-Related Aspects of Intellectual Property Rights 


\section{SUMÁRIO}

INTRODUÇÃO

\section{CAPÍTULO 1 - OS DIFERENTES MOMENTOS DA COOPERAÇÃO ECONÔMICA}

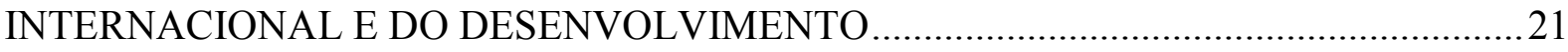

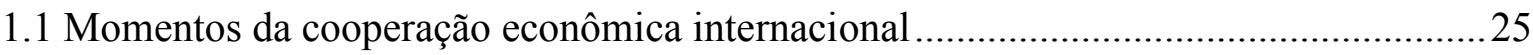

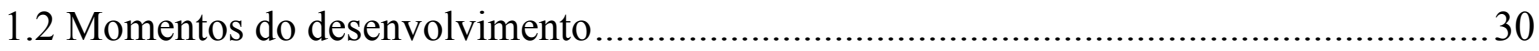

\section{CAPÍTULO 2 - TRÊS VISÕES JURÍDICAS DAS RELAÇÕES INTERNACIONAIS........41}

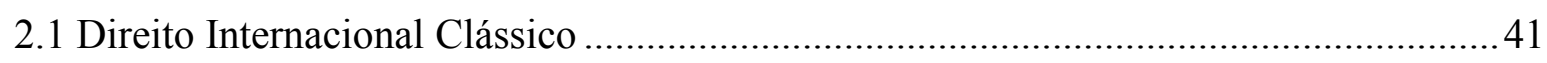

2.1.1 Antecedentes do direito internacional ................................................................ 41

2.1.2 Direito internacional da década de 1870 à Primeira Guerra Mundial: autonomia e

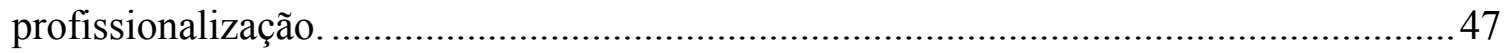

2.1.3 Direito internacional no entreguerras: institucionalização. ................................... 73

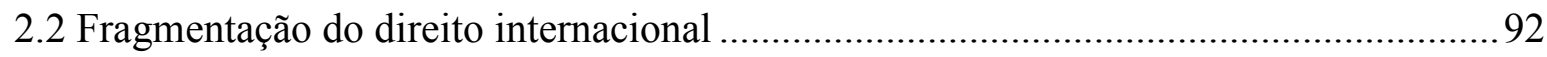

2.2.1 ONU: segurança coletiva e seu enlace com questões socioeconômicas ..................94

2.2.2 Equilíbrio bipolar e conexões entre segurança e cooperação econômica.................98

2.2.3 O espaço dos "outros" no direito internacional: sistema de tutela e nova ordem

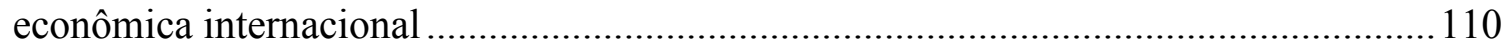

2.2.4 Fragmentação do direito internacional: contornos e respostas .............................. 120

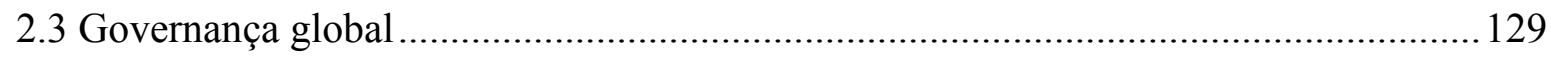

2.3.1 Crise da cooperação econômica internacional e realinhamentos geopolíticos...... 130

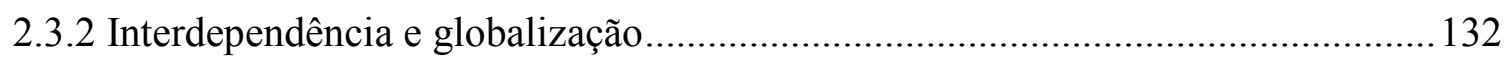

2.3.3 Redefinições institucionais e reformas para a economia de mercado. .................. 137

2.3.4 Governança global: categorias, relações e crítica.................................................. 143

2.3.5 Perspectivas jurídicas da governança global ......................................................... 159

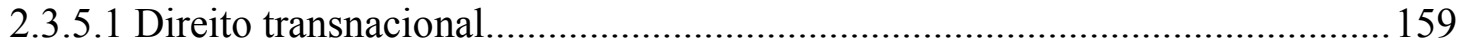

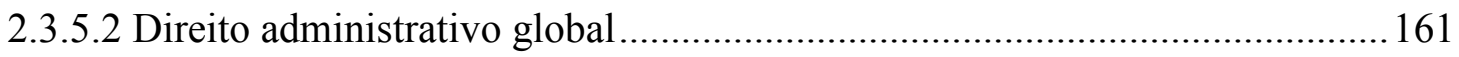

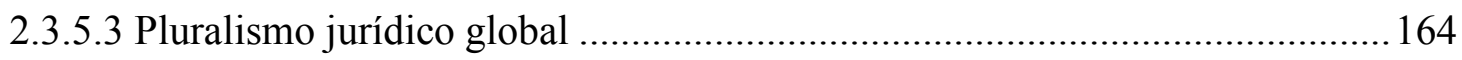

2.3.5.4 Ordenação jurídica transnacional ................................................................ 176 


\section{CAPÍTULO 3 - PERSPECTIVAS ECONÔMICAS SOBRE AS RELAÇÕES}

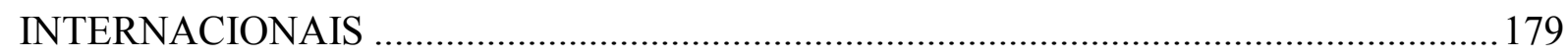

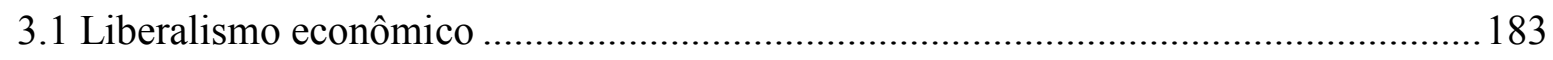

3.1.1 Adam Smith, David Ricardo e contornos definidores da tradição do liberalismo econômico.

3.1.1.1 Da divisão do trabalho à autonomia da perspectiva econômica e à defesa da liberdade de comércio.

3.1.1.2 Smith e a apresentação do domínio econômico como sistema.

3.1.1.3 David Ricardo e o argumento das vantagens comparativas no comércio internacional

3.1.2 Aspectos da ordem econômica internacional no período de predominância da perspectiva econômica liberal

3.1.2.1 Aspectos caracterizadores das relações comerciais internacionais do período

3.1.2.2 Aspectos da cooperação internacional monetária e financeira. 209

3.1.3 Algumas implicações normativas e jurídicas de ideias, práticas e instituições informadas pelo liberalismo econômico.

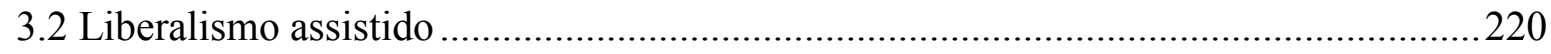

3.2.1 Crise da ordem econômica internacional no entreguerras......................................222

3.2.1.1 Tentativas de retomada do POI no entreguerras.........................................222

3.2.1.2 Dificuldades e crises econômicas no entreguerras ........................................226

3.2.1.3 Crises nas práticas de cooperação econômica internacional do entreguerras 231

3.2.1.4 Crise dos fundamentos do liberalismo econômico ........................................2234

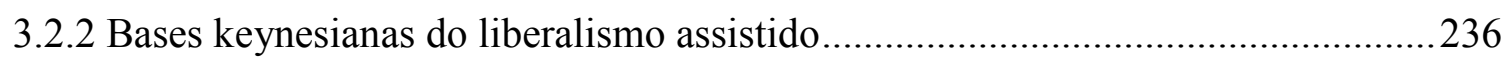

3.2.2.1 Experiências protokeynesianas de combate à depressão econômica no

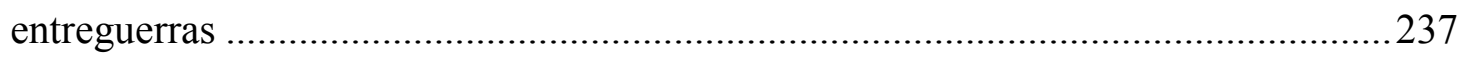

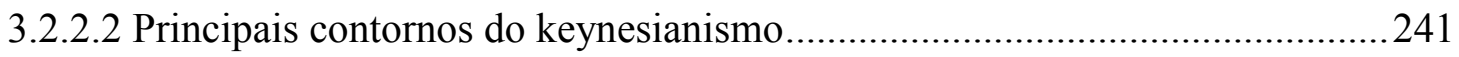

3.2.3 Ordem econômica internacional de Bretton Woods.............................................252

3.2.3.1 Liberalismo assistido: multilateralismo e estabilidade doméstica..................255

3.2.3.2 Aspectos da cooperação monetária e financeira internacional de Bretton

Woods e relação com políticas domésticas redistributivas

3.2.4 Algumas implicações normativas e jurídicas de ideias, práticas e instituições informadas pelo liberalismo assistido. 
3.3 Neoliberalismo

3.3.1 Aspectos do ideário neoliberal, sua ascensão e proeminência política 269

3.3.1.1 Mont-Pèlerin Society e ramificações: intelectuais contra o coletivismo..... 276

3.3.1.2 Conversões neoliberais em contextos domésticos. 278

3.3.2 Crise de Bretton Woods e ascensão do capital financeiro global 286

3.3.3 Regime de comércio: neoprotecionismo e novos temas da liberalização comercial.

3.3.3.1 Neoprotecionismo e a Rodada Tóquio do GATT.

3.3.3.2 OMC: adensamento institucional e novos temas da liberalização comercial.297

3.3.3.3 Uma defesa contemporânea da liberdade comercial internacional 299

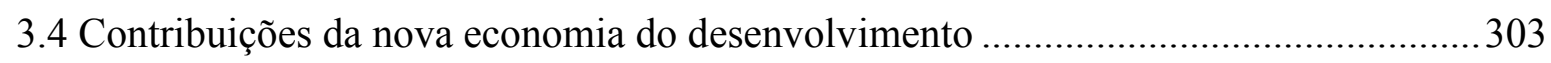

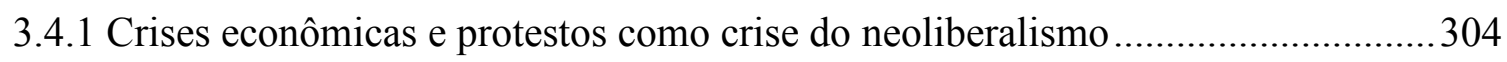

3.4.1.1 Da crise do Sudeste Asiático ao estouro da bolha "dotcom" ..........................304

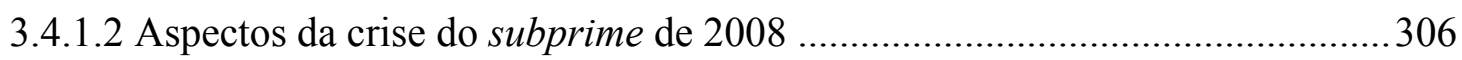

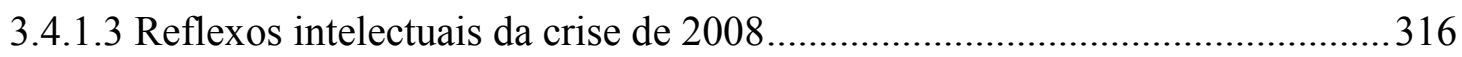

3.4.2 Ascensão de perspectivas econômicas heterodoxas na esteira da crise do neoliberalismo

3.4.2.1 Ha-Joon Chang e a abordagem histórica de instituições e desenvolvimento.319

3.4.2.2 Dani Rodrik: globalização econômica com policy space. 330

\section{CAPÍTULO 4 - EXPERTISES E INTERDISCIPLINARIDADE A SERVIÇO DE}

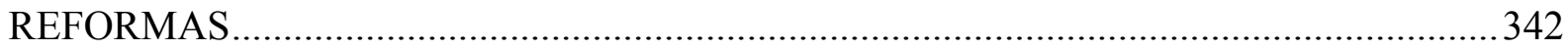

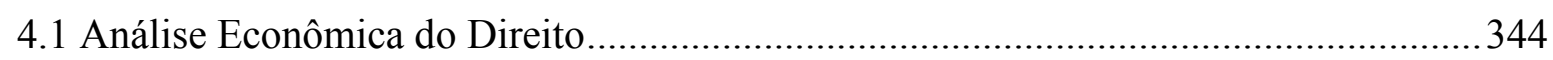

4.1.1 Bases intelectuais imediatas da AED: as contribuições de Ronald Coase .............347

4.1.2 AED em expansão: do nicho antitruste em Chicago à AED abrangente e influente

4.1.3 Principais características e teses da AED ao estilo de Chicago ............................358

4.1.4 Propostas e teses da AED e suas convergências com o paradigma "rule of law".365

4.1.4.1 O lugar da eficiência em relação às instituições jurídicas ................................368

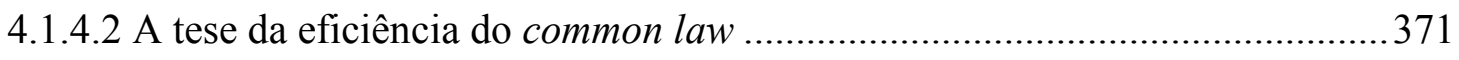

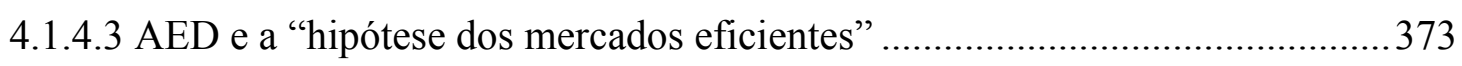

4.1.4.4 A AED e as políticas públicas de caráter redistributivo................................. 374

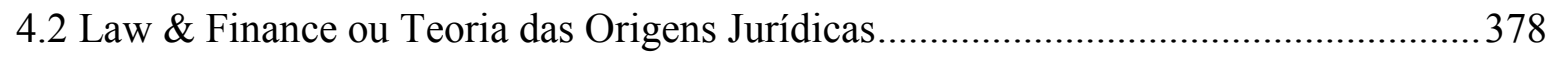

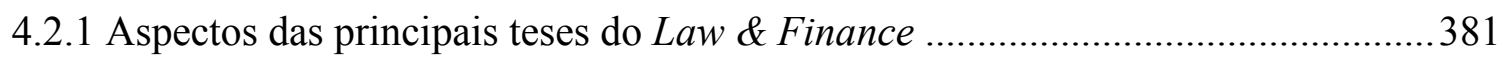


4.2.2 Algumas críticas ao Law \& Finance.

4.2.2.1 Aproximações entre civil law e common law e efeitos da Segunda Guerra

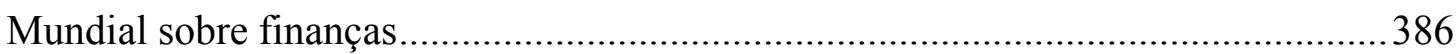

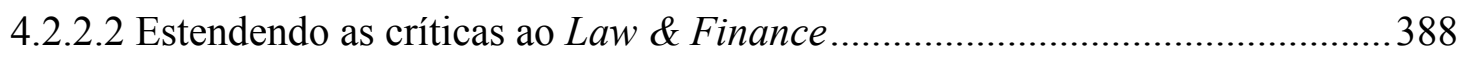

4.2.3 Algumas aplicações do Law \& Finance em reformas no setor de crédito bancário no Brasil 395

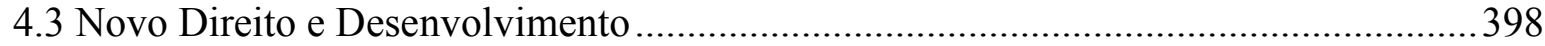

4.3.1 Momentos antecedentes ao Novo Direito e Desenvolvimento..............................399

4.3.1.1 Primeiro momento: direito e Estado desenvolvimentista ................................400

4.3.1.2 Segundo momento: direito e desenvolvimento neoliberal ou do paradigma rule

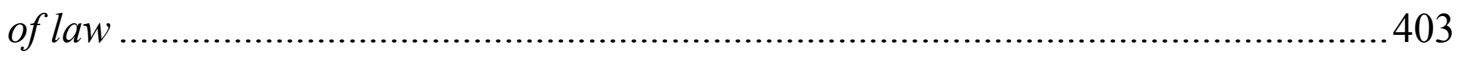

4.3.2 Contornos do Novo Direito e Desenvolvimento .......................................................404

4.3.2.1 NDD e novas concepções sobre desenvolvimento .........................................405

4.3.2.2 NDD e novas formas de ativismo estatal.......................................................406

4.3.2.3 NDD e novas concepções sobre direito como veículo de governança ............407

4.3.3 Novo ativismo estatal e análises jurídicas de políticas públicas no Brasil............413

4.3.3.1 Programa Bolsa Família e dimensão redistributiva do desenvolvimento........414

4.3.3.2 Três momentos da política brasileira quanto à produção e comércio de etanol

4.3.3.3 Alternativas institucionais para o financiamento corporativo ........................420

4.4 Análise Jurídica da Política Econômica ....................................................................... 424

4.4.1 Principais categorias e relações da AJPE ............................................................426

4.4.2 Novas metodologias de análise jurídica e exemplos de sua aplicação ...................430

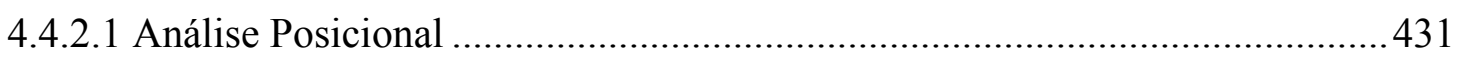

4.4.2.2 Nova Análise Contratual ou Análise de Portfólio ............................................440

4.4.3 AJPE: conexões e contrastes com outras vertentes do debate sobre direito e desenvolvimento 


\section{INTRODUÇÃO}

Em 2008, a bolha imobiliária do mercado norte-americano estourou e arrastou consigo uma série de instituições financeiras e investidores que haviam adquirido produtos financeiros referidos a este mercado. $\mathrm{Na}$ esteira de quebras ameaçadas e concretizadas e de medidas emergenciais de socorro governamental, a crise afetou mais do que aqueles diretamente envolvidos. Tampouco se limitou aos Estados Unidos. Seus impactos alastraram-se em cadeia pela Europa e os mais variados pontos do globo. A crise do mercado imobiliário norteamericano havia se tornado uma crise financeira global. Não a partir da periferia, mas do centro da economia mundial.

$\mathrm{Na}$ base desta crise esteve a liberdade praticamente irrestrita de instituições financeiras de criar papéis, ou "produtos" financeiros, referentes à dívida imobiliária, e de vendê-los nos mercados mundiais, muitas vezes adotando como base de cadeias contratuais empréstimos pouco criteriosos concedidos por bancos. O risco destes papéis foi subestimado, e a inexistência de lastro sólido para a dívida contraída por instituições financeiras em sua comercialização não foi devidamente levada em conta. Quando a inadimplência dos hipotecários norte-americanos aumentou, e o preço dos imóveis começou a cair, o mercado ruiu. Não havia controle sobre o que estes agentes financeiros faziam. Sequer havia clareza sobre o montante envolvido (Whitman, 2009, p. 25). Muitas das transações haviam, afinal, sido conduzidas em "mercados de balcão", isolados de exigências de publicidade. Enquanto o mercado imobiliário era uma bolha a inflar, os ativos financeiros nele baseados não revelavam seu verdadeiro risco. Como na dança das cadeiras, enquanto a música toca, pode haver mais pessoas do que cadeiras, e o jogo prossegue. Mas “a música parou”, e havia muito poucas cadeiras para a quantidade de envolvidos (Whitman, 2009, p. 26).

Ao avaliar esse cenário, Eiiti Sato (2012, p. 202) considera que "a expansão sem controle de derivativos e de outras modalidades de ativos financeiros foi fator decisivo para o desencadeamento da crise". Não havia qualquer arranjo de cooperação internacional para preveni-la. Ao longo de 30 anos, as políticas econômicas e a cooperação econômica internacional haviam sido estruturadas segundo uma sensibilidade que privilegiava a noção de que o mercado era capaz de autorregular-se. Esta visão ligava a prosperidade ao funcionamento o mais espontâneo possível dos mercados. Pouco tempo antes da crise, Ben Bernanke, presidente do banco central norte-americano, havia reafirmado publicamente sua crença de que a disciplina de livre mercado era mais adequada para regular instituições 
financeiras do que regras estatais formais (Whitman, 2009, p. 26). Em agosto de 2007, quando a crise se iniciava, "líderes políticos não clamavam por controles mais estritos ou uma governança global mais eficaz, mas por 'mais transparência'.’(Whitman, 2009, p. 27)

A crise revelou que algo estava errado nos quadros de referência que durante muitos anos orientaram padrões regulatórios e de cooperação internacional. Tais padrões, afinal, permitiram a expansão incontrolada dos mercados financeiros, inclusive internacionalmente. Diversas foram as reações críticas a este estado de coisas.

Em 2009, a Rainha Elizabeth II, da Grã-Bretanha, perguntou por que ninguém havia previsto a crise financeira internacional, e recebeu como resposta uma carta contendo pedido de desculpas de economistas britânicos (Besley et al, 2009). Em 2011, cerca de 70 estudantes em Harvard boicotaram a aula do renomado professor de economia, Gregory Mankiw, em protesto ao que percebiam como um viés teórico e pedagógico complacente para com injustiças sociais, bem como insensível a inconvenientes derivados da ausência de abertura do conhecimento econômico padrão para outras perspectivas, não "ortodoxas", sobre processos econômicos (Delreal, 2011).

Ainda em resposta à crise, ocorreram protestos de rua como Occupy Wall Street, Occupy London, entre outros. Estes protestos tiveram abrangência maior do que os locais apontados em seus nomes, tendo sido articulados por redes sociais virtuais. Tudo isto é indicativo do descontentamento com o predomínio de certa orientação econômica nos governos, nas organizações internacionais e nas universidades, que formulam e ajudam a pôr em prática políticas divorciadas dos anseios sociais de grande parte das pessoas do globo. Como indica Marcus Faro de Castro, "há uma crise no modo de organização da sociedade mundo afora", e que "resulta do fato de que os fundamentos utilizados por autoridades para estabelecer ou manejar estruturas políticas, econômicas e jurídicas flagrantemente envelheceram.” (2014b, p. 3)

A presente tese tem como objeto de pesquisa quadros de referência envolvidos na estruturação da cooperação econômica internacional. Não só aqueles que entraram em crise, senão também os que estiveram em voga durante ordens econômicas internacionais precedentes e os que atualmente se articulam como alternativas de ordens possíveis. Em relação a estes quadros de referência, o problema de pesquisa consiste em perquirir quais foram as visões jurídicas e econômicas das relações internacionais que forneceram materiais ligados à conformação das diferentes estruturas ou "momentos" assumidos pela cooperação econômica internacional. No entanto, padrões regulatórios e de cooperação internacional constitutivos de uma estrutura temporária ou "momento" não foram articulados por seus 
formuladores apenas de modo disciplinarmente "estanque", desde o direito ou a economia, mas também de modo interdisciplinar. Por isso, o problema de pesquisa também compreende o questionamento sobre visões interdisciplinares que integram o debate sobre direito e desenvolvimento.

A abordagem do problema de pesquisa acima delineado é permeada pela tese de que ocorreram duas transformações de sentido ao longo de diferentes momentos da cooperação econômica internacional. A primeira diz respeito ao sentido de "projeto institucional global" articulado por referenciais jurídicos, econômicos e interdisciplinares. A segunda refere-se ao sentido assumido pela interdisciplinaridade direito-economia. Nem este "projeto", nem o modo de trabalhar a interdisciplinaridade, permaneceram os mesmos. Os dois parágrafos seguintes delineiam os contornos principais das transformações de sentido aqui sugeridas.

Quanto à primeira delas, a tese relaciona momentos iniciais dos quadros jurídicos e econômicos de referência para as relações internacionais com as concepções de desenvolvimento versadas em termos de progresso e civilização. Estas implicavam hierarquizações não só entre modelos institucionais de organização econômica como também entre os próprios povos e culturas. Neste sentido, tanto o direito internacional quanto o liberalismo econômico clássicos proveram ideias e formas institucionais que abraçaram o projeto de assimilar os diferentes povos do globo em torno de modos europeus de organização jurídica, econômica e política - com supressão ou substituição de instituições locais. Estes são contornos de um projeto institucional de caráter universalista, em que o "bom" ou o "desejável" é a convergência global em torno de um só referencial. A tese sustenta que este sentido mostrou-se persistente na trajetória dos quadros jurídicos e econômicos de referência por ela abordados, projetando-se também em vertentes interdisciplinares contemporâneas ${ }^{1}$. Em contraste com isso, formulações mais recentes ${ }^{2}$ apresentam outro projeto para a conformação da cooperação econômica internacional, que não compartilha das pretensões assimiladoras ou universalistas do primeiro. Ao contrário: articulando-se em torno de concepções multifacetadas de desenvolvimento que remetem, inclusive, às aspirações peculiares a cada povo e contexto, estas outras visões favorecem um projeto de pluralismo institucional global.

\footnotetext{
${ }^{1}$ Tais como a Análise Econômica do Direito (AED) e o movimento Law \& Finance (favorecedoras da chamada "tese da convergência" ou harmonização institucional global).

${ }^{2}$ São elas: (i) quanto aos referenciais jurídicos das relações internacionais, o pluralismo jurídico global; (ii) no que tange referenciais econômicos, novas contribuições heterodoxas da economia do desenvolvimento; e (iii) relativamente a referenciais interdisciplinares do debate sobre as relações entre direito e economia, o "Novo Direito e Desenvolvimento" e a "Análise Jurídica da Política Econômica".
} 
O segundo componente da tese apresentada sustenta que os usos ou papéis dos referenciais jurídicos e econômicos na configuração de instituições e da cooperação econômica internacional também passaram por modulações. O direito pode exercer o papel de definir os pontos de chegada para o exercício da autoridade, mas pode também situar-se em função de objetivos definidos por outros referenciais, ou seja, sendo empregado de maneira instrumental. Assim, foram as ideias econômicas as predominantemente empregadas para pensar e guiar a estruturação da cooperação econômica internacional. Já os referenciais jurídicos para as relações internacionais, desde a porção final do século XIX, tenderam a desempenhar papel instrumental em relação ao projeto econômico ${ }^{3}$. De modo geral, no século XX, há perda do espaço do direito como quadro de referência para o exercício da autoridade (nacional e internacionalmente), em larga medida suplantado por outros saberes, dentre os quais desponta justamente a economia (cf. Castro, 2012). Este sentido de predominância de referenciais econômicos sobre os jurídicos para pensar padrões regulatórios e de cooperação econômica internacional refletiu-se em formulações interdisciplinares do debate sobre direito e desenvolvimento. Afinal, correntes como a AED e o Law \& Finance concebem o direito como estando essencialmente em função de objetivos econômicos. Pode-se constatar, porém, que novas movimentações intelectuais interdisciplinares trazem elaborações sobre a cooperação econômica internacional que não se caracterizam pelo predomínio dos referenciais econômicos, em parte porque passaram a apresentar a visão de múltiplas funcionalidades para o direito ${ }^{4}$, e noutra parte porque se baseiam em concepções de desenvolvimento que incluem aspectos jurídicos como pontos de chegada (e não apenas como meios para o crescimento econômico). Tais perspectivas, como o Novo Direito e Desenvolvimento (NDD) e a Análise Jurídica da Política Econômica (AJPE), correspondem a movimentações que pretendem orientar padrões regulatórios e de cooperação econômica internacional à consecução de objetivos jurídicos.

\footnotetext{
${ }^{3}$ Este é o caso da expansão global do comércio e finanças europeus no século XIX, que contou com formas jurídicas de apoio como colônias, protetorados, jurisdições consulares, tratados desiguais, entre outras, com marcadas continuidades no pós-Primeira Guerra. Também é o caso da estruturação da ordem econômica internacional do pós-Segunda Guerra Mundial que, apesar de maior densidade de conteúdos jurídicos multilateralmente negociados nos regimes de comércio, moeda e finanças, teve como principal referencial a macroeconomia keynesiana. No período neoliberal, correspondente à ruptura da ordem de Bretton Woods, a instrumentalização do direito em função de referenciais econômicos assume seus contornos mais explícitos, com a lógica de desenhos institucionais jurídicos de apoio à expansão e liberalização dos mercados. Estes contornos são trabalhados ao longo dos capítulos 2 e 3.

${ }^{4}$ Diogo Coutinho (2013) destaca que, para além da dimensão instrumental (direito como ferramenta), o direito pode ser encarado em suas dimensões substantiva (direito como objetivo), estruturante (direito como arranjo institucional) e legitimadora (direito como vocalizador de demandas). Vide, na seção 4.3.2, a discussão sobre as múltiplas funcionalidades do direito.
} 
O objetivo principal do ensaio consiste em abordar diferentes vertentes jurídicas, econômicas e interdisciplinares que, em cada momento, sendo permeadas por diferentes concepções de desenvolvimento, serviram como quadros de referência para a estruturação da cooperação econômica internacional. Tal objetivo é de grande relevância diante do cenário atual de exaustão dos quadros de referência prevalentes. Isto significa que, sob as condições presentes, torna-se necessário compreender que as ideias que instruíram a atual configuração dos padrões regulatórios e de cooperação internacional não são nem as únicas disponíveis, nem devem ser tomadas como necessárias. É, ainda, relevante diante da demanda por referenciais alternativos - uma demanda ínsita aos protestos referidos e decorrente das proporções adquiridas pela crise econômica de 2008. Neste sentido, esta tese delineia quadros de referência alternativos ao mainstream contestado, desde o direito, a economia, e de correntes interdisciplinares do debate sobre direito e desenvolvimento.

A condução da pesquisa é ainda pautada por dois objetivos específicos. O primeiro deles diz respeito ao estabelecimento de pontes entre referenciais de origens distintas (conexões entre discursos jurídicos, econômicos e de desenvolvimento) e entre níveis de análise institucional distintos (doméstico e internacional). Busca-se uma compreensão interdisciplinar dos referenciais jurídicos e econômicos relevantes com respeito à estruturação de padrões de interação econômica internacional. Tais pontes dizem respeito não só a ligações entre elementos jurídicos e econômicos, senão também a concepções de desenvolvimento (ou progresso e civilização) que propeliram as formulações de vertentes nestas duas áreas, ao longo de suas trajetórias. Busca-se, ainda, conectar o que se passa no plano da cooperação econômica internacional com o ambiente institucional doméstico. Propõe-se que os formatos assumidos por instituições domésticas sofrem constrangimentos das - mas também podem contribuir para provocar alterações nas - estruturas da cooperação econômica internacional.

O segundo objetivo específico é propiciar o contato com um debate novo, e que apresenta perspectivas diversas do discurso jurídico padrão no Brasil. O discurso jurídico mais encontradiço, no Brasil, conforme aponta Castro (2012), ainda é preso a categorias do século XIX, e permanece incapaz de orientar de modo adequado a formação e reforma de políticas públicas. O debate novo trava-se mediante discussões sobre as relações entre direito e economia desdobrando-se nas vertentes de Análise Econômica do Direito (AED), Law \& Finance, NDD e AJPE. Tais vertentes do debate trazem concepções relativamente novas, que apresentam o potencial de, no plano das ideias, fornecer materiais intelectuais de melhor qualidade para orientar o exercício da autoridade. Mas fazê-lo de modo meramente instrumental, a serviço da racionalidade econômica, pode ser insuficiente para alterar as 
práticas presentes. O protagonismo do conhecimento jurídico, ressignificado por uma abertura interdisciplinar, é o que está em jogo, diante da percepção de que as insatisfações sociais ventiladas nas manifestações recentes de movimentos sociais são, no fundo, do ponto de vista jurídico, reflexos de percepções de fruição inadequada de direitos. Por isso, a abordagem deste debate tem como objetivo específico apontar quais são as vertentes que favorecem o uso do direito como referencial para a orientação (ou seja, com objetivos pautados por preocupações jurídicas) dos projetos institucionais.

$\mathrm{Na}$ abordagem do objeto de pesquisa, aplicam-se delimitações temporais baseadas no critério de "ganho de autonomia" das respectivas disciplinas ou campos. Assim, são tomadas como propriamente "jurídicas" as perspectivas sobre relações internacionais posteriores à autonomia do direito internacional público, que só se deu na porção final do século XIX ${ }^{5}$. De modo análogo, consideram-se que visões propriamente "econômicas" somente emergiram autonomamente após as contribuições de Adam Smith, na porção final do século XVIII ${ }^{6}$. Por fim, no que diz respeito ao debate sobre direito e desenvolvimento ${ }^{7}$, o critério de autonomia do campo faz com que a análise se inicie em finais da década de 1960 e início da década de 1970, com as contribuições da Análise Econômica do Direito (AED) ${ }^{8}$.

Em linha com os apontamentos acima, a tese encontra-se estruturada da seguinte maneira. O primeiro capítulo pode ser lido como extensão da introdução. Nele, a diferenciação entre langue e parole, tal como empregada por Kennedy (2006), é apresentada como útil para lidar com elementos ideacionais jurídicos, econômicos e interdisciplinares correlatos a diferentes conformações da cooperação econômica internacional, e que se consolidaram como modos de pensamento. Além disso, as seções deste capítulo dedicam-se a caracterizar as trajetórias das ordens econômicas internacionais (1.1) e desenvolvimento (1.2) não como constantes, mas permeadas por diferentes conformações ou momentos. $\mathrm{Na}$ sequência, o capítulo 2 explora perspectivas jurídicas das relações internacionais desde o século XIX, compreendendo (2.1) o direito internacional clássico (com breve abordagem de

\footnotetext{
5 São elas: (i) direito internacional clássico; (ii) fragmentação do direito internacional e (iii) perspectivas jurídicas da governança global.

6 São consideradas as seguintes: (i) liberalismo econômico clássico; (ii) liberalismo assistido (embedded liberalism); (iii) neoliberalismo e (iv) novas contribuições heterodoxas da economia do desenvolvimento.

7 A delimitação feita nesta tese considera como integrantes deste debate as seguintes vertentes: (i) Análise Econômica do Direito (AED); (ii) Law \& Finance; (iii) Novo Direito e Desenvolvimento (NDD) e (iv) Análise Jurídica da Política Econômica (AJPE).

${ }^{8} \mathrm{O}$ debate sobre direito e desenvolvimento é comumente dividido em três momentos, sendo o primeiro deles anterior às contribuições da AED: (i) direito e Estado desenvolvimentista; (ii) direito e mercado neoliberal; (iii) novo direito e desenvolvimento. No entanto, como discutido no capítulo 4, dificilmente se pode considerar que o "primeiro momento" - apesar de sua denominação - tenha se constituído como campo ou disciplina a título próprio.
} 
seus antecedentes $\left.{ }^{9}\right),(2.2)$ a fragmentação do direito internacional e (2.3) perspectivas jurídicas da governança global. O terceiro capítulo é dedicado a suas representações econômicas, englobando (3.1) liberalismo clássico (igualmente precedido de breve abordagem de seus antecedentes); (3.2) liberalismo assistido; (3.3) neoliberalismo e (3.4) contribuições heterodoxas da economia do desenvolvimento. As abordagens feitas nestes capítulos compreendem ideias das principais vertentes delimitadas, bem como as práticas e instituições características de sucessivas conformações históricas que podem ser compreendidas como ordens econômicas internacionais. Já o quarto capítulo volta-se ao debate existente entre expertises interdisciplinares de direito e desenvolvimento que valorizam conexões entre instituições jurídicas e econômicas, bem como entre o que se passa no plano institucional doméstico e as conformações da cooperação econômica internacional. Assim, são abordadas (4.1) a Análise Econômica do Direito (AED), (4.2) o Law \& Finance, (4.3) o Novo Direito e Desenvolvimento (NDD) e (4.4) a Análise Jurídica da Política Econômica (AJPE) ${ }^{10}$.

O presente trabalho foi realizado com o apoio da Coordenação de Aperfeiçoamento do Pessoal de Ensino Superior (CAPES).

\footnotetext{
${ }^{9}$ Justifica-se a necessidade de caracterização dos precedentes para que se possa compreender o contraste entre perspectivas anteriores e posteriores à emergência do campo como esfera autônoma do saber.

${ }^{10}$ Ao longo do trabalho, para tornar a leitura mais fluida, foi feita a opção de manter todo o texto em um só idioma. Exceções ocorrem no emprego de expressões técnicas que, se traduzidas, poderiam implicar prejuízo à precisão conceitual. Em muitos casos, optou-se por traduzir e indicar, ao lado, a expressão no idioma original. De toda forma, as citações de textos em língua estrangeira empregados nesta tese foram traduzidas livremente para o português pelo autor.
} 


\section{CAPÍTULO 1 - OS DIFERENTES MOMENTOS DA COOPERAÇÃO ECONÔMICA INTERNACIONAL E DO DESENVOLVIMENTO}

O presente capítulo aborda os sentidos adquiridos pelos termos "cooperação econômica internacional" e "desenvolvimento", que não devem ser tomados de maneira estática. De fato, ao invés de assumirem sentidos constantes ao longo do tempo (e a tese se ocupa do século XIX até as vertentes que ingressaram no debate na primeira década do século $\mathrm{XXI}$ ), esses dois referenciais discursivos passaram por transformações de sentido que permitem sua caracterização como elementos basilares de distintos "momentos". No presente trabalho, "momento" designa uma configuração temporária de ideias (advindas de uma ou mais disciplinas intelectuais) e de práticas institucionais e articulações de interesses a que se vinculam. Portanto, cada "momento" pode ser descrito como um conjunto de ideias e um conjunto de práticas institucionais e suas interrelações. O "núcleo" de ideias mais importantes em cada momento corresponde a langue (no sentido empregado por Kennedy, 2006), enquanto as várias versões das efetivações práticas das ideias desse núcleo, são exemplos do que esse autor chama de parole. Mais sobre isto será dito abaixo ${ }^{11}$.

Embora a expressão "cooperação econômica internacional" possa ser usada para fazer referência a fenômenos das relações econômicas internacionais tanto do final do século XIX quanto do começo do século XXI, o conteúdo que preencherá este uso será diverso. E o mesmo vale para noções de desenvolvimento ou ideias correlatas e precedentes: "civilização" e "progresso". Como será possível observar, as ideias jurídicas, econômicas e interdisciplinares aqui trabalhadas também passaram por transformações que dialogam com seus respectivos contextos ou momentos e concepções de desenvolvimento. Vale ressalvar, de antemão, que a abordagem feita no presente capítulo tem caráter ainda introdutório, e que os elementos nele sinalizados perpassam a narrativa dos capítulos seguintes.

Cada uma das conformações abordadas nos capítulos seguintes é permeada por formulações intelectuais e configurações institucionais variadas, com controvérsias intelectuais e disputas práticas específicas. Tais circunstâncias não somente tornam necessária a consideração de que os momentos da cooperação econômica internacional e do desenvolvimento são diversos, mas também deixam claro que é preciso lidar com a existência

\footnotetext{
${ }^{11}$ A distinção langue/parole tornou-se famosa a partir do surgimento da linguística estruturalista de Ferdinand de Saussure, considerado também fundador da semiótica. Parte da literatura jurídica recente emprega noções da semiótica como estratégia analítica. Ver, além de Kennedy (2006), Kennedy (2001; 1997, p. 133-5; 1991; 1994).
} 
de posições e atuações variadas em cada momento. Ou seja, a diversidade de ocorrências institucionais, de direito positivo, de medidas de políticas econômicas e de manifestações intelectuais num mesmo "ambiente" ou "momento" histórico pode ser uma fonte de dificuldades para uma análise como a que é feita nos capítulos seguintes.

A estratégia de análise empregada por Duncan Kennedy (2006) em Three globalizations of law and legal thought: 1850-2000 é interessante para navegar por cenários de ocorrências intelectuais e institucionais múltiplas. Basicamente, o autor emprega a distinção entre langue e parole para identificar três globalizações de modos de pensamento jurídico em meio à profusão de manifestações intelectuais e de direito positivo em países variados. Nesta distinção, langue, ou língua, está no plano mais profundo ou básico das manifestações discursivas. Ela diz respeito à "consciência, entendida como vocabulário, de conceitos e argumentos típicos" $(2006, \text { p. 23) })^{12}$. Já parole, ou fala, faz referência ao que pode ser dito mediante o emprego desta linguagem, ou seja, refere-se à infinitude de manifestações particulares possíveis a partir de uma mesma langue. Assim, no caso do direito, diferentes normas positivas adotadas por Estados variados podem ser expressões discursivas (parole) de um mesmo modo de pensamento jurídico (langue) globalizado. Parole faz referência à "diversidade infinita" de "argumentos particulares e de regimes particulares de direito positivo", ao passo que langue indica o "repertório programático", o "vocabulário de políticas públicas", a estrutura de um modo de pensamento (2006, p. 54).

A presente tese encontra inspiração no expediente adotado por Kennedy, interessandose pela caracterização de elementos ideacionais jurídicos, econômicos e interdisciplinares, encarados como langues, correlatos a diferentes conformações (parole) da cooperação econômica internacional. Em outros termos, o foco da tese recai sobre o nível de análise identificado pela ideia de langue, trabalhando parole (manifestações pontuais) como expressão desta, não como foco principal. Tal enfoque não pretende obscurecer a diversidade de manifestações de direito positivo possíveis no interior de uma mesma langue de direito internacional, nem a variedade de medidas de política econômica adotáveis em referência a um mesmo modo de pensamento econômico, e assim por diante. De toda forma, reunindo os elementos até aqui apresentados, a ideia é trabalhar trajetórias de langues em cada área, relacionando-as entre si, com seus "momentos", e observando seu diálogo com concepções de desenvolvimento.

\footnotetext{
${ }^{12}$ De certa forma, o uso que Kennedy faz de "langue" é análogo ao emprego da ideia de "gramática generativa" por John Ruggie (1982) para fazer referência a certos pressupostos compartilhados na estruturação de regimes internacionais em um dado momento (cf. 3.2.3).
} 
A abordagem de Kennedy valoriza elementos ideacionais em sua relação com instituições. Este elemento também perpassa a presente tese, que adota como pressuposto a existência de uma relação dinâmica entre representações intelectuais (ou quadros de referência), de um lado, e instituições, de outro. Ou seja, ideias e instituições se relacionam com influência recíproca. Certos autores trabalham com categorias que auxiliam a percepção dessas influências. Mark Blyth (2001) é um destes autores, e concebe que as ideias podem funcionar como (i) "projetos" (blueprints) para o desenho de novas instituições; (ii) "armas" (weapons), caso em que são empregadas para contestar instituições existentes; e (iii) "travas cognitivas" (cognitive locks), se operam de modo a reforçar as instituições mesmo diante de pressões por mudança, ou seja, desempenhando papel conservador. Estas três funcionalidades são interessantes para lidar com sucessões de quadros de referência ao longo do tempo e suas contribuições para estruturar, contestar e perpetuar práticas de cooperação econômica internacional. Colin Hay (2006) também fornece contribuições interessantes ao conceber que os atores políticos se apropriam estrategicamente de um mundo repleto de instituições e ideias sobre estas. Para Hay, a percepção a respeito do que é viável, legítimo, possível e desejável é tanto moldada pelo ambiente institucional quanto pelos paradigmas e visões de mundo existentes. Tais elementos, que nesta tese são trabalhados como "quadros de referência", "modos de pensamento" ou "sensibilidades", operam, para Hay, como "filtros cognitivos" (2006, p. 65) sobre os padrões de ação de pessoas, governos e organizações ${ }^{13}$.

Não se pode esquecer que, não obstante sua abertura interdisciplinar, esta é uma tese feita desde o direito. A discussão precedente está conectada à importância dos elementos ideacionais jurídicos para a estruturação de relações sociais e econômicas, inclusive no que alcança as relações internacionais. Este é um ponto trabalhado por Marcus Faro de Castro

\footnotetext{
${ }^{13}$ Estes apontamentos (Kennedy, 2006; Blyth, 2001; Hay, 2006) podem ser lidos de modo associado à chamada "virada ideacional", ocorrida no campo da ciência política, e também referida como "institucionalismo discursivo" (cf. Schmidt, 2008). Ao longo do século XX, a ciência política foi permeada por transições paradigmáticas (cf. Peres, 2008). Até aproximadamente a década de 1940, predominou a perspectiva do "antigo institucionalismo", de caráter formalista, com ênfase nas leis e costumes como instituições fundamentais, e marcada por especulações sobre os meios institucionais de alcançar o "bem". Durante as décadas de 1940-60, foi hegemônica a perspectiva do "comportamentalismo", tendo o comportamento individual - e não as instituições como objeto das investigações, com ênfase em hipóteses empiricamente testáveis e uso de análises estatísticas como suas principais características. A partir da década de 1970 emergiram perspectivas que ficaram conhecidas como "neoinstitucionalistas", e que rejeitaram tanto a ausência de preocupações com o contexto institucional nas abordagens comportamentalistas precedentes, quanto o caráter especulativo e formalista do antigo institucionalismo.. O retorno às instituições para o centro das análises dos fenômenos políticos não se deu, porém, de maneira unívoca, mas em vertentes como o neoinstitucionalismo histórico (ênfase em path dependencies), sociológico (ênfase em práticas culturais) e de escolha racional (ênfase em preferências racionais individuais e coletivas). (Peres, 2008; Hall; Taylor, 2003). A virada ideacional, de ocorrência relativamente mais recente, adicionou mais uma camada aos chamados "neoinstitucionalismos", abrindo espaço para ênfase nas ideias como fatores relevantes para a explicação da construção, permanência, mudança e rejeição de instituições (cf. Schmidt, 2008).
} 
(2012) em obra que, apesar de identificar potencialidades transformadoras para o direito, caracteriza os modos de representação jurídica prevalentes no Brasil como marcados pelo formalismo e conceitualismo, do ensino jurídico à prática judicial. A obra sugere que o impacto mais importante deste estilo de formação jurídica seja a inabilitação do jurista para avaliar a adequação de políticas públicas e apontar reformas consequentes, resultando no favorecimento de atuações com sentido conservador:

Três resultados negativos da prevalência dessa visão [formal-conceitualista] sobre o direito no ensino jurídico brasileiro são: um descolamento entre o intelecto do jurista e a realidade social, que é muito mais complexa do que as categorias jurídicas são capazes de analisar; uma dificuldade para avaliar de maneira responsável e analiticamente apta as políticas públicas e seus impactos sobre a vida social, dandolhes um significado jurídico útil; e também uma orientação intelectual para atuar apenas no sentido de preservar a ordem posta, não para reformá-la. (Castro, 2012, p. 9)

Inadequações do fechamento dos referenciais jurídicos prevalentes diante de ocorrências mais complexas da realidade econômica e social são também apontadas por David Kennedy (2013). Para o autor, "as convenções técnicas profissionais que governam a produção acadêmica desencorajam pronunciamentos a respeito das grandes tendências na vida econômica e política global." Em sua visão, a "tendência jurídico-acadêmica é a análise de foco restrito, refinando e restaurando os léxicos existentes para o exercício da autoridade [policy], doutrina e teoria" (2013, p. 9). Kennedy propõe que o direito pode desempenhar papel de reordenação em grande escala da vida política e econômica. Para tanto, seria necessário fundir análise jurídica com elementos da economia política, de modo a passar a perceber "as dinâmicas de desigualdade; as distribuições do crescimento; as reproduções de hierarquias dentro de e entre setores, regiões, nações e culturas na liderança e retardatários." (2013, p 12) O treinamento intelectual e profissional cruzado dos juristas com a economia política é apontado como necessário para reforma (juridicamente pautada) da cooperação econômica internacional (2013, p. 47).

Contribuições como estas convergem para a percepção da necessidade de que o olhar jurídico deva se abrir para capturar, com o auxílio de elementos de outras esferas, fenômenos normativos que contribuem para a construção social do "normal", ou seja, do que se entende como sendo a "ordem" boa ou aceitável. As análises restritas às manifestações de direito positivo mostram-se inadequadas para a representação de elementos com significado 
normativo relevante para relações econômicas e sociais, e que alcançam as relações internacionais $^{14}$. Afinal, como aponta Marcus Faro de Castro,

as decisões de política econômica afetam de maneira diferenciada as ações atuais e planejadas de grupos e indivíduos, com reflexos sobre a formação de suas concepções sobre o que são (em termos da fruição presente), ou devam ser, os seus direitos. Isso precisa ser compreendido pela análise jurídica no tratamento de questões relevantes para a configuração institucional da política econômica, tanto no plano doméstico como no da cooperação econômica internacional. (2009, p. 24)

As considerações acima contribuem para justificar o procedimento da presente tese, de procurar identificar, diferenciar e relacionar modos de pensamento jurídicos, econômicos e interdisciplinares que forneceram elementos para estruturar, contestar ou perpetuar práticas de cooperação econômica internacional. Ao longo desta trajetória, será possível notar a importância dos engastes existentes entre os referenciais apontados e concepções de desenvolvimento, que tampouco permaneceram as mesmas. Com ênfase na mudança e nas relações entre ideias e instituições, as caracterizações destes momentos contribuirão para “preparar o terreno" para a sucessão de referenciais jurídicos e econômicos para as relações internacionais ao longo do tempo, e sua ligação com o debate interdisciplinar hoje existente entre vertentes de direito e desenvolvimento.

\subsection{Momentos da cooperação econômica internacional}

Cooperação econômica internacional é uma expressão que faz referência à coordenação de políticas no campo das relações econômicas internacionais. Tais relações, por sua, vez significam o "conjunto de transações complexas e interdependentes, que se distribuem pelas áreas monetária, financeira e comercial.” (Sato, 2012, p. 23) Ao longo do tempo, os elementos envolvidos na coordenação de políticas passaram por modulações, que permitem falar na existência de diferentes "ordens econômicas internacionais".

Como Eiiti Sato aponta, ordens econômicas internacionais são conformações particulares da cooperação econômica internacional. As ordens econômicas internacionais podem ser compreendidas em termos de três componentes "tangíveis", acompanhados por

\footnotetext{
${ }^{14}$ A "limitação que caracteriza boa parte dos debates jurídicos contemporâneos contrasta com a multiplicidade de instrumentos analíticos, procedimentos de cálculo e critérios operacionais desenvolvidos pelos economistas. Evidentemente, de maneira mais exitosa que os juristas, eles lograram elaborar 'formas' para a 'matéria' do social que se aplicam à sociedade vista como um 'sistema'. Certamente, o direito do Estado de bem-estar social, com suas 'formas' jurídicas viabilizadas pela 'turma do social' e, em seguida, de modo mais tortuoso, também pela análise jurídica das políticas públicas, até agora tem servido apenas como um complemento a políticas econômicas. E a coordenação mais abrangente das políticas públicas é realizada, para o bem ou para o mal, por meio do emprego de categorias macroeconômicas." (Castro, 2012, p. 214). No entanto, a credibilidade das orientações econômicas declinou com a crise global da primeira metade do século XXI (2012, p. 215).
} 
dois componentes "menos tangíveis, embora não menos reais" (2012, p. 26). Os componentes tangíveis dizem respeito a regimes internacionais de (i) comércio, (ii) moeda e (iii) finanças.

Ao passo que o regime internacional de comércio faz referência aos princípios, normas, regras e procedimentos decisórios que recaem sobre a troca de bens e serviços, o regime internacional monetário "diz respeito à forma pela qual se apresenta a disponibilidade de liquidez internacional" (2012, p. 28). Este é composto pelas moedas empregadas nas transações internacionais e pelos mecanismos para ajuste nos balanços de pagamentos ${ }^{15}$. Regime internacional financeiro, por sua vez, remete ao "conjunto de regras, normas e instituições formais e informais que orientam os fluxos de fundos na economia internacional." A movimentação transfronteiriça de fundos é influenciada por diversos fatores, como taxas de juros, "a busca por segurança, as variações nas taxas cambiais, a abertura dos mercados para a promoção do comércio etc.” (2012, p. 30) Já os elementos "menos tangíveis" a que Eiiti Sato se refere são (iv) o "padrão de distribuição de riquezas" e (v) a estratégia de crescimento implícita na ordem econômica (2012, p. 26).

Ora, nem os elementos tangíveis, nem os menos tangíveis, são perenes. Na linguagem de Stephen Krasner (1983), a história da cooperação econômica internacional é pontilhada por mudanças não só nos regimes, mas dos próprios regimes ${ }^{16}$. Mudanças no regime se referem a alterações menos profundas, que alcançam regras e procedimentos decisórios, mas em que princípios e normas permanecem essencialmente os mesmos. Apesar de mudanças na superfície, o núcleo duro é preservado. Já mudanças de regime ocorrem quando princípios e normas são alterados, ou seja, quando seus elementos mais fundamentais são substituídos (1983, p. 3-4). Os parágrafos seguintes objetivam enfatizar, de maneira sucinta, mudanças de regime que sinalizam quatro distintas ordens econômicas internacionais, além da conjuntura crítica contemporaneamente vivida. Cabe registrar que os contornos apontados na abordagem indicativa ou introdutória destes parágrafos - destinados a apontar "ambientes" em transformação - são retomados com maior densidade ao longo dos capítulos 2 e 3 .

\footnotetext{
${ }^{15}$ Por balança de pagamentos compreende-se a "contabilidade [...] que revela todos os fluxos reais e financeiros entre um país e o resto do mundo. Na prática, é um documento contábil em que são registradas as trocas de mercadorias, de títulos e de moedas de um país com o estrangeiro. Em outras palavras, compreende tanto as transações correntes de exportação e importação de bens e serviços quanto as transações financeiras." (Brum; Heck, 2005, p. 157) A balança de pagamentos é conceito mais amplo do que balança comercial, portanto, por englobar tanto esta quanto a balança de operações de capital (2005, p. 158).

${ }^{16}$ Krasner define regimes internacionais como conjuntos de princípios, normas, regras e procedimentos decisórios (todos eles podendo ser implícitos ou explícitos) em torno dos quais as expectativas dos atores convergem numa área das relações internacionais. Os elementos institucionais desta definição são por ele esclarecidos: "Princípios são crenças de fato, causalidade, e retidão. Normas são padrões de comportamento definidos em termos de direitos e obrigações. Regras são prescrições ou proscrições específicas para ação. Procedimentos decisórios são práticas prevalentes para fazer e implementar escolhas coletivas." (Krasner, 1983, p. 2)
} 
Uma primeira ordem se conformou entre 1870 e a Primeira Guerra Mundial. Os regimes internacionais desta ordem eram caracterizados pelo seu alto grau de informalidade. O regime de comércio esteve orientado pelo laissez-faire. Os regimes monetário e financeiro tinham contornos mais fortes, embora igualmente informais, fornecidos pelas regras do Padrão-Ouro Internacional. Neste contexto, exigiam-se três coisas: que as moedas nacionais fossem conversíveis em ouro, que se permitisse o livre fluxo transfronteiriço de ouro, e que o compromisso com manutenção da paridade cambial fosse uma prioridade política para os governos. Neste contexto, a libra esterlina foi, na prática, a moeda de referência para as transações comerciais e financeiras internacionais. Não havia organizações institucionais que dessem apoio para que Estados pudessem manter políticas deficitárias, como políticas redistributivas ou de bem-estar social - pelo contrário, no Padrão-Ouro Internacional, Estados que praticassem déficits eram "punidos" por fugas de capital ameaçadas ou concretizadas (cf. Polanyi, p. 14; Castro, 2012, p. 190) - e era comum que as populações tivessem que conviver com ciclos deflacionários, de retração econômica, para que a paridade cambial pudesse ser mantida. Nesta ordem econômica internacional, a concepção de crescimento estava atrelada à noção de que a liberdade dos mercados era o melhor meio para gerar progresso (Sato, 2012, p. 53-80).

Esta ordem foi, contudo, rompida com a Primeira Guerra Mundial. No período entreguerras, houve uma tentativa de resgate, mas os regimes de comércio, finanças e moedas já não funcionaram como anteriormente. Segundo Polanyi (2001[1944]), o elemento diferente, e responsável por isso, foi o aumento da sensibilidade dos governos às pressões domésticas, relacionadas à conformação de democracias de massa, com expansão do sufrágio e participação política de partidos trabalhistas em democracias capitalistas avançadas. Neste novo cenário, a prioridade do compromisso com a manutenção da paridade cambial tornavase politicamente controvertida. Articulações domésticas por políticas de bem-estar social e pleno emprego ganham voz. Após a crise de 1929, predominaram práticas protecionistas tanto no comércio quanto em moeda, com depreciações competitivas que ficaram conhecidas como políticas beggar-thy-neighbour, voltadas a favorecer as exportações locais em detrimento das vendas e dos empregos em outras partes. Nota-se que, nesse momento da cooperação econômica internacional, permeado por crises, a concepção de crescimento implícita atribui maior relevância prática à atuação estatal, o que provocou o surgimento de contestações à ideologia de "liberdade de mercado" até então prevalente (Sato, 2012, p. 81-104).

Após a Segunda Guerra Mundial, a ordem econômica internacional passou a contar com regimes internacionais dotados de maior institucionalização formal, e que favoreciam 
uma atuação maior do Estado na Economia. Esta ordem do Segundo Pós-Guerra foi informada por uma sensibilidade econômica tipicamente keynesiana, e conformou aquilo a que John Gerard Ruggie (1982) chamou de embedded liberalism, ou "liberalismo assistido", na tradução da expressão feita por Sato (2012). Neste contexto, o objetivo da liberalização comercial, perseguido no âmbito do GATT 1947, foi atrelado aos regimes monetário e financeiro. Houve o fechamento da conta de capitais, isto é, foram adotados controles estatais sobre os fluxos transfronteiriços de moeda. E organizações internacionais foram estabelecidas para apoiar a manutenção da paridade cambial e a solvência dos Estados, papel desempenhado sobretudo pelo Fundo Monetário Internacional. Nesta ordem, o dólar foi formalmente reconhecido como moeda-âncora das transações internacionais, sendo conversível em ouro. Em virtude disso, o regime monetário foi chamado de padrão dólarouro. Quanto à concepção de crescimento implícita nesta ordem, a noção de liberalismo assistido (embedded liberalism) buscava conciliar a liberdade comercial com uma rede de proteção oferecida pela atuação estatal, com válvulas de escape para o arrefecimento de tensões domésticas nos Estados (Sato, 2012, p. 105-38). Porém, mudanças não tardaram a ocorrer.

De fato, em 1971, a conversibilidade do dólar em ouro foi unilateralmente rompida por Richard Nixon. Os fluxos financeiros tornaram-se mais voláteis, de maior monta que os próprios fluxos relativos ao comércio internacional, e passaram a evadir o controle estatal (Sato, 2012, p. 139-66). Esta é uma época de liberalização das finanças internacionais, impulsionada por referenciais econômicos ortodoxos. Os papéis do FMI e do Banco Mundial foram ressignificados. Estas instituições passaram a induzir reformas pró-mercado nas políticas públicas dos países tomadores de assistência financeira (Castro, 2005b, p. 154-6; cf. 2005a). Trata-se, portanto, de uma nova ordem, pós-Bretton Woods. Nela, a concepção de crescimento implícita volta a apostar no livre mercado como promotor do desenvolvimento (Sato, 2012, p. 167-92).

Os fundamentos desta ordem (também adjetivada como "neoliberal") têm sido questionados no século XXI, sobretudo após a chamada crise das hipotecas subprime, de 2007-8, levantando discussões a respeito de quais seriam, ou deveriam ser, os contornos da atual ordem econômica internacional (Sato, 2012, p. 193-212). No campo das políticas públicas e da política econômica, a crise no sistema financeiro foi enfrentada por medidas destinadas a resgatar, com recursos governamentais, instituições financeiras em apuros, numa “socialização dos riscos" (Wolf, 2010, p. 208). As medidas de resgate de bancos e outras instituições foram questionadas em protestos em muitas partes do globo. Paralelamente, 
houve novo fôlego governamental para a adoção de medidas de regulação dos mercados financeiros e maior participação interventiva, sobretudo por meio de estímulos monetários (inclusive cambiais) e fiscais. Essas medidas foram interpretadas como resgates do ideário keynesiano e da "economia da depressão" por autores como Paul Krugman (2009), BresserPereira (2010) e outros.

Embora tais desdobramentos sinalizem a existência de uma conjuntura crítica, em que o prestígio do ideário neoliberal encontra-se abalado, eles não foram suficientes para deslocar de modo completo o primado de referenciais ortodoxos para condução da política econômica. Peck, Theodore e Brenner (2012), questionando se o neoliberalismo teria encontrado, "como muitos sugeriram, seu próprio ‘momento muro de Berlim', de colapso irreversível” (2012, p. 60), sugerem, ao invés, que a crise não representou o seu "fim". Há a permanência de um "neoliberalismo 'morto-vivo", referido como "fase pós-programática" dessa corrente, com “impulsos residuais neoliberais" (2012, p. 78).

De fato, pode-se interpretar que os fundamentos neoliberais para condução da política econômica permanecem incrustados em espaços de decisão e nas molduras cognitivas de membros da imprensa, gozando de receptividade também perante a opinião pública. Aliás, talvez a noção de "impulsos residuais" tenha algum poder explicativo para a persistência do poder prático das agências de classificação de crédito de exercer influência sobre o rumo das políticas públicas em regiões variadas do globo, aspecto que os capítulos de 2 a 4 ressaltam em passagens variadas.

Apesar de estes serem apenas contornos genéricos, de caráter introdutório, já é possível perceber, a partir deles, que a cooperação econômica internacional não se estruturou do mesmo modo sempre, e é esta noção de mudança na conformação dos regimes internacionais, do padrão de distribuição de riquezas e da concepção implícita de crescimento que a categoria de "ordem econômica internacional" permite capturar. Fica sugerido, desta forma, que os referenciais - ou langues jurídicas, econômicas e interdisciplinares - abordados nesta tese estão inseridos numa trajetória de ambientes em transformação. Em outras palavras, os discursos que produziram materiais para estruturar padrões regulatórios e de cooperação econômica internacional dialogaram com problemas e aspirações referentes a ordens econômicas internacionais variadas. 


\subsection{Momentos do desenvolvimento}

Referenciais jurídicos, econômicos e interdisciplinares, em momentos variados, articularam noções do "bom" ou "desejável" para padrões regulatórios e de cooperação econômica internacional em vocabulários de desenvolvimento. Por isso, a discussão sobre desenvolvimento acaba por ser transversal às trajetórias de modos de pensamento abordados nos capítulos seguintes.

Não há um só conceito de desenvolvimento que acompanhe todos os momentos da cooperação econômica internacional. Ao longo do processo, não só a noção de desenvolvimento mudou, como mudaram também os meios considerados apropriados para atingi-lo. Nem mesmo o termo "desenvolvimento" é adequado para cobrir todo o período considerado nos capítulos seguintes. Afinal, no século $\mathrm{XIX}^{17}$, as hierarquizações entre povos - ou a noção de avanço de patamares inferiores a superiores - eram ventiladas em termos de progresso e civilização ${ }^{18}$.

Estas noções deixaram marcas nos momentos inaugurais de perspectivas jurídicas e econômicas das relações internacionais. Como o capítulo 2 narra, o direito internacional do século XIX fundou-se em um contexto no qual se valorizavam distinções entre povos civilizados e não civilizados, que coincidiam com colonizadores e colonizados. O Institut de Droit International, de Ghent, na Bélgica, que reuniu intelectuais identificados com a linguagem do direito internacional clássico, propunha-se ser a "consciência jurídica do mundo civilizado" (Koskenniemi, 2004). A Europa, neste contexto, era apontada como o lugar onde se originava a "comunidade de nações civilizadas" e, portanto, a própria normatividade para as relações internacionais. A colonização era a ferramenta para levar o comércio e o direito, dois instrumentos de progresso, ao restante do mundo. O direito de colonizar emanava da afirmação da superioridade civilizacional do europeu, mas era também um dever: o fardo do homem branco, de levar civilização e progresso aos povos bárbaros e selvagens (Anghie,

\footnotetext{
${ }^{17}$ Robert Nisbet relata concepções de progresso no pensamento ocidental "durante quase três mil anos" (Nisbet, 1985, p. 16). No entanto, durante este longo processo de mudanças, concepções de progresso eram parte de climas intelectuais também marcados por noções míticas de "uma era primordial de ouro seguida de decadência" e de concepções de eterno retorno ou recorrência cíclica. No século XIX, já não há concorrência significativa entre estas noções: a ideia de progresso torna-se uma crença nos círculos intelectuais e se populariza, alcançando seu "zênite". Além disso, a fé no progresso subsume outros valores (justiça, liberdade etc.) como parte de uma só grande narrativa (Nisbet, 1985, p. 181). "Pelo menos do começo do século XIX até algumas décadas atrás, a crença no progresso da humanidade, com a civilização ocidental na vanguarda, foi, para todos os efeitos, uma religião universal de ambos os lados do Atlântico." (1985, p. 19; cf. 181-8)

${ }^{18}$ Para Gilbert Rist, as ideias de progresso, civilização e desenvolvimento têm em comum a sugestão da existência de patamares inferiores e superiores de organização da vida econômica, social, e mesmo cultural (Rist, 2002).
} 
2004; Easterly, 2006). Resta claro, portanto, que a própria expansão do modelo de Estado europeu (isto é, o modelo westphaliano de autoridade territorial) para o restante do mundo foi feita sob a bandeira do progresso (Sbert, 2010, p. 216; Anghie, 2004).

Do lado econômico, abordado no capítulo 3, a noção de progresso reflete sua força na própria valorização do enriquecimento, ou melhoria do bem-estar material, como objetivo a título próprio: algo que a emergência da economia como perspectiva autônoma consegue estabelecer. Em Adam Smith, nesse sentido, a divisão do trabalho e os ganhos de produtividade decorrentes da especialização aparecem como elementos-chave para a riqueza das nações, com a liberdade de comércio ocupando o papel de permitir patamares mais elevados de divisão do trabalho, produtividade e bem-estar (cf. subseção 3.1.1; Nisbet, 1985, p. 196-202). Não é uma concepção estática. No fundo, a afirmação feita é a de que o engajamento autointeressado de cada indivíduo no comércio dispara uma dinâmica de melhoria de bem-estar que aproveita ao todo social, e que, portanto, a proteção da autonomia privada impulsiona. Para além desta dimensão de "progresso" como avanço de estados inferiores a superiores (de divisão do trabalho, produtividade, complexidade de mercados, riqueza, bem-estar etc.), a emergência do pensamento econômico foi acompanhada pela apresentação da expansão internacional do comércio como elemento civilizador, capaz de “suavizar" os modos selvagens ou bárbaros - a noção de doux commerce ${ }^{19}$ (retomada nos capítulos 2 e 3$)$.

No entreguerras, uma segunda distinção aderiu-se à já existente dicotomia entre civilizados e não civilizados. Esta outra distinção já começava a receber matizes mais econômicos, sendo versada em termos de povos "avançados" vs. "retrógrados". Esta linguagem se incorpora, por exemplo, ao Sistema de Mandatos da Liga das Nações. Em todo caso, as duas formas de hierarquização econômica, social e cultural dos povos passam a coexistir. No entanto, o prestígio de ideias como progresso e civilização foi abalado por ocorrências como a Primeira Guerra Mundial, a Grande Depressão dos anos 1930 e a Segunda Guerra Mundial (Sbert, 2010, p. 212). Os velhos termos cederam lugar a uma nova forma de descrever hierarquias mundiais de povos.

Após a Segunda Guerra, o "que havia sido chamado pelos europeus de incivilizado, deseducado e retrógrado em todo o mundo passou a ter um novo nome: subdesenvolvidos"

\footnotetext{
${ }^{19}$ Albert Hirschman (1997) apresenta o doux commerce como um dos argumentos modernos de legitimação a atividades ligadas a comércio e bancos, em contraste com o clima anterior de apresentação de tais atividades como nocivas. O comércio passa a ser encarado como atividade pacífica ou serena, e em todo caso preferível a manifestações de paixões humanas mais violentas, como a pilhagem, a pirataria etc. Nesse sentido, o engajamento de cada um na busca de seu interesse material passa a ser apresentado como socialmente desejável.
} 
(Sbert, 2010, p. 214). A expressão tornou-se corrente no jargão das descrições a respeito das relações internacionais a partir do discurso de Harry Truman, de 1949, em que o presidente norte-americano reafirmou o compromisso dos Estados Unidos com a ONU, lançou as bases do Plano Marshall, da OTAN, e da assistência ao desenvolvimento (Rist, 2002). O desenvolvimento passou a ser visto como algo que poderia ser ocasionado a um país a partir da intervenção externa, ou seja, da assistência oficial ao desenvolvimento (AOD). No fundo, a noção de progresso é preservada como "dogma implícito" na nova terminologia do desenvolvimento (Sbert, 2010, p. 214).

O novo termo passou a nivelar as identidades dos países segundo o desempenho econômico, marginalizando hierarquizações precedentes baseadas em distinções culturais ou raciais. O núcleo da medição deste desempenho era o crescimento do Produto Nacional Bruto (PNB) per capita (Rist, 2002). Países com alto PNB per capita passaram a ser considerados desenvolvidos; do contrário, subdesenvolvidos. A noção de desenvolvimento como crescimento econômico contava ainda com indicadores auxiliares, como o grau de industrialização e a produtividade do trabalho.

Segundo Gilbert Rist, este modo de conceber desenvolvimento alcançou um "admirável consenso", e a "crença inconteste na necessidade do crescimento" fez com que este passasse a ser considerado o objetivo central dos governos, ou seja, a prioridade na atividade política dos Estados (2002, p. 214-5). É importante notar que esta concepção de desenvolvimento surge atrelada à eficiência econômica, mais do que a considerações distributivas ou de equidade, ou seja, de fruição equânime do bem-estar econômico. Segundo Gustavo Esteva (2010), neste sentido, a noção predominante de desenvolvimento enfatizava crescimento econômico, aferido pelo crescimento do PNB per capita, e não a distribuição da riqueza. Em outros termos, o aspecto "econômico" foi divorciado do "social" na construção do conceito.

Diversas áreas de expertise compartilharam a noção de desenvolvimento como tendo em seu "núcleo duro" o crescimento econômico correspondente ao crescimento do PNB. É importante ter em mente, porém, que existiu e existe ainda hoje um debate entre os diferentes campos de expertise a respeito do desenvolvimento, e que este debate abrange tanto seu conceito quanto os meios considerados adequados para sua promoção. Para além disso, atualmente, certos autores chegam a propor o abandono do conceito de desenvolvimento (Rist, 2002; Sachs, 2010; cf. Pahuja, 2009). A sobreposição entre crescimento econômico e desenvolvimento atravessou conformações de pensamento econômico e propostas variadas 
desde a Segunda Guerra Mundial, mantendo sua força até os dias presentes, apesar de sofrer críticas.

Uma das primeiras manifestações que incorporaram a noção de desenvolvimento como crescimento econômico consistiu na busca pelo alívio de desigualdades no padrão internacional de distribuição de riquezas via ajuda externa, ou assistência oficial ao desenvolvimento (AOD). Durante o final da década de 1940 e ao longo da década de 1950, preponderaram iniciativas bilaterais de ajuda externa, sobretudo a partir dos Estados Unidos, mas a AOD se multilateralizou nas décadas de 1960 e 1970, sendo institucionalmente abrigada principalmente no âmbito da OCDE. Na perspectiva de Santos e Carrion (2011, p. 1853), a ajuda internacional foi vista como fator desencadeador de desenvolvimento até a década de 1980, quando perdeu importância para outras concepções. No entanto, manifestações inspiradas por esta ideia permanecem vivas ainda hoje. Proeminente nesta linha de argumentação, o economista Jeffrey Sachs, autor de $O$ fim da pobreza, propõe a ajuda externa como meio de alcançar as Metas do Desenvolvimento do Milênio, da ONU. Para o autor, só com ajuda externa certos países menos desenvolvidos podem escapar de situações de estagnação ou de retrocesso tecnológico que ele descreve como "armadilha da pobreza" (Sachs, 2005). Em síntese, esta primeira vertente identifica na ajuda externa o meio privilegiado para alavancar o processo de crescimento econômico em países menos desenvolvidos.

Mesmo certas perspectivas econômicas de terceiro mundo, que podem ser lidas como contestações ao mainstream entre as décadas de 1950 e 1970, abrigaram a noção de desenvolvimento como crescimento econômico. Este foi o caso dos teóricos da dependência, convergentes com a contribuição cepalina no âmbito da ONU. O ponto fundamental desta linhagem é o questionamento do argumento liberal ricardiano das vantagens comparativas, segundo o qual a abertura ao comércio internacional aumenta o bem-estar independentemente do perfil produtivo do país (Ricardo, 2001 [1817], p. 149-51). Segundo este argumento, o comércio produz progresso ainda que as exportações sejam todas de produtos primários, e as importações, de bens industrializados. De modo contrário a este entendimento, os cepalinos, e com eles os teóricos da dependência, sinalizaram a existência da tendência à "deterioração nos termos de troca”, que contribuiria para minar a posição de países não industrializados, congelando-os em situação de subdesenvolvimento. Em decorrência deste diagnóstico, propuseram a industrialização estimulada pelo Estado, sobretudo via substituição de importações, como principal estratégia para o crescimento econômico dos países periféricos ou do "Sul global". Ou seja, esta vertente identificava no ativismo estatal pró-industrialização 
o meio privilegiado para promoção do crescimento. O prestígio deste tipo de argumentação teve seu auge nas décadas de 1960 e 70, quando se aventava a construção de "nova ordem econômica internacional" (ver seção 2.2 abaixo).

A ênfase na AOD, no primeiro caso, (mainstream desenvolvimentista do pós-Segunda Guerra) ou em estratégias de industrialização, no segundo caso, (contribuição cepalina e teoria da dependência) sinalizam como tais contribuições econômicas subsequentes à Segunda Guerra Mundial associavam desenvolvimento ao ativismo estatal. É na ação do Estado, doméstica ou internacionalmente, que os economistas das diversas tendências deste clima intelectual enxergavam soluções para o desenvolvimento e mudanças no padrão de distribuição de riquezas no globo. Porém, em 1981, na Cúpula Norte-Sul, realizada em Cancun, o governo norte-americano descartou propostas de reforma nas estruturas das relações entre países centrais e periféricos, asseverando que estas relações deveriam ser regidas por mecanismos de mercado (Castro, 2005b, p. 138). Ou seja, as ideias de alteração do padrão mundial de distribuição de riquezas via ações estatais, como a ajuda externa e a substituição de importações, entraram em desprestígio (ao menos do ponto de vista político). Tratava-se do início do primado de uma outra perspectiva econômica, que ficou conhecida como "neoliberalismo" (cf. seção 3.3). Apesar de o prestígio da associação entre desenvolvimento e ativismo estatal ter sido abalado, a ligação entre crescimento econômico e desenvolvimento permaneceu forte.

Já em tempos de primado do neoliberalismo, um primeiro feixe de pesquisas foi orientado para a busca de correlações entre o ritmo do crescimento econômico (isto é, o crescimento do PNB) e o grau de abertura dos países ao comércio internacional. A tese proposta era uma reedição do argumento das vantagens comparativas formulado por David Ricardo: maiores níveis de liberdade comercial seriam correspondentes a ritmos mais acelerados de crescimento econômico ${ }^{20}$. Neste momento, os experts em desenvolvimento, com lugares de fala situados em organizações internacionais como o FMI, o Banco Mundial e a OCDE, passam a recomendar aos diversos países a receita-padrão de abertura comercial como meio privilegiado para a promoção do desenvolvimento. Esta receita é expansível à área das finanças internacionais. Os autores desta corrente não precisavam dar maior atenção ao formato das instituições para fazer a defesa de que a liberdade comercial e financeira conduziria ao crescimento econômico.

\footnotetext{
${ }^{20}$ Como exemplos estão os artigos de Bannister \& Thugge (2001) e de Lankes (2002), que compartilham o argumento de que os entraves ao acesso ao comércio internacional funcionam como barreira ao crescimento econômico dos países em desenvolvimento. As duas publicações estão associadas ao FMI.
} 
Um segundo feixe de ideias, embora animado pela mesma perspectiva econômica (neoliberalismo) da expertise acima descrita, representou uma "virada institucional". O mote é, sim, a preocupação com a importância das instituições na promoção do desenvolvimento. Mas, no fundo, a preocupação central consiste em identificar e propor instituições que favoreçam a atuação considerada ótima do "livre mercado". Ou seja, a visão normativa desta corrente é a de que as instituições devem auxiliar o funcionamento desimpedido, ou "ótimo", dos mercados.

Como descreve Mario Schapiro, o traço comum desta agenda de desenvolvimento é "a confiança na promoção do desenvolvimento a partir da promoção de boas regras do jogo, capazes de amparar um ambiente econômico estável e seguro para as transações privadas." (2010, p. 214) Uma das características desta abordagem é apregoar o rule of law, num modelo "baseado em transações privadas, mediadas pelas garantias jurídicas de proteção à propriedade privada e aos termos contratuais", postulando ainda "um viés definido de políticas públicas, em que prevalece uma relação Estado-economia comprometida com a preservação dos mercados como espaços de alocação de recursos." (Schapiro, 2010, p. 217)

Há variações na abordagem institucionalista do desenvolvimento com o viés particular de rule of law. Aspectos de três delas serão identificados aqui: a Nova Economia Institucional (NEI), cujos principais expoentes são Douglass North e Oliver Williamson, e as contribuições jurídicas da Análise Econômica do Direito (AED) e do Law \& Finance.

Em essência, a argumentação da NEI (cf. subseção 4.1.4) consiste em que países que adotaram contornos institucionais mais favoráveis à "constituição de um ambiente impessoal, seguro e previsível para as trocas de mercado" se desenvolveram mais rapidamente (Schapiro, 2010, p. 217). Em outros termos, países com ambientes institucionais "corretos" se desenvolvem (Schapiro, 2010). E ter instituições "corretas" significa ter regras claras, forte proteção dos direitos de propriedade privada e dos contratos, bem como o "funcionamento célere e independente do Poder Judiciário" (Schapiro, 2010, p. 219). Essa literatura animou as práticas internacionais de "difusão de 'instituições corretas' e 'boas práticas de governança"” (Schapiro, 2010, p. 218), narradas na subseção 2.3 .3 (cf. também seção 4.1), tendo sido influente sobretudo no âmbito do Banco Mundial e FMI.

A Análise Econômica do Direito (AED) dialoga muito proximamente com as preocupações da NEI acerca do desenho "correto" das instituições. Ambas partem do chamado "teorema de Coase", que diz respeito aos custos de transação. De modo muito resumido, a AED (que antecede a NEI) passou a emular a eficiência econômica como parâmetro de validação das instituições jurídicas, ou seja, como medida do "correto", do 
"bom" e do "justo", associando o sentido desta eficiência ao livre funcionamento dos mercados (Mercuro; Medema, 2006, p. 102). As recomendações institucionais da AED convergem com North, no sentido de promover ambientes institucionais que estão em função do funcionamento desimpedido das forças de mercado: sobretudo proteção clara e forte da propriedade privada e dos contratos, com celeridade e independência do Judiciário. Tais convergências são exploradas na seção 4.1 .

$\mathrm{Na}$ área de finanças, o movimento Law \& Finance produziu recomendações convergentes com a AED e a NEI ao atrelar o bom desempenho dos mercados financeiros a dotações jurídicas "corretas", de modo a gerar ambientes institucionais eficientes na atração de investidores ${ }^{21}$. A literatura de Law \& Finance faz duas vinculações fundamentais. A primeira delas é entre a dotação jurídica "correta" e a prosperidade dos mercados financeiros. Neste aspecto, "correto" tem o mesmo significado de derivado do common law. A segunda vinculação é entre a existência de mercados financeiros dinâmicos e o próprio desenvolvimento (La Porta et al, 1998). Juntas, estas vinculações formam a receita do Law \& Finance para o desenvolvimento: universalizar instituições típicas do common law que, por serem mais favoráveis à liberdade financeira, têm maior eficiência para conduzir à prosperidade (cf. seção 4.2).

As três linhagens da literatura institucionalista aqui descritas forneceram materiais para a atuação de organizações como o FMI e o Banco Mundial em sua busca por convergências institucionais ou harmonização institucional. Em linhas gerais, este projeto de boa governança (ver subseção 2.3.3) busca promover reformas domésticas nos diversos países, com vistas à universalização de instituições pró-mercado. A crença é a de que a harmonização global resultaria na aceleração global do desenvolvimento, já que a liberdade de mercado é identificada como motor do desenvolvimento. Cabe observar, neste sentido, que tais abordagens dialogam muito proximamente com o receituário que ficou conhecido como “Consenso de Washington”, associado à perspectiva econômica do neoliberalismo. As políticas advogadas são, de um lado, de liberdades de mercado: liberdade comercial, liberdade cambial, liberdade para as finanças internacionais. De outro lado, são políticas de disciplina e autocontenção estatal: não intervencionismo, diminuição do tamanho do Estado, com opção pela regulação via política de defesa da concorrência ao invés da atividade estatal direta em áreas variadas, como telecomunicações, transportes, mineração e outros setores, bem como a

\footnotetext{
${ }^{21}$ Esta literatura é criticada por Mark Roe (2006), que nega que instituições do common law resultem em mercados financeiros mais robustos. Outra crítica indireta, porém profunda, parte de David Kennedy (2011), que questiona a própria importância da definição clara e forte de direitos de propriedade como receita para o crescimento econômico.
} 
adoção de critérios de disciplina fiscal e monetária (como superávit primário e metas de inflação) enquanto elementos para a conquista da confiança dos agentes nos mercados.

Mais recentemente, o projeto de convergência institucional em escala global fomentado por concepções como as descritas acima tem recebido críticas a partir de frentes distintas. Um primeiro feixe de críticas pode ser encontrado na literatura conhecida como Variedades de Capitalismo (Hall; Soskice, 2001), cujo argumento central é o de que as diferenças institucionais entre os países são capazes de proporcionar-lhes vantagens comparativas institucionais (numa modulação do argumento ricardiano). Ou seja, a existência de ambientes institucionais variados, e não globalmente uniformizados, é encarada como benéfica ao florescimento do comércio e finanças internacionais.

Outro feixe de críticas vem de concepções heterodoxas da Economia do Desenvolvimento (cf. seção 3.4). As contribuições de North e a tese da convergência institucional são atacadas por Ha-Joon Chang (2007) e Dani Rodrik (2007; 2011), que enfatizam a importância de instituições adequadas ao contexto de cada país. Estes autores ressaltam o caráter relativamente contingente das soluções institucionais para o desenvolvimento, bem como a importância do envolvimento estatal. Para eles, as soluções não devem ser buscadas num tipo abstratamente "correto" de instituições. Não há um único padrão institucional aplicável a todas as economias, mas muitas receitas possíveis. A lógica interventiva de desenvolvimento (no sentido de intervenções internacionais top-down) é igualmente refutada por estes autores, que rejeitam a sobrevalorização das expertises articuladas no âmbito do FMI e do Banco Mundial em detrimento da autonomia local na formulação de políticas públicas e das políticas econômicas. O local, e o espaço democrático (policy space), são valorizados.

É possível, assim, observar que concepções segundo as quais a convergência ou harmonização institucional global em torno de instituições pró-mercado são o melhor caminho para o desenvolvimento têm recebido questionamentos desde outras frentes de pensamento econômico. Esta não é, porém, a única transformação relativamente recente do debate. Outra transformação diz respeito à mitigação da própria concepção fechada de desenvolvimento, qual seja, a que o identifica ao crescimento econômico. O principal autor relacionado à expansão da noção de desenvolvimento para além do crescimento econômico é Amartya Sen.

A contribuição de Amartya Sen (2000), de “desenvolvimento como liberdade", é permeada por preocupações que se voltam à fruição de direitos. Liberdades ou direitos políticos, econômicos e sociais estão na base de sua concepção de desenvolvimento, além de 
exigências de "transparência" nos assuntos de Estado e de "segurança protetora", que dialoga com as instituições de seguridade social. O argumento principal de Sen é o de que a mensuração per capita do PNB de um Estado em última análise não é adequada para revelar o real grau de desenvolvimento de grupos no interior desse Estado. A análise do PNB per capita constitui "uma concentração exclusiva sobre a pobreza de renda", que deve ser expandida "para a ideia mais inclusiva da privação de capacidade" ${ }^{22}$ (2000, p. 34). O desenvolvimento poderia então ser identificado como um processo de eliminação das privações às liberdades humanas (2000, p. 53). A proposta de Sen inclui a preocupação constante com a existência do ambiente democrático e de respeito aos direitos humanos. Trata-se de uma concepção de desenvolvimento que privilegia aspectos de equidade econômica, social e política.

As ideias de Amartya Sen tiveram influência sobre articulações intelectuais de caráter interdisciplinar a respeito de direito e economia. Neste sentido, aspectos de sua preocupação com o desenvolvimento em termos de direitos fazem-se perceber tanto na linhagem do Novo Direito e Desenvolvimento (Schapiro; Trubek, 2012, p. 42-3) quanto da Análise Jurídica da Política Econômica (AJPE); correntes abordadas no capítulo 4 (seções 4.3 e 4.4, respectivamente). A título de exemplo preliminar deste diálogo com as ideias de Sen, no âmbito da AJPE, o processo de desenvolvimento é associado à conciliação entre "a funcionalidade e a produtividade da economia, de um lado, e, de outro, a equânime proteção aos direitos fundamentais dos indivíduos e grupos" (Castro, 2009, p. 21). Esta definição concilia os aspectos de eficiência e de equidade na economia, e pode também ser versada em termos de crescimento econômico aliado à coexistência entre o que esta abordagem chama de "direitos de produção" e o que designa por "direitos de consumo"23.

A partir dos elementos aqui levantados, pode-se observar que a ideia de desenvolvimento, inicialmente, não era chavão para as relações econômicas internacionais: em seu lugar, estavam expressões proximamente associadas, como progresso e civilização, e que foram fortemente influentes e importantes para a expansão do direito internacional, da

\footnotetext{
${ }^{22} \mathrm{O}$ "enfoque da capacidade" de Amartya Sen, em sua própria definição, "concebe a vida humana como um conjunto de 'atividades' e de 'modos de ser' que poderemos denominar 'efetivações' (functionings) - e relaciona o julgamento sobre a qualidade da vida à avaliação da capacidade de funcionar ou de desempenhar funções." (1993, p. 315) Em termos mais simples, capacidade pode ser vista como a liberdade e oportunidade que o indivíduo tem de alcançar modos de vida por ele valorados ou desejados. Sen exemplifica o conceito pela comparação do jejum feito pela pessoa rica, de um lado, e a pessoa que passa fome, de outro. Ambas podem ter os mesmos resultados funcionais ou "efetivações", em termos alimentares e nutricionais, a partir da privação de comida. No entanto, a pessoa rica que escolhe a privação de alimento dispõe de um acervo de capacidades diferente da segunda, já que pode escolher nutrir-se, ao contrário da outra pessoa neste exemplo. (cf. Sen, 1993; 2000)

${ }^{23}$ Este desdobramento conceitual, que permite compreender desenvolvimento a partir de uma linguagem jurídica, será aprofundado na seção 4.4.
} 
colonização, e do comércio internacional. A ideia de dividir o mundo entre desenvolvidos e subdesenvolvidos difundiu-se após a Segunda Guerra Mundial, e a definição de desenvolvimento como crescimento econômico alcançou o status de consenso global, tendo feito parte do senso comum econômico até que passasse a ser questionada por contribuições como a de Amartya Sen. Nestas contribuições, a "pobreza de renda" é apenas um tipo de pobreza, mas muitas outras existem, relacionadas à carência de liberdades fundamentais que, no fundo, podem ser traduzidas como deficiências na fruição de direitos subjetivos fundamentais.

Ao longo deste percurso de transformações da ideia de desenvolvimento, é possível observar a grande variedade nos meios identificados como adequados para sua promoção no campo da prática. Momentos variados focalizaram a AOD, o ativismo estatal próindustrialização, a abertura comercial e a adoção de ambientes institucionais pró-mercado como soluções para o desenvolvimento. No plano das preocupações institucionais, as propostas de difusão universal de modelos institucionais "corretos" começaram a ser questionadas por novas abordagens da economia do desenvolvimento, que passaram a incorporar noções já não mais restritas ao crescimento econômico. Por sua vez, esta última vertente tem influências em representações interdisciplinares sobre direito e economia, como o Novo Direito e Desenvolvimento e a Análise Jurídica da Política Econômica.

A partir deste breve apanhado, já é possível ter indícios da riqueza da discussão sobre desenvolvimento. Como se pode notar, diversos dos receituários explicitam elementos jurídicos na base do desenvolvimento econômico. Um olhar mais atento, porém, revelará a presença de bases jurídicas subjacentes a todos os receituários de desenvolvimento e concepções de ordem econômica ${ }^{24}$. Este é um ponto a ser explorado na tese. A presença de elementos jurídicos nas concepções de desenvolvimento se adensa quando as transformações deste conceito são levadas em conta, ou seja, quando se passa de definições unicamente atreladas ao crescimento econômico a outras, que integram preocupações com a fruição de direitos.

\footnotetext{
${ }^{24}$ Esta proposta perpassa a tese que, neste sentido, remete às ideias presentes em Kennedy (2013), sugestivas de que conhecimentos jurídicos, econômicos e políticos sejam fundidos para reformar a cooperação econômica internacional; e Kennedy (2006) que relaciona três momentos do pensamento jurídico a três configurações de políticas públicas e de política econômica no mundo.
} 
O presente capítulo buscou sinalizar alguns pontos introdutórios e úteis para a compreensão da discussão feita nos capítulos seguintes. Primeiramente, os diferentes modos de pensamento ou referenciais jurídicos, econômicos e interdisciplinares nesta tese podem ser encarados como langues que dão ensejo a múltiplas manifestações de parole (como direito positivo, medidas de política econômica etc.) em cada momento. Em seguida, a seção 1.1 procurou brevemente sugerir a importância de se pensar a transformação de contextos ou ambientes nos quais as ideias sobre padrões regulatórios e de cooperação econômica internacional se inserem. Para tanto, enfatizou variações nas relações econômicas internacionais correspondentes a diferentes conformações de ordens econômicas internacionais. Por fim, a seção 1.2 focalizou noções de civilização, progresso e desenvolvimento (reduzidas ao termo "desenvolvimento" em seu título) como concepções transversais aos diferentes momentos de ideias jurídicas, econômicas e interdisciplinares abordadas da tese, e cujas variações também ajudam a compreender a trajetória do debate sobre direito e desenvolvimento.

O capítulo 2, a seguir, inicia o percurso para a compreensão da formação deste debate, a partir do enfoque em três perspectivas jurídicas sobre as relações internacionais. 


\section{CAPÍTULO 2 - TRÊS VISÕES JURÍDICAS DAS RELAÇÕES INTERNACIONAIS}

Neste capítulo, procuram-se abordar, de modo interdisciplinar, três visões jurídicas das relações internacionais. $\mathrm{O}$ direito internacional clássico, cuja origem se atribui às proximidades de 1870, é objeto da seção 2.1. Em seguida, a seção 2.2 se dedica à fragmentação do direito internacional. Por fim, a conformação da normatividade internacional em torno da noção de "governança global" é objeto da seção 2.3.

\subsection{Direito Internacional Clássico}

É comum remeter as origens das instituições jurídicas à antiguidade clássica. Geralmente, o procedimento faz parte de um esforço de legitimar o objeto de estudo, ao passar a impressão de que "sempre foi assim" (Baitz, 2006). Esta não é a perspectiva adotada aqui. $\mathrm{O}$ direito internacional clássico não existiu sempre.

A seção 2.1.1, abaixo, busca sintetizar aspectos de seus antecedentes. O objetivo é diferenciá-los do que veio depois. O direito internacional, como campo autônomo, só é formado no século XIX, e mais especificamente em seu terço final. A expressão direito internacional clássico refere-se a ideias e conjuntos de práticas que existiram desde esse momento, por volta dos anos 1870, até seu declínio com a Segunda Guerra Mundial.

Durante este tempo, o direito internacional não foi algo uniforme. O período anterior à Primeira Guerra Mundial, abordado na seção 2.1.2, é relativamente distinto do direito internacional do entreguerras, objeto da seção 2.1.3. As seções abaixo buscam compreender aspectos desta trajetória, sem perder de vista ligações com condições políticas, econômicas e sociais de cada momento.

\subsubsection{Antecedentes do direito internacional}

Direito internacional faz referência a relações jurídicas entre Estados territoriais soberanos. Não se pode, portanto, chamar de direito internacional as formulações anteriores ao sistema westphaliano de Estados. Nesse sentido, nem mesmo o jus gentium ${ }^{25}$ ou o uso feito

\footnotetext{
25 “(...) em 242 a.C. foi instituído o praetor peregrinus para cuidar das disputas entre estrangeiros e entre estes e cidadãos romanos. Em sua atuação, o praetor peregrinus mistura partes do direito romano com normas estrangeiras (especialmente gregas), tudo sendo perpassado de princípios de equidade. Isto ficou conhecido
} 
do direito romano na idade média na Europa $^{26}$ podem ser considerados manifestações do direito internacional. Nem um deles era aplicável a relações entre Estados (Castro, 2005b).

A política nem sempre foi estruturada em bases territoriais. Na idade média, prevaleciam modalidades pessoais de afirmação de lealdades e definição de identidades, como relações de séquito, "laços de sangue e comunhão de valores religiosos" (Castro, 2005b, p. 103). Além disso, havia concorrência de projetos políticos: príncipes, cidades ou burgos, Igreja e Sacro Império Romano-Germânico. Neste contexto, noções de soberania tinham conotação pessoal, sem implicar exclusividade ou territorialidade. Ademais, admitia-se o exercício concorrente de diversas autoridades sobre o mesmo território.

O cenário mudou na era moderna. Com o sucesso do projeto político dos príncipes, o Estado territorial soberano passou a ser o padrão subjacente ao exercício da autoridade política da Europa. O direito de definir a autoridade em função do território foi inicialmente avançado em termos jurídicos na Paz de Augsburgo, em 1555, com a definição do princípio cujus regio eius religio: quem tem a região, define a religião. Com isto, os príncipes do Sacro Império Romano-Germânico afirmaram seu direito de escolher a religião praticada em seus respectivos territórios, independentemente da vontade do sacro imperador ou dos demais príncipes. A Paz de Augsburgo foi limitada aos territórios identificados com o Sacro Império Romano-Germânico, mas a Paz de Westphalia, de 1648, teve maior abrangência: a Guerra dos Trinta Anos havia sido um conflito religioso praticamente generalizado na Europa. Em seu desfecho, a Paz de Westphalia projetou o princípio cujus regio para as relações europeias. $\mathrm{O}$ território passou a ser a delimitação relevante para o exercício da autoridade política. Sobre ele, cada príncipe tem direito de domínio exclusivo. Esta formulação é expressiva do reconhecimento do Estado territorial como unidade básica e autônoma no cenário político europeu. As formulações da soberania passam a ser territoriais e exclusivas: sobre cada território, apenas se pode reconhecer uma soberania ${ }^{27}$. Dava-se início à era de monarquias territoriais soberanas (de facto e de jure).

\footnotetext{
como jus gentium ou direito das gentes. Mas o jus gentium é apenas um direito romano, que incorpora algumas normas estrangeiras: não é um direito que vige entre Estados territoriais soberanos." (Castro, 2005b, p. 105-6) 26 “(...) nesta época, o direito romano que é apropriado e adaptado, e que se torna dominante, adquire caráter universalista de vocação 'supranacional' e associado a valores cristãos, sendo em tese aplicável a toda a cristandade. Mais uma vez, não se trata ainda de um direito internacional, isto é, um direito que dissesse respeito às relações contratualmente estabelecidas entre Estados territoriais soberanos." (Castro, 2005b, p. 106)

27 A ascensão do projeto de autoridade territorial, com suas afirmações nos séculos XVI e XVII, passou a permitir a distinção jurídica entre o âmbito interno e externo dos Estados. Neste sentido, Francisco Suárez (15481617), nesta época, diferenciou o direito observado pelos Estados internamente - intra se - e em suas relações recíprocas - inter se (cf. Castro, 2005b, p. 107).
} 
Do ponto de vista da filosofia do direito, as fontes de normatividade do direito das gentes moderno variavam: iam desde a revelação religiosa até a "descoberta" por meio da razão. Sua abordagem propunha a existência conteúdos universais, fixos, que existiriam independentemente da vontade dos Estados. Considerava-se válida a norma que estivesse em harmonia com os conteúdos do direito natural. Este direito formava conjuntos de "abstrações especulativas de grande generalidade" e de "uso prático limitado" nas relações internacionais (Castro, 2012, p. 179-80). Sua importância permaneceu restrita aos círculos filosóficos e doutrinários, não tendo sido de grande relevância para influenciar de fato as práticas diplomáticas estruturantes das relações entre Estados.

\section{Concerto europeu, balanço de poder e direito internacional}

"No século que vai de 1815 a 1914, o direito das nações transformou-se em direito internacional.” (Kaplan; Katzenbach, 1964, p. 74) No início do século XIX, porém, o direito internacional ainda não havia se definido como autônomo, dotado de identidade própria. Era assunto de professores, filósofos e diplomatas (Koskenniemi, 2004, p. 28), uma extensão de outros campos do saber.

Mesmo sem a estrita autonomia no campo das ideias, as práticas normativas e as formulações intelectuais mudaram significativamente no início do século XIX. O marco da mudança foi o Congresso de Viena, de 1814-1815.

O Congresso foi uma reação ao expansionismo francês no continente europeu entre os anos 1789 e 1812, como resultado das guerras napoleônicas (Ikenberry, 2001, p. 84). As grandes potências da época (Inglaterra, Rússia, Áustria e Prússia) se reuniram para redesenhar o mapa europeu. Três delas eram monarquias absolutistas e formaram a Santa Aliança (Rússia, Áustria e Prússia), por meio da qual fizeram intervenções para impedir o avanço republicano no continente europeu durante a primeira metade do século. Para além da Santa Aliança, estruturou-se o concerto europeu, que contava com (i) a lógica de balanço de poder e (ii) o sistema de conferências.

Balanço de poder é um conceito de segurança internacional. Ele objetiva estabilidade em cenário multipolar. Este cenário existe quando nenhuma potência, sozinha, é mais poderosa que todas as outras juntas. E o objetivo do balanço de poder consiste justamente em evitar que uma potência (ou, para todos os efeitos, uma aliança) se desiguale das demais ao ponto de poder dominá-las, ou seja, obter a hegemonia. "No sistema de mais de três nações pode haver alguma desejosa de conquistar outras nações, mas haverá sempre oposição a isto.” 
(Kaplan; Katzenbach, 1964, p. 46) Se uma potência cresce, as demais se sentem ameaçadas, e formam aliança para contrabalanceá-la. O efeito do sistema é gerar a dissuasão: é possível esperar, de antemão, a formação de aliança contra qualquer potência que pretenda a hegemonia. A lógica é que, sabendo disso, as potências ficam dissuadidas de tentar dominar as demais. Aspecto indispensável ao funcionamento do sistema de balanço de poder é a flexibilidade das alianças: o inimigo de hoje pode ser o aliado de amanhã. A rotatividade e precariedade das alianças está na base do equilíbrio multipolar (Sheehan, 2005).

Como ressaltado acima, o balanço de poder foi acompanhado do sistema de conferências. Houve inovação institucional: pela primeira vez a diplomacia por meio de conferências existiu em tempos de paz, com o objetivo de preservação da ordem no pósguerra (Ikenberry, 2001, p. 104). Não que conferências internacionais não ocorressem, mas elas eram restritas ao término de conflitos. Configurou-se a prática de realizar consultas diplomáticas entre as grandes potências, sobretudo em assuntos territoriais. Não havia estrutura institucional formal: nada de secretariado, sede, nem de órgãos de solução de controvérsias. Nisto, era muito diferente do que viriam a ser a Liga das Nações ou as Nações Unidas, posteriormente. A configuração era a de série concatenada de conferências, e não de organização internacional.

Quando a França restaurou a monarquia, ela voltou ao clube de que já faziam parte a Grã-Bretanha e os membros da Santa Aliança. Embora não fossem apenas estes cinco os participantes das conferências, na prática, estas funcionavam como colegiado de grandes potências. $\mathrm{O}$ evento brevemente sintetizado a seguir ilustra como potências menores não tinham voz. Em 1832, a conferência em Londres demarcou as fronteiras entre a Holanda e a Bélgica. A Holanda recusou-se a aceitar a demarcação e, como consequência, a França e a Grã-Bretanha, em concerto, impuseram o arranjo por meio da força (Sheehan, 2005, p. 127).

É importante destacar este ponto: o concerto europeu não objetivava excluir a guerra da realidade europeia. $\mathrm{O}$ objetivo era restringir a guerra somente entre grandes potências, mas guerras entre uma grande potência e uma potência menor, ou de potências menores entre si, eram corriqueiras. Isto porque somente o conflito entre grandes potências era capaz de desestabilizar o balanço de poder.

A estabilidade entre os principais Estados foi alcançada com relativo sucesso: "a guerra entre as grandes potências cessou por quarenta anos, e um século inteiro passaria antes que a ordem internacional fosse novamente consumida por uma guerra generalizada na Europa." (Ikenberry, 2001, p. 80) Porém, a estabilidade não era absoluta, nem abrangente: conflitos nas margens aconteceram, bem como conflitos importantes, tais como a Guerra da 
Crimeia (1853-6) e a Guerra Franco-Prussiana (1870-1). A Europa deste período não era segura para potências menores. Ainda assim, o período é considerado como mais pacífico do que os séculos anteriores (Ikenberry, 2001; Polanyi, 2001; Sheehan, 2005).

O concerto europeu conviveu com a hegemonia britânica no restante do mundo. O balanço de poder existia no continente, mas não abrangia o poderio naval nem os domínios coloniais. Nestes dois outros aspectos, a Grã-Bretanha detinha ascendência sobre as demais grandes potências europeias. O século XIX é o tempo da pax britânica. Na perspectiva de John Ikenberry (2001), o concerto europeu foi supervisionado pela hegemonia britânica, que tratou de limitar o poder no continente, deixando os mares e as colônias livres para sua supremacia.

O concerto europeu baseou-se, sim, em considerações de poder. As cartas eram dadas pela política internacional, não pelo direito. Apesar disso, certas representações jurídicas foram instrumentais ao funcionamento do balanço de poder. As categorias não eram derivadas do direito das gentes, mas de certo direito internacional incipiente, de contornos positivistas, embora ainda vinculado à diplomacia. $\mathrm{O}$ direito das gentes pouca ou nenhuma relevância teve na configuração do balanço de poder na Europa após 1815. Ele não oferecia a maleabilidade que o sistema de alianças flexíveis exigia. Seus conteúdos vinham do direito natural, e o direito natural é apresentado como eterno, imutável, e independente da vontade dos Estados. Um direito - como o das gentes - que postulava conteúdos fixos não poderia fornecer as bases para políticas externas contingentes e sensíveis à política de poder.

A categoria da soberania pôde, esta sim, dar as bases para o balanço de poder. Sobretudo quando interpretada pelo positivismo. A soberania esteve nas bases jurídicas (i) do cenário multipolar e (ii) do sistema de alianças flexíveis, ambos pressupostos do balanço de poder. Quanto ao primeiro aspecto (i), a soberania permite a afirmação de unidades políticas independentes (Kaplan; Katzenbach, 1964, p. 46), cuja existência é fundamental para o cenário multipolar. Este pressupõe alguma fragmentação do poder, como em contraste aos projetos de domínio universal do tipo do Sacro Império Romano-Germânico ou do papado católico durante a idade média (Ikenberry, 2001). Quanto ao segundo aspecto (ii), com o positivismo, as unidades políticas soberanas passaram a ser descritas como detentoras de vontade capaz de gerar normatividade. Em outros termos, a norma válida é aquela que decorre da vontade do soberano, ou é por ele reconhecida. E basear a normatividade na soberania permite desprendimento em relação aos conteúdos fixos do direito natural. O positivismo consegue justificar a liberdade do Estado, por baseá-la na própria vontade deste. A política externa pode, então, ser determinada unicamente tendo por referência a vontade estatal, 
desbancando o direito natural. Esta roupagem jurídica veste a flexibilidade de alianças que o concerto europeu exigia. As alianças se fazem e desfazem ao sabor da vontade soberana dos Estados.

Outra maneira de interpretar o papel da afirmação jurídica da soberania é concebê-la de maneira análoga, para os Estados no plano internacional do século XIX, daquilo que a ideia de liberdade significava para os indivíduos no plano interno. Esta observação se faz no contexto em que o liberalismo havia assumido posição hegemônica como filosofia econômica, acompanhado de representações como laissez-faire e harmonia espontânea de interesses. No plano interno, o ideário liberal previa que ações dos indivíduos egoístas e autointeressados levariam a resultados positivos para o todo social, resultando em ganho de bemestar. A lógica da mão invisível permitia despir a vida econômica das restrições morais e da interferência estatal (cf. seção 3.1). De modo análogo, a soberania representava liberdade para o Estado. Seu comportamento, apesar de autonomamente determinado e sem referência à carga moral do direito natural, levaria à estabilidade, em virtude da operação do balanço de poder. No fundo, o balanço de poder, ao buscar a estabilidade espontânea de unidades soberanas, desempenha na política internacional papel semelhante ao da mão invisível na economia (Martineau, 2009, p. 26). Ou, como concebe Eiiti Sato (2012, p. 55-6), o sistema do concerto europeu "se baseava num liberalismo no qual nações soberanas desenvolviam suas políticas de modo autônomo num ambiente de equilíbrio de poder."

É necessário observar, porém, que as formulações a respeito da soberania, embora instrumentais para a formação do concerto europeu, não significavam, na prática, ausência de interferência nos assuntos internos de outros Estados. As grandes potências tampouco se abstiveram da prática da conquista territorial, nem deixaram de se lançar em empreitadas coloniais, que marcaram o século XIX.

\footnotetext{
A doutrina que derivou da ideia básica da soberania do Estado aplicava-se mais fundamentalmente aos grandes Estados que aos pequenos, pois eram os primeiros que mantinham ou alteravam o equilíbrio de poder cuja independência era essencial à existência de uma quantidade mínima de nações necessárias à "balança" e cuja igualdade dentro do sistema aproximava-se da realidade - não, naturalmente, se fossem comparadas uma a uma, mas na capacidade de cada uma de equilibrar a "balança". (Kaplan; Katzenbach, p. 50)
}

O trecho é sugestivo de que, apesar de estar na base do cenário europeu com múltiplas unidades autônomas de poder, a soberania era articulada de maneira pragmática no século XIX. Num cenário em que a qualidade soberana do Estado pretendia-se aplicável à Europa (de maneira extensiva aos Estados Unidos), mas não ao restante do mundo, o direito 
internacional não impediu a aquisição de territórios e colônias pelo uso da força. Nem impediu intervenções como as realizadas pela Santa Aliança.

O que se observa é o emprego da forma jurídica da soberania de modo instrumental em relação à política internacional. Não houve, na prática, relações internacionais significativamente constrangidas por critérios jurídicos: ao menos não para grandes potências. A soberania foi encarada como forma jurídica essencialmente permissiva. O resultado foi o de que o direito internacional do período teve papel instrumental em relação à política das grandes potências. Neste sentido, segundo Marcus Faro de Castro (2005, p. 110), no concerto europeu, a política é esvaziada de seu conteúdo ideológico. Este conteúdo, antes proveniente do direito natural, cede lugar ao "pragmatismo diplomático articulado por meio do direito internacional positivo". Desta forma, "o concerto europeu foi um conjunto de práticas diplomáticas, instrumentalizadas pelo direito internacional de orientação positivista, que pela primeira vez expressava exemplarmente o modelo westphaliano.” $(2005$, p. 110)

\subsubsection{Direito internacional da década de 1870 à Primeira Guerra Mundial: autonomia e profissionalização.}

O direito internacional passou por uma ruptura de caráter radical na década de 1870. A afirmação é de Martii Koskenniemi, que identifica neste período o surgimento de nova sensibilidade a respeito dos assuntos internacionais: o esprit d'internationalité. Ela foi cultivada por juristas que interagiam por dois canais: um periódico científico e uma associação intelectual, ambos dedicados ao direito internacional.

\section{A Revue de droit international}

O periódico era a Revue de droit international et de législation comparée, que teve sua primeira edição publicada ao final do ano de 1868. Entre seus fundadores estavam o belga Gustave Rolin-Jacquemyns (1835-1902), advogado sediado em Ghent, o holandês Tobias Asser (1838-1913), jurista e professor da Universidade de Amsterdã, e o advogado britânico John Westlake (1828-1913). ${ }^{28}$ A intenção original do trio era criar periódico jurídico internacional, de caráter científico, que servisse como meio para propagar ideais liberais e experiências com reforma legislativa na Europa. Na concepção de Rolin e Asser, os

\footnotetext{
${ }^{28}$ A primeira edição da Revue pode ser acessada em <http://gallica.bnf.fr/ark:/12148/cb375752639/date>. Acesso em: 7. out. 2015.
} 
nacionalismos estavam em ascensão na Europa, mas eram temperados pelo novo esprit d'internationalité, que instigava nações e raças a servir princípios comuns tanto em suas relações mútuas quanto em sua legislação doméstica.

O meio privilegiado para propagar ideias liberais de reformas legislativas animadas pelo esprit d'internationalité foi inicialmente identificado com o direito comparado e o direito internacional privado. No entanto, sob a influência do italiano Pasquale Mancini (1817-88), a Revue passou a incorporar assuntos de direito internacional a título próprio. As reformas liberais advogadas pelos fundadores da Revue abrangiam a livre iniciativa, liberdade de associação, supressão dos monopólios, liberação do valor do ouro e da prata, fim do crime de usura, fim da escravidão e da servidão, abolição da pena de morte, humanização das práticas de guerra, maior uso da arbitragem como forma de solução de disputas internacionais, entre uma série de outras (Koskenniemi, 2004, p. 13-4).

Segundo Koskenniemi (2004, p. 28), se antes o direito internacional era assunto de professores, filósofos e diplomatas, com a Revue, o campo ganhou espaço próprio, embora ainda misturado com o direito comparado e o direito internacional privado. $\mathrm{O}$ primeiro aspecto a diferenciar este novo direito internacional das práticas anteriores é, portanto, o da autonomia. O direito internacional é afirmado como expertise a título próprio e com espaços próprios (a Revue de 1868, mas também o Institut de Droit International de 1873, abordado adiante).

Chega-se, aqui, a outro aspecto relevante. Esta expertise de caráter jurídico, agora autônoma (em relação à filosofia, à diplomacia ou política internacional) será empregada como meio de tentar instruir as interações entre Estados (mas também o formato de suas instituições domésticas) a partir de critérios jurídicos. Os homens de 1873 buscam inverter o papel que o direito internacional ocupava em relação à política internacional, à diplomacia. Desde o concerto europeu, estruturado em 1815, o direito internacional forneceu as formas para articulação da política internacional. Era subordinado à diplomacia, instrumento para a condução desta, e para o fornecimento das bases de um sistema de estabilidade baseado no balanço de poder. Agora, o novo esprit d'internationalité buscava articular juridicamente a política internacional. Os membros desta nova expertise (ou falantes desta langue) pretendem informar a diplomacia a partir de critérios jurídicos. Em outros termos, os novos juristas internacionalistas propunham novo corpo de conhecimento voltado a articular reformas e transformar as interações internacionais.

Neste sentido, há rompimento com a literatura internacionalista anterior, percebida pelos juristas da Revue como estática, pouco científica, comprometida com monarquias 
absolutistas, com pouco espaço para a opinião pública e para ideias reformistas, além de old fashioned (Koskenniemi, 2004, p. 23). A ideia era substituir a literatura anterior, criando outra, por sua vez capaz de promover uma agenda para reforma jurídica tanto das relações entre Estados quanto de suas instituições domésticas (Koskenniemi, 2004, p. 26), em bases científicas (Castro, 2012, p. 180).

O esprit d'internationalité dos fundadores da Revue era animado pelo liberalismo e pelo cosmopolitismo. As ideias liberais refletiam-se na valorização do poder da opinião pública, na crença de que a interdependência comercial e o progresso seriam caminhos para a paz, e na pretensão de reformar certas instituições domésticas segundo critérios do liberalismo, como garantia da propriedade, dos contratos e, de modo geral, do rule of law. Há, aqui, elementos de novidade, visto que a "política internacional cooperativa em favor de ideias liberais, até essa época, fazia-se preponderantemente sem recurso às 'formas' do direito internacional." (Castro, 2012, p. 180) Agora, o direito internacional passava a ser encarado como meio de propagação do liberalismo, implicando reformas tanto nas relações mútuas entre Estados quanto em suas instituições internas.

O cosmopolitismo, por sua vez, envolvia a conciliação de aparentes opostos: internacionalismo e nacionalismo. Do lado do internacionalismo, percebia-se como necessidade que o direito acompanhasse a crescente interdependência dos Estados. O comércio havia crescido de modo sem precedentes ao longo do século XIX, facilitado por navios a vapor, estradas de ferro e implementos na comunicação - como o telégrafo. A Revolução Industrial resultou em maior divisão internacional do trabalho, estimulando interações comerciais e tornando os mercados mais complexos. As finanças também se internacionalizaram neste período. Cabe aqui adiantar certo ponto a ser retomado no capítulo 3: o surgimento do direito internacional animado pelo esprit d'internationalité coincide com a estruturação, no campo das finanças internacionais, do Padrão-Ouro Internacional. Não só no comércio e nas finanças, mas também nas ciências, houve internacionalização: de associações científicas, periódicos, publicações e universidades. A ideia é que esta internacionalização também precisava alcançar o direito. Este é o lado do internacionalismo.

O outro lado envolvido nesta visão cosmopolita, o nacionalismo, era trabalhado com enfoque maniqueísta. Rolin-Jacquemyns, por exemplo, concebia dois tipos de nacionalismo: o bom (l'esprit national) e o ruim (le préjuge national). (Koskenniemi, 2004, p. 63) Com a ajuda das ideias jurídicas, o tipo bom deveria ser estimulado, e o ruim, reprimido. Mas não havia clareza sobre o que seriam formas boas ou ruins de nacionalismo: na prática, cada jurista apresentava o seu nacionalismo como pertencente à modalidade boa (Koskenniemi, 
2004, p. 64), e apresentava as pretensões coloniais de seu Estado como desejáveis. O tipo bom de nacionalismo não era avesso à cooperação e à interdependência entre as nações.

O cosmopolitismo dos fundadores da Revue não deve ser entendido como projeto de ausência de nações. A ideia não era superar nem a nação nem o Estado, mas conciliar as divisões nacionais europeias sobre as bases do direito internacional que lhes seria comum: o direito da comunidade de nações. A imagem idealizada era a Europa cooperativa e liberal, organizada conforme o direito internacional da comunidade de nações civilizadas.

A concepção de comunidade de nações independentes, mas crescentemente interdependentes, era o meio para conciliar nacionalismo e internacionalismo. Citando Francis Lieber (1800-72), jurista prussiano-americano do século XIX, Koskenniemi exemplifica: “As nações civilizadas constituíram uma comunidade, e estão a cada dia, mais e mais, formando uma commonwealth de nações, sob a restrição e a proteção do direito das nações." (apud Koskenniemi, 2004, p. 67) As relações europeias pacíficas, assim projetadas, e instruídas juridicamente, seriam reflexo do grau de civilização dos povos da Europa (em oposição ao restante do mundo) e da preponderância da perspectiva liberal, sobretudo por estimular a interdependência comercial.

\section{Institut de Droit International}

O liberalismo cosmopolita que conformava o esprit d'internationalité dos fundadores da Revue também se projetou em outro meio: o Institut de Droit International (IDI), fundado em Ghent, na Bélgica, em 1873. Rolin e Asser, que haviam participado da fundação da Revue, foram também fundadores do IDI. A eles se juntaram juristas como Pasquale Mancini, que também havia influído na concepção da Revue, além de Gustave Moynier, Johann Caspar Bluntschli, James Lorimer, Carlos Calvo e outros ${ }^{29}$. O artigo $1^{\circ}$ do estatuto do IDI definia seu propósito: favorecer o progresso do direito internacional, buscando tornar-se a consciência jurídica do mundo civilizado. A redação é de Bluntschli (Koskenniemi, 2004, p. 41), e revela muito sobre as concepções destes primeiros juristas internacionalistas.

Bluntschli (1808-81) projeta no direito internacional as ideias da escola histórica alemã, de Friedrich Carl von Savigny (1779-1861), com quem Bluntschli estudou. A escola histórica alemã rejeitava o jusnaturalismo e o racionalismo iluminista, e propunha o direito fundado na historicidade orgânica das instituições e na espontaneidade nacional popular. $\mathrm{O}$

\footnotetext{
${ }^{29}$ A lista dos membros fundadores pode ser encontrada em: $<$ http://www.idi-iil.org/idiE/navig_history.html\# founders>. Acesso em: 8. out. 2015.
} 
costume é apresentado como fonte privilegiada, por refletir mais diretamente o espírito de um povo, sua consciência jurídica. Mas Koskenniemi adverte para o caráter conservador das ideias de Savigny: sua referência à consciência popular como fonte de normatividade se refere mais a uma tradição intelectual do que ao povo propriamente dito: "as tradições herdadas faziam do povo o que ele era." (Koskenniemi, 2004, p. 44) Em outros termos, o jurista (e não o próprio povo, nem o legislador) é o meio privilegiado de expressão da normatividade advinda da consciência de um povo. Ou melhor, é o representante exclusivo dessa normatividade (Koskenniemi, 2004, p. 45).

Quando Savigny definiu o jurista como a boca da consciência popular, ele transferiu a este jurista a medida do sistema jurídico: o exame do direito era sempre, também, um exame da alma do jurista; em sua própria virtude pessoal ele encontrava a justiça entranhada no direito. (Koskenniemi, 2004, p. 77)

A opinião pública é valorizada pelos homens de 1873 como fator de influência sobre os Estados. No entanto, não é qualquer opinião pública que importa, senão a qualificada, informada cientificamente. Ela deveria ser encontrada não propriamente na voz do povo, mas na voz dos juristas internacionalistas.

A proposta do IDI de tornar-se a consciência jurídica do mundo civilizado, presente na redação dada por Bluntschli, é reflexo de concepção de normatividade que não é positivista, no sentido de que não está alinhada com a visão do direito como expressão do comando da autoridade, ou como fruto da vontade soberana. Ao invés disso, a normatividade é encarada sob concepção orgânica. Vem da consciência popular, mas é expressa pelo jurista. No caso do direito internacional, a normatividade viria da consciência dos povos, veiculada pelos juristas internacionalistas do IDI. A rejeição ao voluntarismo, ou ao direito internacional fundado na vontade soberana, é feita por Bluntschli e relatada por Koskenniemi: "não cabe à vontade arbitrária do Estado seguir ou rejeitar o direito internacional.” (Koskenniemi, 2004, p. 50) Neste sentido, Koskenniemi sintetiza a noção ao afirmar que a concepção fundadora do direito internacional no final do século XIX não era a soberania, mas a ideia de consciência europeia coletiva (Koskenniemi, 2004, p. 51).

No projeto dos homens de 1873, o conhecimento científico do direito internacional era meio apropriado para captar e expressar a consciência jurídica dos povos. A normatividade residiria nisto, e não propriamente na vontade soberana. "A teoria jurídica e o esprit d'internationalité dos homens de 1873 colocavam o jurista na posição do pretor romano, em quem as funções de reafirmação e reforma estavam inextrincavelmente entrelaçadas." (Koskenniemi, 2004, p. 57) A normatividade deveria ser encontrada não na vontade de cada ente soberano, mas na consciência de uma comunidade europeia de nações, interpretada e 
expressa pelos juristas do IDI. O direito internacional não seria produto da prática das chancelarias, mas da produção acadêmica. Esta perspectiva é exemplificada por Koskenniemi, citando Rolin, a respeito de onde a normatividade deve ser encontrada no cenário internacional:

\footnotetext{
Não nas promulgações expressas que não existem, nem nos precedentes, que podem ser justos ou injustos, mas no testemunho de sua consciência [do acadêmico], iluminada e fortalecida pelo que os mais sábios dos homens decidiram em casos análogos. Portanto, os princípios apresentados pelos doutrinadores no direito externo encontram sua autoridade jurídica e legislativa na sua conformidade presumida com a consciência humana. (apud Koskenniemi, 2004, p. 51)
}

Apesar de ser comum descrever o século XIX como caracterizado pelo primado do positivismo, Koskenniemi rejeita que os homens de 1873 possam ser facilmente classificados. Para ele, os autores do período jogavam com diversas teorias jurídicas, constantemente tomando de empréstimo aspectos de cada uma (Koskenniemi, 2004, p. 92). Em particular, o racionalismo e o naturalismo serviam como "último reservatório de onde retirar argumentos quando outras fontes secavam." (Koskenniemi, 2004, p. 93) Notadamente, a ênfase dos autores do período, como Rolin, Bluntschli e Westlake, em encontrar a normatividade na consciência jurídica e não na vontade soberana representa certo distanciamento de posições positivistas mais radicais como o formalismo voluntarista alemão de Gerber e Laband, ou a escola analítica inglesa de John Austin. Neste sentido, Koskenniemi identifica que, para os homens de 1873, a noção fundamental do direito internacional do período não era soberania, mas a ideia orgânica de comunidade: o direito internacional emanava da família de nações civilizadas. O mesmo argumento é desenvolvido por Anthony Anghie (2004), abordado adiante. A consciência jurídica desta família, cuja interpretação legítima estava a cargo dos juristas internacionalistas do IDI, era a "fonte das fontes" do direito internacional: "a validade dos tratados e do costume era constantemente checada pelo que a consciência comum sustentava conformar-se com a 'necessitas und ratio'." (Koskenniemi, 2004, p. 56) O matiz organicista, aqui, é evidente. A presença simultânea de diversas fontes teóricas faz com que seja infrutífero tentar classificar os homens de 1873 em uma só posição (Koskenniemi, 2004, p. 96). Para Koskenniemi, melhor que caracterizar a identidade intelectual dos fundadores da profissão do direito internacional moderno como pertencente a vertentes jurídicas específicas (positivismo, naturalismo etc.), é descrevê-los por sua sensibilidade característica e compartilhada: o esprit d'internationalité. Parece certo, porém, que este esprit abrigava positivismo e organicismo como notas destacadas. O organicismo, até aqui, foi o matiz mais 
saliente. Porém, a caracterização deste novo direito internacional como científico apelou para raciocínios positivistas.

Cientificismo e sistematização do direito internacional por analogias do direito privado

A sensibilidade do esprit d'internationalité primava pela abordagem científica. O propósito do IDI de ser a consciência jurídica do mundo civilizado, concebido por Bluntschli e influenciado pelas ideias de Savigny, estava associado, como se disse, à posição de que o conhecimento jurídico deveria ser científico. Neste sentido, verifica-se reflexo da postura positivista de emular o método das ciências naturais, depositando crença na possibilidade de neutralidade e objetividade. Mas como expressar cientificamente a normatividade advinda da consciência dos povos europeus? Neste ponto, Bluntschli é influenciado também por Georg Friedrich Puchta (1797-1846), igualmente discípulo de Savigny. Puchta buscou associar a normatividade encontrada na consciência do povo alemão com os textos de direito romano, organizados em conceitos-chave. Propondo rigor lógico-sistemático, a jurisprudência dos conceitos objetivou "sistematizar o direito alemão através da inspiração advinda da organicidade dos textos clássicos do direito romano.” (Wolkmer, 2006, p. 197) O trabalho de Puchta, como adaptação da noção de "instituto jurídico" de Savigny, resultou na apresentação de uma série de "institutos" concatenados (propriedade, contrato, pessoa, capacidade etc.) a partir dos quais a realidade jurídica seria interpretada. Bluntschli e os juristas do IDI, por sua vez, encontraram nisso a forma de abordar "cientificamente" o direito internacional. Em outros termos, eles projetaram o rigor lógico-sistemático da jurisprudência dos conceitos ao plano das relações jurídicas internacionais, transplantando, em decorrência, categorias do direito privado para o direito aplicável aos Estados em suas relações mútuas. Este procedimento está envolvido em múltiplas analogias: "Estado/indivíduo; tratado/contrato; soberania territorial/propriedade; protetorados/incapacidade civil. ${ }^{, 30}$ (Castro, 2012, p. 182)

Koskenniemi descreve diversas dessas analogias a partir do posicionamento doutrinário de autores da época ${ }^{31}$. Assim, para Bluntschli, o Estado equivale aos indivíduos, como entidades dotadas de vontade própria. Além disso, o princípio da autodeterminação dos povos era encarado por Bluntschli como análogo à liberdade individual (Koskenniemi, 2004,

\footnotetext{
${ }^{30}$ Embora a sensibilidade do esprit d'internationalité tenha incorporado as analogias domésticas como meio para atribuir cientificidade ao direito internacional, não se pretende, aqui, passar o sentido de que o uso destas analogias tenha sido uma característica original deste período. Tal procedimento já tinha ocorrências no período antecedente à formação do direito internacional como disciplina autônoma.

${ }^{31}$ As analogias domésticas são trabalhadas aqui como uma característica da sensibilidade jurídica prevalente à época. Não se sugere, no entanto, que todos os juristas internacionalistas do período tenham feito uso delas.
} 
p. 81). William Hall (1835-94) estende a analogia do Estado como indivíduo: os Estados eram encarados como pessoas independentes e que possuíam direitos inalienáveis, e em especial o direito à propriedade. Esta é análoga, portanto, ao território (Koskenniemi, 2004, p. 82). Para Westlake, os tratados são o equivalente, no plano internacional, dos contratos do direito privado (Koskenniemi, 2004, p. 52). James Lorimer (1818-90) comparava os povos orientais sem liberdade interna a indivíduos imaturos ou sem capacidade jurídica, justificando, desta maneira, intervenções europeias em povos apresentados como "incapazes de serem membros plenos na comunidade civilizada" (Koskenniemi, 2004, p. 77-8).

É curioso notar que os homens de 1873 fundavam o caráter científico do direito internacional mais em suas propriedades lógicas do que empíricas. Hoje, a concepção de ciência é tributária do pensamento de Karl Popper (1972), que eleva a empiria aos patamares mais altos ${ }^{32}$. Mas a ideia de ciência para os juristas do IDI era diferente. O que eles chamavam de científico refletia a ordenação lógica do direito internacional a partir do uso do sistema de categorias concatenadas, tomadas de empréstimo do direito privado. E não da empiria propriamente dita. A prática real dos Estados não era a fonte privilegiada de normatividade, e sim o sistema conceitual cultivado na Revuee no IDI, e empregado pelos experts em direito internacional. Anthony Anghie descreve este procedimento como movimento rumo à abstração, caracterizado como:

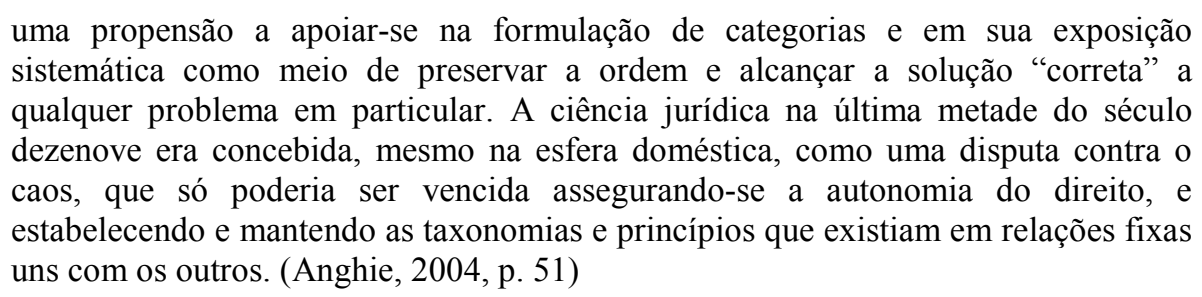

Para Anghie, há substituição de mitos: o naturalismo emprega o mito do estado de natureza como gênese do raciocínio. Aqui, o mito é o da existência de "um conjunto fixo de princípios e um esquema de classificações que se revelam ao escrutínio do jurista expert, que usa este esquema para definir e desenvolver o direito internacional.” (Anghie, 2004, p. 52) É possível depreender, a partir disso, que este modo de "fazer ciência" no direito permite a rejeição (e projeto de reforma) do real a partir de sua pretensa capacidade de readequar a realidade ao sistema conceitual pré-existente, “a priori”. Em outros termos, o que se tem é a engenharia intelectual que permite autoafirmar-se como científica e ainda assim rejeitar certas

\footnotetext{
${ }^{32}$ Popper afirma: "não exigirei que um sistema científico seja suscetível de ser dado como válido, de uma vez por todas, em sentido positivo; exigirei, porém, que sua forma lógica seja tal que se torne possível validá-lo através de recurso a provas empíricas, em sentido negativo: deve ser possível refutar, pela experiência, um sistema científico empírico". (1972, p.42)
} 
práticas políticas dos Estados, isto é, as que forem consideradas contrárias ao direito. A cientificidade encontrada na lógica e não na empiria parece estar associada, portanto, às pretensões dos membros do IDI de reformar a política internacional e as instituições domésticas dos Estados ao mesmo tempo em que mantinham para seu trabalho intelectual o rótulo de cientificidade.

Observa-se, até o momento, que a expertise do direito internacional no final do século XIX, a circular na Revue e no IDI, era informada pelas seguintes características: (i) a sensibilidade que Koskenniemi chama de esprit d'internationalité, que combina liberalismo e cosmopolitismo, conciliando, por sua vez, nacionalismos e internacionalismo; (ii) o projeto de ordenação e reforma das relações entre Estados e mesmo de suas instituições domésticas segundo conhecimentos jurídicos animados pelo esprit d'internationalité; (iii) a visão de que a normatividade no plano internacional decorre não propriamente da expressão da vontade soberana dos Estados, mas da consciência jurídica emanada dos povos europeus; (iv) a concepção de que os intérpretes legítimos desta consciência jurídica e da opinião pública seriam os juristas internacionalistas e, mais especificamente, os membros do IDI e articulistas da Revue; e (v) o projeto de condução científica do direito internacional, feito a partir de sua sistematização lógica, por sua vez obtida por meio de analogias com as categorias do direito privado. Resta abordar o elemento que caracteriza este direito internacional do século XIX como fundado em distinções culturais e raciais: a consciência jurídica que importa, e que conforma o direito internacional, é aquela das nações civilizadas. Os homens de 1873 pressupõem a distinção entre povos civilizados e não civilizados. A história do direito internacional do final do século XIX é a de conexão entre suas formas jurídicas, o comércio, a colonização (e subcategorias, como o protetorado) e a discriminação cultural e racial.

\section{Direito internacional e civilização: encontro colonial e dinâmica da diferença}

Tornar-se a consciência jurídica do mundo civilizado. Partindo desta ênfase, Anthony Anghie (2004) distingue duas narrativas a respeito do período formativo do direito internacional moderno ${ }^{33}$. A primeira delas - tradicional - encara o problema da ordem entre Estados soberanos (ou seja, de como pode haver ordem em cenário anárquico) como central à

\footnotetext{
${ }^{33}$ Vale ressalvar que Anghie emprega marco diferente de Koskenniemi para a formação do direito internacional. Enquanto para Koskenniemi a consolidação deste como disciplina autônoma ocorreu na década de 1870, em virtude dos desdobramentos aqui narrados, Anghie situa as contribuições de Francisco de Vitoria (1483-1546) como suas "origens primitivas" ou "textos fundacionais do direito internacional." (2004, p. 13-4) Feita essa ressalva, considera-se que a diferenciação aqui mencionada permanece útil para os fins da presente exposição.
} 
formação do direito internacional. Esta perspectiva se desenvolveu como reação ao ataque de John Austin (1790-1859), positivista da escola analítica inglesa, que partia da posição de que o direito positivo era o comando do soberano. Na ausência de ente supremo no cenário internacional, Austin negava a existência de direito positivo nas relações internacionais: "o direito entre as nações não é direito positivo: porque todo direito positivo é estabelecido por um soberano a uma pessoa ou pessoas em estado de sujeição a seu autor." (apud Anghie, 2004, p. 41) Para esta primeira narrativa, a formação do direito internacional seria marcada pelo esforço de justificar sua normatividade no cenário internacional anárquico, ou seja, uma situação de ausência de um governo dos governos.

A segunda narrativa a respeito do período formativo do direito internacional moderno é a que identifica o "encontro colonial" como fundacional para este direito. Esta é a postura de Anghie (2004; cf. Rajagopal, 2003; Pahuja, 2009). O segundo capítulo do livro The Gentle Civilizer of Nations, de Koskenniemi (2004), converge em grande parte com esta perspectiva crítica a respeito da formação do direito internacional. Esta visão enfatiza a distinção entre civilizados e não civilizados, e portanto a distinção racial, como nucleares para a formação do direito internacional. Anghie afirma que houve "racialização" do direito, mediante a qual apenas instituições especificamente europeias eram reconhecidas como dotadas de validade jurídica, anulando-se as nativas (Anghie, 2004, p. 55). A racialização do direito vai de mãos dadas com a força do darwinismo no século XIX: assumia-se certa escala evolucionária que ia do selvagem, no nível mais baixo, ao civilizado, no topo. Há, nisto, matizes de universalismo: todos os humanos podem ser situados na mesma escala ${ }^{34}$. Mas há, ao mesmo tempo, a afirmação da diferença cultural e racial de maneira hierarquizada, os europeus sendo o estágio mais avançado (Koskenniemi, 2004, p. 101-4).

A vinculação das características raciais com as instituições políticas, o modo de vida e o progresso fazia parte não somente do senso comum da época ${ }^{35}$, mas também do linguajar de juristas que integravam os quadros do IDI. Koskenniemi exemplifica com Bluntschli, que traçava perfis institucionais estereotípicos de arianos, semitas e negros. Os arianos seriam

\footnotetext{
34 A pretensão de universalidade jurídica emanada uma "comunidade internacional" nos moldes europeus e segundo diferenciações ou gradações de civilização (e posteriormente "desenvolvimento"), com o correspondente paradoxo da exclusão dos casos "particulares" - ou seja, não europeus, os não civilizados e posteriormente subdesenvolvidos - são aspectos especialmente enfatizados na tese de Sundhya Pahuja (2009). O paradoxo se dá pelo fato de que os casos "particulares" ou diferentes precisam passar por transformações para que sejam admitidos à comunidade "universal". Como Pahuja sugere, o "universal" é, na realidade, uma construção normativa de valores que, embora também sejam "particulares" em sua origem, obteve êxito em projetar-se como válido para o todo.

${ }^{35}$ Sobre a relação entre racismo e progresso no final do século XIX, cf. Nisbet (1985, p. 291-300). Robert Nisbet ressalta que, neste período, "dezenas de milhões de ocidentais, em ambos os lados do Atlântico, acreditavam implicitamente numa base racial para o progresso.” (1985, p. 293)
} 
"um povo de Estado", com propensão natural ao progresso, e "nenhuma raça poderia competir com eles na teoria do Estado.” Em razão destas características, caberia aos arianos a missão de "educar outras raças a respeito da teoria política e dos assuntos de Estado". Em outros termos, cabia-lhes "ensinar a civilização ao restante da humanidade.” (apud Koskenniemi, 2004, p. 104) As demais raças seriam sujeitos passivos dessa missão civilizadora ariana. A fala de Bluntschli ilustra de maneira muito forte o modo como o direito internacional foi elaborado a partir de uma distinção racial, que se reflete nas categorias de civilizado e não civilizado.

Na perspectiva crítica de Anghie e Koskenniemi, a relação da Europa com as colônias moldou o direito internacional no período de sua formação, e teve repercussões para suas principais categorias, como a de soberania. Anghie afirma que o positivismo foi instrumental para o colonialismo e o projeto civilizador. Aqui, cabe esclarecimento sobre a perspectiva dos dois autores. Anghie, diferentemente de Koskenniemi, classifica os autores internacionalistas do final do século XIX como positivistas. Refere-se a alguns deles como "exclusivamente positivistas", como Westlake e Hall (Anghie, 2004, p. 43). Para ele, portanto, o positivismo foi a perspectiva teórica que animou a formação do direito internacional, inclusive na Revue e no IDI. Porém, Anghie qualifica este positivismo: a normatividade do direito internacional deste período não seria fundada propriamente na soberania, mas na qualidade do pertencimento dos Estados a uma família de nações civilizadas. É um positivismo, portanto, de matiz organicista. A divergência consiste em que Koskenniemi apresenta o esprit d'internationalité como sensibilidade típica dos homens de 1873, evitando classificações, ao passo que Anghie traduz esta sensibilidade como positivismo de matizes orgânicas.

A distinção entre civilizados e não civilizados está na base da afirmação da soberania dos Estados europeus. Embora a perspectiva positivista represente o direito como emanação da vontade soberana, para os juristas internacionalistas do final do século XIX, somente a vontade dos Estados pertencentes ao mundo civilizado (anglo-europeu) era juridicamente relevante. Outros Estados e povos, por não pertencerem à família de nações civilizadas, estavam excluídos do grupo cuja vontade gerava direito. Por isto, a base da normatividade para estes positivistas no final do século XIX não era o conceito de "soberania", mas a ideia de "sociedade" (Anghie, 2004, p. 35).

O conceito de sociedade é crucial para o esquema positivista porque permite fazer distinção entre diferentes tipos de Estados; o efeito da distinção é excluir Estados não europeus da família de nações e portanto da própria soberania. [...] Este escoramento no conceito de sociedade para estabelecer a soberania parece algo destoante com a alegação de que a soberania seja o núcleo e o princípio essencial do 
direito internacional, e que tudo no sistema deriva da soberania. (Anghie, 2004, p. 99)

É o pertencimento à sociedade de nações civilizadas que gera o atributo da soberania. A doutrina da soberania, neste sentido, foi fundada numa "discriminação cultural e racial" sobre a qual se fazia a distinção entre os civilizados europeus e os não civilizados do restante do mundo (Anghie, 2004, p. 100).

O resultado desta maneira de construir a doutrina da soberania é a concepção de que os Estados europeus soberanos se relacionam, no plano internacional, com entes não dotados de soberania. A isto Anghie se refere como "encontro colonial" ou "confronto colonial". Dado que o direito seja fruto da vontade soberana, pela perspectiva positivista, "o estado soberano pode fazer como desejar em relação à entidade não soberana, que carece de personalidade jurídica para fazer qualquer oposição jurídica.” (Anghie, 2004, p. 34) Koskenniemi exemplifica o ponto, ao narrar que juristas como Westlake e Hall retiravam completamente a aplicabilidade do direito público às relações entre comunidades protetoras (europeias) e protegidas (não europeias): "as únicas obrigações de direito internacional devidas pelo colonizador eram em relação a outros colonizadores.” (Koskenniemi, 2004, p. 108) Mais especificamente, cita Westlake em suas afirmações de que "o direito internacional precisa tratar os nativos como não civilizados" e de que "deixa o tratamento dos nativos à consciência do Estado ao qual é conferida a soberania" (apud Koskenniemi, 2004, p. 127). Nota-se que a construção da doutrina da soberania, feita com base na distinção civilizados/não civilizados, permitiu aos Estados europeus se comportarem de maneira livre e violenta em relação ao restante do mundo: afinal, o direito internacional do período permite a discriminação racial, a subordinação cultural, a tomada de território e a exploração econômica (Anghie, 2004, p. 7). O efeito é o desempoderamento dos povos não europeus (Anghie, 2004, p. 37). Essas características do direito internacional têm ligação com o processo de ampliação comercial experimentado no século XIX. Este ponto será retomado adiante.

A distinção entre civilizados e não civilizados permitia aos positivistas de final de século identificar um gap entre dois grupos. A civilização europeia era apresentada como o modelo do bom e do desejável, para o qual as nações bárbaras deveriam ser conduzidas. Anghie se refere a isto como "dinâmica da diferença": a partir da identificação desse gap, os juristas internacionalistas propunham técnicas para superá-lo (Anghie, 2004, p. 37). Essas técnicas são conducentes à assimilação dos diferentes povos ao direito internacional europeu, e estão na base da universalização deste direito. Em outros termos, os povos não europeus são apresentados como retrógrados, necessitando incorporar-se à “civilização universal da 
Europa". O universal identifica-se com o civilizado; já o particular, a ser suprimido, com o não civilizado (Anghie, 2004, p. 3; cf. Pahuja, 2009). Torna-se possível ler o propósito do IDI, na redação de Bluntschli, de outro modo: ressaltando-se as implicações da civilização para a normatividade do direito internacional e para o modo como este direito definiria as relações entre europeus e o restante do mundo. O significado disto é que os juristas internacionalistas do final do século XIX “elaboraram uma moldura jurídica que justificava a colonização como meio de realizar a missão civilizadora." (Anghie, 2004, p. 10) $\mathrm{Na}$ interpretação de Koskenniemi, esta moldura era ao mesmo tempo excludente e inclusiva. Era excludente na medida em que, diferenciando europeus de não europeus, tornava impossível a extensão dos direitos dos europeus aos nativos. E era inclusiva, mas em sentido qualificado, porque a inclusão se dava pela anulação da alteridade dos nativos (ver também Pahuja, 2009). Só poderiam ser incluídos caso abandonassem suas práticas em favor do modo de vida europeu. Em especial, o discurso do humanitarismo universalista canalizava as pretensões dos juristas internacionalistas de substituir instituições nativas por instituições europeias (Koskenniemi, 2004, p. 130). Trata-se de projeto de assimilação, que se repercutiu nas formas do direito internacional do período.

Categorias jurídicas do encontro colonial: direito internacional e assimilação

Anthony Anghie destaca quatro modos pelos quais a assimilação se refletiu no instrumental jurídico internacionalista: a colonização, a doutrina do reconhecimento, os protetorados e a celebração de tratados entre Europeus e não-europeus (tratados desiguais) (Anghie, 2004, p. 67).

\section{Colônias}

Em termos jurídicos, a colonização suplantava a ausência de personalidade jurídica do colonizado pela incorporação à metrópole. Uma vez colonizado, o território passava à soberania da nação europeia. Deste modo, entrava no direito internacional europeu. Colônias poderiam ser obtidas por descoberta, ocupação, conquista e por cessão territorial. As categorias do direito privado contribuíam para justificar o processo colonizador.

Cessão, terra nullius e uti possidetis são derivadas do direito privado, por sua vez com raízes no direito romano (a partir do esforço de sistematização de Savigny e Puchta). Além da "cessão" pactuada (e o tratado de cessão poderia ser obtido por coação militar, que 
não era proscrita pelo direito internacional da época, nisto não sendo muito diferente da conquista), categorias como "terra nullius" e processos de aquisição por "uti possidetis" habitavam o imaginário jurídico internacionalista da época (Anghie, 2004, p. 82-4), tendo-se refletido na Conferência de Berlim, abordada adiante.

A esse respeito, Anghie cita o jurista germano-britânico Lassa Oppenheim (18581919), em passagem na qual apresenta as "restrições" à prática da ocupação: “Apenas podem ser objeto de ocupação os territórios que não sejam terra de nenhum Estado [no State's land], quer inteiramente desabitadas, como um uma ilha, quer habitadas por nativos cuja comunidade não seja considerada um Estado." (apud Anghie, 2004, p. 83 - acrescentou-se ênfase) Como se observa, a distinção civilizados/não civilizados, juridicamente elaborada em doutrinas como a da ocupação, permitia a espoliação territorial dos povos não europeus. $\mathrm{E}$, a partir dela, o domínio de matérias-primas, a abertura de portos e de novos mercados consumidores, no contexto de uma Europa pós-Revolução Industrial, com economias capitalistas em expansão.

\section{Doutrina do reconhecimento}

A doutrina do reconhecimento dialoga muito bem com a dualidade inclusão-exclusão a que se refere Koskenniemi, e que Anghie chama de dinâmica da diferença. De um lado, ela foi a chave para privar o mundo não europeu em relação à capacidade soberana. De outro, ofereceu o caminho de entrada a outros povos no direito internacional europeu (ou na família de nações), desde que o padrão de civilização fosse atingido. Para que o Estado não europeu fosse considerado soberano, não bastava ter controle sobre o território: a extensão da soberania para além dos Estados europeus passou a estar dependente do reconhecimento. Evidentemente, porém, o reconhecimento não estava na base da formação da soberania dos próprios Estados europeus (Anghie, 2004, p. 57-9). Neste sentido, a doutrina foi concebida para ser aplicada fora da Europa, como uma maneira de realizar a "metamorfose de uma sociedade não europeia em uma entidade jurídica.” (Anghie, 2004, p. 75)

Por sua vez, o reconhecimento estava atrelado à percepção de que certa sociedade não europeia havia se tornado civilizada. Conforme adverte Koskenniemi (2004, p. 134), não havia critério estável ou claro para se saber quando a nação havia alcançado o padrão de civilização. Mas, segundo Anghie, a ideia geral era a de que o "Estado não europeu era considerado civilizado se pudesse prover a um indivíduo, estrangeiro europeu, o mesmo tratamento que o indivíduo esperaria receber na Europa.” (Anghie, 2004, p. 84) Anghie 
exemplifica com Westlake: "Quando pessoas de raça europeia têm contato com tribos americanas ou africanas, a necessidade primária é um governo sob a proteção do qual estas pessoas possam conduzir a vida complexa a que estão acostumadas em suas casas." (apud Anghie, 2004, p. 85)

Tornar-se civilizado implicava garantir aos europeus direitos de residência, de praticar atividades comerciais, de propriedade e de segurança dos contratos. Em outros termos, a doutrina do reconhecimento implicava reformas nas instituições domésticas dos Estados nãoeuropeus, de modo a torná-las mais semelhantes ao modelo a que os europeus já estavam acostumados, e que entendiam ser mais propício à atividade comercial. Dentre as reformas necessárias estava o estabelecimento da jurisdição consular.

Por este procedimento, o nacional europeu não poderia ser julgado pela autoridade ou leis locais, mas por cônsul do país europeu de origem, com o direito correspondente (Anghie, 2004, p. 85-6). Outro modelo de jurisdição consular previa a existência de tribunais mistos, em que europeus e nativos fariam conjuntamente os julgamentos. Segundo Koskenniemi, em alguns casos havia possibilidade de apelo da decisão do tribunal misto a uma corte do Estado europeu (Koskenniemi, 2004, p. 134). A Turquia entrou para a "família de nações” em 1856, com o Tratado de Paris, mas jurisdições consulares europeias já existiam ali desde 1836 (Koskenniemi, 2004, p. 106). Outros Estados, como Japão, Sião (atual Tailândia) e China, também entraram para o rol das nações civilizadas por meio da doutrina do reconhecimento. Similarmente, todos eles conviveram com jurisdição consular europeia até início do século XX. Koskenniemi ressalta o caráter paradoxal deste procedimento de inclusão-exclusão dos não europeus no direito internacional: “[p]ara que obtivessem igualdade, a comunidade não europeia deveria aceitar a Europa como mestre - mas aceitar um mestre era prova de que não se era igual.” (Koskenniemi, 2004, p. 136) E que destino guardava o direito internacional aos Estados que não incorporassem instituições europeias, não sendo, portanto, reconhecidos? Eles estavam sujeitos à colonização, ou à guarda de potência protetora (Anghie, 2004, p. 76).

\section{Protetorados}

Os protetorados são característicos da porção final do século XIX (Anghie, 2004, p. 87). O protetorado é análogo, no direito internacional, à instituição da "tutela" no direito privado. Ainda analogamente, é meio para suprir a "incapacidade civil” do Estado retrógrado. Exemplo desta analogia é dado por Koskenniemi, ao citar o jurista suíço Joseph Hornung (1857-1931), referindo-se aos povos asiáticos e africanos: "são crianças, é claro, mas 
tratemos-lhes como se tratam crianças, por meio da gentileza e da persuasão ... Nós aceitamos a hegemonia e a tutela dos fortes mas somente nos interesses dos fracos e visando sua futura emancipação." (apud Koskenniemi, 2004, p. 130 - acrescentou-se ênfase) A “incapacidade civil” fíca evidente na comparação com as crianças: a forma jurídica para lidar com esta incapacidade é "tutela", até que ocorra o evento jurídico da "emancipação". Todas estas categorias do direito privado estão envolvidas, por transplante, na instituição do protetorado no direito internacional.

Formalmente, o protetorado não conferia soberania da potência protetora sobre o Estado protegido. Por meio de tratado, o Estado protegido cedia apenas o controle sobre seus assuntos externos. Em tese, o Estado protegido retinha autoridade sobre seus assuntos internos. Na prática, porém, a distinção entre soberania interna e externa era "porosa e artificial", e era comum que as potências protetoras interferissem na ordem sucessória do governo do Estado protegido (Anghie, 2004, p. 87-8). Exemplo é o Egito, que foi protetorado britânico, em termos formais, de 1914 a 1922, mas, na prática, ao menos desde 1882. A GrãBretanha interferia na escolha dos governantes e até mesmo dos ministérios (Koskenniemi, 2004, p. 152). "Significativamente, portanto, o mecanismo do protetorado permitia que os Estados europeus exercessem controle sobre um Estado quanto a seus assuntos internos e externos, mesmo que sustentasse que a soberania estava propriamente situada no governante local.” (Anghie, 2004, p. 88) Para Anghie, a distinção entre colônia e protetorado sofreu, na prática, erosão gradual.

Se era desejável explorar as matérias-primas de países asiáticos e africanos e desenvolver novos mercados ali, isto era feito, onde possível, sem assumir controle político sobre o território e com ele todos os custos e problemas de lidar com uma colônia. Visto desta perspectiva, a situação ideal era aquela em que o controle econômico pudesse ser exercido sobre um Estado não europeu que fosse nominalmente, ao menos, "soberano". Como um instrumento jurídico, o arranjo do protetorado era idealmente adequado à implementação de uma política assim. (Anghie, 2004, p. 90)

Em outros termos, o protetorado era a forma jurídica pela qual os Estados europeus - e sobretudo a Grã-Bretanha - expressavam sua preferência pela estratégia de "trade, not rule" (império informal ou indireto) nos cenários em que isto era possível: ou seja, em que governantes nativos fossem capazes de garantir a ordem local necessária à condução do comércio. Em termos econômicos, pode-se interpretar que a forma jurídica do protetorado permitia à potência europeia reduzir custos de viabilização da atividade comercial, transferindo a outros o encargo da administração direta e do policiamento, ao mesmo tempo em que retinha para si o controle sobre o governo local. 


\section{Tratados desiguais}

Por fim, o direito internacional da segunda metade século XIX incluía a celebração de tratados como mecanismo de assimilação. Trata-se de algo paradoxal: os Estados não europeus e não civilizados, e portanto não soberanos, engajavam-se em negócios jurídicos com Estados europeus. Mesmo carecendo de personalidade jurídica formal no esquema conceitual do direito internacional europeu, estes Estados eram, ainda assim, capazes de firmar certos tratados aos olhos dos europeus (Anghie, 2004, p. 76). Embora sem fundamento numa concepção positivista de direito, a prática dos Estados europeus era tomar estes tratados como tendo caráter vinculante para os povos não europeus. Neste ponto, a doutrina internacionalista torna-se apologética da prática dos Estados.

Segundo Anghie, a solução dos positivistas diante da fraqueza da correspondência dessa situação com seu esquema conceitual prévio - segundo o qual o “incapaz” não expressa vontade juridicamente "válida" - era ater-se à letra do tratado, à "forma" do que já estava pronto. Como resultado, não importava se o tratado havia sido obtido sob coerção (Anghie, 2004, p. 72). Exemplo da prática de considerar válido o tratado obtido frente a governos cuja soberania se negava (por não pertencerem ao mundo civilizado) e por coerção é o tratado de Nanking, de 1842, firmado após as Guerras do Ópio de 1839-42 entre China e Grã-Bretanha. Pelo tratado, Hong Kong foi cedida à Grã-Bretanha, cinco portos chineses foram abertos ao comércio, e regime preferencial de tarifas foi estabelecido para as importações britânicas. Além disso, fixou-se o pagamento de indenizações pelas perdas britânicas na Guerra (Anghie, 2004, p. 76), e nacionais britânicos chegaram a estar no controle de alfândegas portuárias chinesas (Brown, 2003, p. 61).

A prática de considerar válidos os tratados obtidos por coerção viria a persistir mesmo após a Primeira Guerra Mundial: o Tratado de Versalhes, dentre várias outras obrigações, forçou a Alemanha a pagar indenizações de guerra, e a internacionalizar o Canal de Kiel ponto que está na origem da controvérsia relativa ao caso Wimbledon, a ser abordado na seção 2.1.3. Dificilmente se poderia, senão na imaginação jurídica, dizer que a Alemanha firmou o Tratado de Versalhes como expressão de sua vontade soberana (e não da capitulação na guerra). Que a Corte Permanente de Justiça Internacional o tenha assim considerado, embora seja outro assunto, não deixa de ser pertinente como expressão do modo como o direito internacional, em seu período clássico, tomou tratados desiguais e obtidos por coerção como 
válidos. Mas, no exemplo da Alemanha do início do século XIX, já não está em jogo o uso da celebração de tratados como meio de entrada na comunidade de nações.

Traduções jurídicas da corrida colonial na Conferência de Berlim

O impacto da racialização do direito - ou seja, da distinção entre civilizados e não civilizados - sobre a maneira como as categorias jurídicas moldavam a percepção da realidade (ou seja, como componentes de uma langue) é evidente na Conferência de Berlim, de 18841885 (como parole correspondente a esta langue). A expansão colonial destacou-se como fenômeno das relações internacionais na porção final do século XIX (Anghie, 2004, p. 65). As pretensões imperiais dos Estados europeus geravam atritos, e a Conferência foi a tentativa multilateral de lidar com a competição pela África por canais pacíficos (Koskenniemi, 2004, p. 123). A Conferência foi arranjo entre europeus a respeito de territórios africanos. As autoridades africanas existentes sobre estes territórios não foram chamadas ao pacto em que os critérios de divisão foram estabelecidos (Anghie, 2004, p. 91). A postura é "coerente" com a doutrina de soberania que encara o mundo europeu civilizado como sujeito da soberania, e o restante, como seu objeto (Anghie, 2004, p. 102). Na Conferência de Berlim,

a diplomacia e a política tradicional do balanço de poder foram combinadas com o direito internacional, conforme as potências imperiais da Europa tentavam criar uma moldura jurídica e política para garantir que a expansão colonial na bacia do Congo acontecesse de maneira ordenada e que minimizasse as tensões entre os três Estados europeus mais poderosos da época: Inglaterra, França e Alemanha. (Anghie, 2004, p. 90-1)

Juridicamente, o sentido da Conferência foi transformar o território do continente africano em terra nullius, sujeitando-o a divisão pelas potências europeias (Anghie, 2004, p. 91). A Conferência teve três objetivos principais: fixar regras para aquisição de territórios, firmar a liberdade de navegação ao longo dos rios Congo e Níger - respectivamente o segundo e o terceiro rios mais longos da África - e estabelecer liberdade comercial na bacia do rio Congo (Koskenniemi, 2004, p. 123).

\section{Normas sobre aquisição de território na disputa colonial}

$\mathrm{Na}$ questão territorial, destacam-se os seguintes pontos: (i) reconhecimento do Estado Independente do Congo; (ii) a afirmação do critério de ocupação efetiva do território; (iii) o estabelecimento precário do dever de notificação de aquisições territoriais e (iv) a criação de regime jurídico à parte para os protetorados. 
A Conferência ficou conhecida por dar as bases para a partilha europeia da África, e por consolidar a criação do Estado Independente do Congo como propriedade pessoal do Rei Leopoldo II, da Bélgica - que só viria a passar ao status de colônia belga (e não de propriedade do Rei) em 1908 (Koskenniemi, 2004, p. 156-9). Inicialmente apresentada como Associação Internacional do Congo, o Estado particular do rei belga foi reconhecido pelos Estados Unidos em 1884, e sua participação na Conferência implicou o reconhecimento formal das demais potências europeias.

Quanto às bases para a partilha da África, a conferência firmou regra de aquisição territorial que rompia com a prática anterior. Até a Conferência, era comum que potências europeias buscassem fundar o título a territórios africanos em tratados de cessão, firmados com autoridades nativas, governantes locais, chefes tribais etc. A prática gerava, como visto anteriormente, dificuldades de justificação diante da perspectiva jurídica positivista predominante. Na Conferência, o padrão de aquisição por cessão foi substituído pela aquisição por ocupação efetiva. Mas não houve definição do que seria considerado efetivo para os fins desta ocupação: tudo o que o Artigo 35 da Ata da Conferência de Berlim exigia era o "estabelecimento de autoridade nas regiões ocupadas", de modo "suficiente para proteger os direitos existentes e, de acordo com o caso, a liberdade de comércio e de trânsito." (Koskenniemi, 2004, p. 124) Com o padrão de ocupação efetiva, os tratados de cessão tornaram-se dispensáveis, tendo sido incorporados apenas subsidiariamente como demonstração de que a ocupação era "pacífica". A prática de continuar a empregar tratados de cessão como parte da justificação apelava para a força moral - e não propriamente jurídica do ato, visto que o direito internacional da época não proscrevia a conquista violenta como forma de aquisição territorial.

A conferência estabeleceu o dever de notificar as demais potências europeias da aquisição de território em solo africano. Outros Estados poderiam, então, apresentar objeções. Mas não havia clareza sobre como resolver as disputas, nem em que foro (Anghie, 2004, p. 94). A concepção era a de que o dever de notificação desse margem à prática de consultas entre os Estados envolvidos na disputa colonial, funcionando, assim, como mecanismo informal de prevenção ou solução pacífica de controvérsias. Na prática, o mecanismo não foi capaz de evitar conflitos armados entre as potências.

Por fim, houve a exclusão dos protetorados do âmbito da exigência de ocupação efetiva. Em outros termos, caso o território fosse protetorado de potência europeia, o exercício de autoridade direta estava dispensado. O efeito da conjunção destas regras a respeito da questão territorial africana, em sua vagueza, é deixar ampla margem de liberdade às potências 
europeias (Koskenniemi, 2004, p. 125). Em outros termos, a colonização não sofreria entraves efetivos por parte do direito internacional, que assim deixava o caminho aberto à expansão do comércio europeu, bem como à sua própria expansão.

\section{Comércio e navegação, civilização e direito na Conferência de Berlim}

Quanto a comércio e navegação, as disposições da Conferência de Berlim (1884-1885) são relevantes por demonstrarem como o direito foi empregado no intuito de favorecer a expansão comercial via colonização. No entanto, nem as disposições de liberdade de navegação, nem as de liberdade comercial se efetivaram. A intenção original era que o centro da África fosse internacionalizado, e isto se faria conferindo sua guarda à Associação Internacional do Congo, a cargo do Rei Leopoldo II da Bélgica. Porém, a incumbência desta tarefa à Associação de Leopoldo, com sua transformação em Estado Independente do Congo, frustrou a internacionalização: o centro da África ficou sob controle belga (Koskenniemi, 2004, p. 127). Na prática, a abertura comercial da África significou apenas abertura exclusiva aos produtos da potência que colonizava cada território específico.

Para além das questões territoriais, de navegação e comércio, a Conferência de Berlim representou mudança no modo como a colonização era feita e justificada. Do modelo anterior, baseado em império informal e justificado pela necessidade de lucro, passa-se a outro, de império formal, e justificado com base no comércio apresentado como ferramenta de civilização. Não houve completa extinção do primeiro, nem o segundo começou apenas a partir da Conferência. A Índia, por exemplo, havia sido administrada pela British East Indian Company, que foi dissolvida em 1858, após o que o território indiano passou a estar sob controle direto da coroa britânica. Antes, portanto, da Conferência. Mas 1885 foi marco simbólico e discursivo da transição no modo como a colonização europeia era conduzida no restante do mundo. Esta transição foi positivada no artigo 35 da Ata de Berlim, que exigia ocupação efetiva, representando a migração do modelo de império informal ou indireto para o formal ou direto, e no artigo $6^{\circ}$, que fixava o propósito da colonização em termos de bemestar material e moral dos nativos (Anghie, 2004).

Como se disse, ocorreu transição de império informal ou indireto para o formal ou direto. A técnica de império informal envolve o emprego de companhias que recebem concessão da potência colonizadora para explorar o comércio no território colonizado, incluindo direitos de administrar, policiar, fazer guerra etc. Por delegação do Estado colonizador, a companhia se comporta na colônia, e em relação a seus competidores externos, 
como se Estado fosse. Mas a colonização propriamente dita é conduzida por companhias privadas. Já o império formal envolve a administração direta da metrópole sobre a colônia, sem intermediários privados, e com afirmação de sua soberania (Anghie, 2004).

Quanto ao aspecto da justificação, a Conferência de Berlim representou a transição da colonização abertamente motivada pela busca do lucro via companhias privadas, típicas do modelo de império indireto ou informal, para outra motivação, mais sofisticada. A redação do artigo $6^{\circ}$ estabelecia que as potências cuidariam da "melhoria das condições de bem-estar moral e material" dos territórios colonizados. O propósito da colonização passa a ser definido também com base em prestação aos não civilizados, e esta prestação consiste em levar-lhes melhorias materiais e morais. Trata-se da positivação da missão civilizadora, também conhecida como "fardo do homem branco" (cf. Easterly, 2006). Aqui, estão envolvidos dois aspectos interrelacionados. De um lado, esta nova justificativa está diretamente associada à distinção entre civilizados e não civilizados. De outro, vincula-se à mudança na forma como o papel do comércio na colonização é apresentado.

Quanto ao primeiro aspecto (civilizados e não civilizados), a colonização passa a ser apresentada como forma de educar os povos não europeus, trazendo-os à cristandade e às instituições características da cultura europeia, percebidas, como se disse, como superiores. Koskenniemi faz referência a três "Cs" empregados como mote nesse processo: civilização, comércio e cristandade (Koskenniemi, 2004, p. 146). Uma das bandeiras levantadas durante a conferência foi a necessidade de "tratamento humanitário dos povos inferiores e submetidos." (Anghie, 2004, p. 96) Como se viu anteriormente, o humanitarismo universalista foi empregado pelos juristas internacionalistas como instrumental para a substituição das instituições nativas por instituições europeias. Isto fazia parte do processo de civilização.

Quanto ao segundo aspecto (novo papel do comércio), a colonização deixou de ser justificada diretamente com base na busca por lucro. Cumpre observar que esta mudança está ligada à transição do modelo de império informal para o formal: ao passo que a motivação de companhias privadas para condução da colonização era justificada em bases abertamente privadas (a busca do lucro), a técnica de império formal, com engajamento direto do Estado, permitiu revestir a empreitada colonizadora de propósitos mais "nobres", associados ao interesse público universal. Houve "deslocamento da linguagem vulgar do lucro para aquela de ordem, governança e humanitarismo." (Anghie, 2004, p. 69) Acentuaram-se, portanto, as notas civilizadoras da competição colonial. Em especial, o comércio é apresentado como meio 
de levar a civilização aos povos $\operatorname{colonizados}^{36}$. A fala de Bismarck na inauguração da Conferência, citada por Anghie, é ilustrativa do ponto: "todos os Governos convidados compartilham o desejo de trazer os nativos da África ao pálio da civilização pela abertura do interior do continente ao comércio.” (apud Anghie, 2004, p. 97) Trata-se da entrada do argumento do doux commerce, tão caro ao liberalismo, no plano internacional (vide seção 3.1). Nota-se o quanto do liberalismo a nova justificativa incorporou: o comércio é apresentado como gerador de bem-estar não só material, como também moral. Por meio dele é possível alcançar a civilização.

Há outro aspecto envolvido na apresentação do comércio como integrante da tarefa civilizadora, em substituição à justificação direta no lucro. Ela poderia ser interpretada como movimento rumo à planificação estatal de atividades econômicas, contrária, portanto, ao espírito liberal do século XIX. Mas não. A mudança "permitiu que o interesse privado desfilasse como interesse público" (Koskenniemi, 2004, p. 126). O ponto é ilustrado pelo comportamento de companhias alemãs de colonização. Após a anexação de Togo e Camarões pela Alemanha, na década de 1880, as companhias coloniais de Hamburgo recusaram-se a assumir a administração. "Em sua visão, era tarefa do Estado estabelecer administração e polícia nestes territórios para criar e manter condições de ordem para o comércio e o assentamento." (Koskenniemi, 2004, p. 145) Percebe-se o seguinte: no modelo de colonização ou império informal, as companhias precisavam arcar com os custos de realizar tarefas de Estado nas áreas colonizadas, como administração pública, segurança, infra-estrutura etc. Com a transição para o modelo de colonização direta ou império formal, estes custos são transferidos ao Estado: as companhias ficam livres para atuar em atividades mais diretamente relacionadas à obtenção de lucros. A transferência do fardo administrativo das companhias de colonização ao Estado é discursivamente reforçada pela roupagem civilizadora e humanitária com que a colonização é vestida após a Conferência de Berlim. É plenamente compatível com o ideário liberal que o provimento de bens públicos, como a ordem, a segurança da propriedade e dos contratos, esteja a cargo do Estado, deixando os indivíduos livres para buscar cada qual o seu próprio ganho ${ }^{37}$.

Os membros do IDI e a Conferência de Berlim

\footnotetext{
${ }^{36}$ Balakrishnan Rajagopal, em linha com Anghie, considera que o nexo entre civilização e capitalismo "forneceu uma justificação moral para a expansão comercial nas colônias" (Rajagopal, 2003, p. 24).

${ }^{37} \mathrm{Em}$ conexão com este aspecto, ver, na seção 3.1, a discussão sobre as bases institucionais da livre atuação dos mercados, em Adam Smith.
} 
E como se posicionaram os juristas internacionalistas do IDI a respeito da Conferência de Berlim? Segundo Koskenniemi, os membros do IDI apregoavam a extensão formal da soberania europeia em território africano como meio de levar a civilização (Koskenniemi, 2004, p. 107-10). Esta posição os inclinava favoravelmente ao propósito da Conferência. O Rei Leopoldo II, da Bélgica, também contou com o conselho jurídico de membros do IDI para fazer sua Associação Internacional do Congo ser reconhecida pelos Estados Unidos (1884) e pelas potências europeias como entidade soberana (Koskenniemi, 2004, p. 143). Em outros termos, o IDI conferiu apoio intelectual inicial à empreitada colonial do Rei Leopoldo II da Bélgica.

Para além da questão do Congo, no geral, embora tenham saudado as disposições da Ata de Berlim a respeito da liberdade de navegação e de comércio, os membros do IDI tiveram postura ambivalente quanto às disposições territoriais (Koskenniemi, 2004, p. 149). Afinal de contas, embora resultassem na exportação da soberania europeia à África, os critérios para a partilha não eram fortes o suficiente: o requisito de ocupação efetiva não havia definido o que efetividade significava; a exclusão dos protetorados do âmbito da regra era excessivamente limitante, já que boa porção do continente africano estava sob o formato de território protegido de potências europeias (sobretudo da Grã-Bretanha); e as previsões de notificação criavam sistema de consultas em base ad hoc, sem detalhamento de como as disputas territoriais seriam resolvidas. De fato, pode-se considerar que a Conferência de Berlim, na questão territorial, não foi bem sucedida nem mesmo em firmar a preponderância do critério de ocupação efetiva como meio de aquisição territorial colonial no direito internacional.

O motivo para o fracasso da doutrina da ocupação efetiva foi a prática das potências europeias em sentido contrário. Ao passo que a Grã-Bretanha matinha pretensões de estabelecimento de domínio do "Cairo ao Cabo", ou seja, do norte ao sul africano, a França tinha como projeto fazer um cinturão de influência que se estenderia do Atlântico ao Mar Vermelho, portanto, de oeste a leste (Koskenniemi, 2004, p. 152). Evidentemente, estes projetos entravam em choque, não podendo coexistir. Além disso, a entrada tardia da Alemanha de Bismarck na disputa colonial acirrava a competição por zonas de influência não só na África, como também na Ásia e no Pacífico. Já em 1898, por exemplo, a Grã-Bretanha ignorou a doutrina de ocupação efetiva para tomar da França a ilha fluvial de Fashoda, no Sudão. A França ocupava o território com pequeno contingente, mas os britânicos o consideravam parte de sua zona de influência. O incidente marcou a queda do critério estabelecido pelo artigo 35 da Ata de Berlim. Em outros termos, o requisito de ocupação 
efetiva falhou, tendo sido, na prática, substituído pela aquisição de território baseada em esferas de interesse abstratamente delimitadas, em áreas de influência (Koskenniemi, 2004, p. 154).

Koskenniemi interpreta esta mudança na forma de justificar a aquisição territorial colonial de maneira associada à alteração da própria justificação do processo colonizador: seu sentido civilizador e humanitário perdeu espaço. Com a escalada de tensões rumo à Primeira Guerra, as roupagens filantrópicas e humanitárias foram sendo deixadas de lado, e a empreitada colonizadora passou a ser encarada como projeção do balanço de poder europeu na África, na Ásia e no Pacífico. Ao chegar o ano de 1914, as justificativas civilizadoras da colonização haviam sido abandonadas (Koskenniemi, 2004, p. 155) e substituídas por considerações de política de poder.

\section{Fracassos e sucessos do direito internacional do período}

Nas proximidades do ano de 1914, praticamente todos os territórios da Ásia, da África e do Pacífico eram controlados pelos principais Estados europeus, quer no formato de colônias, quer no de protetorados (Anghie, 2004, p. 33). Este fato é expressivo do modo como o direito internacional europeu se universalizou (cf. Pahuja, 2009, p. 138): a colonização e doutrinas correlatas (protetorados, doutrina do reconhecimento, tratados desiguais), apoiadas na missão civilizadora, foram instrumentais para sua expansão e exportação ao restante do globo. O comércio se expandiu e atingiu proporções mundiais nesta época. A empreitada colonial envolveu, a um só tempo, o propósito comercial de garantir acesso a matérias-primas e expandir mercados consumidores, e a base jurídica representada por categorias legitimadoras deste propósito.

O direito internacional deste período abrigou a missão civilizadora e, com ela, a expansão do comércio. Muito pouco teve de conteúdos restritivos ao exercício da violência nas relações internacionais, apesar dos esforços dos membros do IDI por interações entre Estados baseadas numa consciência jurídica e apaziguadas por mecanismos de solução pacífica de controvérsias. E a violência esteve a serviço da expansão comercial:

[...] as grandes nações europeias queriam fazer do mundo não-europeu um lugar seguro para o comércio europeu. Isto acarretava vários graus de intervenção nas áreas menos desenvolvidas do mundo - para o pagamento das dívidas, a proteção dos nacionais e seus bens e a garantia dos padrões mínimos da justiça ocidental. Conforme as circunstâncias (vontade e capacidade dos governos locais), as formas de intervenção variavam do desembarque ad hoc de tropas e das ameaças das canhoneiras britânicas às várias formas de controle: colônias, domínios, dependências, protetorados, mandatos, etc. (Kaplan; Katzenbach, 1964, p. 53) 
Este direito não regula o comércio, apenas é instrumental em relação a ele. O direito internacional da porção final do século XIX e inicial do século XX deixa o caminho aberto ao livre exercício da atividade comercial e das finanças, mas o comércio e as finanças são tratados como objetos alheios ao direito. Estão na esfera privada, da autonomia da vontade. Esta é uma das faces do liberalismo: colocar a economia para fora da política, tornando-a autônoma (Kaplan; Katzenbach, 1964, p. 88). E, ao fazê-lo, torna a economia autônoma também em relação ao próprio direito. Em outros termos, cumpriu ao direito dar suporte à expansão econômica, mas não criar regras limitadoras ou direcionadoras das atividades econômicas. O direito dos homens do IDI pretende informar a diplomacia, mas não o comércio.

Houve, sim, normas econômicas, mas estas não provieram do direito internacional. $\mathrm{O}$ Padrão-Ouro Internacional deu as bases para a interação dos Estados em matéria monetária. Este assunto será desenvolvido no capítulo 3, mas a síntese de seus aspectos principais será aqui apresentada para fins de compreensão de seu caráter normativo. Havia três regras básicas, e muitos Estados se comportaram de acordo com elas entre as proximidades de 1870 e 1914. Tinham caráter informal; não estavam positivadas. Eram, antes, articuladas pela classe internacionalizada de financistas que emergiu durante o século XIX, e que ganhou influência econômica e política sobre os Estados em geral: a haute finance (Polanyi, 2001), identificada em grupos como os Rothschild e os Baring Brothers (Ferguson, 2008, p. 88).

A primeira regra estabelecia que o compromisso dos Estados com a estabilidade cambial deveria ser prioritário. O comando era preservar o valor da moeda: não imprimir dinheiro sem lastro, manter o orçamento equilibrado e permitir períodos deflacionários (que causam desemprego) eram algumas das implicações da regra. A segunda exigia que o Estado se comprometesse a trocar sua moeda por ouro, mantendo conversível sua moeda, irrestritamente. Por isso o ouro torna-se a medida universal das moedas do período. E a terceira exigia que o Estado permitisse a entrada e saída de ouro por suas fronteiras. Em outros termos: o investidor estrangeiro deveria poder sacar o investimento em ouro, e sair com ele do país sempre que quisesse. A lógica comum às três regras é a preservação da rentabilidade do investimento. $\mathrm{O}$ investidor que comprasse um título do tesouro britânico a $£$ 100 , com juros de $5 \%$ ao ano, teria o retorno de seu investimento diminuído caso a libra perdesse $1 \%$ de seu valor em relação ao ouro. Ainda que nominalmente as $£ 105$ libras fossem pagas ao cabo de um ano, seu valor real teria sido $1 \%$ minorado $^{38}$. O Padrão-Ouro

\footnotetext{
${ }^{38}$ Ou seja, o investidor que esperava ganho de $£ 5$, teria seu retorno real diminuído para $£ 3,95$, ao resgatar o título e os juros por $£ 105$ após perda de $1 \%$ do valor da libra em relação ao ouro.
} 
Internacional buscava evitar isso pela manutenção da paridade das moedas nacionais em relação ao ouro.

A haute finance possuía interesse na estabilidade das relações internacionais entre grandes potências, necessária à preservação do padrão-ouro, que por sua vez era a base para criar ambiente seguro aos investimentos. Esse "agudo interesse pela paz", articulado por uma classe com ascendência sobre governos, e que "funcionava como a ligação principal entre a organização política e econômica do mundo", é o fator que Karl Polanyi (2001, p. 10) identifica como explicativo da estabilidade conseguida no século XIX. O interesse pela paz, aqui, é privado, e fundado no ganho: sem a paz, o comércio e as finanças sofreriam. Por sua vez, a influência da haute finance sobre os governos é explicada pela existência dos mercados de títulos da divida pública. Ao longo do século XIX, os Estados crescentemente recorreram à venda de títulos públicos para financiar despesas internas, aventuras coloniais e guerras. Ao fazê-lo, tornaram-se dependentes da haute finance. Os Estados passaram a precisar manter a credibilidade em sua capacidade de manter o valor de seus títulos, e a rentabilidade destes, para que conseguissem captar recursos nos mercados financeiros (Ferguson, 2008). Na porção final do século XIX e inicial do século XX, isto significava jogar pelas regras do Padrão-Ouro Internacional e manter a confiança da haute finance.

Depreende-se que, embora o direito internacional não criasse normas substantivas para a atividade econômica, estas ainda assim existiam, embora de maneira informal e não ligada a qualquer discurso jurídico, e constrangiam o comportamento dos Estados em matéria monetária e financeira. A adesão dos Estados a estas regras não foi feita por tratado internacional, mas pode ser compreendida por sua dependência do acesso aos recursos dos mercados financeiros. Para tanto, precisavam agradar à haute finance, detentora de recursos para investimento nesses mercados (Ferguson, 2008, p. 88). A política e o direito internacional encaravam a economia como autônoma, e esta cuidou de produzir a sua própria normatividade. Ainda assim, o direito internacional foi instrumental para a expansão do comércio: colônias e protetorados levavam "ordem” e civilização a terras distantes, abriam mercados consumidores para manufaturas europeias e fornecedores de matérias-primas. Tratados, inclusive obtidos por coerção - a exemplo do mencionado Tratado de Nanking de 1842 -, e ainda assim considerados válidos, providenciavam a abertura de portos ao comércio europeu e a obtenção de tarifas preferenciais. O mecanismo da jurisdição consular tornava o ambiente colonial seguro ao comerciante europeu, ao imunizá-lo contra a jurisdição local de povos considerados atrasados. A propriedade e os contratos eram protegidos até mesmo pelo 
envio de canhoneiras para forçar o pagamento de dívidas, prática considerada lícita pelo direito internacional da época.

O direito internacional animado pelo esprit d'internationalité não foi bem sucedido em evitar o conflito generalizado na Europa. Nisto, nem o balanço de poder, nem o PadrãoOuro Internacional o foram. Mas foi destacadamente bem sucedido em universalizar-se - o direito internacional europeu chegou ao restante do mundo pelas colônias e protetorados - e em oferecer uma moldura jurídica de apoio à expansão do comércio europeu.

\subsubsection{Direito internacional no entreguerras: institucionalização}

O projeto de ordenação jurídica das relações internacionais desenvolvido na porção final do século XIX não foi capaz de evitar a eclosão da Primeira Guerra Mundial. Após o conflito, emergiu uma nova concepção de segurança internacional. Desta vez, versada em termos mais acentuadamente jurídicos, e prevendo instituições para a cooperação entre Estados. Uma nova institucionalidade - com profusão de organizações internacionais - toma contornos neste período, sem romper com o direito preexistente, que permanece a mesma langue em que estas manifestações de parole estiveram inseridas. A institucionalização, ao invés de uma ruptura com a langue precedente, sinaliza seu ganho de relevância prática para a condução das relações internacionais. Paralelamente a isto, as relações comerciais, monetárias e financeiras foram ressignificadas. Embora o Padrão-Ouro Internacional houvesse sido restaurado, a nova versão não contou com o mesmo funcionamento de antes da guerra.

Segurança coletiva como concepção juridicamente informada de segurança internacional

O novo conceito de segurança internacional era a segurança coletiva. Em vários aspectos, esta concepção se assemelha ao balanço de poder. Os dois sistemas: (i) só podem funcionar se não houver um só Estado mais poderoso que todos os outros juntos; (ii) pressupõem que a dissuasão funcione, ou seja, que os aspirantes à hegemonia deixem de atacar por acreditarem que a derrota é inevitável em virtude do funcionamento do sistema; e (iii) compartilham visão sistêmica da segurança, no sentido de que o ataque de um agressor exige resposta conjunta, envolvendo países cujos territórios ou interesses diretos sequer tenham sido diretamente afetados (Sheehan, 2005, p. 155).

Mas, em vários outros aspectos, os sistemas se diferenciam. Primeiramente, a segurança coletiva objetiva a formação de uma só aliança universal, dentro da qual deve haver 
ordem, enquanto o balanço de poder é caracterizado por várias alianças que competem entre si. Em outros termos, a segurança coletiva espera comportamentos cooperativos dos Estados, ao passo que o balanço de poder deposita fé apenas em suas predisposições competitivas.

Em segundo lugar, há diferença naquilo que dispara a resposta do sistema de segurança. Na segurança coletiva, a agressão exige a ação de todos os outros Estados. No balanço de poder, a agressão ou a conquista de território em si não são concebidas como verdadeiras ameaças, mas sim a busca da hegemonia. Ganhos territoriais via guerras podem ocorrer, desde que não resultem em grandes assimetrias de poder, diferenciando excessivamente um Estado dos demais.

Em terceiro, há diferença no grau em que instituições estão envolvidas. O sistema de balanço de poder, tendo lógica competitiva, dispensa instituições complexas para operá-lo. Em tese, pode funcionar espontaneamente, embora o concerto europeu tenha contado com conferências concatenadas, entre as grandes potências, que funcionavam como colegiado para manejar questões territoriais na Europa. Embora este colegiado administrasse aspectos do balanço de poder, o sistema em si era baseado em reações espontâneas aos desequilíbrios de poder. As conferências auxiliavam a coordenação das grandes potências, mas não eram o alicerce do funcionamento do balanço de poder. Já o sistema de segurança coletiva pressupõe maior institucionalização. Nele, o compromisso de responder coletivamente à agressão é transformado em obrigação jurídica (Sheehan, 2005, p. 158). O sistema é organizado em torno do dever de considerar o ataque contra qualquer membro da aliança como ato de guerra contra todos os seus membros (Sheehan, 2005, p. 153). A segurança nacional deixa de ser assunto que diga respeito a um Estado individualmente considerado, e passa a ser "responsabilidade coletiva, compartilhada pela comunidade internacional conjuntamente organizada." (Boyle, 1985 , p. 53)

Esta transição (do balanço de poder à segurança coletiva) pode ser lida como expressão do ganho de relevância da langue do direito internacional para lidar com assuntos de segurança internacional, contexto em que o compromisso juridicamente estabelecido de resposta coletiva à agressão é um exemplo de parole. Este ganho de relevância não deve ser confundido, no entanto, com o sucesso desta modalidade de discurso em reger as relações internacionais do período, como abordado adiante. 
Liga das Nações e idealismo wilsoniano

A instituição concebida para abrigar o novo modelo de segurança internacional foi a Liga das Nações. Sua formação foi fortemente influenciada pelas ideias de Woodrow Wilson, presidente dos Estados Unidos à época das negociações do Tratado de Versalhes, que fixou os termos da paz entre as potências aliadas e as potências centrais (a principal das quais era a Alemanha), e que abrigou o Pacto da Liga das Nações como integrante de seu texto.

O wilsonianismo é caracterizado por sua postura idealista a respeito das relações internacionais. Ikenberry (2001, p. 127) exemplifica o ponto com uma fala de Wilson. "O que objetivamos é o império do direito [rule of law], baseado no consentimento dos governados, e sustentado pelas opiniões organizadas da humanidade." Edward Carr (1946) se refere a esta postura como utópica, e identifica em seu desprendimento com a realidade do funcionamento das relações internacionais uma das causas para o fracasso do projeto de paz no entreguerras. Carr narra que Wilson, a caminho da Conferência de Paz, foi questionado se o projeto da Liga das Nações funcionaria, ao que ele respondeu: "Se não funcionar, deve-se fazer com que funcione.” (apud Carr, 1946, p. 8) Wilson propunha que as interações entre Estados fossem conduzidas em bases jurídicas e morais. O direito deve moldar a realidade. Sua postura é híbrida, entre o legalismo positivista e o moralismo: ao mesmo tempo que apelava para formas jurídicas como ordenadoras das relações internacionais, fundamentava em bases morais a necessidade de que estas formas existissem (Boyle, 1985, p. 52). Interações pacíficas eram percebidas como imperativo moral da humanidade em sua evolução civilizacional.

O projeto de Wilson era criar uma organização internacional de caráter universal, baseada em regras, e que vinculasse Estados democráticos. O balanço de poder seria substituído por mecanismos jurídicos de manejo de poder e de solução de disputas (Ikenberry, 2001, p. 117). A nova organização era postulada por Wilson como o meio para garantir a independência e a integridade territorial de todos os países (Ikenberry, 2001, p. 127).

Ikenberry identifica três fatores na base da crença de Wilson de que a Liga funcionaria. O primeiro deles é a percepção de que o mundo estaria experimentando uma revolução democrática: o czarismo havia caído na Rússia em 1917, e os principais estados vitoriosos na Primeira Guerra eram democracias (Ikenberry, 2001, p. 118). O segundo fator é a opinião pública. A mensagem de Wilson tinha grande apelo popular, e Wilson, coerentemente com o pensamento liberal, acreditava que a opinião pública fosse capaz de moldar a condução da política internacional (Ikenberry, 2001, p. 122). O terceiro fator é a posição dos Estados Unidos como nova potência hegemônica, ocupando o lugar que antes era 
da Grã-Bretanha. Era a nova liderança econômica e militar. Os estoques americanos de ouro igualavam quase a metade das reservas de todo o mundo (Ikenberry, 2001, p. 121). A posição dos Estados Unidos fazia com que Wilson estivesse confiante em sua capacidade de influenciar a ordem no pós-guerra. Exemplo disto, trazido por Ikenberry (2001, p. 122) é a fala de Wilson a um de seus encarregados militares, em 1917, a respeito dos aliados: "Quando a guerra acabar, nós poderemos forçá-los a nosso modo de pensar, porque até lá eles estarão, entre outras coisas, financeiramente em nossas mãos."

Mas as bases da crença de Wilson não se verificaram. Segundo Ikenberry, não ocorreu a revolução democrática mundial que Wilson esperava. "A maré de fermento revolucionário chegou ao topo no início de 1918, e a direção foi decisivamente conservadora à medida que a guerra caminhava para o fim.” (Ikenberry, 2001, p. 162) Paralelamente a isto, Wilson não conseguiu converter a ascendência norte-americana e o apelo moral à opinião pública em mudanças políticas concretas. Wilson postulava uma paz sem vencedores, mas sobretudo a França, embora também a Grã-Bretanha, não dispensava a imposição de reparações de guerra à Alemanha. Wilson desejava que o tratado de paz erigisse novas bases para as relações internacionais. Seus aliados desejavam punir a Alemanha e evitar novas possibilidades de sua ascensão militar (Keynes, 2002 [1919]). Como resultado, embora a Liga das Nações tivesse sido criada, aquilo que Wilson caracterizava negativamente como a velha política internacional mostrou-se persistente (Ikenberry, 2001).

Os Estados Unidos não fizeram parte da Liga. O principal motivo foi a rejeição das implicações da segurança coletiva. Parte do porquê disto está relacionada às eleições legislativas nos Estados Unidos, que tanto no Senado quando na House of Representatives resultaram em maioria republicana, sendo Wilson democrata. Wilson ficou isolado (Ikenberry, 2001, p. 149). A outra parte está relacionada às disposições constitucionais norteamericanas que atribuíam o poder de declaração de guerra ao Congresso e às implicações dos dispositivos do Pacto da Liga das Nações sobre este poder.

O artigo 10 do Pacto trazia a substância daquilo que deveria ser protegido, ao declarar que todos os membros da Liga tinham independência política e integridade territorial invioláveis. Fixava, a respeito deste ponto, o compromisso de ação coletiva contra a agressão externa a um membro da Liga. O artigo 11 reforçava esta posição, ao afirmar que qualquer guerra ou ameaça de guerra seria pertinente a toda a Liga. Os artigos 12 a 15 estabeleciam procedimentos para solução pacífica de controvérsias entre os membros da Liga, dentre os quais a diplomacia, negociações no Conselho da Liga, a arbitragem e submissão à Corte Permanente de Justiça Internacional (CPJI). E o artigo 16 prescrevia que, caso um membro da 
Liga recorresse à guerra ao invés de aos procedimentos de solução pacífica de controvérsias, isto seria considerado um ato de guerra contra todos os demais membros, que deveriam imediatamente impor sanções de interrupção total das relações comerciais, financeiras e de trânsito de pessoas com o Estado infrator. Caberia ao Conselho da Liga recomendar os meios militares, navais e aéreos com os quais os membros deveriam contribuir para fins de resposta armada. O artigo também previa a possibilidade de exclusão do infrator.

No Senado norte-americano, além dos senadores que partilhavam da postura isolacionista a respeito da política externa, a proposta da Liga encontrou resistência por ter sido recebida como a transferência do poder de declaração de guerra do Congresso a uma organização internacional. Em outros termos, o Senado rejeitou o engajamento dos Estados Unidos no sistema de segurança coletiva. Wilson argumentou que o tratado estabelecia que os Estados Unidos seriam membros do Conselho, a quem caberia decidir questões envolvendo uso da força. Ali, os Estados Unidos teriam poder de veto sobre a decisão. Em decorrência disto, não haveria possibilidade de que os Estados Unidos fossem empurrados a guerras indesejadas (Ikenberry, 2001, p. 153). Ainda assim, a argumentação de Wilson não satisfez o Senado (até mesmo porque não deixava de implicar transferência do poder de decisão sobre a guerra do Congresso para os representantes norte-americanos no Conselho da Liga), que rejeitou a ratificação (Ikenberry, 2001, p. 154). A não participação dos Estados Unidos na Liga é apontada como fator para seu fracasso na década de 1930 (Sheehan, 2005, p. 161).

De toda forma, o projeto de segurança coletiva é uma manifestação particular (parole) da projeção da langue do direito internacional para a área da segurança internacional, e que sinaliza seu ganho de relevância.

\section{Organização Internacional do Trabalho e Corte Permanente de Justiça Internacional}

O Tratado de Versalhes, embora sem os Estados Unidos, foi levado a cabo pelos demais aliados. Como resultado, criaram-se novas instituições: além da Liga das Nações, o Tratado estabeleceu a Organização Internacional do Trabalho (OIT) e a Corte Permanente de Justiça Internacional (CPJI).

Sediada em Genebra, na Suíça, e funcionando desde 1919, a presença da OIT no cenário internacional é significativa de transformações socioeconômicas substanciais. Seu funcionamento incorpora a presença de classes, e não só da representação política estatal: para além de representantes do Estado, a organização opera com representantes da classe patronal e dos trabalhadores. A instituição parece poder ser encarada como reflexo das 
pressões domésticas por melhoria das condições de trabalho e das condições sociais, decorrentes da influência da expansão das democracias de massa, da industrialização e da urbanização. Neste sentido, esta nova fase do direito internacional também se dedica "à promoção de objetivos sociais", sendo "informada e moldada por desenvolvimentos sociais e que refletiam as realidades reveladas pela sociologia e a ciência política" (Anghie, 2004, p. 128).

A CPJI, embora prevista no Tratado de Versalhes, só começou a operar em 1922, em Haia. Suas funções eram consultivas e de solução de casos contenciosos. A CPJI poderia tanto emitir opiniões consultivas a partir de questões formuladas pelo Conselho ou Assembleia da Liga das Nações quanto resolver disputas entre Estados. Neste último aspecto, sua jurisdição estava restrita a assuntos de "natureza jurídica" (como em oposição à "natureza política", o que permitia válvula de escape ao exercício de sua jurisdição), e dependia da aceitação dos Estados. Estes poderiam reconhecer diretamente a jurisdição compulsória da Corte (que poderia ser feita com ou sem reservas), comprometer-se por cláusulas jurisdicionais em tratados, ou firmar acordos especiais com o objetivo específico de submeter uma controvérsia à CPJI. Seus juízes eram eleitos pelo Conselho e pela Assembleia da Liga das Nações, e deveriam ser representativos "das principais formas de civilização e dos principais sistemas jurídicos do mundo" (Art. 9). A tonalidade civilizadora da Corte também estava presente em seu artigo 38, que menciona entre as fontes de direito os "princípios gerais de direito reconhecidos pelas nações civilizadas." Estas distinções remetem à discussão anteriormente feita, a respeito da distinção cultural e racial sobre a qual o direito internacional europeu foi fundado, e que é indissociável do modo como este direito se universalizou. Este ponto evidencia como a langue falada permaneceu a mesma nesse período.

A CPJI é representativa da demanda por solução pacífica de controvérsias neste período do direito internacional. $\mathrm{O}$ recurso à arbitragem internacional já havia aumentado desde o final do século XIX, com a Corte Permanente de Arbitragem, de 1899. Mas a criação da CPJI representou passo além na concepção do direito como ferramenta de ordem nas relações internacionais: o direito como projeto ou técnica de paz. Este projeto engloba, além da solução pacífica de controvérsias, também a proscrição da guerra e o compromisso jurídico de resposta coletiva à agressão como partes integrantes do direito internacional. A afirmação de proscrição da guerra precisa, porém, ser aproximada com ressalvas. A Liga das Nações não a excluiu das relações internacionais, nem mesmo no plano do dever ser: a guerra é resposta lícita à agressão contra a independência e a integridade territorial, e continuava cabendo a cada membro interpretar o significado destas categorias. Além disso, o recurso à guerra era 
lícito diante da falha dos mecanismos de solução pacífica. O Pacto Kellogg-Briand, de 1928, ficou conhecido como sendo o documento que positivou a proibição da guerra. Mas, sob o título de autodefesa ou legítima defesa, cujo sentido estava aberto à interpretação de cada Estado (Koskenniemi, 2004, p. 377), a guerra continuava a poder ser conduzida com respaldo jurídico. Estas aberturas interpretativas - sempre relegadas ao arbítrio dos Estados, individualmente - estão associadas ao fracasso do projeto do direito internacional no entreguerras como técnica de paz. Ainda assim, os juristas internacionalistas acreditavam neste projeto, e era esta a linguagem falada nas organizações internacionais do momento. Em outros termos, a diplomacia do interesse nacional juridicamente indomado perdeu espaço, entre os juristas, para a perspectiva de ordenação jurídica das relações internacionais. Que este desdobramento não tenha se refletido efetivamente no comportamento dos Estados é indício do fracasso do projeto de capturar a diplomacia por formas jurídicas.

\section{A moldura cognitiva dos juristas no novo cenário internacional institucionalizado}

A presença acentuada de organizações multilaterais no direito internacional do pósguerra criou novos ambientes de trabalho para os juristas internacionalistas. Entre 1919 e 1925, os agentes de organizações internacionais passaram de cerca de uma centena a milhares, trabalhando na Liga das Nações, na Corte Permanente de Justiça Internacional e na Organização Internacional do Trabalho. As novas organizações criaram demanda por profissionais inclinados à causa universalista do direito internacional, ou seja, com orientação cosmopolita. Este é o novo mercado direto de postos de trabalho. Indiretamente, criou-se "um mercado sem precedentes de consultoria em assuntos públicos internacionais." (Sacriste; Vauchez, 2007, p. 88) Diversos tratados continham cláusulas de solução pacífica de controvérsias, fomentando a demanda por expertise em mediação, arbitragem e disputas judiciais. Segundo Sacriste e Vauchez (2007, p. 99), este fenômeno dos anos 1920 está associado ao ganho de força que o direito internacional teria recebido naquele momento. Como parte de uma "economia da reputação" que veio à tona no período, exigia-se desses profissionais tanto habilidades técnicas no uso do direito internacional quanto independência dos jogos políticos e diplomáticos.

Esta economia da reputação favorecia os profissionais formados nos diversos institutos de direito internacional. Os provedores de "crédito simbólico" eram variados, e integravam aquilo que Sacriste e Vauchez descrevem como um "boom de cosmopolitismo acadêmico." (2007, p. 93) Além do Institut de Droit International de Ghent, de 1873, 
funcionavam como centros de formação a Hague Academy of International Law, fundada em 1913; o Institut de Hautes Études Internationales de Paris, de 1923; e o Institut de Hautes Études Internationales de Genève, de 1926. Todos eles adotavam retórica universalista e currículo voltado ao recrutamento para as novas posições institucionais multilaterais (2007, p. 89). A "moldura cognitiva compartilhada" por estes institutos, e incorporada pelos internacionalistas, envolvia a "técnica jurídica de paz". A obtenção da paz pelo direito era postulada como "único método legítimo e eficiente de impor um conjunto de obrigações e restrições à política do poder." (Sacriste; Vauchez, 2007, p. 85)

A moldura cognitiva dos internacionalistas da época era caracterizada por certos pontos fundamentais ${ }^{39}$. O primeiro deles é a proposta de uso do método científico e da racionalidade como ferramenta mais eficiente para superar o viés das origens nacionais e dos pontos de vista políticos. Neste sentido, nota-se a influência da crença positivista na possibilidade de objetividade e neutralidade no fazer ciência. O segundo ponto é a crença na superioridade do modo judicial de solução de conflitos. E o terceiro, a ele associado, é a afirmação da necessidade de jurisdição permanente, com competência universal e compulsória, apresentada como mecanismo de solução de controvérsias superior à conciliação ou à arbitragem. O mais curioso destes pontos é, sem dúvida, o sentido de desenvolvimento gradual do direito como projeto de paz, que permitia apresentar os fracassos do direito internacional em domar a política do poder como parte de lenta caminhada rumo ao plano superior de rule of law. Por exemplo, a falha na aceitação universal da jurisdição da CPJI era justificada por membros do IDI como "estágio necessário" na construção da ordem, "seguindo os estágios iniciais de anarquia (primeiro passo), balanço de poder (segundo passo), conciliação política (terceiro passo), arbitragem jurídica (quarto passo) e jurisdição permanente (passo atual).” (Sacriste; Vauchez, 2007, p. 104) Nota-se que os primeiros passos são mais informados pela política, ao passo que os últimos, pelo direito. No fundo, o tipo de parole aqui descrito revela o adensamento do projeto de versar as relações internacionais segundo a langue descrita na subseção anterior: uma continuidade aprofundada.

A criação de novas oportunidades de trabalho no plano supranacional conviveu com as posições acadêmicas e políticas dos internacionalistas em seus países. A época é marcada pela “diferenciação e especialização da prática do direito internacional”, associada à maior estruturação jurídica da política internacional na época (Sacriste; Vauchez, 2007, p. 92). Sacriste e Vauchez identificam quatro padrões de carreiras. No plano nacional, continua a

\footnotetext{
39 Tais pontos são encarados aqui como caracterizadores de uma concepção geral prevalente, sem a implicação de que o período tenha sido marcado pela plena adesão dos internacionalistas aos aspectos aqui levantados.
} 
haver posições para experts nacionais (abrangendo tanto jurisconsultos quanto gentlemenpoliticians of law: juristas internacionalistas que assumem cargos políticos) e para acadêmicos produzindo doutrina nacional. No plano internacional, abre-se maior espaço para os international legal experts e para juristas acadêmicos com produção cosmopolita, como Kelsen, Jellinek e outros (Sacriste; Vauchez, 2007, p. 92).

Era comum que juristas assumissem múltiplas posições, nacionais e internacionais, acadêmicas e de expertise. O argumento principal de Sacriste e Vauchez (2007) é o de que a força do direito internacional nos anos 1920 não decorreu de seus atributos intrínsecos, mas da demanda por profissionais pelas novas instituições multilaterais e do capital social da comunidade jurídica que ocupou estas novas posições, animada por um espírito cosmopolita. A nuance consiste em que, ocupando as mais variadas posições, os juristas internacionalistas estavam situados de modo a influenciar a demanda por instituições multilaterais e solução pacífica de controvérsias (ocupando posições de Estado, ou provendo expertise jurídica para a política externa) e, ao mesmo tempo, a prover a força de trabalho para satisfazê-la (cargos na burocracia das instituições multilaterais, arbitragem e CPJI, bem como na formação acadêmica de novos juristas internacionalistas).

\section{Duas abordagens judiciais da soberania pela CPJI: Wimbledon e Lotus}

Com a Liga das Nações, e a emergência de uma ordem internacional institucionalizada, passa-se a querer representar a soberania dos Estados como sendo delimitada pela ordem internacional. Esta não é uma novidade radical: o pensamento dos juristas do IDI, com seus matizes organicistas, já buscava o direito internacional derivado da consciência jurídica (cuja fonte por excelência é o próprio jurista) e não exatamente da vontade soberana livre (Koskenniemi, 2004). Mas este não é o único ponto. A afirmação da limitação dos Estados mesmo diante de sua capacidade soberana - ou em virtude dela - é acompanhada de certo argumento bastante positivista, carregado de voluntarismo e formalismo, e que busca preservar a liberdade dos Estados na ausência de normas positivas. Trata-se da analogia, no plano internacional, daquilo que o "princípio da legalidade" representa no plano interno para o indivíduo no direito privado: pode-se fazer tudo aquilo que a lei não proíba. Estes dois padrões (soberania conciliada com limitação, e liberdade soberana diante da ausência de limitação positivada) ingressaram nos precedentes da CPJI, nos casos Wimbledon - o primeiro contencioso julgado pela Corte - e Lotus, e são instâncias de parole 
que ajudam a exemplificar aplicações da langue do direito internacional neste período. Os dois casos envolvem navios a vapor.

O caso Wimbledon: soberania como feixe de direitos e obrigações

No caso Wimbledon, o navio britânico que deu nome ao caso fazia frete da costa francesa no Mar do Norte à Polônia, carregando munições, no ano de 1921. Mas a Polônia estava em guerra com a Rússia, e a Alemanha havia declarado neutralidade. Por isso, a Alemanha recusou a passagem do Wimbledon pelo Canal de Kiel, que liga o Mar do Norte ao Báltico, passando exclusivamente por território alemão. Porém, em decorrência da capitulação alemã na Primeira Guerra, o Canal de Kiel havia sido internacionalizado. O tratado de Versalhes obrigava a Alemanha a deixar passar navios estrangeiros tanto em tempos de guerra quanto de paz, salvo se se tratasse de navio de país em guerra com a própria Alemanha. Como resultado da recusa alemã, o Wimbledon teve que dar a volta pela Dinamarca, atrasando a viagem em 13 dias.

O litígio foi levado à CPJI por um grupo de aliados na Primeira Guerra: Grã-Bretanha, França, Itália e Japão. A Alemanha se defendeu, entre outras coisas, invocando o direito ao controle de seu território em virtude de sua capacidade soberana. Também alegou que o Tratado de Versalhes contemplava situações de paz e de guerra, mas não de neutralidade. Não contemplaria, assim, esta situação. A CPJI rejeitou os argumentos alemães. Quanto à questão da neutralidade, o raciocínio da Corte foi exegético: se o Tratado de Versalhes houvesse desejado abrir exceção para circunstâncias de neutralidade, isto estaria no texto. A Corte considerou que a obrigação de manter o Canal de Kiel aberto aos navios estrangeiros era suficientemente clara. Quanto ao ponto em que a soberania da Alemanha foi colocada em questão, a Corte afirmou:

A Corte não encara a conclusão de qualquer tratado pelo qual um Estado se vincule
a fazer ou deixar de fazer algo como um ato de abandono de sua soberania. Sem
dúvida, qualquer convenção que crie uma obrigação deste tipo coloca uma restrição
ao exercício dos direitos soberanos do Estado, no sentido de requerer que eles sejam
exercidos de certo modo. Mas o direito de entrar em acordos internacionais é um
atributo da soberania do Estado. (PCIJ, 1923, p. 25)

Ou seja, se a Alemanha tinha obrigação de permitir a passagem, decorrente do direito internacional, esta obrigação existia, no fundo, pelo assentimento soberano da própria Alemanha em se vincular ao Tratado de Versalhes. É claro que, sob esta perspectiva positivista, o fato de que o Tratado de Versalhes foi obtido sob coerção, em contexto de 
capitulação na guerra, não retirou sua validade. O caso é representativo da noção de soberania que se desprende do Estado e se projeta na ordem internacional, para então vinculá-lo. Como ressalta Koskenniemi (2004, p. 173), no caso Wimbledon a soberania é vista como "feixe de direitos e obrigações" delimitados pelo direito internacional, que se sobrepõe ao Estado.

\section{O caso Lotus: liberdade diante da omissão do direito positivo}

No Caso Lotus, a CPJI se posicionou sobre situação inversa: o que acontece quando não há tratado (ou costume) para regular as relações entre Estados? Qual é o padrão de comportamento a se esperar na ausência de normas emanadas da vontade dos Estados?

Em 1926, dois navios colidiram em alto-mar: o SS Lotus, de bandeira francesa, e o Boz-Kourt, de bandeira turca. O navio turco afundou, resultando na morte de oito nacionais turcos. O Lotus seguiu viagem rumo a Constantinopla (atual Istambul). Ao aportar, o capitão francês foi preso, acusado de homicídio. A França levou o caso à CPJI, alegando que a Turquia não poderia exercer jurisdição sobre evento ocorrido em alto-mar. Afinal, tratava-se de jurisdição sobre nacional francês em navio francês. Em 1927, a Corte, por maioria, decidiu o caso contra a França. Na ausência de normas de direito internacional que proibissem o exercício de jurisdição criminal em alto mar, a Turquia não poderia ser impedida de fazê-lo:

O direito internacional governa relações entre Estados independentes. As regras de
direito que vinculam os Estados emanam, portanto, de sua livre vontade, expressas
em convenções e nos costumes geralmente aceitos como expressão de princípios de
direito, e estabelecidos para regular as relações entre estas comunidades
independentes coexistentes, ou buscando alcançar objetivos comuns. Restrições à
independência dos Estados não podem, portanto, ser presumidas. (PCIJ, 1927, p. 18)

Na ausência de proibições, o comportamento dos Estados é livre. A normatividade é fortemente identificada com a soberania: se a vontade soberana não se manifestou no sentido de vincular-se, ela permanece livre para se autodeterminar. A decisão valoriza a postura voluntarista a respeito das relações jurídicas: o direito emana da vontade dos soberanos. E também valoriza o formalismo: o direito deve ser procurado nas formas jurídicas, como tratados e costumes. Na sua ausência, obrigações jurídicas não podem ser presumidas, e o resultado é a liberdade de ação. Por isso a Turquia pôde julgar o capitão do navio francês por fato ocorrido em alto-mar.

Cabe, a este respeito, um parêntese. Que o caso tenha sido submetido à CPJI pela França é representativo de nova sensibilidade no direito internacional do entreguerras, na comparação com o que existia anteriormente: a prática do envio de canhoneiras para afirmar 
interesses europeus (gunboat diplomacy) era corriqueira. Ao longo do século XIX, a França havia contado com regime de jurisdição consular para seus nacionais na Turquia. O direito internacional anterior afirmava, na prática, que as autoridades turcas não poderiam atingir os franceses, nem mesmo no próprio território turco. Agora, afirmava que a Turquia poderia julgar um francês por algo que ocorreu em lugar que não pertence a ninguém. E a resposta não foi o envio das canhoneiras a Constantinopla, mas a judicialização do litígio.

Fechando este parêntese, é possível perceber como os juristas da época encontravam indícios práticos para justificar sua crença no direito internacional como projeto ordenador das relações internacionais, como técnica de paz. Dentre eles, desponta Lauterpacht. Porém, ele não partilhava de raciocínios como o do Caso Lotus, que representa o primado da soberania, e afirma haver lacunas no direito internacional não preenchidas pela vontade soberana. A breve abordagem de alguns contornos do pensamento deste autor servirá para exemplificar, como outra instância de parole, ainda outro projeto de relações internacionais informadas pelo discurso jurídico. Desta vez, com pretensões de completude do direito internacional e valorização do papel do juiz no plano internacional.

Um projeto doutrinário para a soberania e o direito do entreguerras: Lauterpacht

Hersch Lauterpacht (1897-1960) foi um dos juristas internacionalistas que integraram o esforço para ressignificar - e limitar - concepções anteriores de soberania. Lauterpacht criticou a exaltação excessiva do positivismo ao Estado e à soberania, a que atribuía o fracasso do direito internacional em evitar a Primeira Guerra Mundial. "Isto deveria ser trocado por um sistema de direito e ordem cosmopolita sem lacunas e profissionalmente administrado, à imagem do Estado liberal.” (Koskenniemi, 2004, p. 355) Koskenniemi descreve sua perspectiva como nominalista: as regras jurídicas não têm substância imutável ou presa ao texto. São o que delas se interpreta (2004, p. 368). Esta postura permite ao jurista o "pragmatismo institucional" no manejo das formas jurídicas (2004, p. 357). O direito pode ser o que for necessário para levar a cabo o projeto de rule of law nas relações internacionais: não pode estar preso ao voluntarismo dos Estados. Neste sentido, Lauterpacht também concebe a soberania como "feixe de direitos e poderes conferidos ao Estado pela ordem jurídica”, estes podendo ser “divididos e limitados” (Koskenniemi, 2004, p. 365). O problema essencial da afirmação da soberania no direito internacional anterior é atribuir aos Estados a autointerpretação de seus deveres e direitos, bem como dos limites destes. A solução de Lauterpacht para que a soberania não apresente o Estado como juiz de si mesmo é 
institucional, e de matizes judiciais, análogos ao papel do juiz no common law, que articula as formas jurídicas na formação da policy. A existência de jurisdição sobre os Estados é o mecanismo para sua limitação (Koskenniemi, 2004, p. 408).

Lauterpacht apresentava a visão de que o império do direito no cenário internacional evoluiria da fase dominada pela soberania estatal para outra, superior, em que certa administração pública se formaria e implementaria o ideal de rule of law (Koskenniemi, 2004, p. 358). Como se observa, esta postura de desenvolvimento jurídico gradual se encaixa no que Sacriste e Vauchez (2007) chamam de realismo utópico: o fracasso ou insuficiência do direito do momento, frente à política, é justificado como passo em relação a estágio superior mais evoluído, em que a política perde lugar para a ordenação jurídica completa das relações internacionais. Koskenniemi se refere a isto como "visão histórica progressiva" do direito internacional (2004, p. 373). O grande projeto de Lauterpacht é o de direito internacional completo, sem lacunas. Ele afirmava que isto já existia: a interpretação do jurista - ou melhor, a interpretação judicial - supriria todas as lacunas. A implicação é que o juiz seria capaz de suplantar o voluntarismo dos Estados. Também por isso, era crítico da distinção entre controvérsias jurídicas e políticas na CPJI: para ele, todas as controvérsias teriam natureza jurídica, e portanto deveriam ser judicializáveis. No futuro, o direito internacional deveria cumprir a função de "superar a imperfeição contemporânea" rumo ao "governo organizado de Estados" (Koskenniemi, 2004, p. 373). A utopia de Lauterpacht "é um mundo governado por juízes.” (Koskenniemi, 2004, p. 404)

A esse respeito, o sistema de mandatos da Liga das Nações - que foi objeto dos primeiros escritos de Lauterpacht - pode ser visto como uma tentativa, embora mal sucedida, de transferir para a jurisdição da comunidade internacional aquilo que antes estava a cargo do Estado soberano: a administração colonial. A nova institucionalidade para a administração colonial (sistema de mandatos no âmbito de uma organização internacional) é, sim, uma diferença em relação ao período anterior à Primeira Guerra. No entanto, as diferenças podem ser lidas como modulações de parole. No fundo, o substrato que lhe dá sentido permanece o mesmo: a langue do direito internacional contou com distinções civilizacionais em sua origem, e estas distinções habilitavam falas sobre a incapacidade de certos povos para o autogoverno. A mudança de roupagem jurídica, abaixo descrita, tampouco implicou a extinção do papel instrumental que o direito internacional teve em fornecer as formas para expansão comercial por colônias e mandatos. 
O direito internacional dos não soberanos: sistema de mandatos e colonialismo

O sistema de mandatos foi criado como parte do Pacto da Liga das Nações. Foi a nova forma de administração de colônias e protetorados das potências derrotadas na Primeira Guerra Mundial, sobretudo Alemanha e Turquia. As analogias do direito privado (Castro, 2012), elementos bastante salientes da langue do direito internacional clássico, foram preservadas na nova configuração do direito internacional: nos mandatos, continua havendo a ideia de que uma potência exerce tutela sobre um povo incapaz para os atos da vida civil, ou, neste caso, a vida internacional. Afinal, o Pacto afirmava que os mandatos seriam estabelecidos em territórios "habitados por povos ainda não capazes de manterem-se sozinhos nas condições árduas do mundo moderno.” (Art. 22.4) A diferença formal (isto é, de parole) entre as categorias anteriores de colônia e protetorado e o novo sistema de mandatos consiste em que, nas primeiras, a administração é feita em nome da própria potência colonial, ao passo que, no segundo, a administração recebe rótulo distinto. É encargo da potência mandatária, mas exercida em nome da Liga das Nações. Em nome, portanto, de uma organização internacional representativa da comunidade de nações (Koskenniemi, 2004, p. 173). Trata-se de nova vestimenta jurídica para a preservação de práticas coloniais já existentes:

\footnotetext{
O sistema de mandatos, ao adotar o conceito de tutela, justificava o gerenciamento de povos colonizados apresentando-o como guiado pela preocupação com os interesses nativos e pelo desejo de promover seu autogoverno, ao invés de desejos egoístas da potência colonizadora. (Anghie, 2004, p. 140)
}

O critério de discriminação cultural e racial forneceu a base para a diferenciação de três tipos de mandatos: classes A, B e C. Os mandatos classe A eram ex-partes do império turco, e compreendiam territórios do Oriente Médio: Palestina, Iraque, Síria, Líbano e Transjordânia. Estes territórios eram considerados relativamente mais civilizados que os demais, mais capazes de autogoverno, e deveriam se tornar independentes logo. Eram administrados mais analogamente aos protetorados do que às colônias: contavam com governo local próprio. Mas a promessa de independência foi elusiva. Só o Iraque conseguiu independência durante o sistema de mandatos. Os demais, apenas após a Segunda Guerra, e a Palestina permanece no limbo jurídico, seu reconhecimento pleno ainda sendo objeto de disputa.

Os mandatos classe B compreendiam povos considerados como de estágio de civilização inferior, posicionados sobretudo na região central da África, e anteriormente pertencentes à Alemanha. Incluíam Camarões, Ruanda, e territórios correspondentes à atual 
Tanzânia e Togo. Diferentemente da classe A, que contava com autogoverno, estes territórios eram administrados diretamente pela potencia mandatária. Nenhum destes territórios conseguiu se libertar na vigência do sistema de mandatos.

A classe $\mathrm{C}$ era composta de territórios de população esparsa, de território pequeno, que eram remotos ou contíguos ao território do mandatário. Entraram nesta categoria a Namíbia e as Ilhas do Pacífico, como Samoa e Nova Guiné. Eram administrados como se fossem porções do território do próprio mandatário, e sob as leis deste (Anghie, 2004, p. 122). Tampouco estes territórios deixaram de ser mandatos na vigência da Liga das Nações (Hillier, 1998, p. 198; Koskenniemi, 2004, p. 171).

Depreende-se que todas estas classificações são reformulações de categorias jurídicas anteriores (mesma langue), adaptadas para fazer frente a uma ordem jurídica que, discursivamente, é institucionalizada em torno do conceito de comunidade internacional. Assim, os mandatos “A” eram a reedição do protetorado. Os mandatos "B”, das colônias. E os mandatos "C", da conquista por anexação. Em todos estes casos, a diferença consiste em que o novo jugo é feito em nome do interesse coletivo da comunidade internacional de Estados.

Segundo o artigo 22 do Pacto da Liga das Nações, o bem estar e o desenvolvimento destes povos formavam uma "missão sagrada da civilização". Que obrigações jurídicas estariam implicadas nesta missão civilizadora? De acordo com Anghie (2004, p. 120), havia obrigações substantivas e procedimentais. A parte substantiva referia-se ao dever de prover bem-estar moral e material, numa reedição da fórmula da Conferência de Berlim, abordada na seção 2.1.2. Mais uma vez, o comércio e a incorporação de instituições europeias tiveram a dupla função de provê-los. Curiosamente, não houve proscrição do uso de trabalho forçado pelas potências mandatárias: "projetos de infraestrutura eram de tal importância que o Conselho da Liga permitia trabalho compulsório ou forçado como remuneração por 'trabalhos e serviços públicos essenciais"”, como ferrovias, estradas e portos (Anghie, 2004, p. 167).

Cabe, aqui, breve parêntese a respeito do trabalho nativo. A inserção de instituições europeias e do "mercado" nos mandatos contribuía para minar as estruturas tradicionais das sociedades locais. Quando isto acontecia, pessoas que estavam engajadas no modo de vida tradicional e de subsistência passavam a ser "mão de obra livre" (Anghie, 2004, p. 171). Depreende-se que a supressão das instituições tradicionais locais era importante para a criação de mão de obra do tipo "produtivo", capaz, portanto, de engajar-se tanto na produção de excedentes comercializáveis como no tipo de consumo que é conectado a uma cadeia produtiva da sociedade de mercado, e não à mera subsistência. Nota-se, aqui, a direção da relação entre progresso, mercado ou comércio, e instituições locais. "O desenvolvimento 
econômico era o sistema supremo ao qual todas as instituições estavam subordinadas e que todas a outras instituições deveriam servir." (Anghie, 2004, p. 173-4) Saltam aos olhos as notas coloniais desta concepção de progresso.

Entre as obrigações procedimentais das potências mandatárias estava a submissão de relatório anual ao Conselho da Liga. O relatório era apreciado pela Comissão Permanente de Mandatos da Liga. Esta comissão também instituiu sistema pelo qual as populações dos territórios sob mandato poderiam submeter-lhe petições. No entanto, isto só poderia ser feito via potência mandatária, conferindo-lhe, na prática, o poder de filtrar o que chegava aos olhos da Liga (Anghie, 2004, p. 175). Além disso, havia a previsão de que controvérsias a respeito do exercício do mandato fossem submetidas à CPJI. Porém, os territórios sob mandato não tinham personalidade jurídica para fazê-lo: apenas outro Estado poderia ingressar com o processo para questionar as práticas do Estado mandatário. Não é surpreendente, portanto, que os mecanismos de supervisão não tenham sido bem sucedidos (Anghie, 2004, p. 123).

A importância econômica dos territórios sob mandato para as potências que os administravam não pôde ser apagada pelo discurso de missão civilizadora incorporado pelo direito internacional. Formalmente, a missão consistiria em "civilizar", e não em explorar os mandatos. Porém, a empreitada colonial, assim prorrogada, continuava a cumprir funções econômicas e estratégicas para as metrópoles, que agora se apresentavam sob o status jurídico de potências mandatárias. $\mathrm{O}$ acesso a matérias-primas representava tanto a segurança alimentar para a Europa quanto o suprimento de suas cadeias de produção industrial, ao passo que a abertura de novos mercados consumidores era necessária para escoar a produção. Não se pode perder de vista que a Europa, "em casa", contava com pressões de populações já urbanizadas, mais politicamente organizadas, e que clamavam por pleno emprego e melhoria das condições sociais. Anghie traz como exemplo disto a fala "sem rodeios" de Frederick Lugard (1858-1945), cuja "expertise" como conquistador colonial britânico e administrador de Hong Kong e da Nigéria foi, significativamente, aproveitada na Comissão Permanente de Mandatos da Liga das Nações. "As democracias de hoje pedem o direito ao trabalho, e a satisfação deste direito é impossível sem as matérias-primas dos trópicos, de um lado, e seus mercados, de outro.” (apud Anghie, 2004, p. 158)

Paralelamente a isto, os Estados Unidos, que não eram membros da Liga e portanto não integravam o sistema de mandatos, advogavam a "política de portas abertas" para todos os territórios administrados pelo esquema da Liga. "Isto asseguraria que todos os Estados pudessem comerciar e investir em pé de igualdade, e sem medo de discriminação, nos territórios sob mandato.” (Anghie, 2004, p. 143) Quer pelo acesso direto (isto, é, tornando-se 
potência mandatária), quer pelo indireto (via liberdade comercial), os recursos coloniais ou dos territórios sob mandato eram cobiçados pelas potências centrais.

Embora o sistema de mandatos tenha sido feito em nome do princípio da autodeterminação dos povos, uma das principais bandeiras do idealismo wilsoniano (Anghie, 2004, p. 139-40), apenas o Iraque, como anteriormente apontado, conseguiu independência formal durante sua vigência. Para os demais, o sistema de mandatos foi a prorrogação dos arranjos coloniais da fase anterior do direito internacional clássico. Ele representou a reformulação jurídica, e não a extinção, das práticas coloniais (Anghie, 2004, p. 178).

Como Anghie (2004, p. 144) destaca, a configuração do direito internacional do sistema de mandatos é paradoxal. Por um lado, sua motivação é estabelecida em torno do princípio da autodeterminação dos povos. Depreende-se da missão civilizadora envolvida nos mandatos o projeto pedagógico europeu em relação à organização das sociedades atrasadas no formato político Estado, de rule of law, e de sociedade de mercado. Por outro lado, transparece a importância econômica e estratégica dos mandatos para as metrópoles, como partes de seu próprio modelo de desenvolvimento e conectados a suas estruturas sociais. A partir deste outro aspecto, torna-se difícil visualizar como os mandatos poderiam ter efetivamente promovido o autogoverno. Ao passo que o discurso jurídico é de emancipação, as formas jurídicas e a necessidade econômica envolvida nos mandatos em pouco ou nada favoreciam a autodeterminação. O mandato é a atualização, no entreguerras, de categorias jurídicas de universalização do direito internacional europeu via assimilação de povos nãoeuropeus: como as colônias e os protetorados. Agora, a colonização contava com o apoio moral de ser feita em nome da comunidade internacional, e não apenas da potência colonizadora.

Focalizar apenas o propósito anunciado (de autodeterminação dos tutelados) do sistema de mandatos pode conduzir à interpretação de que este falhou. No entanto, esta interpretação pode facilmente ser descartada em favor de outra, que observa a funcionalidade econômica e estratégica do sistema de mandatos: como mecanismo jurídico de legitimação do domínio e expansão do comércio dos países avançados. Nisto, o direito internacional no entreguerras foi bem sucedido. Mais uma vez, o direito internacional funcionou na relação entre os Estados anglo-europeus e os outros. Mas foi incapaz de tornar realidade, em outro aspecto, sua concepção de segurança coletiva, cujos problemas estão relacionados preponderantemente às relações das grandes potências entre si. 


\section{O fracasso do direito internacional clássico como técnica de paz}

Edward Carr (1944) atribuiu o fracasso do projeto de segurança coletiva da Liga das Nações ao caráter idealista ou utópico das aspirações wilsonianas. Viu neste idealismo elementos de perigo: seu divórcio em relação à realidade deve ser suprimido pela postura realista, apresentada como mais apropriada a informar concepções de segurança. $\mathrm{O}$ argumento remonta facilmente à lógica de Maquiavel (2004 [1513], p. 73): aquele que pretende fazer profissão de bondade, entre tantos que são maus, antes alcança a própria ruína. Este é o anúncio da perda de espaço do direito internacional para a teoria das relações internacionais como conhecimento informativo da ordem entre os Estados (e como discurso para representála). Outra possibilidade de leitura enfatiza pontos em que o projeto wilsoniano, sobretudo quanto à Liga das Nações, não se completou como previsto: suas aspirações de mundo governado pelo direito foram minadas por inserções interpretativas baseadas em prioridades políticas dos Estados. O sentido é o de que, ignorando ou contrariando o projeto de Lauterpacht de substituir o arbítrio estatal pelo judicial, os Estados crescentemente submeteram às provisões do Pacto da Liga ao autojuízo soberano estatal.

Neste sentido, Michael Sheehan (2005) aponta o modo como o artigo 10 do Pacto da Liga das Nações foi inoperante. O dispositivo, como se viu, afirmava a integridade territorial e a independência política dos membros, atribuindo o dever de responder coletivamente em caso de agressão a um deles. Na prática, a interpretação conferida ao artigo foi a de que caberia aos próprios Estados, cada qual em seu juízo, decidir que ações deveriam ser tomadas, não implicando obrigação de ir à guerra em defesa do Estado atacado. Embora tenha sido invocado diversas vezes, o artigo nunca foi aplicado na prática: não gerou resposta coletiva a atos de guerra contra membros. O Japão atacou a China, tomando a região da Manchúria, em 1931, e a Liga não enviou tropas em seu socorro. A fraqueza da Europa pós-crise de 1929 pode estar associada à falha em ativar o mecanismo de segurança coletiva. Mas o fato permanece de que o disposto no Pacto não funcionou (Sheehan, 2005, p. 159-60; Koskenniemi, 2004, p. 378).

Igualmente problemático tornou-se o artigo 16, segundo o qual o membro que fizesse ataque em desrespeito a suas obrigações diante do Pacto, como procurar primeiro a solução pacífica de controvérsias (prevista nos artigos 12 a 15), seria considerado como tendo cometido ato de guerra contra todos os demais membros da Liga. Como resultado, sanções comerciais, financeiras e de restrição ao trânsito de pessoas deveriam ser imediatamente impostas. Em 1921, porém, a Assembleia da Liga resolveu que caberia aos próprios membros 
(ao invés da Liga) decidir se os artigos 12 a 15 (solução pacífica de controvérsias) haviam sido violados, e que não havia obrigação automática de engajamento em guerra coletiva.

O artigo 16 só foi implementado uma vez, contra a Itália após sua invasão da Abissínia em 1935. Os membros da Liga não impuseram todas as sanções imediatas, e os seus esforços minguados falharam em impressionar a Itália, levando a uma quebra da confiança na Liga e na segurança coletiva. (Sheehan, 2005, p. 159-60)

Para além desses problemas, a Liga foi politicamente esvaziada. A principal potência econômica e militar da época ficou de fora desde o início. Outras potências se retiraram, como o Japão e a Alemanha, em 1933, a Itália, em 1937. A Liga mostrou apenas formalmente os seus “dentes” em 1939, ao expulsar a União Soviética após a invasão da Finlândia (Ginneken, 2006, p. 20). Mas até lá, já havia se provado incapaz de efetivamente conter a violência nas relações internacionais. O projeto de segurança coletiva pressupunha a adesão das potências, de modo que nenhuma, sozinha, fosse mais forte que a aliança formada (Sheehan, 2005, p. 161). Mas muitas das principais potências estavam fora da Liga quando a guerra eclodiu, em 1939.

Direito, segurança internacional e aspectos de relações econômicas no entreguerras

O fracasso do projeto de paz do direito internacional clássico do entreguerras também pode ser lido de modo a enfatizar sua incapacidade de fomentar relações econômicas cooperativas. Em As consequências econômicas da paz, de 1919, Keynes (2002) havia alertado para os perigos da imposição de pesadas reparações de guerra à Alemanha. Outro aspecto está relacionado à associação que Karl Polanyi (2001) faz entre os períodos de estabilidade nas relações europeias e o funcionamento do Padrão-Ouro Internacional. Este havia se rompido com a Primeira Guerra (vide seções 3.1 e 3.2). Tentou-se ressuscitá-lo na década de 1920, mas ele nunca mais foi o mesmo. Sua operação entrou em choque com as condições políticas, econômicas e sociais do entreguerras, que já não eram as mesmas do final do século XIX. Sufrágio ampliado, partidos trabalhistas e sindicatos organizados representavam maior pressão por direitos sociais. O compromisso dos Estados de priorizar a estabilidade cambial rompeu-se. A crise dos anos 1930, por sua vez, propeliu os Estados a medidas protetivas, inclusive no campo da política monetária, inaugurando a era de desvalorizações competitivas das moedas nacionais, e enterrando de vez o Padrão-Ouro Internacional.

O projeto do direito internacional clássico do entreguerras preservou a tradição anterior, informada pelo liberalismo, de tratar a economia como algo que o direito devesse sustentar, 
mas cuja autonomia não poderia retirar. Garantir a ordem, a propriedade/território, os contratos/tratados: isto cabe ao direito. Fixar regras substantivas para o comércio, a moeda e as finanças estava fora de seu âmbito: este espaço era preenchido pelo Padrão-Ouro Internacional.

O direito internacional clássico teve, sim, atuação de suporte em relação ao comércio. Colônias, protetorados e mandatos foram importantes instrumentais do direito internacional para a garantia de acesso a matérias-primas e a abertura de mercados consumidores. A permissibilidade do uso da força nestas empreitadas, assim como na cobrança de dívidas por meio da diplomacia da canhoneira, também foi relevante para a rentabilidade e a segurança dos investimentos e a garantia da ordem para o comércio.

As formas jurídicas do direito internacional clássico buscaram deixar o caminho aberto ao comércio e, no campo monetário e das finanças, à operação do Padrão-Ouro Internacional. Seu lugar foi de apoio, e nada mais. O positivismo jurídico permitiu ao jurista internacionalista prender-se às formas jurídicas de seu vocabulário, isentando-o de representar intelectualmente a política econômica externa dos Estados e a cooperação econômica internacional. Estes espaços estavam situados no campo autônomo da economia, por mais que tivessem implicações normativas para o comportamento dos Estados.

Nisto o direito internacional clássico é diferente do que viria após a Segunda Guerra Mundial. A economia passa a ser assunto de preocupação direta das instituições jurídicas formais da ordem internacional. O direito internacional se fragmenta, e várias de suas áreas passam a incorporar linguagens econômicas. Paralelamente, no campo da segurança internacional, o direito internacional perde espaço para o apelo realista com que foi inaugurada a teoria das relações internacionais. A técnica da segurança coletiva apoiada em instrumentos jurídicos persiste, mas é logo complementada (ou mais, ultrapassada em importância) pelo equilíbrio bipolar de poder, baseado no balanço de terror implicado na ameaça de guerra nuclear (Sheehan, 2005), e sobre o qual o direito passa a ter pouco a dizer. No campo das ideias, as posturas positivistas preponderantes no entreguerras cedem lugar ao pragmatismo jurídico, que passa a incorporar elementos de outros campos do conhecimento, em seu esforço de articular as diversas áreas do direito internacional fragmentado.

\subsection{Fragmentação do direito internacional}

Em 1948, George Kennan caracterizou o que seria o principal desafio para a política externa dos Estados Unidos, em relatório do Departamento de Estado: 
Temos cerca de $50 \%$ da riqueza mundial, mas apenas $6,3 \%$ da população... Nossa verdadeira tarefa no período que se aproxima é criar um padrão de relações que nos permita manter essa posição de disparidade sem detrimento de nossa segurança nacional. (Kennan, 1976[1948], p. 524)

Durante a Segunda Guerra Mundial, os Estados Unidos singularizaram-se em poder econômico e militar, consolidando seu lugar de superpotência hegemônica. Após a guerra, o principal projeto concorrente a esta hegemonia foi o da União Soviética. Esta, no entanto, nem sempre foi vista como ameaça pelos Estados Unidos. Neste período, buscou-se o ideal de segurança coletiva como esforço conjunto das grandes potências, em negociações que envolveram principalmente os Estados Unidos, a União Soviética e o Reino Unido.

Com o passar de poucos anos e o aumento das tensões, configurou-se a Guerra Fria, e ao projeto da segurança coletiva sobrepuseram-se outros. O bloco capitalista buscou instituições de cooperação econômica e militar entre seus membros, e simultaneamente buscou cooperar contra o avanço da União Soviética. O Plano Marshall, a OTAN, as organizações de Bretton Woods e o GATT foram iniciativas pertinentes a este contexto. $\mathrm{O}$ resultado foi uma nova ordem internacional fragmentária, em que passaram a conviver instituições de propósitos e escopos os mais variados: universais e regionais, de cooperação política, militar, comercial, financeira, monetária e técnica. Como descreve Ikenberry (2001, p. 164), este cenário conta com um "bolo de várias camadas” de organizações internacionais de todo tipo.

Neste processo, também o direito internacional se fragmenta, dando origem a novos campos, que conformam expertises com identidades próprias, comunidades próprias, e vocabulários também próprios. A comunidade da segurança internacional passa a se comunicar em "língua estranha" à dos juristas internacionalistas: emerge a teoria das relações internacionais (TRI). No campo das instituições de Bretton Woods, a nova língua é o direito internacional econômico, diferente da tradição do direito internacional clássico (cujo "vácuo" de regulação econômica havia, em parte, sido anteriormente ocupado pelo POI).

Ao lado do embate de superpotências e seus respectivos blocos, o cenário internacional do período foi marcado pela profusão de Estados recém-independentes. $\mathrm{O}$ encontro colonial não se dava mais sob as formas do sistema de mandatos da Liga das Nações, mas sob o Conselho de Tutela das Nações Unidas. De colonialismo, passa-se a falar em pós-colonialismo, e também este deixa suas marcas no direito internacional. O póscolonialismo foi a sensibilidade que animou não só a proposta de nova ordem econômica internacional, mas também de reformulação de doutrinas do direito internacional, como na área de responsabilidade internacional, sucessão de Estados e soberania sobre recursos 
naturais. Em resposta, países industrializados articularam a formação de novos campos, como o direito dos contratos internacionais e o direito internacional dos investimentos estrangeiros, buscando também fortalecer doutrinas como direitos adquiridos e a de minimum standards, entre outros desdobramentos.

Esta seção identifica tendências fragmentárias do direito internacional em duas vias, que são a configuração organizacional fragmentária no pós-guerra - o bolo de várias camadas, de que fala Ikenberry - e os impulsos fragmentários advindos do processo de independência dos países da África, da Ásia e do Pacífico. Para tanto, primeiro discute o projeto de segurança internacional na ONU (seção 2.2.1). Em seguida, apresenta a lógica de segurança envolvida no equilíbrio bipolar, voltando a atenção primeiramente à OTAN, e então aos engastes econômicos desta concepção de segurança: Plano Marshall, instituições de Bretton Woods e GATT (seção 2.2.2). Por fim, a seção volta-se tanto à administração colonial sob o sistema de tutela da ONU quanto à proliferação de novos países independentes, com impactos para concepções de cooperação econômica internacional (2.2.3). Ao longo destas subseções, enfatizam-se impactos para o direito internacional, de modo a associar os desdobramentos institucionais à formação de novas comunidades de juristas com identidades, objetivos e vocabulários próprios. Ao final desta seção, elabora-se o significado da fragmentação do direito internacional, bem como as respostas surgidas para lidar com ela (2.2.4).

Passa-se, a seguir, a uma das camadas do "bolo organizacional" do pós-guerra, corporificada no sistema da ONU.

\subsubsection{ONU: segurança coletiva e seu enlace com questões socioeconômicas}

É comum que textos de direito internacional público identifiquem a formação da ONU como principal acontecimento para a estruturação jurídica das relações internacionais no pósguerra $^{40}$. Quando a análise é orientada por critérios meramente formais, a Carta da ONU pode ser vista como rico repositório de formas jurídicas para a estruturação de relações pacíficas entre Estados. O texto é permeado pela linguagem jurídica. O preâmbulo fala em direitos

\footnotetext{
${ }^{40}$ Neste sentido: "A Carta da ONU é simultaneamente o marco e o precípuo instrumento instaurador de uma nova ordem internacional" (Saliba, 2008, p. 173). O manual de Accioly (1991), atualmente com 20 edições publicadas, ensina que "Sob a égide das Nações Unidas o direito internacional passa a ter grande importância" (Acccioly, 1991, p. 10). A lição é o inverso do que a presente tese propõe. Menezes (2005) leva a visão ao extremo: "Não se pode deixar de observar que a Carta das Nações unidas, por ser um documento ratificado, sem reservas, por toda a comunidade internacional, seguramente estabelece, a partir de sua edição uma nova ordem jurídica de relação entre Estados, preconizando em seu preâmbulo a renúncia à guerra, o respeito aos tratados e a outras fontes de Direito Internacional, estabelecendo, desse modo, um verdadeiro Estado mundial de direitos, ou uma ordem assentada sobre o Direito Internacional." (Menezes, 2005, p. 44-5)
} 
fundamentais, dignidade e valor do ser humano, igualdade de direitos entre homens e mulheres, e entre nações grandes e pequenas, além de "estabelecer condições sob as quais a justiça e o respeito às obrigações decorrentes de tratados e de outras fontes de direito internacional possam ser mantidos". Na porção final, o artigo 102 cria o dever de que todos os tratados sejam registrados junto ao Secretariado, e o artigo 103 coloca a Carta da ONU como hierarquicamente superior a demais obrigações de direito internacional. A Carta tem como anexo o Estatuto da Corte Internacional de Justiça, órgão que tem a dupla função de emitir opiniões consultivas e de resolver litígios entre Estados que aceitem a sua jurisdição.

De fato, é fácil perceber o teor jurídico da arquitetura da ONU a partir destes elementos: direitos materiais, procedimentos, hierarquias normativas, solução judicial de conflitos. Daí a crer que a organização tenha sido fundamental para a manutenção coletiva da paz e da segurança internacionais é um passo - afinal, este é o primeiro propósito afirmado na Carta da ONU. No entanto, as relações internacionais no pós-guerra se desenrolaram de modo que não pôde ser abrangido pelo projeto de segurança coletiva pensado para funcionar sob a administração da ONU e especificamente do Conselho de Segurança ${ }^{41}$. Ainda assim, cabe descrevê-lo, visto que a ONU foi um "projeto de paz mundial mediante a organização legal da comunidade de Estados.” (Guimarães, 1999, p. 104)

O projeto da ONU buscava evitar a repetição do fracasso da Liga das Nações pela modificação da fórmula de decisão, preservando o ideal de segurança coletiva. Na Liga, o Conselho era composto por membros permanentes e não permanentes, mas todos tinham direito de veto, porque se exigia decisão unânime em assuntos que envolvessem uso da força. A ONU acentua a relativização da "igualdade soberana" entre os Estados ${ }^{42} \mathrm{em}$ seu Conselho de Segurança. Agora, apenas os membros permanentes têm poder de veto: Estados Unidos,

\footnotetext{
${ }^{41} \mathrm{Na}$ interpretação de Samuel Pinheiro Guimarães, o sistema da ONU não se prestou ao controle das relações entre grandes potências, mas foi "o principal sistema de controle das estruturas hegemônicas sobre a periferia, em cujo cerne se encontra o Conselho de Segurança." (1999, p. 103) A ausência de representação da periferia internacional dentre os membros permanentes do Conselho é apontada como uma das razões para tanto, e portanto como fator de déficit de sua legitimidade. O raciocínio está na base da defesa que Guimarães faz de assento permanente para o Brasil num Conselho de Segurança reformado (1999, p. 115-8).

${ }^{42}$ Estabelecendo tensão com o Artigo 2.1 da Carta, que afirma que a ONU é "baseada no princípio da igualdade de todos os seus Membros". Esta crítica, no entanto, pode ser considerada rasa tanto pelos formalistas jurídicos quanto por aqueles, de inclinação realista, que rejeitam o projeto de ordenação jurídica das relações internacionais. No primeiro flanco, o formalismo jurídico permite invocar a noção de que a composição do Conselho de Segurança é disposição especial em relação ao caráter geral da norma do Artigo 2.1. Consegue-se harmonizar a tensão, prescrevendo que o especial prevalece sobre o geral, sem, no entanto, eliminá-lo. No outro flanco, a própria noção de igualdade soberana é descartada como ilusão descabida diante do mundo regido por relações de poder: mera forma, sem expressividade ou reflexo na condução real dos assuntos entre Estados.
} 
União Soviética, Reino Unido, China e França ${ }^{43}$. A restrição no poder de barrar decisões fez com que o novo sistema pudesse funcionar em certas ocasiões. Em comparação com a Liga das Nações, trata-se de formidável mudança. Isto foi visto como virada "pragmática" em relação ao "idealismo" anterior. Afinal, o Conselho da Liga não foi capaz de aprovar respostas armadas coletivas em nenhuma situação (Sheehan, 2005, p. 160). Já o Conselho de Segurança da ONU possui longo histórico de decisões positivas sobre intervenções envolvendo uso da força, missões de peacekeeping e peacebuilding, além de imposição de sanções econômicas. Em épocas de paralisia do Conselho de Segurança, em virtude do jogo bipolar, o emprego de uso da força chegou a ser autorizado pela própria Assembleia Geral da ONU (Saliba, 2008).

Além da concepção de segurança coletiva, o projeto de paz da ONU abrigava a Assembleia Geral, como foro de representação de todos os membros, também encarregada de funções na solução pacífica de controvérsias; a Corte Internacional de Justiça, como órgão judicial de solução de controvérsias, mas sem jurisdição universal nem compulsória; o Conselho de Tutela, como mecanismo de administração colonial ${ }^{44}$, e o Conselho Econômico e Social (ECOSOC).

Neste último aspecto, a Carta da ONU possui um capítulo sobre "cooperação internacional econômica e social", que identifica "condições de estabilidade e bem estar" como "necessárias às relações pacíficas e amistosas entre as nações". Entre as preocupações materiais deste capítulo estão: qualidade de vida, pleno emprego, condições sanitárias, cooperação cultural e educacional, respeito a direitos humanos e não discriminação por raça, sexo, língua ou religião. Outro capítulo da Carta aborda aspectos institucionais e procedimentais da cooperação econômica e social. Ao configurar o Conselho Econômico e Social, atribui-lhe funções de fazer estudos, relatórios e recomendações em temas de cooperação econômica e social e de direitos humanos, bem como de apresentar projetos de convenções e de realizar conferências envolvendo esta temática ${ }^{45}$. Mas nenhum poder efetivamente decisório foi atribuído ao Conselho Econômico e Social (Conforti, 2005, p. 2412).

\footnotetext{
${ }^{43} \mathrm{O}$ arranjo a respeito da composição do Conselho de Segurança foi feito entre Roosevelt, Churchill e Stalin em 1945, e ficou conhecido como "fórmula de Yalta" (Conforti, 2005, p. 3). Na prática, o assento chinês já mudou de mãos, não sendo tão "permanente" quanto à primeira vista se poderia imaginar (Saliba; Pena, 2009).

${ }^{44} \mathrm{O}$ Conselho de Tutela da ONU será abordado na subseção 2.2.3.

${ }^{45}$ Dentre as atividades filiadas ao ECOSOC, destaca-se a Comissão Econômica das Nações Unidas para a América Latina e o Caribe (CEPAL), criada em 1948 e sediada em Santiago, no Chile (Guimarães, 1999, p. 160). Entre suas atribuições estão o estudo das condições econômicas dos países da região e a elaboração de recomendações para o desenvolvimento. A CEPAL ficou conhecida por abrigar a perspectiva dependentista a respeito das relações econômicas internacionais. Vide seção 1.2.
} 
Nota-se, aqui, o enlace entre questões econômicas e sociais e de segurança internacional $^{46}$. A presença destes elementos evidencia transformações na concepção de ordem econômica no pós-guerra: não mais o liberalismo do tipo laissez-faire, que busca a autonomia da economia e o distanciamento de preocupações sociais ${ }^{47}$, mas o liberalismo administrado, assistido - embedded liberalism, nos termos de John Ruggie (1982) -, que busca conciliar o funcionamento de economias internacionalmente integradas com a atenção às condições sociais internas aos países.

A ONU abrigou em sua arquitetura tanto o projeto de segurança coletiva quanto a percepção de que questões socioeconômicas e de segurança estão entrelaçadas. No entanto, a política da segurança internacional migrou para outros espaços de decisão quando a Guerra Fria começou (cf. Mazower, 2008, p. 189, 196). Dizer que o Conselho de Segurança "mostrou seus dentes", na prática, não é o mesmo que afirmar que a ONU tenha sido bem sucedida em seu projeto de segurança coletiva. O Conselho de Segurança, em larga medida paralisado, perdeu importância relativa, apesar de seu alto status formal na estrutura da ONU. O espaço das decisões importantes foi ocupado pela OTAN e pelas políticas externas dos Estados Unidos e da União Soviética, em lógica que não era mais de segurança coletiva mundial, mas de balanço de poder e, especificamente, de balanço nuclear de terror (Sheehan, 2005). Quanto ao Conselho Econômico e Social, este não chegou a se posicionar efetivamente como centro de articulação da cooperação econômica entre os Estados. As iniciativas mais relevantes de cooperação econômica do período se deram por meio do Plano Marshall, das instituições de Bretton Woods e do GATT, além do projeto comunitarista europeu.

Apesar da pretensão de ordenação jurídica das relações internacionais abrigada pela Carta da ONU, de sua grande abrangência temática e de seu escopo universal ${ }^{48}$, a ONU não conseguiu se tornar a base institucional da cooperação internacional nem em segurança, nem em matéria econômica. $\mathrm{Na}$ verdade, o processo de cooperação se desenvolveu em outras

\footnotetext{
${ }^{46}$ A associação entre segurança coletiva e assuntos socioeconômicos integra o histórico das negociações para formação da ONU. A Carta do Atlântico, de 1942, previa o estabelecimento de sistema de segurança coletiva acompanhado de cooperação em assuntos econômicos e sociais. A Conferência de Dumbarton Oaks, de 1944, reafirmou a fórmula, que foi consolidada na Conferência de São Francisco, de 1945, que debateu a redação da Carta da ONU (Conforti, 2005, p. 1-3).

${ }^{47}$ Afinal, no liberalismo clássico o bem-estar social é, em tese, decorrência automática do livre funcionamento do mercado, dotado, pela mão invisível, da capacidade de alocar de maneira ótima os recursos na sociedade. Outra possibilidade de leitura tem matizes darwinistas. Por esta perspectiva, a sociedade se aperfeiçoa pela sobrevivência dos mais aptos à concorrência no livre mercado. Este tema é abordado na seção 3.1.

${ }^{48}$ Segundo Conforti (2005, p. 7-8), é mais fácil caracterizar o que não está sob o escopo da ONU do que aquilo que está. A única exceção temática estabelecida se refere a assuntos sob a jurisdição doméstica dos Estados. Notadamente, é difícil definir o que seja exclusivamente pertinente à esfera doméstica. A vagueza da formula faz com que qualquer assunto possa ser discutido pela ONU.
} 
instituições com o surgimento da Guerra Fria ${ }^{49}$. Neste contexto, a relevância do papel da ONU é secundária.

\subsubsection{Equilíbrio bipolar e conexões entre segurança e cooperação econômica}

A ONU foi fundada com a pressuposição de que "as grandes nações unir-se-iam para manter a paz", mas esta união foi, na prática, comprometida pela divisão bipolar do mundo. Com a Guerra Fria, tornou-se "evidente que os princípios de organização fundamentais das Nações Unidas tinham sido completamente inadequados." (Kaplan; Katzenbach, 1964, p. 5860) No novo cenário, a atuação da ONU ficou restrita na prática: "a mediação, a conciliação e o debate de foro são as principais funções das Nações Unidas.” (1964, p. 327)

A Guerra Fria se estendeu do final de 1947 (acirrando-se após 1950) à queda do Muro de Berlim, em 1989 (Ikenberry, 2001, p. 163). O período não foi caracterizado por embates armados diretos entre Estados Unidos e União Soviética, mas por tensionamentos representados sobretudo pela escalada armamentista e nuclear. $O$ pano de fundo da competição militar era a disputa ideológica, política e econômica, a opor dois modelos de organização da vida em sociedade: capitalismo e socialismo. Embora o embate da Guerra Fria tenha sido de abrangência global, o principal cenário da disputa foi, desde o início, a Europa. Ao final da Segunda Guerra Mundial, o território europeu estava ocupado tanto por tropas de potências capitalistas, sobretudo dos Estados Unidos e do Reino Unido, quanto por tropas soviéticas. A divisão territorial da Europa em dois blocos é representada pela própria divisão da Alemanha e de Berlim em setores capitalista e socialista. Em linhas gerais, a Europa Ocidental ficou sob a esfera de influência dos Estados Unidos, e a Oriental, da União Soviética.

Múltiplos arranjos institucionais se desenrolaram neste contexto. A (i) OTAN foi a organização que coordenou a cooperação em segurança internacional da Aliança Atlântica, e operou no cenário de equilíbrio nuclear bipolar. A partir da concepção de que assuntos de segurança e de economia estavam entrelaçados, outro grupo de iniciativas e instituições desempenhou papel na ordem do pós-guerra entre as economias capitalistas ocidentais,

\footnotetext{
${ }^{49}$ Não por outra razão, Ikenberry (2001) deixa de atribuir maior importância ao Sistema da ONU ao narrar os arranjos do pós-guerra em 1945, focalizando, ao invés, dois arranjos interrelacionados: um deles, voltado à cooperação militar contra o avanço soviético, outro, voltado à cooperação econômica nas áreas monetária, financeira e comercial entre economias capitalistas. Ao passo que o primeiro arranjo representa a cooperação "contra" um elemento externo, o segundo arranjo representa a cooperação "intra" bloco, num contexto em que a força dos laços econômicos é vista como elemento de estabilidade e de prevenção ao avanço do socialismo.
} 
abrangendo o (ii) Plano Marshall e os movimentos iniciais de integração europeia, (iii) as instituições de Bretton Woods e (iv) o GATT.

Estes quatro pontos serão abordados a seguir ${ }^{50}$.

OTAN, equilíbrio de terror e o lugar do direito internacional na política de segurança

No "bolo de múltiplas camadas" de que fala Ikenberry, a OTAN ocupa posição simultânea em duas. A lógica de sua criação atendeu a uma política de "dupla contenção". Uma é extrabloco, outra, intrabloco. No primeiro sentido, a OTAN desempenhava o papel de contenção do avanço soviético ${ }^{51}$. No segundo sentido, ao institucionalizar as relações de segurança na Europa Ocidental, a organização contribuiu para arrefecer temores quanto à Alemanha. Além da dupla contenção, a OTAN também foi a forma de envolver os Estados Unidos nos assuntos de segurança europeia, na posição de garante. Assim, diz-se que a OTAN foi desenhada para "manter os russos fora, os alemães contidos, e os americanos dentro". (Ikenberry, 2001, p. 206)

A contraparte institucional soviética foi a Organização do Pacto de Varsóvia, de 1955. As duas organizações foram a expressão institucional formal do confronto bipolar. No entanto, a concepção de segurança internacional do período não foi contida unicamente pelos espaços decisórios destas organizações. Na realidade, a OTAN e o Pacto de Varsóvia tiveram funções complementares a certa prática informal, e não o contrário. Trata-se da política de dissuasão nuclear ("nuclear deterrence"). Ela foi o elemento central da concepção de segurança a orientar tanto a política externa norte-americana quanto a soviética.

A dissuasão nuclear é fundada no equilíbrio de terror (Sheehan, 2005). Numa primeira etapa da Guerra Fria, apenas os Estados Unidos tiveram potencial estratégico de detonar

\footnotetext{
${ }^{50}$ Cabe justificar, aqui, a não adoção de ordem cronológica na exposição dos desdobramentos relacionados a segurança e cooperação econômica no pós-guerra. Cronologicamente, a ordem é a seguinte: (i) a Conferência de Bretton Woods, responsável pela criação do FMI e do BIRD, antecessor do Banco Mundial, ocorreu em 1944; (ii) o GATT é de 1947; (iii) a Guerra Fria é iniciada em 1947, com a Doutrina Truman; (iv) o Plano Marshall começou a operar em 1948, e (v) a OTAN é de 1949. A abordagem aqui feita privilegiou a lógica de duas camadas integradas de organização no pós-guerra, a primeira voltada à segurança contra a expansão soviética, e a segunda voltada ao fortalecimento econômico interno ao bloco capitalista. Neste sentido, expôs-se primeiro (i) a Guerra Fria e (ii) a OTAN, para enfatizar o aspecto de segurança, e em seguida (iii) o Plano Marshall, (iv) as organizações de Bretton Woods e (v) o GATT. A ressalva é aqui feita no sentido de não passar a impressão de que Bretton Woods e o GATT tenham sido originalmente pensados no contexto de bipolaridade mundial. Não o foram. No entanto, cumpriram um papel de fortalecimento das relações econômicas no bloco capitalista, por sua vez com repercussões na esfera da segurança, como se verá adiante.

${ }^{51}$ Em 1947, a Doutrina Truman inaugurou a "ordem de contenção", conclamando o povo norte-americano à resistência contra os perigos de dominação mundial pelo socialismo soviético (Ikenberry, 2001, p. 171), e é considerada o marco da Guerra Fria. A OTAN, em 1949, neste sentido, foi o mecanismo institucional de engajamento da Aliança Atlântica na Doutrina Truman, envolvendo as potências europeias ocidentais na política de contenção do bloco soviético.
} 
ogivas nucleares em território soviético ${ }^{52}$. Com o passar do tempo, a União Soviética também passou a dominar mísseis balísticos intercontinentais. A partir de então, a segurança dos próprios arsenais nucleares norte-americanos foi posta em risco. Passou-se a temer que, ao sofrer um primeiro ataque nuclear (first strike), a potência atingida perdesse a capacidade de retaliar. Este temor aguçou a corrida nuclear, e os dois Estados passaram a desenvolver políticas de second strike, ou seja, de criar capacidade de retaliação mesmo após sofrer ataque nuclear. Para isso, ampliaram seus arsenais, e criaram múltiplos posicionamentos: em mísseis protegidos em silos subterrâneos, aviões bombardeiros em stand-by e submarinos nucleares. A escalada armamentista resultou na certeza de que o ataque nuclear iniciado por uma parte, ainda que bem sucedido, seria respondido com o second strike, a leva de retaliação, resultando na situação chamada de destruição mútua assegurada ("mutually assured destruction", ou "MAD”). Neste ponto, alcança-se o equilíbrio de terror ${ }^{53}$ (Sheehan, 2005, p. 171-81). O resultado é a dissuasão, pois a partir da configuração da situação "MAD”, nenhuma das partes do conflito nuclear pode obter ganhos com o conflito.

A linguagem ou expertise empregada para manejar a concepção de segurança internacional fundada no equilíbrio de terror e na dissuasão nuclear não foi o direito internacional, mas a teoria das relações internacionais (TRI). A TRI emergiu a partir da crítica realista à perspectiva idealista ou utópica das relações internacionais, associada ao direito internacional do entreguerras. O idealismo deste último "foi completamente desacreditado após a guerra." (Koskenniemi, 2004, p. 466) Um dos expoentes dessa crítica foi Edward Carr (1946), que atribuiu a eclosão da Segunda Guerra Mundial à tradição intelectual liberal que privilegiava ideais morais, princípios e normas jurídicas, conformando modo utópico de pensamento, ao invés da postura científica de descrição das relações de poder no cenário internacional como elas são, e não como deveriam ser.

Nesta linha, Hans Morgenthau, formado na tradição do direito, ajudou a conformar a postura realista ao romper com sua formação inicial. Sua postura era a de que os "juristas

\footnotetext{
${ }^{52}$ Em contrapartida, os soviéticos tinham capacidade estratégica para atingir a Europa Ocidental e o Japão. Os Estados Unidos e a Grã-Bretanha também posicionaram armas nucleares direcionadas contra cidades da Europa Oriental. A prática de fazer povos "reféns" era comum no jogo nuclear. Como Sheehan (2005, p. 181) destaca, o uso de armas nucleares contra estes povos para atingir indiretamente uma das duas superpotências teria sido um "ataque genocida a inocentes". Mas o linguajar de segurança, da época, atenuava o sentido genocida por trás da política de segurança fundada em armas nucleares: "os estrategistas preferiam falar em 'alvo de compensação' [counter-value targeting] e em 'danos colaterais' para descrever genocídio."

${ }^{53}$ No sistema de equilíbrio de poder do século XIX, a guerra era recurso normal e necessário para reequilibrar as potências em cenário multipolar. No sistema de equilíbrio de terror, a ocorrência da guerra nuclear é falha catastrófica do próprio sistema de segurança internacional (Sheehan, 2005, p. 179). Neste sentido, a destruição mútua assegurada, conseguida via abundância de armamentos nucleares, opera de modo a dissuadir o início da guerra nuclear. Apesar de os dois sistemas fundarem-se num "balanço", a estrutura e a lógica de operação é muito distinta nos dois casos.
} 
internacionalistas estavam lidando com uma ilusão" (Koskenniemi, 2004, p. 459). O formalismo do direito internacional fez com que este campo do conhecimento se tornasse alheio ao modo como a normatividade das relações internacionais de fato se expressava ${ }^{54}$. Morgenthau migrou do direito internacional para a TRI, passando a descrever "os principais aspectos da ordem do pós-guerra como um reino de (puro) poder, e da política, mas não de direito." ${ }^{, 55}$ (Koskenniemi, 2004, p. 460) A TRI, e não o direito internacional, passou a prover as formas intelectuais com que a política externa norte-americana passou a ser articulada. (Koskenniemi, 2004, p. 470) A postura realista foi hegemônica até o final da década de 1960 (Castro, 2005b, p. 122).

Observam-se, portanto, algumas transições. O conceito de segurança coletiva da ONU foi erodido, e transferido para organizações regionais de segurança, como a OTAN e o Pacto de Varsóvia. A partir da divisão mundial em blocos contrapostos, a fratura da concepção de segurança coletiva deu lugar à busca da segurança internacional no equilíbrio nuclear de terror. Outra transição ocorreu no plano das representações intelectuais a informar a formulação da política externa, setor em que o direito internacional perdeu exclusividade como linguagem, em boa medida cedendo lugar para a TRI.

Estes desdobramentos representam o aspecto mais marcadamente "de segurança" da nova ordem internacional. Não foram, porém, os únicos desenvolvimentos institucionais relevantes para a estabilidade nas relações internacionais. A partir da percepção do engaste entre questões econômicas e de segurança, outras iniciativas tiveram lugar. Uma delas foi o Plano Marshall.

\section{Plano Marshall, integração europeia e formação do direito comunitário}

Em meados de 1947, o relatório da Agência Central de Inteligência norte-americana, a CIA, afirmou: “o maior perigo à segurança dos Estados Unidos é a possibilidade de colapso econômico na Europa Ocidental e a consequente ascensão ao poder de elementos

\footnotetext{
${ }^{54} \mathrm{Na}$ perspectiva realista da TRI, a normatividade das relações internacionais pode ser encontrada em seis princípios formulados por Morgenthau, segundo os quais (i) leis objetivas fundadas na natureza humana governam a política; (ii) a política é conduzida pelo interesse definido em termos de poder; (iii) o interesse que move a política é determinado pelo ambiente político e cultural; (iv) o Estado deve preferir o sucesso da ação política à conduta moralmente aprovável; (v) o interesse definido em termos de pode suprime a identificação de interesses baseados em nacionalismos particulares ou na providência divina; e (vi) a política é autônoma em relação à economia, a ética, o direito e à religião (Castro, 2005b, p. 120).

${ }^{55} \mathrm{Na}$ perspectiva de Morgenthau, o direito internacional ainda teria papel a desempenhar nas relações internacionais, mas apenas secundariamente, em questões acessórias, fora dos assuntos centrais de política externa, como "os limites da jurisdição territorial, os direitos de navios em águas estrangeiras, e o status de representantes diplomáticos." (Koskenniemi, 2004, p. 464)
} 
comunistas." (apud Ikenberry, 2001, p. 180) O Plano Marshall foi pensado no mesmo ano como resposta a esta preocupação, e começou a operar em 1948. Ele foi reflexo do fato de que os formuladores da política externa norte-americana passaram a conceber questões econômicas e de segurança como interligadas na contenção do socialismo soviético. "Os oficiais de segurança chegaram a esta visão ao reconhecer que a maior ameaça à segurança da Europa (e indiretamente aos Estados Unidos) vinha de dentro destas sociedades, via crises econômicas e conturbações políticas." (Ikenberry, 2001, p. 191)

O plano consistia em transferências, em larga escala, de recursos financeiros para a Europa, com que o consumo e a reconstrução seriam financiados (Ikenberry, 2001, p. 2008). Em termos econômicos, tratou-se de grande injeção de liquidez nas economias europeias. $\mathrm{O}$ plano buscava simultaneamente a (i) reabilitação econômica e (ii) a integração dos países da Europa, ambos vistos como necessários à segurança. Em linhas simples, o objetivo do plano foi criar condições econômicas para um padrão de vida europeia alto o suficiente para evitar revoluções socialistas. Neste sentido, como aponta Lloyd Black (1968, p. 28), a "finalidade declarada do Plano Marshall era combater a expansão soviética por meio do fortalecimento econômico da Europa." $" 56$

O Plano Marshall também esteve expressamente relacionado às iniciativas para integração europeia. Segundo Ikenberry, a concessão da ajuda foi feita mediante "entendimentos específicos de que os Estados europeus se encaminhariam a uma maior unificação econômica e política." (Ikenberry, 2001, p. 211) As preocupações norteamericanas eram não só manter os soviéticos fora da Europa Ocidental, como também evitar o ressurgimento do nacionalismo e do militarismo alemão, e para este aspecto a receita foi a integração. Neste sentido, a integração era mais uma ferramenta na política de "dupla contenção" já mencionada: manter os alemães contidos e os russos fora (Ikenberry, 2001, p. 206). A fala de George Kennan é exemplificativa da instrumentalidade da integração para a segurança na Europa:

No longo prazo, há apenas três possibilidades para o futuro da Europa Ocidental e Central. Uma é a dominação alemã. Outra é a dominação russa. A terceira é uma Europa federada, em que as partes da Alemanha são absorvidas mas em que a influência de outros países seja suficiente para manter a Alemanha em seu lugar. (apud Ikenberry, 2001, p. 207)

\footnotetext{
${ }^{56}$ Além de sua importância geopolítica, o Plano Marshall cumpriu funções econômicas domésticas de relevo nos Estados Unidos. A economia norte-americana havia sido impulsionada pelo esforço de guerra. Estimava-se que se a Europa não pudesse mais arcar com as importações norte-americanas, haveria recessão e aumento do desemprego nos Estados Unidos (Jackson, 1979, p. 1055).
} 
A iniciativa de integração começou com a insistência, por parte do governo dos Estados Unidos, de que os próprios europeus se organizassem para alocar os fundos do Plano Marshall (Ikenberry, 2001, p. 209). Isto foi feito por meio da Organização Europeia de Cooperação Econômica (OECE) $)^{57}$. "Era atribuição da OECE preparar e executar medidas de cooperação econômica e examinar os programas dos Estados-membros para a execução dos programas de recuperação surgidos do Plano Marshall.” (Kaplan; Katzenbach, 1964, p. 342) $\mathrm{Na}$ década seguinte, três outras organizações com caráter supranacional ${ }^{58}$ se somariam à OECE: a Comunidade Europeia do Carvão e do Aço (CECA), a Comunidade Europeia de Energia Atômica (Euratom), e a Comunidade Econômica Europeia (CEE). (Stelzer, 2004)

A CECA foi estabelecida em 1951 entre a Alemanha, França, Itália e os países do chamado "Benelux": Bélgica, Países Baixos e Luxemburgo. Seus objetivos eram a organização da atividade siderúrgica e carbonífera, a regulamentação de relações francoalemãs e a integração desta porção da Europa. Carvão e aço haviam sido fontes de atritos, sobretudo nas disputas franco-germânicas pela Alsácia-Lorena desde o século XIX, e a integração nesta área era componente do projeto de relações pacíficas. A Alta Autoridade da CECA foi dotada com poderes supranacionais, tendo competência para decidir de maneira independente dos Estados-membros. A autonomia política da organização era reforçada no aspecto do financiamento de suas atividades, fundado não em repasses governamentais, mas em tributação supranacional incidente sobre a produção siderúrgica e carbonífera. Como medida de integração, a CECA aboliu as tarifas incidentes sobre o comércio transfronteiriço de carvão e aço em sua jurisdição, criando zona de livre comércio nesta área específica (Stelzer, 2004, p. 32-5).

A Euratom e a CEE foram estabelecidas pelos Tratados de Roma de 1957. O objetivo da Euratom era supervisionar o uso da energia nuclear para fins pacíficos. A CEE teve escopo mais amplo, e foi a responsável pelo estabelecimento do mercado comum europeu ${ }^{59}$, a partir

\footnotetext{
${ }^{57}$ Antecessora da Organização para Cooperação e Desenvolvimento Econômico, a OCDE, estabelecida em 1961.

${ }^{58}$ Segundo Joana Stelzer (2004, p. 76), organizações internacionais têm caráter supranacional quando possuem as três seguintes características: (i) transferência de parcelas de soberania por parte dos Estados; (ii) concessão de poder normativo direto à organização internacional, cujas normas passam a se mesclar aos ordenamentos internos dos Estados membros de modo automático; e (iii) afirmação da integração como finalidade da organização.

59 Segundo a classificação de Bela Balassa (1961, p. 5-6), mercado comum é o arranjo em que há união aduaneira e livre circulação dos fatores de produção. A união aduaneira, por sua vez, é caracterizada pela existência de zona de livre comércio (eliminação de barreiras tarifárias) para as relações comerciais intrabloco, e pela existência de tarifa externa comum, para as relações extrabloco. Neste sentido, há maior integração conforme se caminha na escala: (i) zona de livre comércio; (ii) união aduaneira e (iii) mercado comum. As etapas posteriores da integração são a (iv) a união econômica (caracterizada pela adoção de moeda comum, de banco central e pela harmonização das políticas econômicas) e (v) a integração econômica total (que assume
} 
do qual se buscou, também, a aproximação das políticas econômicas dos países do bloco. Em essência, a CEE postulava quatro liberdades fundamentais, que abrangiam a livre circulação intrabloco de bens, pessoas, serviços e capitais (Stelzer, 2004, p. 37-8). As iniciativas de integração via OECE, CECA, Euratom e CEE são antecessoras do projeto da União Europeia, que tomou corpo após o fim da Guerra Fria, com o Tratado de Maastritcht, de 1992 (Stelzer, 2004).

O processo de integração europeia contribuiu para a fragmentação do direito internacional, por dar origem ao "direito comunitário", que, segundo Stelzer (2004, p. 117), não é nem direito estatal, nem direito internacional. O direito comunitário afirma a sua distinção com base na característica da supranacionalidade, que permeia o processo de integração na Europa. Os juristas que trabalham com direito comunitário fazem questão de afirmar suas diferenças: "devemos nos afastar das categorias tradicionais do direito clássico, do direito internacional público e do direito interno, uma vez que a ruptura consiste precisamente na introdução de elemento diverso", que é a supranacionalidade (Stelzer, 2004, p. 98).

Até o momento, observaram-se tensões fragmentárias em relação ao direito internacional com o surgimento da TRI, que dominou a área de segurança internacional, e do direito comunitário, que se tornou a língua jurídica da integração europeia. Estes novos saberes foram acompanhados de outro, voltado às organizações de Bretton Woods e ao GATT: o direito internacional econômico, por sua vez abrangendo categorias para tratar de relações comerciais, monetárias e financeiras internacionais. Estes desdobramentos são abordados a seguir.

Bretton Woods, GATT e formação do direito internacional econômico

A Conferência de Bretton Woods, de 1944, foi o principal espaço de articulação da cooperação econômica internacional para o pós-guerra, em matéria monetária e financeira. Nela, foram pensados o Fundo Monetário Internacional (FMI) e o Banco Internacional para Reconstrução e Desenvolvimento, que viria a ser o Banco Mundial. A Conferência de 1944 declarou a necessidade de cooperação também na área comercial. Inicialmente, a Conferência de Havana de 1947 buscou estabelecer a Organização Internacional do Comércio, que não

feições federativas). A União Europeia é caracterizada como pertencente ao quarto estágio da classificação de Balassa. 
chegou a sair do papel. A cooperação internacional em matéria de comércio foi articulada por meio da instituição do Acordo Geral Sobre Tarifas e Comércio, o GATT 1947.

Em seu conjunto, as instituições de Bretton Woods e do GATT 1947 articularam a cooperação econômica internacional (financeira, monetária e comercial). Estas instituições foram informadas pela necessidade percebida de conciliar a abertura econômica multilateral com as pressões domésticas por estabilidade política e bem-estar social, em contraste com o ocorrido no entreguerras, quando medidas protecionistas generalizadas "estrangularam o comércio internacional" (Jackson, 2000, p. 36). No pós-Segunda Guerra, procurava-se “abertura manejada" ou administrada (Ikenberry, 2001, p. 185), a que John Gerard Ruggie (1982) se refere como “embedded liberalism": liberalismo assistido (Sato, 2012), administrado ou gerenciado, com influência do Estado na economia.

O liberalismo assistido ou gerenciado é uma resposta à quebra da cooperação econômica internacional do período do entreguerras. A essência da resposta consiste em "elaborar uma forma de multilateralismo que seja compatível com as necessidades de estabilidade doméstica." (Ruggie, 1982, p. 399) O objetivo de liberalização comercial é abraçado de maneira conciliada com a atenção às vulnerabilidades políticas internas geradas por esta liberalização. Em outros termos, o liberalismo assistido faz concessões às necessidades domésticas de estabilidade política e bem-estar social. Kaztenbach e Kaplan (1964, p. 90) se referem a este processo como politização das economias: a autonomia da esfera econômica em relação à política, típica do liberalismo clássico, é relativizada. Esta concepção econômica articula, no plano da cooperação econômica internacional, as bases para o welfare State no plano doméstico ${ }^{60}$ (Castro, 2006).

Como restaurar a cooperação econômica internacional de modo a conciliar abertura comercial, segurança da rentabilidade dos investimentos, e demandas domésticas por bemestar social e pleno emprego? Na resposta concebida em Bretton Woods, o FMI teria a função de estabilizar as relações cambiais. O Banco Mundial foi inicialmente pensado para a reconstrução da Europa. Na prática, sua importância nesta área foi acessória, visto que o Plano Marshall abraçou a causa da recuperação econômica europeia em 1948, movimentando muito mais recursos do que o Banco Mundial possuía. E a cooperação para liberalização comercial ficou a cargo do GATT 1947 (Castro, 2006).

O FMI foi criado para presidir um regime de cooperação cambial que veio em substituição ao do POI, mas mantinha, como um objetivo, a estabilidade cambial. Para tanto,

\footnotetext{
${ }^{60} \mathrm{O}$ liberalismo assistido é uma perspectiva sobre as relações econômicas internacionais, e seus principais contornos são abordados na seção 3.2 .
} 
era necessário criar condições para o equilíbrio na balança de pagamentos dos Estados engajados no comércio internacional ${ }^{61}$. A solução encontrada foi atrelar as diferentes moedas ao dólar ${ }^{62}$, que à época tinha lastro em ouro na paridade fixa de US\$ 35,00 por onça. As pressões econômicas pela variação do câmbio, decorrentes da atividade comercial liberalizada, seriam endereçadas por empréstimos assistenciais feitos pelo FMI. O fundo também contemplava a possibilidade de depreciação da moeda local frente ao dólar em caso de "desequilíbrio fundamental", para que o Estado conduzisse políticas monetárias expansionistas, necessárias, por exemplo, para aquecer a economia e diminuir o desemprego (Ruggie, 1982, p. 395). O resultado foi o regime monetário de taxas cambiais "fixas, mas ajustáveis" (Rodrik, 2011, p. 98).

Além da concessão de empréstimos estabilizadores e da paridade cambial com "válvulas de escape", Bretton Woods significou uma ruptura com a prática anterior de plena liberdade nos investimentos internacionais sob o Padrão-Ouro, que exigia o livre fluxo transfronteiriço de ouro. No novo cenário, os controles governamentais à movimentação internacional de capital (os chamados controles de capital ou "fechamento da conta de capitais") foram não só lícitos (Ruggie, 1981, p. 395), mas vistos como desejáveis e fundamentais à estabilidade das relações monetárias internacionais. A necessidade de controle dos fluxos de capital privados transfronteiriços tornou-se objeto de consenso entre os economistas no período do pós-guerra (Rodrik, 2011, p. 95; cf. Helleiner, 1994b).

A importância do Banco Mundial, neste contexto inicial da ordem do pós-guerra, não foi a mesma que a do FMI para a estabilidade das relações econômicas internacionais. Como se disse, o Banco foi inicialmente projetado para financiar a reconstrução da Europa, mas foi

\footnotetext{
${ }^{61}$ Quando uma economia exporta mais do que importa, há mais moeda entrando no país do que saindo, e isto gera pressões pela valorização da moeda local frente ao elemento de referência (que pode ser o ouro, o dólar ou outra moeda). No primeiro caso, o investidor que tenha patrimônio na moeda local sai beneficiado ao liquidar seus investimentos em dólar, pois consegue mais dólares para cada unidade da moeda local em que o investimento foi feito. No cenário oposto, se há mais importações do que exportações, a saída de dinheiro cria pressões pela depreciação da moeda. Este é cenário de déficit no balanço de pagamentos. Nesta situação, o investidor estrangeiro é prejudicado ao liquidar seu investimento, visto que obtém menos dólares. O equilíbrio no balanço de pagamentos pode ser obtido, neste caso, com a ajuda de empréstimos internacionais, que representam influxo de moeda, e amenizam as pressões pela depreciação.

${ }^{62}$ A prevalência do dólar como resultado das negociações em Bretton Woods é expressiva da ascendência geopolítica dos Estados Unidos. O dólar deslocou o papel antes desempenhado pela libra esterlina, de moeda de referência para as transações comerciais e os investimentos internacionais. Outra expressão prática da ascendência norte-americana foi a fórmula de decisão adotada tanto no FMI quanto no Banco Mundial: não um voto por governo, mas votos proporcionais ao capital investido nestes órgãos. O resultado foi a configuração de poder de veto norte-americano em ambas as organizações, dada a desproporção de sua contribuição de capital em relação aos demais Estados. O veto nas instituições de Bretton Woods somou-se à capacidade norteamericana de barrar decisões no campo da segurança coletiva, no Conselho de Segurança da ONU. A tradução deste cenário é a de que os Estados Unidos estavam na posição jurídica de impedir qualquer alteração na cooperação internacional nas áreas monetária, financeira e de segurança coletiva, reflexo direto de sua posição hegemônica no pós-guerra.
} 
suplantado neste papel pelos fundos do Plano Marshall. Posteriormente, o Banco Mundial voltou suas atividades a políticas de "desenvolvimento" nos países mais pobres (Barral, 2007a, p. 28; Pereira, 2009). ${ }^{63}$ Ao passo que os empréstimos do FMI foram concebidos para desempenhar papel de equilíbrio monetário, as atividades do Banco Mundial foram pensadas para financiar programas (gastos governamentais em políticas públicas genéricas) e projetos (mais específicos), como construção de estradas, usinas, hospitais, escolas, etc. ${ }^{64}$

Além do FMI e do Banco Mundial, o último pilar institucional da cooperação econômica internacional no pós-guerra foi igualmente planejado para ser uma organização internacional: a Organização Internacional do Comércio, a OIC (Jackson, 2000, p. 32). A organização não chegou a existir. Tal como ocorreu com a Liga das Nações em relação a Woodrow Wilson, Harry Truman foi presidente democrata frente a um congresso norteamericano com maioria republicana, que rejeitou o tratado constitutivo da OIC (Jackson, 2000, p. 37-8). A lacuna na regulamentação da cooperação internacional em matéria de comércio foi preenchida pelo GATT, tratado concluído em outubro de 1947, em Genebra, e que originalmente havia sido intencionado como um dos textos normativos da OIC. Embora não configurasse organização internacional formal, acabou por lançar as bases institucionais para uma organização internacional de fato, por meio de séries de conferências concatenadas, apelidadas de "rodadas" de negociação. John Jackson afirma tratar-se de ficção a concepção do GATT como não sendo uma "organização", visto que as rodadas do GATT assumiram alto grau de institucionalização (Jackson, 2000, p. 41).

O principal objetivo do GATT 1947 foi a abertura dos Estados ao comércio internacional, por meio da redução multilateral de tarifas ${ }^{65}$. Duas normas se destacaram no acordo: a cláusula da nação mais favorecida e o tratamento nacional. Pela cláusula da nação mais favorecida, qualquer vantagem concedida a um parceiro comercial deveria ser automaticamente estendida às demais (Barral, 2007a, p. 30). Esta previsão está no artigo I do

\footnotetext{
${ }^{63}$ A expressão "Banco Mundial", na realidade, pode se referir a duas coisas. O "Grupo Banco Mundial" é o agrupamento de sete organizações: (i) Banco Internacional para a Reconstrução e Desenvolvimento (BIRD); (ii) Associação Internacional de Desenvolvimento (AID); (iii) Corporação Financeira Internacional (CFI); (iv) Centro Internacional para Conciliação de Divergências em Investimentos (CICDI - ou ICSID, nome consagrado em inglês), (v) Agência Multilateral de Garantias e Investimentos (AMGI); (vi) Instituto Banco Mundial (IBM) e (vii) Painel de Inspeção. A referência isolada a "Banco Mundial", no entanto, abrange apenas o BIRD e a AID. O BIRD empresta apenas a pessoas de direito público, com juros próximos aos praticados no mercado financeiro internacional. A AID, fundada apenas em 1960, trabalha com empréstimos concessionais a países em desenvolvimento, com taxas de juros menores e prazos maiores de amortização (Pereira, 2009).

${ }^{64}$ Os empréstimos do Banco Mundial sujeitaram-se, com o tempo, à política de condicionalidades, também partilhada pelo FMI, e abordada na seção 2.3, especificamente subseção 2.3.3, com grande reflexo para a discussão feita no capítulo 4 (cf. Pereira, 2009; Santos, 2006; Castro, 2005a).

65 "Tarifa, no comércio internacional, significa qualquer imposição governamental (impostos, taxas, contribuições) sobre a importação de produtos estrangeiros.” (Barral, 2007a, p. 30)
} 
acordo. O princípio do tratamento nacional, previsto no artigo III, complementa esta regra. Segundo ele, a mercadoria importada, exceto pelo pagamento da tarifa negociada, não pode ser discriminada. Buscava-se evitar, assim, que as mercadorias importadas tivessem que preencher requisitos não exigidos para mercadorias localmente produzidas. Em outros termos, "as Partes Contratantes do GATT se comprometiam, por meio desta regra, a não criar barreiras internas à circulação do produto importado.” (Barral, 2007a, p. 31)

A aparente simplicidade do sistema fundado em duas regras é elusiva. Sobre as normas do GATT, Welber Barral (2007a, p. 30) afirma: “já se disse que são compostas por dois princípios e centenas de exceções.” O GATT objetiva a abertura comercial, mas de maneira manejada, com válvulas de escape. A liberalização contou com forte elemento de seletividade, procurando proteger áreas sensíveis das economias industrializadas. Uma das áreas que caíram na exceção foi a agricultura. Outra, foi a do comércio de têxteis e vestuário (Barral, 2007a, p. 69). Em outros termos, o sistema multilateral de comércio focalizou a redução tarifária de produtos industrializados, em que as economias avançadas eram mais competitivas, e abriu exceções para que houvesse proteção nos setores em que os países em desenvolvimento tendem a ser mais competitivos: agricultura e manufaturas têxteis. Esta configuração é indicativa de que o sentido de "liberalismo assistido" aplicado ao GATT buscou conciliar abertura comercial com as necessidades de preservação doméstica de bemestar social, mas apenas para os países de economia industrializada, que compunham o núcleo do bloco capitalista. Para além da agricultura e dos têxteis, o GATT 1947 permitia a proteção comercial, em certos casos, por meio de subsídios domésticos e à exportação, salvaguardas, medidas antidumping, entre outras.

Juntas, as três instituições de Bretton Woods fomentaram uma "abertura gerenciada", um sistema mais ou menos aberto às interações monetárias, financeiras e comerciais, com brechas para permitir que os governos protegessem suas economias (Ikenberry, 2001, p. 191):

\footnotetext{
Ao invés de um simples sistema de livre comércio, as economias industrializadas estabeleceram uma ordem gerenciada, organizada por um conjunto de instituições multilaterais e uma "barganha social", que buscava balancear abertura com bemestar social e estabilidade domésticos. (Ikenberry, 2001, p. 185)
}

A abertura com estabilidade social interna tornava-se possível pela rede de segurança oferecida contra distúrbios cambiais. Os países podiam financiar os déficits na balança comercial, equilibrando suas contas e mantendo as paridades entre as moedas. Em termos mais simples, Bretton Woods e o GATT operavam em conjunto para uma abertura "segura" ao comércio internacional. 
A formação do sistema institucional para cooperação econômica no pós-guerra foi acompanhada da estruturação de novo campo do saber jurídico: o direito internacional econômico. Emergiu uma comunidade de juristas que desenvolveu vocabulário para falar sobre relações monetárias, financeiras e comerciais, e que se distinguia daquele do direito internacional público. Isto se refletiu nos próprios espaços decisórios. Por exemplo, a solução de controvérsias sobre comércio não seria feita pela Corte Internacional de Justiça, lugar da linguagem do direito internacional público, mas pelo sistema de painéis do GATT, que conformavam espaço funcionalmente especializado, em que o jargão era o direito internacional econômico. Encontra-se, aqui, mais um elemento da fragmentação do direito internacional, no sentido de que o "vácuo" existente nesta esfera das relações internacionais não foi preenchido pelo direito internacional público, mas por uma linguagem jurídica nova, especializada, e com pretensões de autonomia.

Observou-se, até aqui, que a ordem do pós-guerra contou com a formação de múltiplas instituições e novas linguagens para articular políticas externas e a cooperação internacional. Viu-se, que a OTAN e a política de dissuasão nuclear pelo balanço de terror foram as repostas à divisão bipolar do mundo, e que neste contexto a TRI ocupou o lugar do direito internacional público na formulação de políticas de segurança internacional. Outra camada institucional buscou articular a coesão econômica do bloco capitalista, num contexto em que se construiu consenso no engaste entre questões de segurança internacional e bem-estar socioeconômico doméstico. Nesta camada, o Plano Marshall e as primeiras movimentações para integração europeia foram destacados, conjuntamente à formação de nova especialidade jurídica: o direito comunitário. Ainda abrigando preocupações de entrelaçamento de segurança e economia, as instituições de Bretton Woods e o GATT, informadas pela sensibilidade do "liberalismo assistido", foram a resposta do pós-guerra para articular a cooperação econômica internacional. Com elas, emergiu mais uma linguagem jurídica fragmentária para falar sobre um setor das relações internacionais: o direito internacional econômico.

Notou-se, no entanto, que estes desdobramentos institucionais tiveram um foco, que pode ser identificado com o bloco capitalista. Dentro deste bloco, mais especificamente, as instituições foram voltadas à estabilidade das relações entre economias industrializadas. Como se observou, há elemento seletivo ou discriminatório, por exemplo, na liberalização comercial de produtos em que países em desenvolvimento conseguem custos menores, como no setor agrícola ou de têxteis. Cabe perguntar, portanto: qual foi o espaço dos "outros" nas instituições do pós-guerra? Como as instituições endereçaram aquele grupo de Estados e 
territórios que, não eram nem economias avançadas (à época se dizia "primeiro mundo"), nem países socialistas ("segundo mundo"), mas países em desenvolvimento ("subdesenvolvidos" ou "terceiro mundo")?

Dois aspectos interrelacionados serão abordados para levantar elementos que permitam compreender o lugar dos "outros" na ordem do pós-guerra. A subseção a seguir aborda, primeiramente, o Sistema de Tutela da ONU e a formação de novos Estados independentes. Passa-se, então, à tentativa de formação de "nova ordem econômica internacional" por parte dos países de terceiro mundo. Esta tentativa é relevante por ter envolvido a articulação de doutrinas jurídicas do direito internacional público, que deram ensejo a uma resposta do mundo industrializado, com contraposição de doutrinas e a formação de novas expertises jurídicas, como o direito internacional dos investimentos estrangeiros, acentuando o processo de fragmentação do direito internacional. Após a abordagem destes dois aspectos, a seção 2.2.4 elabora o significado da fragmentação, bem como as respostas surgidas para lidar com ela.

\subsubsection{O espaço dos "outros" no direito internacional: sistema de tutela e nova ordem} econômica internacional

Entre as primeiras baixas empiricamente ocorridas no direito internacional, no que diz respeito à relação entre as grandes potências e os "outros", estiveram certas doutrinas jurídicas derivadas da noção de soberania. Entre elas, especialmente, o princípio da proibição da intervenção e da proibição do uso da força (ou da ameaça) contra a independência política dos Estados, ambos positivados no artigo $2^{\circ}$ da Carta da ONU. Tais doutrinas mostraram-se, desde cedo, incompatíveis com a operação da ordem bipolar. Conforme indicam Kaplan e Katzenbach (1964, p. 63-7), a bipolaridade induz alianças não flexíveis, econômica e ideologicamente fundadas, e compromete, na prática, o direito da não intervenção, que para todos os efeitos passa a ser um direito da intervenção nos assuntos internos dos Estados por parte dos membros líderes dos respectivos blocos antagonistas ${ }^{66}$ :

Os Estados Unidos e a União Soviética podem procurar impedir que terceiros recorram à força, mas não podem abster-se de empregá-la sempre que necessário para protegerem seus interesses vitais. Não podem deixar de intervir em outras

\footnotetext{
${ }^{66}$ O caso brasileiro é um exemplo familiar. O documentário "O dia que durou 21 anos" (2012) registra as movimentações do governo Lyndon Johnson em relação aos desdobramentos políticos do governo Goulart no Brasil, e o apoio concedido aos militares dissidentes para o golpe 1964. Na ocasião, Johnson autorizou o envio de frota da Marinha dos Estados Unidos à costa brasileira, em suporte à derrubada de João Goulart, numa reedição da "diplomacia da canhoneira".
} 
nações [...]. Por estas razões, o direito de guerra e o direito de represálias não mudaram tanto quanto os autores da Carta das Nações Unidas tencionaram. (Kaplan; Katzenbach, 1964, p. 66)

Esta configuração de intervenções como prática para manter a "disciplina" intrabloco, se somada à arquitetura do Conselho de Segurança, revela como o direito no pós-guerra, ao contrário do que comumente se propaga, não era o direito de proscrição da violência nas relações internacionais. Três considerações contribuem para isto. Primeiramente, a já descrita prática das superpotências de uso e ameaça da força e interferência nos assuntos domésticos de outros Estados, no contexto de sua disputa bipolar. Em segundo lugar, o status de membros permanentes dessas duas potências no Conselho de Segurança, que lhes conferia poder de veto. Em terceiro lugar, a competência atribuída pela Carta da ONU ao Conselho para decidir sobre o uso da força e situações de ameaça ou quebra da paz e segurança internacionais. $\mathrm{O}$ Conselho, além disso, tinha a prerrogativa de avocar matérias em tramitação na Assembleia, e em todo caso esta última não poderia emitir resoluções vinculantes. Como resultado, a ordem jurídica do pós-guerra conferia aos Estados Unidos e à União Soviética a última palavra sobre a licitude de seus próprios atos de uso da força, visto que poderiam impedir qualquer movimentação no Conselho. Nota-se como estas formas jurídicas, assim articuladas, revelam que o direito internacional do pós-guerra era o direito da intervenção e do uso da força ${ }^{67}$.

Noutro aspecto, a ordem internacional do pós-guerra experimentou a proliferação de novos Estados independentes, quer como decorrência direta dos movimentos nacionais de libertação que aproveitaram o ensejo do enfraquecimento europeu com a Segunda Guerra Mundial, quer por meio da operação do Sistema de Tutela da ONU. Neste processo, países da África, da Ásia e do Pacífico foram admitidos como membros da ONU e consequentemente à comunidade de Estados. Estes países passaram a fazer pressão por mudanças no direito

\footnotetext{
${ }^{67}$ Cumpre observar que esta conclusão se choca com aquela de juristas que se atêm aos esquemas conceituais encontrados nas formas jurídicas, e identificam o direito com estes esquemas, ao invés de definir o direito a partir de suas funcionalidades práticas. Um exemplo pode ser retirado de livro de grande circulação no ensino do direito internacional público no Brasil, atualmente na $15^{\mathrm{a}}$ edição: "A Carta de São Francisco ditaria finalmente, em 1945, a proscrição da guerra e de fenômenos variantes, estabelecendo em seu art. $2^{\circ}$, $\S^{\circ}$ : 'Os membros da Organização, em suas relações internacionais, abster-se-ão de recorrer à ameaça ou ao uso da força contra a integridade territorial ou a independência política de qualquer Estado, ou de qualquer outra forma incompatível com os propósitos das Nações Unidas.'. Importa observar que a Carta da ONU teve a oportuna cautela de não se referir nominalmente à guerra - termo sempre capaz de comportar interpretação restritiva -, mas a algo bem mais extenso e abrangente: o uso da força. Dentro do sistema das Nações Unidas, o único emprego legítimo do esforço armado singular é aquele com que certo país se defende de uma agressão, de modo imediato e efêmero: a organização, ela própria, deve dispor de meios para que esse confronto não perdure.” (Rezek, 2002, p. 364) Este tipo de elaboração jurídica tem, de um lado, efeito alienante na formação do jurista e, de outro, efeito de inabilitação para a articulação com outros campos do saber, como as relações internacionais. Somados, estes efeitos contribuem para a desvalorização do saber jurídico na formulação de políticas públicas, da política econômica e da política externa, problema que, por sua vez, é um dos principais focos da abordagem feita em Castro (2012), a respeito da necessidade de reformulação do ensino jurídico em bases interdisciplinares.
} 
internacional (cf. Rajagopal, 2003; Pahuja, 2009), buscando articular a "nova ordem econômica internacional."

Anthony Anghie (2004, p. 199) adverte que a aquisição formal de soberania e igualdade, em decorrência destes processos, não se converteu no poder real que os Estados do terceiro mundo haviam imaginado. O novo status jurídico não operou mágica. Como se verá, estes países não conseguiram articular o direito internacional, e em particular a doutrina da soberania, de modo a obter liberdade de ação similar à dos Estados Unidos ou à de Estados europeus. "As inovações e reformas do período da ONU serviram de importantes maneiras para reproduzir e reafirmar as desigualdades de disparidades de poder que caracterizava o colonialismo formal." (Anghie, 2004, p. 199) Em outros termos, o colonialismo formal cede lugar ao "neo" ou pós-colonialismo, que de modo simplificado pode ser descrito como a permanência das relações desiguais e de exploração econômica dos ex-territórios coloniais, sob novas formas, inclusive formas jurídicas. Primeiramente, esta subseção abordará o Sistema de Tutela da ONU, em parte responsável pelo processo de independência, e em seguida identificará formas jurídicas envolvidas na manutenção de relações internacionais desiguais.

\section{Sistema de Tutela da ONU e transformações na composição internacional}

O sistema de tutela foi introduzido na Carta da ONU "segundo o modelo do (e dando continuidade ao) sistema de mandatos vigente ao tempo da Liga das Nações" (Conforti, 2005, p. 266; cf. Mazower, 2008, p. 63-4, 150).

A continuidade é revelada pela forma como as categorias de tutela foram desenhadas no artigo 77.1 da Carta da ONU. Primeiramente, passavam à tutela todos os territórios que estavam sob mandato da Liga das Nações. Em segundo lugar, os territórios tomados de Estados inimigos na Segunda Guerra. O único caso de tutela nessa categoria foi a Somália, retirada da Itália. Por fim, a terceira categoria era destinada aos territórios voluntariamente submetidos ao sistema de tutela pela metrópole. Nenhuma tutela, na prática, foi estabelecida por esta última modalidade (Conforti, 2005, p. 266-7). Ou seja: com exceção da Somália, todas as tutelas eram antigos mandatos da Liga das Nações. Nesse sentido, a mudança é de nomenclatura.

Em termos procedimentais, houve diferença no que tange o modo como as populações sob tutela eram ouvidas. No sistema de mandatos, petições poderiam ser recebidas pela Liga das Nações, mas apenas por intermédio da potência mandatária. No modelo da ONU, o 
consentimento do Estado tutor não era exigido para que a população do território tutelado fosse ouvida, inclusive pelo envio de representantes ao Conselho de Tutela da ONU (Kaplan; Katzenbach, 1964, p. 184). Este aspecto revela maior coerência das formas jurídicas com o propósito de promover o autogoverno, objetivo em nome do qual a tutela era exercida.

Mas a diferença mais expressiva está no fato de que, ao passo que o único mandato a tornar-se independente sob o sistema da Liga das Nações havia sido o Iraque, todos os territórios postos sob o sistema de tutela da ONU alcançaram a independência ${ }^{68}$. O último foi Palau, em 1994 (Conforti, 2005, p. 121). Com isto, o Conselho de Tutela encerrou as suas atividades (Conforti, 2005, p. 267). De 51 membros originários, em 1945, a ONU passou a contar com 82 em 1959, e 110 em 1963. A maior parte das admissões era de novos Estados independentes. O aumento do número de membros - mais do que o dobro - provocou a reforma da ONU, aprovada em 1963 e efetivada em 1965, que alterou inclusive a composição não-permanente do Conselho de Segurança, expandindo-o ao formato atual (Conforti, 2005, p. 62).

O cenário internacional se transformou com a proliferação de Estados. A questão é saber se os países recém-independentes, ao se juntarem ao grupo dos "subdesenvolvidos", e portanto ao "terceiro mundo", apenas se habilitaram a participar no projeto do direito internacional originalmente europeu, ou se seriam capazes de manifestar sua "vontade soberana" para criar formas jurídicas para a articulação de seus interesses. Neste contexto, o desenvolvimento econômico, descrito em termos de crescimento, industrialização e modernização, tornou-se o objetivo de todo governo terceiro-mundista. Ao passo que no direito internacional anterior à guerra a distinção fundamental era entre civilizados e não civilizados, neste novo contexto operava-se a distinção em função do grau de desenvolvimento (cf. Pahuja, 2009). Se antes a obsessão dos "bárbaros" era entrar na comunidade de nações civilizadas, via doutrina do reconhecimento, agora a dos "subdesenvolvidos" passou a ser tornar-se primeiro mundo. Havia consenso entre desenvolvidos e subdesenvolvidos de que o "desenvolvimento" era desejável. As divergências

\footnotetext{
${ }^{68} \mathrm{O}$ relato de Mark Mazower, em No enchanted palace (2008), ao costurar as origens da ONU com certo projeto de estabelecer uma organização internacional nos moldes da commonwealth britânica - como ventilaram o estadista sul-africano Jan Smuts (que elaborou a redação do preâmbulo da Carta da ONU) e o acadêmico (da área de relações internacionais) britânico Alfred Zimmern - sugere que o anticolonialismo não foi uma força motriz nestas origens. Mazower não focaliza o protagonismo norte-americano nas negociações que levaram à formação da ONU, enfatizando, ao invés, perspectivas associadas ao imperialismo britânico. Em especial, no capítulo 4 da obra, fica sugerido que o início da onda de descolonização no pós-Segunda Guerra Mundial - que levou à formação de uma maioria terceiro-mundista na Assembleia Geral da ONU - não foi efeito da execução de um plano originado nas negociações, mas uma transformação da organização (cf. 2008, p. 152-3, 176-183).
} 
existiam não nisso, mas nos meios identificados para ocasionar o desenvolvimento (Anghie, 2004, p. 207). E aqui entra a controvérsia jurídica.

$\mathrm{Na}$ perspectiva do terceiro mundo, o problema do (sub)desenvolvimento estava inextricavelmente ligado ao passado colonial, de exploração sistemática pelas metrópoles. Mesmo na era pós-colonial, as relações de exploração eram vistas como "acolhidas e perpetuadas por um sistema de direito internacional que continuava a operar após a conquista da independência pelo terceiro mundo." (Anghie, 2004, p. 208) A resposta do terceiro mundo foi a tentativa de reformular doutrinas do direito internacional, sobretudo pelo uso da Assembleia Geral da ONU, espaço em que o terceiro mundo era maioria.

Na década de 1960, as primeiras movimentações foram, além da reforma da ONU de 1963, a formação do "movimento não-alinhado", em 1961, a aprovação da resolução que declarou o princípio da soberania permanente sobre os recursos naturais, em 1962, a formação da UNCTAD e da coalizão que ficou conhecida como G77, ambos em 1964 (Anghie, 2004, p. 207-11). O esforço por transformações só viria a ficar conhecido como "nova ordem econômica internacional" na década de 1970 (Castro, 2005b, p. 137).

A tentativa do terceiro mundo consistiu em utilizar a soberania (recém-adquirida para muitos dos Estados deste grupo) para reverter os efeitos do colonialismo sobre a ordem econômica existente. Buscou-se reformar o direito internacional com o objetivo de facilitar as pretensões terceiro-mundistas de libertar-se de relações de exploração e, assim, alcançar o desenvolvimento. Como indica Anghie (2004, p. 202), o objetivo era reformar o direito internacional, e não rejeitá-lo completamente. Buscava-se a reforma de doutrinas identificadas como perpetuadoras de efeitos das relações coloniais. A tentativa de articulação da nova ordem econômica internacional contou, porém, com contra-articulações por parte de países desenvolvidos, que contestaram as inovações jurídicas pela reafirmação de doutrinas do direito internacional, e pela formação de novas expertises nas áreas de investimentos e contratos internacionais. Estes desdobramentos tiveram impactos para o processo de fragmentação do direito internacional, e são abordados no tópico a seguir.

Nova ordem econômica internacional, articulações e contra-articulações jurídicas

A articulação da nova ordem econômica internacional envolveu disputa em torno de diversas doutrinas de direito internacional, e deu origem a novos campos ou expertises jurídicas. Muitas das doutrinas envolvidas no embate entre o terceiro e o primeiro mundo estão interrelacionadas: soberania permanente sobre os recursos naturais, responsabilidade 
internacional, sucessão de Estados, fontes do direito internacional e direitos adquiridos. Este embate se deu com foco bastante claro: a articulação e contra-articulação doutrinária se referia às relações entre Estados do terceiro mundo e corporações multinacionais ou transnacionais, abrangidos pela categoria mais ampla de "investidores" estrangeiros. As expertises que emergiram deste embate foram repostas conservadoras à tentativa de reforma da cooperação internacional pelo terceiro mundo. Elas podem ser agrupadas sob o nome de "direito internacional dos contratos", embora também seja comum referir-se a elas como "direito transnacional" ou "direito internacional dos investimentos estrangeiros." (Anghie, 2004)

A formulação da doutrina de soberania permanente sobre recursos naturais foi inovação que não remonta ao direito internacional clássico. Na realidade, este esforço foi feito em 1962, na Assembleia Geral da ONU, antecedendo, portanto, a afirmação da nova ordem econômica internacional, que é da década de 1970. Além da Resolução 1803 de 1962, a soberania permanente sobre recursos naturais foi formalizada no Art. 1(2) do Pacto Internacional dos Direitos Civis e Políticos, comum ao Pacto Internacional dos Direitos Econômicos, Sociais e Culturais, ambas de 1966 (Anghie, 2004, p. 217). Ao positivar a doutrina como um princípio de direito internacional, via resolução da Assembleia, os Estados de terceiro mundo esperavam assumir o controle sobre seus próprios recursos, em vista de seus objetivos de desenvolvimento. Esta movimentação se deu no contexto de que os territórios destes países estavam vinculados por concessões de exploração de recursos, conferidas a empresas estrangeiras. A doutrina buscava a nacionalização da exploração de recursos naturais. Na perspectiva do terceiro mundo, a capacidade "soberana" dos Estados dava-lhes a legitimidade jurídica para revisar as concessões a companhias estrangeiras, que no caso dos países recém-independentes haviam sido feitas sobretudo na época colonial (Anghie, 2004, p. 212-3).

A positivação do princípio poderia ser encarada como sucesso dos Estados do terceiro mundo, que argumentavam que a nacionalização deveria ser determinada de acordo com as normas nacionais, e não com base em international standards, questionando, assim, as regras de responsabilidade internacional (Anghie, 2004, p. 213; Pahuja, 2009, p. 143, 157-9, 177). Mas a forma jurídica que o afirmava introduzia uma brecha fundamental. "A resolução 1803 afirmava que, em caso de expropriação, os proprietários deveriam ser pagos 'de acordo com o direito internacional"”, resultando na reafirmação do direito tradicional da responsabilidade internacional de compensação parametrizada por international standards, e não pelo direito local (Anghie, 2004, p. 221). A mesma válvula de escape esteve presente na Carta dos Direitos e Deveres Econômicos dos Estados, resolução aprovada pela Assembleia Geral em 
1974. A resolução afirmava que a compensação do investidor expropriado deveria ser resolvida pelo "direito doméstico do Estado nacionalizante e por seus tribunais", mas complementava: a não ser que outro meio pacífico de solução de controvérsias fosse acordado (Anghie, 2004, p. 211). O efeito foi abrir as portas à arbitragem, como forma de excluir a jurisdição doméstica do Estado sobre o investidor. O detalhe, neste caso como em muitos outros, teve o efeito de se mostrar mais forte do que a regra. A exceção juridicamente assegurada com muita facilidade converte-se em situação-padrão, expressando com mais fidedignidade a norma de fato do que aquilo que no papel se pretendeu como regra ou princípio geral. The devil is in the detail. Os efeitos da inserção da arbitragem na forma jurídica que afirmava a soberania sobre recursos naturais serão retomados adiante.

Outra investida do terceiro mundo para revisar e nacionalizar concessões consistiu em ataque à doutrina da responsabilidade internacional (Anghie, 2004, p. 210; Pahuja, 2009, p. 157-9). Suas regras seriam preexistentes à independência da maior parte dos novos Estados, que não haviam desempenhado nenhum papel em sua formulação, e que portanto não os vincularia (Anghie, 2004, p. 210). Neste argumento, os novos Estados não sucederiam às obrigações de direito internacional contraídas sob a administração colonial, porque não haviam "soberanamente assentido" às regras antigas. Em outros termos, estes Estados contrapunham a doutrina da soberania à da responsabilidade internacional.

Contra este aspecto da investida terceiro-mundista, os países de primeiro mundo responderam articulando a doutrina das fontes e da sucessão de Estados, ambas em conjunto com a doutrina da responsabilidade internacional.

No campo da doutrina das fontes do direito internacional, os ex-Estados metropolitanos argumentavam que a entrada dos novos Estados no sistema internacional implicava a aceitação das regras preexistentes, incluindo o direito da responsabilidade internacional. Este direito era formado por regras costumeiras, vinculantes à comunidade de Estados como um todo. Entre os costumes, estaria a regra de que a compensação por expropriação de estrangeiros deveria ser regida por international standards, e não pelo direito local. A observância de international minimum standards no tratamento da propriedade era também apresentada como questão de direitos humanos. O efeito desta argumentação era apresentar a soberania como não sendo plena, uma vontade estatal livre, mas condicionada pelo direito internacional anterior (Anghie, 2004, p. 210; cf. Pahuja, 2009, p. 216-20).

Ainda no campo das fontes, o primeiro mundo negava que o terceiro mundo pudesse alterar o direito internacional pela afirmação de princípios em resoluções da Assembleia Geral da ONU. Este argumento enfatizava não o fato de que o terceiro mundo era a maioria dos 
Estados, e que as resoluções eram a expressão da vontade dessa maioria, mas o aspecto da ausência de caráter vinculativo (binding character) das resoluções da Assembleia, que possuía apenas poderes de recomendar (Anghie, 2004, p. 221). A força vinculante era reservada ao Conselho de Segurança.

Outro aspecto envolveu a doutrina de sucessão de Estados. O primeiro mundo articulou o argumento do direito adquirido, segundo o qual "os direitos concedidos por um soberano a uma entidade privada tinham que ser respeitados pelo soberano sucessor." (Anghie, 2004, p. 214) O novo Estado sucederia a obrigação de respeitar direitos adquiridos durante o período colonial.

Em conjunto, as contrainvestidas do primeiro mundo tinham o efeito de negar que aquisição formal de soberania pelo terceiro mundo pudesse mudar as regras do jogo das relações econômicas internacionais, especificamente no campo dos investimentos. As técnicas jurídicas empregadas para negar a capacidade dos novos Estados de criar um novo direito internacional por meio do uso de sua condição majoritária na Assembleia Geral envolveram, também, a articulação de novas expertises, que se deu de modo paralelo aos desdobramentos já narrados.

A formação do "direito internacional dos contratos", "direito transnacional" ou "direito internacional dos investimentos estrangeiros", que em Anghie (2004) são apresentados como equivalentes, envolveu (i) sua distinção em relação ao direito internacional público, (ii) o foco nas relações entre soberanos e investidores; (iii) a negação da aplicabilidade do direito local para reger concessões a firmas estrangeiras e sua nacionalização; e (iv) a eleição da arbitragem como espaço privilegiado de decisão ${ }^{69}$.

Os dois primeiros aspectos consistiam na caracterização de que as relações entre investidores estrangeiros e soberanos não era típica do direito internacional clássico, cujos sujeitos por excelência eram os Estados. Nem eram abrangidas pelo direito internacional privado, cujas relações se davam entre particulares. A relação entre soberano e privado, distinta destas outras, deveria ser regida por campo próprio: o dos contratos internacionais (Anghie, 2004, p. 228). Nota-se, aqui, o expediente retórico de negação daquilo que, pelo direito internacional público, poderia ser resolvido pela afirmação de que o Estado exerce jurisdição sobre nacionais estrangeiros (e sua propriedade) em seu território, em virtude de sua capacidade soberana. O direito internacional dos contratos "reenquadra" esta relação

\footnotetext{
${ }^{69}$ Valendo-se da matriz da Nova Análise Contratual da AJPE, é possível fazer a interpretação de que estes ramos tencionavam a migração de conteúdos contratuais de interesse público do direito internacional para a esfera privada. Vide seção 4.4 .
} 
como se ela fosse estabelecida entre entes cuja vontade jurídica tivesse igual peso, negando a ascendência do Estado sobre o particular estrangeiro.

Os dois últimos aspectos também estão interrelacionados. Há um objetivo e um espaço decisório para levá-lo a cabo. O objetivo do direito internacional dos contratos é oferecer garantias ao investidor estrangeiro contra a vontade estatal: a concessão é regida por padrões internacionais $^{70}$, inclusive ao seu término, momento em que a compensação deve ser estimada segundo os critérios oferecidos pela nova expertise (ou seja, com base em international standards), e não pelo direito local. Este é o aspecto material. No aspecto processual, o meio para excluir a jurisdição estatal é a arbitragem (Anghie, 2004, p. 232).

A inserção das cláusulas de arbitragem deve ser compreendida no contexto em que atores privados, como corporações multinacionais, tinham destacada importância econômica (Anghie, 2004, p. 223). Certas corporações tinham faturamento anual maior que o PIB de países. Seu poder econômico lhe conferia influência e poder de barganha. Neste contexto, os países de terceiro mundo, pouco intensivos em capital, competiam pela atração de corporações multinacionais e do investimento estrangeiro em geral (Anghie, 2004, p. 240). Esta configuração explica por que, apesar dos esforços por uma nova ordem econômica internacional no âmbito da Assembleia Geral da ONU, os Estados do terceiro mundo, individualmente, aceitavam contratos que continham cláusulas arbitrais, que na prática negavam a incidência de seu direito material e processual sobre investidores estrangeiros.

As decisões arbitrais sobre contratos entre novos Estados e corporações estrangeiras apresentavam três temas recorrentes. Primeiramente, a afirmação de que estes contratos não eram regidos pelo direito doméstico. Segundo, a ênfase na aceitação "soberana" do Estado em submeter a disputa à arbitragem. Terceiro, a afirmação de que o direito a ser empregado pelos árbitros não era o direito internacional público, mas uma expertise apropriada (Anghie, 2004, p. 226-31).

Exemplo disto foi o laudo arbitral emitido pelo jurista René-Jean Dupuy, de 1977, em controvérsia envolvendo a nacionalização da Texaco pela Líbia. O governo líbio se recusou a participar da arbitragem, alegando que sua soberania lhe conferia o direito de fazer a expropriação de acordo com o direito local. Mas o laudo reafirmou que a concessão havia

\footnotetext{
${ }^{70} \mathrm{Um}$ dos expedientes para imunização dos investidores frente ao direito local, no que diz respeito ao direito material, era a inserção de "cláusulas de estabilização", frequentemente inseridas nos contratos internacionais de investimento. "De acordo com estas cláusulas, considerava-se que o Estado, ao contratar, consentiu em suspender o exercício usual de suas funções públicas, de seus poderes legislativos, no que tange seus efeitos sobre o contrato; consequentemente, qualquer acordo entre o Estado e a corporação somente poderia ser alterado pelo assentimento mútuo das partes." (Anghie, 2004, p. 234) Trata-se de uma proteção contra o que se tornou conhecido como regulatory takings.
} 
sido feita por contrato que previa cláusula arbitral, e que portanto a Líbia havia dispensado sua jurisdição. No mérito, Dupuy afirmou: "o investidor deve ser protegido de incertezas legislativas, quer dizer, dos riscos de o direito doméstico do Estado anfitrião ser modificado, ou de qualquer medida governamental que leve à ab-rogação ou rescisão do contrato.” (apud Anghie, 2004, p. 232) No laudo, Dupuy ainda considerou as resoluções da Assembleia Geral no tema da soberania permanente sobre recursos naturais, descartando-as por seu caráter meramente recomendatório. O direito a reger a concessão era o direito internacional dos contratos, e não o direito internacional público (Anghie, 2004, p. 221).

A nova expertise do direito internacional dos contratos resultava na afirmação, pelo expediente da arbitragem, de personalidade jurídica para que corporações multinacionais litigassem contra Estados no plano internacional (Anghie, 2004, p. 236). Na prática, porém, o direito internacional dos contratos era aplicável apenas às relações entre corporações e Estados de terceiro mundo, visto que "muitos de seus elementos cruciais - relacionados ao direito aplicável e à validade das cláusulas de estabilização - eram rejeitados pelos Estados desenvolvidos." (Anghie, 2004, p. 238) Estes preservavam suas relações com investidores como típicas daquelas entre soberanos e particulares, ou seja, como assunto de direito nacional.

$\mathrm{Na}$ avaliação de Anghie, o novo direito internacional "dos contratos" perpetua desigualdades criadas pelo antigo direito internacional "da conquista". "É desse modo que o 'antigo' direito internacional do imperialismo, baseado na conquista, liga-se ao 'novo' direito internacional do imperialismo, baseado no contrato." (Anghie, 2004, p. 241) Neste sentido, avalia que "o passado colonial é irredimível no direito internacional." (2004, p. 241)

De fato, tem-se a reedição dos "tratados desiguais", desta vez não pela imposição da força militar (gunboat diplomacy), mas pela ascendência econômica das corporações multinacionais em face da posição economicamente fragilizada e dependente do terceiro mundo, escasso em capital, e desejoso de investimentos para atingir o objetivo do desenvolvimento econômico. Outra analogia possível é entre a jurisdição consular e o direito internacional dos investimentos estrangeiros: ambos têm o condão de isolar o estrangeiro (antes o europeu, agora o investidor de país avançado) da incidência do direito local (antes dos bárbaros e selvagens, agora do terceiro mundo) e de seus tribunais.

Depreende-se, portanto, que as tentativas de mobilização doutrinária para articulação da nova ordem econômica internacional resultaram em contra-ataques ${ }^{71}$, a partir dos quais,

\footnotetext{
${ }^{71}$ Na década de 1980, o projeto de nova ordem econômica internacional ruiu: "os interesses dos países do Sul na reforma da estrutura da cooperação econômica internacional acabaram caindo em desprestígio entre os países
} 
numa frente, o direito costumeiro da responsabilidade internacional e dos direitos adquiridos foram reafirmados e, noutra frente, novas expertises se desenvolveram para isolar a incidência tanto do direito nacional quanto do internacional das relações entre Estados do terceiro mundo e investidores estrangeiros. Neste último aspecto, foi possível notar como os desdobramentos relacionados à tentativa de reconfiguração das relações entre "desenvolvidos" e "subdesenvolvidos" resultaram em mais uma camada de fragmentação do direito internacional: o "direito internacional dos contratos", "direito transnacional" ou "direito internacional dos investimentos estrangeiros".

Ao longo das subseções 2.2.1 a 2.2.3, salientaram-se movimentos fragmentários do direito internacional: houve perda de espaço para a TRI, direito comunitário, direito internacional econômico e direito internacional dos contratos ou dos investimentos internacionais. Outros movimentos fragmentários são mencionados na seção 2.2.4, abaixo, cujo propósito é avaliar o sentido da fragmentação, e identificar as principais respostas ao fenômeno.

\subsubsection{Fragmentação do direito internacional: contornos e respostas}

"A história da fragmentação é também uma história de especialização profissional." (Martineau, 2009, p. 2) A fragmentação é o fenômeno de divisão do direito internacional em compartimentos ou regimes específicos. Cada área fragmentária desenvolve seu vocabulário particular para articular interesses e prioridades que também são particulares. Desse modo, as múltiplas expertises dialogam com "audiências especiais, com interesses especiais e ethos especial.” (Martineau, 2009, p. 4) Para tanto, desenvolvem suas próprias categorias e formas jurídicas:

desenvolvidos a partir da Cúpula Norte-Sul, realizada em Cancún, México, em 1981.” (Castro, 2005b, p. 138) As demandas por tratamento especial ou diferencial, e não recíproco, em matéria comercial perderam espaço diante da nova sensibilidade preponderante nas relações econômicas na década de 1980: o neoliberalismo. Vide seção 3.3. Apesar de ser comum considerar que o projeto de nova ordem econômica internacional fracassou, Balakrishnan Rajagopal aponta que a resistência do terceiro mundo teve impacto em instituições internacionais, resultando em criação de novos espaços e transformações de outros, ou seja, em modificações da arquitetura institucional internacional. Ao mesmo tempo, a institucionalização das propostas por nova ordem econômica internacional teve o efeito de "domar" as vertentes mais radicais ao centrar a preocupação na "reforma das instituições internacionais." (2003, p. 94) Nesse sentido, as movimentações por uma "nova ordem" são apontadas pelo autor como exemplo de modificações no direito internacional que não partiram exclusivamente do centro (top-down), mas se deram na interação com resistências desde a periferia. A ênfase em modificações institucionais a partir de resistências do terceiro mundo, e em especial de movimentos sociais, corresponde à proposta de "deselitizar o direito internacional ao inscrever nele a resistência, ao fazê-lo reconhecer vozes subalternas." (2003, p. 45) De certo modo, a valorização da participação de atores não centrais nos processos normativos internacionais, em Rajagopal (2003), guarda proximidade com projetos pluralistas para o direito internacional, como aquele apontado no item 2.3.5.3, por fornecer materiais intelectuais contrários à chamada tese da convergência institucional global. 
Várias áreas importantes do direito internacional desde o segundo pós-guerra - por exemplo, o da cooperação monetária e comercial e também as "formas" jurídicas dos múltiplos "regimes internacionais" [...] - não podem mais ser tornadas inteligíveis ou ser desenvolvidas apenas com o emprego de categorias antigas. (Castro, 2012, p. 183)

As diferentes especializações do direito internacional começaram a reverter as hierarquias jurídicas por implicarem viés estrutural em cada uma das diversas áreas de aplicação (Koskenniemi, 2007a; cf. Koskenniemi, 2007b). Isto é válido para a emergência das áreas fragmentárias narradas até aqui: direito internacional dos contratos, direito internacional econômico, e mesmo a TRI, que apesar de não ser juridicamente informada, desenvolve sua própria visão de normatividade a respeito da política internacional, em termos de poder. Em todo caso, a TRI também reverteu hierarquias, sobretudo na área de segurança, ao "desbancar" o direito internacional e a articulação jurídica da "segurança coletiva" no pósSegunda Guerra.

O "viés estrutural" do direito internacional dos contratos, conforme narrado na subseção anterior, é o de uma normatividade feita sob medida para as relações entre corporações multinacionais e países de terceiro mundo. Já o do direito internacional econômico, no momento de seu surgimento, era o de uma linguagem jurídica que buscava articular a abertura multilateral com as necessidades domésticas de estabilidade política e bem-estar social ${ }^{72}$. O direito internacional público simplesmente não provia as categorias para esta articulação dinâmica da cooperação econômica internacional. A outra fragmentação já abordada, referente ao direito comunitário, reflete o viés de uma linguagem jurídica desenvolvida para articular objetivo econômico e político específico: a integração europeia.

A fragmentação do direito internacional é, porém, ainda mais abrangente. Três áreas que desenvolveram comunidades populosas de juristas foram o direito internacional dos direitos humanos, o direito internacional penal e o direito internacional ambiental.

O direito internacional dos direitos humanos apresentam o ethos específico de "droit de l'hommisme" (Koskenniemi; Leino, 2002, p. 569) ou "human rightism"73 (Pellet, 2000, p. 3). Este ethos é uma das expressões mais diretas da tentativa de domar as manifestações do

\footnotetext{
${ }^{72} \mathrm{O}$ direito internacional econômico, como se viu, surgiu no contexto em que a sensibilidade econômica predominante era a do liberalismo assistido ("embedded liberalism"). Este modelo ruiu entre as décadas de 1970 e 1980, sendo substituído por uma visão neoliberal, que por sua vez entrou em crise na primeira década do século XXI. O direito não fornece materiais com sentido unívoco. As formas jurídicas são articuladas segundo a estrutura predominante de interesses em dado momento. Esta, por sua vez, é influenciada pelas representações intelectuais. Neste sentido, a transição do liberalismo assistido ao neoliberalismo ressignificou o papel do direito internacional econômico, e o desprestígio do neoliberalismo tem dado lugar a discussões sobre rearticulações deste campo.

${ }^{73}$ A expressão é trabalhada por Pellet (2000) em sentido de crítica ao ethos específico da comunidade de juristas internacionalistas de direitos humanos.
} 
exercício da soberania estatal como autoridade suprema sobre o território. Algumas de suas principais características podem ser descritas como sendo: (i) a eleição do indivíduo como seu sujeito por excelência; (ii) o objetivo de frear o exercício arbitrário do poder do Estado sobre o indivíduo e sua propriedade; e especificamente (iii) a limitação do poder do Estado de legislar sobre aspectos considerados intangíveis da esfera individual. Nesse sentido, a lei que permita a tortura como expediente lícito no direito nacional será considerada inválida pela comunidade de direitos humanos. Esta é a face interna.

$\mathrm{Na}$ face internacional, uma das expressões do human rightism é a afirmação de tratamento diferenciado para reservas em tratados internacionais. Ao passo que a juridicidade destas é reconhecida pelo direito dos tratados, os juristas de direitos humanos rejeitam que o Estado possa apresentar reservas a tratados deste campo específico (2002, p. 567). Mesmo no direito brasileiro - não mais no que se refere, porém, às reservas especificamente - a Constituição abre espaço para atribuir posições hierárquicas diferenciadas a tratados de direitos humanos (Galindo, 2013). Estes contornos revelam o esforço de singularizar tratados de direitos humanos como sendo mais importantes que os demais: um esforço que se encaixa na já mencionada "reversão de hierarquias", característica do processo de fragmentação do direito internacional.

A comunidade do direito internacional penal também tem conseguido reverter certas hierarquias em relação ao direito internacional público, sobretudo quanto às formas jurídicas da "imunidade" de agentes governamentais. O direito internacional penal tem como viés estrutural (ou ethos) a orientação contra a impunidade. A soberania, enfatizada pelo direito internacional público, é encarada como fonte de barreiras à realização deste propósito. Tradicionalmente, os indivíduos estavam sujeitos à responsabilização criminal apenas no Estado onde estivessem (Cassese, 2001, p. 245). A emergência de uma comunidade penalista internacional rompeu com isso: favoreceu a criação de tipos penais internacionalizados, promoveu concepções de jurisdição universal, e conseguiu relativizar imunidades diplomáticas e funcionais de Estado, inclusive por meio de espaços internacionalizados de decisão, como os tribunais penais para a ex-Iugoslávia e Ruanda, e o Tribunal Penal Internacional.

Reversões hierárquicas ocorrem também no direito internacional ambiental. Os integrantes desta comunidade jurídica partilham de um ethos que (i) arrola como sujeito privilegiado de direitos as "gerações futuras", (ii) relega soberania e fronteiras a segundo plano e (iii) coloca prioridades universalistas de preservação, sustentabilidade e biodiversidade em planos hierárquicos superiores. Para isso, o direito internacional ambiental 
tanto promove a adaptação de formas jurídicas do direito internacional público, quanto realiza inovações no léxico jurídico. Assim, esta linguagem se articula fazendo uso de categorias como (i) princípio da precaução, (ii) res communis, (iii) responsabilidade "objetiva"; (iv) obrigações "erga omnes" e (v) mesmo jus cogens.

Até o momento, observou-se que a fragmentação do direito internacional está relacionada à formação de novas expertises, cada qual com seu viés estrutural, como se pôde notar em áreas como direitos humanos, direito internacional penal e direito internacional ambiental. Tende-se a associar a fragmentação da normatividade internacional ao aparecimento destas novas expertises de modo exclusivo, isto é, não abarcando a própria expertise chamada "direito internacional público". Não se pode perder de vista, porém, que a comunidade tradicional dos juristas internacionalistas também é caracterizada como portadora de vocabulário e viés estrutural próprio, bem como de seu próprio projeto de hierarquia em relação aos demais ramos fragmentários. Este ponto será retomado adiante. Por enquanto, é suficiente manter em mente que o direito internacional público também é uma visão particular de ordenação das relações jurídicas internacionais.

A existência simultânea de visões particulares a respeito das relações jurídicas internacionais dá origem ao interessante fenômeno dos conflitos entre expertises do direito internacional. Estes conflitos acontecem tanto (i) entre a expertise tradicional do direito internacional público e novas expertises (direitos humanos, ambiental, penal, econômico, investimentos estrangeiros etc.) quanto (ii) em relação às novas expertises entre si. Estes conflitos dão origem a embates sobre qual é o foro apropriado para decisão, qual ramo do direito é especial (lex specialis), e qual é geral (lex generalis), e a como os fatos de determinado caso devem ser categorizados (issue framing).

Exemplo de conflito de expertises do primeiro tipo, acima referido, ocorreu no julgamento do caso Tadic, pelo Tribunal Penal Internacional para a Ex-Iugoslávia (TPII) em 1999. Este caso envolveu um conflito de "testes jurídicos" para caracterizar o conflito na Iugoslávia como “internacional”, como em oposição a um conflito “interno". O tribunal apenas poderia exercer jurisdição sobre o acusado caso o conflito fosse da primeira espécie. Para tanto, era necessário estabelecer que os atos de Tadic na Bósnia-Herzegovina eram atribuíveis à Sérvia. Em 1986, no caso Nicarágua, a Corte Internacional de Justiça (CIJ) havia utilizado o critério de "controle efetivo" para decidir que as ações dos "Contra" na Nicarágua não poderiam ser atribuídas aos Estados Unidos. Esta era, portanto, a perspectiva prevalente no direito internacional público a respeito da atribuição da conduta de indivíduos ao Estado. Rejeitando o precedente estabelecido pela CIJ para a atribuição de conduta de particulares ao 
Estado, o TPII afirmou o teste de "controle geral" (overall control), atribuindo as ações de Tadic à Sérvia, e assim garantindo a condenação do acusado (Ribeiro, 2012, p. 201-3; 211-2). Segundo Koskenniemi (2007a, p. 4), a orientação dos juristas criminalistas contra a impunidade fez com que o direito precedente fosse alterado. O fato de que o caso estava sendo julgado num espaço decisório permeado por membros da comunidade jurídica criminalista fez toda a diferença.

Como se disse anteriormente, as possibilidades de conflito e incoerência sistêmica se dão não só em relação ao direito internacional público, como no caso Tadic, mas também quanto a ramos internacionalistas fragmentários entre si. Exemplo disso é o conflito do direito do comércio internacional com o direito internacional ambiental no caso Carne bovina hormônios, em que o Órgão de Apelação da Organização Mundial do Comércio (OMC) rejeitou a aplicação do princípio da precaução. Nesse sentido, disposições jurídicas de outros corpos que não tenham sido incorporadas às normas específicas do Sistema Multilateral de Comércio são tratadas, segundo Koskenniemi e Leino (2002), como irrelevantes. Há não só “falta de sensibilidade a preferências não-comerciais" (2002, p. 572), como também a visão de que estas preferências são roupagens para artimanhas protecionistas (2002, p. 574). A visão do comércio absorve a maneira de enxergar o mundo. Este ponto é evidenciado pela decisão no caso Camarão-tartarugas marinhas. Como relata Welber Barral:

\footnotetext{
o Painel e o Órgão de Apelação, naquele caso, nada mais fizeram do que interpretar literalmente o artigo XX do GATT, que permite medidas nacionais relacionadas com a proteção da saúde humana e animal, ou necessárias para proteger recursos naturais [...] exauríveis. Entretanto, essas medidas não podem constituir uma restrição disfarçada ao comércio internacional, como ocorria com a medida norteamericana de proteção às tartarugas. (Barral, 2007a, p. 120 - adicionou-se ênfase)
}

Koskenniemi e Leino (2002, p. 560) relatam que, em estudo no ano de 2000, da Comissão de Direito Internacional da ONU identificou conflitos "entre regras da Carta da ONU e outras regras, entre imunidade e direitos humanos, ambiente e comércio, direito do mar e tratados de áreas pesqueiras e assim por diante." Nota-se que a abrangência dos conflitos envolvendo expertises é muito mais ampla do que os exemplos trabalhados aqui. A ordenação jurídica das relações internacionais torna-se caleidoscópica, com cada ramo buscando articular suas próprias "preferências incrustadas" (embedded preferences) (Koskenniemi, 2007a, p. 9)

Diante das prioridades específicas incorporadas pelos diferentes regimes, e da possibilidade de múltiplas caracterizações de um mesmo problema, de modo que ele possa ser tanto de direito ambiental quanto de econômico ou de direitos humanos (múltiplas 
possibilidades de "issue framing"), surge o problema: a quem caberá decidir quando mais de um regime for aplicável? (Koskenniemi, 2007a, p. 5)

Koskenniemi (2007a) afirma que uma visão "constitucionalista" e outra "pluralista" emergiram para endereçar este problema. As duas vertentes representam, respectivamente, a "a necessidade de centralização e controle, numa mão, e de diversidade e liberdade, noutra." (2007a, p. 24) Há, porém, ambivalência na corrente pluralista. Uma primeira vertente pluralista busca "desenvolver uma imagem descritivamente precisa dos modos de influência no mundo contemporâneo" (2007a, p. 23). Outra abordagem é caracterizada pretensões "normativas" de "repensar a natureza da profissão jurídica cuja tarefa é gerenciar novas formas de regulação para além do Estado.” (2007a, p. 23) A primeira vertente é enfatizada por Koskenniemi em sua abordagem do "pluralismo jurídico". A referência a "pluralismo", nesta tese (e de maneira preponderante em Koskenniemi, 2007a), assume este sentido. A segunda é conhecida por "governança global" (Koskenniemi, 2007a, p. 23). Tendo se tornado particularmente influente, ela será o foco da seção 2.3.

Constitucionalismo e pluralismo ${ }^{74}$ fornecem vocabulários para dar sentido a um novo mundo a partir de perspectivas alternativas e portanto para estabelecer a autoridade daquelas formas de expertise abrigadas por estes respectivos vocabulários.” (Koskenniemi, 2007a, p. 25) Esta afirmação pode ser interpretada no sentido de que, numa mão, o projeto constitucionalista favorece o discurso de expertises que buscam unificar o direito internacional ao longo de uma só hierarquia. Assim, o vocabulário constitucional é atrativo para visões que concebem o direito internacional público ou o direito internacional dos direitos humanos como hierarquicamente superiores às demais expertises. Noutra mão, o pluralismo favorece discursos que buscam se singularizar em relação a projetos gerais, como o direito internacional econômico e o direito internacional penal fazem em relação ao direito internacional. No cenário fragmentado, o pluralismo fornece o vocabulário para reconhecer autoridades específicas em matérias específicas, que assim subvertem as hierarquias pretendidas pelo direito internacional tradicional ou intentadas pelos direitos humanos. Cabe, neste momento, apresentar os principais contornos da abordagem constitucionalista e pluralista.

A proposta constitucionalista para o direito internacional enfatiza o discurso da unidade. $\mathrm{O}$ direito internacional público é proposto como meta-regime jurídico a coordenar as diferentes áreas especializadas. Muitos juízes da CIJ incorporaram esta visão. Koskenniemi e

\footnotetext{
${ }^{74}$ A proposta de "pluralismo jurídico global", de Paul Schiff Berman, será abordada na seção 2.3.5.3, mais adiante.
} 
Leino (2002) relatam as posições de Robert Jennings, Stephen Schwebel e Gilbert Guillaume: todos eles, na posição de presidentes da CIJ, fizeram pronunciamentos na Assembleia Geral da ONU em que: (i) expressaram preocupação com a proliferação de tribunais internacionais e de ramos específicos; sinalizaram a possibilidade de conflitos entre decisões, com "sério risco de inconsistência na jurisprudência (case law)" (2002, p. 555); (iii) alertaram para os problemas de "sobreposição de jurisdições (overlapping jurisdictions)", com a possibilidade de escolha estratégica de jurisdição (forum shopping) por parte de litigantes (2002, p. 554); e (iv) propuseram que outras cortes internacionais submetessem pedidos de opiniões consultivas (advisory opinions) à CIJ, com a finalidade de harmonização do direito internacional. Estes juízes, assim como os demais membros do projeto constitucional, enxergam a fragmentação e o choque de regimes e tribunais como uma patologia (2002, p. 560), temendo "perda da supervisão" (loss of overall control) sobre o sistema (2002, p. 556).

Quanto a este aspecto, Koskenniemi e Leino chamam a atenção para a necessidade de caracterizar as intenções constitucionalistas de unidade no DIP como sendo, também elas, um projeto (particular) de poder, e sugerem que a preocupação dos presidentes da CIJ com a "perda do controle" poderia ser traduzida como uma preocupação concreta de perda de controle "por mim" (2002, p. 575 - ênfase no original).

A abordagem constitucionalista é caracterizada pela tentativa de responder à fragmentação do DIP não só pela proposta de hierarquias de regras e instituições (inclusive entre cortes), mas também pela escolha de valores basilares que caracterizariam um projeto de bem comum para o plano internacional (Koskenniemi, 2007a, p. 15). Numa variante, os valores basilares são associados à soberania e ao ponto de vista estatal. Este é o vocabulário do direito internacional público. Noutra variante, o papel constitucional seria desempenhado pelas normas de direitos humanos, elevadas ao status de jus cogens, a derrogar inclusive normas do direito internacional público que lhe sejam contrárias (Galindo, 2013). Os valores basilares seriam relacionados à proteção do indivíduo, não mais priorizando o ponto de vista da soberania estatal. Nota-se que o discurso "constitucional" também dá margem a disputas internas, de expertises com vieses estruturais em choque, e que competem para se situar no topo.

Já a proposta pluralista abandona a pretensão de padrão fixo para a solução de conflitos entre regimes e instituições. O pluralismo jurídico abraça aquilo a que Marcus Faro de Castro se referiu como perda do sistema: “deixa de ser possível ordenar as 'formas' da jurisprudentia de modo hierarquizado, com fundamento em conceitos estáveis e em seu conjunto abrangentes ao ponto de pretender formar um quadro de referenciais normativos 
'completo'.” (2012, p. 204) Segundo Koskenniemi (2007a), a ideia de completude do direito internacional é encarada como uma utopia contraproducente. Esta linhagem enxerga a globalização como expressão, no plano internacional, da divisão do trabalho ocorrida nas sociedades nacionais, o que se associa à existência de múltiplos regimes internacionais especializados. Não há a pretensão de estabelecer hierarquias para resolver choques de regimes e jurisdições: o centro se desloca, e cada expertise tem oportunidade de prevalecer em casos e contextos específicos.

Tampouco há a pretensão de afirmar valores comuns a uma pretensa comunidade internacional: não há a proposição de uma única ideia de bem. Nesse sentido, a crítica de Koskenniemi é a de que o pluralismo, apesar de possuir vocabulário com grande poder descritivo para o cenário de fragmentação, não dá conta do aspecto normativo, ou seja, não elabora a parte do "dever ser" a respeito do direito internacional (isto é, não tem proposta metanormativa) - "não pode sustentar um projeto jurídico a título próprio" (2007, p. 24). Como se indicou anteriormente, para Koskenniemi, a vertente pluralista que de fato tem projeto normativo é a da governança global. Neste ponto, pode-se discordar da visão de Koskenniemi, porque o projeto de "dever ser" do pluralismo consiste justamente em, ao caracterizar a fragmentação, apresentá-la como desejável. Não há afirmação de um só valor para toda normatividade internacional, mas a busca da coexistência da diversidade valorativa é, em si, um projeto de “dever ser".

Para Koskenniemi e Leino (2002, p. 578), entender o debate sobre fragmentação como se ele dissesse respeito apenas à coerência do direito internacional é dirigir a atenção para um ponto equivocado, por não revelar o que realmente está em jogo. A escolha dos regimes especializados é um problema político tratado como se fosse um problema formal de jurisdição (Koskenniemi, 2007a, p. 6, 27). Pode-se depreender que as narrativas de fragmentação e unidade englobam discursos: (i) representativos de uma disputa política, (ii) que expressam visões particulares a respeito do bem; e que (iii) pretendem promover a universalização de sua visão de bem. Cada comunidade - inclusive a da unidade pelo direito internacional público - propõe uma visão particular do bem (Martineau, 2009, p. 27; cf. Koskenniemi, 2007b), que se pretende fazer compartilhar por todos, ainda que seja no reconhecimento de autoridade em determinada matéria. Emerge, neste contexto, a necessidade de atenção ao aspecto do discurso (Koskenniemi, 2007a, p. 7). Conflitos na esfera política passam a ser caracterizados como problemas de expert knowledge (2007a, p. 8), versados em vocabulários específicos. 
Quando as decisões políticas são versadas em vocabulários especializados, dois perigos emergem. Um se refere ao objetivo do controle democrático da atividade política. A sofisticação do vocabulário com que decisões econômicas são tomadas é alienante para quem não tem treinamento específico na área. Neste contexto, as opiniões "leigas" são facilmente descartadas como inadequadas, apesar de o processo eletivo, expresso nas urnas, ser tipicamente "leigo". Além disso, sustentar que uma decisão é "técnica" envolve a invocação de uma posição exterior à esfera de contestação política (cf. Pahuja, 2009, p. 248). Este ponto será retomado ao final da seção 2.3.4. O segundo perigo se refere ao papel do direito. O resultado de áreas altamente informadas por linguagens econômicas, como finanças, comércio e relações monetárias internacionais, é a incapacidade de perspectivas jurídicas tradicionais exercerem protagonismo na articulação da cooperação econômica internacional. Neste contexto, o direito é relegado a funções instrumentais, de implementação ou formalização de imperativos "revelados" pelo conhecimento econômico. Este perigo é, também, desafio para que o conhecimento jurídico se reinvente, a partir de bases interdisciplinares, para assumir papel de articulação das políticas públicas, da política econômica, e da cooperação internacional. Este ponto está relacionado à seção 2.3.5, e é a preocupação central do capítulo 4.

Esta seção narrou transformações no direito internacional a partir da Segunda Guerra Mundial. O processo de fragmentação foi típico da ordem do pós-guerra. Formou-se um "bolo de diversas camadas" de instituições com diferentes propósitos, e houve proliferação de linguagens jurídicas fragmentárias. A ONU, projetada para articular a concepção de "segurança coletiva" em bases jurídicas, perdeu lugar para espaços institucionais e práticas informais orientadas pela TRI e pela estratégia de balanço nuclear de terror, com o início da Guerra Fria. Preocupações de segurança e estabilidade socioeconômica mostraram-se interligadas no pensamento do pós-guerra. O Plano Marshall incentivou a integração europeia, e deu margem à formação do direito comunitário. A cooperação econômica internacional estruturou-se em torno das organizações de Bretton Woods e do GATT, dando origem ao direito internacional econômico, inicialmente informado pela sensibilidade econômica do "liberalismo assistido". Com a formação de novos Estados e a tentativa de nova ordem econômica internacional do terceiro mundo, o direito internacional dos contratos ou dos investimentos estrangeiros foi estruturado como resposta. Viu-se que, para além destes, outros 
ramos fragmentários emergiram no período: direito internacional penal, ambiental, dos direitos humanos, entre outros. Como repostas ao fenômeno da fragmentação, foram identificadas as perspectivas constitucional e pluralista.

A seção 2.3, a seguir, aborda uma terceira resposta, a governança global, que está associada, no plano econômico, à globalização e à ascensão da sensibilidade econômica do neoliberalismo.

\subsection{Governança global}

Entre as décadas de 1970 e 1990, as relações internacionais passaram por transformações que se refletiram nas formas e no exercício da autoridade e da normatividade no cenário internacional. Os novos contornos deram origem ao cenário de "governança global”. Ele é multicêntrico, com difusão de poder. Nele coexistem autoridades públicas e privadas, em múltiplos regimes internacionais e com variados mecanismos de normatividade, em diversas áreas de especialização. Neste contexto, o "internacional" - isto é, o foco na relação entre Estados - cede lugar ao "transnacional" e ao "global": outros tipos de relações, que não só interestatais, tornam-se relevantes.

Esta seção tem o intuito de caracterizar a governança global em seus principais aspectos. Para tanto, a primeira subseção (2.3.1) identifica desdobramentos que estiveram relacionados à mudança na ordem internacional do pós-guerra, tanto no campo da cooperação econômica quanto no de realinhamentos geopolíticos diversos. A segunda subseção (2.3.2) caracteriza contornos principais de duas categorias que ganharam força para descrever as relações internacionais em dois momentos distintos, e que estão envolvidas com a formação do cenário de governança global: interdependência e globalização. A terceira (2.3.3) dedica-se a transformações institucionais, no campo das organizações internacionais governamentais, decorrentes de reorientações na ordem internacional a partir da predominância da sensibilidade neoliberal e do estabelecimento da abertura aos mercados como prioridade política, e seus impactos para reformas domésticas "pró-mercado" no mundo pós-Guerra Fria. Os elementos levantados nas subseções de 2.3.1 a 2.3.3 refletem-se na quarta subseção (2.3.4), que caracteriza a governança global em seus aspectos conceituais e teóricos. Por fim, a quinta subseção (2.3.5) expõe perspectivas jurídicas em torno do projeto de governança global. 


\subsubsection{Crise da cooperação econômica internacional e realinhamentos geopolíticos}

A porção final dos anos 1960 experimentou difusões tecnológicas que tiveram impacto na economia internacional, sobretudo no campo monetário e das finanças. Este é o período da comunicação global por satélites e da introdução do computador pessoal. Os incrementos em comunicação e manejo da informação facilitaram a criação de canais para operações financeiras que se mostraram elusivos ao controle do Estado. Além disso, boa parte das movimentações transfronteiriças de capital passaram a dizer respeito ao comércio intrafirma, ao dinheiro movimentado por corporações multinacionais entre os diferentes pontos de suas cadeias produtivas instaladas ao longo do globo. O fechamento da conta de capitais, uma das bases da ordem de Bretton Woods, erodiu-se. O aumento dos fluxos financeiros e sua crescente volatilidade comprometeram a capacidade dos Estados Unidos de manter o lastro de sua moeda em ouro. Como se verá no capítulo 3, o aumento da volatilidade, embora não tenha sido o único fator relevante, teve peso decisivo. Em 1971, Nixon declarou o rompimento unilateral com esta regra fundamental do FMI: o dólar deixou de ser conversível. A medida foi o marco da ruptura da ordem monetária do pós-guerra (Eichengreen, 2008, p. 119-32).

No campo do comércio internacional, o protecionismo se acentuou na década de 1970, como resposta a diversos fatores, dentre os quais os choques do petróleo (Bhagwati, 1995, p. 54). O primeiro choque aconteceu em 1973, após os membros da Organização dos Países Exportadores de Petróleo (OPEP) declararem embargo aos Estados Unidos e a outros Estados. O embargo foi represália do mundo árabe ao apoio norte-americano a Israel na Guerra do Yom Kipur, do mesmo ano. Como consequência, o preço do petróleo foi de 3 dólares em 1973 para 12 dólares em 1974. Em 1979, novo choque, associado à revolução iraniana e à guerra entre Irã e Iraque elevou os preços a quase 40 dólares. Em uma década, o preço havia sido multiplicado diversas vezes, comprometendo as balanças comerciais e de pagamentos de muitos países.

Nos Estados Unidos e na Europa, o cenário de crise foi complementado pelo desemprego, a diminuição do ritmo de crescimento econômico e a inflação. A ascensão de países com modelo exportador, como Cingapura, Hong Kong, Coreia do Sul e Taiwan, nesta mesma época, foi respondida com pressões políticas internas (lobbies) por proteção das indústrias locais nos países industrializados. Temia-se desindustrialização e "exportação de empregos" (Bhagwati, 1995, p. 64). O resultado foi o apelo a medidas protecionistas. Como a regulamentação do GATT havia dificultado juridicamente o recurso à proteção tarifária, houve aumento do uso de barreiras não tarifárias, como quotas de importação, licenças não 
automáticas, medidas compensatórias e de antidumping, além de constrangimentos para a adoção de medidas voluntárias de restrição de exportações (Bhagwati, 1995, p. 44-5). A Rodada Tóquio buscou endereçar este problema, e durou de 1973 a 1979, mas não foi bemsucedida: o resultado foi "plurilateral", significando que não vinculava a todos os membros do GATT, e apenas 24 Estados aderiram (Jackson, 2000, p. 290).

No campo da cooperação econômica internacional, houve, portanto, ruptura em relação à ordem de Bretton Woods. Nem a cooperação monetária, nem a cooperação comercial sobreviveram intocadas à crise. No campo monetário, o padrão de estabilidade cambial atrelada ao dólar-ouro foi substituído pela livre flutuação das moedas. No campo comercial, a liberalização, até então empreendida na frente tarifária, foi subvertida pela proliferação de barreiras não tarifárias. Em sentido econômico mais amplo, houve ruptura com a própria sensibilidade a orientar a ordem econômica internacional. A coexistência de altos índices de desemprego, inflação, alto nível de endividamento dos Estados, e baixo nível de crescimento, levou à descrença com o modelo de "liberalismo assistido", inspirado na macroeconomia keynesiana. Era o esgotamento do modelo de welfare state. Nos anos 1970 e 1980, o neoliberalismo se afirmou como nova sensibilidade econômica preponderante, ponto a que se dedica a seção 3.3 .

O aspecto econômico não foi, porém, o único a entrar em crise nos anos 1970. Esta também foi época de realinhamentos políticos e de redefinição dos termos das alianças existentes. Três eixos de relações entraram em crise: (i) a aliança atlântica, (ii) o diálogo Norte-Sul e (iii) o confronto Leste-Oeste.

No que diz respeito à aliança atlântica, o final da década de 1960 e a de 1970 foram momentos em que os Estados Unidos passaram a postular a divisão do "fardo" das políticas de ajuda externa e de contenção do socialismo com a Europa. Os países europeus já haviam se recuperado economicamente da Segunda Guerra Mundial, e passavam a ocupar a posição de competidores dos Estados Unidos nos mercados mundiais. Esta fase experimentou a multilateralização da ajuda externa, que migrou da preponderância bilateral da ajuda norteamericana a outro cenário, de maior intensidade da ajuda multilateral abrigada pela OCDE (Lumsdaine, 1993, p. 242, 256). A aliança não chegou a se desfazer, mas os Estados Unidos passaram a enxergar a Europa e o Japão mais como competidores (num cenário econômico multipolar), em contraste com a posição assistencialista caracterizada pela atitude norteamericana do Plano Marshall.

No aspecto Norte-Sul, as articulações por uma nova ordem econômica internacional entraram em crise, e foram encerradas por Reagan no início da década de 1980, conforme 
relatado ao final da seção 2.2. O encerramento do diálogo Norte-Sul pode ser interpretado como expressão da indisposição dos Estados Unidos em conviver com uma "terceira via" entre o socialismo e o capitalismo: os países em desenvolvimento deveriam abraçar o modelo de economia de mercado, que se tornava "único", hegemônico. A pauta para as relações Norte-Sul não seria mais dada em torno da nova ordem econômica internacional, mas pelo Consenso de Washington: reformas domésticas para assimilação à economia global.

O embate Leste-Oeste também passou por transformações. Primeiramente, a visita de Nixon à China em 1972 sinalizou fissuras no bloco socialista, e inaugurou a diplomacia trilateral: Washington-Pequim-Moscou (Dittmer, 1981). A Guerra Fria já não era mais a mesma: a China nuclear emergia, recuperava seu assento no Conselho de Segurança (Saliba; Pena, 2008), e desalinhava suas políticas em relação à União Soviética. O segundo aspecto é o próprio fim da Guerra Fria entre 1989, momento da queda do Muro de Berlim, e 1991, quando ocorreu o desmantelamento da União Soviética. O colapso da União Soviética permitiu a reunificação alemã, formalizada em 1990, que por sua vez esteve na base da intensificação do projeto comunitário europeu dos anos seguintes.

O resultado foi a transformação do mapa geopolítico, somada a significativas reordenações econômicas. No campo das representações intelectuais, duas categorias emergiram em momentos distintos para dar conta das transformações globais deste período. A primeira delas é a interdependência, que se difundiu na década de 1970. A segunda, globalização, tornou-se onipresente nas descrições de mundo desde os anos 1990. Ambas têm traços marcadamente econômicos, mas não se limitam a esta arena das interações internacionais. Ambas, além disso, ressignificam aquilo que se entende por "internacional", e são componentes das representações a respeito da "governança global".

\subsubsection{Interdependência e globalização}

"Interdependência" tornou-se chavão das relações internacionais na década de 1970, assim como "globalização" foi o mote das análises da década de 1990 (Keohane; Nye, 2000). O estudo destas categorias, no contexto da preocupação com a governança global, se justifica pelos seguintes motivos. Primeiramente, como já indicado, as duas expressões refletem modificações percebidas nos padrões de interações no globo. Neste sentido, elas abrem espaço para representações intelectuais de eixos "transnacionais" e "globais". A segunda razão consiste em que, como indica Marcus Faro de Castro (2005b, p. 130), os estudos sobre "regimes internacionais", conduzidos por autores como Stephen Krasner, Robert Keohane, 
Joseph Nye e John Gerard Ruggie, derivaram do estudo da interdependência. Este aspecto é complementado pela informação de que os regimes internacionais são palavra-chave nas representações intelectuais a respeito da governança global. Ou seja, os estudos sobre governança global têm raízes nas articulações sobre interdependência. Em terceiro lugar, tanto a globalização afeta os processos de governança, quanto é, por sua vez, afetada por eles (Keohane; Nye, 2000, p. 1).

Estas considerações evidenciam a importância da compreensão das noções de interdependência e globalização para a abordagem da governança global.

\section{Interdependência}

A perspectiva da interdependência foi concebida como resposta ao realismo nas relações internacionais. Na visão realista, (i) os Estados são os únicos atores relevantes, (ii) a força militar é o meio mais eficaz de expressar o poder, embora outros meios possam ser empregados, e (iii) o tema da segurança militar (high politics) predomina sobre assuntos econômicos e sociais (low politics). (Keohane; Nye, 1988, p. 39-40) Já na perspectiva da interdependência, os três pontos são questionados em virtude de mudanças na "natureza da política mundial" desde a Segunda Guerra. Caem o estatocentrismo, a prioridade da força e a hierarquia de questões. Em seu lugar, a interdependência representa um mundo de múltiplos atores, múltiplos temas na agenda internacional e ausência de hierarquia clara de questões (Keohane; Nye, 1988, p. 41-2).

No pano de fundo destas mudanças estão avanços nas telecomunicações e nos transportes, que propiciaram o aumento dos contatos sociais e econômicos, e contribuíram para a erosão das fronteiras dos Estados. Neste contexto, novos entes deixam de se vincular a limites territoriais específicos, como corporações transnacionais, movimentos sociais transnacionais e organizações internacionais (Keohane; Nye, 1988, p. 15). Aumentam os canais de interação para os fluxos transfronteiriços mais variados: de dinheiro, pessoas, bens, informação etc. (Keohane; Nye, 1988, p. 22) Desenvolvem-se relações que não são apenas interestatais. Corporações e bancos multinacionais ganham relevo, interagem entre si, com Estados e com indivíduos. O próprio sentido de Estado unitário e coerente, como ente monolítico, é quebrado. Concebe-se que relações internacionais possam existir entre subunidades governamentais, no que se denominam relações transgovernamentais. Além disso, há relações entre atores de tipos distintos, como Estados, corporações transnacionais e organizações não governamentais: são relações transnacionais, que rompem a divisão entre a 
política interna e internacional (Keohane; Nye, 1988, p. 41, 52). Canais múltiplos de contatos formam "redes de interações" (Keohane; Nye, 1988, p. 52).

Considerando estes elementos, torna-se mais fácil compreender o sentido de interdependência. Numa formulação simples, dependência é a situação em que forças externas são significativas ou determinantes para o comportamento de um ator. A interdependência, por sua vez, é a situação em que a dependência é mútua. Nesta situação, dois atores são capazes de causar efeitos recíprocos (1988, p. 22). A esta consideração, Keohane e Nye adicionam o elemento de "custos": a interdependência entre dois atores acontece quando há custos recíprocos em suas interações. Dessa forma, a autonomia decisória é reduzida, visto que cada ator precisa levar em conta os custos a enfrentar a partir do comportamento dos demais.

Interdependência não sugere ausência de conflitos nem resultados mutuamente benéficos (Keohane; Nye, 1988, p. 22-3). Diz respeito, antes, à alteração na forma como o poder é exercido, e que passa a levar em conta as sensibilidades e vulnerabilidades dos atores. As diferenças em sensibilidade e vulnerabilidade permitem que os atores explorem assimetrias de dependência, e isto se torna uma fonte de poder. Sensibilidade e vulnerabilidade são conceitos distintos.

A sensibilidade diz respeito ao custo de manter uma política diante de alterações no cenário. Ela pode ser medida pelo volume dos fluxos transfronteiriços e pelos efeitos de mudanças nos custos das transações sobre estes fluxos (Keohane; Nye, 1988, p. 26). Por exemplo, o país dependente da importação de petróleo para satisfazer suas necessidades energéticas é sensível às mudanças no preço desta matéria-prima. Além disso, o país que importe $80 \%$ do petróleo consumido internamente é mais sensível do que outro, cuja dependência de importações seja de $20 \%$. Já a vulnerabilidade se refere aos custos de alteração da própria política, ou seja, de mudança no comportamento de um ator. No caso do petróleo, a vulnerabilidade é tanto maior quanto mais difícil for o acesso a fontes alternativas de energia. "Dois países que importem 35\% do petróleo que consomem parecem igualmente sensíveis ao aumento dos preços; mas se um deles puder recorrer a fontes energéticas internas a um custo moderado, o outro país resultará muito mais vulnerável.” (Keohane; Nye, 1988, p. 27)

A partir desta distinção, Keohane e Nye identificam as assimetrias em vulnerabilidade como fonte mais importante de poder no cenário de interdependência, na comparação com a sensibilidade. Por exemplo, o país mais sensível a alteração dos preços no petróleo pode ser menos vulnerável que outro, por dispor de acesso mais fácil a fontes alternativas. No fundo, é 
a vulnerabilidade que precisa ser levada em conta pelos formuladores de políticas quando tomam decisões: “o que podem fazer, e a que custo?” (Keohane; Nye, 1988, p. 31) No cenário de interdependência, os tomadores de decisão precisam manter em mente que a manipulação das vulnerabilidades implica riscos por conduzir ao surgimento de contraestratégias por parte de outros atores. Os Estados Unidos forneceram apoio a Israel contra Egito e Síria na guerra de 1973, e em resposta países árabes promoveram embargo de petróleo no âmbito da OPEP, atingindo área de grande vulnerabilidade dos Estados Unidos e seus aliados. A vulnerabilidade militar de um lado provocou como contra-estratégia a exploração da vulnerabilidade econômica de outro. As assimetrias em diferentes áreas foram conectadas e manipuladas (Keohane; Nye, 1988, p. 33).

Neste contexto, pode-se entender o porquê da ausência de hierarquia clara de questões na agenda internacional sob a perspectiva interdependentista. "A segurança militar não domina consistentemente a agenda." (Keohane; Nye, 1988, p. 41) As assimetrias de vulnerabilidade podem ser exploradas em temas econômicos, ambientais e culturais, que passam a competir com a segurança na pauta das relações internacionais. Além disso, o próprio lugar da violência física como expressão última do poder é questionada: "[a] força militar, por exemplo, pode ser irrelevante para resolver desacordos sobre aspectos econômicos entre membros de uma aliança" (Keohane; Nye, 1988, p. 41). Neste sentido, Keohane e Nye exemplificam que o temor de dominação militar não está presente na perspectiva canadense em suas negociações econômicas com os Estados Unidos.

No cenário de múltiplos temas sem hierarquia pré-definida, a vinculação entre questões de áreas diferentes (econômicas e ambientais, por exemplo) permite explorar assimetrias e funciona como fonte de poder e barganha. As organizações internacionais, nesse sentido, ganham relevo para a perspectiva da interdependência, por funcionaram como foro em que questões diferentes podem ser colocadas na agenda e conectadas entre si em negociações (Keohane; Nye, 1988, p. 54-5). No paradigma realista, as organizações internacionais são mero reflexo da estrutura de poder entre os Estados, tendo, por isso, papel secundário. "Portanto, a interdependência complexa produz padrões políticos diferentes daqueles da concepção realista de mundo.” (Keohane; Nye, 1988, p. 55)

\section{Globalização}

Na perspectiva de Robert Keohane e Joseph Nye (2000), globalização e desglobalização são processos de aumento e diminuição do "globalismo". Este, por sua vez, é 
definido como "situação mundial que envolve redes de interdependência em distâncias multicontinentais." (2000, p. 2) As redes são estruturas pelas quais correm "fluxos e influências de capital e bens, informação e ideias, pessoas e força, bem como substâncias ambiental e biologicamente relevantes.” (2000, p. 2) Depreende-se que o globalismo possui múltiplas dimensões: monetária, financeira, comercial, informacional, cultural, de transportes, militar, ambiental, epidêmica etc. Nesta esteira, a globalização pode ser definida como "encurtamento de distâncias em larga escala", e contrastada com fenômenos como localização, nacionalização ou regionalização. "Os fluxos de longa distância são volumosos e contínuos, afetando as vidas de muitas pessoas" (2000, p. 7).

A globalização, neste sentido, não é fenômeno novo. Nem mesmo a globalização da economia. "Em algumas medidas, os mercados de capital eram mais integrados no início do século XX, e o fator trabalho é menos móvel hoje do que na segunda metade do século XIX" (Keohane; Nye, 2000, p. 3). Esta descrição é semelhante à caracterização de Barry Eichengreen (2008) a respeito da modalidade do capital: ela assume formato de "U" ao longo da história do século XX, começando com alta mobilidade, passando por momento de controle com a operação das instituições de Bretton Woods, e voltando à mobilidade crescente ao final da década de 1960. No entanto, é certo que os incrementos em comunicação e em transporte intensificaram a velocidade dos fluxos do atual momento globalizatório em relação aos momentos antecedentes.

Apesar das múltiplas dimensões da globalização, cabe destacar duas definições setoriais fornecidas por Keohane e Nye (2000). A primeira delas é a globalização econômica, que se refere ao aumento do "globalismo envolvendo fluxos de longa distância de bens, serviços e capital, bem como das informações e percepções que acompanham as trocas de mercado." (2000, p. 4) Os autores ainda destacam que a globalização econômica "também envolve a organização dos processos que estão ligados a estes fluxos" (2000, p. 4). Esta consideração é particularmente importante para a subseção 2.3.3, a seguir, que aborda mudanças institucionais em organizações internacionais no sentido de promover e estimular reformas domésticas pró-mercado ao final da Guerra Fria. Não só fluxos de bens, serviços e capital podem adquirir escala global, mas também as ideias e as instituições a respeito deles.

Outra dimensão é social e cultural, que “envolve movimentações de ideias, informações, imagens e pessoas - que, é claro, carregam ideias e informações consigo." Esta face da globalização envolve a imitação de práticas e instituições, em práticas de mimetismo e isomorfismo (Keohane; Nye, 2000, p. 5). Este aspecto também é relevante para a subseção 2.3.3: a globalização social e cultural afeta a percepção de como as políticas públicas e a 
política econômica deve ser conduzida, bem como do modo adequado de estruturar a cooperação econômica internacional. Ideias jurídicas também se globalizam, e podem exercer papel de orientação da política, ou tornarem-se instrumentais em relação a ela (Kennedy, 2006). A referida subseção chama atenção para o papel de organizações internacionais na promoção do isomorfismo institucional pró-mercado, a partir do mote da "boa governança".

O rompimento da ordem de Bretton Woods em 1971, o fim do welfare state e a emergência da sensibilidade neoliberal como fonte primária de material intelectual para orientar a atividade econômica, política e jurídica são desdobramentos relacionados à globalização. Como tais, sinalizam mudanças na forma como instituições do plano global interagiram com o plano doméstico para promover reformas pró-mercado. $\mathrm{O}$ aspecto da reconfiguração de organizações internacionais governamentais na era da globalização e do fim da Guerra Fria, pertinente a este contexto, é abordado a seguir.

\subsubsection{Redefinições institucionais e reformas para a economia de mercado.}

A queda do muro de Berlim, em 1989, e o desmantelamento da União Soviética, em 1991, representaram mudança na ordem mundial. O fim da ordem bipolar foi lido como representativo do triunfo das instituições de tipo ocidental, defendidas pelo modelo norteamericano. Outra significativa mudança no mapa se deu com o processo de reunificação da Alemanha, que se desenrolou de maneira rápida e sem resistência por parte da União Soviética (Ikenberry, 2001, p. 222). A reunificação alemã impulsionou o projeto comunitário em torno de uma União Europeia. Nota-se que as portas estavam abertas para as práticas de aproximação institucional, seja na Europa, seja no mundo. Em outros termos, o fim da Guerra Fria e a globalização deram ensejo a processos de isomorfismo, orientados por racionalidades que aqui se buscam evidenciar.

Neste contexto, o papel de organizações internacionais foi afetado com as mudanças geopolíticas:

\footnotetext{
Os Estados Unidos responderam à mudança favorável de poder procurando expandir ou criar uma variedade de instituições de segurança e econômicas - como a OTAN, o Acordo de Livre Comércio da América do Norte (NAFTA), a Cooperação Econômica Ásia-Pacífico (APEC), e a Organização Mundial do Comércio (OMC) como meios para, ao menos em parte, vincular outros Estados a orientações democráticas e de mercado. (Ikenberry, 2001, p. 216)
}

Além dos processos relacionados às instituições mencionadas por Ikenberry, a presente seção aborda também desdobramentos no Banco Mundial e no FMI, sob o lema de 
"boa governança". Estas duas últimas instituições são abordadas tendo por marco a descrição feita por Anthony Anghie (2004).

A condição de promover reformas domésticas para acessão à organização internacional foi traço comum a muitas das instituições, sejam elas de caráter regional ou global (Ikenberry, 2001, p. 235). Na interpretação de Ikenberry (2001, p. 245-6), tais iniciativas podem ser vistas como parte de um padrão geral de política externa norteamericana, que buscava "reforçar e perenizar (reinforce and lock in) reformas políticas e de mercado em países e regiões que passavam por transformações políticas e econômicas." Neste sentido, configurou-se o uso do Estado - e de negociações interestatais - para universalizar reformas pró-mercado, informadas pela sensibilidade neoliberal predominante no momento, e fortalecida com o fim da Guerra Fria e a alternativa socialista. Ainda segundo Ikenberry, este sentido pode ser percebido na fala de Robert Zoellick, à época em que atuava como oficial do Departamento de Estado norte-americano: “[n]ossa intenção foi criar instituições, hábitos, e inclinações que enviesariam a política destes países em nossa direção.” (apud Ikenberry, 2001, p. 246)

Um primeiro eixo envolveu instituições com propósitos regionais, como a OTAN, o NAFTA, a APEC e a União Europeia.

O papel da OTAN foi reconfigurado com o fim da ordem bipolar. De organização para contenção do socialismo, ela passou a formular convites de ingresso a ex-membros do bloco, condicionais à adoção de reformas domésticas. Neste sentido, em 1997, Polônia, Hungria e República Tcheca, por exemplo, foram convidadas a fazer reformas por abertura democrática e de mercado (Ikenberry, 2001, p. 235-7).

A lógica de garantir instituições de abertura política e de mercado também se aplica a projetos regionalistas, de caráter econômico, integrados pelos Estados Unidos, como o NAFTA e a APEC. No caso do NAFTA, de 1992, o acordo de livre comércio era meio de imunizar a abertura do mercado mexicano às transições políticas internas. Garantia-se, assim, a desregulamentação da economia mexicana e a redução de barreiras ao comércio internacional com os Estados Unidos e o Canadá (Ikenberry, 2001, p. 239). Na porção inicial dos anos 1990, a integração regional também começou a acontecer na região asiática do Pacífico, envolvendo Estados Unidos, Austrália e Japão (Ikenberry, 2001, p. 242). O regionalismo europeu envolveu, de modo semelhante, o condicionamento da entrada de países à adoção de reformas em instituições domésticas, atingindo com maior intensidade países do Leste e da periferia da Europa. 
Um segundo eixo envolveu instituições de caráter universal, como a OMC, o FMI e o Banco Mundial.

Para além dos regionalismos, a OMC foi a instituição com pretensões de alcance global que abrigou o ideal de abertura comercial, intensificando o processo iniciado com o GATT 1947, agora em bases jurídicas e formais mais acentuadas. No início da Rodada Uruguai, em 1986, não havia previsão explícita para o estabelecimento de organização internacional formal dedicada ao comércio internacional. A inclusão do projeto para a OMC na pauta da Rodada Uruguai só ocorreu em 1991 (Jackson, 2002, p. 400; cf. subseção 3.3.3). Trata-se, assim, de desdobramento posterior à bipolaridade. Em outros termos, a criação da OMC também foi reflexo do fim da alternativa socialista, com a correspondente consolidação e universalização do modelo de abertura comercial proposto pelos Estados Unidos. A Ata Final de Marraquexe foi assinada em 1994, e a OMC passou a funcionar em 1995 (Jackson, 2000, p. 46).

\begin{abstract}
A nova instituição foi um marco acentuado do estabelecimento de uma base judicial para o direito do comércio internacional. Uma organização formal foi estabelecida, com personalidade jurídica, secretariado independente, e moldura institucional expandida para a cooperação comercial internacional. Ao criar procedimentos para emitir decisões vinculantes, a OMC constitui uma forma de jurisdição compulsória no direito comercial internacional. (Ikenberry, 2001, p. 244)
\end{abstract}

É curioso pensar, nesse sentido, que a visão de "realismo utópico" dos juristas internacionalistas dos anos 1920, narrada por Guillaume Sacriste e Antoine Vauchez (2007), alcançou maiores concretizações não no campo do direito internacional público, mas no direito internacional econômico. Foi neste campo, afinal, que se conseguiu jurisdição permanente e compulsória, “com dentes” para sancionar a violação de acordos da OMC.

Uma das mudanças mais importantes introduzidas pela OMC foi o mecanismo para
solução de disputas comerciais. A abordagem anterior, do GATT, operava de acordo
com práticas de consenso que permitiam às partes perdedoras bloquear a adoção de
relatórios dos painéis. Sob a moldura da OMC, a solução de controvérsias é
incrementada pela existência de retaliação cruzada e a adoção automática dos
relatórios dos painéis. (Ikenberry, 2001, p. 245)

A regulamentação do comércio sob a OMC, além de aproveitar as disposições substanciais do GATT para o comércio de bens, expandiu a abrangência da regulamentação a outros setores do comércio, como serviços, investimentos e propriedade intelectual. A OMC adotou a obrigatoriedade da aceitação conjunta dos acordos negociados, que ficou conhecida como single undertaking (Lafer, 1998, p. 23). Assim, os acordos anexos ao Ato Constitutivo da OMC, referidos como "multilaterais", precisaram ser aceitos por todos como um só pacote, 
englobando o Entendimento sobre Solução de Controvérsias, o $\operatorname{GATS}^{75}$ o $\operatorname{TRIPS}^{76}$ e o TRIMS $^{77}$. Outros acordos tiveram caráter "plurilateral”, de adesão voluntária, e não foram compreendidos no single undertaking, como aqueles que dizem respeito ao comércio de aeronaves civis, compras governamentais, laticínios e carne bovina. Ainda assim, a regulamentação do comércio internacional na OMC continuou discriminatória em setores nos quais países em desenvolvimento tendem a desfrutar de vantagens comparativas, como agropecuária e têxteis. Nisto evidencia-se viés na abertura comercial, a favorecer a posição de economias de industrialização acentuada e de maior desenvolvimento tecnológico. Criar parques industriais e conseguir inovações tecnológicas requer capital, que tende a ser escasso nos países em desenvolvimento. Nesse sentido, o perfil de abertura comercial diferenciada para setores distintos de atividade econômica sugere contribuição para a permanência de desigualdades econômicas internacionais.

Além dos aspectos de juridicização formal da abertura ao comércio internacional e de expansão dos temas abrangidos pela cooperação econômica internacional, a OMC operou condicionalidades de ajustes domésticos "pró-mercado" para a acessão de novos membros, nos moldes do que a OTAN e a União Europeia fizeram em relação ao leste europeu. A acessão à $\mathrm{OMC}$ não se dá automaticamente, sendo conduzida por negociações entre a organização e o potencial membro. Neste processo, alterações em políticas públicas e na política econômica figuram no pacto de medidas para acessão.

As condicionalidades para acessão à OMC são expressão do conjunto de iniciativas para promover a "boa governança" (good governance). O termo é amplo: a definição de boa governança depende de quem a formula. No entanto, pode-se descrever a concepção das instituições que buscaram promovê-la, e que incluem o FMI e o Banco Mundial, como "a criação de governo que seja, entre outras coisas, democrático, aberto, 'accountable' e transparente, e que respeite e promova direitos humanos e 'rule of law'." (Anghie, 2004, p. 248) Nesta perspectiva, a boa governança existe quando um Estado cria condições para o livre desempenho dos mercados.

Porém, de maneira mais crua, a boa governança pode ser interpretada de outro modo: "é um conceito elaborado, no plano internacional, principalmente em relação a Estados de terceiro mundo, porque são estes os países que carecem de boa governança.” (Anghie, 2004,

\footnotetext{
${ }^{75}$ General Agreement on Trade in Services ou Acordo Geral sobre Comércio de Serviços.

${ }^{76}$ Trade-Related Aspects of Intellectual Property Rights ou Acordo sobre Aspectos dos Direitos de Propriedade Intelectual Relacionados ao Comércio.

77 Trade-Related Investment Measures Agreement ou Acordo sobre Medidas de Investimento Relacionadas ao Comércio.
} 
p. 249) Nesse segundo sentido, a boa governança é a técnica de gerenciamento de Estados que foram ex-colônias ou ex-socialistas, e que portanto se situam às margens do sistema capitalista. Passa-se a conceber que a ausência de desenvolvimento nestes países é atribuível à falta de boa governança em sua administração (Anghie, 2004, p. 249), enfatizando-se a existência de governos inaptos, corruptos, e instituições jurídicas que não favorecem o desenvolvimento dos mercados. Dada esta ênfase, as condições estruturais das relações econômicas internacionais ficam em segundo plano: questionar o papel do formato da cooperação econômica na perpetuação de desigualdades não é uma prioridade da linhagem da "boa governança". Nesse sentido, o subdesenvolvimento é tido como problema endógeno às sociedades, especificamente associado à deficiência de suas instituições políticas, jurídicas e econômicas.

A linguagem de direitos humanos foi empregada pela OMC, o FMI e o Banco Mundial como parte do pacote de boa governança. O discurso dá margem à articulação de medidas que sejam "trade-friendly" e "market-friendly", além de possibilitar a justificação da necessidade de adoção de padrões universais. Direitos humanos, afinal, são em princípio extensivos a todos. No pacote de direitos, enfatizam-se aqueles relacionados à proteção da propriedade, de modo a resultar em "direitos humanos desenhados para proteger ocidentais fazendo comércio em países estrangeiros.” (Anghie, 2004, p. 271) Esta concepção está associada à literatura institucionalista que articula noções de desenvolvimento atreladas ao "rule of law" como seu requisito mais básico, tal qual a "ordem aberta" de Douglass North (Fiani, 2011) ou as "instituições políticas e econômicas inclusivas" de Daron Acemoglu e James Robinson (2012). Em essência, porém, estas concepções ventilam a ideia de que o Estado deve prover instituições de apoio ao funcionamento dos mercados (vide subseção 4.2.2); estes, sim, os principais motores do desenvolvimento. Esta literatura fornece materiais intelectuais para a articulação da boa governança por atores como o FMI e o Banco Mundial, sendo apoiada pelas vertentes abordadas nas seções 4.1 e 4.2 .

O mecanismo privilegiado para difusão prática das doutrinas e políticas associadas à boa governança ou ao paradigma "rule of law" é a condicionalidade aplicada à assistência financeira provida pelo Banco Mundial e FMI. Neste sentido, a concessão de empréstimos vem acompanhada de "programas de ajuste estrutural", ou seja, a assistência é condicionada “a que os países façam mudanças profundas em seus sistemas econômico, político e financeiro." (Anghie, 2004, p. 258; cf. Rajagopal, 2003, p. 127-31; Pahuja, 2009, p. 241-5, 278) O ajuste estrutural geralmente apregoa redução de gastos governamentais, liberalização da economia e privatizações (Anghie, 2004, p. 259). As políticas de austeridade 
implementadas afetam direitos econômicos e sociais, como previdência social, saúde e educação, e com frequência são respondidas local e internacionalmente por meio de protestos (Anghie, 2004, p. 259; Castro, 2005a).

Num contexto em que as deficiências no desenvolvimento são vistas como endógenas, e atribuídas às más instituições políticas, jurídicas e econômicas existentes nos países em desenvolvimento, a receita da boa governança replica ou reedita o sentido de "missão civilizadora" do direito internacional de finais do século XIX e início do século XX (Anghie, 2004, p. 249; cf. Pahuja, 2009, p. 354). Bem como reedita, de certo modo, as formas internacionalizadas de administração colonial presentes no sistema de mandatos da Liga das Nações (Anghie, 2004, p. 263). Isto porque a boa governança articula reformas que buscam convergências institucionais em escala global, isomorfismos institucionais, e os modelos de "boas instituições" são retirados dos países avançados. Esta concepção se liga ao que a literatura de Law \& Finance, também conhecida como "teoria sobre as origens" (abordada na seção 4.2), propõe como ideal para o desenvolvimento dos mercados financeiros: instituições típicas do common law. Esta proposta também é sustentada pela tese da eficiência do common law, avançada pela AED (cf. item 4.1.4.2). O projeto de "convergência institucional" em torno desse modelo de instituições é, porém, criticado por certas vertentes da literatura institucionalista sobre desenvolvimento (como Variedades de Capitalismo e as contribuições de Ha-Joon Chang e Dani Rodrik, entre outros), abordadas na seção 3.4.

Neste sentido, é possível, com alguma liberdade de pensamento, fazer a crítica de que instituições financeiras internacionais, como o Banco Mundial e o FMI, ao articular reformas pró-mercado via "boa governança", assumem o papel de levar civilização e comércio ao restante do mundo, em analogia à tarefa do Sistema de Mandatos ou das Partes da Conferência de Berlim de 1884-5 em relação aos territórios africanos. O problema está no caráter institucional "ruim" do que existe localmente - a deficiência intrínseca aos nativos -, e que precisa ser suplantado por instituições "boas”, de tipo anglo-europeu, essencialmente prómercados. Ou seja, instituições do tipo “certo". Instituições políticas, econômicas e jurídicas que não se conciliem com o projeto de economia mundial liberalizada tanto no comércio quanto nas finanças são o reflexo do atraso que precisa ser superado. De modo análogo, no final do século XIX e início do XX, o direito internacional cumpria o papel da "boa governança" ao dar as bases para a universalização de civilização e comércio. Economicamente, instituições tradicionais de povos "retrógrados" eram empecilho à criação de mão de obra "livre" para engajar-se no sistema produtivo e, por consequência, consumir, realizando a dupla função de fornecimento de matérias-primas e de mercados consumidores 
para produtos europeus. Estas instituições tradicionais locais precisavam ser suplantadas por instituições de tipo europeu, integrando povos atrasados ou não civilizados ao sistema capitalista e à família de nações.

Interessantemente, o esforço do Banco Mundial e do FMI quanto ao desenvolvimento é direcionado a reformas das instituições locais, não postulando reformas "das estruturas fundamentais da economia internacional propriamente", e que poderiam ser encaradas como estando na base da situação desvantajosa experimentada por países em desenvolvimento. Estas estruturas são, pelo contrário, reforçadas e mantidas pela atuação do próprio Banco Mundial e FMI (Anghie, 2004, p. 268).

$\mathrm{O}$ que se depreende das transformações institucionais narradas acima é que a cooperação internacional assumiu novo sentido: de coordenação das políticas externas dos Estados, o foco intensificou-se na transformação de instituições domésticas. Existe um padrão institucional, associado à abertura política e à economia de mercado, que é a "boa governança”. E este padrão deve ser adotado por todo o mundo. Esta parece ser uma lição comum à análise dos desdobramentos da OTAN, NAFTA, APEC, União Europeia, OMC, Banco Mundial e FMI.

Embora a "boa governança" tenha sido projeto compartilhado por muitas organizações internacionais, que agiram "em concerto" para a promoção de isomorfismos institucionais (cf. Castro, 2005a), os projetos que compõem a chamada "governança global" (dos quais a boa governança é um) são múltiplos, e podem chocar-se entre si. A seção 2.3.4, a seguir, dedica-se à compreensão da governança global por meio da abordagem de aspectos conceituais e teóricos.

\subsubsection{Governança global: categorias, relações e crítica}

Governança global faz referência às formas de exercício da autoridade no mundo. Mudam tanto o sentido de "autoridade" quanto o de espaço de seu exercício, ou seja, de "mundo". No primeiro aspecto, o Estado e outros atores públicos, como organizações internacionais, passam a conviver com autoridades privadas. No segundo aspecto, é importante lembrar que o "internacional" é um espaço imaginado: as fronteiras são abstrações, construções humanas. Não se trata de entidade que exista por si só (Whitman, 2009, p. 3; Pahuja, 2009, p. 183). O “internacional”, como espaço de interações entre Estados, foi construído com a ordem de Westphalia, no século XVII, como narrado na seção 2.1. No momento característico da governança global, esta concepção de mundo cede lugar a 
outra, que concebe ligações entre o local e o global, entre o individual, o nacional e o internacional (Whitman, 2009, p. 18). São relações transnacionais: que perpassam diferentes níveis: interestatais, intergovernamentais, regionais, supranacionais, nacionais, locais e mesmo individuais. Os processos decisórios conectam ou afetam múltiplos níveis: "diferentes arenas e níveis da atividade humana tornaram-se porosos e facilmente entrecortados." (Whitman, 2009, p. 8) Este é o espaço do "global".

A "governança" é a expressão utilizada para designar o exercício da autoridade sobre este espaço. Não se trata de governo mundial (Keohane; Nye, 2000, p. 19). Ainda assim, a governança se refere ao exercício de autoridade análoga às funções desempenhadas pelos governos no plano doméstico, nos mais variados setores (Finkelstein, 1995). O sentido não é o de que os Estados estejam ausentes das atividades de governança: eles também exercem autoridade no plano global. No entanto, há também atores privados e do "terceiro setor". O próprio Estado deixa de ser visto como ente unitário: seus órgãos e agências engajam-se em redes de políticas públicas, por vezes perseguindo objetivos específicos e contraditórios. Este assunto será retomado adiante.

Falar sobre governança global é fazer referência, portanto, ao exercício de autoridade num mundo multicêntrico, e não mais estatocêntrico. Há difusão de poder (Solingen, 2012). O conceito de governança proposto por Keohane e Nye abarca estes elementos:

\footnotetext{
processos e instituições, tanto formais quanto informais, que orientam e restringem as atividades de um grupo. Governo é o subgrupo que age com autoridade e cria obrigações formais. Governança não precisa ser conduzida exclusivamente por governos e organizações internacionais que recebem sua autoridade por delegação. Firmas privadas, associações de firmas, organizações não-governamentais (ONGs), e associações de ONGs engajam-se todos no exercício da autoridade, frequentemente em associação com órgãos governamentais, para criar governança; algumas vezes sem autoridade governamental. (2000, p. 12)
}

Quando estes processos e instituições que orientam e restringem atividades de grupos humanos incidem sobre relações transfronteiriças, tem-se a governança global. Em outros termos, como define Lawrence Finkelstein: “governança global é governar, sem autoridade soberana, relações que transcendem fronteiras nacionais.” (1995, p. 368) É fazer no espaço global algo análogo ao que governos fazem localmente, porém na ausência de governo mundial. Assim, tal qual os governos afetam praticamente todos os aspectos concebíveis da vida humana, do nascimento à morte, também as atividades de governança se estendem pelas mais diversas arenas (1995, p. 370). Na governança global, as autoridades exercidas pelos variados atores decorrem das funções que eles desempenham internacionalmente: provimento e troca de informação, formulação de princípios e estabelecimento de consensos científicos ou 
técnicos em áreas específicas, esforços para influenciar regras domésticas e o comportamento de Estados, adoção de regras e códigos de conduta para setores específicos etc. (1995, p. 3701)

Whitman (2009) propõe que sejam feitas três perguntas a respeito da governança global: governança por quem, de quê, e para quem? A resposta à primeira pergunta permite identificar os atores relevantes; a segunda, as áreas em que a governança é exercida, e a terceira permite endereçar criticamente a questão da legitimidade, do propósito ou funcionalidade da governança global.

Atores da governança global

No que diz respeito aos atores, observou-se anteriormente que o cenário da governança global é multicêntrico: o Estado conta, mas não é a única autoridade relevante. Por vezes, o Estado interage com outros atores, mas outras formas de exercício de autoridade acontecem fora da supervisão governamental (Whitman, 2009, p. 11).

As classificações dos atores relevantes mudam na literatura sobre governança global. Keohane e Nye (2000) identificam autoridades de tipo governamental, privado e do terceiro setor. Atores governamentais seriam Estados, órgãos que compõem internamente o Estado e seus níveis subnacionais, e organizações internacionais de caráter governamental, como a ONU, a OMC, o FMI e o Banco Mundial. Atores privados seriam corporações transnacionais, empresas e outros. E atores do terceiro setor compreenderiam ONGs e entidades sem fins lucrativos, entre outras.

É comum encontrar, porém, autores que trabalham com classificações que distinguem dois agrupamentos: os atores de caráter público ou governamental, de um lado, e atores privados ou não governamentais, de outro (Whitman, 2009; Hall; Biersteker, 2004). Nesta classificação, o "terceiro setor" é compreendido na categoria dos "atores privados".

No campo dos atores governamentais, aspecto importante é a fragmentação do Estado, a perda de sua concepção como ente monolítico ou unitário. Embora formalmente se possa referir ao Estado como um ator, na prática, os diferentes agrupamentos de pessoas que o compõem perseguem objetivos diferenciados. Em decorrência, diferentes subunidades, como ministérios, secretarias, ou redes de políticas públicas que conjuguem entes governamentais e privados, podem perseguir políticas contraditórias às adotadas ou advogadas por outros setores dentro do mesmo Estado (Keohane; Nye, 2000, p. 19). 
Exemplo de Estado complexo, multifacetado, com subníveis perseguindo políticas em choque é fornecido por Whitman (2009, p. 47): em 13 de dezembro de 2006, o equivalente ao ministério do interior britânico anunciou plano para reduzir as emissões de carbono pela construção de casas mais eficientes no consumo de energia. Com isso, seriam economizadas 7 toneladas métricas de carbono. No dia seguinte, o equivalente ao ministério dos transportes anunciou o plano para expansão dos aeroportos, e o departamento de meio-ambiente estimou que as emissões de carbono decorrentes do aumento do tráfego aéreo aumentariam entre $22 \mathrm{e}$ 36 toneladas métricas até 2006. Nota-se como, neste exemplo, a política pública formulada por uma unidade do governo britânico não só contrariou, como anulou a de outra, perseguida simultaneamente.

A governança global envolve a emergência de atores não estatais, inclusive de autoridades privadas. Rodney Hall e Thomas Biersteker (2004) descrevem três tipos de autoridade privada: autoridades de mercado, morais, e ilícitas. Exercem autoridade privada de mercado os bancos, ao negociar reestruturação da dívida; empresas, ao escolher lugares para instalação, com promessa de geração de empregos; agências de classificação de risco como a Moody`s e a Standard and Poor`s, ao influenciar por suas avaliações o comportamento de investidores internacionais; e a autoridade difusa do capital especulativo e altamente móvel, que pode "recompensar ou punir de acordo com seu julgamento a respeito de como qualquer governo gerencia a política monetária, fiscal e a dívida externa.” (2004, p. 6)

Autoridades morais trabalham com ideias, conhecimento e legitimação. Elas são tanto capazes de influenciar a agenda e as percepções da sociedade a respeito dos temas com que lidam, como também de se tornarem referências em razão de sua expertise. ONGs se enquadram nesta categoria. Como exemplos, os relatórios anuais de direitos humanos da Anistia Internacional são influentes, e outras ONGs adquirem posição de autoridade ao emitirem certificações ambientais, de sustentabilidade, de produtos fair trade ou de não utilização de trabalho escravo ou infantil. O Greenpeace é influente na percepção popular a respeito de assuntos ambientais e proficiente na prática de chamar a atenção pública para a ação de madeireiras, caçadores de baleias e produtores de lixo nuclear. Neste grupo de autoridades morais estão também organizações e líderes religiosos de alcance transnacional (Hall; Biersteker, 2004, p. 14-5).

O terceiro grupo é composto por autoridades de caráter ilícito, que Hall e Biersteker exemplificam como sendo máfias, mercenários e organizações criminais transnacionais. Estas autoridades se desenvolvem no campo da violência organizada, e "frequentemente recebem reconhecimento social de legitimidade por atuarem no vácuo deixado por Estados fracos e por 
prover bens públicos que o Estado deixa de fornecer." (2004, p. 16) Grupos terroristas também lidam com violência organizada e recebem algum reconhecimento de legitimidade em suas comunidades de base, e podem ser encaixados aqui ${ }^{78}$.

Em seu conjunto e em suas respectivas áreas de atuação, estas autoridades privadas "definem agendas, estabelecem fronteiras ou limites para ação, emitem certificação, oferecem salvação, garantem contratos, provêm ordem e segurança”, agindo simultaneamente no plano doméstico e internacional (2004, p. 3), sendo portanto transnacionais.

Ainda no que diz respeito a quem exerce governança, é importante ressaltar que até mesmo indivíduos importam, quer deles emane autoridade de mercado, moral ou ilícita. “Auxiliados pela informação computadorizada e por tecnologias de comunicação, as iniciativas de especuladores monetários, hackers e terroristas (para nomear apenas alguns) são capazes de produzir efeitos sistêmicos nos mais altos níveis de organização política e social.” (Whitman, 2009, p. 21) Os pronunciamentos de Ben Bernanke ou Alan Greenspan, ou as decisões de investimento de George Soros são capazes de moldar comportamento de atores econômicos nos mais diversos cantos do mundo, com consequências diversas para as populações sujeitas a seus impactos sobre a política econômica e as políticas públicas de maneira geral ${ }^{79}$. As revelações de Edward Snowden a respeito de documentos secretos da National Security Agency (NSA) geram impactos para os aparatos militares, diplomáticos e de inteligência dos Estados Unidos. Num cenário de interdependência, mesmo indivíduos podem explorar sensibilidades e vulnerabilidades dos Estados, tais quais a dependência norteamericana em aparatos informatizados de comunicação. Este aspecto não é restrito a indivíduos que, por conhecimento, acumulação de riqueza ou posicionamento estratégico, tenham alcançado poder de criar impactos internacionais. De maneira coletiva e difusa, algo semelhante se dá em relação a todos os engajados na economia de mercado:

\footnotetext{
Nossos comportamentos de consumo (viagens de avião frequentes; comida e bens perecíveis obtidos nos quatro cantos do mundo; bens e serviços dependentes de fontes de energia não-renováveis) eventualmente manifestam-se como crises: peixes em extinção; escassez de água; mudança climática; e perda da biodiversidade pela destruição de habitats. (Whitman, 2009, p. 20)
}

\footnotetext{
${ }^{78}$ Certos grupos mercenários, porém, não parecem se enquadrar na nomenclatura de autoridade "ilícita" de Hall e Biersteker, como a Blackwater, que depois passou a se chamar "Xe" e subsequentemente "Academi". Trata-se de empresa do ramo de segurança que atua como exército privado complementar às forças armadas norteamericanas, como no Afeganistão e Iraque, e que também oferece serviços de escolta a navios mercantes em regiões com alta incidência de ataques piratas. Apesar de legalmente sediada nos Estados Unidos, a Blackwater/Xe/Academi é exemplo de autoridade privada nesta última classificação. A licitude de sua atuação é, afinal, altamente questionável, como sugere Jeremy Scahill (2007).

${ }_{79}$ Capturar estes impactos em termos jurídicos é uma das preocupações da Análise Jurídica da Política Econômica, abordada na seção 4.4 .
} 
As considerações de Whitman permitem refletir, por exemplo, sobre o potencial de decisões difusas da coletividade de investidores internacionais conformarem constrangimentos efetivos à condução da política doméstica. Por exemplo, a fuga de capital é a consequência temida de políticas públicas que abalem a confiança de investidores. Neste sentido, embora não seja formalmente jurídico, este constrangimento desempenha, na prática, funções de "veto" a certos comportamentos governamentais ${ }^{80}$.

Após o breve panorama dos atores envolvidos em atividades de governança, cabe passar à segunda pergunta proposta por Whitman (2009): governança de quê?

\section{Regimes da governança global: temas e formas da normatividade}

Quais são as arenas e setores de atuação dos diferentes atores, ou seja, o que buscam orientar, regulamentar, disciplinar, controlar? Também é relevante desdobrar esta questão: como o fazem? Por que meios exercem autoridade? Há, portanto, dois aspectos envolvidos: (i) os temas da governança e (ii) os modos ou formas pelas quais é exercida. A conjunção destes aspectos dá origem a múltiplos regimes internacionais, mais apropriadamente referidos como transnacionais ou globais.

No primeiro aspecto, Avant, Finnemore e Sell (2010) ressaltam que a governança global implica divisão do trabalho, e as diferentes autoridades, a que as autoras se referem como global governors, fundam seu poder em fontes distintas. A divisão do trabalho engloba as áreas mais distintas: economia (comércio, moeda, finanças), uso da força, internet, certificações dos mais variados tipos (ambientais, de gerenciamento de negócios, de risco de investimento), ambiente, padronização técnica, ciência, esporte, entretenimento etc. Fala-se, assim, em lex mercatoria, lex sportiva e lex informatica ou digitalis, por exemplo ${ }^{81}$.

\footnotetext{
${ }^{80}$ A existência de "freios e contrapesos parcialmente internacionalizados" como elementos da constituição política dos Estados, mas não tradicionalmente representados pelo direito, é abordada em Castro (2006).

${ }^{81}$ Nestes regimes, a normatividade emana tanto de atores governamentais quanto não governamentais. A lex mercatoria é o conjunto de práticas e procedimentos costumeiros que orientam a atividade comercial transfronteiriça. Ela envolve padrões contratuais de transportes, seguros e títulos de crédito, entre outros aspectos. A normatividade emana não só das práticas usuais de comerciantes, como de projetos de codificação no âmbito da United Nations Commission on International Trade Law (UNCITRAL), e é afetada por regulamentações estatais locais a respeito de aduana e sistema bancário, bem como pela atuação da $\mathrm{OMC}$. $\mathrm{Ou}$ seja, há um complexo de interações de atores privados, organizações internacionais e Estados. De forma semelhante, há certo "embaralhamento" de autoridades e expressões de normatividade nos campos da lex sportiva e informatica. A FIFA e o Comitê Olímpico Internacional exercem constrangimentos eficazes, sem caracterizar coerção, nos Estados que sediam eventos como a Copa do Mundo de futebol e as Olimpíadas, redefinindo prioridades de políticas públicas e implicando violações de direitos para "adequação" do espaço urbano. Neste sentido, há projeções de que as obras da Copa no Brasil impliquem o despejo de 250 mil pessoas (BBC Brasil, 2013). A justiça desportiva não tem caráter estatal, mas arbitral, e é internacionalizada. No Brasil, o judiciário estatal também atua no âmbito esportivo, alcançando decisões por vezes contraditórias com a
} 
Nota-se que, na realidade, a governança global não é uma coisa só, mas múltiplos projetos: "não há uma governança global genérica" (Whitman, 2009, p. 6). Ela é “fragmentada e heterogênea" (Keohane; Nye, 2000, p. 26).

Disto decorre que quando empregamos o termo "governança global", no singular e sem referência específica a nenhuma arena em particular (como a do ambiente global) ou atividade (como o comércio mundial), trata-se de um fenômeno somático - isto é, a governança global geral que resulta da ordem produzida por muitas governanças. (Whitman, 2009, p.35)

Sendo heterogêneos, os múltiplos projetos de governança podem entrar em conflito entre si (Whitman, 2009, p. 42), como entre comércio e ambiente, propriedade intelectual e saúde, segurança e direitos humanos etc. Não só entre regimes, como entre os atores que os impulsionam: projetos de livre acesso à informação de empresas como Google, Twitter e Facebook chocam-se com governos, como nos casos da China, Síria e Venezuela. O choque não se restringe a países estereotipicamente descritos como internamente problemáticos, mas também às relações entre Wikileaks, Julian Assange e Edward Snowden, de um lado, e o governo dos Estados Unidos, de outro, no que diz respeito aos projetos conflitantes de transparência governamental e segurança de Estado.

No segundo aspecto, questiona-se como a autoridade é exercida. Avant, Finnemore e Sell (2010) concebem a autoridade como a habilidade de induzir deferência em outros. Nesse sentido, o exercício da autoridade não requer necessariamente coerção, bastando que seja capaz de orientar, influenciar ou moldar o comportamento. Nisso há contraste com concepções tradicionais do exercício da autoridade no plano internacional, essencialmente ligadas ao poder estatal e à capacidade de obrigar, em última instância pelo recurso à violência física, o cumprimento da vontade estatal.

Observe-se que a governança global também conta com autoridades capazes de exercer coerção física, como Estados, organizações criminais transnacionais e organizações paramilitares. No entanto, "com mais frequência os governados aceitam a autoridade dos governantes de algum modo." (Avant; Finnemore; Sell, 2010, p. 8) Assim, autoridades que

adjudicação privada, em questões de organização de campeonato, contratos de trabalho e sanções disciplinares a atletas (Calixto, 2013). Na lex informatica ou digitalis, muito da autoridade administrativa e de solução de controvérsias encontra-se em mãos privadas, como na administração dos nomes de domínio pela Internet Corporation for Assigned Names and Numbers (ICANN). As regulamentações estatais conseguem atingir servidores e provedores situados em seus respectivos territórios, mas não o todo (Pinheiro, 2009). Paralelamente, a atividade de hackers e de grupos transfronteiriços de ativistas virtuais com composição variável (como o Anonymous) exercem autoridade "tirando do ar" sites de empresas, organizações e mesmo de entidades governamentais com cujo comportamento não concordem, inclusive por estratégias de ataque coletivo por sobrecarga de acessos, buscando provocar o chamado denial of service. Observa-se que nos três campos há complexidade de emanações normativas, que compreendem atividades de atores privados (identificáveis e difusos), Estados, organizações internacionais governamentais e não governamentais, empresas e outras modalidades de entidades. 
não contam com poder coercitivo em sentido físico podem conseguir deferência quando são reconhecidas em uma de quatro atividades: (i) definição de agendas e apontamento de situações-problema (issues), (ii) elaboração de normas; (iii) implementação e controle da observância (enforcement); (iv) avaliação, monitoramento e adjudicação (Avant; Finnemore; Sell, 2010). Vale observar que estas são quatro faces dos modos como os regimes da governança global expressam normatividade, tanto no sentido da elaboração quanto no da aplicação.

A definição de agenda e de situações-problema envolve a articulação para persuadir outros de que um assunto é importante, ou seja, quando há esforços para levar temas à pauta de discussão pública (Avant; Finnemore; Sell, 2010). Exemplo disso é a atuação do Greenpeace para chamar a atenção a temas como testes nucleares, aquecimento global, desmatamento e caça a baleias, entre uma variedade de outros temas relacionados ao ambiente.

A atividade de elaboração normativa pode ser tanto formal quanto informal. A elaboração formal se dá nas relações interestatais e no âmbito de organizações internacionais, por meio de tratados, decisões, resoluções etc. A elaboração informal se dá por meio de códigos de conduta de adesão espontânea, resoluções que afirmam princípios, entre outras modalidades de caracterização daquilo que ficou conhecido como soft law (Avant; Finnemore; Sell, 2010; Keohane, Nye, 2000). A soft law introduz elementos de relatividade normativa nas relações jurídicas, dando a entender que certas normas estão em estágio mais finalizado do que outras ${ }^{82}$. Hard law é o direito cuja força vinculante (binding character) é reconhecida. Soft law são normas de caráter propositivo, incipiente, e cuja adesão flui de necessidades técnicas, práticas ou políticas, mas que não têm suficiente obrigatoriedade em sentido jurídico convencional. Ou seja, não são sancionáveis pelos mecanismos coercitivos estatais, é um direito "sem dentes". Assim, resoluções do Conselho de Segurança da ONU a respeito do uso da força são hard law e contam com possibilidade de imposição coercitiva; o padrão de qualidade em gerenciamento "ISO 9000", da International Standards Association, não é hard law mas conta com a adesão prática das empresas. A percepção de que as normas propostas têm embasamento científico, ou que refletem "melhores práticas", contribui para a adesão dos governados. Isto se reflete na questão do expert rule, abordada na porção final

\footnotetext{
${ }^{82}$ Em artigo paradigmático, Prosper Weil (1983) levantou (e atacou) a ideia de relatividade normativa no direito internacional público: as normas vistas ao longo de uma escala de intensidade normativa, umas normas mais normas que outras. No Brasil, o principal estudo sobre o tema foi conduzido por Salem Hikmat Nasser (2006). As normas de soft law não possuem caráter vinculatório, mas meramente programático. Não são, nesse sentido, fonte obrigatória do direito internacional público, como entendidas pelo artigo 38.1 do Estatuto da Corte Internacional de Justiça.
} 
desta subseção. Adianta-se, porém, que a produção dos experts, ao articular informação e conhecimento, é capaz de alcançar "consensos intersubjetivos" em certas comunidades, que por isso assumem caráter normativo. Além disso, é capaz de mobilizar a opinião pública pela apresentação de "verdades" científicas. Ou seja, a expertise de atores ou grupos de atores também é fonte de autoridade e normatividade no cenário da governança global ${ }^{83}$ (Whitman, 2009, p. 11).

A implementação e controle da observância (enforcement) é atividade que busca induzir a observância de normas da governança (Avant; Finnemore; Sell, 2010). Ela pode se referir tanto a hard quanto a soft law. Os tribunais penais para a ex-Iugoslávia e para Ruanda trabalham com controle da observância do direito penal internacional. Já o site "Reclame Aqui”, por exemplo, trabalha com um modo diferente de implementação de direitos do consumidor: não por sanções formais, mas por práticas de name and shame, que conseguem afetar o comportamento inclusive de multinacionais sensíveis à publicidade negativa em torno de seus produtos. Trata-se de implementação normativa obtida não pela coerção física, mas por constrangimentos que incidem sobre a reputação das empresas.

É importante ressaltar este ponto: a governança global implica abertura e expansão das formas de constranger comportamentos. Como assinala David Lake, “embora a coerção ou ao menos uma capacidade coercitiva possa ser essencial para fazer cumprir regras, não decorre disso que o controle da observância (enforcement) seja restrito à violência. $\mathrm{O}$ controle da observância pode assumir muitas formas." ${ }^{84}$ (Lake, 2010, p. 596)

\footnotetext{
${ }^{83}$ Nesse sentido, para Koskenniemi (2007b), o direito internacional público encontra-se "fatiado em regimes regionais ou funcionais que se dirigem a públicos especiais, com interesses especiais e ethos especiais. Uma abordagem gerencialista está emergindo, que concebe o direito para além do Estado como instrumento para valores, interesses e preferências particulares." (2007b, p. 2) Na essência do "gerencialismo" (managerialism) está a abordagem das normas jurídicas como elementos "soft", de conteúdo aberto, que remetem a decisão final ao "melhor julgamento dos experts" em um campo específico, que por sua vez encontram-se comprometidos com a defesa dos valores, interesses e preferências de seu campo. Assim, "órgãos de comércio estão fadados a defender o comércio, órgãos de direitos humanos, os direitos humanos, órgãos ambientais, os interesses ambientais, e assim por diante." (2007b, p. 8) A esse respeito, Koskenniemi afirma que cada regime refletirá necessariamente o "viés estrutural" na base de sua expertise (2007b, p. 13).

${ }^{84}$ Como exemplos da variedade de formas pelas quais a autoridade na governança global se exerce, Lake aponta uma situação interestatal, outra supranacional, e uma terceira de natureza privada. No primeiro caso, Lake destaca que "os Estados Unidos têm governado um império informal sobre Estados do litoral caribenho desde a Guerra Hispano-Americana" (2010, p. 600). No segundo, identifica as regras da OMC como instância de autoridade supranacional: "os índices de observância são geralmente altos" (2010, p. 602), e há inserção de interesses setoriais dentro dos Estados a favor da lógica da OMC. "Ao criar cada vez mais interesses dependentes na abertura internacional e as estruturas de autoridade que buscam preservá-la, a globalização é força motriz no aprofundamento da governança global e da autoridade no âmbito da OMC." (2010, p. 604) Lake exemplifica, ainda, o exercício de autoridade privada sobre os Estados, por meio da referência às atividades das agências de classificação de crédito, dentre as quais "as duas grandes - Standard \& Poor`s e Moody`s - agora detêm considerável autoridade privada dentro e cada vez mais sobre os Estados.” (2010, p. 607)
} 
Quanto ao quarto aspecto levantado, as autoridades da governança global engajam-se em avaliação, monitoramento e adjudicação de conflitos. Estas atividades são exercidas por autoridades tanto de tipo governamental quanto não governamental (Avant; Finnemore; Sell, 2010; Keohane; Nye, 2000). Por exemplo, o Banco Mundial e o FMI fazem monitoramento e avaliação de políticas públicas e da política econômica dos Estados. A OMC conta com o Mecanismo de Exame das Políticas Comerciais, “que serve para avaliar se um Membro está cumprindo as regras" (Barral, 2007b, p. 45). Estas são organizações internacionais governamentais. O monitoramento e a avaliação também são realizados privadamente, pela Standard \& Poor's e a Moody's, que classificam o risco da dívida soberana. Estas agências privadas exercem autoridade de fato, porque influenciam o comportamento dos investidores em suas decisões quanto a onde alocar capital. De modo semelhante, os relatórios de direitos humanos da Anistia Internacional e de níveis de corrupção da Transparência Internacional duas ONGs - assumem caráter de dados autoritativos, com influência sobre a política de Estados (Whitman, 2005, p. 27), embora não contem com a mesma influência prática das agências privadas de classificação de risco.

De igual forma, as atividades de adjudicação ou solução de controvérsias podem se dar em foros internacionais em sentido governamental - na Corte Internacional de Justiça, nos Painéis da OMC, na Corte Penal Internacional - ou em entidades de natureza privada, como na arbitragem ou mesmo na Internet Corporation for Assigned Names and Numbers (ICANN), que tem mecanismos para solução de controvérsias em torno da titularidade de nomes de endereços na internet ${ }^{85}$.

Estas atividades conferem autoridade enquanto a elas houver adesão: "resultados indesejados podem minar a autoridade de um governor ou abrir espaço para sua substituição.” (Avant; Finnemore; Sell, 2010, p. 24) Este aspecto confere feições dinâmicas à governança global. Assim, por exemplo, a deficiência na capacidade da Organização Mundial da Propriedade Intelectual (OMPI) de garantir a proteção "forte" aos direitos de propriedade intelectual levaram a que o tema migrasse para o âmbito da $\mathrm{OMC}$, por meio da inclusão do TRIPS no âmbito das negociações da Rodada Uruguai. Neste sentido, seria de se esperar que a confiabilidade dos ratings emitidos pela Moody's e a Standard \& Poor's ficasse comprometida após a crise do subprime de 2008, não antecipadas por elas, mas estas agências privadas continuam a ser referência para o comportamento de investidores internacionais.

\footnotetext{
${ }^{85}$ Os nomes de endereços na internet são os Domain Name Servers, ou DNS, e fazem a ligação entre números de Internet Protocol (IP), versados em algarismos, e palavras que identificam um endereço, de forma a facilitar a identificação e o acesso ao sites (cf. Pinheiro, 2009).
} 
Até o momento, observou-se que a governança global é exercida por múltiplos atores, em variadas áreas, e com formas de expressão de normatividade que não se limitam ao sentido tradicionalmente identificado como sendo "jurídico". Os regimes internacionais contam simultaneamente com produção normativa de caráter estatal e não estatal, e com formas coercitivas e não coercitivas de controle da observância e de solução de controvérsias. O cenário é bem mais complexo do que o direito que normalmente se ensina, identificado exclusivamente com o Estado ou com entes que recebam seu poder por delegação, como organizações internacionais.

Neste momento, passa-se à questão dos destinatários da governança global: governança para quem? Em nome de quem? Esta questão toca o aspecto da legitimidade do exercício da autoridade no contexto da governança global.

\section{Destinatários da governança global e legitimidade do exercício de autoridade global}

Frequentemente, o discurso a respeito da governança global é associado à emergência de uma "sociedade civil global" (Whitman, 2009, p. 12). O fim da Guerra Fria, com o triunfo dos Estados Unidos e correspondentemente do modelo de instituições políticas e econômicas liberais teria facilitado este processo, com resultante "expansão dramática" dos mercados e da democracia (Avant; Finnemore; Sell, 2010, p. 6). De acordo com este discurso, os novos atores a conformar a sociedade civil global assumem a posição de provedores de "bens públicos”, que os Estados, sozinhos, já não seriam capazes de prover, ou que transcenderiam fronteiras. Assim, por exemplo, o monitoramento da corrupção e de violações de direitos humanos por ONGs, a organização dos domínios da internet pelo ICANN, a classificação do risco dos investimentos pela Moody's e a sistematização da informação pelo Google seriam bens públicos globais oferecidos por entidades não governamentais ou de natureza privada. Do provimento destes bens decorreria a legitimidade do exercício da autoridade, como numa relação de troca.

No entanto, existem críticas no sentido de que os resultados da governança estão frequentemente desconectados tanto do "bem" quanto do "público" (Avant; Finnemore; Sell, 2010, p. 7). Não se pode perder de vista, afinal, a descrição anterior a respeito da governança: não se trata de uma coisa só, homogênea, mas de projetos variados e mesmo concorrentes, perseguidos por atores os mais distintos. Assim, cabe questionar se haveria um mínimo de compartilhamento de projetos para que se chegasse a falar em uma sociedade civil global. Que concepção de bem, afinal, lhe daria unidade? Nesse sentido, como aponta Whitman: 
não há nada inerente em tão amplo espectro de povos e organizações que prometa propósito benigno ou que previna disputas entre suas muitas configurações possíveis - algo bastante evidente se considerarmos corporações como sendo partes da sociedade civil global do mesmo modo como as ONGs. (Whitman, 2009, p. 13)

O choque entre a governança da propriedade intelectual e da saúde é evidência disso (Whitman, 2009, p. 24). De um lado, grupos farmacêuticos, governos de países sedes de laboratórios, e experts em direito da propriedade intelectual mobilizaram-se e mobilizam-se contra a quebra de patentes para a produção de medicamentos. Seu viés estrutural é o da preservação da lucratividade do empreendimento econômico na área de saúde, e seu principal argumento é o de que a quebra de patentes retira os incentivos para investimento privado em pesquisa e desenvolvimento de drogas e vacinas. De outro lado, governos como o do Brasil e da Índia, laboratórios produtores de genéricos e redes sanitaristas de políticas públicas perseguem agendas de universalização do acesso a medicamentos, e articulam sua proposta em termos de direitos à vida e à saúde ${ }^{86}$. Nota-se que, se há sociedade civil global, ela tem caráter faccioso, como neste caso, em que duas coalizões de atores variados perseguem objetivos conflitantes, e que refletem visões distintas de "bem".

A existência de choques de projetos sinaliza haver múltiplas possibilidades de resposta à questão “governança para quem?”. A governança global não está necessariamente atrelada ao provimento de bens públicos. Há diferentes atores, cada qual com seu propósito, sua agenda própria. Projetos de governança global podem ser meios de articulação de grupos de interesse específico ou privado em escala mundial (Keohane; Nye, 2000, p. 36). Do mesmo modo, Whitman aponta que

não há nada a respeito da governança em si que a restrinja a determinar e prover políticas públicas, como o termo geralmente é entendido. A governança não é menos imune ao oportunismo, à busca autointeressada por poder ou à realização de impulsos ideológicos do que a própria globalização. (Whitman, 2005, p. 23)

\footnotetext{
${ }^{86}$ Gunther Teubner e Andreas Fischer-Lescano (2004) trabalharam desdobramentos no campo das patentes de medicamentos como exemplo de colisão e diálogo entre regimes da governança global. De um lado, a posição brasileira (e indiana) era pela quebra de patentes com vistas à produção de genéricos. Esta posição se conciliava com as prioridades da Organização Mundial de Saúde, e portanto encontrava simpatizantes neste âmbito. De outro lado, a posição dos Estados Unidos era a da proteção das patentes, que encontrava respaldo na OMC, e especificamente no TRIPS. Dada a política brasileira de quebra de patentes, os Estados Unidos iniciaram procedimentos no sistema de solução de controvérsias da OMC contra o Brasil, em janeiro de 2001. Pouco tempo depois, a Assembleia Geral da ONU endereçou o tema do HIV/AIDS, e o Brasil articulou resolução, na Comissão de Direitos Humanos, que enfatizava a importância do acesso a medicamentos para a fruição da saúde. Os Estados Unidos votaram contra, mas a resolução foi aprovada por maioria. O evento moldou a opinião pública a respeito do combate do HIV/AIDS, e colocou a prioridade dos Estados Unidos em relação às patentes sob pressão. Em decorrência, os Estados Unidos desistiram dos procedimentos na OMC. Neste caso, as pretensões dos Estados Unidos mudaram quando se tornaram accountable a uma audiência maior, com simpatias diversas das patentes.
} 
Este é o problema da apropriação privada da governança. Atores, isoladamente ou coligados, podem exercer governança "para fins que são tanto autorreferenciais quanto exclusivos.” (Whitman, 2005, p. 24) Assim, por exemplo, a governança das agências de classificação de risco dialoga com a comunidade específica dos investidores, mas não com as populações afetadas pelas movimentações transfronteiriças de capital. A segurança e a rentabilidade dos investimentos são o objetivo privado prioritário. Noções de bem público, como emprego, saúde, educação, previdência etc., se presentes, são secundárias ao viés estrutural da haute finance.

A apropriação privada também diz respeito a práticas que, embora ilícitas em sentido tradicional, não deixam de ser formas de governança, como as relativas a organizações criminosas transnacionais, mercenários e entidades paramilitares. Empresas transnacionais engajam-se em práticas de propina a agentes públicos, por vezes conseguindo moldar o comportamento estatal em matéria de concessões administrativas, compras governamentais, comportamento legislativo e judiciário ${ }^{87}$. "Formas variadas de corrupção de governos e agentes de governo por atores externos também são claras instâncias de governança do modo como ela foi amplamente definida e compreendida.” (Whitman, 2005, p. 24). Se a governança se refere ao exercício da autoridade no espaço global, o fluxo transfronteiriço de propina que consegue alterar comportamentos governamentais também se enquadra na governança.

Aspecto relacionado à apropriação privada da governança global é a ascensão do expert rule, ou tecnocracia. Este aspecto poderia ser igualmente trabalhado para responder a pergunta "governança por quem?", mas, dadas as suas implicações sobre a legitimidade, optou-se por abrigá-lo neste espaço dedicado ao questionamento "governança para quem?"

Keohane e Nye (2000, p. 28) se perguntam: o que está faltando no projeto da governança global? E identificam: "a atividade legitimadora de políticos de base ampla dialogando diretamente com públicos domésticos." A formulação das decisões não está ancorada na vontade popular, mas em saberes de caráter técnico-científico. A governança se desenvolve em diversas esferas de autoridade, muitas das quais articulam saberes especializados, como o FMI, o Banco Mundial e as agências de classificação de crédito fazem em relação à economia internacional. A linguagem, ali, é essencialmente economicista. Noutros campos, outras linguagens preponderam. Exemplo é a experiência com criptomoedas, como a BitCoin, cujos algoritmos controlam e armazenam o fluxo de moedas virtuais em

\footnotetext{
${ }^{87}$ Em fevereiro 2014, por exemplo, a imprensa brasileira noticiou o envolvimento da Siemens, multinacional com sede na Alemanha, na corrupção de licitações no Estado de São Paulo para obras do metrô paulistano (Jornal do Brasil, 2014).
} 
redes formadas de computador a computador (peer-to-peer), sem centro, e que inclusive contêm mecanismos para remunerar usuários que disponibilizem suas conexões para o fluxo de dados necessário à operação da moeda. Este tipo de empreendimento é transnacional, versado em linguagem de programação inacessível aos leigos ${ }^{88}$, e escapa aos controles governamentais.

Estes exemplos, replicáveis em outras áreas, sinalizam que a articulação de projetos de governança global em linguagem especializada é capaz de "isolar os agentes de pressões populares" (Keohane; Nye, 2000, p. 36). Como aponta Lake, no caso das agências de classificação de risco, o isolamento é proposital, inerente ao caráter técnico-econômico da avaliação de risco, que exige independência de pressões políticas (Lake, 2010, p. 609). Notase, aqui, o efeito da tecnocracia, porque, na prática, uma avaliação negativa da Moody`s e da Standard \& Poor`s é, em si, um fator gerador de instabilidade na dívida pública de um país. O caráter político da avaliação de risco é isolado sob a roupagem de uma atividade técnica, pautada por critérios não acessíveis ao escrutínio público. Os leigos, que são afetados por esta política, nada podem dizer sobre ela. Os eleitores dos países julgados pelas agências de classificação de risco não podem manifestar nas urnas sua opinião: elas encontram-se isoladas da política democrática. Neste sentido, David Kennedy (2005, p. 24) aponta que "permanecemos sujeitos à mão invisível - não do mercado - mas da expertise que nega sua política." Isto porque:

Em todo o globo, experts comunicam-se uns com os outros em jargão próprio, e seu significado em todos os sistemas nacionais é aumentado em detrimento dos políticos convencionais por processos a que frequentemente nos referimos como "globalização". (Kennedy, 2005, p. 6)

O saber científico define sua identidade em contraste com o senso comum, e afirma sua superioridade em relação a este. A percepção popular (e midiática) defere o posicionamento a respeito de um tema à fala dos experts. $\mathrm{O}$ próprio senso comum sacraliza o conhecimento científico. Quando o saber científico se dirige ao formato de políticas públicas, consegue o efeito de ser recebido como fonte mais adequada de materiais intelectuais do que a percepção dos indivíduos afetados. A percepção de que o expert tem acesso privilegiado aos critérios corretos para avaliação e solução de problemas esconde as divergências internas que existem em cada campo de expertise. Neste sentido, David Kennedy (2006, p. 15) caracteriza a atividade dos experts como envolvendo escolhas entre - e acoplamentos de - métodos,

\footnotetext{
${ }^{88}$ Neste sentido, reportagem do The Economist (2014) considera: "Uma das coisas curiosas (e reveladoras) a respeito da Bitcoin é que seus detalhes técnicos básicos são complicados o suficiente para fazer com que qualquer texto a respeito do assunto seja precedido de algum tipo de elucidação."
} 
preferências políticas e teorias. $\mathrm{O}$ acoplamento de método e preferência política permite ao expert apontar um curso de ação (policy). O acoplamento de teoria e preferência política conforma a doutrina (doctrine). A doutrina posta em ação (policy + doctrine) gera o resultado prático (outcome) da atividade do expert. O senso comum, ao sacralizar a tomada de posição dos experts a respeito do formato de políticas públicas, não leva em conta o fato de que os próprios experts dispõem de acervos divergentes de teorias, métodos e inclinações políticas, e de que resultados "científicos" distintos são possíveis a partir das combinações alquímicas destes elementos.

Uma sensibilidade ou estilo de expertise, em especial, ganhou ascendência com a globalização. Trata-se da expertise econômica, e em especial da vertente informada pelo neoliberalismo, que articula preferências específicas de método, teoria e políticas. Um modelo específico de instituições globalizou-se de maneira predominante: instituições pró-mercado. $\mathrm{O}$ vácuo de regulação estatal e as novas formas de interação transnacional favoreceram a emergência de autoridades privadas em detrimento do poder público, e da tecnocracia em detrimento da política democrática, que remonta às urnas. Há processo de retroalimentação e autorreferência: formuladores de políticas públicas geram demanda por avaliações e soluções tecnocráticas, e os experts que suprem essa demanda promovem a noção de que soluções tecnicamente informadas são superiores aos resultados de deliberação junto às bases eleitorais. O tecnocrata é caracterizado como neutro, ágil, e produtor de resultados. O político é parcial, possivelmente corrupto, lento, e está mais preocupado com a autoperpetuação no poder do que com resultados efetivos. Ao fenômeno de superação da política democrática pela tecnocracia, Dani Rodrik (2011) se refere como perda do policy space, tema retomado na seção 3.4 .

Existência questionável de uma sociedade civil global, apropriação privada de regimes, manifestações ilícitas de normatividade transnacional, emergência e autorreferência da tecnocracia em detrimento da política democrática: estes elementos levam a questionamentos a respeito da legitimidade da governança global. "Baseado no que sabemos sobre os padrões de governança e suas causas, podem suas atuais ordens, regras e autoridades serem transformadas para promover maior democracia, igualdade, e outros objetivos socialmente desejáveis?" (Lake, 2010, p. 610) Como reformá-la? A partir de que perspectiva?

Se o modo "jurídico" de pensamento é escolhido para a tarefa, torna-se necessário manter em mente que a governança global é um fenômeno que facilmente escapa às formas jurídicas tradicionais, dada a maior variedade de fontes de normatividade, sua relatividade (hard e soft law), a pluralidade de meios de controle de observância (constrangimentos que 
vão do sutil à coerção), e a proliferação de autoridades privadas, muitas das quais fundadas em saberes técnicos. Deste modo, o jurista que pretenda articular reformas em aspectos da governança global, buscando torná-la mais socialmente justa, precisará reinventar suas categorias de trabalho (Castro, 2012; cf. 2009; 2011; 2014b).

Por que não deixar que os teóricos das relações internacionais, dos estudos políticos comparados ou da economia cuidem da governança global? Como aponta Koskenniemi, a virtude do direito consiste mais na forma de dizer do que no conteúdo do que é dito. "Requerer um direito é, neste sentido, diferente de pedir benefício ou apelar à caridade." (2004, p. 253) Da maneira como está articulada, a governança global tente a favorecer a linguagem dos mercados (prestações, serviços, custo-benefício) em detrimento da linguagem jurídica (direito-dever, justiça, Estado democrático) na orientação do exercício do poder pelas diversas autoridades. A economia, sendo um saber que lida com recursos escassos, tem facilidade de justificar o porquê de determinado medicamento não chegar a todos os que precisavam. Estes viram uma estatística que, se não for expressiva, opera o efeito de legitimar a exclusão: apenas tantos por cento não têm acesso a saúde, trabalho, educação, saneamento básico, transporte, propriedade. Apenas tantos por cento das empresas fecharam as portas no primeiro ano, não tiveram acesso ao crédito, não conseguiram competir com concorrentes internacionais etc. ${ }^{89} \mathrm{Na}$ visão jurídica, a perspectiva dos que não tiveram acesso ao medicamento ou dos que fecharam as portas de seu negócio pode ser formulada em termos de direitos, identificando e expressando necessidades específicas de reorientação de políticas públicas para a fruição de direitos fundamentais, sejam estes voltados ao consumo (saúde, educação etc.), sejam à produção (propriedade comercial, acesso ao crédito etc.). Estes contornos remetem à Análise Jurídica da Política Econômica, abordada na seção 4.4, e que propõe instrumentais analíticos a partir dos quais reformas nos regimes da governança global podem ser pensadas com vistas à fruição de direitos.

A atual subseção abordou aspectos conceituais e teóricos da governança global: seus atores, temas e expressões de normatividade que configuram regimes, e os problemas relacionados a seus destinatários e à sua legitimidade, com destaque, neste último aspecto, à ascensão do expert rule e o afastamento da política democrática como forma de administração dos regimes da governança global. Cumpre observar que esta abordagem foi feita preponderantemente a partir da perspectiva das relações internacionais, como se pôde notar pelas fontes preponderantemente citadas (Avant; Finnemore; Sell, 2010; Keohane; Nye, 2000;

\footnotetext{
${ }^{89} \mathrm{Na}$ AJPE, casos como estes correspondem ao "congelamento" posicional - ou inabilitação econômica - de indivíduos e grupos. Vide seção 4.4.
} 
Whitman, 2009; Whitman, 2005; Lake, 2010; Solingen, 2012). De fato, o tema da governança global tem sido desenvolvido sobretudo no campo das relações internacionais. No entanto, existem contribuições intelectuais que articulam visões e projetos jurídicos a respeito da governança global, embora permeados de elementos de interdisciplinaridade. A subseção 2.3.5, a seguir, busca fazer um panorama destas contribuições.

\section{$\underline{\text { 2.3.5 Perspectivas jurídicas da governança global }}$}

Em linhas gerais, o cenário que ficou conhecido como "governança global" pode ser sintetizado como tendo mais fontes de normatividade, maior variedade de meios de controle da observância (enforcement) e maior presença de autoridades privadas. Além disto, as fronteiras entre o nacional e o internacional tornam-se imprecisas, permeáveis.

Houve articulações jurídicas para endereçar estes novos contornos da normatividade no plano internacional. O próprio uso do termo "internacional” é questionado pelas vertentes desta literatura, que propõem expressões como "transnacional" ou "global" em seu lugar. As visões jurídicas aqui abordadas são consideravelmente distintas umas das outras, embora seja possível encontrar afinidades, complementaridades e convergências entre alguns dos projetos.

Um projeto jurídico precursor foi o direito transnacional, de Philip Jessup. Outras perspectivas vieram a se consolidar no século XXI, como o direito administrativo global, associado a nomes como Benedict Kingsbury, Nico Krisch e Richard Stewart; o pluralismo jurídico global e o direito e globalização, de Paul Schiff Berman; e a ordenação jurídica transnacional, cujo expoente é Gregory Shaffer. Os principais contornos destas vertentes serão abordados a seguir.

\subsubsection{Direito transnacional}

Philip Jessup descreve, já na década de 1950, uma comunidade mundial complexamente interrelacionada. Sua análise toma como relevantes sujeitos os mais variados: indivíduos, empresas, Estados e organizações de Estados. Para Jessup, o termo "internacional” não é adequado para refletir as relações existentes entre os sujeitos desta comunidade mundial. O termo é excessivamente restrito, por abranger apenas relações entre Estados. Para relações jurídicas que não são nem exatamente internacionais, nem 
compreendidas pelo direito doméstico, Jessup propõe o termo transnacional ${ }^{90}$. Seu sentido abrange "todo o direito que regule ações ou eventos que transcendam fronteiras nacionais." (Jessup, 1956, p. 2)

Trata-se de um direito aplicável a situações "transnacionais". Uma companhia petrolífera americana fazendo negócios na Venezuela, negociações entre os Estados Unidos e a União Soviética a respeito da unificação alemã, o envio pela ONU de mediador à palestina, e indivíduos invocando direitos contra Estados em foros internacionais de direitos humanos, ou contra a ONU em questões trabalhistas (por funcionários de seu Secretariado) são situações transnacionais (1956, p. 3).

Situações transnacionais, para Jessup, geram problemas de jurisdição em três eixos: foro de decisão (poder para lidar com problemas); escolha da legislação aplicável, e convergências entre problemas cíveis e criminais de jurisdição (Jessup, 1956, p. 102-3). Desta forma, o direito transnacional erode a noção de que uma jurisdição tenha um corpo de legislação específico a aplicar, como se o judiciário local aplicasse sempre o direito do Estado; a corte internacional, o direito internacional público, e assim por diante. O tribunal local, a depender da situação, pode aplicar tanto a lei local, quanto a estrangeira ou o direito internacional público. Assim, a relação entre o Estado e a corporação transnacional pode ser regida por outras regras que não o direito local, como viria a ser o caso da formação já narrada do direito internacional dos investimentos internacionais. Cortes internacionais podem aplicar direito internacional público, privado, ou mesmo o direito doméstico de algum Estado (Jessup, 1956, p. 102).

O projeto de Jessup para o direito transnacional parece ser o de afirmar a liberdade do juiz diante das novas situações do cenário global. Depreende-se a defesa da liberdade na escolha de exercício jurisdicional e de legislação aplicável aos casos, seja em cortes locais ou internacionais. Esta liberdade é proposta pela erosão das fronteiras entre os diferentes ramos do direito, como se pode verificar no trecho a seguir:

\footnotetext{
O direito transnacional inclui, portanto, aspectos cíveis e criminais, inclui o que conhecemos como direito internacional público e privado, e inclui direito nacional, tanto público quanto privado. Não há razão inerente para que um tribunal judicial, seja nacional ou internacional, não esteja autorizado a escolher de todos estes corpos jurídicos a regra considerada como a mais conforme à razão e à justiça para a solução de qualquer controvérsia em particular.” (Jessup, 1956, p. 106)
}

\footnotetext{
90 A abordagem jurídica tradicional é criticada por Jessup por ser insensível ao aspecto trans, já que é excessivamente voltada à produção do Estado. Nesta perspectiva, ou o assunto envolve o governo de um Estado em relação a outros governos, caso em que o assunto é "internacional”, ou não, caso em que é um problema "doméstico" (Jessup, 1956, p. 11).
} 
O foco de Jessup no julgador como medida do direito transnacional parece dar sequência, ao menos neste aspecto, à tradição de Hersch Lauterpacht, que também tinha projeto de direito internacional centrado na capacidade do juiz de preencher vaguezas normativas, num ordenamento completo, sem lacunas. Jessup, analogamente, trabalha a emergência de novas situações transnacionais apelando à necessidade de erosão das fronteiras entre campos do direito, cujo resultado é a liberdade do juiz para navegar normativamente e formar a decisão.

A perspectiva de Jessup é precursora à governança global. Embora seja anterior ao restante da literatura sobre o fenômeno, já se destaca, ali, o aspecto da normatividade transnacional, da variedade de fontes normativas, e da emergência de sujeitos privados do direito internacional, como indivíduos e corporações. Seu direito transnacional é como que um mix de critérios de determinação de jurisdição e de legislação aplicável, um composto de direito local, direito internacional público e privado a conferir liberdade de escolha ao julgador, e projetado para ser aplicado a situações transnacionais.

Já no início do século XXI, outra resposta jurídica à governança global viria na forma do direito administrativo global.

\subsubsection{Direito administrativo global}

Para compreender a proposta do direito administrativo global, é útil tomá-lo em comparação com as pretensões de leitura constitucional do direito internacional, tópico abordado ao final da seção 2.2. De certo modo, ambas as propostas emulam soluções do plano doméstico para um cenário jurídico internacional fragmentário. Ou seja, buscam refletir globalmente instituições jurídicas originalmente concebidas para operar internamente. A solução do constitucionalismo para o problema da fragmentação é, como se viu, reproduzir no plano internacional as estruturas hierárquicas disponíveis domesticamente. Apesar de dispensar a ideia de governo global como projeção dos governos domésticos, o constitucionalismo aplicado à governança global prevê hierarquias de normas e de cortes. Prescreve, nesse sentido, que certos tratados - que podem ser desde a Carta da ONU a convenções de direitos humanos, passando pelo acordo constitutivo da OMC - assumam posição constitucional para o sistema internacional, bem como que determinadas cortes possam fazer o controle das decisões de outras instâncias frente a estes tratados. O projeto busca tornar o todo fragmentário coerente com base na ideia de unidade. 
O direito administrativo global (global administrative law) também propõe transposição de certas instituições jurídicas domésticas. No entanto, como o nome sugere, a fonte de materiais não é a doutrina constitucionalista, mas a administrativista. Dois aspectos traduzem grandes diferenças entre as duas abordagens. Primeiro, quanto ao foco. O direito administrativo global pretende dirigir-se a atividades de regulação. Sua preocupação é com regulação bancária transnacional, regimes de manejo florestal, padrões de produção para o setor têxtil, pesos e medidas, padrões internacionais para licitações, regimes da água etc. Segundo, quanto à forma de organizar: as soluções propostas são heterárquicas, ao invés de hierárquicas. A coerência é buscada em torno da ideia de pluralidade (Krisch, 2006). Ainda assim, certos valores da esfera jurídica interna são projetados ao plano global para coordenar, mesmo que horizontalmente, as relações entre as diferentes esferas de autoridade regulatória global.

Direito administrativo global refere-se às "estruturas, procedimentos e padrões normativos para decisão em matéria de regulação", abrangendo entidades regulatórias as mais diversas: intergovernamentais formais e informais, decisões de governos nacionais que sejam afetadas por regimes internacionais e entidades transnacionais de natureza híbrida, que agrupam atores públicos e privados (Kingsbury; Krisch; Stewart, 2005, p. 5). A proposta básica deste direito é a de que as interações entre as diferentes autoridades regulatórias, que se dão num cenário em que as fronteiras entre direito internacional e nacional não são claras, reflita certas aspirações normativas como accountability, transparência, proteção de direitos individuais, participação democrática etc. Neste sentido, pode-se notar que, embora não proponha soluções hierárquicas, há aproximações com o constitucionalismo, no sentido de que certos valores são eleitos como elementos de coordenação da vida em sociedade, ou, neste caso, das interações entre autoridades regulatórias. Estes valores seriam a maneira de resgatar a legitimidade da governança global. De maneira simplificada, pode-se sintetizar o projeto do direito administrativo global como sendo o de promover coordenação entre diferentes regimes ou entidades regulatórias, em seus pontos de contato e conflito, com base em um set de valores eleitos, sem hierarquias pré-estabelecidas entre tratados, cortes ou outros espaços decisórios.

Carol Harlow (2006) elabora uma crítica a respeito deste projeto. Os "valores" do direito administrativo global, embora pretendam-se aplicáveis ao "universal", têm origens particulares. A autora identifica quatro fontes. Dos sistemas administrativos nacionais ocidentais, foram projetados os princípios de "legalidade" e "devido processo", indicadores de um governo limitado pelo direito, inclusive em suas interações com particulares (2006, p. 
191). Do direito internacional econômico aplicado ao desenvolvimento e dos proponentes do livre comércio e do liberalismo econômico, o direito administrativo global aproveitou a ênfase em rule of law. Do vocabulário dos direitos humanos, aproveitou direitos de caráter procedimental, como "devido processo", de modo convergente com os direitos administrativos nacionais ocidentais. E do vocabulário do FMI e do Banco Mundial, a boa governança e seus consectários: transparência e acesso à informação, accountability, participação etc. (2006, p. 194) Harlow destaca haver "considerável sobreposição" dessas fontes (2006, p. 188), que ela descreve como "amálgama de valores da moda da 'boa governança' e de princípios do direito administrativo clássico" (2006, p. 195). Apesar de Nico Krisch defender o caráter pluralista do direito administrativo global (2006, p. 247), em virtude de seu caráter policêntrico e heterárquico, pode-se notar que, na realidade, as "regras do jogo" da interação entre entidades de regulação estão sendo dadas a partir de origens específicas, identificadas sobretudo com o modelo institucional ocidental. Ou seja: o modelo pretende ser pluralista no manejo dos regimes internacionais, mas está assentado num conjunto de valores promovidos especificamente pelas democracias ocidentais avançadas.

Um exemplo do que seria este direito administrativo global é trabalhado por Nico Krisch (2006, p. 256-63), no campo da regulação dos organismos geneticamente modificados (OGM). Primeiramente, Krisch descreve duas abordagens quanto aos OGM: uma permissiva, identificada com os Estados Unidos, outra precaucionária, identificada com a União Europeia. Pela primeira, o comércio de OGMs só pode ser restrito com evidências científicas do risco à saúde ou ao ambiente. Pela segunda, não havendo prova científica de que o OGM é seguro, seu comércio deve ser proibido. As duas correntes entraram em choque em relação ao comércio transfronteiriço de OGMs destinados à União Europeia.

No campo da OMC, o Acordo sobre a Aplicação de Medidas Sanitárias e Fitossanitárias adota a abordagem permissiva. Aqui, começa o diálogo de regimes. Por um lado, o regime da OMC busca vincular decisões nacionais à cooperação comercial internacional, dispondo para tanto de mecanismos de solução de controvérsias. Por outro, o direito comunitário europeu não incorpora automaticamente o direito produzido na OMC: as decisões carecem de reconhecimento para poderem ser aplicadas por cortes europeias. Neste aspecto, há um balanço. E outros fatores entram no debate: a Codex Alimentarius Commission, que agrega praticamente todos os países do globo e tem ONGs como observadoras; e o Protocolo de Biossegurança de Cartagena, em cuja confecção participaram ativamente países em desenvolvimento e ONGs. Estes últimos são levantados por Krisch para mostrar como o debate se amplia, e atinge outras audiências. O Codex Alimentarius não tem 
posição definida quanto aos OGM, mas o Protocolo de Biossegurança se aproxima da posição europeia, e funciona de modo a contrabalançar a posição da OMC.

A estes processos de interação e diálogo interinstitucional, Nico Krisch se refere como "mecanismos de accountability", uma vez que "fazem os processos regulatórios responder a preocupações e audiências particulares e prover freios em relação aos excessos regulatórios”. Eles ajudam a "dar voz a audiências sub-representadas nos procedimentos formais" (2006, p. 262). Ou seja: mesmo quem não tem voto na OMC, pode entrar no diálogo. É o percurso da interação entre as diferentes autoridades regulatórias que determinará o resultado final. Neste contexto, a função do direito administrativo global é dar o vocabulário para que haja transparência, accountability, participação etc. Mas não há resultados predeterminados (Krisch, 2006).

Assim, contrariamente ao projeto constitucionalista, que pretende hierarquias e prioridades claras, o projeto do direito administrativo global, embora emule um set particular de valores relacionados às democracias ocidentais, fornece uma linguagem para interações entre regimes regulatórios, sem predeterminar soluções. A impressão é a de que este direito se faz on the go, absorvendo e legitimando juridicamente os resultados dos embates entre autoridades regulatórias globais, a partir dos vieses estruturais correspondentes às origens específicas dos valores eleitos como guias.

\subsubsection{Pluralismo jurídico global}

Diferentemente do direito administrativo global, a proposta do pluralismo jurídico global de Paul Schiff Berman (2005; 2007) não é uma tentativa de projeção de critérios do direito administrativo interno dos países avançados ocidentais como fonte de solução dos atritos entre regimes internacionais ou entre autoridades da governança global. Trata-se de perspectiva que se dirige tanto à necessidade de reformar o olhar jurídico, migrando do direito internacional ao "direito e globalização", quanto de conceber mecanismos procedimentais, instituições e práticas para manejar o hibridismo jurídico global - a sobreposição de ordens normativas -, sem buscar eliminá-lo. O pluralismo jurídico global, assim, compreende uma proposta acadêmica - um novo olhar - e uma proposta institucional para o direito na era da globalização.

No aspecto acadêmico, o pluralismo jurídico global afirma a inadequação do direito internacional para o entendimento do desenvolvimento transfronteiriço de normas (Berman, 2005, p. 555). A ênfase excessiva no Estado tornou-se inadequada diante da relevância de 
atores não estatais. A própria exclusividade da construção da identidade, vínculos e afiliações em torno do território é colocada em questão: as pessoas não mais se identificam apenas como nacionais de tal ou qual Estado, mas definem seus vínculos com outras comunidades não territoriais, inclusive virtuais. A concepção de um direito internacional feito de cima para baixo, que emana dos pronunciamentos oficiais no plano internacional e daí parte para o local, é colocada em questão. Há migração de normas, imitações institucionais nas burocracias dos Estados, normas elaboradas por atores privados que influenciam comportamentos ainda que careçam de mecanismos coercitivos. A gênese normativa é mais complexa. Diante desse cenário, Berman afirma que o direito internacional tornou-se incapaz de capturar a grande variedade de fenômenos normativos:

sem uma concepção mais ampla de direito que reconheça articulações não soberanas
(e mesmo não governamentais) de normas, estamos propensos a ignorar tais
articulações em geral ou a negar-lhes o status de direito, e a com isso deixar de
perceber a força real que tais normas têm e o modo como elas interpenetram a
doutrina jurídica oficial. (Berman, 2005, p. 556)

Ao invés do direito internacional, Berman propõe "direito e globalização" (2005, p. 490). O novo campo implica quatro expansões de foco em relação ao direito internacional: (i) ampliar a concepção do que conta como direito, (ii) abrir o olhar jurídico à interdisciplinaridade, (iii) superar a distinção entre relações de direito público e privado, e (iv) abrir mão da concepção clássica de soberania estatal inviolável, concebendo um direito para além da emanação soberana (2005, p. 491). Estes aspectos serão brevemente relatados a seguir. Além deles, Berman identifica dez objetos ou áreas de aplicação para o direito e globalização, que serão abordados posteriormente.

No primeiro ponto, Berman propõe que o direito seja concebido para além das instituições governamentais. Tradicionalmente, direito internacional era identificado com a produção estatal, ou com os atos derivados desta produção, como emanações de cortes ou organizações internacionais. Este foco restrito faz com que o jurista perca muito da complexidade com que o direito opera na prática (Berman, 2005, p. 492). Em resposta, acadêmicos da sociologia jurídica propuseram uma mudança do olhar: ao invés de focalizar o "direito nos livros", passar a enxergar o "direito em ação" (2005, p. 493). Esta mudança de foco permitiu uma concepção ampliada do que se entende como direito, e que enfatiza: (i) a significância da consciência jurídica ${ }^{91}$; (ii) o papel de aparatos burocráticos na maneira como

\footnotetext{
${ }^{91}$ Nesta perspectiva, o direito é uma parte constitutiva da cultura, determinando e moldando relações sociais. Ele não está preso às atividades oficiais estatais, mas reflete a maneira como as pessoas concebem como o modo normal ou natural de fazer as coisas, os padrões habituais de ação e de fala, e a maneira de conceber o mundo pelo senso comum. Esta concepção dispensa a definição formalista que atrela direito à capacidade de imposição
} 
as normas emergem e são aplicadas na prática ${ }^{92}$; (iii) a superação da visão do Estado unitário ou monolítico, em favor da visualização de redes governamentais e não governamentais, inclusive transnacionais, envolvidas na articulação de normas e políticas ${ }^{93}$; e (iv) a adoção de uma perspectiva jurídica pluralista ${ }^{94}$, que captura a "variedade de afiliações comunitárias que as pessoas reconhecem em suas vidas, bem como as múltiplas e por vezes conflitantes normas que estas comunidades geram.” (Berman, 2005, p. 493)

O segundo ponto diz respeito ao aspecto da interdisciplinaridade, em conexão com a ruptura da associação entre direito e território. Tradicionalmente, o direito associou a produção normativa às fronteiras do Estado, mas outras leituras, como da antropologia, sociologia, geografia crítica e estudos culturais questionaram a ideia de Estado-nação como única forma relevante de afiliação comunitária. Por sua vez, este questionamento esteve implicado no reconhecimento de normatividades que transcendem fronteiras territoriais e que se disseminam em "múltiplas, e por vezes entrelaçadas, comunidades.” (Berman, 2005, p. 511) Tais contribuições abrem o olhar para outros modos de afiliação comunitária que não são baseados unicamente no espaço, no território, mas também em identificação simbólica e em psicologia social, e que têm reflexos normativos: definem papéis sociais, modos de ser e de se comportar etc. Diante disso, "não há razão intrínseca para privilegiar as comunidades formadas em torno de Estados-nação a outras identificações comunitárias possíveis compartilhadas pelas pessoas.” (Berman, 2005, p. 518) Neste contexto, a abertura do olhar jurídico à interdisciplinaridade é necessária para capturar afiliações comunitárias e suas expressões normativas para além do oficial.

coercitiva pelo Estado, e atrela o "jurídico" a expressões de normatividade no dia-a-dia das pessoas, que influenciam seus comportamentos na prática e contribuem para a definição do que elas entendem como normal (Berman, 2005, p. 493-7).

92 A perspectiva jurídica convencional tende a privilegiar os pronunciamentos oficiais (tratados, leis, acórdãos, sentenças etc.) como fontes de normas e da mudança destas. Em contraste, a atenção aos aparatos burocráticos enfatiza "modos como o direito acaba sendo aplicado (ou subvertido) na prática, pelos atos discricionários de burocratas dos escalões inferiores", de modo a revelar "que o direito quase nunca é 'entregue' na prática na forma pura indicada em tratados, a legislação, ou decisões da corte constitucional.” (Berman, 2005, p. 498)

${ }^{93}$ Neste aspecto, Berman ressalta que redes governamentais e não governamentais assumem importância para a cooperação internacional e a geração de normas, ao lado das estruturas governamentais oficiais tradicionalmente concebidas pelo direito internacional. Em especial, "a ascensão de uma sociedade civil global (e articulada via internet) tem chamado a atenção aos papéis que ONGs podem desempenhar na formulação transnacional de normas." (Berman, 2005, p. 501) As redes articulam a governança global de maneira complexa, multinível. Elas não são constituídas por tratado, nem precisam de personalidade jurídica ou sede, mas, ainda assim, são espaços relevantes de articulação normativa. Há não só redes da sociedade civil global (ativistas ambientais, economistas, desenvolvedores da web etc.) como de oficiais do Estado: redes transgovernamentais de agentes de ministérios, secretarias, e mesmo juízes (Berman, 2005, p. 500-7). O Estado não é descartado da análise, mas é um espaço de produção normativa ao lado das redes transnacionais emergentes.

94 “[P]luralistas jurídicos recusam-se a focalizar somente em quem tem a autoridade formal para articular normas ou o poder coercitivo para aplicá-las. Ao invés disso, procuram estudar empiricamente quais afirmações de autoridade tendem a ser tratadas como vinculantes na prática real, e por quem. (...) Correspondentemente, ao Estado-nação é negado qualquer status especial como produtor de normas jurídicas." (Berman, 2005, p. 510) 
O terceiro ponto implica superação da divisão entre direito público e privado, concebida por Berman como uma "fronteira artificial" (2005, p. 520). Certos desdobramentos práticos contribuíram para a erosão desta fronteira, e acordos privados misturam-se a problemas anteriormente tidos como de "direito público". O tratado constitutivo do NAFTA é um caso em pauta. Celebrado entre Estados, ele permite, no entanto, que investidores individuais possam questionar atos governamentais que violem disposições do tratado no campo dos investimentos. O interesse privado ganha curso numa interface que normalmente se reconheceria como pública. Para Berman, este e outros desdobramentos são indicativos de que "a distinção entre política estatal e acordo privado, embora sempre problemática, torna-se cada vez menos relevante." ${ }^{95}(2005$, p. 523)

O quarto e último aspecto relacionado à expansão de foco é o abandono da vinculação entre direito e soberania, de modo a poder compreender "processos de desenvolvimento normativo que não estão restritos aos éditos dos Estados-nação." A "permeabilidade das fronteiras e a fluidez dos vínculos comunitários desafiam ideias de inviolabilidade da soberania", e comprometem o espaço do Estado como único ator relevante na arena internacional (Berman, 2005, p. 524). A própria soberania muda, torna-se difusa, convive com espaços normativos supranacionais e mesmo sub-nacionais, com sub-unidades governamentais perseguindo objetivos próprios (2005, p. 527), como exemplificado anteriormente no caso das medidas contraditórias adotadas simultaneamente por dois setores do governo britânico no campo das emissões de carbono. A concepção tradicional do direito atrela a norma jurídica à existência de sanção, e isto, em parte, explica a insistência na associação entre direito e soberania. No entanto, esta vinculação é desnecessária para a concepção ampliada de direito, capaz de enxergar a articulação de normas jurídicas mesmo na ausência do poder de obter sua observância por coerção.

Como anteriormente apontado, esses quatro aspectos estão envolvidos na expansão de foco em relação ao direito internacional tradicional. Além desta mudança no olhar, Berman propõe objetos ou áreas de aplicação para o direito e globalização, que seriam fenômenos abrigados sob seu guarda-chuva teórico. São identificadas, ao todo, dez áreas de estudo, num rol de temas que Berman não pretende como exaustivo (2005, p. 530). Em comum, os temas implicam transições em relação a perspectivas tradicionais do direito internacional.

\footnotetext{
95 A ausência de formas jurídicas "puras" de direito público ou privado é refletida na matriz da Nova Análise Contratual proposta pela AJPE, e abordada na seção 4.4. A matriz leva em conta, lado a lado, elementos normativos públicos e privados envolvidos em determinada política pública ou aspecto da política econômica. Este é um dos elementos que evidenciam convergências entre a crítica de Berman e a perspectiva da AJPE.
} 
Os dois primeiros temas referem-se a mudanças na ideia tradicional de jurisdição. Assim, o primeiro deles diz respeito à determinação da jurisdição com base na localização física, que predomina na perspectiva do direito tradicional. Berman propõe superar este modelo, e concebe o juiz como um ator jurídico transnacional que se abre a novas maneiras de delimitar a jurisdição para além da localidade física, enfatizando as afiliações comunitárias. Neste sentido, um juiz francês pode exercer jurisdição sobre o Yahoo! a respeito da venda online de antiguidades nazistas ainda que a empresa esteja constituída nos Estados Unidos e com seus servidores posicionados lá, porque o Yahoo! forma uma comunidade de pessoas que o acessam, inclusive na França. O segundo tema é a jurispersuasão, como alternativa à jurisdição tradicional de caráter coercitivo. Neste sentido, é a reconcepção da jurisdição como espaço em que normas são invocadas e articuladas, sem necessidade de que o desfecho seja imponível por sanção. Assim, mesmo que cortes dos Estados Unidos não se vinculem pelas decisões da Corte Internacional de Justiça (CIJ), que carece, para todos os efeitos, de mecanismos coercitivos para fazer valer suas decisões, ainda assim uma corte em Oklhahoma determinou a suspensão de uma execução de um condenado ao levar em consideração o julgamento da CIJ no sentido de que a condenação houvera sido feita em violação a tratados internacionais (Berman, 2005, p. 353).

Os temas de três a seis podem ser agregados sob a ideia de pluralidade das fontes normativas. O terceiro campo de estudos é o das fontes plurais de autoridade jurídica e quase jurídica, que dá espaço à produção normativa de comunidades inclusive de natureza não governamental. $\mathrm{O}$ quarto setor é o de direito e cosmopolitismo. A este respeito, o cosmopolitismo não é concebido como um universalismo utópico, nem como tendo caráter uniformizador, mas como o reconhecimento de que as pessoas têm múltiplas afiliações (Berman, 2005, p. 540). Neste sentido, o "cosmopolitismo oferece uma rubrica promissora para analisar o direito em um mundo de vozes normativas diversas." (2005, p. 542) Na mesma esteira, o quinto tópico refere-se a processos sociológicos e psicológicos de consciência jurídica, inclusive de caráter transnacional, que configuram alternativas à produção normativa centrada no Estado e com bases territoriais. O papel normativo das ONGs é o sexto tema proposto, e Berman exemplifica sua relevância na formulação de "códigos de conduta" nas áreas de direitos humanos, proteção ambiental e de padrões de trabalho, muitas vezes adotados por corporações que abraçam uma "ética corporativa" e de "responsabilidade social" diante de pressões de ONGs que se articulam pela mídia em geral e em especial por campanhas na internet (2005, p. 547-8). Outra importância normativa das ONGs decorre de 
sua capacidade de colocar itens na agenda dos governos, influenciando seu comportamento (2005, p. 549).

Os temas de sete a nove têm em comum o desfazimento da ideia monolítica de Estado. O sétimo, neste sentido, refere-se à importância das instituições: "o foco nas instituições permite-nos enxergar que os Estados-nação não são atores unitários que perseguem seu autointeresse no cenário mundial." No lugar disso, "são entidades organizacionais incrustadas num ambiente social mais amplo de normas internacionais", e cujas unidades burocráticas recebem pressões “do internacional, do subnacional, e do transnacional." (2005, p. 550) O oitavo tema, por sua vez, é a privatização de funções estatais, a abranger até mesmo atividades militares, como na atuação norte-americana no Iraque e no Afeganistão por meio de empresas como a Blackwater. Este aspecto permite focalizar a emergência de autoridades privadas e de suas implicações normativas. E o nono tema refere-se à multidirecionalidade das normas locais, nacionais e internacionais. Ao passo que a concepção tradicional do direito internacional é, como se disse, orientada de cima para baixo, o direito e globalização expande o foco para compreender processos em que atores locais assimilam normas de outras localidades por imitação, ou invocam normas internacionais ou de outros locais para contestar projetos políticos concorrentes, e assim obter vantagens políticas ou estratégicas. Há processos de retroalimentação na produção normativa dos três níveis, e o direito e globalização busca capturar esta multidirecionalidade: o direito atravessa fronteiras em múltiplas direções $(2005, \text { p. } 553)^{96}$.

Por fim, a décima área de estudos é a das problemáticas da globalização. Berman compreende globalização como "a intensificação da interconectividade global, em que capital, pessoas, commodities, imagens e ideologias atravessam distâncias e fronteiras físicas com velocidade e frequência crescentes." (2005, p. 552) No entanto, salienta que há muitos sentidos para a globalização, muitos processos que se globalizam, e que têm importância diferente para populações diferentes. Há um sentido hegemônico, associado à globalização econômica, à liberalização dos mercados e a rule of law. Mas há também sentidos contrahegemônicos, em que atores se articulam para questionar posições dos mais poderosos, como Brasil e Índia começaram a fazer na OMC em relação a políticas protecionistas dos Estados Unidos e da União Europeia (2005, p. 554). A proposta de Berman é de abertura às múltiplas

\footnotetext{
${ }^{96}$ Como se observará no tópico seguinte, este ponto encontra convergências com a perspectiva da ordenação jurídica transnacional, de Gregory Shaffer (2013). Em Shaffer, o nome para esta multidirecionalidade de influências normativas recíprocas é "recursividade".
} 
possibilidades de significação da globalização de acordo com as comunidades normativas enfocadas.

Estes elementos de expansão do foco de análise em relação ao direito internacional tradicional e a proposta de novos objetos de estudo conformam o campo do direito e globalização, que pretende dar conta de "um mundo habitado não só por Estados, mas por uma variedade de comunidades normativas", com "fronteiras permeáveis, múltiplas afiliações e interesses sobrepostos" (Berman, 2005, p. 556). Outra parte da contribuição de Berman a respeito do pluralismo jurídico global é dirigida a mecanismos procedimentais, instituições e práticas para lidar com espaços jurídicos híbridos, em que "um mesmo ato ou ator é potencialmente regulado por múltiplos regimes jurídicos ou quase-jurídicos.” (Berman, 2007, p. 1155)

Neste aspecto, a proposta de Berman, à primeira vista, parece dialogar ou aproximarse do direito administrativo global. Ambas, afinal, buscam soluções institucionais para manejar conflitos ou colisões de regimes. Ambas, além disso, são alternativas às soluções soberanistas. No entanto, ao passo que o direito administrativo global o faz a partir de uma seleção específica de valores, como anteriormente caracterizado, Berman elege o pluralismo em si como valor a ser preservado nas relações transnacionais. O hibridismo jurídico, nesse sentido, é visto positivamente, como algo que se deve resguardar, e não eliminar.

E o que seria o hibridismo jurídico? Como Berman descreve, "vivemos num mundo de múltiplas comunidades normativas” (2007, p. 1157), que fazem do sistema jurídico global uma "rede entrelaçada de afirmações jurisdicionais por parte de Estados, comunidades internacionais e não-estatais." As sobreposições dos diferentes tipos de jurisdição criam espaços jurídicos potencialmente híbridos "e que não são facilmente elimináveis.” (2007, p. 1159) Neste contexto, Estados competindo pela regulação de uma mesma atividade são apenas “a ponta do iceberg” (2007, p. 1160), visto que dividem autoridade jurídica com cortes internacionais e regionais, outras entidades regulatórias e mesmo com normas de origem não estatal:

As pessoas sentem vínculos com, e agem baseadas em afiliações com, múltiplas comunidades além das territoriais. Estas comunidades podem ser étnicas, religiosas, ou epistêmicas, transnacionais, subnacionais ou internacionais, e as normas afirmadas por tais comunidades frequentemente desafiam a autoridade baseada no território. (Berman, 2007, p. 1161)

O hibridismo jurídico refere-se, portanto, a cenários de sobreposição normativa num contexto de pluralismo jurídico global, com múltiplas esferas de autoridade jurídica. Duas respostas possíveis, e distintas do pluralismo, são, de um lado, a tentativa de resolver os 
conflitos oriundos do hibridismo pela reimposição do primado da autoridade territorial - que configura uma resposta soberanista - e, de outro lado, a tentativa de obtenção de harmonização universal - mais afeita aos projetos de releitura do direito internacional a partir do vocabulário constitucionalista. Estas são tentativas de resolver os problemas de sobreposição normativa pela eliminação do hibridismo que está em sua raiz. Em contraste, a abordagem do pluralismo jurídico global "deliberadamente busca criar ou preservar espaços para o conflito entre múltiplos sistemas jurídicos sobrepostos." Trata-se de "manejar, sem eliminar, o híbrido" (2007, p. 1164), buscando "preservar os espaços de oportunidade para contestação e variação local” (2007, p. 1165).

O pluralismo jurídico global não oferece respostas definitivas para as sobreposições normativas: "não há uma métrica autoritativa para determinar que normas devem prevalecer neste mundo híbrido bagunçado." Tampouco indica definitivamente a quem cabe decidir o conflito normativo (2007, p. 1165). O que se observa é a proposta de soluções contingenciais, localizadas, para o conflito de normas, com a preocupação maior de preservação do próprio pluralismo. Neste sentido, a busca é por procedimentos, instituições e práticas que sejam capazes de "trazer múltiplos atores a um espaço social compartilhado" (2007, p. 1166), em que suas diferenças possam ser trabalhadas, e não eliminadas. Neste sentido, como observa Berman, o "pluralismo observa que diversos atores perseguem normas e estuda suas interações, mas não propõe uma hierarquia de normas substantivas ou valores.” (2007, p. 1666) A exceção é o "valor independente do pluralismo", ou seja, a preservação da pluralidade normativa como um bem em si (2007, p. 1235).

Como o direito pode contribuir para a coexistência das diferenças? Berman apresenta nove mecanismos procedimentais, instituições e práticas para lidar com o hibridismo jurídico. O primeiro deles são as interações jurídicas dialéticas, em que dois espaços de decisão, embora não estejam formalmente vinculados um pelas decisões do outro, efetivamente levam as respectivas posições em consideração. Um painel do NAFTA entendeu que a decisão obtida por uma corte no Mississipi violava direitos contratuais e de antitruste de uma corporação canadense. O painel, no entanto, não tem poder de revisão das decisões de cortes norte-americanas. Ainda assim, na prática, as autoridades federais norte-americanas, em resposta à decisão do NAFTA, passaram a fazer pressões sobre cortes domésticas para que as decisões tornassem-se conformes ao tratado e ao precedente estabelecido (2007, p. 1197-8). As interações jurídicas dialéticas acontecem quando há observação do comportamento decisório de outro ator, ainda que este não se dê em virtude de obrigação formal. 
O segundo mecanismo são as margens de apreciação. É um mecanismo interpretativo que busca manter espaço para variações locais diante de um padrão mais geral. Assim, por exemplo, a Corte Europeia de Direitos Humanos aplica a margem de apreciação para permitir “às entidades políticas domésticas alguma margem de manobra na implementação das decisões da Corte, de modo a acomodar a variação local.” (2007, p. 1201) Berman sugere que o mesmo deveria ser feito em relação ao regime de proteção da propriedade intelectual no TRIPS, que assim "permitiria a países em desenvolvimento espaço adicional para tentar assegurar que o acesso ao conhecimento não seja impedido por proteções estritas da propriedade intelectual.” (2007, p. 1203)

Regimes de autonomia limitada conformam a terceira ferramenta do pluralismo jurídico global, e pretendem-se aplicáveis às interações entre regimes jurídicos estatais e não estatais. Estes regimes abrem a possibilidade de que minorias étnicas ou religiosas vivam ao menos em certos aspectos com normas próprias, num cenário de coexistência com outras etnias ou religiões. Berman exemplifica que o Canadá, o Egito, a Índia e Cingapura reconhecem decisões cíveis de comunidades muçulmanas em seus territórios, que frequentemente contam com suas próprias cortes (2007, p. 1206).

$\mathrm{O}$ quarto instrumento descrito por Berman são os esquemas de subsidiariedade. A ideia central é alocar autoridade primária ao nível local, e exigir que a supressão desta autoridade por uma de nível mais alto somente se dê mediante justificação (2007, p. 1208). "Ao contrário da soberania, um regime de subsidiariedade não coloca uma barreira direta à governança pelo nível de autoridade 'mais alto'. Mas tampouco oferece um cheque em branco." (2007, p. 1208) Assim, por exemplo, o artigo 5 do Tratado da Comunidade Europeia estabelece que uma medida que seja da competência concorrente da Comunidade Europeia e dos Estados Membros só pode ser tomada pela Comunidade caso seus objetivos não possam ser suficientemente atingidos pelos Membros. O espaço decisório mais abrangente torna-se subsidiário aos espaços mais localizados.

A redundância jurisdicional, o quinto mecanismo, guarda traços em comum com o anterior. Nele, há sobreposição jurisdicional, e esta situação leva a negociações implícitas ou explícitas entre as comunidades que buscam exercer jurisdição. Redundâncias são possíveis entre jurisdições estatais ou de outros tipos. Como exemplo do primeiro tipo, Berman relata as tentativas do juiz Garzón, em 2003, na Espanha, de exercer jurisdição sobre pessoas acusadas de abusos contra direitos humanos cometidos por argentinos em território argentino. Até então, a Argentina estava sob leis de anistia, que eram contestadas por certos grupos domésticos. A tentativa de Garzón alavancou o grupo do presidente Néstor Kirchner, 
partidário da derrubada da anistia. Um mês após os pedidos de extradição formulados pela Espanha, as duas casas do Congresso argentino revogaram as leis de anistia, e em 2005 a Suprema Corte argentina derrubou os efeitos protetivos destas leis, abrindo o caminho a processos criminais referentes a crimes da ditadura. Numa análise tradicional (soberanista), a Espanha não teria jurisdição territorial sobre estes crimes. Mas sua pretensão de exercê-la contribuiu para o realinhamento do embate político argentino em torno das leis de anistia, fazendo alterar o status quo. Coisa semelhante aconteceu no Chile, com a revogação da imunidade vitalícia do General Pinochet, também em decorrência das pretensões de Garzón de exercer jurisdição extraterritorial (Berman, 2007, p. 1211-3). Outro exemplo de redundância jurisdicional, agora envolvendo jurisdições de tipos diferentes, refere-se ao regime de complementaridade do Tribunal Penal Internacional, que pode exercer jurisdição criminal caso os Estados Membros mostrem-se incapazes ou não propensos a fazê-lo (2007, p. 1215). Os exemplos, porém, não se restringem à função judiciária:

quando a ONU cria comissões internacionais de apuração de fatos concernentes a possíveis atrocidades, ou quando ameaça processos em cortes internacionais, estes atos podem empoderar reformadores dentro das burocracias locais, que podem então argumentar por mudanças institucionais como meio de evitar a interferência internacional. (Berman, 2007, p. 1214)

A redundância institucional é, assim, interessante meio de interações dinâmicas entre pontos diferentes de autoridade normativa. Uma visão negativa da redundância enfatizaria problemas de "forum shopping, incerteza quanto às regras aplicáveis, custos de litigância, e assim por diante", mas uma moldura pluralista permite conceber "meios pelos quais a redundância jurisdicional pode por vezes ser uma feição geradora de um mundo jurídico híbrido, e não apenas um problema a ser eliminado.” (Berman, 2007, p. 1218)

O sexto mecanismo identificado por Berman são os arranjos de participação híbrida. A analogia é o tribunal do júri misto, em que "membros de duas comunidades distintas sentam-se lado a lado para resolver disputas quando pessoas das duas comunidades entram em atrito.” (2007, p. 1218) No plano global, estes arranjos aplicam-se, por exemplo, a cortes mistas de direitos humanos, compostas por juízes nacionais e internacionais, como os tribunais de justiça de transição no Kosovo, Timor Leste, Serra Leoa e Camboja (2007, p. 1220). Na avaliação de Berman, estes arranjos híbridos podem propiciar legitimidade tanto para a opinião pública "internacional" quanto para a "doméstica":

a presença de juizes da comunidade internacional mais ampla pode contribuir para um sentido de justiça tanto para pessoas que observem o processo de longe quanto para as populações domésticas que temam que juízes locais decidam de acordo com preconceitos sectaristas. Noutra mão, a presença de juízes locais pode ser uma proteção contra a rejeição da corte como sendo completamente "estrangeira", uma 
percepção que, por exemplo, contaminou o Tribunal Penal para a Ex-Iugoslávia. A corte híbrida pode ser encarada como o melhor acordo disponível. (2007, p. 1220)

Regimes de reconhecimento mútuo, o sétimo arranjo institucional abordado, referemse ao aproveitamento transfronteiriço de padrões normativos. Em outros termos, duas comunidades aceitam reconhecer os padrões aplicáveis na jurisdição uma da outra para determinado ramo de produção ou atividade, ao passo em que retêm padrões para produtos ou atividades nacionais (2007, p. 1224). O Brasil, por exemplo, tem acordo de reconhecimento mútuo para carteiras de habilitação de motoristas com Moçambique, que "autoriza os titulares de documento de habilitação emitido por um país a conduzirem veículos no território do outro por até 180 dias", prazo após o qual os condutores podem requerer documento país em que sejam residentes sem passar por exames teóricos ou práticos (Brasil, 2012). Da mesma forma, há reconhecimento mútuo quando certificações estrangeiras de pesos e medidas ou de inspeção sanitária são válidas em países estrangeiros, com reciprocidade. Outra modalidade desse regime é o reconhecimento transfronteiriço de decisões judiciais (Berman, 2007, p. 1225), pelo qual um país pode até mesmo vir a executar em seu território uma decisão adotada no estrangeiro que seria ilegal de acordo com o direito local.

O penúltimo mecanismo narrado por Berman são os acordos de porto seguro (safe harbor agreements), mediante os quais um "plano intermediário é criado entre exigências normativas conflitantes de duas comunidades distintas.” (2007, p. 1227) Assim, exige-se que "empresas que façam negócios no estrangeiro sigam alguns, mas não todos, os padrões da comunidade estrangeira", em troca de que há o compromisso de não imposição de maior fardo regulatório (2007, p. 1227). Por exemplo, os padrões de proteção de privacidade de informações são mais rigorosos na União Europeia do que nos Estados Unidos. Empresas norte-americanas que atuem na União Europeia podem aderir aos "princípios de porto seguro sobre privacidade da informação", que são um meio termo entre as duas regulamentações. Dessa forma, submetem-se a padrões normativos mais rigorosos do que os dos Estados Unidos, mas evitam a aplicação direta das normas da União Europeia (Berman, 2007, p. 1227).

Por fim, Berman propõe uma abordagem pluralista do conflito de normas, ou do direito internacional privado. Tradicionalmente, os três grandes problemas do conflito internacional de normas são a determinação da jurisdição (foro), a escolha da legislação aplicável e o reconhecimento de decisões estrangeiras. Em outros termos, estas são as três formas pelas quais o manejo do hibridismo normativo é proposto na perspectiva convencional. Berman aplica os insights do direito e globalização para reformar estes pontos. 
Assim, por exemplo, a crítica aos critérios usuais de determinação da jurisdição consiste em que estes são excessivamente presos a vínculos territoriais de afiliação. Ao invés disso, outras afiliações ou vínculos comunitários relevantes podem ser utilizados pelos juízes como bases para o exercício da jurisdição, de modo a refletir a realidade híbrida do pluralismo jurídico global. No plano da escolha de legislação aplicável, ao passo que os regimes tradicionais "requerem uma escolha de uma norma nacional, uma abordagem pluralista permite aos juízes desenvolver uma regra híbrida que pode não corresponder a nenhum regime nacional em particular." (2007, p. 1231) Ou seja, formular normas transnacionais. Semelhantemente, "uma visão pluralista do reconhecimento de julgados requer que juizes encarem-se como parte de uma rede internacional de comunidades normativas". Do mesmo modo, devem encarar as partes diante de si como "potencialmente afiliadas a múltiplas comunidades, tanto estatais quanto não-estatais." E o resultado é o de que estes juízes "não devem necessariamente assumir que as políticas públicas locais devam prevalecer sobre os ditames de julgados internacionais." (2007, p. 1232) Com estas propostas, os critérios para conflitos de normas são transformados para dar conta de uma realidade normativa híbrida, e sem buscar eliminar o hibridismo, como faz o direito internacional privado tradicional, sobretudo ao apontar uma jurisdição e uma legislação aplicável em seus receituários.

Os mecanismos procedimentais, instituições e práticas referidos por Berman conformam meios de manejar o cenário de pluralismo jurídico global de modo informado pelo valor da preservação do próprio pluralismo. O hibridismo jurídico, nesse sentido, é algo a manter-se. Esta perspectiva tem a interessante face de oferecer vocabulários para a preservação das diferenças no cenário global. Neste ponto, abre-se espaço para convergências com contribuições da economia do desenvolvimento (abordadas na seção 3.4) que enfatizam a necessidade de soluções contingenciais, localizadas, e muitas vezes experimentais para políticas públicas. Em comum, as duas visões rejeitam instituições inspiradas em "padrões globais", do tipo one-size-fits-all, típicas de projetos de harmonização ou convergência institucional universal, tal qual o da "boa governança", abordado anteriormente. Estes contornos fazem com que estas literaturas também dialoguem com as propostas do NDD e da AJPE, abordadas nas seções 4.3 e 4.4, respectivamente.

Em muitos aspectos, o pluralismo jurídico global de Paul Schiff Berman e a ordenação jurídica transnacional de Gregory Shaffer também apresentam complementaridades interessantes, embora o foco de análise seja diferente. A perspectiva de Shaffer é o tema do tópico a seguir. 


\subsubsection{Ordenação jurídica transnacional}

A perspectiva de ordenação jurídica transnacional (transnational legal ordering) apresenta convergências com o pluralismo jurídico global. As duas abordagens podem ser vistas como complementares. Enquanto o foco do pluralismo jurídico global está no hibridismo jurídico, a perspectiva da ordenação jurídica transnacional enfatiza interpenetrações entre direito local e processos jurídicos transnacionais. Neste sentido, sua principal afirmação é a de que "em vastas áreas do direito hoje, não é possível compreender a prática e a mudança jurídica doméstica sem compreender a ordenação jurídica transnacional.” (Shaffer, 2013, p. 2) Ou seja, há engastes entre o que se considera direito local e processos transfronteiriços de migração de normas jurídicas.

Para compreender o que ordenação jurídica transnacional significa, é necessário estabelecer o contraste entre esta perspectiva e a de direito transnacional de Philip Jessup. A expressão "direito transnacional" sugere a existência de um corpo específico de normas voltadas para situações que não caiam nem no âmbito do direito interno, nem do direito internacional. O direito transnacional seria, portanto, o direito voltado a regular eventos e atividades transnacionais. A isto Shaffer se refere como "direito transnacional das situações transnacionais". A ordenação jurídica transnacional é diferente. Não conforma um corpo específico de normas; a referência, ao invés disso, é a um processo de geração e mudança normativa. Nem faz referência a situações necessariamente transnacionais. Desse modo, o que Shaffer considera "direito transnacional como ordenação jurídica transnacional" é a "produção transnacional de normas jurídicas e formas institucionais em campos específicos e sua migração transfronteiriça, independentemente de serem voltadas a atividades transnacionais ou puramente nacionais.” (2013, p. 6) Assim, por exemplo, educação primária e serviços municipais de fornecimento de água "são atividades exclusivamente nacionais, mas que podem ser significativamente moldadas pela construção e fluxo transnacional de normas, quer de direitos humanos, do direito neoliberal ou de normas do desenvolvimento." (2013, p. 8) O foco é, portanto, no engaste entre mudanças na ordem jurídica doméstica e arenas transnacionais, na permeabilidade entre o doméstico e o transnacional.

A explicação da permeabilidade transnacional das ordens jurídicas é feita por meio da categoria de "processo jurídico transnacional" (transnational legal process), definido como "processo pelo qual a construção e transporte transnacional de normas jurídicas acontece." $(2013$, p.8) Shaffer salienta que as normas não viajam por si sós, mas são levadas por atores de tipos variados: agentes governamentais, secretariados de organizações internacionais, 
profissionais, empresários e ativistas da sociedade civil (2013, p. 8). Isto permite compreender por que a ordenação jurídica transnacional não se refere a um corpo específico de normas: o processo de gênese e deslocamento de normas é feito segundo os campos específicos em que os atores se movimentam, afetando as áreas mais diversas do direito. Shaffer destaca, ainda, que os processos jurídicos transnacionais têm caráter "recursivo", significando que "o transnacional e o nacional são interpenetrados em um dado setor de atividade”, em diálogos e atritos multidirecionais e dinâmicos:

o transnacional e o nacional se situam em tensão, com atores em processos jurídicos transnacionais buscando influenciar a prática e a elaboração normativa local, e em que normas jurídicas nacionais, adaptações e resistências fornecem modelos para, e retroalimentam, a elaboração jurídica transnacional. (2013, p. 13)

O livro de Shaffer (2013) fornece exemplos empíricos de processos e ordenação jurídica transnacional nos temas de lavagem de dinheiro no Brasil e Argentina, organizações internacionais e reconstrução de Estados no Leste Asiático, normas educacionais, acesso a medicamentos na África do Sul e em regimes regulatórios de fornecimento de água.

Ao longo desta subseção 2.3.5, foram abordadas respostas jurídicas ao cenário da governança global. Como se pôde observar, todas elas desenvolvem vocabulários e ferramentas analíticas para lidar com um mundo de maior complexidade normativa: mais sujeitos relevantes (inclusive privados), mais fontes de norma (e com maior variedade, inclusive de graus de vinculação: por exemplo, hard/soft), mais amplitude de meios de constranger a observância (enforcement), que muitas vezes dispensa elementos propriamente coercitivos e, por fim, menor clareza sobre a separação entre o doméstico e o internacional. Para dar conta destas representações, as respostas jurídicas modulam o "internacional”, passando a enxergá-lo quer como "global”, quer como "transnacional”.

Certas respostas envolvem projeções de instituições domésticas. Em muitos sentidos, a proposta de Jessup não é tão distante do modo como um juiz nacional maneja conflito de leis. O que é proposto sob o nome de "direito administrativo global" é uma tentativa de ordenar a regulação no plano global de modo análogo ao plano doméstico. E o projeto do constitucionalismo internacional, não enfatizado nesta subseção, mas relatado brevemente na seção 2.2, busca transpor hierarquias de normas e espaços decisórios do plano doméstico ao global. 
Outras respostas parecem aceitar mais frontalmente o caráter sui generis do plano normativo global ou transnacional, de modo a refletir-se no vocabulário e ferramentas analíticas empregadas por perspectivas como o pluralismo jurídico global e a ordenação jurídica transnacional. A "coerência" do todo normativo é deixada de lado em favor do pluralismo, do hibridismo, e do fornecimento de vocabulários para a coexistência de modos de vida e de atividades diferentes. Em especial, a ordenação jurídica transnacional fornece ferramentas para conceber o direito nacional como necessariamente engastado com processos normativos transnacionais. Entender e trabalhar o direito passa a ser, desta forma, articular conteúdos normativos cuja origem não remete exclusivamente ao Estado local. Estas duas vertentes, conforme se salientou, dialogam com as propostas do NDD e da AJPE, descritas no capítulo 4. 


\section{CAPÍTULO 3 - PERSPECTIVAS ECONÔMICAS SOBRE AS RELAÇÕES INTERNACIONAIS}

O capítulo anterior explorou aspectos do percurso de linguagens de normatização jurídica das relações internacionais. No presente capítulo, outro gênero de discursos é abordado: a economia. Apesar de o ponto ser frequentemente negligenciado por juristas, os discursos econômicos estão recheados de implicações normativas. Assumindo diferentes sentidos em momentos variados, muitas delas se fizeram sentir nas instituições e práticas da cooperação econômica internacional.

Em linha com essas considerações, o presente capítulo tem o objetivo de delinear quatro projetos de estruturação das relações econômicas internacionais. Ao longo das seções, busca-se abordar (i) ideias econômicas que conformam uma corrente de pensamento (ii) em seu contexto, buscando relacionar esses dois fatores à (iii) configuração da ordem econômica internacional de cada período. O questionamento sobre o lugar das instituições jurídicas nos diferentes projetos econômicos para as relações internacionais assume posição transversal na abordagem feita.

O capítulo compreende quatro momentos, projetos ou perspectivas econômicas (langues). A seção 3.1 dedica-se ao liberalismo econômico e à sua influência sobre a ordem econômica internacional do século XIX à Primeira Guerra Mundial. A seção 3.2 aborda o liberalismo assistido, ou embedded liberalism, que instruiu a ordem de Bretton Woods com matizes fortemente keynesianos. A seção 3.3 caracteriza a ascensão do neoliberalismo e sua proeminência intelectual e política a partir da década de 1970, com a correspondente reconfiguração das relações econômicas internacionais e de políticas econômicas domésticas ao longo do globo. Por fim, a seção 3.4 aborda a crise do neoliberalismo e a ascensão de propostas heterodoxas ligadas à economia do desenvolvimento.

De plano, é importante salientar que nem sempre existiu algo como uma "perspectiva econômica". Hoje, temas como produção, consumo, trocas, moeda e riqueza são facilmente identificados como econômicos. Antes da modernidade, a abordagem destes temas encontrava-se vinculada a outras esferas de saber, outros gêneros de discurso ou langues. Assim, desde a religião ou a filosofia moral, escrevia-se sobre a condenação da usura ou o "preço justo". Desde a filosofia política e a retórica, a preocupação com o poderio do reino ou a manutenção do príncipe no poder projetava-se sobre a riqueza material. E assim por diante. Quando temas "econômicos" apareciam, encontravam-se subordinados a outras prioridades, 
como a justiça ou o poder. Não havia o gênero de discurso econômico no sentido que lhe é atribuído hoje. Compreender o que singulariza a economia de outras perspectivas é um passo para perscrutar suas implicações normativas, inclusive sobre as relações internacionais. Por isso, antes de passar à abordagem do liberalismo econômico, a formação do olhar econômico é um ponto digno de indagação.

"A economia, em todas as suas manifestações modernas, está centrada no mercado; num mundo em que o mercado era um aspecto subsidiário, até mesmo esotérico, da vida, a economia como nós a conhecemos ainda não existia." (Galbraith, 1989, p. 23) No medievo, relações hierárquicas, não as de mercado, determinavam a produção, a troca e o consumo. As sinalizações de preço eram menos relevantes para determinar a produção e distribuição dos bens do que a tradição e o medo de punições (Galbraith, 1989, p. 28). Neste contexto, era comum a percepção negativa acerca de mercadores e banqueiros, ou, de modo geral, da busca privada do enriquecimento.

Condenadas por séculos como ganância, amor ao lucro e avareza, tais atividades tornaram-se honradas na modernidade (Hirschman, 1997, p. 9). A busca do interesse privado passa a assumir contornos de virtude. As atividades comerciais e bancárias começaram a ser vistas como inofensivas, suavizadoras de modos humanos, dotadas de atributos civilizadores: sobretudo quando contrastadas com atividades violentas de exércitos e da pirataria (Hirschman, 1997, p. 63). Trata-se da visão do doux commerce. A busca do enriquecimento passa a ser encarada como paixão calma ou serena, bastante preferível às manifestações violentas motivadas por outras paixões humanas (Hirschman, 1997).

O que haveria mudado? Para John Kenneth Galbraith, a prodigiosa expansão dos mercados e multiplicação de bancos e pessoas engajadas na vida comercial conduziram ao arrefecimento do estigma contra os mercadores na modernidade (1989, p. 30). Com o crescimento da importância dos mercados na vida de comunidades diversas, ao lado da ascensão de uma classe mercantil, a busca e o acúmulo da riqueza tornaram-se "respeitáveis" (1989, p. 34).

A ascensão dos mercados na modernidade esteve na base da formação da perspectiva econômica. Este é um aspecto contextual. Outros aspectos importantes dizem respeito ao próprio modo como as ideias sobre temas econômicos passaram a ser articuladas. Que características do modo de pensar implicaram o surgimento da economia como algo novo? Louis Dumont (2000) responde a questão valendo-se de dois critérios: autonomia e sistematização. 
Estes dois critérios só foram atendidos de modo conjunto com o liberalismo econômico inaugurado por Adam Smith, ao final do século XVIII. Perspectivas antecedentes falharam em atender um ou ambos. Esta última hipótese é o caso do mercantilismo, cuja abordagem de temas econômicos não era nem sistematizada, nem autônoma. Ao invés, esses temas eram trabalhados em coleções de conselhos dirigidos ao príncipe. Suas recomendações para o acúmulo de metais e para adoção de medidas para gerar superávits na balança comercial eram feitas desde preocupações originadas na política. Mais especificamente, esses autores lidavam com temas econômicos objetivando, no fundo, o aumento do poderio do reino.

Já os fisiocratas chegaram a trabalhar o domínio econômico a partir da sistematização feita por François Quesnay no quadro econômico (tableau economique). O tableau descrevia uma sociedade dividida em três classes com fluxos interligados de bens e moeda, formando ziguezagues em sucessivas interações a ligar todas elas. Na origem da circulação da riqueza está a concepção fundamental para o pensamento fisiocrata: apenas a natureza é capaz de gerar o novo, e multiplicá-lo. O comércio apenas "multiplica compras e vendas sem multiplicar coisas" (Quesnay, 2003 [1766], p. 99). Assim também a manufatura é descrita como capaz de transformar, mas não de multiplicar a riqueza. A receita dos fisiocratas para organização da atividade econômica é reflexo desses elementos. A boa organização não é aquela feita em função do interesse material individual nos mais variados setores de atividade econômica, mas aquela que se enquadra nos ditames de uma "ordem natural" que privilegia a atividade agrícola sobre todas as outras. O "direito natural” ocupa, assim, na fisiocracia, posição de influência análoga à do "poder" no pensamento mercantilista. Não é, portanto, o motivo propriamente econômico (ou seja, aquele ligado ao interesse material) que orienta o olhar fisiocrata, mas a noção de ordem natural.

Adam Smith inaugura a tradição econômica ao abordar seus temas de modo a um só tempo sistematizado e autônomo em relação a outras esferas de saber. O modo como Smith realiza a sistematização será abordado na seção 3.1. Mesmo a noção de um sistema de ideias pressupõe certa coerência entre os elementos que o compõem. No caso da fisiocracia, a coerência da sistematização de Quesnay no tableau era dada pela ordem natural. No caso de Smith, o elemento a ligar as partes do sistema é o mesmo que está na base da emancipação do campo econômico: o argumento da harmonia natural dos interesses.

Este argumento já havia aparecido, no início do século XVIII, nos escritos de Bernard de Mandeville. Sua fábula das abelhas descreve dois momentos de uma colmeia. No primeiro, ela é forte, próspera, temida e invejada, mas permeada pelo vício (Mandeville, 1988 
[1714], p. 66-70). No segundo, após certa intervenção divina moralizante, as abelhas passam a se comportar de modo estritamente correto. Paradoxalmente, o resultado é a ruína econômica e o enfraquecimento da colmeia, que chega a ser abandonada (1988, p. 70-4).

O subtítulo da fábula é "vícios privados, benefícios públicos." Mandeville sugere que o comportamento viciado das abelhas no primeiro momento tinha utilidade econômica e contribuía para o bem-estar da colmeia (Mandeville, 1988; Dumont, 2000, p. 101). As abelhas eram egoístas, gananciosas, orgulhosas, buscavam o luxo e estavam preocupadas primariamente com o interesse material de cada uma. Assim, o comportamento da abelha alcoólatra que gastava o ordenado do mês na taverna beneficiava aqueles que lá trabalhavam, bem como o cervejeiro, o açougueiro e todos aqueles envolvidos na cadeia produtiva vinculada àquela atividade (Mandeville, 1988, p. 73). E mesmo o crime tinha sua função econômica: após a moralização da colmeia, Mandeville descreve o cenário em que não só juizes e advogados perderam suas fontes de renda, como também policiais, carcereiros, ferreiros e toda uma gama de atividades que dependiam materialmente da existência do comportamento criminoso (Mandeville, 1988, p. 71-2).

Por meio da fábula, Mandeville apresenta a visão de que certo mecanismo automático conduz à transformação dos comportamentos autointeressados, ainda que viciados, para gerar resultados benéficos ao todo social. Esta é a base da afirmação da harmonia natural dos interesses. Com isso, Mandeville fornece elementos para possibilitar a apresentação do domínio econômico como dotado de moralidade específica. Passa a ser possível justificar o comportamento individual autointeressado ainda que este seja visto como "vício" pela moralidade geral. É uma nova forma de pensar ${ }^{97}$.

A busca da riqueza ou do interesse material torna-se digna de preocupação intelectual como objeto em si, acompanhando a nova visão do doux commerce. O estudo das formas para aumento da riqueza não está mais em função do poder político, de promover sua conformidade com a moralidade geral ou com o direito natural. Curiosamente, quando o interesse material ou a riqueza surgem como objetos de análise intelectual a título próprio, ocorrem impactos para o modo como o poder político, a justiça e a sociedade são pensados. Como se observará ao longo do presente capítulo, a perspectiva econômica passará a conter pretensões de reformar as instituições políticas e jurídicas, por vezes em função de objetivos

\footnotetext{
97 "Há certamente emancipação em relação ao curso geral e comum da moralidade, mas ela é acompanhada da noção de que a ação econômica é, por si mesma, orientada para o bem, que ela possui um caráter moral que lhe é especial, e em virtude deste caráter especial lhe é permitido escapar da forma geral de julgamento moral. Em suma, haveria aí apenas uma especialização da moral, ou mais exatamente, o econômico só escaparia dos entraves da moralidade, assumindo um caráter normativo próprio.” (Dumont, 2000, p. 95)
} 
econômicos desprendidos de considerações sociais mais amplas. Não é à toa que Louis Dumont se refere ao processo que originou a perspectiva econômica como tendo envolvido certo "deslocamento de primazia" (2000, p. 145) e uma "revolução nos valores" (2000, p. $19)^{98}$.

Ao contrário do projeto pré-moderno ou tradicional de organização da sociedade com base em hierarquias bem estabelecidas - em que os mercados são aspectos subsidiários da vida social -, a modernidade e a emancipação da perspectiva econômica abrem a possibilidade de enxergar e organizar a sociedade como "adjunta ao mercado" (Dumont, 2000; Polanyi, 2001 [1944]). “Ao invés de a economia estar incrustada (embedded) em relações sociais, as relações sociais estão incrustadas no sistema econômico." Além disso, "uma vez que o sistema econômico esteja organizado em instituições separadas, baseadas em motivos específicos e com status especial, a sociedade deve ser moldada de tal modo a permitir que este sistema funcione segundo suas próprias leis.” (Polanyi, 2001, p. 100)

Em síntese, esta introdução ao capítulo 3 busca chamar a atenção para o seguinte: o nascimento da perspectiva econômica é, também, o nascimento de uma nova visão normativa de mundo. O relato contido nas seções 3.1 a 3.4, a seguir, pode ser interpretado como incursões no modo como diferentes perspectivas econômicas resultaram em projetos normativos para a estruturação das relações econômicas internacionais em contextos históricos variados.

\subsection{Liberalismo econômico}

A presente seção busca entender o projeto do liberalismo clássico para estruturação das relações econômicas internacionais. Primeiramente, algumas das ideias que caracterizaram essa perspectiva são relatadas na subseção 3.1.1. O objetivo não é o de cobrir todos os autores desta tradição, mas o de compreender seus elementos principais. Para tanto, o

\footnotetext{
98 A revolução de valores mencionada por Dumont é expressão da transição da ideologia holista, típica de sociedades tradicionais, para a individualista, característica das sociedades modernas. Três tipos de transformações estão envolvidos nesta passagem. Primeiramente, ao passo que na ideologia holista as necessidades e aspirações dos indivíduos são ignoradas ou subordinadas às do todo social, o inverso se dá nas sociedades modernas de ideologia individualista. Em segundo lugar, sociedades tradicionais valorizam mais as relações dos homens entre si do que aquelas entre homens e coisas, ao passo que nas sociedades modernas, mais uma vez, ocorre o oposto. Por fim, nas sociedades tradicionais, a forma de riqueza mais valorizada é a imóvel, vista, porém, como estando em função de outros objetivos, como o estabelecimento de relações hierárquicas. Na ideologia individualista, não só a riqueza de tipo móvel passa a ser a mais valorizada (o que guarda relação com a possibilidade de seu desprendimento de relações hierárquicas, dada a sua mobilidade) como também a riqueza passa a ser valorizada a título próprio, não necessariamente estando em função de outras finalidades. $\mathrm{O}$ nascimento da economia é encarado por Dumont como expressão dessa transição ideológica (Dumont, 2000).
} 
foco recai primariamente sobre as ideias econômicas de Adam Smith, que inaugurou a tradição, e secundariamente sobre as de David Ricardo ${ }^{99}$. A subseção seguinte (3.1.2) explora aspectos da ordem econômica internacional que se formou no século XIX e perdurou até a Primeira Guerra Mundial, abrangendo aspectos comerciais, monetários e financeiros. Por fim, a subseção 3.1.3 explora repercussões normativas e jurídicas das ideias e da ordem econômica internacional típicas do liberalismo clássico.

\subsubsection{Adam Smith, David Ricardo e contornos definidores da tradição do liberalismo econômico}

$\mathrm{Na}$ tradição mercantilista, a riqueza é identificada com o acúmulo de metais. Já a fisiocracia afirma que a única fonte verdadeira da riqueza é a natureza, e mais especificamente a agricultura. Na Riqueza das nações, Smith discorda das posições mercantilistas, às quais refere como "sistema comercial", bem como dos fisiocratas, correspondentes ao que denomina "sistema agrícola" (Smith, 1996a [1776], p. 413). O sistema que Adam Smith apresenta se difere dos precedentes, inaugura a tradição do liberalismo econômico e serve de marco para a própria economia. A riqueza não está nem nos metais, nem exclusivamente na agricultura, mas sim nos ganhos de produtividade impulsionados pela divisão do trabalho e a liberdade de comércio.

Os itens 3.1.1.1 e 3.1.1.2 são dedicados ao pensamento de Smith. O item 3.1.1.1 procura explicar como Smith parte da identificação da riqueza com o trabalho e consegue tanto definir a perspectiva econômica de modo emancipado de outras esferas do saber como derivar, daí, a necessidade de liberdade para o comércio internacional. O item 3.1.1.2, por sua vez, fornece uma visão geral da apresentação do domínio econômico como um todo sistematizado.

O item 3.1.1.3, a seu turno, endereça as limitações da defesa da liberdade de comércio internacional em Smith a partir de seu argumento de vantagens absolutas, apresentando os refinamentos introduzidos por David Ricardo ao formular o argumento das vantagens comparativas ou relativas do comércio internacional, que resultou numa defesa mais forte, abrangente e influente da liberdade comercial.

\footnotetext{
99 A centralidade da perspectiva de Smith e Ricardo para a formação do pensamento econômico clássico é apontada por Bernard Semmel, segundo o qual, no século XIX, "aqueles que aderiam à economia política tinham seus virtualmente irreprimíveis teólogos 'ortodoxos' em Smith e Ricardo, com Malthus, por vezes, sendo honrado como parte deste grupo" (Semmel, 1970, p. 208). Cabe ressalvar que o presente texto não faz abordagem de outros expoentes relevantes do liberalismo clássico - como Jean-Baptiste Say, John Stuart Mill ou Thomas Malthus -, mas toma as ideias de Smith, complementadas por Ricardo, como indicativas dos contornos principais desta corrente de pensamento.
} 
3.1.1.1 Da divisão do trabalho à autonomia da perspectiva econômica e à defesa da liberdade de comércio

A caracterização que Smith faz do trabalho como fator-chave para a geração de riqueza se reflete na organização de sua obra. A divisão do trabalho é o ponto de partida para elaborações que conduzem tanto à caracterização do domínio econômico como algo autônomo - via harmonia natural dos interesses -, quanto à defesa da liberdade de comércio internacional - via vantagens absolutas ou naturais.

O primeiro capítulo (de $A$ riqueza das nações) focaliza a divisão do trabalho e começa com o exemplo da fábrica de alfinetes. Segundo o relato de Smith, o processo de fabricação do alfinete envolve 18 operações distintas. Se uma só pessoa fizer todas estas operações, ao final de um dia conseguiria fabricar, na melhor das hipóteses, 20 alfinetes. Mas a divisão das tarefas numa fábrica com 10 funcionários, alguns deles cumulando operações, resulta na produção total de 48 mil alfinetes por dia, ou 4800 por trabalhador. A partir desse exemplo, Smith enuncia que a divisão do trabalho "gera, em cada ofício, um aumento proporcional das forças produtivas do trabalho.” (1996a, p. 66)

Tal aumento se deve a três fatores, que são (i) a maior destreza adquirida por cada trabalhador; (ii) a poupança do tempo perdido na passagem de uma atividade a outra e (iii) a invenção de maquinas que facilitam o trabalho, de forma a permitir que uma só pessoa faça o trabalho correspondente ao de muitas (1996a, p. 68). A "grande multiplicação das produções de todos os ofícios", que decorre da divisão do trabalho, é responsável pela riqueza de uma "sociedade bem dirigida" (1996a, p. 70). Em Smith, o "criador de riqueza e do valor é o homem. O homem, e não mais a natureza, como queria Quesnay.” (Dumont, 2000, p. 136)

O próximo passo na exposição de Smith consiste em atrelar a divisão do trabalho ao comércio. A possibilidade de trocar o que é produzido condiciona a divisão do trabalho. Sem comércio, cada um precisa prover-se por si só de tudo aquilo que lhe seja necessário. Smith caracteriza essa situação como típica de animais. Porém, a natureza humana é distinta, e apresenta como traço a "propensão a intercambiar, permutar ou trocar uma coisa pela outra" (Smith, 1996a, p. 73). Ao contrário de diversos animais, que na idade adulta conseguem prover-se por si sós, o homem "tem necessidade quase constante da ajuda dos semelhantes, e é inútil esperar esta ajuda da benevolência alheia." Ao engajar-se nas trocas com os demais, cada indivíduo é movido pelo autointeresse ${ }^{100}$. Cada um "terá maior probabilidade de obter o

\footnotetext{
${ }^{100}$ A este ponto se refere famosa passagem do texto de Smith: "Não é da benevolência do açougueiro, do cervejeiro ou do padeiro que esperamos nosso jantar, mas da consideração que eles têm pelo seu próprio
} 
que quer, se conseguir interessar a seu favor a autoestima dos outros, mostrando-lhes que é vantajoso para eles fazer-lhe ou dar-lhe aquilo de que ele precisa." (1996a, p. 74) A busca autointeressada da satisfação material é um componente natural, ao lado da propensão à troca. Como aponta Louis Dumont, em Smith, "a troca nasce do interesse egoísta; o interesse egoísta - e não alguma coisa como um desejo de cooperar - é, assim, a causa dos benefícios trazidos pela divisão do trabalho.” (Dumont, 2000, p.126)

Para Adam Smith, a busca do interesse individual conduz ao bem do todo social. Cada indivíduo busca satisfazer sua necessidade material, e o faz melhor ao buscar se especializar na produção, de modo a gerar maiores excedentes comercializáveis. $O$ aumento da produtividade de cada indivíduo reflete-se no benefício da riqueza geral. Smith ecoa, aqui, o argumento de "vícios privados, benefícios públicos" de Bernard de Mandeville - a harmonia natural dos interesses -, com a ressalva de que o egoísmo não chega a ser trabalhado como “vício" por Smith, e a busca do interesse próprio não se reveste de conotação pejorativa.

Todo indivíduo empenha-se continuamente em descobrir a aplicação mais vantajosa de todo capital que possui. Com efeito, o que o indivíduo tem em vista é sua própria vantagem, e não a da sociedade. Todavia, a procura de sua própria vantagem individual natural [...] leva-o a preferir aquela aplicação que acarreta as maiores vantagens para a sociedade. (Smith, 1996a, p. 436)

Noutra passagem, Smith aponta que o indivíduo, na busca de seu "próprio ganho", acaba promovendo também o "interesse público", sendo "levado como que por mão invisível a promover um objetivo que não fazia parte de suas intenções." ${ }^{\text {101 }}$ E reforça a ideia: "[a]o perseguir seus próprios interesses, o indivíduo muitas vezes promove o interesse da sociedade muito mais eficazmente do que quando tenciona realmente promovê-lo." (Smith, 1996a, p. 438)

A presença do argumento da harmonia natural dos interesses - ou da mão invisível no pensamento de Smith é importante por pelo menos dois aspectos. Primeiramente, ela funciona como elemento normativo próprio à esfera econômica, capaz de conferir-lhe a moralidade própria mencionada na introdução deste capítulo. Assim, a atividade econômica é orientada à (e movida pela) busca do interesse material de cada um. $\mathrm{O}$ "bom” é equiparado à

interesse. Dirigimo-nos não à sua humanidade, mas à sua auto-estima, e nunca lhes falamos das nossas próprias necessidades, mas das vantagens que advirão para eles." (1996a, p. 74)

${ }^{101}$ John Kenneth Galbraith observa que a ideia do mercado autoajustável, guiado pela "mão invisível”, "acabou por adquirir uma beneficência teológica", tornando-se um ponto de fé. "Não obstante, como uma questão puramente secular, foi um tremendo passo este que Smith deu. Até então, a pessoa preocupada com seu próprio enriquecimento havia sido objeto de dúvida, desconfiança e suspeita, sentimentos que vinham desde a Idade Média, dos tempos bíblicos e das próprias Escrituras Sagradas. Agora, justamente por causa do seu interesse próprio, esse indivíduo se tornara um benfeitor público.” (Galbraith, 1989, p. 58) Esta passagem lança luz sobre a importância do argumento da harmonia natural dos interesses para que a perspectiva econômica adquirisse autonomia em relação a outras esferas. 
riqueza. Há, aqui, rompimento fundamental com posturas antecedentes que situavam o critério de "bem", a orientar a atividade econômica, em outras esferas (aqui recordadas): o mercantilismo, na política ("bom" é orientar a economia para a grandeza do reino), e a fisiocracia, na metafísica ("bom” é que a economia seja conduzida segundo a ordem natural).

Em segundo lugar, a harmonia natural dos interesses conduz à defesa da liberdade individual e da noção de que a ordem é obtida espontaneamente, e não por construção deliberada. A liberdade individual encontra-se ligada à liberdade de iniciativa e de comércio. Por isso, antes de prosseguir nas repercussões do argumento de harmonia natural sobre as noções de liberdade e ordem espontânea, é relevante apresentar a relação que Smith faz entre a divisão do trabalho e a extensão dos mercados, dado que ele formula a partir desta relação o argumento mais específico pela liberdade de comércio.

"Quando o mercado é muito reduzido, ninguém pode sentir-se estimulado a dedicar-se inteiramente a uma ocupação, porque não poderá permutar toda a parcela excedente de sua produção [...] pela parcela de produção do trabalho alheio, da qual tem necessidade." (1996a, p. 77) Já o cenário de maior amplitude de mercados favorece a divisão do trabalho e por conseguinte a geração de riqueza. A consequência da argumentação de Smith é a de que a liberdade de comércio deve ser a mais ampla possível, já que a maior extensão dos mercados para a produção favorece a divisão do trabalho, que faz aumentar a produtividade, que por sua vez é sinônima de riqueza.

É interessante observar, contudo, que a liberdade de comércio não aparece como antônima perfeita da atuação estatal. Certos papéis desempenhados pelo Estado, ou o "soberano", são reconhecidos por Smith como compatíveis com a "liberdade natural", e mesmo como necessários para sua existência:

Segundo o sistema da liberdade natural, ao soberano cabem apenas três deveres [...]: primeiro, o dever de proteger a sociedade contra a violência e a invasão de outros países independentes; segundo, o dever de proteger, na medida do possível, cada membro da sociedade contra a injustiça e a opressão de qualquer outro membro da mesma, ou seja, o dever de implantar uma administração judicial exata; e, terceiro, o dever de criar e manter certas obras e instituições públicas que jamais algum indivíduo ou um pequeno contingente de indivíduos poderão ter interesse em criar e manter, já que o lucro jamais poderia compensar o gasto de um indivíduo ou de um pequeno contingente de indivíduos, embora muitas vezes ele possa até compensar em maior grau o gasto de uma grande sociedade. (Smith, 1996b, p. 170)

É possível fazer a leitura de que certos elementos da atuação estatal estão na base do florescimento do comércio e da possibilidade de expansão dos mercados, dada a preocupação de Adam Smith com que a lei proteja o cumprimento dos contratos (1996a, p. 143-4) e os "os 
sagrados direitos da propriedade privada" (1996a, p. 208) para que o sistema de trocas funcione. A seguinte passagem acentua esta relação:

O comércio e as manufaturas raramente podem florescer por muito tempo em um
país que não tenha uma administração de justiça normal, no qual as pessoas não se
sintam seguras na posse de suas propriedades, no qual a fidelidade nos contratos não
seja garantida por lei e no qual não se possa supor que a autoridade do Estado seja
regularmente empregada para urgir o pagamento das dívidas por parte de todos
aqueles que têm condições de pagar. Em suma, o comércio e as manufaturas
raramente podem florescer em qualquer país em que não haja um certo grau de
confiança na justiça do Governo. (Smith, 1996b, p. 360)

Nota-se, desta forma, que o aspecto de "ordem espontânea" envolvido no argumento da "harmonia natural dos interesses" encontra-se temperado pela apresentação que Smith faz de uma base institucional, estatal e jurídica, fundamental à atividade econômica. É adequado abordar esse ponto com cuidado, porque ele é sutil. Smith não despreza a importância do Estado ou do direito. "A concepção clássica da economia política repousa sobre uma função jurídica." (Sally, 1998, p. 26) Mas tampouco defende que o Estado se imiscua na orientação da atividade econômica. A chave para a distinção reside na concepção de um papel para o Estado e o direito que, embora existente, é limitado e condicionado pelo objetivo de favorecer a atividade econômica privada.

Trata-se de uma concepção "procedimental" (ou formal) do direito e da justiça. Ou seja, o direito é concebido em termos de provedor das "regras do jogo" da atividade econômica - "especialmente pela defesa da propriedade e dos contratos", mas não como meio de atuação positiva do Estado, como pela realização de políticas redistributivas ou de justiça social (Sally, 1998, p. 185). "O Estado não deve desviar-se desta agenda pela interferência no funcionamento de mercado, ou seja, interferindo na liberdade de produção e de consumo por meio da fixação de preços e de outros controles." (Sally, 1998, p. 185) Será possível apreciar, posteriormente, como esta concepção do papel do Estado e das instituições jurídicas se reflete na estruturação das relações econômicas internacionais do século XIX à Primeira Guerra Mundial.

Em razão destes contornos, Razeen Sally considera que a concepção do papel limitado do Estado em Smith não resulta na afirmação do laissez faire "extremo" ou "absoluto" (Sally, 1998, p. 184). Os indivíduos não interagem num cenário de desregulamentação completa, mas de regulamentação limitada da atividade econômica. O laissez faire existe, sim, na concepção de que, para além do provimento das bases institucionais mínimas para o funcionamento dos mercados, o Estado deve abster-se de interferir. Nesse sentido, Smith coleciona uma série de críticas, dentre as quais: (i) à concessão de monopólios, (ii) à regulamentação de profissões 
por corporações de ofício ou pelo Estado - cabe ao empregador julgar se o trabalhador é apto ao exercício da profissão (1996a, p. 167), e a inspeção do resultado de seu trabalho não deve caber ao Estado ou corporação de ofício, mas ao cliente que se depara com o produto no mercado (1996a, p. 173) -; aos (iii) obstáculos à livre circulação de mão de obra e de capital, tanto de uma profissão para outra como de um lugar para outro (1996a, p. 164), que por sua vez envolvem (iv) proibições de migração (1996a, p. 173) e (v) regulamentações de salários e lucros (1996a, p. 183-4). Todas elas restringem a liberdade de concorrência e afetam negativamente a expansão dos mercados e a divisão do trabalho. Além disso, é relevante que Smith posicione o trabalho exercido pelos agentes de Estado como "improdutivo", o que funciona como complemento à sua defesa do comedimento da atuação estatal:

O soberano, por exemplo, com todos os oficiais de justiça e de guerra que servem sob suas ordens, todo o Exército e Marinha, são trabalhadores improdutivos. Servem ao Estado, sendo mantidos por uma parte da produção anual do trabalho de outros cidadãos. Seu serviço, por mais honroso, útil ou necessário que seja, não produz nada com o que igual quantidade de serviço possa posteriormente ser obtida. A proteção, a segurança e a defesa da comunidade, o efeito do trabalho dessas pessoas, neste ano, não comprarão sua proteção, segurança e defesa para o ano seguinte. (Smith, 1996a, p. 334)

Além destas críticas, no Livro IV, Adam Smith dirige especial atenção às barreiras ao comércio internacional. Neste ponto, estabelece-se a ligação entre o tamanho dos mercados e esta modalidade de comércio. $\mathrm{O}$ argumento fundamental consiste em que a divisão do trabalho é favorecida pelo comércio exterior, implicando níveis maiores de produtividade e riqueza:

O comércio exterior valoriza as mercadorias supérfluas do país, trocando-as por
alguma outra que pode atender a uma parte de suas necessidades e aumentar seus
prazeres. Devido ao comércio exterior, a estreiteza do mercado interno não impede
que a divisão do trabalho seja efetuada até à perfeição máxima em qualquer ramo do
artesanato e da manufatura. Ao abrir um mercado mais vasto para qualquer parcela
de produção de sua mão-de-obra que possa ultrapassar o consumo interno, o
comércio exterior estimula essa mão-de-obra a melhorar suas forças produtivas e a
aumentar sua produção ao máximo, aumentando assim a renda e a riqueza reais da
sociedade. O comércio externo presta continuamente esses grandes e relevantes
serviços a todos os países entre os quais ele é praticado. (Smith,1996a, p. 430)

A defesa da divisão do trabalho no comércio internacional é feita com base no argumento das vantagens naturais, que também ficou conhecido como vantagens absolutas no comércio internacional. É aqui que se encontra a semente da elevação da liberdade comercial à categoria de valor fundamental para as relações econômicas internacionais.

Smith começa o argumento com a proposição de que "[t]odo pai de família prudente tem como princípio jamais tentar fazer em casa aquilo que custa mais fabricar do que comprar." (1996a, p. 438) Está envolvida, aqui, a noção daquilo que viria a se chamar "custo 
de oportunidade", segundo a qual o preço de uma coisa pode ser estimado naquilo de que se é necessário abrir mão para adquiri-la (cf. Mankiw, 2008, p. 557). Desse modo, por exemplo, o "alfaiate não tenta fazer seus próprios sapatos, mas compra-os do sapateiro", porque o tempo que dedicaria à produção do par de sapatos, que não é sua atividade habitual, seria superior ao que teria que empreender para fazer roupas com que comprá-los. Tal qual o alfaiate e o sapateiro, o "agricultor não tenta fazer ele mesmo seus sapatos ou sua roupa, porém recorre aos dois profissionais citados." (Smith, 1996a, p. 438) Deste modo,

[t]odos eles consideram de seu interesse empregar toda sua atividade de forma que aufiram alguma vantagem sobre seus vizinhos, comprando com uma parcela de sua produção - ou, o que é a mesma coisa, com o preço de uma parcela dela - tudo o mais de que tiverem necessidade. (Smith, 1996a, p. 438-9)

A partir do exemplo do que ocorre com o "pai de família", Smith transporta seu argumento - numa falácia de composição ${ }^{102}$ - para a conduta do reino ou país, asseverando que o sensato para a família dificilmente será insensato para um "grande reino":

Se um país estrangeiro estiver em condições de nos fornecer uma mercadoria a preço mais baixo do que o da mercadoria fabricada por nós mesmos, é melhor comprá-la com uma parcela da produção de nossa própria atividade, empregada de forma que possamos auferir alguma vantagem. (Smith, 1996a, p. 439)

Toma forma uma divisão do trabalho entre países engajados no comércio internacional, cada qual especializando sua produção segundo suas "vantagens naturais". A Inglaterra tem vantagens na manufatura, a Polônia e as colônias americanas são descritas como "agrícolas", e quanto à Escócia - seu país natal -, Smith aconselha que, por seu clima, não tente competir no mercado de vinhos, por implicar desperdício de forças produtivas:

\begin{abstract}
Utilizando vidros, viveiros e estufas pode-se cultivar excelentes uvas na Escócia, podendo-se com elas fabricar vinhos muito bons, com uma despesa aproximadamente trinta vezes superior àquela com a qual se pode importar de outros países vinhos pelo menos da mesma qualidade. Seria porventura uma lei racional proibir a importação de todos os vinhos estrangeiros, simplesmente para incentivar a fabricação de vinho clarete e borgonha? Ora, se é verdade que seria absurdo evidente canalizar para algum emprego trinta vezes mais capital e atividade nacionais do que o necessário para comprar de fora quantidade igual das mercadorias desejadas, logicamente é também absurdo, ainda que não tão gritante, mas certamente do mesmo gênero, canalizar para tal emprego a trigésima ou até mesmo a trecentésima parte mais de capital e de atividade. (Smith, 1996a, p. 440)
\end{abstract}

Consoante esta linha de argumentação, cada país será levado a focalizar na produção daquilo que faz melhor, ou seja, dos setores em que desfrutam de vantagens absolutas, engajando-se no comércio internacional para troca dos excedentes. Com isso, cada um obterá volume final de bens superior ao que teria caso tentasse produzir tudo aquilo de que necessita,

102 “[A] falácia de composição estende a economia da unidade familiar à do governo.” (Galbraith, 1997, p. 225) 
sem atenção às suas vantagens naturais. Neste esquema, o comércio internacional é o elemento de ligação entre as vantagens absolutas de cada país. E o resultado final é benéfico para os que se engajam no comércio.

Há, porém, importante limitação ao argumento de Smith. Ele não favorece a ocorrência do comércio internacional para todos os países. Afinal, caso um país não seja melhor do que os demais em pelo menos um setor produtivo, não gozará de "vantagens absolutas". Nesse sentido, a argumentação de Smith em favor do livre comércio encontra-se condicionada pela presença de tais vantagens, empecilho que David Ricardo conseguiu superar ao desenvolver argumentação mais refinada (ver item 3.1.1.3).

Em todo caso, o argumento das vantagens naturais ou absolutas soma-se à condenação de Smith à intervenção indevida do Estado no domínio econômico, especificamente no que diz respeito ao protecionismo comercial. Tarifas à importação e outras medidas de política comercial, como subsídios à exportação, são encaradas como tendo o efeito "de dirigir forçosamente a atividade ou comércio de um país para um canal muito menos vantajoso do que seria aquele para o qual ele se orientaria natural e espontaneamente" (1996b, p. 14).

Smith ressalva, porém, haver duas situações para as quais a intervenção do Estado é necessária para restringir o comércio internacional. "O primeiro ocorre quando se trata de um tipo específico de atividade necessária para a defesa do país.” (1996a, p. 444) Dessa forma, considerando que a defesa da Grã-Bretanha "depende muito do número de seus marujos e navios", Smith julgou apropriada a lei de navegação que conferiu "aos marinheiros e à esquadra britânicos o monopólio do comércio de seu próprio país [...] sob pena de confisco do navio e da carga" (1996a, p. 444), porque a defesa assume prioridade sobre a riqueza ${ }^{103}$ (1996a, p. 445).

A segunda hipótese prevista por Smith para restrição ao comércio internacional “ocorre quando dentro do país se impõe alguma taxa aos produtos nacionais. Nesse caso, parece razoável impor uma taxa igual ao produto similar do país estrangeiro.” (1996a, p. 445) O ponto consiste, no fundo, na defesa de tratamento nacional ${ }^{104}$ para produtos estrangeiros, que "não asseguraria à indústria nacional o monopólio do mercado interno, nem canalizaria

\footnotetext{
${ }^{103}$ Este ponto pode ser interpretado como uma concessão à política. Mas pode-se, igualmente, recordar que Smith posiciona a defesa externa, juntamente com a administração da justiça e as obras e instituições públicas, como fundamentais ao curso normal do comércio. Há, portanto, certa circularidade nesta concessão à política, já que a preocupação retorna com facilidade à esfera econômica.

${ }^{104} \mathrm{O}$ princípio da não discriminação no comércio internacional, que se reflete na regra de tratamento nacional, foi incorporado à regulamentação do sistema multilateral de comércio criado após a Segunda Guerra Mundial, por meio do GATT 1947 (ver seções 2.2 e 3.2).
} 
para um emprego específico uma parcela de capital e de mão de obra do país maior do que a que naturalmente para ele seria canalizada." (1996a, p. 445)

Os elementos expostos acima permitem enxergar como Smith passa da divisão do trabalho à defesa do livre comércio, alcançando, na esfera do comércio internacional, um argumento pela abertura, baseado nas vantagens naturais ou absolutas de cada país. Viu-se que a defesa da liberdade de comércio casa-se com a concepção de uma ordem espontânea, orientada segundo a harmonia natural dos interesses, em que a produção da riqueza (e do bem do todo social) é favorecida pela busca que cada um faz de seu próprio interesse material. Não pelo direcionamento estatal da produção, troca e consumo.

No item seguinte, será possível notar o reaparecimento - com peculiar importância das noções de harmonia natural dos interesses e de ordem espontânea. Estas conduzem à concepção de mercado autorregulado, pautado na livre atuação do mecanismo de preços. Será possível notar, ainda, o papel de verdadeiro elemento de ligação que os preços (e suas sinalizações) exercem na representação sistematizada do domínio econômico feita por Smith. No fundo, expressando-se via mecanismo de preços, a harmonia natural dos interesses faz a ligação entre os diversos componentes do sistema econômico.

\subsubsection{Smith e a apresentação do domínio econômico como sistema}

"Adam Smith deu à economia sua estrutura moderna." (Galbraith, 1989, p. 59) Embora não se valha de um quadro econômico, como Quesnay fez, Smith representa, ao longo da Riqueza das Nações, o domínio econômico pela descrição de setores interligados, com dependências mútuas, e entre os quais há fluxos de bens, trabalho e dinheiro. Tais fluxos estão em função de sinalizações de preços.

Um primeiro conjunto de componentes do sistema envolve três fatores de produção ligados a três tipos de remuneração e atribuídos (ambos) a três agrupamentos sociais. Estes elementos encontram-se esquematizados no Quadro 3.1, abaixo. Dessa forma, os fatores (i) trabalho, (ii) capital e (iii) terra correspondem às remunerações chamadas de (i) salário; (ii) lucros e juros e (iii) renda e a aos grupos sócio-econômicos de (i) trabalhadores (ii) capitalistas e (iii) proprietários de terra. Neste esquema, as remunerações dos fatores de produção são componentes dos preços na base de toda a produção econômica. No fundo, os preços fazem a costura do sistema. 
Quadro 3.1 - componentes gerais do sistema econômico de Smith

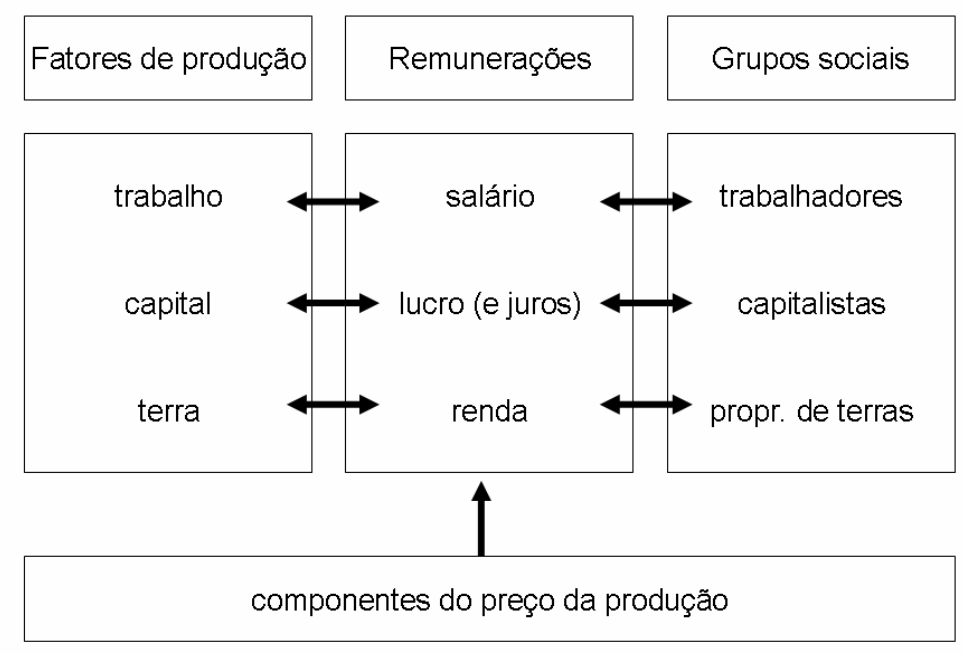

Fonte: elaborado com base em Smith, 1996a.

A renda é a remuneração pela propriedade da terra. O lucro ${ }^{105}$ remunera o patrimônio investido e o risco assumido, ou seja, o capital. E o salário é o nome da remuneração pelo trabalho. Smith, em diversos pontos da obra, faz ligações entre fatores de produção, suas remunerações e grupos correspondentes, como o exemplifica a passagem a seguir:

\begin{abstract}
A produção anual total da terra e do trabalho de cada país [...] naturalmente se divide, como já foi observado, em três partes: a renda da terra, os salários da mãode-obra e o lucro do capital, constituindo uma renda para três categorias de pessoas: para aquelas que vivem da renda da terra, para aquelas que vivem de salário, e para aquelas que vivem do lucro. Essas são as três grandes categorias originais e constituintes de toda sociedade evoluída, de cuja receita deriva, em última análise, a renda de todas as demais categorias. (Smith, 1996a, p. 272)
\end{abstract}

Um segundo conjunto de sua sistematização - que na realidade parece ser um subconjunto afeito à categoria do "capital", diz respeito a três divisões do chamado "estoque total da sociedade" (vide Quadro 3.2, abaixo). A abordagem que Smith faz do "estoque" expõe certos fluxos monetários entre os extratos sociais. Há, em primeiro lugar, itens de consumo, que compreendem comida, roupas, móveis etc., e cuja característica é não serem destinados a gerar renda nem lucro (Smith, 1996a, p. 289). Em segundo lugar, há o "capital fixo", categoria que engloba máquinas, instrumentos, construções que constituem meio de renda, melhorias e benfeitorias da terra, e as habilidades dos habitantes - ou o que se poderia hoje chamar de capital humano (a expressão não é empregada por Smith). A característica do capital fixo é proporcionar renda ou lucro sem mudar de proprietário (1996a, p. 290). Por fim, há o "capital circulante", caracterizado por proporcionar renda ou lucro mudando de dono, ou

\footnotetext{
105 Smith não distingue claramente lucro e juros (Galbraith, 1989, p. 60), mas aponta que os juros são o pagamento pelo emprego do capital alheio (Smith, 1996a, p. 101-5).
} 
seja, pela circulação. O capital circulante compreende quatro itens, que são: (i) o dinheiro em circulação; (ii) as provisões disponíveis para venda, nas mãos de agricultores e manufatores; (iii) as matérias-primas e a produção em andamento; e (iv) os estoques de bens manufaturados que ainda estão em poder de intermediários e comerciantes, não tendo sido vendidos ou distribuídos aos consumidores (1996a, p. 290-1).

Os três tipos de capital encontram-se concatenados no esquema de Smith. Assim, por exemplo, o autor afirma que "[t]odo capital fixo deriva originalmente de um capital circulante, devendo ser continuamente mantido por ele", e que "[o] único objetivo e finalidade, tanto do capital fixo como do circulante, consiste em manter e aumentar o capital que pode ser reservado para o consumo imediato. É este capital que alimenta, veste e dá moradia à população.” (Smith, 1996a, p. 291)

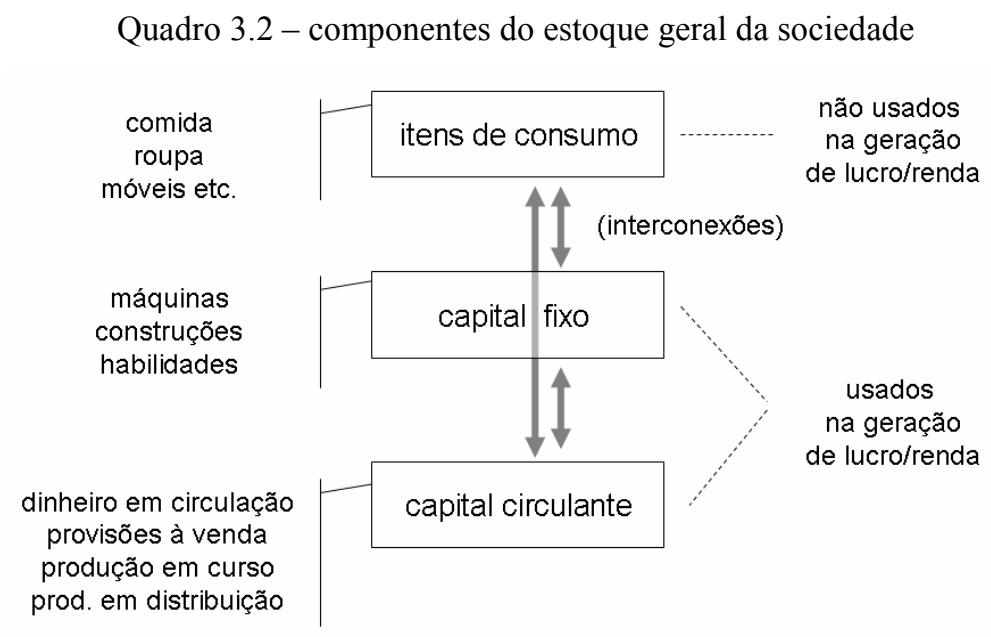

Fonte: elaborado com base em Smith, 1996a.

Há, ainda, relações entre o capital e outros aspectos, inclusive institucionais, com repercussões para o direito. "Em todos os países onde houver uma segurança razoável, toda pessoa de bom senso procurará empregar todo o capital sob seu controle, para desfrutá-lo atualmente ou para auferir dele um lucro no futuro.” (1996a, p. 292) Já nos países “onde as pessoas estão continuamente expostas à violência de seus superiores, estas muitas vezes escondem grande parte de seu capital” (1996a, 293). Smith faz, ainda, advertências contra excessos estatais na exação de tributos, diferenciando seus efeitos sobre o capital "fixo" e o móvel, ou "circulante". Ao passo que o dono de terras não pode escapar a estes excessos com facilidade, o detentor de capital móvel pode escolher deslocar sua riqueza para outro país. 
Aparece em Smith o elemento da valorização da riqueza móvel, que Dumont (2000) associa à ideologia individualista das sociedades modernas:

O proprietário de terra é inevitavelmente um cidadão do país em que está localizada sua propriedade. O proprietário de capital é propriamente um cidadão do mundo, não estando necessariamente ligado a algum país determinado. Ele facilmente deixaria o país no qual estivesse exposto a uma sindicância vexatória, visando onerá-lo com um imposto incômodo e transferiria seu capital a algum outro país em que pudesse continuar seu negócio ou desfrutar de sua fortuna mais à vontade. Ao retirar seu capital, ele poria fim a todo o trabalho que esse capital havia mantido no país que deixou. O capital cultiva a terra; o capital emprega a mão-de-obra. Sob esse aspecto, um imposto que tendesse a desviar capital de determinado país tenderia a fazer secar toda fonte de receita, quer para o soberano, quer para a sociedade. Com a retirada desse capital, inevitavelmente diminuiria, em grau maior ou menor, não somente o lucro do capital, mas também a renda da terra e os salários do trabalho. (Smith, 1996b, p. 303)

Até o momento, foi possível observar que Smith estabelece vínculos entre componentes como fatores de produção, remunerações, grupos sócio-econômicos e modalidades do "estoque total da sociedade" e, dentro destas, inclusive entre a influência das instituições e o capital. Mas as ligações não param por aí.

Vale relembrar que as três remunerações há pouco descritas - salário, lucro e renda figuram como componentes do preço dos bens comercializados. Smith chama de "valor real" ou "natural" o preço dado ao produto em referência à soma destas remunerações. O valor real "mede o valor não somente daquela parte do preço que se desdobra em trabalho efetivo, mas também daquela representada pela renda da terra, e daquela que se desdobra no lucro devido ao empresário." (1996a, p. 103) Logo, o "valor real” é igual ao conjunto das remunerações dos três fatores necessários para produzir o bem na perspectiva de Smith (trabalho, capital e terra).

Ao propor a noção contrastante de "valor nominal" das mercadorias, Smith amplia a análise para abarcar outras relações, como as de oferta e demanda. Afinal, valor nominal é o "preço de mercado" ou "preço efetivo", podendo coincidir ou não com o valor real ou natural (1996a, p. 110):

O preço de mercado de uma mercadoria específica é regulado pela proporção entre a quantidade que é efetivamente colocada no mercado e a demanda daqueles que estão dispostos a pagar o preço natural da mercadoria, ou seja, o valor total da renda fundiária, do trabalho e do lucro que devem ser pagos para levá-la ao mercado. (1996a, p. 110)

Assim, se a "quantidade de uma mercadoria colocada no mercado é inferior à demanda efetiva" (que é a demanda daqueles que não só querem, como podem pagar pelo bem

\footnotetext{
${ }^{106} \mathrm{O}$ ponto levantado nesse trecho é uma sinalização remota daquilo que a literatura de Law \& Finance enfatiza na contemporaneidade: a necessidade de que as instituições jurídicas sejam moldadas com uma preocupação nas possíveis reações dos investidores. Vide seção 4.2.
} 
desejado), o preço de mercado subirá em relação ao preço natural, porque alguns consumidores "estarão dispostos a pagar mais". "Daí o preço exorbitante dos gêneros de primeira necessidade durante o bloqueio a uma cidade ou em caso de fome generalizada." (1996a, p. 110) Em contraste, o preço de mercado cairá em relação ao preço natural se a quantidade de mercadorias levadas ao mercado ultrapassar a demanda efetiva, não havendo possibilidade de que todas sejam vendidas "àqueles que desejam pagar o valor integral da terra, dos salários e do lucro, que devem ser pagos para colocar essa mercadoria no mercado." Nessa situação, parte das mercadorias "deve ser vendida àqueles que só aceitam pagar menos, e o preço baixo que pagam pela mercadoria necessariamente reduz o preço total.” (1996a, p. 110-1) ${ }^{107}$ Este conjunto de motivadores do comportamento conforma o mecanismo de preços, a cargo do qual se situa a coordenação espontânea e automática de interesses diversos dos indivíduos (harmonia natural ou mão invisível), cada qual procurando seu bem-estar material $^{108}$.

Ainda a respeito da relação entre oferta e demanda, para Smith (ao contrário da posição de Jean-Baptiste Say ${ }^{109}$ ), a demanda é determinante da oferta. Em outros termos, havendo demanda, a oferta se ajustará para atendê-la:

A quantidade de cada mercadoria colocada no mercado ajusta-se naturalmente à demanda efetiva. É interesse de todos os que empregam sua terra, seu trabalho ou seu capital para colocar uma mercadoria no mercado, que essa quantidade não supere jamais a demanda efetiva; e todas as outras pessoas têm interesse em que jamais a quantidade seja inferior a essa demanda. (Smith, 1996a, p. 111)

\footnotetext{
${ }^{107}$ A lei da oferta e demanda também é determinante do preço dos fatores de produção. Para Smith, a mão-deobra está sujeita a esta lei assim como "qualquer outra mercadoria", de forma que, havendo "trabalhadores disponíveis do que a demanda efetiva por eles, os salários cairão, ao passo que a "escassez de mão-de-obra provoca uma concorrência entre os patrões", de que resultam aumentos na remuneração do trabalho (1996a, p. 121). A variação desse componente monetário da produção (salário) se reflete no preço final das mercadorias, porque o aumento da remuneração do trabalho "necessariamente" faz subir-lhes o preço, "tendendo assim a reduzir seu consumo tanto no país como no exterior." (Smith, 1996a, p. 135) Smith faz interconexões análogas a respeito dos lucros (1996a, 137) e da renda da terra (1996a, p. 187), configurando múltiplas conexões entre as partes que compõem o sistema econômico.

108 "As variações de preços transmitem as informações necessárias para a coordenação das atividades econômicas ao sinalizarem para os vários agentes o que deverão fazer [...]. Assim, do lado da produção, os agentes econômicos irão canalizar os seus recursos para as atividades cujos preços estiverem subindo, devido à perspectiva de lucros, e contraindo-os nas atividades cujos preços estiverem caindo, em virtude da perspectiva de prejuízos. Do lado do consumo, os agentes econômicos irão adquirir os bens cujos preços estiverem mais baixos, em detrimento daqueles que estiverem relativamente mais altos." (Teixeira, 2002, p. vii)

109 "A lei de Say, uma proposição bastante simples, dizia que o resultado da venda de um bem era distribuído em parte a alguém sob a forma de salários, ordenados, juros, aluguéis ou lucros (ou era tirada do homem que absorvesse um prejuízo), sendo esses os recursos necessários para comprar tais bens. O que ocorria com um bem ocorria com todos. Sendo assim não podia haver falta de poder de compra na economia." (Galbraith, 1997, p. 213) Cumpre ressalvar que a posição de Say a esse respeito foi mais influente sobre o pensamento econômico liberal posterior do que a do próprio Smith. A noção de Say seria, porém, severamente atacada por John Maynard Keynes nos anos 1930 (vide seção 3.2).
} 
Ainda a respeito da abordagem dos preços em Smith, é significativo que não haja qualquer discussão sobre "preço justo", forma tradicional de lidar com a questão. Aliás, a doutrina do preço justo pode ser interpretada como tendo o propósito domar a paixão da avareza ou a busca privada pelo ganho. Este componente normativo externo - porquanto fundado na ética ou em preceitos costumeiros ou religiosos - é substituído por outro, interno ao domínio econômico, ou seja, o "preço de mercado", a que corresponde o cenário em que a busca privada dos interesses encontra-se livre e a visão de doux commerce é triunfante. A normatividade que emana do preço de mercado é como que a de uma "lei física" (descritiva de fenômenos, ao invés de prescritiva de comportamentos), a reger o funcionamento do mundo econômico.

No esquema de Smith, portanto, não é o "preço justo", mas a livre operação da oferta e da demanda, que determina o "valor de mercado". É importante ressaltar que o mecanismo de preços (cujas sinalizações respondem às relações entre oferta e demanda) liga os mais variados componentes do sistema descrito por Smith. Não só a quantidade a ser produzida quanto o preço das mercadorias respondem à oferta e à demanda, como também as remunerações e a própria disponibilidade de fatores de produção como trabalho, capital e terra. Estes se encarecem ou barateiam conforme sejam mais escassos ou abundantes, e viceversa. O Quadro 3.3, abaixo, busca fornecer representação visual mais abrangente e concatenada de diversos elementos sistematizados por Smith. Cumpre fazer a ressalva de que este esquema não tem a pretensão de ser completo. Ainda assim, já é possível observar como as diferentes partes do sistema encontram-se ligadas, e o papel dos preços nessas ligações. Aqui esta a base para uma organização da atividade econômica que não é pautada na hierarquia, nem em predeterminações do direito natural, mas que permite sustentar que os mercados funcionam por si sós (dada a base institucional apontada por Smith).

Juntos, os itens 3.1.1.1 e 3.1.1.2 buscaram fornecer um panorama de aspectos do pensamento de Smith que serão úteis para compreender a influência do liberalismo econômico na estruturação da ordem econômica internacional que tomou forma no século XIX. Esta influência vai além, dado que Smith inaugura uma forma nova de pensar, consistente na própria perspectiva econômica. Além disso, o resgate extremado do projeto de liberdade dos mercados marcará a estruturação das relações econômicas internacionais dos anos 1970 em diante, como a seção 3.3 relatará. Estes, porém, são temas para momentos posteriores do texto. A seguir, o item 3.1.1.3 focaliza um componente das ideias de David Ricardo, um dos principais nomes associados ao liberalismo econômico. Não se tem o propósito de abordar o conjunto de suas ideias, mas de fazer um destaque para complementar 
a exposição dos contornos centrais do liberalismo, que não pode prescindir do argumento das vantagens comparativas ou relativas no comércio internacional. Afinal, a perspectiva de Ricardo sobre o comércio internacional se revelou mais influente que a do próprio Smith.

Quadro 3.3 - representação esquemática de aspectos do sistema de Smith

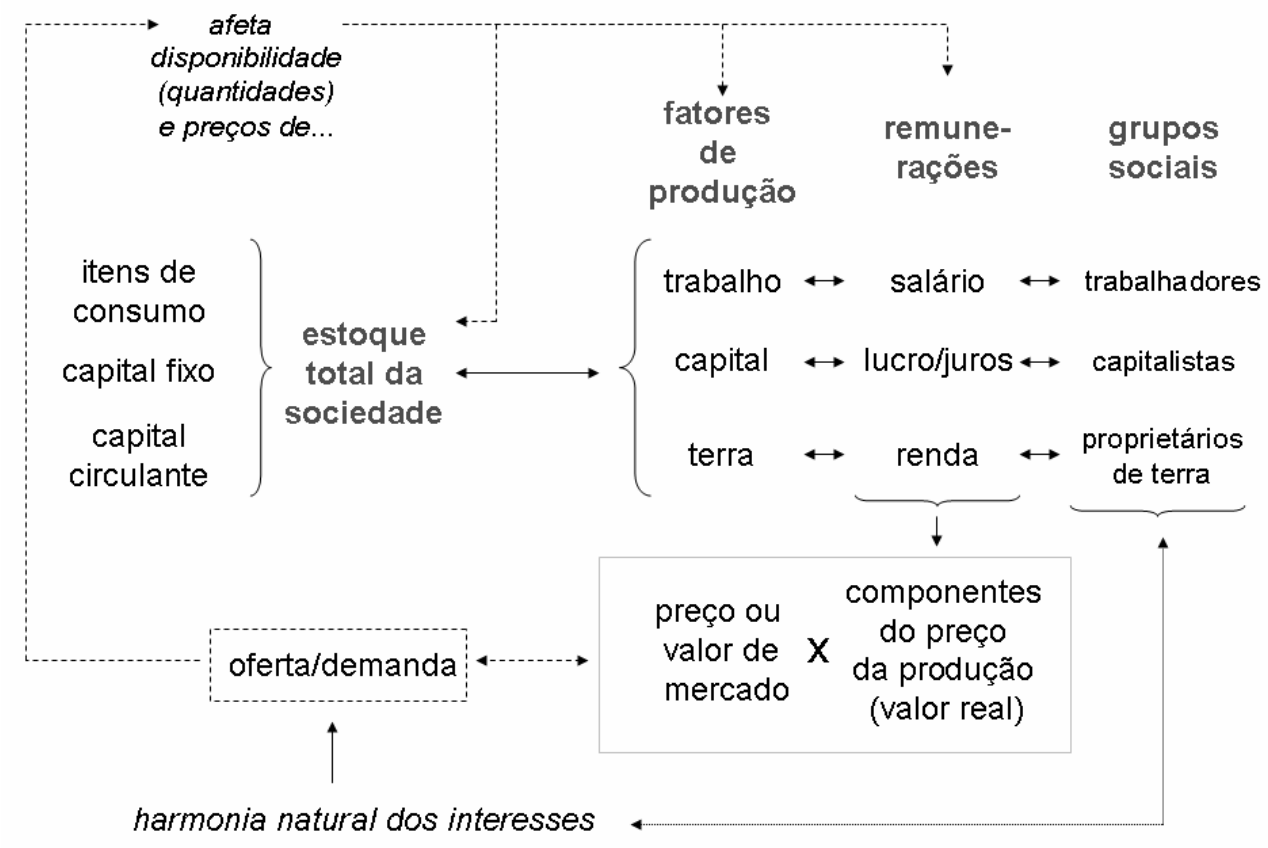

Fonte: elaborado com base em Smith, 1996a.

3.1.1.3 David Ricardo e o argumento das vantagens comparativas no comércio internacional

Assim como Smith, Ricardo (2001[1817]) defendeu os benefícios gerados pela especialização (divisão) do trabalho entre países ligados pelo comércio. Diferentemente, porém, a argumentação de Ricardo resultou no favorecimento de uma liberdade ampla de comércio, a abranger mesmo a situação em que determinado país não seja melhor produtor que outro em setor algum. Esta seria uma situação em que, para Smith, não haveria vantagem absoluta ou natural.

Ricardo precede seu argumento pela consideração de que a divisão do trabalho e a harmonia natural dos interesses encontram-se vinculadas, formando um princípio gerador de bem-estar universal. Aqui, é possível notar sua inserção na tradição de Smith:

Num sistema de comércio perfeitamente livre, cada país consagra o seu capital e trabalho às atividades que lhe são mais rendosas. Esta procura da vantagem individual coaduna-se admiravelmente com o bem estar universal. Deste modo, estimulando-se a indústria, premiando-se os inventos e empregando-se o mais eficazmente possível as possibilidades especiais concedidas pela natureza, o trabalho é melhor distribuído e com maior economia enquanto que, aumentando a produção 
total, se espalha o bem-estar por toda a parte e se ligam todas as nações do mundo civilizado com os elos do interesse e do intercâmbio. É este princípio que faz com que o vinho seja produzido em França e Portugal, que se cultive o trigo na América e na Polônia e que se fabriquem ferramentas e outros produtos na Inglaterra. (Ricardo, 2001, p. 149 - acrescentou-se ênfase)

A consequência desta linha de argumentação já é conhecida: o comércio permite difundir os ganhos de bem-estar obtidos com a divisão do trabalho, e o melhor uso do trabalho disponível reside na atividade em que ele é mais produtivo. Se Portugal e Inglaterra, por exemplo, tentassem isoladamente produzir tudo aquilo de que necessitam, estariam em posição pior do que aquela obtida pela especialização em setores específicos e o engajamento em trocas mútuas (Ricardo, 2001, p. 150). A parte "nova" do argumento começa a partir da sugestão da seguinte situação hipotética:

\begin{abstract}
A Inglaterra pode encontrar-se em tais circunstâncias que para produzir os tecidos necessita do trabalho de 100 homens durante um ano e se tentasse produzir o vinho poderia precisar do trabalho de 120 homens durante o mesmo período. [...] Em Portugal, a produção de vinho poderia só necessitar do trabalho de 80 homens durante um ano e a produção dos tecidos exigiria o trabalho de 90 homens durante o mesmo período. (Ricardo, 2001, p. 150-1)
\end{abstract}

Neste cenário, Portugal teria maior produtividade que a Inglaterra tanto na produção de vinhos quanto de tecidos, dado que precisaria de menor quantidade de trabalho para obter o mesmo volume de produção. Caso o argumento de Smith fosse aplicado, Portugal teria vantagens absolutas nos dois setores de produção; a Inglaterra não teria o que ganhar a partir do comércio com Portugal... Ricardo, entretanto, sugere que cada um dos países deva especializar-se naquilo em que é mais produtivo, considerando-se a gama de possibilidades para a produção interna e não a produtividade dos concorrentes estrangeiros. E, em seguida, deve abrir-se ao comércio internacional.

Ricardo identifica, então, que na Inglaterra há vantagens relativas para a produção têxtil (que demanda menos homens/ano que a produção vinícola). Não importa que Portugal conte com maior produtividade em ambos os setores. E o mesmo ocorre para Portugal, em que o ramo mais produtivo é o vinícola (que precisa de 10 homens/ano a menos do que na produção têxtil). A receita de vantagens comparativas ou relativas de Ricardo consiste em que cada país focalize sua produção naquilo que faz melhor, diante de suas próprias possibilidades, e dirija seus recursos produtivos para tal setor. O resultado será maior volume de produção e troca para ambos os países, que se sairão melhor do que se buscassem, cada qual, satisfazer autarquicamente todas as suas necessidades produtivas:

Embora Portugal pudesse fabricar os seus tecidos só com 90 homens, importá-los-ia de um país onde são necessários 100 homens para os produzir porque teria mais vantagem em empregar o seu capital na produção de vinho, em troca do qual obteria 
da Inglaterra uma maior quantidade de tecidos do que a que poderia produzir desviando uma parte do seu capital utilizado na cultura da vinha para a fabricação de tecidos. (Ricardo, 2001, p. 151)

$\mathrm{O}$ argumento das vantagens comparativas permite a apresentação da abertura ao comércio internacional como benéfica a todos os envolvidos ${ }^{110}$. No entanto, cumpre observar que, na situação descrita por Ricardo, o comércio será mais vantajoso para Portugal, por ser o país mais produtivo no exemplo. Em termos mais simples, Portugal terá maiores ganhos de bem-estar com a abertura ao comércio internacional do que a Inglaterra, no exemplo fictício proposto por Ricardo. Na competição de um país com os demais, os ganhos do comércio internacional são desiguais, mas este ponto não é tomado por Ricardo como ressalva a seu argumento pela liberalização generalizada do comércio exterior.

Valendo-se da terminologia do estudo das relações internacionais, é possível afirmar que a proposta de David Ricardo para interação entre países espera que estes prefiram ter ganhos absolutos a ganhos relativos no comércio internacional. Ou seja, seria mais importante a cada país ter maiores ganhos de bem-estar em relação à situação de ausência de comércio internacional (ganhos absolutos do comércio), do que a comparação dos ganhos obtidos pelos países, uns em relação aos outros (ganhos relativos). No cenário hipotético de Ricardo, tanto a Inglaterra quanto Portugal têm ganhos absolutos ao engajarem no livre comércio um com o outro, mas Portugal ganha relativamente à Inglaterra, tendendo a distanciar-se dela na acumulação de riqueza. Evidentemente, o cenário proposto por Ricardo é uma inversão da ascendência britânica sobre Portugal no comércio internacional do século XIX. Em todo caso, a defesa pela liberdade de comércio com base nas vantagens comparativas contém uma pressuposição de que os Estados tenham preferência por ganhos absolutos e não por ganhos relativos, o que é controverso no campo das relações internacionais (cf. Castro, 2005b, p.153).

\subsubsection{Aspectos da ordem econômica internacional no período de predominância da perspectiva econômica liberal}

Na esteira da expansão comercial britânica e das revoluções industriais, as elaborações intelectuais do liberalismo econômico - na tradição de Smith, Ricardo e outros - ganharam influência no século XIX e estiveram associadas aos contornos assumidos pela ordem econômica internacional nesse período.

\footnotetext{
${ }^{110}$ Por isso, é possível afirmar o argumento das vantagens relativas de Ricardo favorece a defesa absoluta da liberdade comercial, ao passo que o argumento de vantagens absolutas de Smith resulta em defesa relativa de tal liberdade.
} 
É importante esclarecer que somente com o aumento da relevância das trocas comerciais e financeiras entre países pôde-se vislumbrar o surgimento de algo como uma ordem econômica internacional. $\mathrm{E}$ as trocas se tornam mais intensas justamente ao longo do século XIX. Como Eiiti Sato aponta, em 1800, apenas 3\% de todo o produto mundial estava relacionado ao comércio internacional. Já às vésperas de 1914, esta fatia havia crescido para $33 \%$. Essa progressão nos números indica que os países tornaram-se mais significativamente dependentes de suas interações com mercados externos. O comércio exterior se tornou um "sistema" relevante para as economias dos países (Sato, 2012, p. 63). Assim como ocorreu no comércio, transações financeiras e interações monetárias se tornaram expressivamente mais internacionalizadas no período.

É nesse contexto que se pode falar na conformação de uma ordem econômica internacional, compreendida entre o século XIX e a Primeira Guerra Mundial, e intelectualmente marcada pelo primado da perspectiva econômica liberal. Para compreender aspectos essenciais dessa ordem, o item 3.1.2.1 busca delinear os principais contornos de relações comerciais internacionais do período. Na sequência, o item 3.1.2.2 abrange o sentido assumido por relações monetárias e financeiras sob o Padrão-Ouro Internacional, um regime informal estabelecido por volta de 1870 e que, apesar de tentativas posteriores de resgate até os anos 1930, desintegrou-se com a Primeira Guerra Mundial.

\subsubsection{Aspectos caracterizadores das relações comerciais internacionais do período}

O período de prestígio ideológico do liberalismo econômico contou com aumentos nos fluxos internacionais de comércio expressivos o suficiente para que a época seja hoje referida como uma "primeira globalização" econômica. Como Dani Rodrik $(2007 ; 2011)$ destaca, em certos aspectos essa globalização foi até mais profunda do que aquela experimentada após a Segunda Guerra Mundial e intensificada a partir da década de 1970, bastando, para tanto, considerar que o fator trabalho jamais chegou a resgatar a mobilidade internacional de que gozou durante o século XIX.

Não parece ser possível compreender o avanço da liberdade comercial neste período sem relacioná-la à ascendência industrial, comercial e política da Grã-Bretanha. Afinal, foi ali que as ideias do liberalismo adquiriram influência mais precocemente, projetando-se sobre a política externa e vindo a influenciar o comportamento de outros países. Aliás, é curioso 
notar, seguindo a caracterização histórica feita por Ha-Joon Chang (2002) ${ }^{111}$, que a GrãBretanha buscou proteger ativamente seu setor industrial têxtil incipiente até que este pudesse superar seus concorrentes, só então abraçando a postura de livre comércio.

\section{Difusão da liberdade de comércio no século XIX}

Ao contrário do que a percepção comum sugere, a Revolução Industrial britânica do século XVIII foi acompanhada de medidas restritivas ao comércio internacional. Medidas de proibição ou restrições a importações buscavam dar espaço a setores econômicos domésticos que não estavam à altura da competição internacional. Havia, igualmente, restrições e proibições de exportações de caráter estratégico para as manufaturas. Na Grã-Bretanha, matérias-primas fundamentais à indústria, como lã e carvão, não podiam ser livremente vendidas ao exterior. Outras restrições a produtos agrícolas advinham das chamadas corn laws. Políticas comerciais protetivas eram comuns no século XVIII e início do XIX também em outros países europeus (Kindleberger, 2003, p. 73-6).

O movimento pela liberalização do comércio britânico era incipiente ao final do século XVIII, e só tomou fôlego após as guerras napoleônicas, encerradas em 1815 (Kindleberger, 2003, p. 75). Na perspectiva de Polanyi, porém, apenas na década de 1830 o liberalismo econômico adquiriu verdadeira ascendência sobre a política britânica (Polanyi, 2001, p. 143).

Para Kindleberger, a difusão das medidas de livre comércio - primeiro na GrãBretanha, depois pela Europa - deu-se por razões diversificadas, e variáveis segundo o momento histórico (2003, p. 87). Sua explicação para a defesa britânica do livre comércio abrange três motivações. Uma delas relaciona-se ao "autointeresse direto de grupos particulares dominantes", com interesses protegidos (vested interests) na exportação (2003, p. 88). Kindleberger explica que o fator de produção abundante tende a pressionar medidas políticas pela liberdade de comércio, ao passo que, tornando-se escasso, tende a fazer lobby por proteção. A influência deste fator parece atemporal no relato do autor. Num momento inicial, referente aos anos 1830, outra motivação residiu na tentativa britânica de impedir ou retardar a industrialização na Europa continental, num "imperialismo de livre comércio". A estratégia consistia em, a partir da liberdade de comércio, baixar os preços dos produtos industrializados exportados para o continente, considerando-se que as tarifas de importação existentes contribuíam para a alta dos preços destes produtos e, consequentemente, atraíam

\footnotetext{
${ }^{111}$ Vide seção 3.4 .
} 
competidores locais às exportações britânicas (2003, p. 80). Por fim, entra o papel da influência do "credo liberal”. Na Grã-Bretanha do século XIX, tornou-se generalizada a crença de que os "ensinamentos de economistas ortodoxos, incluindo os defensores do livre comércio, eram cientificamente exatos, universalmente aplicáveis, e demandavam assentimento.” (2003, p. 81)

A postura de abertura unilateral ao comércio por parte da Grã-Bretanha ocorreu ao lado de negociações britânicas bilaterais em tratados de comércio, amizade e navegação. Uma característica destes tratados era a inclusão de cláusula de "nação mais favorecida" (NMF). "A cláusula de nação mais favorecida é a regra segundo a qual uma vantagem concedida a qualquer outro Estado se estende automaticamente ao parceiro comercial (que é, portanto, o mais favorecido)." (Barral, 2007a, p. 30) Cumpre ressalvar que esta cláusula já estava presente em tratados britânicos anteriores à era vitoriana. O Tratado de Comércio e Navegação celebrado entre Grã-Bretanha e Portugal, em 1808, quando da vinda da família real portuguesa ao Brasil, incluía a cláusula NMF. Significava, portanto, que "qualquer vantagem concedida por Portugal a outros Estados se estenderia automaticamente aos produtos ingleses, e vice-versa." (Barral, 2007a, p. 31)

Como Andrew Brown destaca, após a década de 1860 - quando da celebração do Tratado Cobden-Chevalier, com a França -, cláusulas NMF tornaram-se padrão nos acordos comerciais de outras potências europeias. Mudou-se a prática de "acordos bilaterais que confinavam as concessões às partes da negociação". Deste modo, formaram-se redes de cooperação comercial costuradas por meio de tratados bilaterais que continham a cláusula, com o efeito de transmitir as concessões feitas a um país aos demais favorecidos (Brown, 2003, p. 56).

Em outros termos, a Grã-Bretanha, por meio da inclusão das cláusulas de NMF em seus tratados bilaterais do período, promoveu a liberalização do comércio para além das bases de reciprocidade. Isto porque, com referida cláusula, as partes de uma relação de NMF poderiam beneficiar-se de negociações que uma delas fizesse com terceiros, sem que da outra fossem exigidas concessões recíprocas. A política unilateral britânica de liberalização do comércio era, portanto, acompanhada de "tratados comerciais bilaterais que estendiam, de modo incondicionado, status de Nação Mais Favorecida a terceiros países." (Sally, 1998, p. 199).

Cumpre salientar, no entanto, que a promoção britânica da abertura comercial no século XIX - embora contasse com os elementos de sua própria postura unilateral e das negociações bilaterais de tratados com cláusulas de NMF - era acompanhada do uso da força, 
favorecido pela hegemonia de que gozava no domínio naval. O período vitoriano é, afinal, também o período da pax britanica, de alcance máximo de sua extensão imperial. A força era “empregada para defender mercadores britânicos e para ampliar seus mercados", inclusive por meio de políticas de "guerra e anexação", muito comuns à presença britânica na Ásia e em outros pontos do globo (Semmel, 1970, p. 206). Não se pode deixar de lado a existência de elementos coercitivos nas práticas comerciais do século XIX. Tampouco se pode esquecer que, apesar do status britânico de hegemon, a porção final do século XIX e inicial do século $\mathrm{XX}$ foi marcada por disputas coloniais entre as potências europeias imperialistas. Em outros termos, o uso da força acompanhou a expansão comercial das potências comerciais de modo geral, e não apenas no caso da Grã-Bretanha.

A adoção de políticas de livre comércio não ficou adstrita à Grã-Bretanha. $\mathrm{O}$ caso da França é explicado por Kindleberger primariamente com base no argumento dos vested interests. "O movimento de livre comércio na França tinha suporte em Bordeaux, a região exportadora de vinhos; de Lyon, com interesses na seda; e Paris, produtora dos chamados 'artigos de Paris' para venda no exterior (móveis, perfumes, imitações de joias, brinquedos e assim por diante).” (2003, p. 82) Outros países, sem setores industriais expressivos, contaram com abertura comercial após meados do século XIX com base no "triunfo intelectual dos economistas políticos” (2003, p. 81). Após 1857, Espanha, Portugal, Noruega e Suécia reverteram restrições e proibições de importação (2003, p. 83). Além destes países, Kindleberger atribui ao peso das considerações ideológicas, mais do que aos interesses econômicos de grupos locais específicos, a abertura comercial ocorrida na Holanda, Bélgica e Dinamarca no mesmo período (2003, p. 88).

\section{Padrões de interação comercial}

Embora a expressão "liberalismo econômico" possa sugerir que a estruturação das atividades econômicas aconteça "livre" de hierarquias, coerções e outras modalidades de constrangimento, é importante ressaltar que o período em análise é caracterizado por padrões assimétricos de interação econômica (Sato, 2012, p. 62). Tais padrões guardam aproximações com a configuração das hierarquias políticas internacionais. Nesse sentido, relações desiguais de poder parecem ter se refletido em relações também desiguais de comércio. 
O pano de fundo das relações comerciais desiguais do século XIX é um ambiente político que Eiiti Sato caracteriza por meio de três traços: o eurocentrismo ${ }^{112}$; o colonialismo como forma de relação entre a Europa com outras partes do mundo; e a existência de um sistema que "se baseava num liberalismo no qual nações soberanas desenvolviam suas políticas de modo autônomo num ambiente de equilíbrio de poder.” (2012, p. 56) Neste cenário, não estavam dadas as condições para qualquer pretensão à afirmação de igualdade de termos comerciais entre potências anglo-europeias e povos de outras partes do globo.

Os três elementos acima se refletem em aspectos que caracterizam padrões de comércio no século XIX. O primeiro é divisão internacional do trabalho. A especialização dos países em setores produtivos distintos deu-se de modo a caracterizar dois grandes agrupamentos. De um lado, países do mundo anglo-europeu se industrializaram. De outro, partes do globo que antes contavam com produção manufatureira significativa se desindustrializaram conforme o contato comercial com a Europa se intensificou (Sato, 2012, p. 64), a exemplo do ocorrido com a produção têxtil chinesa e indiana (Sato, 2012, p. 62). A expansão do comércio internacional colocou em contato regiões distintas e provocou mudanças em suas estruturas de produção:

Em seus estágios iniciais, pode-se dizer que o comércio produziu um processo smithiano de especialização, isto é, dadas as diferenças de custos (principalmente depois que os transportes internacionais também ganharam o impulso de muitas melhorias, que reduziram tempo e custo), os produtos vindos dos países que estavam se industrializando rapidamente deslocaram as atividades manufatureiras nas regiões periféricas. (Sato, 2012, p. 61-2)

Desse modo, certos países especializaram-se como "fábricas", ao passo que outros se tornaram "celeiros/minas" (Sato, 2012, p. 65). O comércio global do século XIX foi marcado pela troca de bens primários, como alimentos, minérios e outras matérias-primas, por manufaturas. É interessante observar que, na composição do volume total de comércio internacional, dois terços correspondiam a produtos primários, e apenas um terço a manufaturas (Sato, 2012 p. 74). Este é outro aspecto importante da configuração desigual do comércio. Países especializados na produção agrícola não passam pelo mesmo processo de mudança estrutural associada à industrialização e ao desenvolvimento (vide seção 3.4). Neste sentido, a configuração pode ser lida como tendente à perpetuação de desigualdades econômicas entre países. Não se pode deixar de lado, aliás, a existência de sobreposição entre

\footnotetext{
${ }^{112}$ Bernard Semmel aponta, a este respeito, que "havia uma percepção generalizada, amplamente compartilhada por economistas políticos, acerca da superioridade europeia, dos benefícios que poderiam ser conferidos pelo domínio europeu e, em particular, pelo domínio inglês.” (1970, p. 209) Semmel exemplifica fazendo menção à postura de Jean-Baptiste Say em relação à administração colonial da Índia pela Grã-Bretanha. Segundo este, “o povo da Ásia 'dificilmente pensa ser possível viver sem um mestre.” (Say apud Semmel, 1970, p. 209-10)
} 
aqueles países que eram especializados na produção primária (celeiros/minas) e aqueles que eram escassos em capital. Estes consumiam não só produtos industrializados do exterior, como também investimentos das economias mais importantes: sobretudo a Grã-Bretanha (pela maior parte do século), e posteriormente também Estados Unidos, Alemanha e França.

Ainda outro aspecto se refere a certa configuração "triangular" dos fluxos de comércio e investimento no século XIX. A Grã-Bretanha, pólo da ordem econômica internacional, obtinha superávit em seu comércio com a Índia. Esta era superavitária em relação ao restante do mundo. Por sua vez, a Grã-Bretanha tinha déficits comerciais com o restante do mundo, importando persistentemente mais do que exportava. A situação não era desequilibrante para a Grã-bretanha por dois fatores. Primeiramente, porque seus déficits com o restante do mundo eram compensados pelos superávits mantidos em relação à Índia. Em segundo lugar, porque os chamados "itens de comércio invisível", como seguros, fretes, e retornos de investimentos feitos no exterior (Sato, 2012, p. 74), pesavam positivamente no balanço de pagamentos britânico. Esta estrutura triangular de comércio (e finanças) provia à Grã-Bretanha uma forma de equilibrar suas contas (Sato, 2012).

A caracterização dos elementos de assimetria nas relações comerciais do século XIX guarda conexões com o que foi observado no relato sobre o período inicial do direito internacional (seção 2.1). Ali, observou-se que as formas jurídicas do direito internacional foram instrumentais para a legitimação do avanço coercitivo do comércio europeu, além de se encontrarem mescladas com o propósito civilizador. Ao passo que instituições como colônias e protetorados davam as bases para a condução metropolitana da economia e comércio das colônias, a jurisdição consular isolava cidadãos europeus da justiça local, representando segurança para sua propriedade e seus contratos, elementos fundamentais à realização do comércio. Não se pode deixar de lado que o direito internacional reconhecia a normatividade de tratados obtidos por meio da coerção e a prática da gunboat diplomacy. Eram válidas as práticas coercitivas de abertura de portos, obtenção de reduções tarifárias ou tratamento preferencial, e para garantir o pagamento de dívidas. Além disso, o direito internacional era marcado por um tratamento peculiar da noção de soberania, que não chegava a ser atributo de todos os Estados. Como se viu, era um atributo essencialmente europeu, mas que podia, atendidas as condições de "civilidade", estender-se a outros cantos do globo. O comportamento dos países da periferia global era permeado por condicionamentos que partiam desde o centro europeu. Assim, por exemplo, ocorria com a China, que não controlava seus portos de modo autônomo: "um cidadão britânico foi inspetor-geral das autoridades alfandegárias chinesas entre 1863 e 1908” (Brown, 2003, p. 61). 
$\mathrm{O}$ argumento, em síntese, é o de que o direito internacional proveu "formas" que abrigaram "práticas" de relações comerciais desiguais, além de frequentemente coercitivas. Neste contexto de padrões assimétricos de interação comercial, os países periféricos, como Eiiti Sato salienta, eram verdadeiros "elementos de equilíbrio da ordem econômica". Sua importância para a ordem econômica internacional consistia em sua posição como: (i) fornecedores de alimentos e matérias-primas aos países industrializados; (ii) destinos das emigrações europeias, "aliviando as pressões econômicas e sociais decorrentes da superpopulação da Europa"; e (iii) mercados consumidores para "produtos industriais e recursos financeiros dos centros industriais." (Sato, 2012, p. 75).

\section{Pontos fora da curva do livre comércio}

A promoção do livre comércio, inspirada nos fundamentos do liberalismo econômico, não foi, porém, a única tendência nas relações comerciais do período (cf. Chang, 2002; Rodrik, 2011). Ao longo do século XIX e da porção inicial do século XX, certos países valeram-se de modelos alternativos que não dialogavam diretamente com as ideias de Smith ou Ricardo, mas que remetiam a outras fontes. Em particular, práticas de proteção a setores econômicos domésticos sensíveis - e em especial à indústria nascente -, encontravam guarida nas contribuições intelectuais de autores como Alexander Hamilton, que escreveu na porção final do século XVIII, e de Friedrich List, cuja produção é da primeira metade do século XIX.

Ao longo do século XIX e até a década de 1920, os Estados Unidos, embora fizessem tratados comerciais bilaterais com cláusulas de NMF, rejeitavam as formulações britânicas de cláusulas incondicionadas (Sally, 1998, p. 199). A postura norte-americana era a de "conceder reduções tarifárias em bases estritamente bilaterais", de modo que eram estendidas a outros países "somente se estes conferissem aos Estados Unidos concessões equivalentes". Em outros termos, os Estados Unidos rejeitavam a ideia de que concessões comerciais pudessem ser obtidas por um país via cláusula de NMF, sem que este último também tivesse que reduzir suas tarifas para as exportações norte-americanas. Era uma visão "condicional da cláusula de nação mais favorecida" (Brown, 2003, p. 56). Segundo Brown, os Estados Unidos desfrutavam do status de "caroneiro" (free rider), "beneficiando-se de tratamento incondicionado de nação mais favorecida por outros países que adotavam a cláusula, mas não estendendo o mesmo tratamento a estes." (Brown, 2003, p. 57) Sobretudo após a Guerra de Secessão norte-americana, o comportamento dos Estados Unidos tornou-se "mais deliberadamente protecionista". O Sul agrícola favorecia políticas de livre comércio. No 
entanto, ao perder a disputa para o Norte industrializado na década de 1860, a política comercial norte-americana pendeu para maiores níveis de proteção tarifária (Brown, 2003, p. 60; Galbraith, 1989, p. 142).

Para Brown, no momento da virada do século, as políticas comerciais de diversos países europeus haviam assumido contornos mais protecionistas. A Alemanha, após a unificação na década de 1870, promoveu política de proteção comercial e industrial no governo de Otto von Bismarck. Nesse contexto, o país de unificação e industrialização tardias emergiu como "líder mundial em indústrias nos setores de aço, químicos e elétrico", de modo que, no ano 1900, "as manufaturas correspondiam a aproximadamente $70 \%$ do total de exportações alemãs, uma proporção maior do que aquela atingida até mesmo pela GrãBretanha" (Brown, 2003, p. 59).

A França também experimentou mudanças na orientação comercial na porção final do século. Após condução mais liberal sob o regime de Luis Napoleão, ocorreu certa guinada protecionista, marcada pela derrota para a Prússia na guerra franco-prussiana, de 1870-1. Em termos gerais, a política francesa passou a ser a de praticar tarifas elevadas para produtos estrangeiros (Brown, 2003, p. 60).

Até mesmo na Grã-Bretanha houve certo "desencantamento com o liberalismo laissez-faire" na virada do século, diante da ascensão de outras potências econômicas e do acirramento das tensões com projetos imperialistas em choque. A partir de 1903, Joseph Chamberlain, líder do partido conservador, "começou a advogar alguma proteção para a indústria doméstica e a formação de uma área de comércio preferencial no império britânico" (Brown, 2003, p. 60). No momento anterior à Primeira Guerra Mundial, no entanto, Chamberlain não obteve sucesso em suas pretensões protecionistas, que só se materializariam na década de 1930 (Semmel, 1970, p. 226).

Estes são apenas destaques pontuais de práticas mais amplas e generalizadas de protecionismo que estiveram na base dos percursos de desenvolvimento de muitos países, inclusive dos mais frequentemente associados à promoção do liberalismo econômico (Chang, 2002). A partir deste breve relato, porém, foi possível notar que não se pode caracterizar o século XIX e início do século XX como tendo sido de plena adesão ao ideário liberal. Feita esta ressalva, os demais elementos aqui relatados permitem perceber que o liberalismo econômico esteve associado à conformação e expansão das relações comerciais internacionais do período, inclusive no que diz respeito à estruturação de padrões desiguais que se podiam justificar como decorrências de processos de autorregulação pela ação das forças de mercado 
(que conduziam alguns à industrialização e outros à desindustrialização/especialização em matérias-primas).

Outras esferas de influência do liberalismo econômico no período em questão foram as relações internacionais em moeda e finanças. O Padrão-Ouro Internacional abraçou a ideia de mercados autorregulados e constituiu um regime informal que em muitos sentidos pode ser apontado como ainda mais influente que o comercial. Suas características e repercussões principais são objeto do item 3.1.2.2 a seguir.

\subsubsection{Aspectos da cooperação internacional monetária e financeira}

O Padrão-Ouro Internacional (POI) foi um regime informal estruturado nos anos 1870 e que regeu com expressivo sucesso a cooperação internacional tanto monetária quanto financeira ${ }^{113}$ das principais potências da época e mesmo de outras economias periféricas, estas últimas com participações pontuais, oscilantes ou instáveis.

Num cenário em que cada país emite sua própria moeda nacional, é fácil perceber como investidores e comerciantes possam experimentar insegurança para conduzir negócios em outras economias. No que diz respeito exclusivamente à moeda - e não a outras instituições, como propriedade privada, garantia judicial ao cumprimento dos contratos etc. tal insegurança está em grande parte associada à possibilidade de que o lucro ou juros esperados em negócios estrangeiros venham a ser corroídos por alterações na paridade entre as moedas, ou seja, por mudanças no câmbio (cf. Polanyi, 2001; Eichengreen, 2008; Galbraith, 1997). Se a moeda local perde valor entre o momento em que o investimento é feito, e aquele em que é liquidado, o investidor estrangeiro pode perder dinheiro (Broz, 2003,

\footnotetext{
${ }^{113} \mathrm{Na}$ caracterização feita por Ernani Teixeira, "o corte entre o monetário e o financeiro decorre da definição de moeda. Quaisquer componentes, além daqueles que figuram no conceito de moeda, são denominados recursos não monetários ou simplesmente financeiros." (Texeira, 2002, p. 33) O autor aponta ainda que a composição dos ativos que cumprem a função de moeda (reserva de valor, unidade de referência e meio de pagamento) é variável. Há uma "convenção universal" em torno de uma composição mínima a compreender "o papel moeda em poder do público mais o saldo dos depósitos à vista", porém "as definições de moeda têm se alterado ao longo do tempo", podendo incorporar também depósitos a prazo, títulos públicos e privados, e até mesmo outros ativos dotados de grande liquidez (2002, p. 21-2). Outra forma de separar o monetário do financeiro pode ser versada nos seguintes termos. Ao passo que o aspecto do "monetário" faz referência à existência e emprego da moeda como elemento que faz o intermédio das transações, o "financeiro" representa as transações em que o objeto transacionado é a própria moeda, com expectativa de ganho. Em todo caso, a distinção é sutil, e as duas áreas apresentam implicações mútuas e sobreposições. A AJPE (seção 4.4) oferece critérios para o recorte analítico entre o monetário e o financeiro. Vide, na seção indicada, a discussão sobre a Nova Análise Contratual.
} 
p. 207). A instabilidade monetária compromete, em especial, o retorno de investimentos de longo prazo ${ }^{114}$ (Polanyi, 2001, p. 16).

Entre os fatores percebidos como de maior importância para a estabilidade ou instabilidade do valor da moeda local encontra-se o comportamento governamental, e em particular o modo como o orçamento público é gerido. Afinal, para além da tributação, governos podem levantar recursos para cobrir déficits orçamentários por meio do endividamento e da emissão de dinheiro novo. Ao fazê-lo, no entanto, colocam pressões sobre a moeda nacional no sentido de inflação (internamente) e depreciação do câmbio (externamente). Não fazê-lo, por sua vez, implica limitação significativa na capacidade que os governos têm de agir sobre os rumos da economia local e mesmo sobre demandas sociais.

O POI foi expressão de um consenso econômico e político que priorizava a segurança e a rentabilidade dos investimentos por meio da preservação de paridades fixas entre moedas nacionais distintas. O novo compromisso prioritário implicou limitações ao comportamento estatal. Em especial, a necessidade de manter orçamentos equilibrados alcançou status dogmático, restringindo significativamente a capacidade de governos de financiar déficits por meio de manobras monetárias (debasement of the coin). A institucionalização do POI, acima mencionada, não se deu formalmente, nem foi positivada em tratados internacionais. Como aponta Barry Eichengreen, o POI não resultou de "discussões centralizadas [...] a respeito do desenho do sistema monetário internacional.” (2003, p. 233) Ainda assim, até o final do século XIX, o POI "havia sido adotado pela maior parte das grandes nações comerciais do mundo, efetivamente estabelecendo o primeiro sistema cambial efetivamente global." (Kettell, 2004, p. 34; cf. Eichengreen, 2008)

A instituição informal do POI contava com três regras: (i) paridades fixas entre moedas nacionais; (ii) conversibilidade da moeda nacional em ouro a uma taxa fixa de conversão e (iii) livre movimentação transfronteiriça de ouro (Sato, 2012, p. 69; Kettell, 2004, p. 33). Assim, durante a operação do POI, “por exemplo, uma libra esterlina podia ser convertida no Banco da Inglaterra em troca de 113 gramas de ouro, que por sua vez poderiam ser convertidas nos Estados Unidos por $\$ 4,86$, estabelecendo desta forma uma paridade entre as duas moedas em $£ 1=\$ 4,86$, ou $\$ 1=£ 0,205$.” (Kettell, 2004, p. 34)

\footnotetext{
${ }^{114} \mathrm{Um}$ exemplo ajudará a esclarecer o ponto. Um investidor inglês do século XIX adquire da coroa portuguesa um título público, denominado em réis portugueses, e com valor correspondente a $£ 100$. O investimento promete remuneração de $10 \%$ ao cabo de um ano. Este investidor projeta auferir ganhos, portanto, de $£ 10$, ao obter, com o decurso do tempo, o montante total equivalente a $£ 110$. No entanto, caso neste meio termo a taxa de conversão do real português em ouro seja alterada, a rentabilidade do investimento poderá ser comprometida. Em especial, se um real português passar (num exemplo extremo) a resgatar 50\% menos ouro na data do resgate do título pelo investidor inglês, ao sacar este montante em ouro e levá-lo à Inglaterra, ele conseguirá apenas $£ 55$, resultando em prejuízo, ainda que, formalmente, o governo português tenha honrado o contrato.
} 
Cabe ressalvar que a adesão a tais regras não foi uniforme ${ }^{115}$ por todos os países participantes em todos os momentos (Eichengreen, 2008, p. 6-42; Broz, 2003). O comportamento da Grã-Bretanha é o que mais se aproxima do modelo ideal do POI, ao passo que a França e a Alemanha adotaram posturas heterodoxas em momentos variados, conforme narra Lawrence Broz (2003). Apesar de variações momentâneas de comportamento, uma das características do POI até a Primeira Guerra Mundial foi a confiança generalizada da comunidade internacional de investidores - haute finance - na adesão dos países participantes a suas três regras. A solidez da confiança no compromisso prioritário com a preservação do valor relativo das moedas nacionais contribuiu para que mesmo os fluxos especulativos de curto prazo (hot money) assumissem, nesta época, sentidos “estabilizantes” (Eichengreen, 2008), ponto que será retomado adiante.

Como decorrência das regras do POI, emergiu uma "taxa fixa de câmbio entre as moedas mais importantes." (Galbraith, 1997, p. 37) A preservação da paridade entre as diferentes moedas pressupunha a operação de um mecanismo autorregulado de equilíbrio dos fluxos transnacionais de ouro, determinado pelo mercado (Sato, 2012, p. 78), e em que os Estados não deveriam interferir. Era necessário aos países em déficit comercial conviver com fluxos de ouro rumo ao exterior (que tendiam a ocasionar deflação e desemprego), ao passo que países superavitários teriam influxos em contrapartida (e inflação). Estes deslocamentos tenderiam, segundo o modelo ideal, a gerar realinhamentos entre os países (cf. Eichengreen, 2008, p. 29). Na prática, porém, os Estados e bancos centrais apresentavam resistências à livre movimentação do ouro, procurando evitá-la ${ }^{116}$ (Eichengreen, 2008; Broz, 2003).

\footnotetext{
${ }^{115} \mathrm{Na}$ França, por exemplo, a conversibilidade de notas de dinheiro em ouro não era garantida por lei, "mas deixada à discrição do banco central" (Broz, 2003, p. 210). O Banco da França cobrava ágio pela troca do valor de face das notas em ouro. Em outros termos, quem descontasse as notas receberia uma quantia menor do que o valor nominal. A medida desestimulava a saída de ouro ao exterior. O custo desta política de proteção aos estoques nacionais de ouro - além de minar a credibilidade do compromisso francês com o POI - foi a limitação da expansão das atividades bancárias francesas no exterior, e da posição do franco como moeda de relevância internacional. Como consequência, apenas a Rússia matinha "ativos substanciais em francos", dadas suas vinculações políticas com a França na porção final do século XIX (Broz, 2003, p. 211).

${ }^{116} \mathrm{O}$ principal instrumento de política monetária para tal fim, empregado extensivamente inclusive pelo Banco da Inglaterra, era a manipulação da taxa de redesconto (Broz, 2003, p. 204), também chamada de taxa interbancária (Galbraith, 1997, p. 36) ou taxa básica de juros. Aumentos em referida taxa tornam mais cara a captação de dinheiro por bancos comerciais, e portanto dificultam a concessão de novos empréstimos. Do contrário, reduzindo a taxa de redesconto, o banco central estimula que dinheiro seja injetado na economia por meio da atividade bancária. Diante destas relações, "o Banco da Inglaterra observava o tamanho de suas reservas de ouro ao definir a taxa de redesconto. Dado que a proporção de reservas era afetada primariamente por movimentações de ouro, o princípio operacional do Banco era o de responder a reduções em suas reservas por saída de ouro ao exterior por meio de aumentos na taxa de redesconto.” (Broz, 2003, p. 204) Com esta orientação monetária, o Banco da Inglaterra expunha a atividade econômica doméstica a "frequentes variações nas taxas de juros". Em outros termos, quando a Inglaterra perdia ouro para o exterior, o Banco da Inglaterra aumentava a taxa de juros com o objetivo de manter o valor da libra esterlina em relação ao ouro, "quer ou não estas ações estivessem de acordo com as necessidades da economia doméstica.” (Broz, 2003, p. 209) Na perspectiva de
} 
O POI alcançou o efeito de "unir as atividades e políticas econômicas das nações", tendo sido "um instrumento notável de coordenação do comportamento econômico em diferentes países." (Galbraith, 1997, p. 141) A estabilidade monetária era, porém, atingida a certo preço. A "deficiência marcante" do POI consistia em exigir a subordinação da administração econômica doméstica "a um mecanismo internacional e impessoal, capaz de gerar dificuldades e perturbações consideráveis." (Galbraith, 1997, p. 142) Isto porque "política monetária", neste contexto, era sinônimo de preservação da paridade, conversibilidade e mobilidade da moeda. Obedecer às regras do POI significava abrir mão de instrumentos de política econômica que pudessem reverter períodos deflacionários, o desemprego e a recessão econômica. Em outros termos, o POI trazia repercussões para o comportamento doméstico dos Estados, no sentido de restringir as políticas públicas e as medidas de política econômica que estes poderiam adotar (Castro, 2006, p. 48-9; Galbraith, 1997, p. 141; Kettell, 2004, p. 34).

A segurança e rentabilidade dos investimentos de longo prazo e das transações comerciais podia ser priorizada no século XIX porque ainda não havia pressões fortes o suficiente para subordinar a estabilidade da moeda a outros objetivos (Polanyi, 2001; Eichengreen, 2008, p. 30; Castro, 2006). Dois fatores são de especial relevância para explicar por que os governos encontravam-se isolados da pressão doméstica para atender a outros objetivos políticos, permanecendo "livres" para priorizar a política monetária segundo as exigências do POI. O primeiro deles é a existência de formatos restritivos de democracia nos Estados liberais neste momento. Com o voto censitário, longe de universalizado, ainda não haviam sido formadas as democracias de massa do século XX. Este fator contribuía para restringir a representação de interesses de setores sociais afetados por medidas adversas de política monetária sob o POI (Eichengreen, 2008, p. 2). A esse respeito, Galbraith afirma que uma das coisas mais perigosas para o funcionamento do POI viria a ser a democracia (1997, p. 39; cf. Polanyi, 2001, p. 216, 243-4; Semmel, $1970^{117}$ ). O segundo fator é o "sindicalismo não completamente desenvolvido". A organização e mobilização incipiente dos trabalhadores era insuficiente para fazer com que objetivos de pleno emprego ascendessem na agenda de

Broz, a preferência pela constância da libra em relação ao ouro, em detrimento da inconstância das taxas de juros, é explicada pela ascendência das classes financeiras na política britânica naquele momento, maior do que a de setores da economia real ou produtiva, até mesmo que o pujante setor industrial.

${ }^{117}$ Para Bernard Semmel, houve mudança a partir das décadas finais do século XIX, "quando a efetividade dos sindicatos trabalhistas em melhorar salários e as condições de trabalho estavam sendo regularmente demonstradas, e quando não apenas na Inglaterra, mas no continente [europeu], uma grande movimentação pela redistribuição da renda nacional, por sistemas de pensões a idosos e seguros de saúdo e desemprego, havia conseguido impressionantes sucessos iniciais.” (Semmel, 1970, p. 222) No pós-Primeira Grande Guerra, as pressões por políticas redistributivas viriam a se intensificar (vide seção 3.2). 
prioridades governamentais (Eichengreen, 2008, p. 2, 30). A esse respeito, cumpre lembrar que os cenários deflacionários, frequentes no POI, dificultavam o desempenho econômico e aumentavam a parcela desempregada das populações.

O referido isolamento dos governos em relação às pressões de massa no século XIX dava as bases para existência da confiança generalizada na adesão dos governos (e dos bancos centrais, onde estes existiam) às regras do POI. Dois efeitos peculiares estão atrelados a esta confiança: a tolerância a desvios temporários e o sentido estabilizante dos fluxos especulativos (Eichengreen, 2008).

Num contexto de sólido compromisso dos Estados com a estabilidade monetária, havia certa "margem de manobra" para que a proporção de reservas (lastro) em relação à massa monetária em circulação caísse abaixo do piso legal em circunstâncias excepcionais. Ou seja, a taxa de conversão da moeda em ouro poderia modificar-se temporariamente, sem que o país fosse abandonado pelos investidores. Possibilitava-se, ainda, a suspensão temporária da conversibilidade da moeda, diante da certeza de que tanto esta quanto a paridade original em relação ao ouro voltariam mais à frente (Eichengreen, 2008, p. 37). As regras do POI não deixavam de ser um ponto de fé neste período. Isso se dava em tal proporção que mesmo o comportamento estatal em contravenção às regras era interpretado, em função desta fé, como desvio que só poderia ser temporário.

Outro efeito da confiança generalizada era a ocorrência peculiar dos fluxos especulativos com sentido estabilizante para a economia local em dificuldades para manter a paridade de sua moeda em relação ao ouro (Eichengreen, 2008, p. 36). Quando a moeda de um país começava a se depreciar em relação ao ouro, investidores tinham incentivos para adquirir a moeda mais barata, na certeza de que, no futuro, ela restauraria o seu valor, e poderia ser vendida com ganho. Como numa profecia autorrealizante, a movimentação dos investidores contribuía para a revalorização da moeda deste país ${ }^{118}$. O ponto é explicado por Eiiti Sato:

esses movimentos de capitais de curto prazo até ajudavam a compensar problemas de balanço de pagamentos de uma forma "automática": um país em déficit tinha sua taxa cambial pressionada para baixo, até níveis próximos do ponto de saída do ouro e, como consequência, especuladores estrangeiros eram atraídos a comprar essa

\footnotetext{
${ }^{118}$ Galbraith explica como a especulação pode atingir o autorreforço, fazendo com que a projeção de ganhos se concretize de fato. "A especulação ocorre quando os indivíduos compram ativos, sempre com o apoio de alguma doutrina racionalizadora, porque esperam que os preços subam. Essa expectativa e a ação resultante então servem para confirmar a expectativa. No momento, a realidade não é o que o ativo em questão - as terras, ou mercadorias, ou ações, ou companhia de investimento - renderá no futuro. Ao contrário, é somente importante que pessoas em número suficiente estejam esperando que o objeto da especulação tenha o seu preço aumentado, para que esse aumento realmente ocorra, o que atrairá mais pessoas ainda para estimular a realização de novas expectativas de aumentos adicionais." (Galbraith, 1997, p. 102)
} 
moeda na esperança de obter lucros quando medidas corretivas fossem tomadas pelas autoridades monetárias daquele país a fim de melhorar a posição do seu balanço de pagamentos. (Sato, 2012, p. 72)

Em contraste com os fluxos especulativos estabilizantes do período anterior à Primeira Guerra Mundial, o período posterior seria marcado pela "fuga de capital" (capital flight), ou desinvestimento, diante do comportamento do Estado que tendesse a minar a segurança e a rentabilidade dos investimentos ${ }^{119}$ (Polanyi, 2001, p. 25).

A segurança e rentabilidade dos investimentos dependiam não só de comportamentos restritivos dos Estados no tocante às medidas de política econômica, que inspiravam a confiança dos investidores, como também da existência da paz entre grandes potências. Este é um dos tópicos de relevo na obra The great transformation, de Karl Polanyi (2001[1944]), segundo o qual o sistema internacional europeu do século XIX deveu a existência da paz não ao funcionamento isolado do balanço de poder, mas à sua operação conjugada com o POI. O elemento de peso na explicação de Polanyi é a emergência do "agudo interesse pela paz" (Polanyi, 2001, p. 7) por parte de uma classe de investidores internacionais com ascendência sobre os governos, e cujos negócios privados seriam comprometidos pela eclosão de guerras entre grandes potências. "A vasta maioria dos portadores de títulos governamentais, bem como de outros investidores e comerciantes, seria a primeira a perder em tais guerras, especialmente se as moedas fossem afetadas." (Polanyi, 2001, p. 14) Estes grandes investidores internacionais com interesses comerciais privados vinculados à manutenção da paz internacional eram a haute finance (Polanyi, 2001, p. 10).

A haute finance, uma instituição sui generis, peculiar ao último terço do século XIX
e primeiro terço do século XX, funcionava como elo principal entre a organização
política e econômica do mundo. Ela fornecia os instrumentos para um sistema de
paz internacional, que era operado com a ajuda das potências, mas que as potências
não poderiam por si próprias ter estabelecido ou mantido. (Polanyi, 2001, p. 10)

Essa classe se tornou influente sobre os rumos das políticas econômicas nos pontos mais variados do globo. "Independente de cada governo, mesmo dos mais poderosos, ela estava em contato com todos; independente dos bancos centrais, mesmo do Banco da Inglaterra, ela estava proximamente conectada com ele.” (Polanyi, 2001, p. 10) O poder da haute finance é explicado principalmente pela dependência que os governos experimentavam em relação à disponibilidade de recursos financeiros nos mercados internacionais. Ao lado da tributação e da impressão de papel-moeda, governos poderiam recorrer a estes mercados para arcar com seus gastos, seja contraindo empréstimos em instituições bancárias, seja oferecendo títulos da dívida pública à venda. Num contexto em que capacidade de exação de tributos é

\footnotetext{
${ }^{119}$ Vide seção 3.2.
} 
legalmente limitada (Estado liberal de direito), e a impressão de dinheiro sem lastro censurada pelo POI, a disponibilidade de recursos nos mercados internacionais havia se tornado relevante para a composição das finanças estatais. "Empréstimos, e a renovação de empréstimos, dependiam do crédito, e o crédito, do bom comportamento." (2001, p. 14; cf. Ferguson, 2008)

As regras do POI eram informais, mas funcionaram por período considerável. A influência da haute finance, e seu poder de punir pela ameaça ou concretização da negação de crédito ou fuga de capital, é uma explicação para o funcionamento do regime monetário internacional. Outra explicação reside na influência intelectual do liberalismo econômico, e em particular da noção mercado autorregulado, que estava embutida na proposta do POI para a ordenação das relações monetárias internacionais. Ambas encontram-se presentes na caracterização feita por Polanyi (2001). Estes elementos podem lançar alguma luz sobre as fontes da ordem monetária internacional do século XIX, a respeito da qual é notável a ausência de papel de coordenação por parte do direito internacional. Embora informais, sem serem jurídicas, as regras do POI foram emanações normativas concretas para as relações internacionais do período.

$\underline{\text { 3.1.3 Algumas implicações normativas e jurídicas de ideias, práticas e instituições informadas }}$ pelo liberalismo econômico

$\mathrm{Na}$ introdução deste capítulo, deu-se importância à emergência da economia como maneira nova de pensar, sua autonomia encontrando-se carregada de implicações normativas inclusive para o modo como as relações internacionais e suas instituições jurídicas são estruturadas. A abordagem do POI, na subseção anterior, permitiu evidenciar alguns elementos desta expressão de normatividade, com regras informais que "despolitizavam a moeda" (Kennedy, 2006, p. 29) e traziam significativos constrangimentos à gama permitida de comportamentos estatais. Essa expressão de normatividade na esfera monetária e financeira é um dos componentes de um projeto mais amplo para a organização das relações econômicas internacionais, a envolver posição peculiar para o direito.

Viu-se que a noção de normatividade interna à economia, sob a perspectiva liberal, é baseada no argumento da harmonia natural dos interesses. Este favorece a livre atuação das "forças de mercado", e aponta que a coordenação espontânea das vontades privadas dispersas (e autointeressadas) conduz ao benefício do todo social. Apesar de não deixar de ser um item de fé, o argumento, em todo caso, resulta na postura de aversão a mecanismos de coordenação 
política (ou hierarquizada) da produção, troca e consumo. Ou seja, resulta no não intervencionismo estatal na esfera econômica. No campo jurídico, sua consequência é relegar o direito à formalidade (cf. Castro, 2012, p. 211). Não há lugar para que conteúdos previamente preenchidos pelo próprio direito orientem a produção, a troca ou o consumo. Sua função é prover as formas fundamentais ao livre desenrolar da autonomia privada, que corresponde à atuação desimpedida das forças de mercado, em linha com o argumento da harmonia natural dos interesses. O direito provê as formas, e a vontade privada as preenche de conteúdo. Notadamente, esta concepção encontra-se abrigada pelo formato de Estado liberal, que separa direito público e privado: o direito público limitando comportamentos estatais em função do objetivo maior de habilitação e preservação da esfera privada de autonomia, em linha com o individualismo. Estas considerações se casam com a concepção de Adam Smith a respeito do papel fundamental que instituições jurídicas - como propriedade privada, contratos e a garantia judicial destes - têm em sua projeção do que seria o domínio econômico ótimo, sem referência a papéis mais ampliados do direito e do Estado (que deve permanecer limitado até mesmo sob o argumento de que o trabalho realizado por seus agentes é improdutivo, no sentido que Smith confere a tal expressão).

Internacionalmente, a projeção de instituições desenhadas para dar livre curso à autonomia privada ("forças de mercado") reflete-se numa ordem internacional que se pretende espontânea. No POI, por exemplo, os fluxos transfronteiriços de ouro devem permanecer livres, em linha com a crença de que os mercados autorregulados (cf. Polanyi, 2001, p. 3-5, 31) cuidarão dos ajustes necessários para preservar a paridade entre as moedas. Ao Estado cabe comportar-se de maneira restritiva (abstendo-se de gastar demais, desequilibrar o orçamento ou conduzir políticas econômicas de caráter intervencionista ou redistributivo), converter a moeda local em ouro sempre que instado a fazê-lo, e permitir o livre deslocamento de ouro por suas fronteiras. Embora nacional, a moeda isola-se da política e alinha-se à normatividade que emana da economia e que, nesse contexto - vale lembrar vem da noção de harmonia natural dos interesses.

Esta concepção de moeda isolada da política reverte-se, em termos jurídicos, em barreiras para a afirmação concreta de direitos sociais, que são a linguagem jurídica para fazer referência às políticas econômicas de caráter redistributivo (cf. Castro, 2006). A pretensão que a afirmação destes direitos traz a uma parcela da composição do orçamento público encontrase, afinal, limitada pelo compromisso prioritário com a sustentação da segurança e rentabilidade dos investimentos, objetivo último das regras do POI. A economia (sob o 
liberalismo) não só se autonomizou da política e do direito, como moldou-os em função de sua visão de mundo.

No campo do comércio internacional, a noção de ordem espontânea espelha-se na ausência da pretensão de negociar multilateralmente instituições para as relações comerciais. A liberdade de formatação do comércio internacional com virtualmente qualquer conteúdo parece conciliar-se com o sentido de soberania privilegiado no século XIX. Esta noção, vale lembrar, não se refletia na afirmação de igualdade entre os Estados, que se encontravam, afinal, hierarquizados até mesmo segundo seu grau de civilização (atributo do mundo angloeuropeu), selvageria ou barbárie (atributos dos demais), hierarquias estas que refletiam o eurocentrismo ou anglo-eurocentrismo do projeto do direito internacional público. A soberania era, ao contrário, a base para o comportamento estatal na esfera internacional que se dava como análogo da livre expressão da autonomia privada na esfera interna (vide capítulo 2).

Já foi mencionado que o objetivo de resguardar a autonomia privada resulta na defesa liberal de que o Estado deve, internamente, assegurar a propriedade privada, garantir os contratos e prover soluções judiciais para as disputas, entre outros. Externamente, estes papéis, no contexto da ordem econômica internacional aqui analisada, também eram desempenhados como projeções da soberania dos Estados. Para esta finalidade, as formas e práticas admitidas pelo direito internacional público mostraram-se úteis. Colônias e protetorados funcionaram como mecanismos para extensão transfronteiriça das garantias metropolitanas à propriedade e aos contratos. A diplomacia da canhoneira exerceu semelhante papel, auxiliando no respeito aos compromissos internacionalmente assumidos por países periféricos, na cobrança de dívidas e na abertura de portos e mercados. Tratados desiguais (juridicamente válidos mesmo se obtidos sob o constrangimento de canhoneiras) asseguravam a abertura comercial, reduções tarifárias, obtenção de termos comerciais preferenciais e o estabelecimento de jurisdições consulares. Estas, por sua vez, permitiam que as controvérsias envolvendo comerciantes e investidores metropolitanos fossem isoladas do judiciário local, operando como mecanismo de segurança para estes, suas propriedades e seus contratos, via discriminações baseadas na nacionalidade.

As formas jurídicas do direito internacional público, e as práticas por ele admitidas, foram instrumentais na configuração de padrões assimétricos de comércio no século XIX e início do século XX, que em larga medida acompanharam as assimetrias de poder existentes. Pode-se perceber o papel de fundo desempenhado pela forma jurídica da soberania para esta configuração. As instituições que apoiaram a expansão do comércio europeu foram reflexos 
desta. O cenário não propiciava aos participantes qualquer recurso a instituições da cooperação internacional que determinassem conteúdos para que relações comerciais pudessem ser qualificadas como "justas". A noção liberal de autorregulação (de mercados) não se chocou com a existência de práticas comerciais desiguais ou coercitivas, nem com a noção jurídica de soberania.

Outro mecanismo para a segurança das relações econômicas internacionais do período, em particular em aspectos monetários e financeiros, foi o balanço de poder. Seu mecanismo guarda afinidades bastante próximas com as noções de mercado autorregulado e ordem espontânea do pensamento econômico liberal. A diferença consiste em que os alinhamentos e desalinhamentos entre Estados, que visam preservar o equilíbrio do sistema contra a ameaça da dominação por um hegemon, não respondem às sinalizações das variações de preços, mas de poder no cenário internacional. Em todo caso, o balanço de poder foi uma instituição informal das relações internacionais do período que desempenhou externamente, e quanto aos negócios transfronteiriços e sobretudo financeiros, parte do papel correspondente ao dever estatal de prover segurança interna, porém de forma descentralizada. A outra parte, como se viu, era provida por projeções transfronteiriças das próprias soberanias das metrópoles em relação a suas colônias, protetorados e outros engajamentos internacionais. Esta configuração política - e sua maneira peculiar de equilibrar o poder - foi acessória à despolitização da moeda sob o POI.

Somados, estes elementos são sugestivos de movimentações tanto no sentido de autonomizar a esfera econômica quanto de posicionar o direito e a política em função de motivos favorecidos pelo liberalismo econômico, dentre os quais desponta a noção de mercados autorregulados. No aspecto jurídico, outra maneira de caracterizar o mesmo fenômeno consiste em afirmar que o direito passou a incorporar como suas as noções privilegiadas pelo liberalismo econômico. Nesse sentido, a livre atuação das forças de mercado corresponde, no direito, à autonomia privada ou da vontade privada. A noção econômica de mercados autorregulados que substituiu a coordenação hierárquica das relações de produção, troca e consumo, corresponde, no direito, não só à livre iniciativa como também à separação entre o direito público e o privado, que limita o Estado e habilita a liberdade privada de reger negócios via contratos. E, no plano da ordem internacional do comércio, a ausência de parâmetros multilateralmente estabelecidos para disciplinar as transações casa-se, juridicamente, com o cenário em que o direito internacional privado era, possivelmente, a única linguagem disponível para fazer referência a tais transações, e em que um direito internacional econômico simplesmente não existia. 
Em linhas gerais, a caracterização aqui feita encaixa-se no sentido de "primeira globalização do direito e de pensamento jurídico" proposta por Duncan Kennedy (2006). Para ele, o pensamento jurídico clássico globalizou-se entre 1850 e 1914, baseado, sobretudo, no pensamento jurídico alemão. Segundo o autor, esta concepção de direito (langue) "não tinha essência" (2006, p. 20). Esta afirmação interpreta-se no sentido de que a concepção de justiça nele incorporada não era baseada na afirmação de conteúdos, mas tinha caráter procedimental ou formal. Outra característica da primeira globalização jurídica descrita por Kennedy era a visão do direito como sistema (2006, p. 25), cuja coerência interna era dada por três traços: a separação entre direito público e privado, o individualismo e o comprometimento com o formalismo na interpretação jurídica (2006, p. 25-6).

Um dos principais resultados práticos desses contornos é a concepção de uma esfera privada que ao Estado cabe resguardar, mas em que não deve intervir. Assim, "o governo deveria proteger os direitos dos sujeitos de direitos, o que significava ajudá-los a realizar suas vontades, restritas apenas conforme a necessidade de permitir que outros fizessem o mesmo." (2006, p. 26) Noções positivas de justiça, envolvendo projetos de igualdade substancial e políticas redistributivas, estavam fora da ordem do dia.

Em sua face internacional, essa concepção jurídica se refletiu no "primeiro sistema global de direito internacional econômico", que se baseava "no livre comércio, no padrãoouro, e no direito internacional privado (frequentemente aplicado por árbitros) para resolver disputas." $\mathrm{Na}$ caracterização de Kennedy, esse sistema foi acompanhado de práticas coercitivas como a gunboat diplomacy ou diplomacia da canhoneira (2006, p. 29).

A noção de que uma primeira globalização jurídica possa ser lida ao lado da primeira globalização econômica é útil e permite estabelecer - como aqui se ensaiou fazer - pontes entre ideias e instituições jurídicas e econômicas. Uma das lições que podem ser retiradas desta primeira globalização é que, de certo modo, o direito cumpriu papel largamente instrumental em relação à economia, que conseguiu prover os objetivos últimos, o que equivale a dizer, o sentido da organização social (dentro e fora das fronteiras estatais). A noção de autorregulação dos mercados desponta na ordem econômica internacional inspirada nas ideias do liberalismo e tem, como reflexo jurídico, uma noção de justiça negativa, formal ou procedimental, que não dá margem a atuações estatais mais substanciais no sentido de coordenar ou participar da produção, troca, consumo, ou ainda de promover redistribuições econômicas na sociedade. 
A seção 3.2, a seguir, relata a crise desta globalização, e a construção de projeto alternativo que privilegiaria certa noção de justiça diferente daquela que o direito do século XIX incorporou e que se aliava às noções fomentadas pelo liberalismo econômico clássico.

\subsection{Liberalismo assistido}

A ocorrência da Primeira Guerra Mundial interrompeu a ordem econômica internacional iniciada no século XIX. O POI, apesar de tentativas de resgate, não voltaria a ser o mesmo. Relações comerciais também foram transformadas. Nesse contexto, o próprio liberalismo, como moldura cognitiva ou langue orientadora do conjunto de relações econômicas e políticas, entrou em crise.

A seção 3.2 aborda a formação de uma sensibilidade econômica alternativa ao liberalismo na tradição de Smith e Ricardo. Trata-se do que veio a ser chamado por John Gerard Ruggie (1982), em expressão que se tornou clássica, de embedded liberalism, que pode ser traduzido como liberalismo assistido. A ideia de assistência faz alusão a um capitalismo que não seria mais selvagem, a funcionar segundo forças desimpedidas do mercado, e que não deposita exclusivamente nestas forças a condução ao bem-estar geral, à prosperidade ou ao equilíbrio. Começava a ganhar a noção de que o capitalismo precisava ser auxiliado nos momentos de crise. Neste novo contexto, o Estado passou a ser concebido com novo papel no domínio econômico. Formou-se um "capitalismo sob vigilância" (Gazier, 2009, p. 91).

Karl Polanyi, em A grande transformação, não utiliza a expressão "liberalismo assistido" para referir-se ao novo conjunto de ideias a conformar-se no período do entreguerras. Entretanto, narra profundas alterações neste tempo. A expressão "grande transformação" parece fazer referência à singularidade do modelo de organização da sociedade em torno dos mercados ${ }^{120}$ que emergiu no século XIX com instituições como o Estado liberal, a economia de mercado, livre mercado e o POI, permeado pelo tema fundamental do "mercado autorregulado" (Polanyi, 2001, p. 3-5, 31-2). Mas poderia, por extensão, cobrir também a derrocada deste modelo, que deu origem a algo novo.

\footnotetext{
120 "Todos os tipos de sociedades são limitadas por fatores econômicos. Somente a civilização do século dezenove foi econômica em sentido diferente e distinto, porque escolheu basear-se num motivo só raramente reconhecido como válido na história das sociedades humanas, e certamente nunca antes alçado ao nível de justificador da ação e do comportamento na vida cotidiana, qual seja, o ganho. O sistema de mercado autorregulado é singularmente derivado deste princípio.” (Polanyi, 2001, p. 31)
} 
O processo de mudança no pós-Primeira Guerra não foi, porém, de abandono imediato da fé na regulação espontânea dos mercados. Polanyi diferencia o espírito das décadas de 1920 e 1930. Enquanto a primeira havia sido "conservadora", a segunda foi "revolucionária". Nesse sentido, os anos 1920 foram de emulação e tentativa de resgate do sistema anterior a 1914 como chave para a paz e a prosperidade (Polanyi, 2001, p. 23). A crença no POI foi a “fé da era" (2001, p. 26), e a tentativa de restaurá-lo tornou-se "símbolo da solidariedade internacional" nessa década (2001, p. 27). Governos nacionais continuavam, "em regra, a acomodar suas políticas à necessidade de resguardar a moeda, em particular as políticas que diziam respeito a comércio exterior, empréstimos, bancos e câmbio.” (2001, p. 28)

Contudo, assinala Polanyi, esse esforço falhou. Daí originaram-se as transformações da década de 1930 (2001, p. 23), quando "elementos inteiramente novos entraram no curso da história ocidental.” (2001, p. 24) Diante dos efeitos da Grande Depressão e de cenários políticos domésticos que já não eram os mesmos de antes da Primeira Guerra Mundial, países abandonaram o POI um após o outro. Reverteu-se, assim, a tendência de submeter a política doméstica ao imperativo de preservação da paridade das moedas (2001, p. 28). Além do POI, ruíram nesta década a Liga das Nações e mesmo a haute finance. Por outro lado, em alguns lugares o Estado liberal foi trocado por "ditaduras totalitárias". Tais ditaduras, por sua vez, substituíram a "instituição central do século [XIX]" - ou seja, a produção baseada no livre mercado - por outras formas de organização econômica (2001, p. 29). Além disso, outros países reinventaram a atuação do Estado no domínio econômico com base em novas ideias, práticas e instituições, num momento que Duncan Kennedy (2006) caracteriza como "globalização do "social'".

A seção 3.2 objetiva caracterizar as transformações brevemente apontadas acima. Para tanto, a subseção 3.2.1 aborda aspectos do cenário posterior à Primeira Guerra Mundial, em que a ordem econômica internacional precedente entrou em crise, apesar das tentativas de resgate orientadas pelo ideário econômico liberal ainda predominante. Destaca, também, elementos referentes a transformações na política doméstica dos Estados, a crises econômicas e da própria cooperação internacional do período. Em seguida, a subseção 3.2.2 enfatiza certas experiências com políticas econômicas de combate à depressão (medidas anticíclicas), bem como o novo ideário econômico que se tornou associado a elas: o keynesianismo. Em seguida, a subseção 3.2.3 descreve contornos principais da estruturação da ordem econômica internacional no pós-Segunda Guerra Mundial (ordem de Bretton Woods), num contexto de prevalência de uma sensibilidade econômica que Ruggie caracterizou como liberalismo 
assistido. Por fim, a subseção 3.2.4 busca trazer à tona aspectos do lugar das instituições jurídicas em meio às transformações caracterizadas ao longo da seção 3.2.

\subsubsection{Crise da ordem econômica internacional no entreguerras}

A presente subseção contém itens que abordam: a tentativa de retomada do POI no cenário do entreguerras (3.2.1.1); as crises econômicas iniciadas na década de 1920 (3.2.1.2); as crises de cooperação econômica, tanto comercial quanto financeira/monetária, que marcaram a década de 1930 (3.2.1.3); e a crise dos fundamentos econômicos do liberalismo clássico (3.2.1.4), cujos pontos cegos e deficiências seriam enfatizados pelo keynesianismo, que por sua vez é tema de outra subseção (3.2.2).

\subsubsection{Tentativas de retomada do POI no entreguerras}

A Primeira Guerra Mundial interrompeu o funcionamento do POI. No início do conflito, Alemanha, França, Grã-Bretanha e Áustria suspenderam a conversibilidade de suas moedas em ouro (Galbraith, 1997, p. 131), e em parte passaram a custear suas despesas com impressão de papel-moeda novo. Ao final da guerra, todos os países beligerantes, com exceção dos EUA, haviam abandonado completamente as regras do POI, e em todo caso “[n]enhum país importante permitia mais a livre exportação do ouro.” (Galbraith, 1997, p. 142)

O abandono do POI durante o conflito foi, porém, mais uma "interrupção" do que um repúdio completo. Ainda assim, pode-se caracterizar a ordem econômica internacional do POI como tendo sido encerrada em 1914, porque o retorno ao padrão, embora tenha acontecido, não se deu de modo sustentado. As circunstâncias internacionais e domésticas alteradas colocariam obstáculos à retomada do POI, mas elas não impediram a tentativa de restauração do sistema. Como se apontou anteriormente, o POI era artigo de fé de uma ordem liberal, e este elemento ideacional sobreviveu ao conflito mundial. Na nostalgia da ordem monetária precedente, uma série de países retornou à conversibilidade da moeda nacional em ouro: a Grã-Bretanha o fez em 1925, tendo restaurado inclusive a paridade praticada anteriormente à guerra $^{121}$ (Galbraith, 1997, p. 161); e a França, em 1928 (1997, p. 145), assim como outros

\footnotetext{
121 "Retornando ao ouro à antiga paridade, a Grã-Bretanha aceitava a necessidade de uma dolorosa redução de preços e salários, com a consequente estagnação e com o desemprego, fontes de ricas tensões sociais." (Galbraith, 1997, p. 161)
} 
países $^{122}$. Mas os pressupostos para operação do POI já não eram os mesmos. Para compreender o porquê, os aspectos de segurança e economia internacionais precisam ser levados em consideração.

No campo da segurança internacional, o mecanismo para manutenção da paz internacional (entre grandes potências) do sistema internacional antecedente - o balanço de poder - havia sido substituído pela concepção de segurança coletiva da Liga das Nações, que depositava esperanças no compromisso jurídico assumido pelos Estados participantes de frear coletivamente a agressão sofrida por qualquer dos membros. Como o capítulo 2 aponta, esta concepção alternativa de segurança falhou. Na perspectiva de Polanyi, o Conselho da Liga poderia, ao menos, ter funcionado uma espécie de diretório de grandes potências à moda do concerto europeu, mas a inserção da regra de unanimidade para a tomada de decisões posicionava o "ruidoso Estado pequeno como árbitro da paz mundial." (2001, p. 23) A falência do sistema de paz internacional minou as bases para a operação do POI porque a estabilidade monetária pressupunha a ausência de conflitos entre grandes potências, como Polanyi (2001) enfatiza em sua obra.

No aspecto econômico internacional, a década de 1920 foi acompanhada por novos elementos de crise, como hiperinflação em certos pontos da Europa, e cenários deflacionários e de altos índices de desemprego em outras partes do mundo. Além disso, o crash da Bolsa de Nova Iorque, marco da Grande Depressão, evidenciou a instabilidade das finanças internacionais, que passaram a contar com ocorrências de "fuga de capital". O novo cenário mostrou-se convidativo a medidas protecionistas por parte dos Estados, que comprometeram a mobilidade desimpedida dos fluxos de ouro pressuposta pelo POI.

As transformações no plano internacional foram acompanhadas por mudanças que se difundiram nos cenários políticos domésticos. Em especial, as transformações mais importantes estiveram relacionadas ao formato de democracia nas principais potências, com maiores níveis de organização e articulação de trabalhadores do que antes da Primeira Guerra Mundial. De movimentos sindicais a partidos trabalhistas, estes alcançaram maiores espaços em disputas eleitorais e no jogo partidário. Beneficiaram-se da (e pressionaram pela) expansão do sufrágio, transformando os formatos censitários antecedentes de "democracia" em direção às democracias de massa. Rodrik relata, a este respeito, que a proporção da

\footnotetext{
${ }^{122}$ Segundo Barry Eichengreen, os países que primeiro restabeleceram a conversibilidade em ouro foram os que passaram por cenários de hiperinflação: Áustria, Alemanha, Hungria e Polônia. Eles emitiram novas moedas lastreadas em reservas de ouro e com valores de conversão estabelecidos por lei. Outros países que passaram por inflação moderada restauraram a conversibilidade sem trocar de moedas, como no caso da França, que tornou o franco conversível a um quinto da paridade praticada antes da guerra (2008, p. 45).
} 
população britânica com direito a voto quadruplicou nos dez anos posteriores à Primeira Guerra. Nesse contexto, aliás, a imprensa passava por processo de massificação de seu alcance, sobretudo via jornais e rádio, contribuindo para colocar a política econômica sob o crivo da opinião pública (Rodrik, 2011, p. 43). Como resultado desses elementos, as pressões populares por políticas redistributivas passaram a alcançar os governos nacionais, comprometendo a prioridade exigida pelo POI de defesa inequívoca da estabilidade monetária.

Este ponto merece ser enfatizado, porque conecta as estruturas da cooperação econômica internacional a aspectos jurídicos "internos" que podem ser expressos na forma de direitos sociais (cf. Castro, 2006). A democracia ampliada mostrou-se incompatível com a operação do POI porque as demandas populares e trabalhistas por políticas redistributivas ameaçavam o compromisso político prioritário com a estabilidade monetária. No fundo, os novos elementos de política doméstica comprometeram a própria visão "ideal" do liberalismo econômico a respeito do funcionamento dos mercados de trabalho e suas relações com a moeda. Dani Rodrik explica o ocorrido em três etapas que mesclam aspectos políticos e econômicos.

Numa primeira etapa, Rodrik toma em perspectiva o "modelo dos manuais" a respeito do ajuste sob o POI, que presumia mercados de trabalho individualistas (sem organizações coletivas de trabalho, como sindicatos) e descentralizados, com salários flexíveis. Neste contexto, a remuneração do trabalho está sujeita à lei da oferta e da demanda, podendo aumentar ou diminuir segundo o grau de sua escassez. Em razão desta flexibilidade, pressupõe-se não haver margem para existência do "desemprego involuntário", porque havendo pessoas excedentes em busca de trabalho, as remunerações cairão até que mais contratações tornem-se atrativas para os empresários. O modelo liberal "dos manuais" tornouse cada vez mais "fantasioso com o tempo conforme os trabalhadores tornaram-se mais organizados e os sindicatos se afirmavam. Houve significativo aumento da sindicalização nas duas décadas posteriores a 1920." (Rodrik, 2011, p. 42) A maior influência tanto sobre o jogo partidário quanto sobre as negociações remuneratórias com empresários resultou em inflexibilidade dos salários, que não mais poderiam ser facilmente reduzidos, ao menos em termos nominais, sem despertar reações de trabalhadores e de conjuntos mais amplos da sociedade. Na Grã-Bretanha, a resistência da classe dos mineiros à redução salarial resultou na adesão de outras categorias de trabalhadores e na greve geral de 1926. "A habilidade dos trabalhadores de manter a remuneração passou a significar que contrações monetárias significativas decorrentes da saída de ouro (ou de sua ameaça), como as ocorridas na Grã- 
Bretanha, agora resultariam em desemprego prolongado.” (Rodrik, 2011, p. 43) Em outros termos, as novas condições políticas romperam com o modelo de autorregulação dos mercados de trabalho e da moeda segundo forças espontâneas de mercado. Agora, a deflação não resultaria em salários menores, mas em desemprego.

Numa segunda etapa de sua explicação, Rodrik destaca que, na nova conformação política das democracias de massa, os bancos centrais e as elites políticas “já não poderiam permanecer alheios às consequências políticas da recessão econômica e do alto desemprego. Os trabalhadores não só formaram sindicatos; eles agora tinham também o voto." (Rodrik, 2011, p. 43) Exercendo o sufrágio, pressionavam a política doméstica rumo a medidas redistributivas, como implementação e ampliação de sistemas de assistência e seguridade social, saúde pública, seguro-desemprego etc. As prioridades políticas desviavam-se da estabilidade monetária e migravam para o pleno emprego e outras formulações de direitos sociais, face às pressões populares nas urnas, protestos, greves e opinião pública (vide Quadro 3.4, abaixo).

Quadro 3.4 - contraste entre aspectos do primeiro momento do POI (1870-1914) e do segundo momento de tentativas de sua restauração no entreguerras (décadas de 1920 e 1930)

\begin{tabular}{|c|c|c|}
\hline & POI & entreguerras \\
\hline cenário político & democracias censitárias & democracias de massa \\
\hline $\begin{array}{l}\text { influência sobre } \\
\text { governos }\end{array}$ & haute finance & $\begin{array}{l}\text { opinião pública, } \\
\text { partidos trabalhistas } \\
\text { sindicatos }\end{array}$ \\
\hline $\begin{array}{l}\text { visão de política } \\
\text { fiscal }\end{array}$ & orçamentos equilibrados & $\begin{array}{l}\text { políticas redistributivas } \\
\text { pleno emprego }\end{array}$ \\
\hline $\begin{array}{l}\text { visão de política } \\
\text { monetária }\end{array}$ & $\begin{array}{l}\text { paridades cambiais fixas } \\
\text { conversibilidade em ouro } \\
\text { convivência com deflação }\end{array}$ & $\begin{array}{l}\text { política expansionista } \\
\text { intolerância à deflação }\end{array}$ \\
\hline $\begin{array}{c}\text { instrumentos de } \\
\text { pressão }\end{array}$ & $\begin{array}{l}\text { fuga de capital; } \\
\text { mercados de títulos } \\
\text { da dívida pública }\end{array}$ & $\begin{array}{l}\text { voto; greves; } \\
\text { protestos; imprensa }\end{array}$ \\
\hline
\end{tabular}

Fonte: elaborado a partir de elementos presentes em Polanyi, 2001; Galbraith 1997; Rodrik, 2011; Castro, 2006; 2012 
$\mathrm{Na}$ terceira etapa, o deslocamento nas prioridades políticas dos Estados em atendimento às pressões das massas é respondido pelas finanças internacionais via ameaças e concretizações do desinvestimento ou fuga de capital, capazes de desestabilizar governos locais:

\begin{abstract}
Uma vez que os mercados financeiros começaram a questionar a credibilidade do compromisso de um governo com a paridade fixa em relação ao ouro, eles se tornaram uma força de instabilidade. A partir de então, os governos tornaram-se presas fáceis para ataques especulativos. À menor indicação de que as coisas estavam saindo do trilho, os investidores vendiam a moeda doméstica, compravam moedas estrangeiras, e moviam capital para fora do país. (Rodrik, 2011, p. 43)
\end{abstract}

A instabilidade e volatilidade dos fluxos internacionais de capital no entreguerras serão retomadas à frente, na abordagem das crises na cooperação internacional (3.2.1.3). Vale adiantar, porém, que o aumento do perigo e da frequência da fuga de capital correspondeu à fuga do POI, praticada em série pelos países na década de 1930, em meio a cenários domésticos de depressão econômica, deflação e altos índices de desemprego.

\title{
3.2.1.2 Dificuldades e crises econômicas no entreguerras
}

Os anos posteriores à Primeira Guerra Mundial e à suspensão do POI foram marcados por processos inflacionários em pontos diversos na Europa. A onda de (hiper)inflação pode ser atribuída a certo conjunto de fatores, a incluir a depreciação das moedas na ausência do POI; a escassez de recursos em virtude da destruição das estruturas de produção e a demanda (acentuada) por estes recursos no período de reconstrução da Europa. Em geral, os anos posteriores à guerra foram seguidos de depressão e queda nos preços, mas em outros lugares a inflação continuou. $\mathrm{O}$ caso de hiperinflação na Alemanha é o mais famoso, e só foi contornado em 1924, mas moedas nacionais também foram "praticamente destruídas" na Áustria, Hungria, Polônia e Rússia (Kenwood; Lougheed, 1999, p. 182). As maiores dificuldades para a economia e a cooperação econômica internacional do período não seriam, no entanto, advindas de processos inflacionários. A deflação e problemas de fluxos de capitais em economias financeiramente vinculadas umas às outras seriam os fatores de destaque neste período de crises.

A deflação é a queda geral e continuada de preços. Entre os fatores associados à deflação na década de 1920 estão não só a rigidez monetária imposta pelo retorno ao POI em diversos países, como também mudanças na produção e comércio de bens primários e secundários. 
O mercado de bens primários experimentou aumento da produção mundial em virtude de progressos tecnológicos e do surgimento de novas fontes de suprimento. Novos maquinários e técnicas foram aplicados à agricultura, e também a mineração experimentou, além da mecanização, avanços em especial nos processos de perfuração e refinamento de petróleo, bem como a abertura de novos campos de extração (Kenwood; Lougheed, 1999, p. 166). Ao passo que os produtos primários apresentaram contínuo crescimento dos estoques, seus preços tiveram tendências declinantes da metade da década de 1920 em diante (Sato, 2012, p. 93). Isso num contexto em que bens primários representavam dois terços da composição do comércio internacional, e de modo altamente concentrado: apenas 11 produtos agrícolas correspondiam a quase a metade do total de exportações mundiais (Sato, 2012, p. 90). A superprodução destes itens esteve, assim, relacionada às tendências deflacionárias do período.

No caso dos bens secundários ou industrializados, as mudanças se deram em virtude da expansão da industrialização. A Primeira Guerra Mundial comprometeu as estruturas produtivas na Europa e deu margem à "industrialização da periferia" (Sato, 2012, p. 103). Os abalos nos fluxos europeus de exportação de produtos industrializados, em virtude da guerra, foram estímulos à industrialização em diversos países. Kenwood e Lougheed noticiam altas taxas de industrialização, por exemplo, no Brasil, Finlândia, Índia, Nova Zelândia, África do Sul e Japão neste período (1999, p. 172). Como resultado, houve "significativas mudanças na distribuição da produção mundial de manufaturas", bem como "declínio relativo nos quinhões das potências industriais europeias antigas, como Grã-Bretanha, França e Alemanha.” (1999, p. 172) Evidentemente, a ascensão dos Estados Unidos como fornecedor-chave de produtos primários e secundários - e de recursos financeiros - à Europa não pode ser ignorada, apesar de ser difícil enquadrá-lo na "periferia" mundial neste período de mudanças relativas no status econômico e político dos países, com o declínio da hegemonia britânica. Além disso, a produção industrial na Europa recuperou-se ao longo da década de 1920 com o avanço da reconstrução (Kenwood; Lougheed, 1999, p. 190). O saldo desta configuração foi o aumento da produção de bens industrializados, que pressionou a redução dos preços.

A deflação associada à superprodução de bens primários e secundários - com acúmulo nos estoques e queda nos preços - foi um dos componentes nos chamados círculos viciosos da depressão econômica que marcou o entreguerras. Outro relevante componente diz respeito a problemas nos fluxos de capital entre economias financeiramente vinculadas, interdependentes, em um cenário de grande mobilidade de capital. Como aponta Eiiti Sato, "a crise dos anos 1930 foi fruto da associação das dificuldades dos mercados de commodities 
com a volatilidade dos capitais em um ambiente de completa inadequação do sistema monetário internacional à realidade" (2012, p. 87).

As vinculações financeiras entre as economias se davam não somente porque o POI interconectava as diferentes moedas nacionais e estimulava investimentos transfronteiriços, mas também em virtude: (i) das dívidas de guerra entre aliados e obrigações de reparação, estas últimas estabelecidas com o Tratado de Versalhes, de 1919; e (ii) dos fluxos internacionais de capital especulativo.

Quanto ao primeiro aspecto, os aliados encontravam-se encadeados em relações de dívida. "Itália, França e Bélgica haviam saído da guerra em dívida umas com as outras e com a Grã-Bretanha" (Kenwood; Lougheed, 1999, p. 183), ao passo que todos estes e ainda outros países encontravam-se na posição de devedores dos Estados Unidos. Aqui, entra o elemento das reparações. Muitos dos aliados "passaram a considerar os pagamentos de reparações alemãs como meio para liquidar suas dívidas americanas". O resultado foi o desenvolvimento de um encadeamento de pagamentos de dívida que tinha origem na Alemanha e acabava nos Estados Unidos (Kenwood; Lougheed, 1999, p. 183). Por sua vez, a Alemanha foi a principal importadora de capital dos Estados Unidos entre 1924 e 1929 (Kenwood; Lougheed, 1999, p. 186), ligando as pontas dos elos financeiros internacionais. A posição dos Estados Unidos como provedores de capital associava-se a seu status comercial superavitário com a Europa. Quando a absorção da produção norte-americana pela Europa entrou em declínio, o padrão de pagamentos internacionais entrou em crise (Kenwood; Lougheed, 1999, p. 186; Eichengreen, 2008, p. 67-9).

Quanto ao segundo aspecto, movimentos frequentes e imprevisíveis de capital de curto prazo, ou capital especulativo, tornaram instáveis as finanças internacionais do entreguerras. "Por mais que as entradas deste capital fossem benéficas aos países receptores, elas representavam fluxos desestabilizantes de capital, dado que sua retirada rápida poderia ocasionar grave crise financeira no centro que experimentava perda de fundos." (Kenwood; Lougheed, 1999, p. 187) Trata-se da já aludida fuga de capital. Dada a prática bancária de tomar empréstimos de curto prazo e concedê-los a longo prazo, as movimentações repentinas de capital especulativo apresentavam o potencial de "disparar reações em cadeia na esfera das finanças internacionais, a envolver toda a comunidade de devedores e credores internacionais.” (Keenwood; Lougheed, 1999, p. 187)

A estrutura internacional de pagamentos decorrentes do saldo da guerra e a instabilidade nas movimentações internacionais de capital entrecruzaram-se em Wall Street. O crash de 1929 na Bolsa de Nova Iorque representou a reversão dos fluxos internacionais de 
capital (Kenwood; Lougheed, 1999, p. 191). Se antes da crise o capital norte-americano fluía ao exterior, no momento posterior houve pressões de reversão dos fluxos em virtude de "saques" de capital nos mercados em que ele se encontrava investido (desinvestimento). A drenagem resultante dos fluxos de capital norte-americano "colocou constrições financeiras severas em diversos países devedores, com resultante declínio da atividade econômica nestes países." (Kenwood; Lougheed, 1999, p. 228) Houve diminuições súbitas de poder aquisitivo a partir de perdas das economias aplicadas em investimentos. Encadeamentos de falências bancárias nos Estados Unidos contribuíram para "secar" a disponibilidade de recursos financeiros e acentuar as pressões deflacionárias (Galbraith, 1997, p. 183). Neste cenário, diversos países desenvolveriam mecanismos de controle do capital que comprometeriam a livre circulação transfronteiriça do ouro e, por consequência, a existência do POI (ver item 3.2.1.3).

Quadro 3.5 - esquematização de encadeamentos econômicos relacionados a círculos viciosos

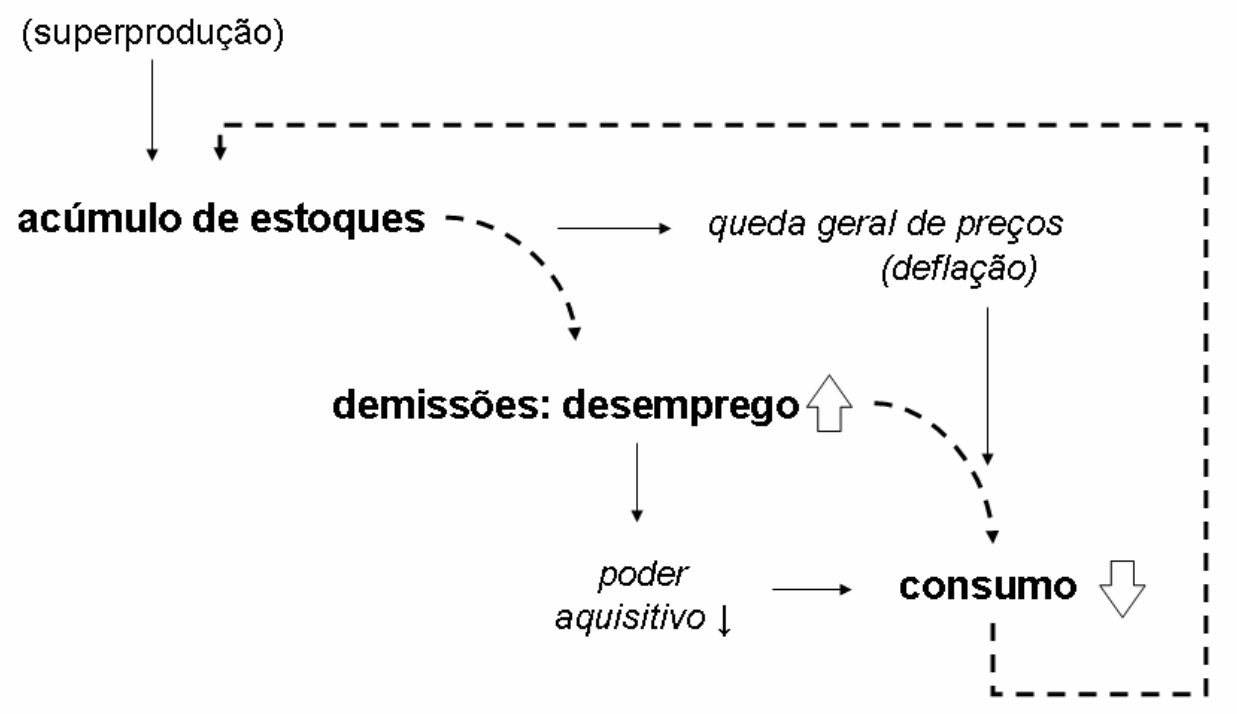

Fonte: elaborado a partir de elementos colhidos em Gazier, 2009; Keynes, 1996.

Estes contornos remetem à ocorrência de círculos viciosos (vide Quadro 3.5, acima). Ao caracterizar a crise de 1929, Bernard Gazier (2009) descreve a ocorrência de séries "de reações em cadeia, como num "efeito dominó"” a abranger diferentes economias. Com estoques acumulados e queda de preços nos países, os incentivos à produção pelas empresas se esvaem. A produção e o consumo são ainda desestimulados pela escassez de recursos financeiros. Neste cenário, a resposta das empresas é a demissão de funcionários. Como Gazier aponta, a demissão pode ser a solução para uma empresa individual, mas quando diversas empresas a praticam, o resultado é a restrição generalizada dos mercados 
consumidores, em virtude da perda do poder de compra das famílias dos trabalhadores. Diante da retração do consumo, há novas rodadas de demissão, e novas contrações do consumo, caracterizando a espiral descendente. "No pessimismo ambiente, se verificam primeiro reflexos restritivos, como, por exemplo, limitar as compras ao mínimo necessário, não investir, aguardar; depois, acontecem verdadeiros pânicos." (Gazier, 2009, p. 37; cf. Keynes, 1996) Nota-se que a presença da deflação gera pressões pelo aumento do desemprego e pela escassez de capital (ou perda de liquidez), que por sua vez reforçam o processo deflacionário. O ideário econômico liberal clássico descartava a possibilidade de "desemprego involuntário": o equilíbrio espontâneo com pleno emprego era dogma a partir da flexibilidade da remuneração do trabalho, mas o dogma não guardava correspondência com o mundo real. A análise econômica tradicional carecia de instrumentos para endereçar um fenômeno situado num "ponto cego" (vide item 3.2.1.4).

Os círculos viciosos domésticos de depressão tiveram impactos sobre as transações comerciais e financeiras internacionais. No aspecto do comércio internacional, os países tornaram-se mais sensíveis à ameaça que as importações de produtos estrangeiros representavam para os postos de trabalho nacionais, em cenários de desemprego em ascensão e demandas sociais por proteção. Como Rodrik aponta, entre os anos de 1929 e 1937 o volume do comércio mundial caiu pela metade (2011, p. 45). No aspecto das transações financeiras, o capital tornou-se mais escasso, e a dúvida dos investidores quanto à segurança e a rentabilidade dos investimentos - a partir do aumento de pressões domésticas por políticas redistributivas e de pleno emprego que ameaçavam a prioridade da política monetária com o POI - contribuiu para a instabilidade financeira. Nesse sentido, a década de 1930 foi marcada por crises bancárias de contágio internacional que afetaram as moedas nacionais vinculadas pelo POI.

$\mathrm{Na}$ década de 1930, a fé no ideário liberal cedeu lugar a medidas de política econômica que procuravam atender às pressões domésticas por políticas de Estado que aliviassem os efeitos da Grande Depressão. A adoção de tais políticas esteve associada ao aumento do protecionismo comercial e financeiro (item 3.2.1.3, a seguir), rompendo com as práticas anteriores de cooperação econômica internacional instruídas pelo liberalismo econômico clássico. Em alguns casos, a alternativa ao modelo liberal de capitalismo foi encontrada no autoritarismo. Noutros, o liberalismo foi modificado, recebendo matizes significativos de intervenção estatal no domínio econômico, num caminho ligado à formação do Estado de bem-estar social, ou welfare state. 
3.2.1.3 Crises nas práticas de cooperação econômica internacional do entreguerras

As adversidades econômicas do entreguerras refletiram-se em crises de cooperação internacional. Para além das rachaduras políticas internacionais que se desenharam ao longo da década de 1930 e que sinalizaram o fracasso do projeto de paz da Liga das Nações, a cooperação comercial, financeira e monetária entre os países também falhou. Os principais elementos representativos da cooperação em crise em cada uma destas áreas são: (i) o aumento do protecionismo comercial; (ii) o contágio internacional de crises bancárias; (iii) a acentuação de ocorrências de fuga de capital; (iv) o abandono do POI, na prática substituído por uma política de depreciações competitivas - uma espécie de guerra cambial - na década de 1930 .

Para Dani Rodrik, o recurso a medidas protecionistas no comércio internacional tem uma causa próxima e outra profunda. A causa próxima foi a Grande Depressão ${ }^{123}$, ao passo que "as raízes mais profundas do protecionismo [correspoderam a] mudança[s] do papel do governo na sociedade." Afinal, extratos sociais como os dos trabalhadores encontravam-se mais organizados, com mais poder de voto, e uma sociedade mais "politicamente empoderada e ativa [...] demandava maior proteção econômica do governo em face da adversidade extrema." (Rodrik, 2011, p. 45)

Diante de tal cenário, a reação dos países foi recorrer a "medidas autônomas" - e não de cooperação, para proteção de suas economias (Sato, 2012, p. 87). No campo da proteção comercial, as medidas de intervenção do Estado incluíam aumentos de tarifas de importação, restrições via exigências de licenças ou estabelecimento de quotas e mesmo proibições, bem como controles cambiais (vide parágrafo seguinte). A preocupação com a proteção agrícola difundiu-se com a queda dos preços, e "um movimento em busca da autossuficiência agrícola tornou-se generalizado na Europa nesta época" (Kenwood; Lougheed, 1999, p. 178). A política de proteção comercial cumpria ainda a função, no que diz respeito à indústria, de procurar gerar empregos domesticamente pelo atendimento nacional "a demandas antes satisfeitas por importações cujo acesso ao mercado doméstico passou a ser negado pelo uso de tarifas e outras medidas restritivas." (Kenwood; Lougheed, 1999, p. 179) O saldo da década de 1930 é a "falha generalizada da cooperação comercial” (Rodrik, 2011, p. 44).

\footnotetext{
${ }^{123}$ As adversidades da Grande Depressão são sintetizadas por John Kenneth Galbraith: “A depressão tinha três características visíveis. A primeira, a implacável deflação dos preços gerando falências no setor industrial e na agricultura. A segunda, o desemprego. A terceira, as privações que trazia para grupos particularmente vulneráveis: os velhos, os jovens, os doentes e os mal-abrigados, para não falar nos desempregados.” (1989, p. 176)
} 
No parágrafo anterior, fez-se menção aos controles cambiais, que são instrumentos monetários da política comercial. Por meio dos controles cambiais, as autoridades monetárias podem restringir o acesso a moedas estrangeiras por meios diversos, que incluem venda local a preços oficialmente fixados e por rol restrito de bancos autorizados (restringindo a oferta de moeda estrangeira que poderia ser utilizada para importações) e restrições a remessas de dinheiro ao exterior. Outros mecanismos incluem a "venda obrigatória, ao Estado, da moeda estrangeira recebida pelos exportadores" e a "limitação para a aquisição de divisas pelos que viajam ao exterior" (Sandroni, 1999, p. 129).

Além dos controles cambiais, a política protecionista dos anos 1930 contou com depreciações cambiais competitivas. Tais políticas, também conhecidas pela expressão beggar-thy-neighbour (Sato, 2012, p. 83) - algo como "empobreça vosso vizinho" -, tiveram como pressuposto o abandono do compromisso com a manutenção da paridade entre as moedas. Como explica Barry Eichengreen, os países que abandonaram o POI e fizeram a depreciação de suas moedas passaram a gozar de vantagem competitiva em suas exportações, que ficaram mais baratas. Ao mesmo tempo, gerou-se aversão doméstica às importações, que se tornaram mais caras em virtude do mesmo expediente (Eichengreen, 2008, p. 84, 87). "Existe um aspecto de guerra econômica na 'cascata' de depreciações monetárias." (Gazier, 2009, 49) Afinal, o impulso à atividade doméstica pela proteção cambial que estimula exportações e inibe importações implica a criação local de empregos em detrimento dos empregos no exterior que se encontravam atrelados à produção estrangeira comprometida. Portanto, um aspecto da guerra cambial é a disputa por empregos. Outro aspecto é a exportação da deflação que, como se viu, está relacionada à recessão e ao desemprego. A decisão nacional de depreciar a moeda "significa a transferência e eventualmente a acentuação das pressões deflacionárias sobre outros países, já que terão mais dificuldade ainda em vender e precisarão resistir aos produtos estrangeiros subitamente transformados em negócios mais interessantes." (Gazier, 2009, p. 48-9)

$\mathrm{O}$ uso da depreciação cambial competitiva esteve associado ao abandono do POI. Outros aspectos da desintegração da cooperação econômica internacional no entreguerras envolveram expectativas de investidores refletidas no comportamento do capital internacional (perda da confiança), crises bancárias e contágios encadeados de moedas nacionais distintas.

Barry Eichengreen explica que, antes da Primeira Guerra Mundial, havia confiança generalizada de que os governos estavam comprometidos com a manutenção do POI. No cenário do entreguerras, não havia mais a certeza do mercado de que a fraqueza experimentada por determinada moeda nacional seria temporária. Antes, tal certeza havia 
estimulado que os fluxos de capital especulativo (hot money) assumissem sentidos "estabilizantes" que buscavam obter rendimentos com moedas em dificuldade, tomando-se por certo que elas eventualmente voltariam à taxa de conversão em ouro legalmente estabelecida (vide seção 3.1). No POI do entreguerras, já não era possível prever qual seria a atuação das autoridades diante da escolha entre a defesa da paridade da moeda e medidas para estímulo da produção doméstica e redução do desemprego. Contrariamente à tendência de fluxos de capital internacional estabilizantes do século XIX, agora os movimentos de capital "de um tipo causador de distúrbios" tornaram-se generalizados, fugindo de moedas que apresentavam sinais de suspensão da conversibilidade ou de depreciação (2008, p. 71).

Nem mesmo as moedas das duas principais economias do sistema internacional - $\mathrm{o}$ dólar americano e a libra esterlina - estavam a salvo do medo descrito acima. Esse aspecto é importante na medida em que tais moedas serviam de lastro para aquelas de tantos outros países $^{124}$, de modo que a desconfiança em relação a elas estimulava corridas para a conversão das reservas de divisas estrangeiras em ouro (Eichengreen, 2008, p. 72). Trata-se, em outros termos, de elemento de encadeamento monetário internacional, que cria uma corrente de transmissão dos efeitos da desconfiança em relação a uma moeda para as demais.

Estas conexões se verificaram no contágio transfronteiriço de crises bancárias. Em 1931, na Áustria, o banco Kredit Anstalt encontrava-se em dificuldades em virtude de "uma série de compras de ações e de empréstimos, saldados com enormes perdas." A notícia da situação do banco gerou dúvidas quanto a sua solvência, e deu origem a "uma onda de saques massivos" que em três dias o fizeram quebrar (Gazier, 2009, p. 45-6). Como Eichengreen expõe, diante do dilema de salvar o sistema bancário, garantindo a liquidez por meio de injeção de novos recursos monetários, ou de permanecer no POI, a Áustria optou por sair (2008, p. 76). Segundo Eichengreen, apesar de os ativos austríacos depositados na Alemanha não serem significativos, o temor a respeito da solvência dos bancos austríacos acabou por contaminar o sistema bancário alemão. O governo alemão decretou feriado bancário, impôs controles aos fluxos monetários transfronteiriços e, como resultado, a mais importante economia da Europa central, e segunda maior potência industrial mundial, não mais aderia às regras do POI (2008, p. 78).

De uma economia central para o sistema internacional, a crise bancária e monetária alemã gerou efeitos sobre a Grã-Bretanha. Investidores internacionais começaram a promover

\footnotetext{
${ }^{124}$ Em muitos casos, as moedas nacionais não eram diretamente conversíveis em ouro, mas em outras moedas de aceitação internacional, como a libra e dólar, que operavam como lastros intermediários de ligação ao ouro (cf. Eichengreen, 2008; Galbraith, 1997).
} 
uma fuga da libra esterlina, vendendo-a em grandes quantidades, e forçando "aumentos da taxa de juros a uma magnitude que nenhum governo democraticamente eleito passando por 20 por cento de desemprego poderia suportar" (Eichengreen, 2008, p. 81-2). Como resultado, a Grã-Bretanha suspendeu a conversibilidade da libra em ouro, e abandonou a paridade legal em setembro de 1931.

A queda da libra esterlina contaminou o dólar americano ${ }^{125}$. Com medo de que o dólar pudesse ser depreciado, investidores internacionais e bancos centrais que detinham reservas em dólares começaram a vender a moeda e convertê-la em ouro (Eichengreen, 2008, p. 82-3). Com isso, o dólar foi depreciado em 1933 (2008, p. 84). A saída dos EUA em relação ao POI “incentivou que outros países seguissem o mesmo caminho" (2008, p. 85). Apesar de o POI como regime monetário internacional ter-se esvaído com a fuga das principais economias, alguns países persistiram nele, apesar das adversidades econômicas, até 1936. Nesse ano, abandonaram-no "França, Itália, Países Baixos, Bélgica, Suíça e algumas nações da Europa do Leste" (Gazier, 2009, p. 81), encerrando o sistema.

Desponta, a partir do relato de crises financeiras e monetárias concatenadas que levaram ao fim do POI, o papel que a confiança - ou a falta dela - no compromisso dos governos com a manutenção da paridade cambial desempenhou. Vale lembrar, mais uma vez, que a mudança na disposição a confiar nos governos esteve atrelada às novas condições políticas domésticas, com democracias de massa e movimentos trabalhistas organizados, em que demandas populares por políticas redistributivas passavam a competir pela atenção governamental, antes monopolizada pelos imperativos da política monetária segundo o POI e a haute finance.

\subsubsection{Crise dos fundamentos do liberalismo econômico}

O período do entreguerras foi marcante para a economia não apenas em virtude de crises econômicas e de cooperação econômica internacional, mas também pelo impacto sobre a primazia do ponto de vista do liberalismo clássico. Diante da persistência de crises econômicas, com círculos viciosos de deflação e desemprego, a sustentação de que os mercados eram capazes de autoequilíbrio espontâneo e geração de resultados ótimos foi colocada em xeque. Certos pontos cegos no esquema liberal clássico tornaram-se aparentes com a crise.

\footnotetext{
${ }^{125}$ É notável que a crise bancária tenha acompanhado o sentido dos fluxos de pagamentos do entreguerras: da Alemanha à Grã-Bretanha e desta aos Estados Unidos.
} 
O principal deles é a ausência de formulações teóricas a respeito das depressões econômicas, que se refletia na incapacidade de prover soluções diante de sua ocorrência empírica (Galbraith, 1989, p. 174). Em outros termos, o liberalismo econômico não pôde remediar uma enfermidade cuja existência era negada por seu esquema intelectual. Galbraith ressalva que a ausência de uma teoria das depressões não quer dizer que o ciclo econômico não fosse estudado em parte alguma nos anos anteriores à Grande Depressão, mas que estes não eram estudados ou ensinados como componentes centrais do pensamento econômico (Galbraith, 1989, p. 174).

$\mathrm{O}$ ponto cego relativo à negação das depressões remonta a dois componentes do esquema liberal: o dogma do equilíbrio de pleno emprego e a lei de Say. Não só o pensamento clássico tomava como pressuposto o uso ótimo dos fatores de produção, como também pressupunha que o fator trabalho tinha sua remuneração tão sujeita às variações de preços quanto os demais fatores. Nesse esquema teórico, já mencionado anteriormente, a flexibilidade salarial conduzia ao pleno emprego. Caso houvesse "excesso" de mão de obra disponível, esta seria absorvida mediante a queda na remuneração: o valor mais barato do trabalho encontraria um novo ponto de equilíbrio da linha de "demanda" por parte das empresas, que passariam a empregar maiores quantidades de trabalhadores a preços menores. "No contexto clássico, quando havia desemprego [...] a causa aceita eram os salários elevados ou rígidos demais." (Galbraith, 1989, p. 210) No período do entreguerras, a rigidez salarial passaria a ser a regra, divorciando a empiria de um pressuposto liberal fundamental a respeito do funcionamento da economia.

Outro componente era a lei de Say - dogma segundo o qual a oferta cria sua demanda -, porque implicava a negação da possibilidade de "superprodução". Com o funcionamento desimpedido do mecanismo de preços, tudo o que é produzido é consumido. A lei de Say reforça a noção de que a resposta apropriada ao eventual acúmulo de estoques é a queda de preços, nada devendo ser feito para evitar a redução de salários (Galbraith, 1997, p. 214). Com preços livres para alcançar o ponto em que toda a produção é demandada, a lei de Say resulta na negação de que possa haver demanda insuficiente. Segundo Galbraith, a economia clássica empregava termos como falácia de subconsumo para expressar tal negação. "Se uma escassez de demanda não poderia existir, era bastante óbvio que também não havia como defender medidas governamentais para estimular esta demanda.” (Galbraith, 1989, p. 200)

No lugar de medidas governamentais de intervenção no domínio econômico, o receituário ortodoxo postulava soluções purgativas para os problemas econômicos, baseados precisamente na livre operação do mecanismo de preços. A recomendação consistia em deixar 
que os mercados superassem por si sós as dificuldades econômicas, promovendo os ajustes necessários, por mais dolorosos e socialmente adversos que fossem. Assim, John Kenneth Galbraith explica que, pela postura prevalente num primeiro momento a respeito de como lidar com a Grande Depressão, a recuperação econômica ocorreria naturalmente uma vez que as "distorções prejudiciais" fossem espontaneamente eliminadas:

A deflação e as falências eram os corretivos naturais. Joseph Schumpeter, Ministro
das Finanças de seu país durante a maior parte da inflação austríaca, estava agora
surgindo como figura de destaque no cenário econômico americano. Argumentava
que o sistema econômico precisava expelir os seus próprios venenos através da
depressão. Examinando a história dos ciclos econômicos ele concluía que nenhuma
recuperação havia sido permanente sem que isso acontecesse e que qualquer
intervenção pública para acelerá-la apenas adiava a terapia e, portanto, a
recuperação. (Galbraith, 1997, p. 180)

Nada deveria ser feito: “a depressão deveria seguir seu curso até esvair-se por si mesma." (Galbraith, 1989, p. 175-6) Apesar das recomendações purgativas da postura ortodoxa, a depressão persistiu, com etapas sucessivas de acentuação de deflação e desemprego, deterioração das condições sociais e aumento das pressões políticas por medidas governamentais por proteção contra a crise. O novo contexto implicou a perda de espaço para os economistas da tradição clássica (Galbraith, 1989, p. 175). No contexto de crise do pensamento econômico liberal, novas formulações econômicas endereçaram-lhe críticas e alcançaram espaço junto a certos governos. O período do entreguerras daria origem à ascensão de uma nova sensibilidade econômica, que viria a ser sistematizada por John Maynard Keynes, e a ficar conhecida como keynesianismo (ou liberalismo keynesiano, ou ainda economia da depressão). Tal perspectiva encontra-se na base da sensibilidade econômica que acompanhou a conformação da ordem internacional do pós-guerra (liberalismo assistido).

\subsubsection{Bases keynesianas do liberalismo assistido}

A noção de liberalismo assistido (embedded liberalism) é empregada por John Gerard Ruggie para descrever a concepção de economia que forneceu materiais para estruturação da ordem do pós-Segunda Guerra Mundial. A noção envolve a fusão entre elementos da economia e preocupações sociais mais amplas. Faz oposição, nesse sentido, à concepção econômica liberal clássica. O liberalismo assistido buscou conciliar os objetivos de performance e abertura econômicas com as demandas domésticas por estabilidade, estabelecendo contraste com o projeto do liberalismo econômico clássico de mercados autorregulados (Ruggie, 1982). 
Entre os autores mais influentes para o formato de políticas econômicas no pósSegunda Guerra Mundial está John Maynard Keynes. Suas ideias promovem a noção de que o Estado é responsável pelo funcionamento adequado da economia. Diferindo do liberalismo ortodoxo, o keynesianismo busca fundamentar as vantagens da adoção de políticas redistributivas, que seriam de caráter anticíclico, dando margem a um capitalismo com espaço mais amplo para medidas de proteção social. O keynesianismo, assim, acaba convergindo com ideias associadas ao Estado de bem-estar social, que também guarda elementos de contraposição à concepção clássica do Estado liberal.

Apesar de as políticas econômicas de caráter anticíclico terem entrado para a história econômica como sendo associadas ao nome de Keynes, a subseção 3.2.2.1 aborda experiências no entreguerras que precederam a sistematização teórica feita por este autor, em países como a Suécia, os Estados Unidos e a Grã-Bretanha. São, nesse sentido, experiências protokeynesianas. Mais adiante, a subseção 3.2.2.2 destaca certos elementos da economia keynesiana que serviram como fundamento não só para novos formatos de política econômica doméstica, como também para novos arranjos da cooperação econômica internacional no pósSegunda Guerra Mundial.

\subsubsection{Experiências protokeynesianas de combate à depressão econômica no entreguerras}

A Grande Depressão dos anos 1930 colocou em xeque o esquema liberal clássico a respeito de como os governos deveriam se comportar em relação à economia. Em especial, passou-se a questionar "a convicção predominante de que o governo deve manter seu orçamento equilibrado, manter o padrão-ouro, e deixar que os negócios se equilibrem sozinhos em épocas de declínio econômico." Num contexto social e político transformado, havia demandas por "ações governamentais extraordinárias voltadas a operários da indústria, fazendeiros e outros grupos ameaçados", em meio a "volumes inéditos de desemprego em economias súbita e severamente contraídas." (Weir; Skocpol, 1985, p. 107) A Grande Depressão rompeu os esquemas clássicos de pensamento e práticas econômicas, "abrindo novas possibilidades para que o Estado em democracias capitalistas liberais se tornasse agente de bem-estar social por meio da síntese de gastos sociais e gerenciamento macroeconômico.” (1985, p. 148)

O keynesianismo emergiria da crise como a "linguagem transacional do discurso sobre economia pública” (1985, p. 149). No entanto, Margaret Weir e Theda Skocpol, assim como 
outros autores ${ }^{126}$, advertem que muitas das políticas dessa era só retroativamente foram chamadas de "keynesianas" (1985, p. 107). As ideias de John Maynard Keynes, na obra que sistematizou os novos preceitos econômicos para lidar com períodos de recessão - $a$ Teoria geral do emprego, dos juros e da moeda, de 1936 (vide item 3.2.2.2) - só viriam a ter influência sobre o formato de políticas públicas num momento posterior. Por isso, Weir e Skocpol apelidam medidas divergentes do pensamento ortodoxo, adotadas em países como a Suécia, os Estados Unidos e a Grã-Bretanha, como "estratégias macroeconômicas protokeynesianas" (1985, p. 125). Apesar de divergirem da ortodoxia liberal em muitos aspectos, as respostas dos países à Grande Depressão não conformaram caminho único. Aliás, cumpre salientar que nem todos os países experimentaram respostas macroeconômicas no estilo keynesiano. Ao passo que alguns permaneceram vinculados à "estase conservadora", outros responderam com modelos autoritários de coordenação da economia e da sociedade, como no caso alemão (1985, p. 107).

Na Suécia, desde 1932 houve movimentações para a construção de um "Estado de bem-estar social de pleno emprego" (1985, p. 109). O modelo adotava "frentes de trabalho público financiadas por déficits como estratégia explícita tanto para a recuperação econômica nacional quanto para o alívio do desemprego" (1985, p. 120). A versatilidade para incorrer em déficits governamentais é atribuída, em parte, ao fato de que o Banco da Suécia era público ao contrário do caso britânico - e responsável perante o parlamento sueco (1985, p. 129). Outra parte da explicação reside no acesso que economistas de inclinação heterodoxa tinham, desde muito cedo e de maneira sustentada, a centros administrativos estratégicos de formulação de políticas públicas, como comissões governamentais (1985, p. 132, 149). Em especial, destacava-se a influência da chamada "Escola de Estocolmo" - formada por economistas como Dag Hammarskjold, Alf Johansson, Gunnar Myrdal e Bertin Ohlin - sobre a política econômica heterodoxa do governo sueco (1985, p. 130). Referindo-se às características do pensamento da Escola de Estocolmo, John Kenneth Galbraith chega a afirmar que a "revolução keynesiana" na economia poderia ser mais propriamente apelidada de "revolução sueca", embora saliente que a sistematização das ideias que viriam a ficar

\footnotetext{
${ }^{126}$ Nesse sentido, John Kenneth Galbraith aponta que "[h]avia keynesianos muito antes de Keynes" (Galbraith, 1997, p. 200). Numa referência mais abrangente que aquela feita por Weir e Skocpol (1985), Bradley Bateman (2006) rotula de "protokeynesianas" certas políticas "de gerenciamento da demanda e de uso de déficits no período do entreguerras" ocorridas também no Japão, Itália, Alemanha e França. Salienta, ainda, que estas políticas foram rotuladas como keynesianas "ex post" (Bateman, 2006, p. 283).
} 
conhecidas como "macroeconomia"127 é devida a Keynes e não à Escola de Estocolmo (Galbraith, 1989, p. 202).

Nos Estados Unidos, “os primeiros raciocínios para políticas de recuperação baseadas em gastos deficitários não vieram nem de Keynes nem de círculos acadêmicos.” Somente no final dos anos 1930 a influência keynesiana, sobretudo por meio de economistas oriundos de Harvard e recrutados ao serviço público ou a órgãos consultivos, se faria sentir por meio da adoção de déficits orçamentários deliberadamente planejados como estratégia antirrecessiva (Weir; Skocpol, 1985, p. 116). Diferentemente do ocorrido no caso sueco, economistas americanos não tiveram acesso precoce às estruturas governamentais de formulação de políticas públicas contra a depressão, e sua influência foi menor (1985, p. 136). Mesmo no período compreendido entre 1938 e 1946, a resposta norte-americana, embora também contasse com frentes públicas de trabalho, favoreceu reduções tributárias e “ajustes automáticos' (ao invés de discricionários) dos gastos públicos para manejar a economia, com mais ênfase no controle da inflação do que na eliminação do desemprego." (1985, p. 108) Em outros termos, a adesão inicial dos Estados Unidos ao modelo de welfare state se deu parcialmente, em menor extensão do que na experiência sueca.

No caso da Grã-Bretanha, instituições como o seguro-desemprego, pensões por idade e seguros de saúde já haviam sido implementadas antes da Primeira Guerra Mundial, não podendo ser atribuídas a qualquer influência da Teoria Geral de Keynes (Weir; Skocpol, 1985, p. 108, 121). Porém, as estruturas de seguridade social britânicas operavam segundo o modelo de autofinanciamento por meio de contribuições compulsórias pagas pelos segurados, e não de gastos governamentais deficitários (1985, p. 108, 122). Em parte, as autoras atribuem às estruturas de seguridade social pré-existentes à Grande Depressão o fato de que a GrãBretanha não adotou estratégias "keynesianas" antirrecessivas antes da Segunda Guerra Mundial, só tendo ampliado suas instituições de seguridade social rumo a um "Estado de bem-estar social abrangente" após a guerra (1985, p. 109).

\footnotetext{
${ }^{127}$ Na caracterização de John Kenneth Galbraith, aquilo que Keynes abordou e que compõe "o estudo e o ensino de como o pleno emprego e a estabilidade de preços poderiam ser atingidos passariam a constituir um ramo especial da economia, a ser chamado de macroeconomia." Já "aquilo que Keynes não abordou, nem mencionou, passaria a chamar-se microeconomia". A distinção entre os dois campos é criticada por Galbraith por implicar "grave prejuízo para a compreensão econômica", dado que "a vida econômica é uma entidade única, e a separação entre macroeconomia e microeconomia impediu uma apreciação adequada da poderosa influência macroeconômica sobre os eventos microeconômicos - sobre as grandes empresas modernas, os sindicatos e a interação entre preços e salários em particular.” (Galbraith, 1989, p. 212) Na perspectiva de Paulo Sandroni, ao passo que a macroeconomia "se interessa pelo estudo dos agregados como a produção, o consumo e a renda da população", a "microeconomia ocupa-se da forma como as unidades individuais que compõem a economia consumidores privados, empresas comerciais, trabalhadores, latifundiários, produtores de bens ou serviços particulares etc. - agem e reagem umas sobre as outras." Destaca, ainda, que a separação entre os dois ramos, ocorrida na década de 1930, "é frágil”" (Sandroni, 1999, p. 388).
} 
Na Grã-Bretanha, nenhuma resposta keynesiana à Grande Depressão foi lançada por governos britânicos antes ou depois da Teoria Geral. Nem a presença de Keynes como escritor e consultor de políticas públicas, nem as conquistas de Keynes como grande teórico acadêmico foram suficientes para persuadir sua pátria a usar suas ideias para elaborar uma estratégia de recuperação. (Weir; Skocpol, 1985, p. 116)

Parte da explicação para a impenetrabilidade do Estado britânico às ideias keynesianas, ainda que Keynes estivesse dentro do Estado, se deve às características das estruturas estatais na Grã-Bretanha. Desde 1924, o Tesouro havia assumido controles expressivos sobre outros ministérios, dado que os projetos de políticas públicas que acarretassem aumento dos gastos governamentais, vindos de qualquer departamento, deveriam "passar pela avaliação do Tesouro antes que pudessem ir ao gabinete do dia" (1985, p. 127). Nesse sentido, o Tesouro britânico poderia vetar preventivamente as propostas que comprometessem o objetivo do orçamento equilibrado, ainda muito caro a seus funcionários, de modo que um "viés profundo contra inovações políticas em choque com a ortodoxia econômica espalhou-se por todo o aparato burocrático britânico.” (1985, p. 127) Assim, diferentemente do que ocorria na Suécia, ideias econômicas heterodoxas foram cortadas na raiz, impedindo que o keynesianismo tivesse influência nos momentos iniciais de resposta à Grande Depressão. O cerne das respostas britânicas consistiu em ampliar os esquemas de seguro-desemprego e não, por exemplo, em adotar a via das frentes de trabalho financiadas com déficits governamentais.

As experiências da Suécia, dos Estados Unidos e da Grã-Bretanha narradas por Weir e Skocpol, além daquelas de outros países como Japão, Itália (Bateman, 2006, p. 271) e Alemanha (Galbraith, 1997, p. 220) são marcas de um período em que governos nacionais passaram a assumir responsabilidade por novos objetivos econômicos, como a estabilização econômica $^{128}$, a busca do pleno emprego e por elementos de bem-estar social, que antes não eram encarados como sendo de sua alçada. A política econômica passou a contar com postura governamental ativa na política monetária e fiscal, com permissibilidade de orçamentos governamentais propositalmente deficitários, promoção de frentes públicas de trabalho para aliviar o desemprego e injetar recursos na economia, e medidas de seguridade social (Weir; Skocpol, 1985, p. 107) que envolviam transferências de renda. Tais experiências sinalizam a virada no pensamento e nas práticas econômicas rumo a um capitalismo que é vigiado e auxiliado pelo Estado, sem implicar controle ou planificação central da economia. Ao invés

\footnotetext{
${ }^{128}$ Eric Helleiner aponta que diante de "crises econômicas domésticas, tanto o Japão quanto a Alemanha começaram a experimentar com políticas financeiras domésticas não ortodoxas, como financiamentos deficitários e política monetária ativa", e que, conforme a militarização se acentuou nos anos 1930, "ambos os Estados começaram amplas intervenções diretas em seus sistemas financeiros domésticos para assegurar que recursos escassos de capital fossem alocados conforme objetivos nacionais." (Helleiner, 1994b, p. 29)
} 
de esperar ajustes automáticos via livre jogo das forças de mercado segundo alguma noção de harmonia natural dos interesses, as novas concepções econômicas atribuem ao Estado papel fundamental no funcionamento e preservação do capitalismo - isto é, salvar o capitalismo de si mesmo (cf. Rodrik, 2011).

Este sentido permeia o keynesianismo. A grande contribuição de Keynes, como apontado anteriormente, consistiu mais na sistematização dos novos saberes econômicos para orientar a ação estatal em tempos de crise do que na invenção completamente original destes saberes. De toda forma, Keynes é o principal expoente teórico de nova concepção de política econômica que posiciona o Estado como responsável pelo funcionamento adequado da economia (Galbraith, 1989, p. 212).

\subsubsection{Principais contornos do keynesianismo}

Na Teoria Geral, Keynes formula ataques à concepção econômica clássica, a que ele também se refere como "ortodoxa". Os ataques não são dirigidos contra a consistência lógica do liberalismo econômico, mas contra o caráter abstrato do sistema que este pressupõe, por não guardar correspondência com o funcionamento concreto da economia (Keynes, 1996, p. 345). Assim, para Keynes:

Os teóricos da escola clássica são comparáveis aos geômetras euclidianos em um
mundo não euclidiano, os quais, descobrindo que, na realidade, as linhas
aparentemente paralelas se encontram com muita frequência, as criticam por não se
conservarem retas, como único recurso contra as desastrosas interseções que se
produzem. Sendo esta a realidade, não há, de fato, nenhuma outra solução a não ser
rejeitar o axioma das paralelas e elaborar uma geometria não euclidiana. A ciência
econômica reclama hoje uma medida desse gênero. (Keynes, 1996, p. 54)

Apesar do desprendimento em relação à economia empírica, a perspectiva clássica ainda era dominante nos "meios acadêmicos e dirigentes" da geração de Keynes (1996, p. 44). Keynes propõe que a teoria econômica "deve ser capaz de explicar o fenômeno do ciclo econômico" e de endereçar o cenário de persistência da depressão nos anos 1930. Na sua perspectiva, os principais defeitos do modo como o capitalismo encontrava-se organizado eram "a sua incapacidade para proporcionar o pleno emprego e a sua arbitrária e desigual distribuição de riqueza e das rendas." (1996, p. 341)

$\mathrm{Na}$ explicação dos ciclos econômicos, Keynes propõe abordagem que, diferentemente da teoria clássica, não atribui peso primário à operação do mecanismo de preços. Para ele, muitos dos comportamentos individuais e coletivos das pessoas nos mercados são devidos a suas inclinações psicológicas, capazes de afetar não só as decisões de consumir e de investir 
(produzir ou especular), mas também a de reter moeda ou passá-la adiante. O principal objetivo da obra de Keynes, em meio à operação destes fatores em mercados interconectados (bens, trabalho, capital, moeda), consiste em:

descobrir o que, em dado sistema econômico, determina em um momento preciso a
renda nacional e (o que vem a ser quase a mesma coisa) o volume de emprego que
lhe corresponde [...]. Nossa tarefa final poderia consistir em selecionar as variáveis
que a autoridade central pode controlar ou dirigir deliberadamente no tipo de sistema
em que realmente vivemos. (Keynes, 1996, p. 239)

A ênfase "no tipo de sistema em que realmente vivemos" é acompanhada de críticas a afirmações da teoria clássica. Em meio a diversas críticas, algumas delas parecem assumir maior importância no corpo da obra. Serão abordadas aqui as críticas às pressuposições de que: há pleno emprego dos fatores de produção; a poupança e os investimentos são favorecidos pela existência da desigualdade de renda; e de que juros altos incentivam a poupança necessária para investimentos.

Segundo Keynes, a economia ortodoxa simplesmente pressupõe o emprego ótimo dos fatores de produção, como trabalho e capital, sem analisar "os determinantes do emprego efetivo dos recursos disponíveis" (1996, p. 45). Em outros termos, o economista clássico imagina uma situação de pleno emprego como ponto de partida para seu raciocínio. Esta imaginação é fundada em certa perspectiva dogmática, por sua vez assentada sobre o argumento da harmonia natural dos interesses, segundo a qual o comportamento individual autointeressado conduz a resultados socialmente ótimos. Em contraste, Keynes está interessado em saber quais são as condições que permitem alcançar o pleno emprego. Evidentemente, o laissez-faire não tem o condão de levar espontaneamente o nível de atividade econômica ao pleno emprego na concepção keynesiana.

A crítica de Keynes envolve ataque à teoria clássica do emprego e à formulação mais abrangente da lei de Say. A teoria clássica do emprego nega a existência do desemprego "involuntário". Somente admite as modalidades de desemprego friccional e voluntário. O desemprego friccional tem suas causas no lapso de tempo existente durante a mudança de trabalho por uma pessoa, ou seja, decorre "do fato de que a transferência de um emprego para outro não se realiza sem certa demora" (Keynes, 1996, p. 46). Já o desemprego voluntário acontece quando os trabalhadores se recusam a trabalhar por remunerações menores, ou quando a pessoa considera que a remuneração oferecida pelo trabalho não compensa o lazer de que abriu mão (Keynes, 1996, p. 47), ou seja, o custo de oportunidade. O desemprego involuntário inexistiria, segundo a concepção clássica, porque esta pressupõe a flexibilidade salarial. Os salários variam segundo a oferta e demanda de mão de obra, encontrando seu 
equilíbrio no "pleno emprego". Ou seja, os trabalhadores aceitariam trabalhar por menos no caso de queda da demanda por mão de obra, e o nível de emprego se manteria, ao passo que, caso as necessidades de produção demandassem mais trabalhadores, os salários tenderiam a subir.

$\mathrm{O}$ ataque de Keynes à teoria clássica do emprego consiste principalmente em questionar o postulado de que a aceitação de menores salários seja o remédio necessário para o desemprego (1996, p. 55). Segundo sua análise, os trabalhadores e sindicatos são sensíveis a reduções nominais nos salários - isto é, aos salários denominados em valores expressos em dinheiro -, mas não tendem a fazer greve quando seus salários reais - o que equivale a seu poder de compra - são diminuídos. Nesse sentido, ao passo que a explicação clássica atribuiria o desemprego de fato verificado na década de 1930 à inflexibilidade dos salários, Keynes parte para outras explicações do fenômeno. Em sua visão, não há razão para que a economia encontre seu equilíbrio no nível de "pleno emprego", em decorrência das relações entre emprego, consumo e investimentos $\left(1996\right.$, p. 62) ${ }^{129}$.

Antes de passar a tais relações, é necessário complementar a crítica de Keynes com o ataque feito à lei de Say. "Desde o tempo de Say e de Ricardo os economistas clássicos têm ensinado que a oferta cria sua própria procura" (Keynes, 1996, p. 56). A lei de Say "equivale à proposição de que não há obstáculo ao pleno emprego.” (1996, p. 61) Segundo Keynes, a ideia de que a oferta possa condicionar sua própria demanda e propiciar o equilíbrio de pleno emprego é baseada na "noção de que se o dinheiro não for gasto de uma forma, o será de outra." (1996, p. 57) O dinheiro não escaparia do sistema econômico, não haveria vazamentos.

No esquema clássico orientado pela lei de Say, mesmo que o indivíduo deixe de consumir imediatamente, sua decisão é encarada como ato que "equivale a um investimento na produção de riqueza sob a forma de capital.” (Keynes, 1996, p. 56) Em outros termos, a poupança, que é a parcela não consumida da renda ${ }^{130}$, é igualada ao investimento ${ }^{131}$. Aqui reside o ponto fundamental atacado por Keynes (explicado nos parágrafos seguintes), que considera que a suposição de igualdade necessária entre poupança e investimento é o “axioma das paralelas" da teoria clássica, sendo o restante deduzido a partir dele: "vantagens

\footnotetext{
${ }^{129} \mathrm{Na}$ interpretação de Paul Davidson, na "moldura lógica keynesiana", a redução salarial não gera o efeito automático de conduzir a economia ao equilíbrio de pleno emprego (Davidson, 1981, p. 156).

${ }^{130}$ No esquema keynesiano, renda equivale ao que se obtém com a produção, sendo também o mesmo que a soma do consumo e dos investimentos (Keynes, 1996, p. 91). A poupança é definida como "excedente do rendimento sobre os gastos de consumo" (1996, p. 90), ou pela expressão "Poupança = renda - consumo." (1996, p. 91)

${ }^{131}$ Investimento designa "a compra de um ativo, velho ou novo, por um indivíduo ou uma empresa." (Keynes, 1996, p. 101)
} 
sociais da poupança individual e nacional, a atitude tradicional para com a taxa de juros, a teoria clássica do desemprego, a teoria quantitativa da moeda, as vantagens ilimitadas do laissez-faire quanto ao comércio externo e muitos outros aspectos” (1996, p. 58).

Keynes nega a existência de relação necessária entre a abstenção do consumo imediato e a decisão de investimento ou de consumo futuro, em razão do fator psicológico que chama de "preferência por liquidez" (1996, p. 58). Trata-se do desejo de reter moeda, ou seja, de consumir um ativo extremamente líquido, e esta preferência pode se tornar mais forte que o desejo de obter rendimentos com a aplicação dos recursos financeiros. Keynes explica que o "motivo da liquidez", que pode diminuir a propensão a consumir, pode estar relacionado ao desejo de "garantir recursos líquidos para enfrentar as emergências, dificuldades e crises." (1996, p. 128) Quando a preferência por liquidez é forte, há “entesouramento". Assim, Keynes afirma que o:

ato de poupança individual hoje significa - por assim dizer - uma decisão de não
jantar hoje, mas não implica, necessariamente, a decisão de jantar ou de comprar um
par de sapatos daqui a uma semana ou um ano, ou de consumir uma coisa específica
numa data especificada. Assim sendo, produz um efeito depressivo sobre as
atividades econômicas aplicadas na preparação do jantar de hoje, sem estimular as
que preparam algum ato futuro de consumo. Não é uma substituição da demanda de
consumo presente por uma demanda de consumo futuro, mas apenas uma
diminuição líquida desta demanda. (Keynes, 1996, p. 209)

Na terminologia keynesiana, o efeito do aumento da preferência por liquidez sobre o sistema econômico é a redução da "demanda efetiva" ". Como a lei de Say pressupunha que toda a oferta seria demandada, não concebia a existência de obstáculos - como o entesouramento - para que tal demanda se tornasse concreta:

O celebrado otimismo da teoria econômica tradicional [...] tem como origem, no meu entender, o fato de não haver sido levado em conta o empecilho que uma insuficiência da demanda efetiva pode significar para a prosperidade, pois em uma sociedade que funciona de acordo com os postulados clássicos deveria existir uma tendência natural para o emprego ótimo dos recursos. (Keynes, 1996, p. 66)

Em outros termos, quando as pessoas praticam o entesouramento, diminuem o seu consumo, e como o "volume de emprego depende do nível de receita que os empresários esperam receber da correspondente produção", estes tenderão a "fixar o volume de emprego ao nível em que esperam maximizar a diferença entre a receita e o custo dos fatores”, quer dizer, seu lucro. Ainda em outros termos, a redução da demanda efetiva implica a redução do nível de atividade econômica em função das expectativas diminuídas dos empresários em

\footnotetext{
${ }^{132}$ Como explica Galbraith, "nada garante [que] aquilo que foi poupado será investido, o que vale dizer gasto." (1989, p. 210) "Se a renda é poupada e não gasta, o efeito será uma redução da demanda total de bens e serviços - da demanda total efetiva - e, portanto, da produção e do nível de emprego.” (1989, p. 210)
} 
relação a seu lucro, e portanto envolve demissão de trabalhadores (Keynes, 1996, p. 60, 113, 210). No fundo, a preferência pela liquidez significa simplesmente que o desejo de reter moedas ou ativos líquidos por parte das pessoas, em certas circunstâncias, pode ser maior que o de consumir bens e serviços disponíveis nos mercados ou de investir. O grande problema consiste em que, diferentemente dos bens e serviços, a produção de moeda para satisfazer a demanda por liquidez não gera empregos em quantidade significativa ${ }^{133}$.

A preferência por liquidez é um dos três fatores psicológicos fundamentais na teoria keynesiana. Outros são a propensão ao consumo e a eficiência marginal do capital.

A propensão ao consumo é a função psicológica que trata da "relação entre a renda de uma comunidade e o que se pode esperar que ela gaste em consumo" (Keynes, 1996, p. 63). O ponto de partida do raciocínio para compreender a propensão ao consumo é a afirmação de que "os homens estão dispostos, de modo geral e em média, a aumentar o seu consumo à medida que a sua renda cresce" (1996, p. 118). No entanto, o aumento do consumo não se dá em proporção fixa com o aumento da renda: "quando nossa renda sobe, nosso consumo também sobe, embora menos. A chave do nosso problema prático encontra-se nesta lei psicológica." (1996, p. 64) O raciocínio por trás desta afirmação é o seguinte:

a satisfação das necessidades imediatas de um indivíduo e de sua família é, normalmente, mais forte que os seus motivos para poupar, que só adquirem predomínio efetivo quando se alcança determinado nível de conforto. Essas razões fazem com que, em geral, uma proporção maior da renda seja poupada à medida que a renda real aumenta. (Keynes, 1996, p. 119)

A consequência desta configuração da propensão ao consumo é a de que o enriquecimento da sociedade não tende a levar a níveis maiores de consumo suficientes para justificar o pleno emprego. A livre operação das forças de mercado tende a conduzir a um equilíbrio econômico com desemprego (1996, p. 64), já que "se o emprego e, portanto, a renda agregada aumentam, nem todo o emprego adicional será requerido para satisfazer as necessidades do consumo adicional.” (1996, p. 119) Keynes está apontando como o acúmulo de renda pode se converter em fator de instabilidade para o funcionamento do capitalismo. Esta sinalização se dá em oposição à concepção econômica ortodoxa, que promove a "ideia de que o aumento do capital depende do vigor dos motivos que impelem à poupança, e de que uma grande proporção desse crescimento depende das poupanças dos ricos a partir do que lhes é supérfluo.” (1996, p. 341) Em contraste, Keynes afirma que “o crescimento do capital

\footnotetext{
${ }^{133}$ Referindo-se à situação em que há aumento da preferência por liquidez, Keynes afirma que "o desemprego aumenta porque as pessoas querem a Lua; os homens não podem conseguir emprego quando o objeto de seus desejos (isto é, o dinheiro) é uma coisa que não se produz e cuja demanda não pode ser facilmente contida." (1996, p. 229)
} 
não depende absolutamente de uma baixa propensão a consumir, mas é, ao contrário, reprimido pela mesma" (1996, p. 341). Afirma, ainda, que "a abstinência dos ricos mais provavelmente tolhe do que favorece o crescimento da riqueza. Fica assim invalidada uma das principais justificativas sociais da grande desigualdade de riqueza.” (1996, p. 342)

Parte da solução de Keynes para endereçar o problema da propensão decrescente ao consumo diante de patamares maiores de renda consiste em favorecer políticas econômicas de caráter redistributivo, que serão abordadas mais à frente. A outra parte consiste em fazer com que a poupança (isto é, o excedente da renda sobre o consumo) se reverta em investimentos na produção. Ou seja, os recursos monetários têm, de uma forma (consumo) ou de outra (investimentos), que voltar para a produção para que o sistema econômico não reduza seu nível de atividade e induza empresários a oferecer menores volumes de emprego (1996, p. 62). "Se a propensão a consumir e o montante de novos investimentos resultam em uma insuficiência da demanda efetiva, o nível real do emprego se reduzirá até ficar abaixo da oferta de mão de obra potencialmente disponível ao salário real em vigor”, com a consequência de que "a insuficiência da demanda efetiva inibirá o processo de produção". Conforme a sociedade enriquece, cria-se uma lacuna entre "a sua produção efetiva e a potencial" (1996, p. 64). O investimento precisa preencher a lacuna (1996, p. 120), mas o “incentivo para investir” está atrelado a outra função psicológica: a eficiência marginal do capital.

A eficiência marginal do capital refere-se à "expectativa psicológica do rendimento futuro dos bens de capital" (1996, p. 238). Trata-se da expectativa em relação ao que "o empresário pode esperar ganhar sob a forma de rendimentos futuros" decorrente de novos investimentos na produção (1996, p. 77-8). A taxa de juros desempenha papel fundamental na escolha por investir ou não na produção ${ }^{134}$. Se o retorno esperado de investimentos na produção for menor do que a taxa de juros prometida para outras aplicações de tipo "financeiro" ou "de portfólio" - o tipo de investimento especulativo que caracteriza o rentier -, então os incentivos ao investimento serão diminuídos, com impacto sobre o nível de atividade econômica e portanto do emprego. Para Keynes, em vista disso, a taxa de juros deve

\footnotetext{
${ }^{134}$ A respeito da eficiência marginal do capital na Teoria geral de Keynes, Gazier explica que a decisão do empresário de investir resulta de comparação entre a rentabilidade do investimento produtivo e a da especulação. "O empresário vai comparar essa taxa de rentabilidade à taxa do mercado, isto é, a que resulta da preferência pela liquidez e da oferta de moeda decorrente da política dos bancos e dos poderes públicos. Se ela for superior, há estímulo em investir. Este desaparece no caso de projetos que apenas rendem a taxa de mercado, pois as eventuais somas disponíveis serão mais bem empregadas (sem os esforços e os riscos ligados à implantação desse investimento na empresa) em empréstimos diretos a essa taxa." (Gazier, 2011, p. 73) Este ponto é capturado pela AJPE como um aspecto da categoria de deflexão monetária interportfólio, parte do conjunto integrante da Nova Análise Contratual. Vide seção 4.4.
} 
ser fixada de modo a estimular o nível de investimentos que conduza ao pleno emprego (1996, p. 216). Keynes sugere que o rentier precisa perder o lugar de destaque que ocupou no capitalismo no século XIX e início do século XX, favorecendo-se, em seu lugar, o “empreendimento" (1996, p. 217).

A taxa de juros sobre o dinheiro parece, portanto, representar um papel especial na fixação de um limite ao volume de emprego, visto marcar o nível que deve alcançar a eficiência marginal de um bem de capital para que ele se torne objeto de nova produção. (Keynes, 1996, p. 218 - acrescentou-se ênfase)

O pensamento keynesiano em torno da eficiência marginal do capital e sua relação com a taxa de juros vai de encontro às formulações do pensamento liberal clássico. "A justificativa de uma taxa de juros moderadamente elevada foi encontrada, até aqui, na necessidade de proporcionar estímulo suficiente à poupança.” (1996, p. 343) Vale lembrar que, no esquema clássico, poupança e investimento se igualam, presumindo-se que toda poupança, de uma forma ou de outra, reverta-se em capital aplicado na produção. Porém, Keynes desiguala poupança e investimento ${ }^{135}$, e chega a conclusões opostas a respeito de como a taxa de juros deva ser definida:

a extensão da poupança efetiva é rigorosamente determinada pelo montante de investimento, e que este montante cresce por efeito de uma taxa de juros baixa [...]. Assim sendo, o que mais nos convém é reduzir a taxa de juros até o nível em que, em relação à curva de eficiência marginal do capital, se realize o pleno emprego. (Keynes, 1996, p. 343 - ênfase no original)

$\mathrm{Na}$ operação das três funções psicológicas aqui referidas - preferência por liquidez, propensão ao consumo e eficiência marginal do capital - reside a grande "sacada" da Teoria geral de Keynes: estes fatores psicológicos estão na base de certo desvio de recursos que precisariam retornar à produção para que o nível de atividade econômica e de emprego pudesse se sustentar próximo ao pleno emprego. Assim, a preferência por liquidez drena recursos que poderiam ser investidos na produção, resultando na acumulação de ativos "líquidos" e mesmo do entesouramento, ou seja, de poupança não investida. A propensão ao consumo é uma função inversa do aumento da renda, significando que, na afluência, a sociedade tenderá a consumir menos do que o necessário para manter a produção no nível de pleno emprego, de modo que, se novos investimentos não migrarem para a produção, haverá

\footnotetext{
${ }^{135}$ Como se observou anteriormente, a função psicológica da propensão a consumir implica que o aumento da renda na sociedade é acompanhado por montantes maiores de poupança do que de consumo adicional. Em razão disso, as decisões dos empresários de investir na produção são afetadas, resultando em diminuição dos investimentos em produção nas sociedades mais afluentes. Esta é uma das razões para que Keynes desiguale poupança e investimento, rompendo com o esquema clássico. A outra razão consiste na possibilidade do entesouramento, em que a moeda é poupada de forma a ser privadamente retirada de circulação, não se convertendo em nenhum investimento economicamente útil enquanto assim permanecer.
} 
desemprego. Por fim, a eficiência marginal do capital explica que as pessoas prefiram especular a investir na produção se as perspectivas de retorno do investimento produtivo forem menores do que as da atividade rentista, determinadas pela taxa prevalente de juros.

As três funções psicológicas permeiam a exposição que Keynes faz das interconexões entre os diversos mercados (de bens, capital, trabalho e moeda). Diante da percepção de como as relações entre os elementos que descreve afetam o "volume de emprego e a renda nacional" (1996, p. 237), Keynes dirige sua preocupação à identificação das medidas que o Estado pode adotar para guiar o sistema econômico ao nível de atividade em que se verifique o pleno emprego (1996, p. 239-40).

Não se pode esquecer que a Teoria geral foi escrita no período da Grande Depressão dos anos 1930. Nesse sentido, é uma resposta não só à teoria clássica, mas também à crise econômica. Por isso, as ideias defendidas por Keynes traduziram-se em medidas de política econômica que podem ser adotadas para sair da depressão, ou seja, de medidas anticíclicas.

A ideia de "ciclo econômico" implica alternância de períodos de expansão e contração do nível de atividade econômica, e contraria a noção ortodoxa de equilíbrio de pleno emprego propiciado automaticamente pela livre operação das forças de mercado. Nesta concepção, os desequilíbrios seriam apenas friccionais, ou seja, situados no período em que os mercados estão se ajustando de um ponto de equilíbrio a outro. Diferentemente da concepção ortodoxa, Keynes enxerga o processo econômico como sendo de "movimentos cíclicos", em que fases de expansão da atividade econômica são sucedidas por crises, contrações, depressões e recuperações.

Keynes aponta que as depressões têm certas características conducentes ao autorreforço do processo depressivo, que envolvem círculos viciosos de desempenho econômico (vide Quadro 3.5, acima). Este ponto implica a rejeição das concepções purgativas a respeito das crises econômicas, mencionadas anteriormente, que consistem essencialmente em tolerar as dores do deslocamento de equilíbrio da economia e dos ajustes que ele implica. Quando, após uma crise, a produção é acumulada em estoques, os preços baixam “o bastante para causar uma restrição da produção que assegure a reabsorção dos estoques excedentes". A medida "representa um investimento negativo, que também contribui para diminuir o emprego (Keynes, 1996, p. 297). A espiral descendente prossegue, porque menores níveis de emprego diminuem a renda da população, que por sua vez enfraquecem novamente a demanda pelo que é produzido, reforçando a tendência ao acúmulo dos estoques. Este jogo pode continuar indefinidamente se algo não for feito. A participação do Estado é fundamental 
para reverter a depressão via medidas de incentivo ao consumo, ao investimento e ao nível de emprego, ou seja, adotando medidas anticíclicas.

As funções do Estado consistem em manejar o nível de atividade econômica por meio da política fiscal - inclusive com políticas de redistribuição de renda - e monetária, entre outras. Não se trata, porém, de estatização do controle da produção, das trocas ou do consumo:

Os controles centrais necessários para assegurar o pleno emprego exigirão, naturalmente, uma considerável extensão das funções tradicionais de governo. [...] Todavia, subsistirá ainda uma grande amplitude, que permita o exercício da iniciativa e responsabilidade privadas. Nesse domínio, as vantagens tradicionais do individualismo continuarão ainda sendo válidas. (Keynes, 1996, p. 346)

Noutra passagem, Keynes encontra-se preocupado em distinguir seu projeto da alternativa socialista ao capitalismo ${ }^{136}$ :

uma socialização algo ampla dos investimentos será o único meio de assegurar uma situação aproximada de pleno emprego, embora isso não implique a necessidade de excluir ajustes e fórmulas de toda a espécie que permitam ao Estado cooperar com a iniciativa privada. Mas, fora disso, não se vê nenhuma razão evidente que justifique um socialismo do Estado abrangendo a maior parte da vida econômica da nação. Não é a propriedade dos meios de produção que convém ao Estado assumir. (Keynes, 1996, p. 345)

Como se pôde notar, um dos elementos do projeto keynesiano para lidar com as depressões envolve a redistribuição de renda. Este elemento pauta as medidas de política fiscal sugeridas por Keynes como obras públicas ${ }^{137}$ (1996, p. 137) e seguro-desemprego (1996, p. 119), entre outras medidas que envolvem também a receita genérica de "nova distribuição dos rendimentos" para estimular a propensão a consumir (1996, p. 299). Quanto ao modo de arcar com estas despesas estatais, Keynes sugere que o Estado pode se valer do “déficit orçamentário", trabalhando com "dinheiro emprestado." (1996, p. 119) "Se assim não fosse, o declínio do emprego e da renda, uma vez iniciado, poderia ir muito longe.” (1996, p. 119)

\footnotetext{
136 “Keynes não deseja uma intervenção pública que oriente as iniciativas privadas e permanece um defensor da economia capitalista de mercado" (Gazier, 2011, p. 79).

${ }^{137}$ Numa das passagens da Teoria geral, Keynes defende que o gasto público pode gerar efeitos econômicos desejáveis ainda que seja empregado em atividades economicamente consideradas inúteis, como "abrir buracos no chão". A seguinte passagem, a este respeito, é bastante conhecida: "Se o Tesouro se dispusesse a encher garrafas usadas com papel-moeda, as enterrasse a uma profundidade conveniente em minas de carvão abandonadas que logo fossem cobertas com o lixo da cidade e deixasse à iniciativa privada, de acordo com os bem experimentados princípios do laissez-faire, a tarefa de desenterrar novamente as notas (naturalmente obtendo o direito de fazê-lo por meio de concessões sobre o terreno onde estão enterradas as notas), o desemprego poderia desaparecer e, com a ajuda das repercussões, é provável que a renda real da comunidade, bem como a sua riqueza em capital, fossem sensivelmente mais altas do que, na realidade, o são. Claro está que seria mais ajuizado construir casas ou algo semelhante; mas se a tanto se opõem dificuldades políticas e práticas, o recurso citado não deixa de ser preferível a nada.” (Keynes, 1996, p. 145)
} 
As medidas de política fiscal sugeridas por Keynes envolvem a estruturação dos tributos de modo a favorecer a "propensão da comunidade a consumir", o que equivale a dizer: diminuir (ainda que temporariamente) as desigualdades de renda. Além de exaltar a tributação sobre a renda - e não sobre o consumo -, Keynes considera "inegável” o caráter favorável ao consumo trazido por "uma política fiscal de altos impostos sobre heranças", por colocar obstáculos à acumulação (1996, p. 342).

Outro aspecto importante das medidas defendidas por Keynes se refere à política monetária. Na visão de Keynes, "há dois caminhos para aumentar a produção" (1996, p. 302), sendo um interferir no consumo e o outro nos investimentos. $\mathrm{O}$ autor indica que "o mais prudente seria avançar em ambas as frentes ao mesmo tempo", de modo a procurar "conseguir um fluxo de investimento controlado socialmente" e, ao mesmo tempo, empreender "toda sorte de medidas para aumentar a propensão a consumir", como as relatadas acima (1996, p. 302). Keynes defende aquilo que se pode considerar "política monetária expansiva" para os ciclos de depressão e para a preservação da prosperidade. A política monetária deve funcionar de modo a estimular o investimento produtivo em detrimento da aplicação meramente especulativa.

Quadro 3.6 - comparação entre algumas categorias e caracterizações fundamentais do liberalismo econômico e da economia keynesiana

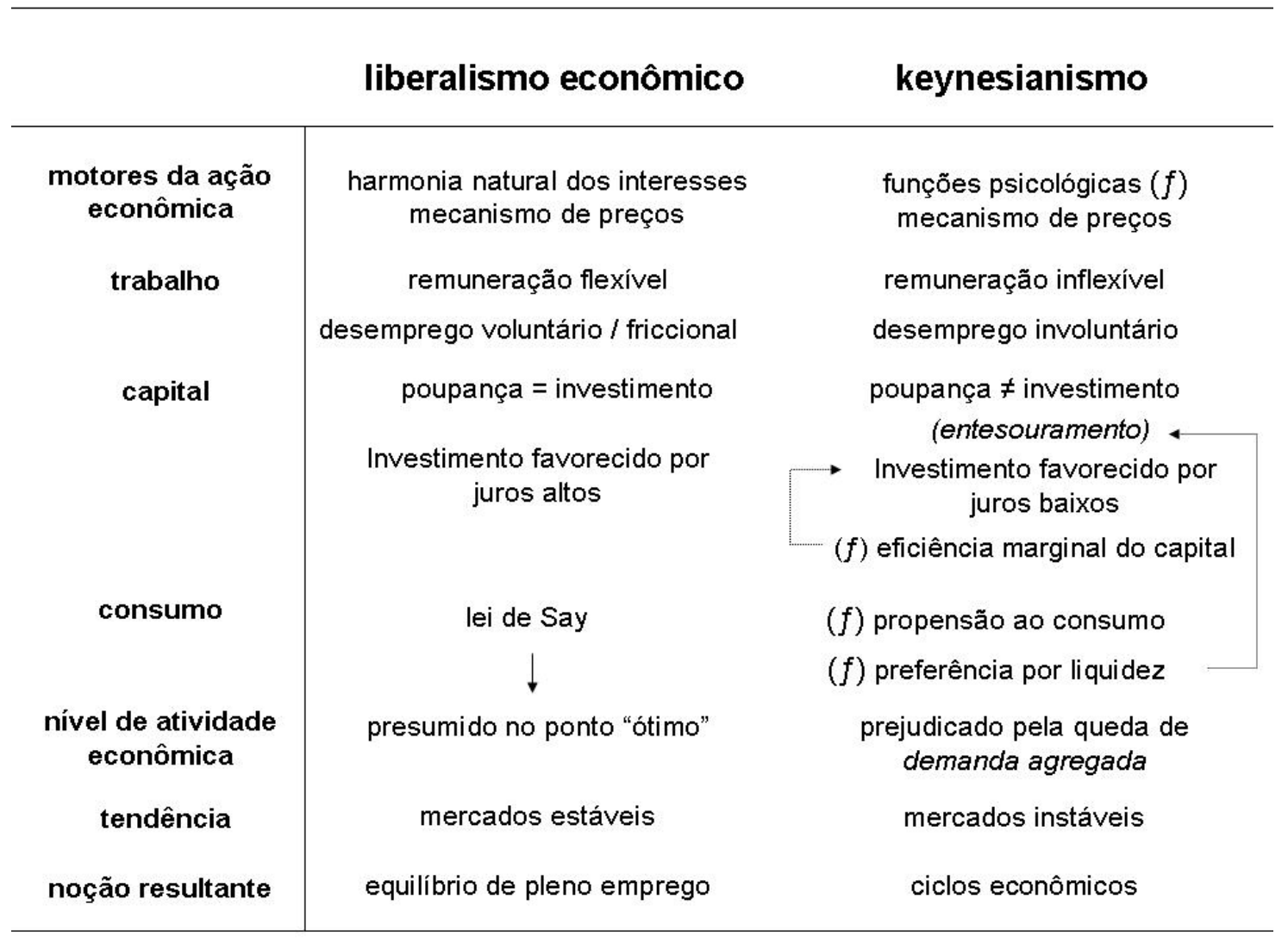

Fonte: elaborado a partir de elementos presentes em Keynes, 1996;

Galbraith, 1989; 1997; Gazier, 2011; Bateman, 2006 
Para endereçar o problema criado pela preferência por liquidez, que é capaz de drenar dinheiro da economia por meio do entesouramento, Keynes defende juros baixos como meio de estimular o investimento: “o que mais nos convém é reduzir a taxa de juros até o nível em que, em relação à curva de eficiência marginal do capital, se realize o pleno emprego." (1996, p. 343) Baixas taxas de juros contribuem para que as escolhas de investimento favoreçam a produção, por comprometerem a rentabilidade de aplicações de caráter especulativo, que remuneram segundo os "juros do dinheiro". É importante frisar que a baixa na taxa de juros não é indicada somente como remédio para a fase depressiva do ciclo econômico, mas também para fazer perdurar ou prolongar o auge da expansão (1996, p. 299-300).

A partir dos elementos acima, foi possível observar como Keynes articula medidas de política fiscal e monetária - com matizes expansivos e redistributivos - para endereçar os efeitos nocivos ao consumo e ao investimento (e por consequência ao nível de emprego) das funções psicológicas de (baixa) propensão ao consumo, preferência por liquidez e eficiência marginal do capital. É interessante notar que as justificativas por medidas de redistribuição de renda se dão em bases econômicas: são necessárias à própria viabilidade do capitalismo. Embora considerações humanísticas possam ser acrescentadas a tais justificativas ${ }^{138}$, o discurso permanece matizado pelo aspecto econômico. Em Keynes, o político é chamado ao auxílio do econômico. Não se pode chegar a dizer que haja subordinação do econômico ao político. A autonomia do domínio econômico certamente não é a mesma daquela pensada sob o argumento clássico da harmonia natural dos interesses, mas os objetivos sociais - como redistribuição de renda e pleno emprego - recebem justificações econômicas para serem perseguidos, no sentido de que a prosperidade material torna-se condicionada por estes objetivos $^{139}$.

Ao final de sua obra, Keynes sugere impactos que a organização do sistema econômico segundo seu sistema poderia ter sobre as relações internacionais. "Observei, de passagem, que o novo sistema poderia ser mais favorável à paz do que o antigo.” (1996, p. 348) Em curto trecho, ele avalia o modelo antigo, instruído pela ortodoxia clássica:

sob o regime de laissez-faire interno e de padrão ouro internacional, como era o correto na segunda metade do século XIX, não havia qualquer outro meio disponível a um governo para aliviar a miséria econômica interna a não ser lutar pela conquista

\footnotetext{
138 "Sua análise favorece amplas justificações às transferências em favor dos mais pobres, que conciliam uma preocupação de justiça social e uma contribuição eficaz à retomada da atividade.” (Gazier, 2011, p. 78)

139 Afinal, como aponta Bernard Gazier, a Teoria geral de Keynes "quer mostrar que o capitalismo tem tendências permanentes à depressão, e que estas são cada vez mais fortes à medida que ele se desenvolve e algumas classes sociais enriquecem. O mecanismo é simples: à medida que o rendimento aumenta, a propensão a gastar tende a diminuir entre os mais ricos, o que tende a deprimir a atividade. A saturação das necessidades de consumo dos ricos freia a expansão do sistema." (Gazier, 2011, p. 77)
} 
de mercados externos. Isso porque todos os remédios eficazes para o desemprego crônico ou intermitente estavam excluídos, à exceção das medidas destinadas a melhorar o balanço de pagamentos em conta corrente. (Keynes, 1996, p. 348)

Relaciona, portanto, a expansão do comércio a práticas violentas. Em contraste, a orientação doméstica do Estado ao pleno emprego, com maior controle sobre a política fiscal e monetária, favoreceria a estruturação de relações econômicas internacionais compatíveis com a paz:

O comércio internacional deixaria de ser o que é, um expediente desesperado para manter o emprego interno, forçando as vendas nos mercados externos e restringindo as compras, o que, se tivesse êxito, simplesmente deslocaria o problema do desemprego para o vizinho que levasse desvantagem na luta, e se converteria num livre e desimpedido intercâmbio de mercadorias e serviços em condições de vantagens mútuas. (Keynes, 1996, p. 348)

O elemento de preservação da estabilidade econômica doméstica, aqui representado pela orientação do Estado ao objetivo do pleno emprego, somado a perspectiva de um "livre e desimpedido intercâmbio de mercadorias e serviços em condições de vantagens mútuas" expressam, de certa forma, as bases do liberalismo assistido ${ }^{140}$. Keynes teria participação nas negociações da ordem de Bretton Woods, sobretudo nos aspectos da cooperação monetária e financeira internacional. Como se verá, esta ordem procurou conciliar liberdade de comércio internacional e estabilidade econômica e social doméstica por meio da estruturação de uma ordem econômica internacional que fornecesse condições para uma abertura "segura" da economia ao exterior, sem abrir mão do welfare state e da liberdade governamental para definir estratégias de desenvolvimento (Ruggie, 1982; cf. Rodrik, 2011; Castro, 2006).

\subsubsection{Ordem econômica internacional de Bretton Woods}

No pós-segunda guerra, o meio econômico já se encontrava em larga medida sob a influência do pensamento keynesiano ${ }^{141}$. De modo geral, economistas compartilhavam "uma forte crença de que o Estado tinha um importante papel a desempenhar na vida econômica, em especial nas situações como aquela que tinham que enfrentar naqueles anos de reconstrução.” (Sato, 2012, p. 125) O keynesianismo teve influência na estruturação da ordem

\footnotetext{
${ }^{140}$ Cabe fazer a ressalva de que a ordem de Bretton Woods não promoveu desimpedimentos no comércio internacional de serviços.

141 Segundo John Kenneth Galbraith, a guerra "instalou keynesianos em grande número em posições de influência”, tanto nos Estados Unidos quanto em variados países da Europa Ocidental (1989, p. 220). Além disso, afirma que "[e]ntre os economistas, uma nova visão de governo e uma nova confiança na sua intervenção seriam as principais consequências econômicas da guerra." (1989, p. 226) Estas afirmações são feitas num contexto em que Galbraith relaciona os incentivos que a Segunda Guerra Mundial representaram ao nível de atividade econômica nos Estados Unidos - que sanaram as tendências recessivas da década de 1930 - ao sucesso e propagação da economia keynesiana.
} 
econômica internacional do pós-guerra. O próprio Keynes participou das negociações de Bretton Woods, como representante britânico. Harry Dexter White, principal figura da delegação dos Estados Unidos, era ele mesmo um economista keynesiano (Helleiner, 1994b, p. 32). Com o status de perspectiva econômica preponderante, o keynesianismo contribuiu para que a cooperação econômica internacional incorporasse novos objetivos, antes vistos como assuntos domésticos, como pleno emprego e estímulo estatal à atividade econômica. A cooperação multilateral deveria passar a favorecê-los. A busca conjunta da abertura multilateral com a preservação da estabilidade doméstica dá o tom do liberalismo assistido (cf. Ruggie, 1982; Rodrik, 2011).

Os economistas da época tomavam em perspectiva as relações econômicas do período do entreguerras, apontando um aspecto que desejavam conservar e outro que desejavam evitar. $\mathrm{O}$ aspecto a ser conservado, como sugerido anteriormente, é o compromisso estatal com o pleno emprego ou, de forma mais englobante, com políticas associadas ao welfare state. A preservação desse elemento decorria não só da influência do ideário keynesiano, como também dos novos cenários domésticos de massas urbanas assalariadas e politicamente empoderadas no Ocidente industrializado. Aliás, como Helleiner destaca, se nos anos do POI a coalizão mais influente politicamente havia sido aquela formada por banqueiros e financistas internacionais, após o entreguerras ela perdeu espaço para nova coalizão social composta por industrialistas, líderes trabalhistas e funcionários públicos de "mentalidade keynesiana" (Helleiner, 1994b, p. 27). Estes setores eram favoráveis a abordagens econômicas de feições mais intervencionistas e capazes de posicionar as finanças domésticas e internacionais em função de objetivos políticos e econômicos mais amplos (1994b, p. 28).

Por sua vez, o aspecto do entreguerras cuja repetição se desejava evitar consistia no rompimento da cooperação econômica internacional. As transações comerciais internacionais encontravam-se dificultadas por medidas protecionistas variadas. Políticas de depreciação cambial competitiva acentuavam o problema, com impactos negativos sobre as possibilidades de cooperar nos campos monetário e financeiro. O comportamento dos Estados, orientado nestes moldes, fazia com que a busca dos objetivos domésticos de estabilidade representasse dificuldades para as economias dos demais. O jogo estava sendo jogado de forma que cada movimentação de um país em busca de bem-estar econômico interno causava impactos negativos para as demais economias. No novo cenário, desejava-se o retorno da cooperação internacional, sobretudo no campo do comércio de bens. O resgate da liberdade comercial internacional necessitaria também de medidas de cooperação monetária e financeira, mas que 
já não se dariam segundo o modelo do POI, ou seja, ao estilo laissez-faire, senão segundo a perspectiva keynesiana que percebia com desconfiança a atividade do rentier.

Por isso, a ordem de Bretton Woods envolveu o estabelecimento de instituições da cooperação econômica internacional que propiciassem o resgate da abertura ao comércio ${ }^{142}$. A cooperação monetária se constituiu de maneira a propiciar bases cambiais estáveis para transações comerciais internacionais. Além disso, atuaria como elemento internacional favorecedor da autonomia dos Estados para adoção doméstica de políticas redistributivas, com espaço para que a política monetária e fiscal destes fosse moldada segundo os requisitos do welfare state (Ruggie, 1982; Rodrik, 2011; Castro, 2006). Por sua vez, o aspecto financeiro, além de contemplar empréstimos emergenciais multilaterais voltados a garantir a estabilidade cambial, passava a contar com uma ordem fortemente restritiva aos fluxos internacionais de capital ${ }^{143}$. Ainda neste aspecto, emergiu "uma consciência baseada no pressuposto de que a disponibilidade de capital era a variável independente do crescimento das economias." (Sato, 2012, p. 135) Tal visão contribuiu para que a cooperação financeira internacional se voltasse a fluxos de ajuda externa. Desponta, no campo financeiro, o sentido de que os Estados passaram a se posicionar como controladores e direcionadores das finanças internacionais no pós-segunda guerra, em marcado contraste com o que prevalecia sob o POI, ou seja, a noção de que os fluxos transfronteiriços de capital devessem ser privadamente orientados.

A presente subseção está organizada de forma a, primeiramente (3.2.3.1), dirigir-se à sensibilidade econômica predominante na época, o liberalismo assistido que, como se disse, tem forte tonalidade keynesiana. Pode-se mesmo pensá-lo como projeção internacional do que

\footnotetext{
${ }^{142}$ Vide seção 2.2 .

143 Uma abordagem detalhada dos aspectos monetários e financeiros da ordem de Bretton Woods pode ser encontrada em Eichengreen (2008, p. 91-133). Em síntese, segundo o autor, o sistema monetário de Bretton Woods pretendia a estabilidade das moedas por meio de pegged rates. As moedas eram vinculadas ao dólar, e este, ao ouro, ao preço estatutário fixo de $\$ 35$ a onça. O cenário inicial do sistema foi o de uma Europa deficitária em relação aos EUA na balança de pagamentos. Nesse contexto, a ajuda externa por meio do Plano Marshall foi fundamental para permitir a preservação da paridade entre as moedas, dadas às pressões por desvalorização representadas pelo déficit de comércio europeu. Os controles de capital foram centrais para a manutenção do sistema, diminuindo a volatilidade e dando fôlego aos governos nos contextos de pressão por depreciação de moedas. No entanto, esse mecanismo apenas ganhava tempo, não eliminando as razões subjacentes, determinantes da necessidade de ajuste. $\mathrm{O}$ aumento da mobilidade de capital representado pelo crescimento das multinacionais e incrementos tecnológicos na comunicação comprometeram os controles governamentais e colocaram em xeque a ordem de Bretton Woods. A sobrevivência do sistema passou a depender da cooperação internacional no Atlântico Norte - incentivada pelo contexto da Guerra Fria -, até que as pressões para a desvalorização do dólar tornaram-se insustentáveis; o preço do ouro no mercado (\$40) distanciou-se do preço nominal em dólar, e eliminou-se o lastro em ouro do dólar em 1971 (após suspensão desde 1968), visto que a conversibilidade não poderia mais ser garantida. A partir disso, houve fuga do dólar, que se depreciou ainda mais. O sistema, na prática, permitiu a conversibilidade das moedas em taxas estáveis entre 1959 e 1970.
} 
as políticas keynesianas representaram para o plano doméstico. Num segundo momento (3.2.3.2), destacam-se aspectos da cooperação internacional monetária e financeira, em especial ressaltando a importância dos controles de capital na ordem de Bretton Woods, e sua relação com a expansão doméstica de políticas redistributivas. Por meio do destaque dos elementos abordados em 3.2.3.1 e 3.2.3.2, será possível realizar marcado contraste tanto com a ordem econômica internacional do POI, que precedeu a de Bretton Woods, como também, posteriormente, com aquela que se formaria a partir dos anos 1970, instruída pelo neoliberalismo. Em outros termos, trata-se de destacar o papel das ideias e das instituições, sobretudo no campo das finanças ${ }^{144}$.

\subsubsection{Liberalismo assistido: multilateralismo e estabilidade doméstica}

Uma forma de compreender os regimes internacionais consiste em focalizar suas instituições formais e informais. Para John Gerard Ruggie, no entanto, a compreensão adequada dos regimes precisa abarcar também a sua "gramática generativa"145. Trata-se de elemento ligado às ideias ou sensibilidades predominantes em determinado momento, ou "princípios subjacentes à ordem e ao sentido que moldam a maneira como [regimes internacionais] se formam e se transformam." Ruggie compara regimes internacionais à linguagem, e as unidades que integram tais regimes a "falantes de uma língua comum" (Ruggie, 1982, p. 380). Como decorrência, para compreender a ordem de Bretton Woods, é necessário caracterizar sua linguagem econômica fundamental.

Para Ruggie, os regimes são decorrências da internacionalização da autoridade política (1982, p. 380). O autor atribui à expressão "autoridade política" certo sentido que não se confunde meramente com a estrutura de poder existente no mundo - como a hegemonia, bipolaridade ou multipolaridade -, embora este aspecto não deixe de ser relevante. Mais do que o poder por si só, autoridade política implica a fusão entre o poder e o propósito social legítimo (1982, p. 382; cf. Lake, 2010). É justamente no papel do propósito social legítimo que reside a importância da "gramática generativa" dos regimes internacionais, anteriormente mencionada.

\footnotetext{
${ }^{144}$ Esta abordagem se justifica, ainda, pelo objetivo de evitar repetições na caracterização da ordem de Bretton Woods. No capítulo anterior, a seção 2.2 descreveu contornos da cooperação internacional nos campos comercial (tentativa da OIC e estruturação do GATT), monetária (FMI) e financeira (Banco Mundial e Plano Marshall).

${ }^{145} \mathrm{O}$ ponto é análogo à caracterização que Duncan Kennedy (2006) faz a respeito de "langue", abordada no capítulo 1.
} 
As concepções sobre o modo adequado de configurar as relações entre Estado e sociedade são componentes definidores do propósito social tido por legítimo em um determinado momento (1982, p. 413). A gramática do liberalismo clássico consolida como legítima a atuação estatal voltada para permitir máxima extensão das forças de mercado, ou seja, da atuação privada, sendo ilegítimo restringi-las em sua atuação econômica (1982, p. 381-2). De modo associado a essa gramática, o regime do POI incorporou "pressuposições particulares" a respeito do comportamento do Estado em sua relação com a sociedade. A linguagem da política monetária só continha palavras para igualá-la à preservação da paridade da moeda local em ouro, ao passo que a postura aceita para o comportamento estatal em uma economia concebida como "autoequilibrante” era a de abstenção (Ruggie, 1982, p. 389). Estavam de fora desta gramática a orientação da política monetária para incremento do nível de atividade econômica ou a intervenção estatal em busca do pleno emprego.

No cenário do entreguerras, a noção de propósito social legítimo transformou-se. $\mathrm{O}$ Estado passaria a assumir "responsabilidade direta pela segurança social e estabilidade domésticas" (1982, p. 388), em linha tanto com as mudanças internas no cenário político quanto com as prescrições do pensamento keynesiano. De modo correspondente, houve recurso generalizado a "formas cada vez maiores de intervenção na economia doméstica para afetar os níveis de preços e emprego, e para protegê-los contra fontes externas de distúrbios.” (1982, p. 390)

A gramática generativa da ordem de Bretton Woods é diferente, portanto, daquela do POI. Não mais o liberalismo clássico, mas um liberalismo modificado, que concebe certa presença ativa do Estado na economia como necessária para o funcionamento do capitalismo e sua orientação a objetivos domésticos de estabilidade e pleno emprego, associados ao welfare state:

elaborar uma moldura que resguardasse e mesmo auxiliasse a busca por estabilidade
doméstica sem, ao mesmo tempo, disparar as consequências externas mutuamente
destrutivas que contaminaram o período do entreguerras. Essa era essência do
compromisso do liberalismo assistido (embedded liberalism): diferentemente do
nacionalismo econômico dos anos trinta, seria de caráter multilateral; diferentemente
do liberalismo do padrão ouro e do livre comércio, seu multilateralismo seria
baseado no intervencionismo doméstico. (Ruggie, 1982, p. 393 ) Multilateralismo e estabilidade doméstica passavam a ser concebidos complementarmente, de modo que "o movimento rumo à maior abertura da economia internacional" foi atrelado a "medidas concebidas para proteger a economia doméstica de 
distúrbios externos.” (1982, p. 405) ${ }^{146}$ Esta era a nova concepção de propósito social legítimo, componente da autoridade política internacionalizada que moldou a ordem de Bretton Woods. Na perspectiva de Dani Rodrik, o novo regime incorporou um "delicado compromisso": "permitir disciplina internacional suficiente e progresso rumo à liberalização para assegurar comércio mundial vibrante, mas dar bastante espaço aos governos para que respondessem às necessidades sociais e econômicas domésticas.” (Rodrik, 2011, p. 69) Ainda segundo o autor, a ordem de Bretton Woods significava que os objetivos da política doméstica, como "pleno emprego, crescimento econômico, equidade, seguro social, e o welfare state" assumiam prioridade sobre a "política econômica internacional", e não o contrário. Consoante a isso, afirma que o "objetivo seria a globalização moderada, não a hiperglobalização." (Rodrik, 2011, p. 70; cf. seção 3.4)

O sentido de globalização moderada, associado ao liberalismo assistido, favorecia a criação de meios para expansão do comércio internacional. O GATT foi a principal instituição envolvida nesse propósito. Apesar de favorecer a liberdade de comércio, o regime continha, como se viu, exceções (como os temas de agricultura e serviços, que não chegaram a ser abrangidos), válvulas de escape para a proteção comercial (como a facilidade na adoção de medidas antidumping e de salvaguardas) e um sistema de solução de controvérsias que poderia ser bloqueado por qualquer membro da organização (dado que exigia unanimidade para aprovação dos relatórios dos painéis). "Na realidade, o comércio tornou-se (e permanceu) livre somente nos aspectos em que apresentava pouca ameaça às instituições domésticas, às preferências distributivas, ou a valores.” (Rodrik, 2011, p. 75) Ainda segundo Rodrik, o "propósito do GATT nunca foi maximizar o livre comércio. Foi conseguir a maior quantidade de comércio compatível com diferentes nações seguindo cada qual o seu caminho [different nations doing their own thing]." (2011, p. 75)

A abertura comercial foi acompanhada da cooperação monetária e financeira voltada tanto para prover as bases de estabilidade cambial de que dependia a expansão do comércio, quanto a fornecer a liquidez (ou seja, de disponibilidade de recursos financeiros) necessária à reativação de economias (sobretudo europeias) no pós-guerra ${ }^{147}$. Como observado no capítulo

\footnotetext{
${ }^{146}$ Na perspectiva de Dani Rodrik, o "[m]ultilateralismo significava que a aplicação de regras e os sistemas de crenças funcionariam por meio de instituições internacionais - o Fundo Monetário Internacional, o Banco Mundial e o GATT - ao invés de por exercício puro de poder ou imperialismo." Como ressalva, afirma que as instituições multilaterais "nunca se tornaram verdadeiramente autônomas dos Estados Unidos ou de outras destacadas potências econômicas, mas tampouco foram meras extensões dessas potências." (Rodrik, 2011, p. 70) ${ }^{147}$ Vale lembrar que o provimento internacional de liquidez inicialmente foi pensado como função do Banco Mundial (ou, à época, Banco Internacional para Reconstrução e Desenvolvimento). Nos primeiros anos da ordem de Bretton Woods, no entanto, o Banco Mundial teve importância reduzida em face da prioridade conferida pelos Estados Unidos à canalização de recursos à Europa via Plano Marshall. Vide seção 2.2.
} 
2, a cooperação cambial implicou o estabelecimento de paridades fixas, porém ajustáveis, entre as moedas nacionais. A conversibilidade de todas as moedas estava ancorada no dólar, por sua vez conversível em ouro. A sustentação das paridades fixas já não se daria segundo as regras do POI, que exigiriam ajustes automáticos a partir da livre movimentação transfronteiriça do ouro. Esse esquema teria inviabilizado políticas relacionadas ao welfare state e à estabilidade doméstica, como se verá adiante (3.2.3.2). Ao invés, a estabilidade cambial do padrão dólar-ouro foi fundada, por um lado, em empréstimos voltados a sanar desequilíbrios nos balanços de pagamentos dos Estados que passavam por dificuldades, permanecendo, paralelamente à estrutura de empréstimos multilaterais, a possibilidade de reajustar a relação de câmbio entre a moeda nacional e o dólar para refletir a situação da balança de pagamentos. Ou seja, admitia-se que a paridade fosse modificada para dar espaço à autonomia doméstica necessária a políticas redistributivas, em linha com o propósito do liberalismo assistido de conciliar o multilateralismo com a estabilidade doméstica. A estabilidade cambial era ainda fundada, por outro lado, na presença de controles de capital. Como Dani Rodrik caracteriza, a ordem de Bretton Woods refletiu a noção de que o “comércio, e não as finanças de curto prazo, necessitavam de promoção.” (Rodrik, 2011, p. $97)^{148}$

Essa descrição de como a ordem de Bretton Woods favoreceu a busca conciliada de multilateralismo e estabilidade doméstica levanta a necessidade de fazer ao menos duas ressalvas importantes. Em primeiro lugar, no que diz respeito à cooperação multilateral, não se pode pensar que os Estados se movessem de maneira perfeitamente concertada. Como Ruggie aponta, permaneceram “enormes diferenças” entre os países a respeito de que políticas e arranjos institucionais, tanto domésticos quanto internacionais, seriam condizentes com o objetivo do multilateralismo (1982, p. 393). Em segundo lugar, sobretudo no que diz respeito à orientação da cooperação internacional em favor da estabilidade doméstica dos países, os ares do liberalismo assistido não foram "completamente estendidos aos países em desenvolvimento", num contexto em que a postura do FMI em relação a estes favorecia "medidas ortodoxas de estabilização" (1982, p. 413), e em que as regras do GATT "beneficiavam relativamente poucos dentre eles.” (1982, p. 414)

\footnotetext{
148 Eric Helleiner aponta que Keynes e White compartilhavam a "crença de que uma ordem financeira internacional liberal não era compatível com um sistema de taxas de câmbio com paridades estáveis e com um sistema mais liberal de comércio internacional" (Helleiner, 1994b, p. 35). Helleiner afirma, ainda, que "as finanças ocuparam certo status de segunda classe na visão do pós-guerra de uma ordem econômica internacional liberal." (Helleiner, 1994a, p. 165)
} 
Mesmo com essas ressalvas ou limitações, o liberalismo assistido deixou sobre a ordem econômica internacional a marca do gerenciamento estatal da economia. Trata-se de componente da gramática keynesiana que se faria presente, em alguma medida, em todos os campos da cooperação econômica internacional: comércio, moeda e finanças.

Os controles de capital, característicos da ordem de Bretton Woods, são fortes exemplos da importância que o gerenciamento estatal da economia assumiu no período do pós-guerra, em linha com a sensibilidade prevalente do liberalismo assistido. Eles foram componentes fundamentais da autonomia doméstica vinculada à adoção de políticas redistributivas, segundo o modelo do welfare state. Configuram um elemento concreto de uma modalidade de estruturação da cooperação econômica internacional essencialmente distinta do POI ou da hiperglobalização favorecida pelo ideário neoliberal.

3.2.3.2 Aspectos da cooperação monetária e financeira internacional de Bretton Woods e relação com políticas domésticas redistributivas

Barry Eichengreen afirma que os fluxos transnacionais de capital privado existentes durante a ordem de Bretton Woods se deram apesar das instituições da cooperação econômica internacional, e não em razão delas (2008, p. 91). A afirmação introduz a descrição do cenário monetário e financeiro do pós-guerra, em que os governos mantiveram controles sobre a movimentação de capital ${ }^{149}$. Tais controles eram essenciais à manutenção de taxas de câmbio relativamente estáveis, na ausência de um mecanismo automático de ajuste, como aquele do POI (2008, p. 94). "Seria difícil descrever exageradamente a força do consenso em favor dos controles de capital no período posterior à Segunda Guerra Mundial.” (Rodrik, 2011, p. 95) O acordo constitutivo do FMI reconheceu explicitamente a licitude do emprego do controle de capitais pelos Estados. A maior parte dos países europeus valeu-se dos controles até meados da década de 1980. A exceção consistiu nos Estados Unidos, que não adotaram controles de capital até a década de 1960, e em todo caso não os mantiveram por muito tempo (Rodrik, 2011, p. 99).

\footnotetext{
${ }^{149}$ Dani Rodrik explica que a imposição de controles de capital restringe a capacidade dos residentes de investir em bolsas de valores estrangeiras e de adquirir ativos financeiros estrangeiros, bem como limitações severas ao acesso de bancos e firmas a empréstimos obtidos no exterior. Além disso, os governos "tipicamente impunham regulamentos intricados - tributos, requisitos para licenciamento, proibições diretas - que tornavam o ato de mover dinheiro pelas fronteiras do país um pesadelo. A maior parte dos países era receptiva às empresas multinacionais e aos investimentos de longo prazo, mas os empréstimos de curto prazo e os fluxos de portfolio (alcunhados de 'hot money') eram vistos de modo diferente, como fontes de instabilidade financeira e não de crescimento econômico." (Rodrik, 2011, p. 90)
} 
Os controles de capital são o aspecto mais evidente da intenção de colocar a liberdade financeira em lugar subsidiário. Não se desejava que fluxos volumosos e repentinos de capital pudessem ameaçar a paridade entre as moedas e, com ela, o comércio internacional. Se há duas liberdades favorecidas neste período, elas são a de comércio e de adoção de políticas públicas de caráter redistributivo, mas não a liberdade financeira. Vale lembrar que, durante a primeira fase do POI (1870-1914), a mobilidade do capital não entrou em conflito com a estabilidade cambial porque não havia pressões domésticas relevantes para desviar os governos do compromisso prioritário com a conversibilidade das moedas nacionais em ouro a paridades fixas, que representava, simultaneamente, a adesão ao modelo de gestão estatal de orçamento equilibrado e não intervenção na esfera econômica. No cenário do entreguerras e de Bretton Woods, a mobilidade do capital entrava em choque não apenas com a estabilidade do câmbio, mas também com as políticas domésticas de caráter redistributivo. Afinal, ela "impede que as nações adotem políticas monetárias e fiscais que difiram daquelas em outras economias, e portanto minam a condução de políticas apropriadas à economia doméstica." (Rodrik, 2011, p. 107) Tanto Keynes quanto Harry Dexter White - os principais formuladores dos acordos de Bretton Woods - estavam convencidos que o "o novo welfare state tinha que ser protegido da fuga de capital (capital flight) iniciada por 'razões políticas' ou induzida pelo desejo de evadir o 'fardo da legislação social'.” (Helleiner, 1994b, p. 34)

O sistema de Bretton Woods se diferenciava do POI, no entanto, não apenas em razão da adoção dos controles de capital. O aspecto da estabilidade cambial pode parecer semelhante ao que havia no POI: ambos tinham a pretensão de fixar as paridades, de alguma forma, em relação ao ouro, embora o regime de Bretton Woods posicionasse o dólar como lastro intermediário. Ainda assim, as taxas cambiais fixas (pegged rates) do pós-segunda guerra eram ajustáveis, ou "fixas, porém flexíveis". Ao passar por dificuldades no balanço de pagamentos - o que se conhecia como "desequilíbrio fundamental" -, os países poderiam reajustar as taxas de câmbio junto ao FMI (Eichengreen, 2008, p. 92). No POI, não havia esta possibilidade. A resposta ao "desequilíbrio fundamental" consistia em permitir a livre entrada e saída de ouro até que a relação de câmbio voltasse à paridade anterior ao desequilíbrio: uma solução purgativa. Considerando que a existência de controles de capital seja a primeira diferença em relação ao POI, a relativa flexibilidade das pegged rates de Bretton Woods é a segunda.

Outra diferença consiste nos papéis desempenhados pelo FMI, tanto no sentido de monitoramento das políticas nacionais como, principalmente, de concessão de financiamentos a países em risco de alteração cambial em virtude de déficits na balança de pagamentos 
(Eichengreen, 2008, p. 91). "Os recursos do FMI forneciam uma linha adicional de defesa para países que tentavam manter paridades cambiais fixas [pegged exchange rates] face a pressões de mercado." (2008, p. 92) À época do POI, o regime internacional monetário baseava-se em instituições informais. Não havia qualquer organização internacional encarregada de supervisionar sua operação e de prestar auxílio nos momentos de crise. Vale lembrar que a haute finance supervisionou de fato o funcionamento do POI, e que no primeiro período deste regime os fluxos privados especulativos internacionais tendiam a assumir caráter estabilizante, indo ao auxílio dos governos em dificuldades cambiais. No entanto, este auxílio baseado na livre atuação das forças de mercado vinha ao preço da impossibilidade de adotar medidas que minassem a confiança da haute finance na segurança e rentabilidade dos investimentos.

Na caracterização feita por Dani Rodrik, os regimes monetário e financeiro de Bretton Woods refletiram o princípio de que os Estados precisavam de espaço para gerenciar suas economias nacionais rumo ao pleno emprego e a ritmos de crescimento adequados. Trata-se do espaço para formulação de políticas (policy space). Em Rodrik, o policy space encontra-se associado à noção de política democrática e em contraste às medidas que são adotadas em função de constrangimentos oriundos das finanças internacionais, de outros elementos da cooperação econômica internacional e de soluções tecnocráticas. Pode-se interpretar que, no contexto do POI, não havia policy space para a adoção de políticas redistributivas, dados os encadeamentos entre a estabilidade cambial e o comportamento das forças privadas - e desimpedidas - nos mercados financeiros internacionais. Para Rodrik, a existência dos controles de capital, do provimento de empréstimos emergenciais do FMI para auxílio dos países em dificuldade no balanço de pagamentos e a possibilidade de reajustar as relações de paridade entre as moedas no evento de "desequilíbrio fundamental" eram elementos da cooperação monetária e financeira internacional que favoreciam a existência de policy space no pós-guerra (2011, p. 98). Nesse sentido, afirma que:

Se as projeções de crescimento e emprego de um país entrassem em conflito com
seus pagamentos externos, mesmo depois de recorrer a controles de capital e a
financiamentos do FMI, a incompatibilidade poderia ser removida pelo ajuste da
taxa de câmbio, ao invés de deixar que a economia local sofresse. "Fixas, mas
ajustáveis" era um novo conceito na política cambial. O compromisso foi pensado
para prover estabilidade ao comércio internacional, mas não à custa de danos ao
emprego e crescimento domésticos. (Rodrik, 2011, p. 98)

A descrição acima é sugestiva de que os regimes internacionais de moeda e finanças de Bretton Woods encontravam-se relacionados ao propósito de resguardar o espaço para que os Estados pudessem adotar medidas de política monetária e fiscal de caráter redistributivo, 
de modo condizente com o modelo de welfare state. Nesse sentido, a cooperação econômica internacional encontrava-se estruturada de modo a refletir os anseios políticos de massas urbanas assalariadas e da coalizão que a ela correspondia - industrialistas, organizações trabalhistas e funcionários públicos de mentalidade keynesiana. Feita esta relação, é importante compreendê-la: por que o incentivo aos controles cambiais, as paridades fixas mas ajustáveis entre as moedas nacionais e os empréstimos emergenciais do FMI, no plano da cooperação internacional, favoreceriam as políticas relacionadas ao welfare state?

No que diz respeito aos controles de capital, especificamente, Eric Helleiner aponta quatro elementos que ressaltam sua instrumentalidade para o modelo do welfare state (Helleiner, 1994a, p. 163-4).

Primeiramente, “os controles de capital eram necessários para proteger os novos mecanismos de planejamento macroeconômico, desenvolvidos nos anos 1930, de movimentos financeiros especulativos que poderiam causar desequilíbrio no sistema." Em especial, as políticas redistributivas e de incentivo ao pleno emprego tendiam a ser favorecidas - segundo o esquema keynesiano - por uma taxa de juros relativamente baixa, que incentivasse o consumo e o investimento produtivo. Num cenário de alta mobilidade de capital, os países não têm plena autonomia de fato para fixação da taxa de juros local em função de objetivos políticos. Baixar as taxas de juros num cenário de capital internacional volátil significa ter que conviver com o desinvestimento, ou fuga de capital, que tenderá a migrar em busca de maiores patamares de rentabilidade. Nesse sentido, a existência de controles de capital propiciava a liberdade de fixar a taxa de juros segundo os objetivos da política doméstica, "sem referência às taxas prevalentes em outros pontos do mundo" (Helleiner, 1994a, p. 164), imunizando o welfare state do perigo representado pela fuga de capital.

O segundo elemento da relação entre controles de capital e welfare state pode ser encontrado nas implicações que os gastos governamentais têm para a política tributária. $\mathrm{O}$ Estado consegue realizar despesas mediante fundos obtidos pela tributação ou pelo endividamento (ou ainda, num cenário de moeda de curso forçado, pela impressão de dinheiro novo). Com o aumento dos gastos, há pressões econômicas para que a tributação e o endividamento aumentem. No que diz respeito especificamente ao aspecto da tributação, as perspectivas de carga tributária maior podem motivar pessoas e empresas a deslocar fundos ao exterior (arbitragem tributária). Diante desse risco, os controles de capital tornavam-se necessários para evitar a evasão tributária internacional (Helleiner, 1994a, p. 164), contribuindo para manter as bases orçamentárias de sustentação do welfare state. 
O terceiro elemento remete ao aspecto da competição institucional. As modulações do formato das instituições em diferentes países resultam em graus variados de atratividade aos investimentos. Diante disso, a mobilidade do capital tende a incentivar certa desregulamentação financeira competitiva por parte de países desejosos de atrair capital novo. O modelo do welfare state implicava maior densidade de regulamentação financeira doméstica "para facilitar o planejamento industrial e macroeconômico". Esses objetivos seriam "erodidos se os poupadores e tomadores de empréstimos domésticos tivessem acesso a mercados financeiros no exterior." (Helleiner, 1994a, p. 164) Os controles de capital eram necessários para evitar que as regulações financeiras domésticas fossem contornadas, ou seja, para evitar fluxos rumo a mercados menos regulados no exterior (arbitragem regulatória).

O último dos motivos levantados por Helleiner refere-se à necessidade de evitar a fuga do capital de curto prazo (hot money) induzida por "razões políticas" ou pelo "desejo de influenciar a legislação" (Helleiner, 1994a, p. 164).

Ao lado dos controles de capital, os empréstimos do FMI também desempenhavam importante papel para o welfare state. O contraste com o POI ajudará a compreender o ponto. Sob este regime, a manutenção do orçamento equilibrado era prioridade da política físcal. Com investidores tranquilizados quanto à segurança e a rentabilidade de seus investimentos, o Estado evitava deslocamentos massivos de ouro que comprometessem a paridade da moeda local em relação a seu lastro metálico.

No cenário de Bretton Woods, as prioridades da política fiscal eram o pleno emprego e o estímulo à atividade econômica, e não o equilíbrio orçamentário. Os desequilíbrios nas contas públicas geram pressões inflacionárias. A inflação é a depreciação da moeda, que equivale ao aumento contínuo e generalizado dos preços de bens e serviços. Como consequência, quando uma moeda passa por processo inflacionário, a tendência é a de que o câmbio se deprecie em relação à moeda de referência que, no caso de Bretton Woods, era o dólar. Para evitar que o modelo de política fiscal do welfare state comprometesse o regime de paridades cambiais da ordem do pós-guerra, o FMI concedia empréstimos emergenciais, de curto prazo, para Estados que sofriam pressões momentâneas pela depreciação do câmbio. Nesse sentido, pode-se compreender a afirmação de Michael Webb de que, dado o cenário de baixa mobilidade de capital em virtude dos controles estatais nas décadas de 1950 e 1960, os desequilíbrios em balanças de pagamentos criados por políticas monetárias e fiscais autonomamente definidas podiam ser endereçados por medidas como empréstimos emergenciais do FMI, além de por intervenções coordenadas de bancos centrais nos mercados de divisas internacionais (Webb, 1994, p. 185). 
3.2.4 Algumas implicações normativas e jurídicas de ideias, práticas e instituições informadas pelo liberalismo assistido

Dadas suas interrelações, é importante compreender as repercussões que as ideias e instituições econômicas do período abordado na seção 3.2 tiveram sobre o direito. Duncan Kennedy se refere a este momento como segunda globalização do direito e do pensamento jurídico, que foi simultaneamente uma crítica à primeira globalização e um projeto de reconstrução inspirado no "social" (2006, p. 37).

A visão do social tinha por base a percepção de interdependências na sociedade e entre os diferentes setores que formam uma economia moderna. A afirmação das interdependências pode ser lida como base para deslocar o primado do indivíduo (fundado na noção de harmonia natural dos interesses) e passar a associar direito a pluralidades de indivíduos, como classes sociais (2006, p. 42). Um mote jurídico em ascensão seria a noção de "interesse público", levantado como base para coordenar as diferentes "atividades interdependentes de modo a maximizar o bem-estar social." Como consequência dessa segunda globalização, ganharam prestígio o direito público em geral, abrangendo direito do trabalho, direito administrativo e modalidades de "legislação social" (Kennedy, 2006, p. 42) associadas ao welfare state, como seguridade social, com "titularidades baseadas em necessidades" (2006, p. 54). Os motivos de comunidade e solidariedade, de certo modo, passavam a ocupar o lugar, nesta langue, que o interesse material individual, associado ao liberalismo econômico, havia conseguido atingir no pensamento e nas instituições jurídicas daquilo que Castro (2012) se refere como direito burguês.

No campo da estruturação jurídica da ordem econômica, a segunda globalização refletiu-se na concepção de uma "economia de mercado nacional e internacionalmente regulada" que a ordem de Bretton Woods promoveu. Nesse sentido, favoreceu o "programa de reforma social progressiva de reestruturação das titularidades como base para uma economia capitalista mista altamente regulada que perseguia uma estratégia de paz social por meio do desenvolvimento econômico.” (Kennedy, 2006, p. 57) A reestruturação de titularidades pode ser lida como correspondente à passagem da ênfase em direitos individuais para direitos sociais e econômicos. Nesse projeto, as ideias de Keynes foram importantes:

A contribuição de Keynes nessa área consistiu em mostrar que a política fiscal e monetária poderia funcionar racionalmente de modo "anticíclico", contrabalanceando, por meio da ação estratégica centralizada, a lógica capitalista e individualista de bolha seguida de estouro [boom followed by bust], e assim beneficiando a todos na sociedade. Mas as políticas fiscal e monetária também significavam gastos deficitários em períodos de contração econômica, e portanto 
abriram a possibilidade de financiar todo o programa dos reformadores sociais nos cruciais períodos em que historicamente eles haviam sido forçados a interromper suas atividades. (Kennedy, 2006, p. 57)

Analisando este período de segunda globalização, é possível notar que ele foi fértil em interações entre instituições jurídicas e econômicas. $O$ próprio desmantelamento das condições de sustentação do POI no entreguerras esteve associado à expansão de direitos políticos. A expansão do direito ao voto está na base da formação das democracias de massa. O uso de direitos de representação política está associado à participação de partidos trabalhistas na elaboração e contestação das políticas de governo, canalizando novos interesses como o pleno emprego à pauta da atenção pública. Notadamente, estes aspectos jurídicos estiveram envolvidos no choque com a priorização da estabilidade monetária que o POI exigia dos Estados.

Instituições jurídicas também estiveram na base da erosão da primazia do pensamento liberal. Vale recordar que uma das razões para o desprestígio da ortodoxia clássica no cenário do entreguerras foi a sua incapacidade de responder às demandas práticas por soluções contra a depressão econômica. Um dos principais pontos cegos da economia a esse respeito veio a ser a concepção teórica que simplesmente presumia o equilíbrio econômico de pleno emprego, negando o desemprego (salvo o voluntário e o friccional). Na base dessa negação estava o raciocínio de que o desemprego não poderia existir porque a remuneração da mão de obra se ajustaria automaticamente às variações em sua demanda. A flexibilidade da remuneração do trabalho era presumida. No entreguerras, porém, legislações trabalhistas e a ascensão do direito do trabalho - correspondentes a pressões sociais via greves, protestos, opinião pública e urnas - enrijeceram o preço do "fator trabalho" pela positivação do direito à irredutibilidade salarial, entre outros. O liberalismo econômico não conseguiu prover soluções a um cenário empírico transformado, de convivência com o desemprego crônico, perdendo lugar para concepções protokeynesianas e keynesianas de políticas econômicas.

As novas concepções econômicas corresponderam, como indicado anteriormente, ao deslocamento da primazia dos direitos individuais aos direitos sociais e econômicos. Não se pode deixar de considerar a existência da tensão entre as duas categorizações. Lendo-se Keynes com um olhar jurídico, é possível percebê-las. Tome-se, por exemplo, o aspecto do direito individual à propriedade privada. A lógica liberal não apresentava qualquer obstáculo à sua fruição por aqueles que já a detinham, nem à sua acumulação irrestrita. A autonomia privada era uma esfera individual em que o Estado não deveria interferir. Em Keynes, em contraste, a possibilidade de acumulação irrestrita da propriedade privada recebe um ataque 
por meio da função psicológica da propensão ao consumo. Recorda-se, aqui, que tal função afirma que a propensão a consumir diminui na proporção que a renda aumenta. Esta é a base para que Keynes perceba a ameaça da concentração de renda para o nível de atividade econômica, que pode colocar em ação a espiral viciosa que leva à depressão. Sugere, então, medidas de política fiscal de redistribuição de renda que podem assumir a forma de direitos à seguridade social, renda mínima, seguro-desemprego entre outros. No aspecto tributário, Keynes recomenda dirigir a legislação à exação progressiva focada na renda ao invés do consumo. Ainda no campo tributário, pode-se considerar a limitação ao direito de propriedade privada que decorre da limitação keynesiana de tributação progressiva da herança. É possível agrupar estes exemplos quanto ao sentido geral que assumem em relação ao direito de propriedade privada, e lê-los como representativos da substituição de sua inviolabilidade pelo Estado (resguardo da autonomia individual) por ações de disciplina estatal dos rumos econômicos adequados para a propriedade individual que correspondem, no direito, à afirmação da "função social” da propriedade.

Além desses elementos, não se deve esquecer que a promoção de direitos sociais (políticas redistributivas) implica pretensões a parcelas do orçamento público, composto em larga medida pela tributação. Em última análise, portanto, a afirmação desses direitos tem como contrapartida aumentos na carga tributária que atinge a propriedade privada. Em conexão a este aspecto, a possibilidade de lançar mão de déficits orçamentários esteve na base dos projetos de expansão de direitos sociais associados ao welfare state. A afirmação jurídica desses direitos se deu num contexto de transição do formato de política físcal considerado apropriado. Se antes o mote era orçamentos equilibrados, com o advento da ordem de Bretton Woods, os Estados passam a contar com estruturas de cooperação econômica internacional desenhadas para permitir a convivência entre desequilíbrios orçamentários e um regime global de moedas conversíveis a paridades fixas, porém ajustáveis. Como Rodrik (2011) enfatiza, tratou-se de arranjo internacional que deu às economias avançadas espaço para aprofundar o modelo de welfare state, e aos países em desenvolvimento, para perseguir estratégias heterodoxas de industrialização (via substituição de importações ou modelos voltados à exportação). Num caso como no outro, certa leitura jurídica é possível: a cooperação econômica internacional foi estruturada de modo a dar curso à atuação expandida das formas do direito público.

Regressando ao tema anterior, algo semelhante ao ocorrido com a propriedade privada pode ser afirmado em relação aos contratos, no sentido de que a autonomia privada é relativizada em função da presença de conteúdos elaborados segundo o interesse público. A 
negociação privada não mais pode livremente determinar todos os aspectos, por exemplo, do contrato de trabalho, porque certos conteúdos encontram-se previamente determinados por processos de negociação de caráter público (legislativos, administrativos e judiciais). (cf. Castro, 2011; 2014a)

Marcus Faro de Castro aponta, porém, que o momento aqui indicado como correspondente à segunda globalização também representou a perda da capacidade do direito de prover as formas para a organização do todo social. Nesse sentido, a posição do direito foi subsidiária às formulações intelectuais provenientes da macroeconomia, que proveu os materiais intelectuais (e consequências institucionais correlatas) para reorganização da economia e da sociedade. O papel do direito na transformação das instituições e práticas do período foi complementar, e não de coordenação direta, que passou a ser feita "por meio do emprego de categorias macroeconômicas." (Castro, 2012, p. 214) Pode-se interpretar que as formas jurídicas abrigaram conteúdos provenientes de outras esferas de saber. Ou seja:

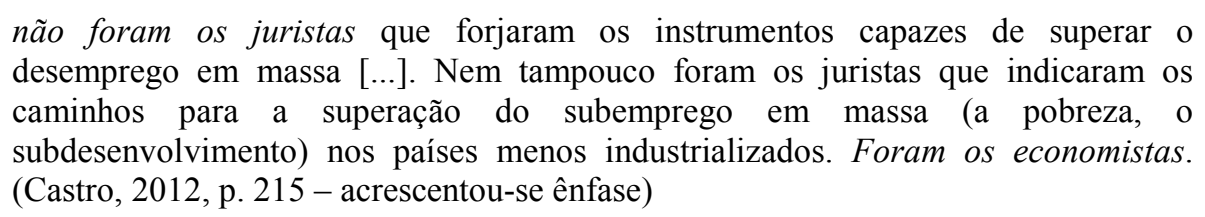

\subsection{Neoliberalismo}

$\mathrm{Na}$ década de 1960, iniciou-se a transição na ordem monetária e financeira internacional rumo à reemergência das finanças globais (Helleiner, 1994b, p. 82, 99). As décadas de 1970 e 1980 já caracterizariam um cenário bastante transformado. Da autonomia doméstica baseada na cooperação cambial e nos controles de capital, típicos da ordem de Bretton Woods, passou-se a maiores patamares de mobilidade e volatilidade do capital internacional.

Diversos fatores concretos estiveram implicados na transição. No aspecto da cooperação monetária e financeira, foram particularmente relevantes: (i) a ruptura do padrão dólar-ouro pelos Estados Unidos, em 1971, com o abandono da conversibilidade da moeda norte-americana; (ii) a promoção do mercado de eurodólares desde a década de 1960 por parte dos Estados Unidos e da Grã-Bretanha, com menor densidade de regulamentação; (iii) o 
incremento tecnológico ${ }^{150}$ que, refletindo-se sobre as telecomunicações, proveu maior agilidade às transações financeiras internacionais (era dos satélites) e, ainda, (iv) o ganho de importância das corporações transnacionais e de suas movimentações comerciais e financeiras entre pontos diversos do globo.

Ao lado destes fatores, aspectos ideacionais desempenharam relevante papel. Um ideário de contestação ao que era percebido como "coletivismo" - e o liberalismo keynesiano enquadrava-se aqui por seu apoio à redistribuição de renda, ao planejamento econômico e, de modo geral, ao welfare state - manteve-se vivo desde o final da década de 1930. No cenário do pós-guerra, este ideário encontraria voz por meio de associações transnacionais de intelectuais, a começar pela Mont-Pèlerin Society. Nela, nomes como Friedrich Hayek, Ludwig von Mises e Milton Friedman faziam o intercâmbio de ideias voltadas ao convencimento de elites políticas no sentido de promover a organização social em torno dos mercados. Estes intelectuais buscavam manter viva a "chama do liberalismo clássico", reeditando-o para uma nova realidade. A proposta de resgate envolvia aspectos de transformação e adaptação.

Embora o ideário neoliberal estivesse sendo assim gestado, foi com a conjuntura crítica dos anos 1970 que ele ascendeu à proeminência acadêmica e política. Nesta década, tornou-se comum, nas economias avançadas, a coexistência de altos níveis de inflação e baixo crescimento, acompanhado, ainda, por aumentos no desemprego. O cenário de estagflação implicou o descrédito do receituário keynesiano, disparando a procura por referenciais intelectuais alternativos para a orientação da economia. A resposta neoliberal veio na forma de aversão ao Estado, recomendando a redução de seu papel na economia, a desregulamentação da atividade econômica e a valorização dos mercados como "principal fonte de dinamismo para um novo ciclo de crescimento." (Sato, 2012, p. 167) Esta resposta encontrou guarida política em diversos pontos do mundo, consolidando-se com os governos de Margaret Thatcher, na Grã-Bretanha, e Ronald Reagan, nos Estados Unidos, que marcaram a década de 1980 .

A presente seção 3.3 narra, primeiramente, o momento formativo do ideário neoliberal, bem como a ocorrência de "conversões" a este ideário em contextos políticos domésticos, a exemplo do ocorrido na Grã-Bretanha, nos Estados Unidos e na Suécia (3.3.1). Aspectos da transformação na ordem econômica internacional são abordados em seguida. A

\footnotetext{
${ }^{150}$ Para Robert Guttmann, o "capitalismo dirigido pelas finanças”, que caracteriza o momento pós-Bretton Woods, experimentou a trasformação das finanças internacionais a partir de "uma combinação de desregulamentação, globalização e informatização.” (2008, p. 15)
} 
subseção 3.3.2 tem foco nos aspectos monetários e financeiros, tomando em perspectiva o fim do padrão dólar-ouro e os contornos principais das novas bases para a cooperação internacional em câmbio e finanças. Traz, ainda, exemplo contemporâneo de defesa intelectual da liberdade das finanças internacionais. A seu turno, a subseção 3.3.3 aborda aspectos do comércio internacional. Inicialmente, descreve a acentuação do protecionismo sob novas roupagens na década de 1970, que foi (tentativamente) respondido pela Rodada Tóquio do GATT. Em seguida, aborda o adensamento institucional do regime multilateral de comércio com a OMC e a liberalização de novos temas (já na década de 1990), que antes escapavam às regras do GATT. Por fim, tal qual foi feito na área de finanças, exemplifica uma posição intelectual contemporânea de defesa à liberdade comercial internacional e à atuação das corporações internacionais.

Antes de prosseguir, é apropriado explicar que as considerações jurídicas relacionadas à perspectiva econômica neoliberal não foram agrupadas em subseção separada neste capítulo, diferentemente da estrutura adotada para as seções 3.1 e 3.2. A opção é justificada pelas densas conexões entre esta perspectiva, a Análise Econômica do Direito e o Law \& Finance, que integram o debate contemporâneo sobre direito e economia. Por isso, entendeuse mais adequado apresentar as pontes entre ideias e instituições econômicas e jurídicas do contexto do neoliberalismo nas seções 4.1 e 4.2, já que o capítulo 4 é dedicado a tal debate. Evidentemente, esta opção não trouxe prejuízo para destaques pontuais a elementos jurídicos ao longo da seção 3.3, nem à sua presença transversal ou subjacente na narrativa sobre ideias, práticas e instituições econômicas e da cooperação internacional.

\subsubsection{Aspectos do ideário neoliberal, sua ascensão e proeminência política}

O termo "neoliberalismo" foi cunhado pelo economista alemão Alexander Rüstow nos anos 1930 para "indicar a distinção entre o ethos pró-coletivista prevalente e os princípios do liberalismo tradicional." (Turner, 2008, p. 4) Nesse sentido, o projeto neoliberal trazia a proposta de "novo entendimento de Estado, economia e sociedade dentro da moldura ideológica balizada pelo liberalismo tradicional.” (2008, p. 4) Mais do que mero projeto de resgate dessas ideais, o neoliberalismo estruturou-se como reação ao que era percebido como “ameaça coletivista" (2008, p. 14).

Essa ameaça era identificada a partir de diversas fontes nos anos 1930. Algumas delas eram localizadas, mas poderiam se espalhar por revolução, como o projeto socialista em curso na União Soviética. Outras podiam propagar-se pela força ou anexação, como o projeto 
nacional-socialista na Alemanha. Por fim, havia a ameaça mais generalizada representada por novas modalidades de política econômica que viriam a associar-se ao nome de Keynes. Todas elas, em alguma medida, implicavam certo desapego às noções de laissez-faire e acentuações variadas do grau de intervenção do Estado na economia. Esses projetos "coletivistas" ameaçavam os valores liberais da autonomia individual e da propriedade privada (Turner, 2008).

O conceito de neoliberalismo é escorregadio. Não há definição única; além disso, é difícil encontrar autores que se autointitulem neoliberais. Em geral, tende-se à rejeição do rótulo ou à busca de outras adjetivações. Assim, é comum que autores cujos críticos alcunham de "neoliberais" prefiram sua caracterização como "liberais", ou, no caso norte-americano, como "neoconservadores" ou "libertários" ${ }^{151}$ (Turner, 2008, p. 6). Apesar da grande variação de escolas, é possível encontrar elementos nucleares ou fundamentais, que demarcam a moldura cognitiva neoliberal. Entre estes estão um motivo e quatro princípios ou crenças genéricas.

O motivo - no sentido de tema que perpassa a produção intelectual, situando-se no plano de fundo de toda a argumentação - é "desconfiança em relação ao Estado" (Turner, 2008, p. 15). A crença neoliberal não deposita suas "fichas" na iniciativa pública ou em noções como "interesse público", mas na iniciativa privada e na liberdade de ação do indivíduo (autonomia privada).

O comportamento econômico individual desimpedido conduz aos melhores resultados. Essa reedição do argumento da harmonia natural dos interesses, que remonta a Mandeville e a Smith, é o primeiro princípio que marca as correntes pertencentes ao "guarda-chuva" neoliberal: a afirmação da "importância da ordem dos mercados como mecanismo indispensável para a alocação eficiente dos recursos e para a salvaguarda da liberdade individual." (Turner, 2008, p. 4) Sob o ponto de vista neoliberal, os mercados "são sacrossantos ao funcionamento da economia; eles são parte da ordem natural espontânea de valores civilizados e cooperação mútua que sustenta o capitalismo.” (Turner, 2008, p. 15)

O segundo princípio é a adesão à ideia de "Estado de direito" ou Rechtsstaat, na expressão da escola austríaca. “A função do Estado é assegurar a coesão e estabilidade sociais

\footnotetext{
${ }^{151}$ Segundo Rachel Turner, há diversas linhagens de neoliberalismo que agrupam intelectuais com propostas relativamente distintas, mas que preservam núcleo ideológico fundamentalmente comum, abordado a seguir. Assim, tem-se uma lista (exemplificativa) de nomes e vertentes: Hayek e von Mises são expoentes da "escola austríaca"; Lionel Robbins capitaneou o pensamento neoliberal na London School of Economics; o "grupo de Friburgo" tem nomes como Alexander Rüstow; Walter Eucken e Franz Böhm; os "ordoliberais alemães" incluem Wilhelm Röpke e Alfred Muller-Armack; a vertente monetarista do neoliberalismo conta com Milton Friedman e Alan Walters; e a escola de "public choice", com James Buchanan e Gordon Tullock (Turner, 2008, p. 6).
} 
pela preservação das liberdades individuais." (Turner, 2008, p. 4) Essa concepção propõe que o direito exerça função essencialmente limitadora da ação do Estado, de modo a impedir inclusive suas incursões sobre a ordem dos mercados (Turner, 2008, p. 188). A ideia de "justiça" a ser promovida é fundamentalmente "negativa", de preservação da autonomia individual, sem implicar o caráter "positivo" associado às medidas de redistribuição de renda e participação estatal na economia. Na "constituição" ideal, a economia é deixada ao direito privado, e o Rechtsstaat se pauta pela "estrita separação de poderes, o governo submetido às leis e ao rule of law efetivo." (Turner, 2008, p. 189)

De certa forma, o segundo princípio conduz ao terceiro, que consiste na defesa da intervenção estatal mínima. "Os neoliberais defendem que o Estado deva ser forte porém mínimo.” (Turner, 2008, p. 5) Forte, no sentido de que a autoridade política deve ser capaz de assegurar a ordem, resguardar a liberdade individual e prover o essencial ao funcionamento dos mercados. Mínimo, no sentido de abstenção em relação à participação ativa na economia. Esta configuração traz impactos para um projeto distinto de "bem-estar social", que substitui os conceitos "provimento estatal [de bem-estar], justiça social, igualdade social e direitos sociais positivos por seus conceitos adjacentes, tais como o valor da liberdade, igualdade de oportunidades, responsabilidade individual e direitos negativos." Em assuntos de welfare, a responsabilidade já não recai primariamente sobre o Estado, mas sobre a caridade e as estruturas de suporte providas por atores privados, como membros da comunidade, da família ou organizações voluntárias. É comum, como traço da argumentação neoliberal, a afirmação de que as medidas assistenciais do Estado, ao assegurar o bem-estar individual independentemente de seu mérito, "minam as fundações morais da sociedade" e "levam à ineficiência e ineficácia econômicas.” (Turner, 2008, p. 163)

O último princípio demarcador do neoliberalismo é a afirmação fortalecida da propriedade privada. "O conceito atinge o cerne da divisão o público e o privado e, consequentemente, do próprio liberalismo, ao delinear conceitualmente o domínio e autonomia privados nos quais nenhuma instituição estatal pode legitimamente invadir." (Turner, 2008, p. 5) Como a propriedade privada delimita um espaço do indivíduo que não pode ser afetado pelo Estado, ela é expressão da liberdade individual. Além disso, está na base dos incentivos econômicos para a "iniciativa individual que leva à competição no livre mercado e à eficiência econômica." (Turner, 2008, p. 212) É, ainda, um "veículo para a descentralização das decisões [econômicas] e para situá-las no nível do indivíduo." (Turner, 2008, p. 5) Para além desse significado, a defesa da propriedade pela perspectiva neoliberal denota também que todo meio de produção deva ser privado, excluindo-se, portanto, o Estado. 
"Como proponentes do livre comércio e de livres mercados, eles proclamam que as firmas ou corporações devam sempre ser associações privadas ao invés de agentes do interesse público." (Turner, 2008, p. 213)

O ideário neoliberal conformou-se tendo os elementos acima como núcleo. Diversas vertentes, no entanto, contribuíram para sua formação a partir de influxos diferentes. Como apontado anteriormente, os principais nomes do neoliberalismo (em suas representações teóricas) foram Hayek, Mises e Friedman. Os dois primeiros encabeçaram a "escola austríaca"; o último, a corrente monetarista. Ambas as vertentes partilham daquilo que Ronaldo Fiani (2011) caracteriza como "abordagem dos mercados”. Entre os elementos desta abordagem estão concepções hoje consideradas "microeconômicas", como a teoria do equilíbrio geral e os critérios de eficiência de Pareto. A compreensão destes dois pontos ajuda a caracterizar a abordagem neoliberal.

A teoria do equilibrio geral foi inicialmente formulada por Léon Walras, em 1874 (Fiani, 2011, p. 22). A abordagem de Walras tem esse nome porque propõe a ideia de "equilíbrio entre oferta e demanda de todos os mercados que compõem a economia simultaneamente" (Fiani, 2011, p. 23). Como que por meio de "vasos comunicantes", alterações de oferta e demanda num mercado repercutem-se sobre os demais, e os preços se ajustam automaticamente para refletir as novas posições de equilíbrio em cada um deles (2011, p. 24-5). O “equilíbrio geral” não trabalha, porém, com mercados empíricos, e sim com certa concepção abstrata e estilizada dos mercados. Entre elas estão pressuposições de que os mercados sejam "competitivos" e "completos".

Ao trabalhar mercados como "competitivos", a teoria parte de quatro pressuposições: (i) informação perfeita e completa dos indivíduos a respeito das oportunidades nos mercados; (ii) ausência de impedimentos para que os agentes econômicos realizem suas atividades, aplicando seus recursos livremente nos melhores negócios; (iii) existência de grande número de compradores e vendedores - ou seja, negação de monopólios e monopsônios, oligopólios e oligopsônios -; e (iv) produtos tomados como homogêneos pelos compradores, sem que haja efeitos "da reputação ou da marca do produtor sobre a decisão dos consumidores" (Fiani, 2011, p. 26-7). Por sua vez, a "hipótese dos mercados completos" parte da suposição de "que há mercados para todos os bens e serviços desejados pelas pessoas, ou seja, existiria um mercado, preferencialmente operando de acordo com as quatro hipóteses acima, para qualquer produto que alguém desejasse." (Fiani, 2011, p. 27)

Outro elemento relevante para a chamada "abordagem dos mercados" consiste nas propostas de Vilfredo Pareto acerca da eficiência econômica. Pareto afirmou e ilustrou, por 
meio de modelos econômicos, que a eficiência econômica é atingida quando não é possível melhorar a situação de um sem piorar a de outros na economia. Ao alcançar-se esse cenário, tem-se um "ótimo de Pareto" ou uma situação "Pareto-eficiente" (Fiani, 2011, p. 30). "Inversamente, quando é possível melhorar a situação de alguém sem piorar a situação de ninguém, essa situação é dita Pareto-ineficiente.” (2011, p. 31).

A abordagem dos mercados conecta as contribuições de Walras e Pareto. Afirma, no que considera um teorema, que uma situação de equilíbrio, como proposta por Walras, conduz à eficiência de Pareto no ponto ótimo. Em outros termos, dado que os mercados sejam competitivos e completos, "o resultado será sempre uma alocação eficiente de recursos na produção de bens e serviços." (Fiani, 2011, p. 31) O resultado do teorema é tornar "difícil argumentar em favor de uma política que seja diferente da total liberalização dos mercados." (2011, p. 35)

As contribuições de Walras e Pareto eram componentes da economia ao tempo das formulações de Hayek, von Mises e Friedman. Para Rachel Turner, o "paradigma austríaco" de Hayek e von Mises incorpora uma "interpretação particular do conceito de 'mercado"”. Assim, a concepção de Hayek enxerga os mercados como provedores de uma ordem espontânea, capazes de conduzir à eficiência econômica e lidar com informações (pela livre operação do mecanismo de preços) melhor do que o planejamento estatal poderia fazer (Turner, 2008, p. 121). O papel do Estado é o de garantidor das "regras do jogo", da autonomia individual e das condições para que as trocas nos mercados se dêem de modo desimpedido. Há certas tonalidades evolutivas ou darwinianas nessa concepção, como Turner destaca:

\begin{abstract}
A ordem econômica espontânea do mercado maximiza a renda individual média ao aumentar as chances de todos tanto quanto possível. O sucesso econômico é atribuído às forças impulsionadoras da competição nos mercados $\mathrm{e}$ ao aproveitamento da iniciativa individual. Como na seleção natural darwiniana, a competição na ordem do mercado age de modo a suprimir a ineficiência negativa ao preservar os vencedores por sua obtenção de lucros e eliminar os ineficientes realizadores de perdas. Isso torna a sociedade de mercado, para os neoliberais, a ordem econômica mais produtiva e eficiente. (Turner, 2008, p. 124)
\end{abstract}

Milton Friedman, expoente da chamada "escola de Chicago", tinha proximidade com as perspectivas intelectuais austríacas de Hayek e von Mises. Vale lembrar que todos os três estiveram na reunião inaugural da Mont-Pèlerin Society, em 1947. Além disso, Hayek entrou para o corpo docente da Universidade de Chicago nos anos 1950, tendo permanecido ali por uma década (Turner, 2008, p. 222). O sentido das ideias de Friedman não era o de "reparar" aquelas da escola austríaca, mas de aplicar o mesmo espírito geral a um assunto específico: 
Friedman e o neoliberalismo da escola de Chicago foram além de Hayek e Mises em sua aplicação de uma instância ideológica de ultraliberdade de mercado a medidas políticas práticas. Os escritos de Friedman adotavam uma posição clássica de livre mercado por um meio específico: a moeda. (Turner, 2008, p. 101)

A pedra fundamental da perspectiva monetarista é a afirmação de que o nível de preços está vinculado à quantidade de moeda em circulação. Quanto mais moeda estiver disponível para uma mesma quantidade de bens e serviços no comércio, mais altos tenderão a ser os preços. "Se a oferta de moeda fosse infinitamente grande, como na Alemanha em 1923, os preços seriam infinitamente altos." A oferta de moeda depende não somente das cédulas que circulam de mão em mão, mas também da capacidade que os bancos têm de reproduzi-la. Em última instância, a oferta de moeda encontra-se atrelada ao nível de atividade econômica. Quanto maior este for, mais empréstimos serão demandados e mais depósitos bancários existirão, resultando em maior oferta de moeda. Além desta proposição fundamental, a perspectiva monetarista leva em consideração o ritmo ao qual a moeda é gasta (Galbraith, 1997, p. 202).

Esses contornos do monetarismo receberam expressão algébrica por Irving Fisher, que “indicou que os preços dependem do volume de dinheiro ou moeda em circulação e da taxa à qual ela gira, além do volume de depósitos bancários e da taxa a qual estes giram, todos divididos pelo volume de transações comerciais." Com ele, emergiu a chamada "teoria quantitativa da moeda", que resultava na recomendação de que a oferta de moeda fosse manejada como forma de manter os preços estáveis, evitando inflação e deflação (Galbraith, 1997, p. 203).

A contribuição de Friedman ao neoliberalismo consistiu no emprego da teoria quantitativa da moeda como "fórmula para minimizar o papel do governo": Friedman, um "conservador devoto", "voltou a Irving Fisher" e afirmou que a tarefa do Estado na economia consistiria em controlar o estoque de moeda. As demais intervenções diretas do Estado no mercado estariam excluídas de legitimação por sua perspectiva monetarista (Galbraith, 1997, p 273). Se os agregados monetários "fossem controlados de maneira a permitir um aumento moderado e constante em relação [...] ao crescimento da atividade econômica, a tarefa da administração da economia estaria concluída. Nada mais precisaria ser feito.” (Galbraith, 1997, p. 274) ${ }^{152}$ Em outros termos, o monetarismo em Friedman é a chave intelectual para resguardar a liberdade de ação individual nos mercados.

152 A esse respeito, Bernard Gazier caracteriza o monetarismo de Friedman como proponente de "uma antipolítica, pois ela se limita a formular uma regra, a estabelecer uma barreira às autoridades quando estas determinam, por suas intervenções de desconto e de open market, por exemplo, o estoque de moeda de um país." (2009, p. 103) 
Essa perspectiva é irreconciliável com o keynesianismo em ao menos dois aspectos. Para Keynes, a política monetária, por si só, não é suficiente para seu objetivo de intervenção estatal na economia com vistas ao incremento do nível de atividade econômica. Como um barbante que arrasta um objeto ao ser puxado, mas não o movimenta ao ser empurrado, a oferta de moeda não aumenta o nível de atividade se os indivíduos não estiverem dispostos a contrair novos empréstimos, num cenário que configura a chamada "armadilha de liquidez". Nesse caso, o "nível de atividade econômica poderia ser indiferente à oferta de moeda." (Galbraith, 1997, p. 212) Por isso, a ferramenta privilegiada de estímulo econômico reside na política fiscal. O segundo aspecto refere-se à maneira de conceber a relação entre inflação e emprego. Em Keynes, alguma inflação é desejável como estímulo a maiores níveis de consumo e de produção, e como desestímulo ao entesouramento. Friedman, porém, faz uma associação diferente. Para ele, a redução da inflação conduz à redução do desemprego e à produção da prosperidade (Turner, 2008, p. 102). A inflação é, afinal, o sintoma de desajuste entre a oferta de moeda e o nível de atividade econômica: um "erro" que cabe à política monetária corrigir.

Uma importante característica do pensamento econômico neoliberal reside no uso de modelos abstratos para estruturação do raciocínio. Como Bresser-Pereira aponta, os modelos de "macroeconomistas neoclássicos" e "economistas financeiros neoclássicos" fazem uso intensivo da matemática, "e esse uso respalda sua alegação de que os modelos que propõem são científicos." (Bresser-Pereira, 2010, p. 63) Nesse sentido, a avaliação do caráter científico da teoria econômica que propõem não reside em sua correspondência necessária com a realidade, "mas à sua consistência matemática" ${ }^{153}(2010$, p. 64). A crítica que Bresser-Pereira faz a esse expediente do raciocínio neoliberal é amplamente compartilhada nas contribuições de autores da nova economia do desenvolvimento no início do século XXI, como Ha-Joon Chang e Dani Rodrik (vide seção 3.4):

Os modelos neoclássicos hipotético-dedutivos são castelos matemáticos erguidos
sobre o ar e que não têm utilidade prática, a não ser para justificar mercados auto-
regulados e eficientes, ou, em outras palavras, agir como metaideologia. Esses
modelos tendem a ser radicalmente irreais na medida em que presumem, por
exemplo, que não possa haver insolvências, ou que a moeda não precise ser
considerada, ou que os intermediários financeiros não têm papel a desempenhar nos
modelos, ou que o preço de um ativo financeiro reflete todas as informações
disponíveis relevantes para seu valor etc. etc. (Bresser-Pereira, 2010, p. 64)

${ }^{153} \mathrm{O}$ ponto é, de certo modo, análogo ao formalismo dos juristas internacionalistas do final do século XIX, que remetiam a cientificidade de sua empreitada intelectual a um sistema abstrato e pré-estabelecido de formas e conceitos jurídicos (vide seção 2.1). 
Os elementos levantados acima são a base para identificação dos principais contornos do neoliberalismo como perspectiva econômica que agrega contribuições intelectuais provenientes de diferentes escolas, mas com núcleo comum. A identificação de certos aspectos de suas principais vertentes, como a escola austríaca e o monetarismo de Friedman, ajudaram a complementar o quadro descritivo desta perspectiva econômica. Esta caracterização foi um primeiro passo da subseção 3.3.1. Compreender como o neoliberalismo se difundiu transnacionalmente é uma tarefa diferente, a que se dedica o item 3.3.1.1. Por sua vez, o item 3.3.1.2 dedica-se a ainda outro aspecto relevante para a compreensão da influência do pensamento neoliberal sobre a cooperação econômica internacional: sua incrustação na política doméstica em diversos países, dentre os quais a Grã-Bretanha, Estados Unidos e Suécia.

\subsubsection{Mont-Pèlerin Society e ramificações: intelectuais contra o coletivismo}

A Mont-Pèlerin Society (MPS) foi estabelecida na Suíça a partir de um encontro de intelectuais ocorrido em 1947. Seu principal idealizador e porta-voz foi Friedrich Hayek (Miller, 2010, p. 26). A proposta da MPS era manter a "chama da economia de livre mercado acesa" durante o período "adverso" em que o coletivismo se encontrava em alta (Turner, 2008, p. 69). Os intelectuais da MPS, em linha com Hayek, preocupavam-se com a orientação keynesiana da política econômica em diversas partes do mundo. Para Hayek, "toda forma de coletivismo, mesmo as formas racionalistas liberais mais amenas, conduz à ditadura e à catástrofe econômica." (Turner, 2008, p. 75) Os membros da MPS “encaravam como perigosos a crescente intervenção pública na economia e na sociedade, e não menos o welfare state; o poder e influência de sindicatos e monopólios; e a contínua ameaça e realidade da inflação" (Turner, 2008, p. 72). Tanto Hayek quanto von Mises consideravam que a proposta keynesiana de redistribuição de renda feria a propriedade privada ao penalizá-la com a tributação necessária ao sustento da intervenção governamental, sendo uma forma de socialismo (Turner, 2008, p. 101).

Os motes dos membros da MPS eram livre mercado, livre iniciativa e Estado limitado (Turner, 2008, p. 74). Para Hayek, o resgate do liberalismo seria determinado pelo sucesso dos intelectuais de inclinação liberal em recapturar o espaço ideológico perdido para os coletivistas. Para tanto, os esforços da MPS deveriam ser direcionados a conquistar intelectualmente as elites políticas, recrutando-as ao suporte da causa neoliberal (Turner, 2008, p. 70). Tratava-se de "vencer a batalha das ideias" (Miller, 2010, p. 37). 
A organização criada na década de 1940 foi o embrião de uma "extensa rede intelectual de fundações, institutos, centros de pesquisa, ideólogos e acadêmicos" de inclinação neoliberal (Turner, 2008, p. 2). Na Grã-Bretanha, destacam-se o papel do Institute for Economic Affairs ${ }^{154}$, do Centre for Policy Studies e do Adam Smith Institute (Turner, 2008, p. 220). Esses think tanks ajudaram a formular ideias cuja influência fez-se sentir no governo de Margaret Thatcher. Muitas de suas propostas foram incorporadas pela plataforma do partido conservador britânico (Turner, 2008, p. 223).

Nos Estados Unidos, Friedman e Hayek foram membros de número considerável de think tanks voltados à defesa do livre mercado e de Estado mínimo, associados à direita conservadora ou libertária: os já existentes Hoover Institute, de 1919 - alguns de seus membros viriam a formar os quadros do governo Reagan - e o American Enterprise Institute de 1943; e a nova Heritage Foundation, de 1973 (Tuner, 2008 , p. 102, 106). Nesta, Friedman e Hayek participaram ao lado de Ronald Coase, expoente da Análise Econômica do Direito, e Douglass North, uma das principais figuras da virada institucional da economia do desenvolvimento, e influente sobre a AED e o Law \& Finance. Além desses, tinham ligações e participações, juntamente com outros membros da MPS, no Cato Institute, de 1974, e na John Birch Society, fundada nos anos 1950, que realizava trabalho "de base" junto à população, por meio de livrarias e vínculos com escolas, igrejas e comunidades locais, pelos quais difundia ideias contrárias à intervenção governamental, tributação elevada e desequilíbrios orçamentários (Turner, 2008, p. 100).

Muitos dos mencionados think tanks, por sua vez, fomentavam periódicos de difusão de ideias neoliberais. Alguns eram voltados ao grande público, outros, à academia. Exemplo de periódico do primeiro tipo foi a National Review, inicialmente publicada em 1955, e que "posicionava-se pelo livre-mercado, anticomunismo agressivo, bem como pelos valores tradicionais conservadores cristãos." A revista “tornou-se uma das mais importantes fontes de ideias para a reascensão do pensamento conservador nas décadas seguintes”. Exemplos do último tipo foram a Modern Age, de 1957, e The Public Interest, de 1965, ambas de caráter neoconservador (Turner, 2008, p. 101).

Como membros da MPS também eram participantes e colaboradores de muitos destes think tanks e publicações, a enumeração acima permite perceber como espaços variados de

\footnotetext{
${ }^{154}$ David Miller atribui a MPS, e especificamente às movimentações de Hayek, o impulso inicial para criação do Institute for Economic Affairs em 1955 (Miller, 2010, p. 26). Igualmente, traça a influência da MPS no estabelecimento de outras "organizações de direita", como o Centre for Policy Studies de 1974 e o Adam Smith Institute de 1976. Para Miller, estas organizações serviram de espaço para fomento de uma investida intelectual baseada no "fundamentalismo de mercado, especialmente na forma de privatização e desregulamentação", que teve sucesso em ser absorvida, na Grã-Bretanha, na forma do "thatcherismo" (Miller, 2010, p. 30).
} 
difusão de ideias neoliberais em contextos nacionais distintos "encontravam-se unidos em suas aspirações por meio de suas conexões à Mont-Pèlerin Society.” (Turner, 2008, p. 107) Nesse sentido, a MPS foi a incubadora para a projeção transnacional da perspectiva intelectual de seus participantes.

A seguir, o item 3.3.1.2 aborda aspectos da conversão da política doméstica ao neoliberalismo em três contextos nacionais distintos, em que o papel da "batalha das ideias" mostrou-se relevante. Trata-se, no fundo, de desdobramentos nacionais correlacionados a mudanças na ordem econômica internacional, por sua vez abordadas nas subseções 3.3.2 (aspectos monetários e financeiros) e 3.3.3 (aspectos comerciais).

\subsubsection{Conversões neoliberais em contextos domésticos}

Condições econômicas adversas - como a estagflação e os choques do petróleo refletiram-se no desprestígio do keynesianismo, motivando a busca por alternativas em diversos contextos domésticos. Como resultado, governos marcadamente neoliberais emergiram na Grã-Bretanha, nos Estados Unidos e na Suécia, como exemplos de um fenômeno mais amplo de transição política no mundo, correlacionado à mudança de paradigmas econômicos. Nas palavras de Bresser-Pereira, na década de 1970 "a macroeconomia neoclássica substituiu a keynesiana" (2010, p. 54). Os intelectuais da perspectiva econômica em ascensão viram suas ideias apropriadas e acopladas ao projeto de grupos domésticos disputando espaços de poder.

\section{Grã-Bretanha e ascensão do governo Thatcher}

Na década de 1970, a Grã-Bretanha passou por profundas transformações na política econômica. A década iniciou-se com atuação governamental marcadamente keynesiana. Encerrou-se, porém, com a rejeição do keynesianismo nos quadros de governo e absorção das ideias monetaristas, que se institucionalizaram e tornaram-se o novo paradigma. Para Peter Hall, essa virada foi resultado de "mudanças na economia mundial, choques entre interesses políticos e sociais, e uma disputa entre interpretações econômicas que competiam entre si." (1992, p. 91)

Segundo Hall, a Grã-Bretanha passou a conviver com níveis crescentes de inflação ao mesmo tempo em que passava por cenário de estagnação econômica e aumentos do desemprego, após os choques do petróleo em 1973-4 (1992, p. 94). Este fenômeno não era exclusivamente britânico. Fazia parte de uma tendência nas economias capitalistas avançadas. 
O cenário escapava ao receituário keynesiano, cuja orientação principal era antideflacionária, e tendia a enxergar na inflação um fator impulsionador do dinamismo econômico e do nível de emprego ${ }^{155}$. A desilusão sentida com a orientação econômica keynesiana foi acompanhada pela abertura de espaço político para a busca de alternativas:

A disponibilidade e apelo de ideais monetaristas foi central para a direção da
mudança na política macroeconômica britânica. Como os problemas de inflação e
desemprego mostraram-se persistentes em face das recomendações keynesianas, os
formuladores de políticas públicas naturalmente começaram a procurar por soluções
alternativas; e, entre as opções aceitas, a doutrina monetarista apresentava méritos
especiais. Em particular, ela endereçava diretamente o problema da inflação, que se
tornava crescentemente preocupante aos britânicos, num ponto em que as soluções
keynesianas pareciam ser cada vez mais de difícil manejo e focadas em questões de
desemprego. (Hall, 1992, p. 94)

Outro fator que contribuiu para impulsionar a mudança em direção ao monetarismo foi a ascensão dos mercados financeiros e da dependência do governo britânico em relação às vendas de títulos públicos nesses mercados. As políticas keynesianas anteriormente adotadas mediante déficits orçamentários estimularam o endividamento junto aos mercados financeiros. Por sua vez, a necessidade de acesso governamental aos recursos disponíveis nesses mercados tornaram o "governo cada vez mais sensível às visões sobre a política econômica expressas nesses mercados." (1992, p. 100) No cenário de dificuldades econômicas, o governo britânico havia se tornado, de certo modo, "refém" da confiança de investidores: "o governo frequentemente se encontrava simultaneamente incapaz de vender títulos públicos ou de evitar uma fuga da libra esterlina a não ser que aumentasse a taxa de juros ou reduzisse seus gastos públicos.” (1992, p. 103) Os representantes políticos da classe trabalhista, que favoreciam políticas ao estilo keynesiano, perderam espaço para os "portavozes do capital", que se inclinavam pelo monetarismo (1992, p. 94).

Em meio a esse cenário, a atuação de think tanks - como os mencionados anteriormente - e da imprensa mostrou-se relevante. Publicações dirigidas ao público geral como The Times, The Financial Times, The Economist e The Daily Telegraph realizaram uma "expansão sem paralelos da cobertura dada a assuntos econômicos sofisticados pela imprensa britânica" (1992, p. 105). Como Hall aponta, três dos quatro maiores jornais britânicos “deram uma quantidade extraordinária de cobertura a ideias monetaristas num momento em que elas ainda eram majoritariamente rejeitadas pelos economistas britânicos.” (1992, p. 108)

\footnotetext{
155 "Inflação e desemprego começaram a crescer simultaneamente na Grã-Bretanha durante os anos 1970, lançando dúvidas sobre o trade-off que a maior parte dos keynesianos afirmava existir entre essas duas variáveis, bem como sobre os efeitos que os modelos keynesianos tinham dificuldade em prever ou explicar." (Hall, 1992, p. 104)
} 
Para Hall, o papel da imprensa foi mais importante do que aquele que a academia teve na popularização do ponto de vista monetarista (1992, p. 105). Essas ideias tinham um "apelo especial" aos membros do Partido Conservador, que "encontravam no monetarismo raciocínios altamente coerentes para muitas das iniciativas políticas que há muito eles favoreciam", como redução dos gastos públicos, da tributação e da dívida pública, rejeição de políticas de renda mínima, redução do setor público e introdução de limitações legais ao poder de sindicatos (1992, p. 105). Afinal, o monetarismo fornecia uma plataforma de ideias pela qual "o governo poderia controlar a inflação - e os sindicatos - simplesmente por aderir a uma meta rígida para o crescimento da massa monetária.” (1992, p. 106)

Embora a virada em direção ao monetarismo na Grã-bretanha tenha começado de modo hesitante em 1976, apenas em 1979 a doutrina se tornou o mote central da política econômica, com a ascensão de Margaret Thatcher (Hall, 1992, p. 100). Nesse momento, o monetarismo já havia se tornado "uma alternativa completamente elaborada ao paradigma keynesiano reinante", e adquirido uma "base de suporte institucional na City [comunidade financeira de Londres], entre economistas em diversas universidades, e na mídia." (1992, p. 97) A política monetária, antes vista como subsidiária ou complementar à política fiscal, tornou-se o principal instrumento de política econômica do governo. "A redução da inflação tornou-se a prioridade destacada da política governamental, e a redução do déficit do setor público, o principal meio para esse fim." (1992, p. 104) No discurso de Thatcher, a disciplina fiscal era um imperativo ${ }^{156}$. Além disso, certos programas que haviam sido marcas do welfare state britânico por décadas foram revertidos, como políticas de renda mínima (1992, p. 91).

A Grã-Bretanha havia embarcado no modelo de políticas públicas que postulava a "flexibilização" das leis de proteção ao trabalho, a "redução dos benefícios sociais proporcionados pelo Estado" e do "porte do aparelho do Estado", bem como a desregulamentação de "todos os mercados, principalmente os financeiros." (Bresser-Pereira, 2010, p. 55)

Estados Unidos e ascensão do governo Reagan

O nome de Ronald Reagan está para a conversão política ao neoliberalismo nos Estados Unidos assim como o de Margaret Thatcher está para a Grã-Bretanha. Reagan

\footnotetext{
${ }^{156}$ Segundo Bradley Bateman, o fato de que mais déficits orçamentários governamentais ocorreram sob o governo de Margaret Thatcher do que de qualquer outro primeiro ministro britânico na segunda metade do século XX é uma das "ironias" da história da política fiscal (Bateman, 2006, p. 290). Tal como Thatcher, Reagan, nos Estados Unidos, governou com grandes déficits fiscais, associados a incrementos nos gastos militares e cortes na tributação, apesar do discurso de equilíbrio nas contas públicas.
} 
representa o momento em que o paradigma tornou-se dominante na política doméstica, como uma alternativa "organizada, coerente e plausível" à orientação econômica anteriormente prevalente (Turner, 2008, p. 106). Porém, mesmo antes de Regan, “defensores do pensamento neoliberal" já haviam adquirido alguma influência sobre a política dos governos Nixon e Ford, na década de 1970 (Helleiner, 1994b).

Eric Helleiner, nesse sentido, aponta que a nomeação de George Shultz como secretário do Tesouro em 1972 é uma instância representativa da influência da "posição neoliberal" em virtude de sua "afiliação próxima com a Universidade de Chicago e Milton Friedman." (Helleiner, 1994b, p. 115) Shultz e outros nomeados para cargos elevados da burocracia governamental norte-americana rejeitavam medidas de política econômica e cooperação internacional concebidas sob o paradigma anterior. Além de Friedman, inspiravam-se em "Hayek, Röpke e outros neoliberais europeus" (Helleiner, 1994b, p. 115, 204). No campo das finanças internacionais, eram contrários ao regime permissivo aos controles de capital de Bretton Woods, e buscavam "promover uma alocação mais eficiente de capital não apenas entre países, como também dentro deles, por meio do estímulo à competição financeira doméstica." Além disso, ao invés de paridades fixas, defendiam o regime cambial da livre flutuação (1994b, p. 115-6). No aspecto da concepção de Estado, entendiam que o uso coercitivo do poder de polícia estatal era incompatível com a liberdade individual (1994b, p. 116). Esta nova concepção "aplaudia os mercados financeiros internacionais" por sua capacidade de "disciplinar a política governamental e induzir Estados a programas fiscais e monetários mais 'sãos'.” (1994b, p. 116)

Assim como no caso britânico, a existência simultânea de inflação em alta com crescimento econômico e nível de emprego em baixa, na década de 1970, produziu “desilusão" com medidas econômicas ao estilo keynesiano ou do New Deal (Helleiner, 1994b, p. 119). Havia a percepção de que a orientação econômica anterior do governo havia contribuído para "destruir a autonomia individual por meio da aplicação de tributação confiscatória da renda sobre indivíduos privados e por encorajar a dependência na assistência estatal.” (Turner, 2008, p. 103) A descrença na capacidade da economia keynesiana de prover soluções neste cenário era um dos elementos que conformavam uma conjuntura favorável a mudanças:

Nesse clima intelectual de incerteza, intelectuais neoliberais - incluindo americanos como Milton Friedman - estavam, em contraste, autoconfiantes, e ativamente difundiram a mensagem neoliberal por meio de think tanks britânicos como o Institute of Economic Affairs (que havia sido fundado sob a liderança de Friedrich Hayek em meados dos anos 1950). A mensagem neoliberal encontrou suporte 
particularmente forte entre banqueiros privados e oficiais financeiros no governo. (Helleiner, 1994b, p. 130)

No relato de Helleiner, a ascensão do neoliberalismo na década de 1970, nos Estados Unidos como em outros países, foi impulsionada pelo expressivo crescimento do volume e importância dos mercados financeiros internacionais e da formação de "redes" de funcionários governamentais que compartilhavam visões neoliberais sobre finanças (1994b, p. 130). Além disso, em referência específica ao ocorrido nos Estados Unidos, Helleiner sinaliza para a importância dos lobbies formados por corporações multinacionais e bancos, influentes desde os governos de Nixon e Ford, ou seja, desde o início da década de 1970 (1994b, p. 120). Esses lobbies contribuíram para que a influência do ideário neoliberal se materializasse na forma de políticas de governo.

A culminância da influência política do neoliberalismo nos Estados Unidos aconteceu com Ronald Reagan. Segundo Bresser-Pereira, a vitória de Reagan nas eleições representou “a subida ao poder de uma coalizão política de rentistas e financistas" (2010, p. 54). O projeto de Reagan enxergava o "Estado grande" como prejudicial ao progresso por interferir na "livre competição" e por "enfraquecer a fibra moral do indivíduo ao inibir a conquista pessoal." Para Turner, a história pessoal de Reagan contribuía para reforçar a ideia do "self-made man". Afinal, de um começo relativamente humilde, Reagan alcançou o estrelato em Hollywood e a presidência. Reagan podia assim exemplificar "o que indivíduos podiam conseguir por meio do livre mercado", sem depender da orientação ou suporte estatais (Turner, 2008, p. 106).

Ao invés do modelo de welfare state, Reagan defendia uma concepção de "trickle down economics" 157 segundo a qual a prosperidade gerada sobretudo pela redução da carga tributária das parcelas mais ricas da sociedade beneficiaria indiretamente - por "respingos" as parcelas mais pobres. Este deveria ser o mecanismo privilegiado para geração de bem-estar que, no fundo, era atribuído exclusivamente ao dinamismo dos mercados e à atuação privada. O ponto está ligado a sua orientação econômica focada na oferta, ou supply-side economics, segundo a qual a facilitação da oferta (produção, comércio etc.), sobretudo por meio de reduções tributárias, seria o modo correto de incentivar a economia (e não a redistribuição de renda ou a participação estatal ativa no domínio econômico). Além disso, Reagan adotou a perspectiva monetarista e sua ênfase no combate à inflação pelo controle da massa monetária (Turner, 2008, p. 107). O discurso econômico empregado para justificar a adoção de medidas como as apontadas acima ficou conhecido como Reaganomics.

\footnotetext{
${ }^{157}$ Algo como economia de respingos, ou ainda economia de efeitos indiretos.
} 
Apesar de Reagan ter sido um dos mais influentes defensores políticos do modelo neoliberal, Helleiner registra certos contornos práticos de seu governo que não se enquadram a rigor nesta cartilha. Se por um lado Reagan efetuou cortes tributários (1994b, p. 147) e apresentou entusiasmo por programas ortodoxos de estabilização econômica no exterior (1994b, p. 181) - em linha com o pensamento neoliberal -, por outro seu governo promoveu aumento dos gastos militares (1994b, p. 147) e conviveu com déficits maiores, por sua vez financiados por "enormes influxos de capital estrangeiro" (Helleiner, 1994b, p. 148).

Este aspecto encontra-se vinculado às motivações para o estímulo governamental norte-americano à liberalização dos mercados financeiros internacionais e à erosão dos controles de capital, que comprometeram a ordem de Bretton Woods, e serão retomados adiante (3.3.2). Antes, porém, é importante abordar a fuga da política econômica de orientação keynesiana na Suécia - país que, segundo Galbraith (1989, p. 202), mereceria a substituição da expressão "revolução keynesiana" por "revolução sueca"-, com o declínio da influência da Escola de Estocolmo e ascensão do ideário neoliberal. Na estrutura deste capítulo, esta narrativa é uma contrapartida à exposição das origens suecas do estilo de políticas econômicas protokeynesianas da década de 1930, que originaram o chamado "modelo sueco".

Fim do "modelo sueco" nos anos 1980

Mark Blyth analisa as transformações no chamado "modelo sueco" como instância em que ideias estiveram na base de processos de transformação institucional. Sua perspectiva atribui grande importância aos chamados "fatores ideacionais". Para o autor, as ideias econômicas desempenham três papéis fundamentais em relação aos rumos da política e a suas instituições (cf. capítulo 1). Elas podem operar como projetos ou plantas arquitetônicas (blueprints) de instituições, hipótese em que o arcabouço teórico é empregado para suprir incertezas, dar expressão a interesses e possibilitar a construção institucional. Também podem operar como armas, ou base para criticar o status quo: "ideias econômicas permitem aos agentes desafiar os arranjos institucionais existentes e os padrões de distribuição que eles implicam." (Blyth, 2001, p. 4) Por fim, operam como travas cognitivas: os formuladores de políticas públicas podem tornar-se "prisioneiros intelectuais" (2001, p. 24) de um paradigma existente, de modo a induzir path dependencies, ou seja, dependências da trajetória ${ }^{158}$.

\footnotetext{
${ }^{158}$ Para Paul Pierson (2004), o que caracteriza um processo de dependência da trajetória institucional ou path dependency é a existência de retroalimentação ou autorreforço (positive feedbacks). Uma vez que uma escolha seja feita num ponto crucial, de inflexão, a existência de positive feedbacks reforça o rumo inicialmente adotado.
} 
Diante dessas considerações, Blyth sugere que o "modelo sueco" formou-se no período do entreguerras segundo quatro proposições-chave, que lhe serviram de planta:

Primeiro, a expansão de toda a economia era vista como solução tanto para o desemprego quanto para a deflação. Segundo, a estabilidade do nível de preços era encarada como objetivo político vital para todos os grupos. Terceiro, o Estado resolveu garantir a confiança dos negócios argumentando que iria equilibrar o orçamento ao longo do ciclo econômico e não do ano fiscal. Quarto, esperava-se que o Estado desempenhasse papel ativo no gerenciamento econômico, mas principalmente como mediador entre empresariado e trabalhadores e como provedor das instituições que tornavam os três primeiros objetivos possíveis. (Blyth, 2001, p. $5-6)$

As instituições do "modelo sueco" haviam se sedimentado nos anos 1950 como resultado de uma coalizão entre a classe empresarial e trabalhadora, cujos representantes compartilhavam ideias que podem ser rotuladas como keynesianas, por procurar promover o welfare state, o pleno emprego e medidas de redistribuição de renda destinadas a preservar o poder de consumo e o nível de atividade econômica (2001, p. 7). Nos anos 1970, porém, houve rompimento nesta coalizão. De acordo com Blyth, representantes laborais apresentaram ao parlamento sueco propostas legislativas de democratização da produção, segundo o ideal de que a "democracia não pode parar nos portões da fábrica." (2001, p. 8) O sentido fundamental era o de que os trabalhadores haviam se empoderado junto ao governo, mas continuavam subordinados no interior das fábricas. Entre as soluções intencionadas para lidar com o déficit democrático percebido nessa situação, havia a pretensão de estabelecer tributação de $20 \%$ sobre o lucro das empresas. A renda seria destinada a fundos, geridos por sindicatos, e "usados para facilitar a democracia econômica real" por meio da compra de empresas suecas. A proposta foi recebida como "ataque frontal à santidade da propriedade privada", e marcou o fim da coalizão entre empresários e trabalhadores. A resposta empresarial - além de lockouts realizados em protesto - foi o início de uma campanha política e intelectual orientada para minar as bases do "modelo sueco" em busca de um ambiente institucional mais favorável aos negócios (Blyth, 2001, p. 9-11).

O sentido geral do processo é o de abandono do compromisso empresarial sueco com o estilo keynesiano ou da Escola de Estocolmo de política econômica, e a busca por

Essa caracterização favorece a ideia de tendência à "inflexibilidade" dos processos de path dependence dado que os "custos da mudança" tenderiam a aumentar com o passar do tempo. A visão de Pierson privilegia a explicação de processos de continuidade institucional, com mudanças significativas ocorrendo apenas em conjunturas críticas. Outros autores, em contraste, enfatizam a possibilidade de mudança institucional ao longo de path dependencies. Assim, por exemplo, Streeck e Thelen (2005) e Mahoney e Thelen (2010) dão atenção a processos de mudança institucional gradual ou incremental, sugerindo que nem toda mudança significativa envolve quebra brusca com o formato institucional anterior (Streeck; Thelen, 2005, p. 4), podendo acontecer por processos mais delongados de deslocamento, sobreposição, desvio, conversão e exaustão institucional (Streeck; Thelen, 2005, p. 20-9; Mahoney; Thelen, 2010, p. 16-7). 
alternativas, que foram encontradas no neoliberalismo e especificamente no monetarismo. A ofensiva contra o keynesianismo deu-se sobretudo na forma de levantamento de fundos em montantes expressivos que permitiram ao empresariado financiar um "ataque sustentado" ao modelo sueco e à representação laboral (2001, p. 11). Receberam tais fundos think tanks como o Center for Business and Policy Studies e Timbro (criado em 1978), que passaram a "promover as mesmas ideias neoliberais vistas em países como o Reino Unido e os Estados Unidos (embora com alguns elementos distintamente suecos).” (Blyth, 2001, p. 16)

As movimentações surtiram impactos no ambiente intelectual dos economistas suecos. Segundo Blyth, na década de 1970, a maior parte deles era de keynesianos. Porém, nos anos 1980, a maioria passou a ser de monetaristas, que formavam uma "nova ortodoxia" na economia sueca (2001, p. 16). O debate sobre a política econômica foi reconfigurado. Medidas destinadas a promover redistribuição de renda ou equidade econômica passaram a ressignificadas como "perda de eficiência ao invés de expressão política de solidariedade." (Blyth, 2001, p. 17) O próprio modelo do welfare state passou a ser encarado a partir de abordagem que enfatizava aspectos de perda da eficiência econômica. Os economistas suecos desenvolveram modelos para medir o tamanho dessa perda. Em seguida, o debate rumou para a elaboração de propostas concretas para "revisão radical" das instituições do welfare state que haviam integrado o modelo sueco (Blyth, 2001, p. 17).

O caso sueco integra um padrão transnacional nas economias capitalistas avançadas, nos anos 1970 e 1980, de conversão política ao neoliberalismo. "Desnacionalização, desregulamentação e liberalização de mercados, bem como medidas para beneficiar empresas e enfraquecer sindicatos, tornaram-se quase rotineiras.” (Pollard, 1997, p. 81) O processo não se restringiu, porém, a estas economias. Um fator impulsionador de sua difusão global foram "condicionalidades" e programas de "ajuste estrutural" promovidos por instituições da cooperação econômica internacional neste momento. Outro, igualmente relevante, foi a dinâmica de desregulamentação competitiva. "Quando um Estado começava a desregulamentar e a liberalizar seus mercados financeiros, outros Estados eram forçados a seguir sua liderança caso esperassem permanecer competitivos na atração de fundos erráticos e negócios financeiros.” (Helleiner, 1994b, p. 167) Apesar de esta dinâmica referir-se à

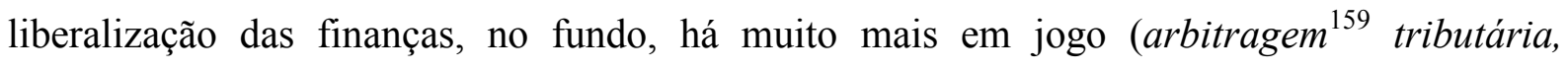
arbitragem de padrões trabalhistas etc.), dado que o discurso sobre instituições propícias à

\footnotetext{
${ }^{159}$ Arbitragem, aqui, não é abordada como espécie do gênero "solução de controvérsias", mas como analogia à atividade de busca de ganho pela negociação de ativos que possam, em mercados distintos, receber preços diferentes num mesmo momento, como ocorre nos mercados internacionais de câmbio.
} 
expansão dos mercados financeiros envolve reformas institucionais abrangentes ${ }^{160}$. A subseção 3.3.2, a seguir, aborda transformações nas finanças internacionais, bem como certos impactos sobre instituições domésticas, que se deram no cenário de ascensão e predominância da sensibilidade econômica do neoliberalismo.

\subsubsection{Crise de Bretton Woods e ascensão do capital financeiro global}

A ordem econômica internacional de Bretton Woods havia sido fundada no pressuposto de que o dólar norte-americano poderia ser convertido em ouro a uma proporção fixa. Nos anos 1960, embora os Estados Unidos permanecessem como principal economia no mundo, passou a haver acúmulo de déficits em sua balança de pagamentos com o exterior ${ }^{161}$. Em parte, esse fenômeno se deveu ao crescimento acelerado na Europa e na Ásia. Outra parte, porém, corresponde ao crescimento das despesas militares, sobretudo com a Guerra do Vietnã. Em qualquer caso, a continuidade dos déficits lançava dúvidas a respeito da capacidade do governo norte-americano de honrar o pagamento em ouro para todos os dólares emitidos (Rodrik, 2011, p. 100). Em meio a essas dúvidas, aumentaram os fluxos de capital especulativo - num cenário em que os controles de capital já começavam a se erodir -, que contribuíram para acentuar a dificuldade de sustentação do padrão dólar-ouro (Helleiner, 1994b, p. 102). Assim, em agosto de 1971:

confrontados com demandas crescentes de países estrangeiros para conversão de
seus estoques de dólares em ouro, o presidente Richard Nixon e seu secretário do
Tesouro John Connolly precisavam fazer uma escolha: fazer o aperto das políticas
econômicas domésticas ou suspender a conversibilidade de dólares em ouro a uma
taxa fixa. Eles naturalmente escolheram a segunda opção. (Rodrik, 2011, p. 100)

O aumento da mobilidade do capital esteve na base do rompimento da base monetária de Bretton Woods, que implicou o próprio fim dessa ordem econômica internacional ${ }^{162}$. É comum atribuir este aumento a (i) adventos tecnológicos que afetaram a área das finanças e (ii) à proporção crescente de recursos canalizados por meio de corporações multinacionais.

No primeiro aspecto, a "era dos satélites" representou o desenvolvimento de meios mais rápidos e baratos para as telecomunicações, inclusive a partir da "revolução dos transistores" na fabricação de dispositivos eletrônicos menores e mais baratos. $\mathrm{Na}$ área de

\footnotetext{
${ }^{160}$ Aspecto abordado na seção 4.2, que discute aspectos da literatura de Law \& Finance.

161 Segundo Kenwood e Lougheed, o primeiro déficit na balança de pagamentos dos Estados Unidos foi registrado em 1958 (1999, p. 270).

${ }^{162} \mathrm{O}$ início do regime de flutuação cambial foi oficialmente incorporado à regulamentação do FMI em 1973 (Eichengreen, 2008, p. 137).
} 
finanças, tais inovações tecnológicas representaram maior acesso a oportunidades variadas e mais amplas de investimentos, bem como maior velocidade na condução de transações.

Quanto ao segundo aspecto, o crescimento das corporações multinacionais implicava que fluxos monetários relativos a transações comerciais e financeiras passavam a ligar diferentes pontos do globo dentro de uma mesma estrutura empresarial (cadeias produtivas globais). Nesse sentido, o aumento da mobilidade do capital é associado ao crescimento da importância do comércio intrafirma na parcela de todas as transações comerciais internacionais.

No discurso padrão a respeito da erosão da ordem de Bretton Woods, estes fatores contribuíram para tornar as finanças internacionais mais fugidias aos controles de capital pretendidos pelos Estados. Embora tais fatores tenham de fato desempenhado importante papel, esse relato passa a impressão de que o desfazimento da ordem de Bretton Woods aconteceu por eventos alheios à vontade estatal. Eric Helleiner (1994b) aponta, no entanto, que comportamentos estatais foram relevantes para o renascimento da mobilidade do capital.

Entre eles estão inclinações favoráveis dos Estados Unidos e da Grã-Bretanha em relação ao mercado de eurodólares na década de 1960, quando os controles de capital eram comuns ao longo do mundo. Estes países adotaram medidas de liberalização unilateral das finanças internacionais, diante de vantagens estratégicas percebidas com a existência de referido mercado (Helleiner, 1994b, p. 99). Antes de abordar tais medidas, é necessário compreender, ainda que elementarmente, o significado dos “eurodólares".

Eurodólares são depósitos feitos a prazo, denominados em dólares norte-americanos, mas em bancos situados no exterior, não nos Estados Unidos. Como os depósitos não eram à vista, eles não poderiam ser sacados de imediato. Por isso, o banco que recebia os eurodólares poderia emprestá-los a terceiros. O estímulo para a existência do mercado de eurodólares residia no fato de que os juros pagos aos depositantes de dólares norte-americanos no exterior eram maiores do que aqueles que poderiam ser encontrados em bancos nos Estados Unidos, ao mesmo tempo em que os juros cobrados para obtenção de empréstimos em eurodólares eram menores. Na década de 1970, o mercado de eurodólares seria importante fonte de recursos para as nações endividadas diante dos choques do petróleo ${ }^{163}$ (Kenwood; Lougheed, 1999, p. 274). A origem desse mercado remonta ao final da década de 1950, tendo Londres

\footnotetext{
${ }^{163}$ A relação com os choques do petróleo é dupla. Por um lado, o mercado de eurodólares era um destino para os depósitos dos excedentes obtidos por países exportadores de petróleo. Tais excedentes ficaram conhecidos como "petrodólares". Por outro, o mercado de eurodólares operava, como já indicado, como fonte para o financiamento do consumo de países em dificuldades financeiras a partir dos choques do petróleo da década de 1970.
} 
por principal centro financeiro. Era um espaço em que transações poderiam ser conduzidas sem os impedimentos das regulações estatais (Helleiner, 1994b, p. 82).

$\mathrm{O}$ apoio britânico à existência desse mercado remetia à pretensão de restaurar a posição histórica de Londres como centro mundial de finanças. A existência de um mercado financeiro desregulamentado, à parte das finanças britânicas nacionais, era vista como meio de conciliar o welfare state - que dependia de controle estatal das finanças - com referida pretensão. Era a chance de manter os mercados em geral sob controle, mas ter um mercado dinâmico à parte. Diante disso, as transações financeiras realizadas por operadores privados nesse mercado eram "ativamente encorajadas pelas autoridades financeiras britânicas." (Helleiner, 1994b, p. 84)

Por sua vez, os Estados Unidos foram tolerantes com a evasão de fundos de bancos nacionais para depósitos no mercado de eurodólares em Londres, apesar da existência de um programa de controle de capitais começado nos anos 1960 em resposta às dificuldades no balanço de pagamentos (Helleiner, 1994b, p. 84). Ao manter fundos nesse mercado, bancos norte-americanos poderiam evitar a incidência de regulações bancárias domésticas que determinavam taxas de reserva compulsória e fixavam tetos para a taxa de juros (1994b, p. 88). De certa forma, configurava-se um arranjo entre governo e setor bancário no sentido de possibilitar a coexistência da regulação financeira doméstica com a liberdade financeira externa. Ao passo que a regulação financeira doméstica era essencial à preservação da autonomia da política econômica, a liberdade financeira internacional dialogava com os interesses de financistas e do próprio governo. Afinal, a existência do mercado de eurodólares representava um meio para estimular estrangeiros a manter suas reservas denominadas em dólares, de modo que estes acabavam por financiar os déficits no balanço de pagamentos norte-americano (Helleiner, 1994b, p. 112; Rodrik, 2011, p. 102), evitando que este tivesse que recorrer a medidas de austeridade. Além disso, percebia-se que um "sistema não negociado e orientado pelos mercados preservaria a posição dominante dos Estados Unidos nas finanças internacionais", numa espécie de exercício do poder fundado nos mercados (Helleiner, 1994b, p. 113-4).

“Ao apoiar a criação e crescimento do mercado de eurodólares, no entanto, os Estados Unidos incentivaram o primeiro desvio decisivo em relação à ordem financeira restritiva de Bretton Woods." (Helleiner, 1994b, p. 99) As finanças internacionais tornavam-se mais expressivas, mais voláteis, e mais desprendidas das transações comerciais. Como aponta Eichengreen, o aumento da mobilidade do capital gerou instabilidade nas relações de câmbio entre diferentes moedas nacionais $(2008$, p. 134, 183), encontrando-se relacionado à quebra 
do padrão dólar-ouro de Bretton Woods. Paralelamente, ocorreram mudanças nas percepções a respeito da liberdade financeira internacional, em linha com a ascensão do pensamento neoliberal: "o sistema de crenças que apoiou o controle de capitais começou a diluir-se nos anos 1970 e foi substituído nas décadas subsequentes por uma narrativa alternativa que enfatizava a inevitabilidade da liberalização e os benefícios da mobilidade do capital." (Rodrik, 2011, p. 101) Além do aspecto da influência das ideias econômicas, não se pode deixar de lado a existência de pressões pela liberalização em razão da dinâmica de desregulamentação competitiva ou arbitragem regulatória (Helleiner, 1994b, p. 161, 167; Eichengreen, 2008, p. 135), num cenário em que "países que impusessem controles onerosos arriscavam perder seus negócios financeiros para mercados estrangeiros.” (Eichengreen, 2008, p. 135)

O resultado foi a emergência de uma nova ordem financeira e monetária internacional baseada na liberdade dos fluxos internacionais de capital - com a remoção dos controles estatais de capital - e na livre flutuação das moedas nacionais. Para Bresser-Pereira, esta nova era representou a financeirização do capitalismo, "ou capitalismo encabeçado pelo setor financeiro" (Bresser-Pereira, 2010, p. 55). Não mais, como na era keynesiana, por uma aliança entre empresariado, trabalhadores e oficiais governamentais. A expressão é sugestiva de que a economia financeira não só se autonomizou, como ganhou ascendência sobre a economia real e os setores sociais a ela vinculados ${ }^{164}$.

$\mathrm{Na}$ nova ordem financeira e monetária internacional, as relações de câmbio deveriam ser determinadas pela livre atuação dos agentes privados nos mercados. Endossando a proeminência da determinação espontânea das taxas de câmbio, a receita para o comportamento governamental passou a ser de disciplina orçamentária no lugar dos controles de capital ${ }^{165}$. Assim, por exemplo, já no início de 1972, representantes dos Estados Unidos:

esperavam desencorajar que outros países controlassem movimentos de capital em
geral. De acordo com os representantes dos Estados Unidos, uma ordem financeira
internacional mais completamente liberal permitiria que os movimentos
internacionais de capital encorajassem "o crescimento do comércio internacional" e
o aumento "do bem-estar econômico de países desenvolvidos e em
desenvolvimento". Eles também questionavam a visão de que movimentos
desequilibrantes de capital fossem necessariamente indesejáveis, afirmando que tais

${ }^{164}$ Além do aspecto de preponderância dos mercados financeiros e da autonomia das finanças em relação à economia real, Robert Guttmann atribui à financeirização do capitalismo as características de movimento em sentido à ausência de regulamentação das finanças e, no plano corporativo, de "maximização do valor do acionista”. (Guttmann, 2008)

${ }^{165}$ Eiiti Sato sintetiza o significado da mudança para a orientação do comportamento dos Estados: "[n]a esteira da crise da ordem de Bretton Woods, privatização, redução do tamanho do Estado, equilíbrio dos gastos públicos e desregulamentação são expressões que se tornaram cada vez mais frequentes nos pronunciamentos oficiais dos governos a respeito de políticas e mesmo de objetivos governamentais." (Sato, 2012, p. 181) 
movimentos demandavam que os países tomassem medidas apropriadas de ajuste. (Helleiner, 1994b, p. 106)

As mudanças no caráter da ordem financeira internacional foram acompanhadas de sobreposições institucionais, no sentido de que as estruturas organizacionais de Bretton Woods - como o FMI e o Banco Mundial -, embora não tenham deixado de existir, foram deslocadas do "núcleo" formulador das políticas de cooperação monetária e financeira internacional, passando a assumir outros papéis. Como se observou no capítulo 2, tais papéis relacionavam-se com a promoção da "boa governança", que pode ser lida como reformas por instituições mais favoráveis à liberdade dos agentes privados nos mercados, por meio da concessão de empréstimos e "pacotes de resgate" condicionados à realização de tais reformas.

Consequentemente, conforme destacado por Sato, “[o] FMI foi aos poucos passando a não mais desempenhar um papel central no sistema monetário internacional." (Sato, 2012, p. 172) Assumiram importância central na definição de assuntos monetários e financeiros espaços menos formais como o G-7 $7^{166}$, e instituições internacionais como o Banco de Compensações Internacionais (Bank of International Settlements - BIS), e reuniões entre atores públicos e privados, como o Fórum Econômico Mundial.

Como Eiiti Sato aponta, "questões que tradicionalmente seriam tratadas no âmbito do Fundo Monetário Internacional, do GATT ou em reuniões do Banco Mundial, passaram a ser discutidas e negociadas nas reuniões do G-7.” (2012, p. 170). Com início em meados da década de 1970, ministros das finanças e diretores de bancos centrais das sete principais economias do mundo passaram a se reunir, compartilhando a noção de que o consenso entre as economias centrais $(2012$, p. 173) era o ponto de partida para a orientação da cooperação econômica internacional (cf. Smith, 2011).

Outro desses espaços era o Banco de Compensações Internacionais. Apesar de fundado em 1930 como mecanismo para administrar fluxos relacionados ao pagamento de reparações pela Alemanha a distribuição dos pagamentos entre os Estados aliados, desempenhou papel secundário na cooperação monetária internacional até o reavivamento de sua importância como espaço de tomada de decisões por ministros de finanças e diretores de bancos centrais. Em reuniões informais, com "atmosfera de clube" (Helleiner, 1994b, p. 97),

\footnotetext{
${ }^{166}$ O G-7, ou "Group of 7", foi o espaço informal de cooperação internacional, estabelecido na década de 1970, que teve por membros as sete maiores economias industriais da época: Estados Unidos, Japão, Alemanha Ocidental, Canadá, Itália, França e Reino Unido. Atualmente, as reuniões incluem a Rússia, dando origem ao termo "G-8". Além disso, a composição do grupo permanece "uma questão de acidente histórico", já que parte de seus membros já não se encontra no topo do ranking das economias mundiais (Stiglitz, 2002, p. 14-5). Outro relato da transformação do G7 em G8, que abrange ainda a formação do G20 no final da década de 1990, pode ser encontrado em Gordon Smith (2011). Vide, ainda, seção 3.4.
} 
swaps cambiais entre as principais economias passaram a ser acordados como meio para enfrentar dificuldades transitórias, diminuindo a importância que a assistência cambial emergencial do FMI havia representado sob a ordem de Bretton Woods. Além disso, em contraste com o estilo "antimercado" das regulações de Bretton Woods, o Banco de Compensações Internacionais promoveu a harmonização internacional das regulações bancárias com estilo "pro-market." (Helleiner, 1994b, p. 191)

Em meio às reuniões entre ministros de finanças e diretores de bancos centrais, espaços como o G-7 e o Banco de Compensações Internacionais abrigaram "uma comunidade epistêmica transnacional nascente" (Helleiner, 1994b, p. 198), que partilhava visões neoliberais a respeito da gestão das finanças internacionais. Outro espaço que abrigou esta comunidade, a partir de 1971, foi o Fórum Econômico Mundial, realizado anualmente em Davos, na Suíça (Miller, 2010, p. 36). Mais amplo em escopo, ele inclui não apenas agentes das finanças governamentais, mas grandes empresários, acadêmicos de áreas variadas e membros da imprensa “que se reúnem para moldar a agenda global.” (Miller, 2010, p. 36)

Tanto no plano doméstico quanto no das estruturas de cooperação econômica internacional, a perspectiva econômica do neoliberalismo alcançou a proeminência política. $\mathrm{O}$ regime monetário e financeiro da ordem econômica internacional neoliberal foi marcado pela mobilidade e volatilidade dos fluxos de capital, além do abandono dos mecanismos multilaterais para preservação da estabilidade cambial. Além disso, correspondeu a reorientações acerca do papel apropriado do Estado no domínio econômico. A ordem do dia passou a ser liberalizar finanças e comércio, privatizar empresas públicas, flexibilizar legislações trabalhistas e remover os obstáculos institucionais à livre realização dos negócios. Os constrangimentos para que tais mudanças fossem realizadas decorriam não apenas do novo discurso das instâncias de cooperação econômica internacional, mas das próprias características dos mercados financeiros internacionais, a incentivar a dinâmica de competição pela desregulamentação financeira e a disciplina nas contas públicas como imperativo para evitar a "fuga de capital".

O resultado mais expressivo da nova conformação da cooperação monetária e financeira internacional parece ter sido a "emergência no mundo de um novo poder financeiro, mesmo que difuso e sem controle unificado, a rivalizar e eventualmente prevalecer sobre as políticas econômicas elaboradas por governos democráticos.” (Pollard, 1997, p. 42) Como mencionado anteriormente, Bresser-Pereira refere-se a essa configuração como capitalismo financeirizado $(2010$, p. 54). O cenário guarda certa semelhança com a ascendência da haute finance sobre a política econômica de Estados variados sob o regime do 
POI. Tal como no POI, reemergiu a "tendência de as taxas de juros, devidamente modificadas pelos graus de risco, alinharem-se umas com as outras pelo mundo.” (Pollard, 1997, p. 42) Por sua vez, o fenômeno representou a perda do poder de cada país para definir a taxa de juros de acordo com suas prioridades políticas, visto que "desalinhamentos" serão explorados (a exemplo do chamado carry trade ${ }^{167}$ ) por fluxos especulativos com tendências desestabilizantes. Em outros termos, foi resgatado o elemento de "veto privado" a políticas governamentais que pudessem ser vistas como atentatórias à segurança e rentabilidade dos investimentos, como acontecia sob a ordem do POI. Afinal, a autonomia política doméstica propiciada sob o esquema de Bretton Woods foi comprometida pelo desmantelamento dos controles de capital.

Diferentemente do que ocorria sob o POI, porém, os fluxos financeiros passaram a ocorrer de modo relativamente desprendido de transações comerciais ${ }^{168}$. Segundo Rodrik, em 2007, a média diária de transações financeiras no mundo havia chegado a 3.2 trilhões de dólares norte-americanos, ao passo que o volume diário de comércio correspondia a uma fração disso: 38 bilhões de dólares (Rodrik, 2011, p. 107), ou seja, as finanças eram mais que 84 vezes maiores do que o comércio. Outro dado ilustrativo do crescimento das finanças na era de desregulamentação diz respeito a seu tamanho em relação ao produto anual mundial no mesmo ano: 11 vezes maior ${ }^{169}$ (Birch; Mykhnenko, 2010, p. 132).

Crises passaram a ser comuns no cenário de agigantamento dos mercados financeiros internacionais. Rodrik cita a ocorrência de "124 crises bancárias, 208 crises cambiais e 3 crises da dívida soberana entre 1970 e 2008.” (2011, p. 108-9) ${ }^{170}$ O período foi marcado por “ondas de crises financeiras à mercê dos mercados internacionais de capital”:

Primeiro foi a crise da dívida na América Latina nos anos 1970, que, agravada pelo gerenciamento econômico ruim, engoliu os países da região e produziu uma "década

\footnotetext{
${ }^{167}$ Pela estratégia do carry trade, investidores tomam dinheiro emprestado em mercados com juros baixos, e por sua vez emprestam adiante em outros mercados a juros mais altos. Dessa forma, exploram diferenciais nas taxas de juros para obter o spread como ganho. O carry trade não deixa de ser uma forma de exercer arbitragem no campo das taxas de juros.

168 "Os fluxos financeiros [...] tornaram-se praticamente independentes do comércio, isto é, os impulsos que levam à movimentação de fundos no plano internacional apenas marginalmente passaram a referir-se ao comércio." (Sato, 2012, p. 176)

169 Essa proporção leva em consideração as transações financeiras em mercados "over-the-counter" ou "de balcão" (vide seção 3.4), que ocorrem sem publicidade e alheios às práticas contábeis, que corresponderam, em 2007, à maior fatia das operações financeiras no mundo (Birch; Mykhenko, 2010, p. 13). Em cálculo diferente, feito por Bresser-Pereira, "entre 1980 e 2007 os ativos financeiros cresceram cerca de quatro vezes mais que a riqueza real - o crescimento do PIB.” (2010, p. 57) Parece inequívoco que a economia financeira ganhou autonomia em relação à economia real, embora o contrário não possa ser afirmado.

${ }^{170}$ Bresser-Pereira trabalha com números menores, mas considera período menor: "enquanto no período de 1945 a 1971 [Bretton Woods] o mundo passou por apenas 38 crises financeiras, entre 1973 e 1997 [neoliberalismo] passou por 139 delas, ou seja, no segundo período houve entre três e quatro vezes mais crises que no primeiro." (Bresser-Pereira, 2010, p. 58)
} 
perdida" de estagnação econômica. Nos anos 1990, foi a vez da Europa, quando negociantes de câmbio especularam com sucesso contra os bancos centrais de diversos países europeus (como Inglaterra, Itália e Suécia). Esses países haviam tentado limitar a flutuação cambial ao vincular suas moedas de modo próximo ao marco alemão, mas os mercados financeiros forçaram suas desvalorizações. Em meados dos anos 1990, ocorreu outra rodada de crises financeiras, a mais severa das quais foi a "crise da tequila" no México (1994) ocasionada pela reversão súbita dos fluxos de capital. A crise asiática seguiu-se em 1997-8, e em seguida gerou efeitos em cascata sobre Rússia (1998), Brasil (1999), Argentina (2000), e ao final a Turquia. Esses são apenas os casos mais conhecidos. (Rodrik, 2011, p. 108)

Além da instabilidade financeira, outras repercussões da era do neoliberalismo se deram sobre as taxas de crescimento e a distribuição de renda ${ }^{171}$, como se pode perceber na comparação feita por Bresser-Pereira:

Enquanto a era dourada [Bretton Woods] foi marcada por mercados financeiros regulados, estabilidade financeira, elevadas taxas de crescimento econômico e uma redução da desigualdade, o oposto ocorreu nos anos do neoliberalismo: as taxas de crescimento diminuíram, a instabilidade financeira aumentou rapidamente e a desigualdade cresceu, privilegiando principalmente os dois por cento mais ricos de cada sociedade nacional. (Bresser-Pereira, 2010, p. 54)

Mesmo depois de crises como a do Sudeste Asiático e o estouro da bolha dotcom nos Estados Unidos, a defesa da liberdade de capital permaneceu viva. Nem todos os autores concordam com a afirmação de que a moldura neoliberal tenha sido responsável por maior instabilidade financeira, acirramento da desigualdade social ou por menores índices de crescimento.

Um exemplo pode ser encontrado na obra In defense of global capitalism, de Johan Norberg (2003), publicada pelo Cato Institute, um think tank libertário fundado em 1974 e voltado à promoção de políticas públicas segundo os ideais de "liberdade individual, governo limitado, livre mercado e paz." (Cato Institute, 2015) O livro deu origem ao documentário "Globalisation is good”, que foi ao ar na Grã-Bretanha ${ }^{172}$.

${ }^{171}$ Para Robert Guttmann, um dos impactos do capitalismo financeirizado (ou "capitalismo dirigido pelas finanças") foi a "distribuição da renda favorável aos mais ricos, nas mãos dos quais a maior parte dos ativos financeiros está concentrada" (2008, p. 14). A afirmação de Guttmann encontra-se alinhada ao trabalho de Thomas Piketty. Com base na análise estatística de séries históricas sobre distribuição de renda, distribuição de riqueza e relações entre riqueza e renda, Piketty apresenta a tese de que a desigualdade econômica tende ao agravamento dada certa progressão histórica de distanciamento (a maior) da renda obtida a partir do capital em relação à renda oriunda do trabalho. Em especial, afirma que "há um conjunto de forças de divergência associadas ao processo de acumulação e concentração de renda quando o crescimento é baixo e o retorno do capital é alto." (Piketty, 2014, p. 23) A tese de Piketty é sumarizada pela fórmula " $r>g$ ", onde "r" significa a "taxa anual média de retorno do capital" e "g" é "a taxa de crescimento na economia" (2014, p. 25). As constatações de Piketty levam-no a sugerir "instituições e políticas públicas que contrabalançariam os efeitos dessa lógica implacável: por exemplo, uma tributação progressiva global sobre o capital.” (2014, p. 27) Dani Rodrik (2011) é outro autor favorável à tributação global do capital (vide seção 3.4).

${ }^{172}$ No documentário, Norberg estabelece uma comparação entre Quênia e Taiwan. Em sua análise, os dois países tinham níveis semelhantes de pobreza nos anos 1950, mas ao início do século XXI, encontram-se em posições econômicas díspares. A razão apontada para o desenvolvimento acelerado de Taiwan em contraste com o Quênia é a orientação pró-mercado assumida por aquele (Globalisation..., 2003). 
Norberg realiza a defesa da liberdade financeira internacional de modo duplo. Primeiramente, trabalha o acesso aos mercados financeiros internacionais como uma questão de liberdade individual. Em seguida, deriva da eficiência de alocação de recursos pelos mercados a necessidade de sua liberalização.

No primeiro aspecto, a liberdade do capital associada à globalização é defendida como decorrência do direito individual de liberdade. Para Norberg, pessoas e negócios devem poder decidir livremente o que fazer com seus recursos, estando livres para aplicá-los onde quer que acreditem ser melhor fazê-lo e para obter empréstimos onde encontrarem os melhores termos (2003, p. 242-3).

O segundo aspecto envolve a defesa da liberdade financeira com base na eficiência dos mercados. A essência do argumento é que os mercados financeiros devem ser livres porque produzem os melhores resultados econômicos.

Mercados de capital [...] permitem que pessoas e negócios com muitos recursos
ganhem ao disponibilizar capital aos que não o têm, mas parecem capazes de usá-lo
de forma mais eficiente. Desse modo, capacitam pequenas empresas a competir com
as já estabelecidas. Quanto mais flexíveis os mercados e menores os impedimentos,
mais facilmente o capital fluirá para aqueles que podem fazer melhor uso dele.
(Norberg, 2003, p. 244)

Para Norberg, a pretensão de regular os mercados financeiros é um "meio para evitar reformas dolorosas", mas necessárias, como aquelas voltadas ao controle da inflação e à disciplina fiscal (2003, p. 252). "E se os controles de capital induzem políticos a pensar que estão livres para conduzir qualquer política que desejem, as chances são de que eles agravarão a crise.” (2003, p. 251) A introdução de controles de capital sinaliza para os investidores a impossibilidade de retirar seus investimentos do país no momento em que desejarem. Em vista disso, demandarão maiores taxas de retorno para compensar o risco do investimento, tornando o acesso ao capital mais caro. E, em todo caso, o país passa a correr o risco de sofrer escassez financeira (Norberg, 2003, p. 249).

Apesar de relatar essencialmente as mesmas crises listadas por Rodrik, Norberg não considera incrementos regulatórios como componentes de possíveis soluções. A causa das crises financeiras é atribuída à existência de "políticas ruins" (Norberg, 2003, p. 251). "Há vários métodos para evitar crises financeiras e cambiais, mas o mais essencial deles para um país é simplesmente ter uma política econômica saudável.” (2003, p. 264) A chave consiste em manter o controle sobre o orçamento governamental e a inflação, de modo a preservar a confiança dos mercados. A confiança dos mercados internacionais é conquistada com “compromissos de longo prazo", expressos por reformas nas instituições jurídicas e 
financeiras (getting institutions right). Nesse sentido, as reformas devem produzir maior abertura às finanças e ao comércio internacional, além de abolir pretensões de controle sobre o câmbio, que deve ser flutuante (2003, p. 266).

Por fim, a respeito da crítica de que este sentido de reformas aliena a condução da política doméstica dos desejos expressos nas urnas, Norberg rebate: "[o] que os críticos realmente percebem como ameaçadas pelo mercado não é a democracia, mas as políticas que eles gostariam que as democracias adotassem - políticas que envolvem maior poder governamental sobre as decisões econômicas das pessoas." (2003, p. 273) Nesse sentido, o autor enxerga com bons olhos o caráter disciplinar exercido pelos mercados financeiros internacionais sobre a política doméstica, um elemento que não é negado em sua narrativa da globalização. "Os governos ainda detêm a liberdade de gerenciar mal suas economias; encontram-se apenas privados da capacidade de forçar que outros financiem seu mau gerenciamento" (2003, p. 271), caso em que são penalizados por investidores por meio da fuga de capital.

Embora a defesa extremada da liberdade do capital financeiro internacional, como a feita por Norberg, ainda possa ser encontrada contemporaneamente, a crise do subprime nos Estados Unidos, que chegou ao auge em 2008, contribuiu para lançar dúvidas sobre a defesa neoliberal de desregulamentação das finanças internacionais. Esse assunto será retomado adiante. Até o momento, foram abordados aspectos da estruturação da ordem econômica internacional do neoliberalismo que disseram respeito à emergência e predominância de uma perspectiva econômica e seus impactos sobre a conformação dos regimes internacionais de moeda e finanças. A subseção 3.3.3, a seguir, aborda aspectos do regime de comércio internacional relacionados ao período do neoliberalismo.

\subsubsection{Regime de comércio: neoprotecionismo e novos temas da liberalização comercial.}

A orientação econômica neoliberal concebe a iniciativa privada como motor da economia. A receita para o crescimento econômico e a geração de bem-estar encontram-se atrelada ao comportamento livre dos agentes no mercado, não ao comportamento governamental ativo. Tal como nas finanças, a sustentação da liberdade para transações internacionais estende-se ao comércio. De certa forma, a promoção da liberdade comercial não configura rompimento em relação à ordem de Bretton Woods, que também procurava incentivar maior integração comercial mundial sob a moldura do GATT 1947. Mas mesmo nesse aspecto há diferença fundamental entre os dois períodos: Bretton Woods promovia 
liberdade comercial e restrição financeira, ou uma abertura manejada. A ordem neoliberal pretende liberdade nas duas áreas, ou abertura irrestrita. Outras características singulares dessa ordem econômica internacional são o relativo desprendimento do mundo das finanças em relação à produção e ao comércio (elemento abordado no tópico anterior) e a maior ocorrência de fluxos comerciais atinentes às corporações transnacionais.

$\mathrm{O}$ agigantamento e volatilização dos mercados financeiros internacionais foram correspondidos pelo surgimento de novas práticas protecionistas no início dos anos 1970. Algumas dessas práticas eram abrigadas por "interpretações extensivas” do que o GATT 1947 permitia, podendo ser lidas como "abusos". Outras eram inovações que não haviam sido previstas na regulamentação do sistema multilateral de comércio. As dificuldades no manejo do câmbio e no balanço de pagamentos experimentadas nesses anos converteram-se no neoprotecionismo comercial.

Na década de 1990, a liberalização comercial recebeu novos impulsos por meio da formação da OMC. Novos temas foram abrangidos pelo regime internacional do comércio, como serviços, investimentos e propriedade intelectual. A reconfiguração do regime contou ainda com expressivo adensamento institucional, sobretudo por meio da reforma do mecanismo de solução de controvérsias. Estes aspectos são abordados nos tópicos a seguir.

\subsubsection{Neoprotecionismo e a Rodada Tóquio do GATT}

No campo do comércio, a década de 1970 foi marcada pelo ressurgimento do protecionismo, expresso sobretudo pela imposição de barreiras não tarifárias (Bhagwati, 1995, p. 43). Entre as práticas restritivas encontravam-se a proliferação de medidas compensatórias, salvaguardas e medidas antidumping. Embora estivessem previstas no GATT 1947, seu uso com ânimo renovado, nessa época, pode ser lido como "abuso" das válvulas de escape na regulamentação do sistema multilateral de comércio. Outras medidas eram, porém, inovadoras. Entre elas, a imposição de barreiras técnicas ${ }^{173}$ e a celebração de acordos de "restrição voluntária às exportações". Ao longo dessa década, os Estados Unidos, por exemplo, celebraram diversos destes acordos com o Japão, com a finalidade de restringir as importações americanas de carros, aço e de outros produtos japoneses (Rodrik, 2011, p. 73). Jagdish Bhagwati faz referência, inclusive, à formação de uma "rede" desses acordos por

173 Barreiras técnicas "se efetivam por mecanismos que vão desde a proibição direta até exigências administrativas que inviabilizam ou encarecem a importação de produtos.” (Barral, 2007a, p. 80) Alguns exemplos incluem a exigência de certificações sanitárias, de origem ou padronização segundo a legislação nacional. 
parte dos Estados Unidos como meio de obter proteção comercial ao largo do GATT 1947 (Bhagwati, 1995, p. 53).

No âmbito do regime do comércio internacional, a resposta veio na forma da Rodada Tóquio, que ocorreu entre os anos de 1973 e 1979. Ao passo que as rodadas anteriores do GATT tiveram por objeto principal as reduções tarifárias, a Rodada Tóquio distinguiu-se por dar prioridade às barreiras não tarifárias (Kenwood; Lougheed, 1999, p. 293), embora reduções tarifárias também tenham sido negociadas (Jackson, 2002, p. 52). As negociações, no entanto, resultaram em acordos "pluri" e não "multilaterais", significando que sua adesão não era obrigatória a todos os membros do GATT, no que ficou conhecido como "GATT à la carte." (Jackson, 2002, p. 401; 2000, p. 47) Dessa forma, ainda que acordos tenham sido alcançados no campo dos subsídios e medidas compensatórias, salvaguardas, antidumping e compras governamentais, entre outros, a intenção de contenção jurídica do neoprotecionismo foi comprometida logo no início pelo baixo número de membros signatários (Jackson, 2000, p. 290). Apesar de seu foco nas barreiras não tarifárias, Bo Södersten e Geoffrey Reed afirmam, ao fazer o balanço das negociações, que "a principal conquista da Rodada Tóquio [foi] a continuação da liberalização no comércio por reduções tarifárias.” (Södersten; Reed, 1994, p. 364)

\subsubsection{OMC: adensamento institucional e novos temas da liberalização comercial}

A criação da Organização Mundial do Comércio (OMC) foi resultado da Rodada Uruguai. Porém, quando as negociações da rodada começaram em 1986, não havia qualquer previsão explícita a respeito da criação de organização internacional formal dedicada ao comércio internacional. Somente após a queda da União Soviética e a percepção generalizada do fim da alternativa socialista ao capitalismo é que a proposta de formação da organização entrou nas negociações, em 1991. O nome "OMC" só entrou na pauta da Rodada Uruguai em 1993 (Jackson, 2002, p. 400). Em 1994, a Ata Final de Marraquexe foi assinada (Jackson, 2000, p. 46), e a OMC começou a funcionar em janeiro de 1995, em Genebra.

A OMC representou alterações institucionais relevantes para o regime internacional do comércio. Institucionalmente, para além do status de organização internacional formal - que o GATT 1947 não detinha -, introduziu-se a possibilidade de adotar decisões por maioria, e não apenas por consenso (Jackson, 2002, p. 401). O novo formato decisório permitiu que as decisões fossem vinculantes a todos, pondo fim à prática do GATT à la carte. Outra reforma que fortaleceu a capacidade de decisão multilateral, baseada na instituição, foi a do 
mecanismo de solução de controvérsias. Sob o regime do GATT, os relatórios dos painéis que decidissem uma disputa comercial estavam sujeitos à rejeição caso não fossem unanimemente adotados pelos membros ${ }^{174}$. Em outros termos, a parte perdedora da disputa poderia bloquear a decisão contrária a seus interesses. Com a OMC, inverteu-se a lógica da unanimidade, passando a ser necessário obter os votos de todos os membros para impedir que o relatório do painel seja adotado. Além disso, as inovações compreenderam a criação do Órgão de Apelação como instância recursal, o estabelecimento de prazos para os procedimentos - que não mais poderiam desenrolar-se indefinidamente - e para o cumprimento das decisões (Jackson, 2002, p. 408; Barral, 2007b, p. 49). Estas mudanças representaram adensamento institucional e marcadamente jurídico do regime internacional de comércio.

Outra mudança que resultou da Rodada Uruguai foi a drástica expansão do volume de comércio abrangido pela regulamentação da OMC. O GATT 1947 era essencialmente voltado à regulamentação do comércio de bens. $\mathrm{Na} \mathrm{OMC}$, a expansão se deu não somente no sentido de passar a abranger o comércio de serviços (por meio do General Agreement on Trade in Services, ou GATS), mas também certos temas que apenas indiretamente encontravam-se relacionados ao comércio, tais como propriedade intelectual (Agreement on Trade-Related Aspects of Intellectual Property Rights, ou TRIPS) e investimentos (Agreement on Trade-Related Investment Measures $)^{175}$. Por isso, Welber Barral considera que "a OMC tornou-se o grande foro para as relações econômicas internacionais, e não apenas para as relações comerciais.” (Barral, 2007a, p. 105)

Vários são os fatores relacionados à migração de temas como propriedade intelectual e investimentos para a moldura da OMC. Primeiramente, o maior poder de sanção da organização, em comparação com outras organizações cujas normas dependem do cumprimento voluntário das partes. Em segundo lugar, o fato de que a acessão de novos membros à $\mathrm{OMC}$ é condicionada à aceitação completa de seus acordos multilaterais. Por isso, temas que são de "adesão voluntária" em outras organizações e tratados encontram-se, na OMC, vinculados à liberalização do comércio. Nesse sentido, a condicionalidade utiliza o

\footnotetext{
174 O GATT 1947, em sua redação original, não chegou a estabelecer o mecanismo para solução de controvérsias, que apenas foi adicionado à regulamentação multilateral do comércio ao fim da rodada Tóquio (Barral, 2007b, p. 18)

${ }^{175}$ Cabe esclarecer que o TRIMS pretende a regulamentação dos investimentos estrangeiros diretos e não dos chamados "investimentos de portfólio", de curto prazo e feições especulativas. Por exemplo, a regulamentação pretende incidir sobre o caso do investidor que instale indústria em outro país, e não sobre aquele que compre títulos da dívida soberana. O TRIMS aplica aos investimentos princípios fundamentais do GATT como "tratamento nacional", de modo a coibir a discriminação do investidor estrangeiro, e restrição a medidas nacionais de caráter protecionista, tais quais "restrições quantitativas quanto aos investimentos, a exigência de compra de produtos locais, a restrição de acesso a moedas estrangeiras”, entre outros (Barral, 2007b, p. 86).
} 
interesse pelo acesso a mercados como alavanca para obter o consentimento de novos membros a regulamentações de uma gama mais ampla de temas que compõem um só pacote (Barral, 2007a, p. 104). Por fim, não se podem deixar de lado os constrangimentos mais diretos que compõem negociações internacionais, como ocorreu no caso da inclusão da propriedade intelectual por meio da vinculação de temas distintos como parte do processo de barganha política (issue-linkage). "Na Rodada Uruguai, os EUA deixaram claro que não negociariam qualquer outro tema, a não ser que a proteção à propriedade intelectual fosse incluída como um dos acordos multilaterais obrigatórios para todos os Membros da OMC." (Barral, 2007a, p. 112)

\subsubsection{Uma defesa contemporânea da liberdade comercial internacional}

Em 1999, protestos contra a globalização econômica ocorreram durante a conferência ministerial da OMC em Seattle. Os protestos conseguiram frustrar as negociações ${ }^{176}$, e foram representativos do impulso que movimentos transnacionais contrários ao neoliberalismo haviam adquirido. Eram respostas não só à percepção de que a liberalização do comércio ameaçava empregos locais, explorava condições de trabalho deterioradas no exterior ou ameaçava o ambiente, mas também à sucessão de crises econômicas ocorridas na década de 1990, e associadas à liberalização do capital (Stiglitz, 2002). Além disso, insatisfações eram dirigidas à atuação de corporações internacionais ${ }^{177}$.

Os protestos representaram o ganho de visibilidade de perspectivas alternativas à liberalização radical do comércio e das finanças internacionais. No entanto, não implicaram o fim da defesa do livre comércio. Um dos principais expoentes dessa linha é Jagdish Bhagwati, um autor que, curiosamente, faz a defesa da liberalização unilateral do comércio como desejável, mas propõe que a liberalização das finanças seja abordada com cautela.

Bhagwati é contrário a estratégias de liberalização financeira aceleradas, ao estilo da “terapia de choque" aplicada à Rússia na década de 1994, sob a orientação do economista

\footnotetext{
${ }^{176} \mathrm{O}$ colapso das negociações da OMC em Seattle é interpretado por Rajagopal como indicativo de que "as instituições internacionais são hoje abertamente confrontadas pela resistência de massas.” (Rajagopal, 2003, p. 44)

${ }^{177}$ O documentário canadense "A corporação" - The corporation, no original - (2003) sugere que práticas das corporações transnacionais poderiam levar à sua caracterização como expressões de "psicopatia", caso utilizadas as categorias para diagnósticos de pessoas naturais. Entre os casos abordados pelo documentário encontra-se a privatização do serviço de distribuição de água na cidade de Cochabamba, na Bolívia, para o grupo corporativo estadunidense Bechtel. Após a privatização, cobranças passaram a incidir inclusive sobre o uso que os munícipes faziam de água acumulada da chuva. Este último aspecto, em particular, contou com representação cinematográfica - neste caso, uma dramatização motivada em contexto fático verídico, e não um documentário por meio do filme espanhol "Conflito das águas" (2010), cujo título no original é "También la lluvia".
} 
Jeffrey Sachs (Bhagwati, 2004, p. 235; cf. Sachs, 2005, p. 164-81). Nesse sentido, defende o “direcionamento cuidadoso e velocidade ótima de mudanças em políticas públicas, não uma velocidade máxima" de reformas pela liberalização financeira (Bhagwati, 2004, p. 32). Para ele, a "liberalização apressada e imprudente dos fluxos de capital [...] certamente ajudou a precipitar a crise econômica e financeira asiática iniciada em 1997.” (2004, p. 35) O caso do comércio é encarado diferentemente. "Aqui as consequências da liberalização apressadas dificilmente serão tão desastrosas quanto às da liberalização dos fluxos de capital.” (2004, p. 254)

O autor estabelece encadeamentos entre quatro categorias: globalização, comércio, crescimento e pobreza. A globalização econômica é encarada como estímulo à liberdade do comércio. Este último é visto como promotor do crescimento econômico, que Bhagwati apresenta como principal força na redução da pobreza (2004, p. 53, 64-5). Embutida nessa caracterização está a noção de efeitos de respingos do crescimento econômico, ou spillover effects, no sentido de que o enriquecimento de certos setores da sociedade acaba beneficiando os mais pobres. Esta visão permite apresentar a concentração de renda como algo compatível com o bem do todo social, tal como a concepção de trickle down economics de Ronald Reagan. Tais encadeamentos conduzem à conclusão de que a globalização "ajuda, e não ameaça, as causas de redução da pobreza nos países pobres” (2004, p. 66). Por isso, ela é caracterizada como portadora de uma "face humana" e "socialmente benéfica"178 $(2004$, p. 221).

A defesa que Bhagwati faz da globalização e da abertura comercial endereça não apenas a crítica relativa ao aumento da pobreza, mas também aquelas dirigidas a tópicos como trabalho, democracia e atuação de corporações transnacionais.

A crítica relacionada a efeitos nocivos da globalização sobre o trabalho levanta aspectos como tendência à deterioração de padrões trabalhistas a partir de flexibilização competitiva, reduções salariais e aumento do desemprego, bem como incentivo ao trabalho infantil. Certas correntes defendem a entrada de padrões trabalhistas na regulamentação da OMC. Bhagwati é contrário a tais movimentações, defendendo uma "abordagem sem sanções" comerciais, que reserve a competência para questões trabalhistas à Organização Internacional do Trabalho (2004, p. 34).

\footnotetext{
${ }^{178}$ Bhagwati caracteriza os resultados socialmente benéficos da globalização como uma "tendência central", não chegando a afirmar que seja efeito necessário em todos os casos. Os "efeitos adversos" da liberalização comercial, "se e quando surgirem", devem ser endereçados por meio de mecanismos institucionais (2004, p. 32). O sentido da argumentação é o de que a globalização gera efeitos benéficos mediante a presença de instituições domésticas corretas.
} 
Para o autor, a globalização tem por tendência central ajudar trabalhadores menos qualificados a conseguir empregos que teriam sido perdidos em razão do aumento da mecanização e de mudanças tecnológicas (2004, p. 123), justamente por permitir que a produção se desloque para os locais em que a mão de obra é mais barata. O argumento deságua, por sua vez, na questão salarial. O autor afirma que a demanda por mão de obra por parte de corporações transnacionais que se instalam em um país conduz a elevações salariais ${ }^{179}$ (2004, p. 124). Além disso, na visão do autor, não procede a crítica de que tais corporações procurariam lugares com menores níveis de proteção trabalhista para se instalar, estimulando que governos diminuam direitos trabalhistas de forma a competir pela atração dessas empresas (flexibilização competitiva dos direitos trabalhistas). Em sua perspectiva, as grandes empresas levam em conta "efeitos reputacionais", que são "suficientemente sérios hoje para prevalecer, para muitas multinacionais, sobre os lucros adicionais que poderiam ser obtidos pela estratégia de aproveitamento.” (2004, p. 131)

Por sua vez, ao reconhecer que empresas subcontratadas por multinacionais violam direitos trabalhistas "de vez em vez", o autor afirma, em socorro destas últimas, que "uma vez que o problema reside na falta de aplicação efetiva da lei do país anfitrião, tornaremos as multinacionais responsáveis por qualquer coisa que comprarem nestes países, mesmo se não produzidas diretamente por elas?” (2004, p. 173-4) A presença das corporações multinacionais não poderia ser vista como causa de prejuízos à economia e sociedade locais, porque o fator de peso para a geração de tais efeitos seriam, ao invés, "políticas domésticas ruins”, que poderiam ser mudadas pelos países anfitriões (2004, p. 178). É, essencialmente, um problema de boa governança (good governance).

Por sua vez, a relação entre liberalização comercial e desemprego é encarada nos seguintes termos:

Mesmo que trabalhadores demitidos venham a encontrar-se no grupo dos
desempregados, outros que se encontravam sem emprego conseguiriam trabalho nos
setores exportadores. Dessa forma o índice geral de desemprego poderia permanecer
inalterado, com alguns trabalhadores perdendo e outros ganhando empregos. Então
não haveria perda na renda nacional causada por aumento líquido no desemprego
geral, e há ganhos de produtividade - uma expressão técnica usada por economistas
para dizer que recursos se deslocaram de setores menos eficientes para os mais
eficientes. Os ativistas de direitos humanos precisam encarar o fato de que ao passo
que os direitos humanos daqueles que perdem seus empregos são violados, os
direitos humanos daqueles que ganham empregos são aumentados. Mas mesmo se o
desemprego viesse a aumentar, ele somente produziria uma perda de renda que deve
ser contrabalançada pelos ganhos dos consumidores, então os efeitos líquidos da

179 “Ao incrementar a demanda por trabalho no país anfitrião, é fortemente provável que as multinacionais aumentem os níveis salariais de modo geral, melhorando com isso a renda dos trabalhadores nesses países." (Bhagwati, 2004, p. 173) 
liberalização comercial podem ainda assim ser favoráveis. ${ }^{180}$ (Bhagwati, 2004, p. 255)

Ainda no que diz respeito a questões de trabalho, o autor endereça a crítica segundo a qual a globalização estimula a exploração do trabalho infantil. Para ele, tal problema é historicamente persistente e precede à globalização, não estando diretamente associado à liberdade de comércio, mas à existência da pobreza. "A verdade é que a globalização - onde quer que ela se traduza em maior prosperidade geral e pobreza reduzida - só faz acelerar a redução do trabalho infantil e aumentar as matrículas no ensino fundamental, e consequentemente a alfabetização.” (Bhagwati, 2004, p. 68)

$\mathrm{O}$ último ponto aqui destacado refere-se à crítica que relaciona globalização a déficits democráticos, bastante salientados por autores como Dani Rodrik ${ }^{181}$ (2011). Bhagwati defende existir relação de mão dupla, no sentido de que "a globalização promove a democracia ao mesmo tempo em que a limita." (2004, p. 93) Por um lado, a prosperidade econômica e a redução da pobreza associadas à globalização produzem o aumento da classe média, que por sua vez cria "demanda efetiva pela democratização da política." (2004, p. 94) Por outro lado, a globalização limita a democracia ao restringir a "habilidade de mudar políticas públicas radicalmente à esquerda", bem como de "conduzir gastos sociais, e mesmo de manter os níveis de gastos gerais, numa economia globalizada.” (2004, p. 96) Isso porque o equilíbrio das contas públicas é fundamental para a confiança internacional na solvência do Estado, que caso contrário arrisca sofrer fuga de capital.

A descrição elaborada a respeito do efeito constritor que a globalização tem sobre a política democrática contemporânea guarda forte semelhança com a influência que Polanyi (2001) atribuiu à haute finance sobre os governos durante o POI (ver seções 3.1 e 3.2):

Se uma só nação, mesmo com governo popularmente eleito, muda para políticas radicais, o capital financeiro pode evadir-se; mesmo a burguesia ("capital humano") pode emigrar, votando com seus pés. Ao mesmo tempo, novas fontes estrangeiras de financiamento podem secar, exacerbando a crise. Governos, contemplando tal resultado, podem rejeitar guinadas políticas à esquerda, ou mesmo ao tentá-las, podem ser forçados a retraçar seus rumos em meio ao caos. (Bhagwati, 2004, p. 97)

Embora o poder dos mercados internacionais de induzir comportamentos estatais "em linha" com o motivo da liberalização econômica e com a desregulamentação da iniciativa privada seja emulado pela perspectiva neoliberal, existem hoje perspectivas alternativas que levantam críticas à promoção da harmonização institucional ou convergência institucional

\footnotetext{
${ }^{180}$ Note-se como Bhagwati ensaia uma lógica de ponderação de direitos a partir de resultados econômicos. Ver, a esse respeito, a abordagem da Análise Econômica do Direito, na seção 4.1.

181 Vide seção 3.4.
} 
global. Tais críticas apontam não apenas para o aspecto da perda de espaço democrático implicada na condução de políticas públicas segundo as expectativas dos mercados, como também a inexistência de receita única para o desenvolvimento e geração de bem-estar econômico. Nesse sentido, enfatizam experiências de crescimento econômico que não foram pautadas pelo absenteísmo estatal na economia, nem pela adoção dos formatos institucionais preferidos pelo discurso neoliberal, bem como outros objetivos que podem ser compreendidos pelo rótulo de "desenvolvimento" segundo as aspirações de cada sociedade, que não só o aumento do PNB per capita. Este é o tema da seção seguinte, que aborda uma conjuntura crítica em que o neoliberalismo encontra-se balançado, ao passo que contribuições heterodoxas da economia do desenvolvimento ganham projeção.

\subsection{Contribuições da nova economia do desenvolvimento}

A transição do século XX para o século XXI marcou o momento em que a preponderância da perspectiva econômica neoliberal foi posta em xeque. Este também é o momento em que emergiram novas contribuições da economia do desenvolvimento. Em comum, os autores pertencentes a esta vertente divergem de pressupostos da perspectiva econômica neoliberal.

A seguir, a subseção 3.4 .1 contextualiza o momento de crise do neoliberalismo. Em particular, busca-se relacionar crises financeiras (com especial atenção para a crise do subprime), protestos antiglobalização e a perda da proeminência do pensamento econômico ortodoxo. Uma vez estabelecido este contexto, a subseção 3.4 .2 focaliza algumas contribuições da nova economia do desenvolvimento, apresentando ideias de autores como Ha-Joon Chang e Dani Rodrik e suas repercussões em termos de propostas para reforma da cooperação econômica internacional.

Antes de prosseguir, é adequado fazer a ressalva de que as repercussões e traduções jurídicas dos contornos narrados na seção 3.4 não foram reservados a uma subseção específica no corpo deste capítulo, diferentemente do que foi feito na descrição dos momentos do liberalismo econômico (3.1) e do liberalismo assistido (3.2). Ao invés disso, tal como feito a respeito do momento neoliberal (3.3), preferiu-se deslocar a análise para o capítulo 4. Será possível notar que as contribuições da nova economia do desenvolvimento guardam relações com correntes do debate contemporâneo sobre direito e economia, tais como o Novo Direito e Desenvolvimento (vide seção 4.3) e a Análise Jurídica da Política Econômica (4.4). 


\subsubsection{Crises econômicas e protestos como crise do neoliberalismo}

No período de prestígio do neoliberalismo ocorreram mais crises bancárias e financeiras do que durante o período em que operou a ordem econômica internacional de Bretton Woods (vide seção 3.3). A seguir, o item 3.4.1.1 focaliza crises econômicas e o fortalecimento de movimentos antiglobalização na porção final do século XX e inicial do século XXI, ou seja, abordando aspectos do período compreendido entre a crise financeira do Sudeste Asiático ao estouro da bolha dotcom, nos Estados Unidos. O item 3.4.1.2 focaliza a crise do subprime, também conhecida como crise do mercado imobiliário norte-americano ou simplesmente "crise de 2008". A crise chacoalhou as estruturas das finanças internacionais e alterou comportamentos governamentais tanto domesticamente quanto no âmbito da cooperação econômica internacional. Por sua vez, certos legados intelectuais da crise do subprime (no campo econômico) são destacados no item 3.4.1.3.

\subsubsection{Da crise do Sudeste Asiático ao estouro da bolha "dotcom"}

A crise do Sudeste Asiático eclodiu em países cujas políticas econômicas em meados da década de 1990 encontravam-se em linha com as recomendações do chamado Consenso de Washington. Tendo anteriormente abolido controles de capital, liberalizado mercados financeiros e incorporado instituições pró-mercado, países como Tailândia, Indonésia e Coreia do Sul viram-se subitamente atingidos por evasões de capital ligadas a mudanças igualmente súbitas e de motivação incerta, entre investidores internacionais dispersos ao longo do globo, acerca da rentabilidade e da segurança dos investimentos nesses países. $\mathrm{O}$ desinvestimento repentino provocou crises cambiais em cadeia a partir de 1997. A onda atingiu a Rússia, o Brasil e a Argentina nos anos seguintes, revelando-se uma crise de proporções globais (Rodrik, 2011).

Ainda na virada do século, o prestígio da promoção da liberdade dos mercados financeiros foi balançado após o estouro da bolha especulativa envolvendo empresas participantes do índice Nasdaq, nos Estados Unidos. Impulsionada por generalizações feitas a partir de casos pontuais de sucesso de empresas no ramo de internet (empresas dotcom), a procura por ações de companhias do setor aumentou. A valorização dos papéis era promovida pela própria procura. Quem os havia adquirido viu seu patrimônio multiplicar-se entre os anos de 1998 e 2000. Porém, a bolha estourou em março de 2000 e ao longo dos dois anos seguintes estas ações perderam em média 40\% de seu valor (Krugman, 2009, p. 147; 
Guttmann, 2008, p. 25). A crise sinalizou a posição precária em que se colocaram pessoas (em muitos casos arriscando as economias para aposentadoria), empresas e fundos de investimento ao vincular seu patrimônio a mercados financeiros que, ao contrário dos modelos empregados por economistas de orientação ortodoxa, não eram perfeitos ou estáveis, mas sujeitos ao pânico e ao colapso.

Paralelamente às crises financeiras, insatisfações com a organização dos mercados segundo a perspectiva neoliberal passaram a ganhar expressão em protestos antiglobalização (Stiglitz, 2002, p. 20, 248). Estes compreendiam não apenas contestações à ordem financeira internacional, mas também ao regime de comércio. Enfatizavam impactos negativos da globalização econômica sobre a vida dos setores mais pobres da população e levantavam questionamentos quanto a seus impactos ambientais e sobre a diversidade cultural, entre outros temas (Stiglitz, 2002, 6-7; 247-8).

Como anteriormente apontado, possivelmente o grande marco destes protestos tenha sido o de Seattle, em 1999 (Stiglitz, 2002, p. 3). O acontecimento viria a ser parte de onda mais ampla de contestações ao neoliberalismo, que incluíram protestos em Praga, em 2000, por ocasião de conferência do FMI e do Banco Mundial e em Davos, em 2001, quando da realização do Fórum Econômico Mundial. Outra expressão dessas movimentações consistiu na formação, em Porto Alegre, do Fórum Social Mundial, também no ano de 2001, em contraposição direta ao Fórum de Davos, e cuja atividade prosseguiu nos anos seguintes.

Apesar de a ocorrência de movimentos antiglobalização e de crises financeiras nas imediações da virada de século terem contribuído para impulsionar visões contrárias ao projeto neoliberal, ainda assim, no interior da disciplina econômica, este projeto mantinha-se bem sedimentado na posição de ortodoxia. Krugman (2009) relata que a economia voltada aos tempos de depressão (depression economics), ou seja, a economia ao estilo keynesiano, permanecia como heterodoxia rejeitada pelo mainstream econômico, mesmo após a crise do Sudeste Asiático e o estouro da bolha dotcom. Como evidência, narra que, em discurso no encontro de 2003 American Economic Association, Robert Lucas, vencedor do Nobel em economia em 1995 e presidente da associação, declarou que o problema central da prevenção das depressões havia sido resolvido (Krugman, 2009, p. 9), e que os economistas deveriam voltar sua atenção a questões como progresso tecnológico e crescimento de longo prazo (Krugman, 2009, p. 183). Ou seja, passado o estouro da bolha dotcom, o problema das crises econômicas havia sido relegado a posições periféricas, mesmo diante da história recente.

Os anos de 2007-8 trariam as crises de volta ao centro da discussão econômica. No percurso histórico do neoliberalismo, a crise do subprime parece ter funcionado como ponto 
de inflexão ou início de uma conjuntura crítica. Seu prestígio intelectual foi severamente abalado (cf. Castro, 2012, p. 215). Com origem na maior economia do mundo e proporções muito maiores do que o estouro da bolha dotcom, a crise disseminou-se e alcançou proporções globais, sendo comparada à Grande Depressão dos anos 1930. Em sua esteira, revigoraram-se protestos contra as estruturas de organização econômica predominantes no mundo, sobretudo em 2011, com o movimento Occupy que, a partir de Nova Iorque (Occupy Wall Street), difundiu-se a outros pontos do globo (Occupy London etc.), com ocorrência de manifestações em cidades de todos os continentes.

Para compreender como o prestígio do neoliberalismo foi fragilizado pela crise de 2008, o item 3.4.1.2 busca ressaltar aspectos da estruturação das finanças associados à formação da bolha no mercado imobiliário americano e ao subsequente colapso financeiro internacional, apontando suas ligações com os formatos institucionais instruídos pelo neoliberalismo.

\subsubsection{Aspectos da crise do subprime de 2008}

A desregulamentação das práticas financeiras e o alcance global dos mercados financeiros internacionais são temas de destaque na ocorrência da crise do subprime, que teve como pano de fundo investimentos no mercado imobiliário norte-americano. Inovações financeiras desempenharam papel fundamental na disseminação dos riscos deste mercado para a economia global. Antes de avançar nesta caracterização, é importante estabelecer, como ressalva, que os aspectos levantados a seguir não pretendem exaurir todas as causas que economistas apontam para a ocorrência da crise (cf. Krugman, 2009; Wolf, 2009; 2010). A pretensão, mais singela, é a de fornecer as bases para compreensão do papel que a promoção da desregulamentação financeira teve no desenrolar de uma crise tão importante.

A formação da bolha especulativa no mercado imobiliário norte-americano foi $o$ momento preparatório para crise. Baixas taxas de juros e alta disponibilidade de capital (inclusive com participação de poupança originada em outros países e investida nos Estados Unidos) criaram o cenário de incentivo ao aumento do endividamento por famílias norteamericanas (Wolf, 2009, p. 106; Krugman, 2009, p. 148). Basicamente, elas passaram a dispor de dinheiro barato. Segundo Martin Wolf, os Estados Unidos absorveram nesse período cerca de $70 \%$ dos excedentes de poupança do restante do mundo, e canalizaram esse capital principalmente para o consumo (2009, p. 77). Uma forma importante de endividamento consistia nas hipotecas imobiliárias: quer para a aquisição de imóveis novos, 
quer para levantar dinheiro por meio do refinanciamento de propriedades já existentes. $\mathrm{O}$ mercado imobiliário tinha incentivos para crescer, e a demanda em alta também impulsionava o aumento de preços. Havia, aliás, uma crença generalizada de que os preços de imóveis não poderiam cair, sendo investimentos "seguros" (Wolf, 2010, p. 202; Krugman, 2009, p. 149).

A estrutura do sistema financeiro norte-americano (e suas conexões globais), bem como suas práticas peculiares de concessão de empréstimos e de "terceirização" de riscos, tiveram papéis relevantes para o crescimento da bolha e para o caráter devastador que a crise viria a assumir.

No aspecto da estrutura, são relevantes (i) a concentração em torno de poucas instituições financeiras (aumentando os riscos sistêmicos em caso de quebra de uma delas) e (ii) a emergência do sistema bancário "paralelo", ou shadow banking system (Cintra; Farhi, 2008; Wolf, 2010, p. 200; Krugman, 2009, p. 161-4).

A estrutura concentrada é bem sintetizada pelo documentário Trabalho interno (2010), segundo o qual a "indústria financeira" era dominada por:

cinco bancos de investimento (Goldman Sachs, Morgan Stanley, Lehman Brothers, Merrill Lynch e Bear Sterns), dois conglomerados financeiros (Citigroup e JP Morgan), três companhias seguradoras (AIG, MBIA e AMBAC) e três agências de classificação (Moody's, Standard \& Poor's e Fitch). (Trabalho interno, 2008, 28'15")

Essa estrutura bancária e financeira "formal" - que Cintra e Farhi (2008) apelidam de "bancos universais" - estava interconectada pela transação de ativos das chamadas "finanças estruturadas" (abordados adiante). Além disso, interagia com outras instituições financeiras e investidores nos "opacos mercados de balcão". Os agentes que operavam nesses mercados "formavam o chamado global shadow banking system".

Nesse sistema, instituições que não eram formalmente constituídas como bancos realizavam operações análogas às destes, "captando recursos no curto prazo, operando altamente alavancadas e investindo em ativos de longo prazo e ilíquidos." No entanto, eram instituições alheias à incidência da regulação e ao "acesso aos seguros de depósitos, às operações de redesconto e às linhas de empréstimos de última instância dos bancos

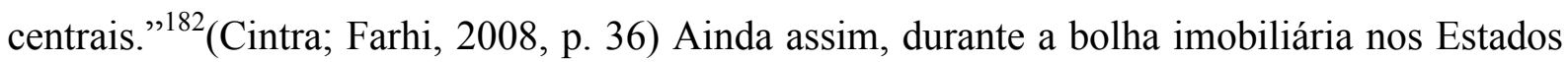
Unidos, houve "crescimento dramático na proporção de ativos mantidos fora do sistema bancário tradicional” (Krugman, 2009, p. 161): os fluxos de capital eram atraídos para as

\footnotetext{
${ }^{182}$ Segundo Cintra e Farhi, "uma grande variedade de instituições financeiras optou por participar do global shadow banking system. As principais foram os grandes bancos de investimentos (brokers-dealers), seguidos pelos hedge funds e outros investidores institucionais, sobretudo as seguradoras, os fundos de pensão e as Government Sponsored Enterprises (GSE).” (2008, p. 39)
} 
estruturas menos regulamentadas, que prometiam (e por certo tempo conseguiram prover) maior rentabilidade.

Os chamados "mercados de balcão" constituíam uma "teia opaca de interrelacionamento financeiro internacional" em que o global shadow banking system operava em conjunto com instituições financeiras tradicionais ou formais. Nestes espaços, estavam ausentes "normas e especificações das operações", cotações oficiais e mesmo a transparência, uma vez que as transações livremente negociadas entre as partes não eram tornadas públicas (Cintra; Farhi, 2008, p. 48). Além disso, estavam ausentes instituições para compensação de ganhos e perdas entre credores e devedores:

\footnotetext{
Nos mercados organizados, a transferência dos ganhos e perdas é organizada e garantida pelas câmaras de compensação. Nos mercados de balcão, a inexistência dessas câmaras de compensação coloca em evidência um elevado risco de inadimplência da contraparte perdedora. Dessa forma, aumentam os riscos potenciais dos derivativos de balcão em relação aos negociados em mercados organizados. (Cintra; Farhi, 2008, p. 50)
}

Os mercados de balcão eram a ponte entre dois sistemas. Por essa ponte, os riscos mais acentuados de um cenário menos regulamentado e não sujeito a garantias (shadow banking system) migravam para o sistema bancário tradicional, porque os bancos formais também negociavam ativos nesses mercados, como derivativos financeiros (abordados a seguir). O resultado é descrito por Cintra e Farhi (2008, p. 53): “prejuízos das instituições participantes do global shadow banking system acabaram, em parte, achando seu caminho para os balanços dos bancos."

O sistema de shadow banking desempenhou importante papel na crise do subprime por ter sido grande fonte de financiamento para o mercado imobiliário. Paul Krugman argumenta que, conforme este sistema se expandiu a ponto de rivalizar com - e mesmo ultrapassar a importância do sistema bancário convencional, os "políticos e oficiais de governo [...] deveriam ter respondido pela extensão da regulação e da rede de segurança financeira para cobrir essas novas instituições." (Krugman, 2009, p. 163) Porém, a "ideologia do governo de George W. Bush [...] era profundamente antirregulação", e mesmo as tentativas estaduais de impor limites às transações destes mercados foram bloqueadas no âmbito federal norteamericano (Krugman, 2009, p. 164). Mais do que evitar tentativas de regular este mercado, "as pessoas que deveriam ter se preocupado com a fragilidade do sistema estavam, pelo contrário, entoando loas à 'inovação financeira'.” (Krugman, 2009, p. 164) Tampouco se pode desprezar o papel desempenhado por lobbies da indústria financeira norte-americana para 
prevenir que iniciativas regulatórias se tornassem legislação ou encontrassem expressão na atuação prática (prudencial) dos órgãos de supervisão financeira nos Estados Unidos ${ }^{183}$.

Os riscos no mercado financeiro foram favorecidos não somente por sua estrutura concentrada e conectada ao shadow banking system, mas também por práticas peculiarmente arriscadas de empréstimos amparadas em inovações financeiras. Tais inovações criaram incentivos para a concessão de empréstimos cada vez mais "predatórios", ao mesmo tempo em que estimulavam a "terceirização" dos riscos por instrumentos financeiros variados e complexos. Criava-se a ilusão de dissipação do risco.

Entre as inovações estavam CDOs (collateralized debt obligations ou obrigações de dívida colateralizada, ou garantida), CDSs (credit default swaps ou swaps de inadimplência em crédito) e instrumentos financeiros "sintéticos" (abordados adiante). Tais inovações parecem técnicas, mas é importante compreender seus contornos principais. O olhar jurídico tende a descartar elementos da economia quando esses se apresentam complexos, mas justamente essa atitude pode estar nas raízes da perda de espaço que o direito experimentou ao longo do século XX no direcionamento das políticas públicas (como oposto à sua mera instrumentalidade ${ }^{184}$ ) - uma perda em grande medida suplantada pelo ganho de espaço de economistas (cf. Castro, 2012) em posições de orientação dos governos e da cooperação econômica internacional.

CDOs, CDSs e instrumentos financeiros "sintéticos" desempenharam o papel de fazer a conexão entre hipotecas do mercado imobiliário norte-americano, bancos de investimento, conglomerados financeiros, companhias de seguros, agências de classificação de riscos e investidores. Mais do que isso, esses ativos eram fluxos que conectavam os sistemas financeiros convencional e paralelo (shadow) por meio das estruturas providas pelos "mercados de balcão", numa só "cadeia alimentar de securitização"185. Era "um novo sistema que conectava trilhões de dólares em hipotecas e outros empréstimos a investidores em todo o mundo." (Trabalho interno, 2010)

\footnotetext{
${ }^{183}$ A influência dos lobbies e as ligações entre oficiais de governo e personalidades da comunidade financeira são abordados nos documentários Money, Power and Wall Street (2012) e Trabalho interno (2010).

${ }^{184}$ No sentido do papel jurídico de validar ou invalidar políticas públicas com base em critérios como legalidade, constitucionalidade ou mesmo convencionalidade. O direito permaneceu investido no papel de legitimar ou contestar, a partir de suas formas, o comportamento governamental, ainda que a principal influência intelectual sobre este comportamento não tenha sido de caráter jurídico, mas sobretudo econômico. O uso aqui feito da expressão é convergente com aquele de Pahuja, que emprega a ideia de "instrumentalização" (do direito) para fazer referência ao "esforço feito para abordar o direito como estando essencialmente a serviço de algum valor superior ao qual está subordinado" (Pahuja, 2009, p. 350).

${ }^{185}$ Securitização é o processo de "conversão de empréstimos bancários e outros ativos em títulos (securities) para a venda a investidores que passam a ser os novos credores dessa dívida." (Sandroni, 1999, p. 548) A expressão securitization food chain é empregada no documentário Trabalho interno (2010).
} 
Cabe esclarecer o significado da securitização pelo contraste com o modelo antecedente de transações financeiras, mais simples, e por vezes apelidado de plain vanilla. No sistema anterior de financiamento imobiliário, devedores de hipotecas faziam pagamentos mensais às instituições financeiras que lhes haviam concedido empréstimos. Como as hipotecas são empréstimos de longo prazo, estas instituições financeiras tinham incentivos para emprestar cautelosamente, buscando assegurar-se de que os devedores teriam condições de saldar as dívidas. No modelo de securitização dos empréstimos imobiliários, as instituições financeiras que emprestavam capital mediante hipotecas passaram a vendê-las a bancos de investimento. "Os bancos de investimento combinaram milhares de hipotecas e outros empréstimos - incluindo empréstimos para aquisição de automóveis, financiamentos estudantis e de cartão de crédito - para criar derivativos complexos, chamados de collateralized debt obligations, ou CDOs.” (Trabalho interno, 2010)

“CDO” pode ser livremente traduzido como "obrigação de dívida colateralizada". A ideia de "colateralização" remete ao caráter de garantia colateral que a hipoteca exerce nos financiamentos imobiliários: caso o pagamento do empréstimo não seja feito, o imóvel vai a leilão e o valor apurado é destinado aos credores. CDOs são derivativos porquanto originados de outros ativos financeiros ${ }^{186}$ : ou seja, ao passo que a hipoteca é o ativo financeiro primário (e o imóvel o ativo da economia real), o CDO é o ativo financeiro secundário porque cria a possibilidade de transacionar papéis ligados a hipotecas, de modo indireto. Tendo compreendido esse ponto, é possível prosseguir na "cadeia alimentar financeira". Os bancos de investimento, uma vez que tenham agrupado direitos sobre hipotecas (ou seja, formado mortgage pools) em CDOs, pagavam às agências de classificação de risco para que os derivativos assim originados recebessem suas notas ${ }^{187}$. Muitos dos CDOs foram enquadrados

\footnotetext{
${ }^{186}$ Paulo Sandroni define derivativos como operações financeiras "cujo valor deriva (daí o nome derivativos) de outros ativos [...] com a finalidade de assumir, limitar ou transferir riscos." (1999, p. 165)

${ }^{187}$ Agências de classificação de riscos, como Moody's, Standard \& Poor's e Fitch Ratings, são frequentemente apontadas como impulsionadoras do shadow banking system e da crise do subprime, dado que chancelaram inovações financeiras como investimentos seguros, mas que se revelaram altamente arriscados. O ponto é explicado por Cintra e Farhi (2008): "Essas agências tiveram um crescimento acelerado e registraram forte elevação de lucros com a expansão da securitização dos ativos de crédito (asset backed securities). Ao auxiliar as instituições financeiras na montagem dos 'pacotes de crédito' que lastreavam os títulos securitizados de forma a garantir a melhor classificação possível, as agências tiveram participação relevante na criação do mito de que ativos de crédito bancário podiam ser precificados e negociados como sendo de 'baixo risco' em mercados secundários. Ademais, elas incorreram em sério conflito de interesses na medida em que parte substancial de seus rendimentos advinha dessas atividades." (Cintra; Farhi, 2008, p. 40) Guttmann aponta ainda que as agências também "serviam como consultores para a montagem de pacotes de securitização de empréstimos que concordavam em avaliar como de grau máximo.” (2008, p. 28)
} 
na classificação máxima, ou seja, "AAA". ${ }^{188}$ Em seguida, os CDOs eram oferecidos a investidores $^{189}$.

É importante notar, nesta configuração de finanças securitizadas, que as instituições financeiras passaram a poder conceder empréstimos sem ter que permanecer com o risco a eles associado. Ao vender os direitos sobre hipotecas a bancos de investimentos, e tendo estes últimos agrupado e fatiado tais direitos em derivativos oferecidos a uma pluralidade de investidores ao longo do globo, o risco da inadimplência já não estava mais com as instituições financeiras, mas com os investidores que haviam adquirido esses papéis. Se os devedores de hipotecas não pagassem suas prestações, seriam os investidores acima mencionados aqueles que perderiam o capital aplicado na compra dos direitos sobre as hipotecas. O resultado das finanças securitizadas foi a percepção, por parte das instituições financeiras, de que estas tinham encontrado meios para livrar-se do risco (Krugman, 2009, p. 149; Wolf, 2010, p. 200 ${ }^{190}$. Por conta disso, houve incentivos para a concessão de empréstimos cada vez mais arriscados, inclusive a devedores com alta chance de insolvência, que ficaram conhecidos como subprime ${ }^{191}$.

O credit default swap (CDS) - "swaps de inadimplência em crédito" (Bresser-Pereira, 2010, p. 56) - também esteve entre os instrumentos financeiros mais utilizados para

\footnotetext{
${ }^{188}$ Houve uma febre de classificação de ativos em notas altas, inclusive concedidas a ativos subprime. Martin Wolf critica a classificação do risco como "pseudo-AAA". Para ele, as inovações financeiras acumulavam "grandes proporções de risco", mas eram "perfeitamente desenhadas para ocultar o risco - do ponto de vista de quase todos os participantes da crise." (Wolf, 2010, p. 199) Como Wolf aponta, em janeiro de 2008, ao passo que apenas 12 empresas no mundo inteiro eram classificadas como "AAA", havia 64 mil ativos financeiros estruturados com esta mesma classificação (Wolf, 2010, p. 204). Como resultado, "[m]ais de um trilhão de dólares foram canalizados ao mercado de hipotecas subprime, que abrangia os devedores mais pobres e menos solventes nos Estados Unidos.” (Wolf, 2010, p. 203)

${ }_{189}$ Classificações "AAA" abriram as portas para que investidores institucionais de toda a parte do mundo ingressassem na bolha imobiliária norte-americana (Krugman, 2009, p. 113; Wolf, 2010, p. 200). Investidores institucionais - como fundos de pensão e bancos de investimento - frequentemente encontravam-se restritos por políticas de investimento a determinar que seu capital fosse posicionado em investimentos considerados "seguros" por agências de classificação de risco como a Standard \& Poor's, a Moody's e a Fitch Ratings. Apenas ativos classificados no extrato superior, "AAA", por agências desse tipo, poderiam compor as carteiras desses investidores, dado que eram associados a menores riscos. A demanda que estes investidores institucionais tinham pela participação no rentável mercado imobiliário norte-americano foi satisfeita por inovações financeiras destinadas a elevar a classificação dos ativos deste mercado. "Do lado da demanda, muitos investidores precisavam de retornos reais maiores que os fornecidos por títulos governamentais [...]. Havia, portanto, um mercado mais amplo para ativos de maior rentabilidade classificados como AAA. Esse foi o papel desempenhado pela inovação: ela deu aos compradores, em todo o mundo, aquilo que eles procuravam, em uma escala gigantesca, pelas finanças estruturadas." (Wolf, 2010, p. 203)

190 "Mas, o fato desses riscos terem sido transferidos não os anulou, eles permaneceram presentes no mesmo montante consolidado. Essa transferência de riscos significou apenas que eles deixaram de incidir no balanço da instituição que originou o crédito e passaram a ser de responsabilidade da outra instituição que constituiu a contraparte da operação." (Cintra; Farhi, 2008, p. 52)

191 "No início dos anos 2000, houve imenso aumento nos empréstimos mais arriscados, chamados de subprime. Quando milhares de empréstimos subprime foram cominados em CDOs, muitos deles ainda assim receberam a classificação de risco 'AAA'.” (Trabalho interno, 2012).
} 
transacionar riscos. Basicamente, ele cumpria a função de uma apólice de seguro contra o inadimplemento do devedor. Mas não estava sendo negociado no mercado de seguros regulado, supervisionado por governos e garantido por resseguros -, mas sim nos "mercados de balcão". O funcionamento dos CDSs é explicado por Cintra e Farhi:

\begin{abstract}
Por esse mecanismo, o detentor de uma carteira de crédito compra proteção (paga um prêmio) do vendedor de proteção. Em troca, esse assume, por um prazo predeterminado, o compromisso de efetuar o pagamento das somas combinadas nos casos especificados em contrato, que vão de inadimplência ou falência à redução da classificação de crédito ou outros eventos que possam causar queda no valor da carteira. (Cintra; Farhi, 2008, p. 51)
\end{abstract}

A explosão no mercado de credit default swaps "fez com que as pessoas acreditassem que estavam adequadamente asseguradas contra o risco, quando não estavam.” (Wolf, 2010, p. 200) O risco apenas mudava de mão, mas não desaparecia dos mercados financeiros ${ }^{192}$.

A negociação de derivativos, como CDO e CDS, foi apenas o "primeiro momento" de inovação financeira relacionado à bolha imobiliária. Um "segundo momento", ainda mais preocupante em razão de seus riscos sistêmicos, se deu quando instituições financeiras "passaram a emitir versões 'sintéticas' desses instrumentos com lastro em derivativos de crédito e não em créditos concedidos." (Cintra; Farhi, 2008, p. 39) Os ativos financeiros sintéticos são ativos "virtuais", e "possuem tal propriedade porque negociam compromissos futuros de compra e venda de ativos, mediante o pagamento de um 'sinal', o que abre a possibilidade de vender o que não se possui elou comprar o que não se deseja possuir." (2008, p. 53 - acrescentou-se ênfase) Em outros termos, os derivativos sintéticos permitem que os investidores apostem no valor futuro de ativos que não necessariamente são de propriedade dos envolvidos na negociação.

Nada impedia que, valendo-se de derivativos sintéticos, diversos investidores fizessem "apostas" no destino de um mesmo papel. Não é de se admirar que a introdução das finanças sintéticas tenha elevado exponencialmente o risco de quebra do sistema financeiro: "[n]a construção dessa pirâmide, os riscos originais foram multiplicados por um fator $n$ e sua distribuição passou a constituir uma incógnita.” (2008, p. 53) É espantoso que essa qualidade de ativos possa ter se multiplicado e adquirido tanto peso no sistema financeiro sem guardar

\footnotetext{
${ }^{192}$ Uma explicação deste ponto é feita por Robert Guttmann: "O novo modelo 'gerar e distribuir' de fazer empréstimos, reembalá-los em valores mobiliários e se desfazer deles vendendo-os é um convite para que os banqueiros pensem de forma equivocada que tal mecanismo de transferência de risco para outros equivale a se livrar dos riscos de uma vez por todas. O que a securitização faz, se é que faz algo, é transformar um risco de crédito em uma combinação de riscos de mercado e de terceiros. Os delírios que os bancos têm quanto aos riscos foram piorados pela natureza mal compreendida dos seus instrumentos complexos e também pela opacidade intencional dos seus negócios." (2008, p. 29) O argumento também é feito pelo documentário Money, Power and Wall Street (2012), com foco na crise do mercado imobiliário norte-americano, nos protestos e no comportamento governamental subsequente.
} 
correspondência com ativos da economia real: eram castelos financeiros feitos de ar. Mas ainda assim eram altamente atraentes aos investidores, e proporcionaram interessante rentabilidade enquanto a bolha permaneceu a inflar.

$\mathrm{O}$ que esses dois momentos de inovação representaram para o sistema financeiro e bancário? Desponta, como elemento para a resposta, a transmissão e multiplicação de riscos em cadeia, perpassando os participantes desse sistema ${ }^{193}$. Como Bresser-Pereira destaca, a "mistura de inovações financeiras ocultava e ampliava o risco envolvido em cada inovação." (Bresser-Pereira, 2010, p. 56) Enquanto os riscos permaneciam como tais - isto é, como eventos possíveis, porém não materializados -, a estrutura do sistema financeiro manteve-se intacta e os fluxos de derivativos inovadores conservaram sua rentabilidade. Entretanto, problemas começaram quando o mercado imobiliário norte-americano mostrou sinais de saturação e os preços dos imóveis começaram a cair.

A queda dos preços começou em 2007 e ganhou impulso em 2008 (Wolf, 2010, p. 206). O valor descendente dos imóveis transmitiu pelos mercados financeiros a mensagem de que as hipotecas haviam se tornado investimentos de retorno duvidoso. Os juros aumentaram e as hipotecas, que eram contratadas a juros variáveis, passaram a contar com maiores índices de inadimplência. Com a queda no preço dos imóveis, muitas hipotecas passaram a ter valor de face maior que o valor de mercado dos próprios imóveis financiados, significando que nem a realização de leilões para liquidar tais ativos poderia resolver a situação problemática em que os credores agora se encontravam. A metáfora para a situação é a dança das cadeiras: enquanto a música estava tocando e as pessoas mantinham-se em circulação (fase de crescimento da bolha, ou boom), não houve problemas. Mas quando a música parou (queda dos preços dos imóveis, ou bust), descobriu-se não haver cadeiras para todos. A espiral descendente, ou o círculo vicioso da crise, foi posto em funcionamento.

Investidores que haviam adquirido papéis relativos ao mercado imobiliário (CDOs, CDS, derivativos sintéticos, entre outros) amargaram perdas com o aumento da inadimplência. As perdas espalharam-se por todo o sistema financeiro, shadow e convencional. Investimentos feitos em derivativos sintéticos desabaram em sua virtualidade. Bancos comerciais tradicionais também estavam envolvidos em investimentos no setor

\footnotetext{
193 "Este sistema era uma bomba-relógio. Emprestadores já não se importavam se os devedores poderiam pagar as dívidas. Então começaram a conceder empréstimos cada vez mais arriscados. Os bancos de investimento tampouco se importavam. Quanto mais CDOs vendessem, maiores seus lucros. E as agências de classificação de risco, que eram pagas por bancos de investimentos, não tinham responsabilidade jurídica no caso de suas avaliações de CDOs mostrarem-se equivocadas.” (Trabalho interno, 2010)
} 
imobiliário norte-americano ${ }^{194}$. O mesmo ocorria com conglomerados financeiros e seguradoras (como a AIG, socorrida pelo governo norte-americano em 2008) que haviam assumido posições relevantes no shadow banking system (Cintra; Farhi, 2008, p. 46). O contágio não se restringiu aos Estados Unidos, dadas as interligações globais criadas em torno dos investimentos no mercado imobiliário norte-americano (Krugman, 2009, p. 167-77).

Quando a bolha estourou, ativos mantidos por instituições financeiras tornaram-se objeto de insegurança generalizada. Dúvidas sobre a solvência das instituições que negociavam derivativos precipitaram o análogo das corridas bancárias no global shadow banking system (Cintra; Farhi, 2008, p. 41). Porém, logo estas corridas atingiram bancos tradicionais ou formais. A primeira delas aconteceu em 2007 com o banco alemão IKB, que havia feito dos derivativos subprime expressiva fatia de seu portfolio. Mas os problemas revelaram-se um dominó global: em 2008, bancos faliram ou foram "resgatados" por pacotes governamentais nos Estados Unidos, Grã-Bretanha, Islândia, Irlanda, Espanha e assim por diante. Apesar de seu alcance global, o colapso do sistema financeiro originou-se, como se viu, nos Estados Unidos - o que pode estar associado à percepção de que ela desferiu golpe mais profundo à predominância do neoliberalismo (vide item 3.4.1.3). Normalmente, economistas ortodoxos explicavam crises financeiras da periferia global por referências a politicas ruins ou formatos institucionais inadequados. Desta vez, porém,

a crise não emanou de países emergentes. Nem veio de um pequeno grupo de países avançados. Dessa vez, a fonte da crise foram os próprios Estados Unidos. Esta é, portanto, uma crise no núcleo da economia global. Ela gerou pânico financeiro extraordinário, aversão global ao risco, queda acentuada na produção global, colapso agudo no comércio mundial, desintegração parcial do sistema financeiro global, e ondas de crises em economias vulneráveis em amplas áreas do globo. (Wolf, 2010, p. 193)

A "socialização dos riscos" do sistema financeiro (Wolf, 2010, p. 208) foi uma das marcas das medidas de políticas públicas e de política econômica adotadas para o resgate de instituições à beira da falência, pela injeção de recursos governamentais. Protestos ao longo do globo questionaram as medidas de resgate de bancos e outras instituições financeiras. Paralelamente aos resgates, emergiu novo clima favorável à regulação dos mercados financeiros e à maior participação interventiva do Estado nestes mercados, sobretudo por mecanismos de política monetária e fiscal.

\footnotetext{
194 A lei Gramm-Biley-Leach ou Financial Services Modernization Act, de 1999, revogou as restrições às atividades bancárias introduziadas pela lei Glass-Steagall, após a Grande Depressão dos anos 1930 nos Estados Unidos (Guttmann, 2008, p. 17). Para uma explicação da lei Glass-Steagall, vide Krugman, 2009, p. 157. Como consequência da retirada da barreira que separava bancos comerciais de bancos de investimento, os primeiros "assumiram o controle da criação de mercados de balcão, informais e descentralizados, nos quais muitos dos novos instrumentos de derivativos e securitização passaram a ser negociados.” (Guttmann, 2008, p. 21)
} 
No campo da cooperação econômica internacional, já ao final de 2007 (início da crise), o G-7 reuniu-se para discutir meios de evitar a quebra sistemática de instituições financeiras importantes. Uma das decisões tomadas foi a condução de estímulos fiscais e relaxamento monetário (Wolf, 2010, p. 208), ou seja, de adotar, de modo coordenado, políticas econômicas de caráter expansivo para aliviar a crise ${ }^{195}$. Bresser-Pereira salienta que as respostas governamentais não foram de caráter uniforme ou de intensidades equivalentes:

É preciso observar que a resposta dos europeus foi por demais conservadora em termos monetários e fiscais ${ }^{196}$ se comparada à resposta dos Estados Unidos e da China [...]. Por outro lado, os europeus parecem mais dedicados a regular mais vezes seus sistemas financeiros do que os Estados Unidos ou o Reino Unido. (BresserPereira, 2010, p. 67)

No ano seguinte, em 2008, o G-20 ${ }^{197}$ passou por alterações em seu formato que representaram o ganho de importância dessa instituição informal. O G-20 havia sido criado como espaço de coordenação econômica entre ministros de finanças e diretores de bancos centrais após a crise financeira que afetou países na Ásia e América Latina, ao final da década de 1990. Sua criação resultou da percepção de que "economias emergentes importantes estavam insuficientemente incluídas nos esforços globais de coordenação econômica." (Smith, 2011, p. 5) Após a crise de 2008, o caráter do G-20 mudou, no sentido de que passou a ser mais do que um espaço para reuniões ministeriais, assumindo também feições de reuniões de cúpula, isto é, com a participação direta de chefes de Estado e de governo. A medida foi vista como necessária para "mitigar os danos da crise financeira de 2008" (Smith, 2011, p. 6) e "evitar uma futura repetição." (CNN, 2009) Certas interpretações sugerem que o G-20 passaria a ser o núcleo da cooperação econômica internacional, ao passo que o G-8 atuaria de modo mais focado em questões de segurança internacional e com menor influência sobre assuntos econômicos (CNN, 2009).

Entre as decisões adotadas no G-20 estão a coordenação de pacotes de estímulo econômico, a triplicação do capital do FMI - de modo a fortalecer essa instituição com maior participação das economias em desenvolvimento - e o propósito de adotar "regras mais

\footnotetext{
${ }^{195}$ Bresser-Pereira sintetiza as decisões mais comumente adotadas pelos governos em resposta à crise em quatro grupos: (i) redução da taxa de juros como meio de aliviar o "aperto de crédito" gerado pela crise; (ii) resgate e recapitalização dos principais bancos; (iii) adoção de políticas fiscais expansionistas; e (iv) "regular novamente o sistema financeiro, tanto doméstica quanto internacionalmente.” (Bresser-Pereira, 2010, p. 67)

${ }^{196}$ É notável que a ênfase na austeridade e na confiança dos mercados exercem influência crucial sobre a política econômica alemã, que tem peso considerável sobre os espaços de decisão econômica da União Europeia. Nesse sentido, os "pacotes" montados para endereçar crises no interior do bloco ainda guardam semelhança com o estilo de reformas conhecido como "Consenso de Washington".

${ }^{197}$ Grupo formado pelos países do G8, pela União Europeia, e pelos seguintes países: "Argentina, Austrália, Brasil, China, Índia, Indonésia, México, Arábia Saudita, África do Sul, Coreia do Sul e Turquia." (Smith, 2011, p. 5) Juntas, estas economias respondem por cerca de $90 \%$ da produção mundial.
} 
estritas para bancos, hedge funds e outros atores financeiros." (Smith, 2011, p. 6) Esse último propósito encontra, porém, grande resistência (Bresser-Pereira, 2010, p. 70).

Em relação à necessidade de regulação financeira internacional ou global, parece que o aprendizado a respeito disso foi insuficiente, ou que, apesar dos avanços representados pelas ações econômicas do G-20, a capacidade internacional de coordenação econômica permanece fraca. (Bresser-Pereira, 2010, p. 67)

Embora o reconhecimento formal da necessidade de coordenação mais ampla da cooperação internacional, com maior espaço a países em desenvolvimento, possa ser vista como consequência política positiva da crise em termos de ganhos de legitimidade ou democratização no núcleo da cooperação econômica, permanece incerto se o novo modelo surtirá eficácia, e se de fato suplantará o G-8 como espaço privilegiado para as decisões econômicas mais fundamentais.

\subsubsection{Reflexos intelectuais da crise de 2008}

Entre os legados da crise de 2008 estão aqueles de natureza palpável, como perdas econômicas, consequências sociais adversas e difusão global de protestos. Outros se caracterizam como promissores, embora cercados por muitas dúvidas, como a transformação institucional por que passou o G-20. E houve legados expressivos de natureza intelectual, em termos de ideias econômicas e de sua influência sobre a política. Estas últimas são o foco deste item 3.4.1.3.

No meio econômico, uma consequência imediata da crise foi a perplexidade. Acadêmicos, autoridades, jornalistas e indivíduos em diversas partes do mundo perguntavamse como os conhecimentos econômicos haviam falhado em originar previsões acerca da crise. Além disso, emergia a percepção de que o mainstream econômico havia falhado não só por omissão (deixando de prever), mas por comissão. Seus postulados estariam nas bases da formação do cenário propício à ocorrência da bolha especulativa. Entre eles, estão a promoção intelectual da desregulamentação, da extensão global dos mercados financeiros, das inovações e a caracterização teórica dos mercados como inerentemente estáveis. Nesse contexto de perplexidade intelectual e de cenários econômica e socialmente conturbados, certos eventos peculiares simbolizaram a perda de prestígio do neoliberalismo na economia (cf. Castro, 2012).

Um desses acontecimentos se deu durante a visita da Rainha Elizabeth II, da GrãBretanha, à London School of Economics, em novembro de 2008. Na ocasião, a Rainha questionou como os economistas poderiam ter deixado de perceber eventos que 
desembocaram numa crise de tão grandes proporções (Besley et al, 2009). Em 2009 um grupo de economistas, repórteres econômicos, políticos e servidores públicos assinou uma carta endereçada à Rainha, que assumiu o sentido de pedido de desculpas. Este grupo afirmou que a ausência de previsão da crise, “embora tenha tido múltiplas causas, deu-se principalmente por falha da imaginação coletiva de muitas pessoas inteligentes, tanto neste país quanto internacionalmente, de compreender os riscos do sistema como um todo." (Besley et al, 2009) Outro acontecimento, que já simboliza pressões para reformas no ensino da economia, foi o walkout ocorrido em Harvard em 2011, no curso de economia ministrado por Gregory Mankiw, autor de um dos mais difundidos manuais didáticos no mundo (Mankiw, 2008), já relatado nesta tese.

Esses eventos são manifestações pontuais da conjuntura crítica mais ampla por que passa a perspectiva econômica neoliberal. Nesse momento, ganham espaço propostas heterodoxas variadas que questionam as bases teóricas da desregulamentação financeira e da promoção da mobilidade internacional do capital, conformando agendas de superação do neoliberalismo.

Segundo Eiiti Sato, na esteira da crise, "há grande preocupação com a volatilidade do sistema financeiro, havendo consenso no sentido de que os mercados de ativos financeiros precisam ser alvos de regulamentação e controle.” (2012, p. 201) Por isso, um de seus produtos "será um movimento no sentido de buscar na autoridade uma solução para as falhas de mercado no mundo globalizado.” (2012, p. 202) Remetendo à noção de que crises sistêmicas, tais como a de 2008, "abalam todas as instituições e práticas no sistema de relações econômicas tanto no âmbito internacional como na esfera das economias nacionais" (2012, p. 193), Sato identifica a necessidade de reformas em estruturas da cooperação econômica internacional, dentre as quais a seguinte:

o regime financeiro internacional, caracterizado pelo princípio do livre mercado,
deve ser substituído por outro regime no qual esse princípio, mesmo que não seja
totalmente abandonado, dê lugar a regras e a mecanismos de controle que limitem as
ações dos agentes financeiros, reduzindo, assim, a volatilidade dos fluxos de
capitais. Esse controle incidiria sobre os mercados de títulos e sobre as instituições
financeiras, incluindo-se também os chamados "paraísos fiscais". (Sato, 2012, p.
202)

A noção de buscar na autoridade soluções para as consequências geradas por mercados desregulados também pode ser percebida nas indicações de Bresser-Pereira a respeito do que deve ser feito no pós-crise:

A principal tarefa agora é restaurar o poder regulador do Estado de maneira a permitir que os mercados cumpram sua função de coordenação econômica. Há diversas inovações ou práticas financeiras que poderiam ser simplesmente proibidas. 
Todas as transações deveriam ser muito mais transparentes. O risco financeiro deveria ser sistematicamente limitado. (Bresser-Pereira, 2010, p. 70)

A postura ativa do Estado na coordenação econômica e a proposta de manter finanças sob controle, mencionadas por Bresser-Pereira, estão em linha com outras contribuições econômicas heterodoxas contemporâneas. Algumas delas ganharam forma mesmo no período em que o neoliberalismo encontrava-se plenamente em voga, como na década de 1980, a exemplo das formulações de Alice Amsden e Peter Evans. Outras ascenderam no embalo de crises e protestos de virada do século, como as crises do Sudeste Asiático e os protestos de 1999 em Seattle, conformando-se entre meados da década de 1990 e meados da década de 2000. Apesar dos momentos variados de conformação, o certo é que o interesse por essas literaturas contrapostas ao ideário neoliberal ganhou impulso com a crise do subprime. Embora tais literaturas pareçam em geral tomar o ideário keynesiano em alta conta, promovendo mesmo o "resgate" de certas contribuições dessa corrente de pensamento, é certo que não são mera "reedição" do keynesianismo. Nesse sentido, embora o diálogo com elementos da economia keynesiana exista, as propostas heterodoxas abordadas a seguir conformam um novo momento do pensamento econômico.

No fundo, estas perspectivas intelectuais travam um embate com os resquícios neoliberais a respeito dos caminhos que a cooperação econômica internacional deve assumir. Aplicando-se a categorização sugerida por Mark Blyth (2001), é possível considerar que, no presente contexto, as ideias heterodoxas têm cumprido o papel de armas para a contestação das instituições formatadas ao estilo neoliberal (ideas as weapons); bem como o de prover projetos ou plantas arquitetônicas para reformas e elaboração de formatos diferentes para a cooperação econômica internacional (ideas as blueprints).

Em contrapartida, o neoliberalismo, apesar de abalado, permanece como ortodoxia. Nesse sentido, suas ideias ainda operam a função de travas cognitivas (ideas as cognitive locks) e continuam a ter influência sobre formuladores de políticas econômicas de países variados, que, afinal, formaram-se em sua tradição. Tal influência se materializa pela continuidade da adoção de medidas como ajustes fiscais e estruturais, foco no tripé macroeconômico, valorização das notas de agência de classificação de risco, recurso a medidas de austeridade etc. - que podem ser encaradas como "impulsos residuais neoliberais" (Peck; Theodore; Brenner, 2012, p. 78). 
3.4.2 Ascensão de perspectivas econômicas heterodoxas na esteira da crise do neoliberalismo

Em contrariedade à proposta de convergência ou harmonização institucional em torno de mercados desregulados favorecida pela perspectiva econômica ortodoxa ou neoliberal, diversas correntes de pensamento econômico heterodoxo enfatizam a importância da diversidade institucional e de mecanismos de coordenação de interesses e da atividade econômica que não são exclusivamente regidos pelas sinalizações de preços, mas que contam com a participação do Estado.

Ataques às propostas de convergência ou harmonização institucional global são aspectos comuns às contribuições de Alice Amsden, Peter Evans e Erik Reinert, bem como da literatura de variedades de capitalismo (Hall; Soskice, 2001). A perspectiva heterodoxa tende a valer-se de exemplos históricos dos percursos de desenvolvimento de países variados - com ênfase peculiar, embora não exclusiva, em experiências asiáticas posteriores à Segunda Guerra Mundial - para criticar as receitas formuladas pela economia ortodoxa. Em particular, a tese de que menores níveis de presença do Estado nos mercados são conducentes a graus mais elevados de desenvolvimento é severamente atacada a partir de exemplos históricos.

Do corpo mais amplo desta literatura, serão aqui destacadas as perspectivas de HaJoon Chang e de Dani Rodrik, respectivamente abordadas nos itens 3.4.2.1 e 3.4.2.2 a seguir. A delimitação justifica-se tanto pelo fato de que estes autores são os principais expoentes contemporâneos do debate heterodoxo sobre instituições e desenvolvimento, quanto por suas sugestões (em graus variados de detalhamento) para reforma das estruturas de cooperação econômica internacional, que interessam ao presente estudo.

\subsubsection{Ha-Joon Chang e a abordagem histórica de instituições e desenvolvimento}

Ha-Joon Chang escreve em contraposição direta à perspectiva econômica "ortodoxa" ou "neoliberal". Em contraste com recomendações feitas a partir de modelos com sofisticação matemática e pressuposições hipotéticas variadas ${ }^{198}$, o autor propõe que a análise do papel das instituições no desenvolvimento seja feita pela abordagem histórica da economia (2002, p. 5).

\footnotetext{
${ }^{198}$ Chang ressalta que nas duas décadas finais do século XX a abordagem neoclássica da economia projetou-se sobre ramos como a economia do desenvolvimento e mesmo a história econômica, produzindo o "resultado infortuno" de que "a discussão contemporânea sobre formulação de políticas para o desenvolvimento econômico tem sido peculiarmente a-histórico.” (2002, p. 7)
} 
Esta abordagem é a base para a crítica das recomendações de reforma institucional feitas pelo mainstream econômico e articuladas por meio de programas de ajuste estrutural e empréstimos condicionais a países em desenvolvimento.

A percepção mais difundida é a de que estas propostas de reformas refletem as "melhores práticas" dos países desenvolvidos. Mas em Kicking away the ladder (Chutando a escada), Chang aponta que as instituições e políticas (industriais, comerciais, tecnológicas e macroeconômicas) de que se valeram os países avançados atuais para seu próprio desenvolvimento não foram as mesmas que estão nas recomendações de reforma. Por isso, estariam "chutando a escada" de acesso ao desenvolvimento. Instituições como as da lista a seguir teriam sido posteriores à industrialização e ao crescimento econômico, não podendo ter sido causas destes processos:

democracia, "boa" burocracia; judiciário independente, direitos de propriedade
privada fortemente assegurados (incluindo direitos de propriedade intelectual); e
instituições financeiras e de governança corporativa transparentes e orientadas aos
mercados (incluindo um banco central independente). (Chang, 2002, p. 1)

Ao lado destas instituições, Chang aponta que a orientação ortodoxa recomenda formatos de políticas que ocorreram nos países desenvolvidos após o desenvolvimento. Assim, no campo do comércio, o mainstream econômico prega a liberdade de comércio com base nas vantagens comparativas, descartando o intervencionismo estatal como indutor de ineficiências econômicas. Chang, porém, aponta que políticas de liberalização comercial apenas foram perseguidas depois que países como a Grã-Bretanha e os Estados Unidos - cada qual a seu tempo - alcançaram a primazia econômica ${ }^{199}$. No caso britânico, depois da Revolução Industrial; no caso dos Estados Unidos, após a Segunda Guerra Mundial, "com sua supremacia industrial incontestada" (2002, p. 29). Entre os componentes das políticas comerciais, industriais e tecnológicas destes e de outros países estiveram barreiras tarifárias, espionagem industrial (2002, p. 41, 55), exploração colonial e celebração de tratados desiguais para a obtenção de termos preferenciais de comércio com países mais fracos ou “semi-independentes" (2002, p. 53); proibições à exportação de maquinário industrial e emigração de trabalhadores qualificados (2002, p. 55); “importações" de trabalhadores qualificados (mesmo em violação a leis locais que restringiam sua saída), com o objetivo de acesso a novas tecnologias (2002, p. 64); concessões de subsídios à exportação (2002, p. 61); atribuições de direitos de monopólio e incentivo a formação de cartéis; abertura de linhas de

\footnotetext{
${ }^{199}$ Os dados de Chang sugerem que o uso da proteção tarifária mostrou-se mais agressivo nas políticas da GrãBretanha e dos Estados Unidos, sendo importantes para o restante dos países agora desenvolvidos. Exceções foram a Suíça, os Países Baixos e, em menor medida, a Bélgica (2002, p. 59).
} 
crédito governamental voltadas à produção; e medidas de apoio à pesquisa e desenvolvimento técnico-científico (2002, p. 65).

Essa coleção de comportamentos estatais destoa marcadamente da noção de laissezfaire que instrui as reformas recomendadas a países em desenvolvimento. A partir da caracterização feita por Chang, o desenvolvimento deixa de ser visto como decorrência da atuação natural ou desimpedida das "forças de mercado", diante da importância histórica do Estado nos processos de mudança estrutural das economias hoje avançadas (2002, p. 126). As instituições recomendadas aos países em desenvolvimento como componentes dos pacotes de "boa governança" foram "resultados, ao invés de causas, do desenvolvimento econômico" dos países avançados (2002, p. 129). Tais países buscaram ativamente moldar seus perfis econômicos na direção de "atividades de maior valor agregado" e diversificação, processo este que, para Chang, está na base do desenvolvimento econômico (2002, p. 126). Nesse sentido, afirma que

o pacote de "boas políticas" atualmente recomendado, que enfatiza os benefícios do
livre comércio e outras políticas ICT [industriais, comerciais e tecnológicas] ao
estilo laissez-faire, parece destoar da experiência histórica. Com uma ou duas
exceções (como os Países Baixos e a Suíça), os países hoje desenvolvidos não se
tornaram bem-sucedidos com base nesse pacote de políticas. As políticas que
empregaram para chegar onde atualmente estão - isto é, políticas ICT ativistas - são
precisamente aquelas que os países hoje desenvolvidos dizem que os países em
desenvolvimento não deveriam usar, em razão de seus efeitos negativos sobre o
desenvolvimento econômico. (2002, p. 127)

Em linha com esta caracterização, Chang e Illene Grabel (2004, p. 70), ao apontar que muitas das práticas de política comercial, industrial e tecnológica são hoje contrárias às regras da OMC, sugerem que os países em desenvolvimento devem buscar a reforma da regulamentação do sistema multilateral de comércio, com vistas a torná-lo mais receptivo às políticas interventivas ou ativistas de que precisam.

A história é semelhante no campo das instituições, para além de políticas de comércio, indústria e tecnologia. No ponto de vista ortodoxo, a democracia é pré-requisito para o desenvolvimento. Sem se posicionar de forma contrária à importância da deliberação política democrática, Chang aponta que o sufrágio foi fortemente censitário durante os períodos em que os países agora desenvolvidos se industrializaram (2002, p. 76). Outra afirmação é a de que, considerando-se o mesmo nível de desenvolvimento relativo, os países em desenvolvimento de hoje têm instituições mais amplamente democráticas do que os países atualmente desenvolvidos tinham em suas respectivas épocas de industrialização. Nos moldes da crítica à vinculação entre democracia e desenvolvimento, o autor endereça diversas outras 
das instituições cuja adoção universal é recomendada pelo neoliberalismo. Dentre elas, são exemplos a propriedade privada e a propriedade intelectual, destacados a seguir.

Segundo o discurso ortodoxo, a proteção forte dos direitos de propriedade privada é imperativa por seus efeitos sobre os incentivos dos agentes nos mercados, a criação de riqueza e o desenvolvimento econômico. Porém, Chang aponta que a segurança da propriedade privada não pode ser tomada cegamente como um imperativo, porque há "exemplos históricos nos quais a preservação de certos direitos de propriedade mostrou-se danosa ao desenvolvimento econômico.” (2002, p. 82) Entre os exemplos está o reconhecimento dos direitos de espoliadores de terras - usucapientes - no Oeste americano, que foi crucial ao desenvolvimento daquela região, embora tenha consistido "em violação aos direitos dos proprietários anteriores." Outros exemplos fazem referência aos processos de reforma agrária conduzidos no Japão, Coreia do Sul e Taiwan após a Segunda Guerra Mundial, que "violaram os direitos de donos de terra mas contribuíram para o desenvolvimento subsequente desses países." Com base nestas e noutras indicações históricas, Chang conclui que "o que importa para o desenvolvimento econômico não é simplesmente a proteção de todos os direitos de propriedade existentes, qualquer que seja sua natureza, mas a definição de quais direitos de propriedade são protegidos e sob que condições."200(2002, p. 83)

A perspectiva ortodoxa também encara a proteção da propriedade intelectual como crucial ao desenvolvimento, porque a concebe na base para os incentivos à inovação tecnológica. Sem ter segurança de desfrutar os retornos de seus inventos, os agentes nos mercados perderiam os incentivos para buscar inovações. Com base nesse raciocínio, as reformas sugeridas a países em desenvolvimento apontam para instituições segundo os moldes do TRIPS, no âmbito da OMC, que constitui um regime "forte" de proteção da propriedade intelectual. Chang observa, porém, que o processo de industrialização dos países hoje avançados se deu em meio a recusas de reconhecer direitos de propriedade intelectual a

\footnotetext{
${ }^{200}$ A crítica ao foco na proteção "forte" de direitos de propriedade privada, em Chang, adquire feições adicionais. Para ele, o modelo de proteção mais adequado a contextos específicos pode não ser necessariamente "privado": como "direitos genuinamente comunais de propriedade privada que não permitem apropriação privada mas que são baseados em regras claras sobre acesso e uso (por exemplo, regras comunais para coleta de lenha em florestas de propriedade comunal, regras que impedem a comercialização lucrativa de um software construído a partir de um 'shareware' livre)." (Chang, 2007b, p. 22) Além da propriedade comunal, há formas híbridas, como o caso das Township Village Entreprises (TVE) na China, que são "propriedade de jure dos governos locais, mas que em alguns casos operam sob direitos de propriedade privada de facto (embora não claramente) detidos por poderosas figuras políticas locais" (Chang, 2007b, p. 23). A crítica, aqui, é de ordem empírica: nesse contexto específico, como dizer que a ausência de regras claras sobre propriedade privada na China operaram como empecilho ao seu desenvolvimento econômico, diante do forte ritmo de crescimento verificado em décadas recentes? A linha de argumentação de Chang endereça aquilo que Dani Rodrik intitulou private property reductionism. Abordagens mais detalhadas dessa crítica podem ser encontradas ainda em Some caution about property rights as a recipe for economic development (Kennedy, 2011).
} 
inventos estrangeiros (2002, p. 85). Estes países se valeram da possibilidade de "copiar" avanços tecnológicos enquanto não alcançaram a dianteira em pesquisa e desenvolvimento industrial em setores econômicos importantes para cada contexto. Em outra obra, Chang e Illene Grabel apontam que a adesão a regimes "fortes" de proteção da propriedade intelectual não é favorável a países em desenvolvimento. Esta proteção deve se dar de forma estratégica, segundo uma visão de desenvolvimento adequada ao contexto, ou seja, como parte de uma política industrial. Os autores sugerem que os países em desenvolvimento desafiem o regime do TRIPS e busquem sua reforma (Chang; Grabel, 2004, p. 101, 104).

Uma importante lição retirada do percurso histórico traçado por Chang é a de que o desenvolvimento dos países hoje avançados não foi alcançado por adesão a modelos institucionais ideais e padronizados. Pelo contrário, "os países bem-sucedidos foram aqueles capazes de habilmente adaptar seu foco às mudanças nas condições", com "formas e ênfases" de políticas industriais, comerciais e de tecnologia que variaram segundo os diferentes contextos (2002, p. 127). Neste rol de países bem-sucedidos incluem-se aqueles que souberam encontrar seu próprio caminho, como as políticas de industrialização ao estilo do Sudeste e Leste Asiáticos, ou o caso da China, descrita como país que soube aproveitar a globalização a seus próprios termos, ou seja, sem aderir às reformas sugeridas pela perspectiva econômica ortodoxa, mas criando suas próprias instituições.

\section{Das reformas uniformizantes à diversidade institucional}

As recomendações de reforma para adoção de instituições pró-mercado por países em desenvolvimento integram o fenômeno mais amplo de "reversão do papel do Estado" (rolling back of the state) ocorrido nas décadas de 1980 e 1990. Outras faces desse processo consistiram no descrédito do modelo de welfare state e no desmantelamento das economias socialistas e sua transição para o capitalismo (Chang, 2003, p. 19), num contexto de difusão global do ideário neoliberal.

A investida que Chang faz ao neoliberalismo e ao rolling back of the State não implica, segundo o autor, "simplesmente o retorno a alguma era dourada anterior". Sua proposta é "formar uma nova síntese em que os insights válidos do neoliberalismo sejam despidos de sua bagagem ideológica e integrados a uma moldura intelectual mais ampla e objetiva." (2003, p. 39) Em sua caracterização, entre o capitalismo laissez-faire e a planificação econômica do socialismo "há uma terceira via, ou melhor, há muitas terceiras vias." (2003, p. 28) 
Um dos componentes mais gerais destas "terceiras vias" consiste na valorização do ativismo estatal sem descarte do papel das "forças de mercado". O Estado não é chamado a suprimi-las ou ocupar plenamente o seu lugar, mas a ele são conferidas tarefas de orientação, coordenação, impulso e disciplina destas forças, por meio de políticas ativas e seletivas de comércio, indústria, tecnologia e crédito, além de políticas macroeconômicas (cf. Chang; Grabel, 2004). Outro componente é a ênfase na busca de soluções contextualmente específicas, adequadas às necessidades e características de cada país em desenvolvimento. Ao falar em "terceiras vias" ao invés de uma só "terceira via" possível, Chang espelha sua rejeição à proposta de convergência institucional global (adoção de global standard institutions) ou de reformas que buscam implementar instituições de "tamanho único" (onesize-fits-all). (Chang, 2007a, p. 11)

\section{Novas proposições sobre instituições, atuação estatal e desenvolvimento}

A abordagem histórica dos percursos de desenvolvimento permite a Chang rejeitar as instituições embutidas nas recomendações a países em desenvolvimento como inadequadas a suas necessidades. Partindo deste "desmonte", Chang introduz suas próprias recomendações sobre instituições e atuação estatal na economia ${ }^{201}$.

Entre as recomendações heterodoxas de Chang sobre instituições estão alertas contra práticas comuns de reforma institucional em países em desenvolvimento. Um primeiro alerta se refere às global standard institutions que, pelas razões apontadas em Kicking away the ladder (2002), recomendam aos países em desenvolvimento instituições e políticas que não estiveram na base dos processos de mudança econômica dos países avançados. Além disso, não há "receitas-padrão" ou "fórmulas mágicas" que funcionem independentemente do contexto. Por isso, as reformas institucionais não podem ser de caráter universal. Posicionando-se contrariamente à tentativa de introduzir reformas que emulam instituições de "alto-padrão" (essencialmente aquelas do mundo anglo-americano), Chang afirma que "os países não têm que começar com instituições de alta qualidade para que iniciem o desenvolvimento econômico, [...] o desenvolvimento institucional é consequência, ao invés da causa, do desenvolvimento econômico.” (Chang, 2007a, p. 13)

\footnotetext{
${ }^{201}$ Além de recomendações sobre instituições e papéis do Estado na economia, Chang também faz contribuições específicas sobre formatos de políticas comerciais, industriais, tecnológicas e macroeconômicas, incluindo políticas creditícias, adequados às pretensões de países em desenvolvimento (Chang; Grabel, 2004). Devido ao seu nível de detalhe, estas não serão relatadas aqui.
} 
Outro ponto é o acautelamento quanto ao "mimetismo institucional",202. A crítica à importação de receitas-padrão não implica que nada possa ser feito "para melhorar a qualidade das instituições nos países em desenvolvimento de hoje”. Chang não descarta a possibilidade de que estes "se beneficiem da capacidade de imitar as instituições que sejam adequadas às suas circunstâncias", como em oposição a imitações derivadas de um pacote de reformas apregoado independentemente da situação de cada um (Chang, 2007a, p. 13).

Um problema frequentemente associado ao mimetismo consiste em negligenciar o modo como instituições funcionam no mundo real. Segundo Chang, a literatura ortodoxa sobre instituições enfatiza soluções formais, sem maior atenção a outros aspectos relevantes, como sua interação com instituições informais já existentes no contexto local. Estas podem ser cruciais para determinar se as “criarão raízes" ou se permanecerão apenas no papel:

Instituições não funcionam no vácuo, mas interagem com outras instituições. Se um
país tenta mudar suas instituições pela importação de novas formas (ou mesmo pela
importação de tipos de instituição atualmente ausentes), elas podem não funcionar
bem se forem incompatíveis com instituições locais; talvez porque fundadas em
valores morais incompatíveis com os valores morais locais, talvez porque
pressuponham a existência de certas outras instituições que faltam no contexto local.
(Chang, 2007a, p. 6)

Outros argumentos se referem a possibilidades de overdose e perversão institucionais. A overdose se refere à ênfase excessiva na aplicação de uma instituição, independentemente de resultados benéficos de acordo com o contexto. Assim, por exemplo, as patentes criadas como estímulos à inovação podem, ao invés, atuar como obstáculos se aplicadas em áreas como a genética, travando pesquisas baseadas no genoma humano (Chang, 2007a, p. 10-11). Já a perversão é o desvirtuamento da intenção ou função originalmente desempenhada por uma instituição. O lado negativo ocorre quando "uma instituição benéfica é tornada maléfica pelas ações deliberadas de certos indivíduos ou grupos”. Mas há um lado positivo que sugere

\footnotetext{
${ }^{202}$ Quanto ao mimetismo institucional, Chang enxerga um aspecto positivo em que países em desenvolvimento possam importar instituições sem arcar com os mesmos custos de desbravamento e experimentação. Um exemplo disso se refere aos bancos centrais: "por terem introduzido bancos centrais em níveis de desenvolvimento econômico relativamente mais baixos, os países em desenvolvimento de hoje mostraram-se capazes de lidar melhor com crises financeiras do que o foram os países hoje em desenvolvimento em níveis comparáveis de desenvolvimento econômico." Todavia, Chang não apregoa o mimetismo como estratégia suficiente para garantir o desenvolvimento institucional bem sucedido: "uma instituição formal que parece funcionar bem num país avançado pode estar funcionando bem apenas porque é sustentada por certo conjunto de instituições informais que não são de fácil observação." (2007b, p. 29) Além do problema da limitação da importação formal de instituições, permanece a necessidade de base política adequada para que a instituição importada ou adaptada possa operar com sucesso: "[a] menos que a nova instituição desfrute de certo grau de legitimidade política entre os membros da sociedade em questão, ela não funcionará. E para ganhar legitimidade, a nova instituição tem que guardar ressonância com as instituições e a cultura existentes, o que limita a abrangência possível da inovação institucional.” (2007b, p. 30) A receita de Chang não é, portanto, nem o mimetismo alheio ao contexto local, nem o fechamento local às experiências institucionais de outros países, mas o meio-termo entre os dois extremos, a sugerir o aprendizado institucional contextualmente específico.
} 
que "uma instituição não precisa de um pedigree 'nobre' para ser utilizada em bons propósitos." Como exemplo disso, Chang relata que a prática de administrative guidance ascendência estatal forte sobre negócios privados - na Coreia do Sul e no Japão, embora possam ser considerados "desvios" do ideal de "rule of law" (em virtude de seu foco na preservação da esfera de autonomia privada), operaram bem nestes dois contextos (Chang, 2007a, p. 11).

Apesar de não haver soluções do tipo "one-size-fits-all", Chang propõe três princípios para a "tecnologia de construção institucional", essencialmente diferentes da abordagem ortodoxa.

O primeiro é reflexo direto da noção de perversão institucional: "instituições que em certo momento foram benéficas podem, com a passagem do tempo, tornar-se empecilhos ao desenvolvimento." (2007a, p. 12) Logo, os países não devem aderir a qualquer modelo institucional formal, mas verificar o que funciona de acordo com seu contexto.

O segundo princípio reflete a lição de que "boas" instituições são mais a consequência do que a causa do desenvolvimento econômico: "é frequentemente mais eficaz começar o processo de reforma institucional pela introdução das atividades econômicas desejadas do que pela introdução das instituições desejadas" (Chang, 2007a, p. 12). Nesse sentido, o foco primário dos países deve estar na migração para atividades econômicas de maior valor agregado e na diversificação econômica. Este ponto é importante porque está diretamente relacionado à ênfase no ativismo estatal em geral, e em políticas industriais em particular.

Por fim, de acordo com o terceiro princípio, "mesmo quando concordamos que uma instituição possa ser "boa" para quase todos os países ao menos quanto a algum propósito, sempre há o risco de [...] 'overdose institucional'." Assim, embora se possa apontar no aspecto geral que alguma forma de proteção da propriedade (não necessariamente privada) é desejável, "é errado inferir disso que quanto mais forte esta proteção, melhor será, como sugere a sabedoria convencional." (Chang, 2007a, p. 12)

Estes são contornos gerais das contribuições de Chang sobre instituições e desenvolvimento. Vale destacar que Chang enxerga as "instituições sancionadas pelo Estado na vida econômica moderna" como sendo de fundamental importância para o desenvolvimento (2007a, p. 4). Nesta esteira, é apropriado delinear os dois papéis gerais que o autor atribui ao Estado, e que constituem parte importante de sua perspectiva por embasarem um novo ativismo estatal. 
Papéis do Estado diante das mudanças estruturais intrínsecas ao desenvolvimento

A perspectiva econômica ortodoxa enxerga a intervenção estatal na economia como indutora de ineficiências. Como Chang aponta, esta visão pressupõe que os investimentos e as pessoas possam migrar espontaneamente das áreas menos para as mais rentáveis. Quando esta concepção é acoplada ao argumento das vantagens comparativas no comércio internacional, ela resulta na sustentação da liberalização comercial. A perspectiva ortodoxa não nega que "deslocamentos" econômicos e sociais ocorrerão com a liberalização. Tanto empresários quanto trabalhadores prejudicados pela falência de seus setores econômicos (ineficientes) migrarão para atividades "mais eficientes". A perspectiva tem tonalidades de seleção natural darwiniana: alguns indivíduos ficam para trás, mas o resultado final é visto como evolução em termos do bem-estar econômico e da competitividade que se tinha antes. Nestas linhas, a intervenção do Estado atrapalha a tendência de os mercados desimpedidos alcançarem o equilíbrio do modo mais eficiente, seguindo seu curso próprio de evolução rumo a patamares cada vez mais altos de bem-estar agregado.

Ha-Joon Chang discorda desta caracterização. Para ele, a visão ortodoxa não leva em conta a presença de "ativos específicos" na economia (1994, p. 304). Estes são os ativos que não podem ser facilmente transpostos de um setor econômico a outro. Ao menos, esta transposição não pode ser feita sem perda, depreciação ou prejuízo, em face de sua “mobilidade limitada" (Chang, 1994, p. 301; cf. Fiani, 2011). Em outros termos, são ativos cuja aplicação em setores diversos daqueles em que foram originalmente investidos resulta em prejuízo econômico. Para ilustrar o aspecto humano, Chang faz referência ao metalúrgico de meia-idade que, perdendo seu emprego, passa a "fritar hambúrgueres no McDonald's" (1994, p. 302). No aspecto físico, o investimento feito no laboratório de pesquisa fechado dificilmente poderá ser recuperado por sua transposição a outro setor econômico, dada a alta especificidade dos instrumentos envolvidos. Em ambos os casos, o abandono da aplicação inicial representa prejuízo (Fiani, 2011, p. 215-6).

A noção de que a economia do mundo real conta com ativos específicos serve como base para que Chang teorize a importância da atuação do Estado na busca do desenvolvimento. Este implica mudança estrutural, significando "mudanças econômicas de larga escala que envolvem alterações tecnológicas e institucionais substanciais" (Chang, 1994, p. 294). Por um lado, estas mudanças geram conflitos sociais que podem acabar por impedir a continuidade das próprias mudanças. Por outro, não há que se esperar que as mudanças se iniciem espontaneamente, ou segundo "forças de mercado". Estas duas 
afirmações estão relacionadas aos dois papéis gerais que Chang atribui ao Estado frente ao processo de mudança estrutural: o de gestor de conflitos e o de empreendedor (Chang, 1994; cf. Fiani, 2011).

O Estado precisa atuar como gestor de conflitos porque o processo de desenvolvimento gera deslocamentos de fatores produtivos que o tornam socialmente conflituoso. Quando há mudanças tecnológicas, novos setores ganham o espaço de antigos setores. Alguns ganham emprego e aumentam lucros, ao passo que outros perdem, e "aqueles propensos a perder tentarão se mobilizar contra novos arranjos institucionais e por vezes conseguirão fazê-lo." Como as transformações no sistema econômico representam perdas para aqueles que investiram em ativos específicos, há a necessidade de administrar os conflitos decorrentes dos deslocamentos associados ao processo de desenvolvimento (Chang, 1994, p. 301). O ludismo na Grã-Bretanha, no início do século XIX, é um bom exemplo da resistência à mudança estrutural: trabalhadores que percebiam o incremento da mecanização da produção têxtil como ameaça às suas condições de vida mobilizaram-se para a destruição do maquinário.

Contrariamente, portanto, à abordagem laissez-faire que prevê atuação mínima do Estado, Chang sugere que o papel estatal de gestão de conflitos é essencial para manter os incentivos para investimentos em ativos específicos nos setores econômicos mais complexos e sensíveis. O Estado pode fazê-lo criando mecanismos de proteção para os setores negativamente afetados, a exemplo das quotas de importação impostas a automóveis japoneses por países europeus, que buscavam proteger suas próprias indústrias automotivas das condições adversas da exposição à competição internacional (1994, p. 302). Nessa hipótese, a atuação do Estado se dá por meio de políticas comerciais e industriais. Outra possibilidade reside em políticas monetárias e fiscais voltadas a compensar grupos afetados. A política monetária pode operar transferências de renda indiretas por meio do nível de inflação (1994, p. 303), ao passo que a política fiscal pode realizar redistribuições de renda de modo mais direto por meio de "benefícios de desemprego, apoio à renda e reduções tributárias correspondentes a quedas na renda." (1994, p. 303) "O Estado, em seu papel de gerenciador de conflitos, pode ser visto como provedor de seguro aos membros da sociedade, ao fornecer a estrutura de governança que garantirá algum nível justo de renda a todos mesmo diante das circunstâncias mais adversas." (Chang, 1994, p. 304)

Como apontado anteriormente, o outro grande papel do Estado é o de empreendedor. Numa economia complexa, os fatores de produção distribuídos nos diversos setores de atividade são interdependentes, mas a propriedade desses fatores encontra-se dispersa entre 
agentes variados (1994, p. 298). Esta situação pode servir como obstáculo à mudança estrutural implicada no processo de desenvolvimento, dado que este processo "pode requerer mudanças coordenadas em muitos setores da economia.” (1994, p. 298) Emerge, neste ponto, a descrença quanto à capacidade de mudança espontânea rumo ao desenvolvimento, capitaneada pelas livres forças de mercado, já que:

aqueles que controlam componentes individuais podem ser incapazes de iniciar ou
conseguir a mudança, visto que podem sofrer de carência de visão "sistêmica" e/ou
de incerteza estratégica a respeito dos comportamentos dos outros agentes
relevantes. Portanto, há necessidade de coordenação por algum agente central (seja o
Estado ou não) para que uma mudança econômica ampla possa acontecer. (Chang,
1994, p. 298)

Na perspectiva de Chang, cabe ao Estado assumir o papel de impulsionar a economia rumo a atividades de maior valor agregado, como a industrialização. Para tanto, seu papel de empreendedor envolve tanto projetar uma visão de futuro quanto construir as instituições necessárias à concretização desse projeto (1994, p. 297). A projeção de uma visão significa que "o Estado pode guiar agentes do setor privado a agir concertadamente, sem que estes tenham que gastar recursos na coleta e processamento de informações, em processos de barganha e assim por diante.” (1994, p. 298) Para tanto, o Estado precisa construir "novos veículos institucionais" que estimulem os empreendimentos privados na direção projetada. Como parte disso, é necessário decidir os tipos de "direitos e obrigações" que o Estado reconhecerá e apoiará. Afinal, "só o Estado tem o poder de legalizar os (ou ao menos dar apoio implícito aos) novos direitos de propriedade e às novas relações de poder (tanto no nível social quanto das empresas), que fornecem uma realidade institucional à nova estrutura de coordenação." (Chang, 1994, p. 300) Outra parte envolve a atuação direta do Estado na atividade econômica. Chang e Grabel apontam, em linha com este papel, que o "setor de empresas estatais tem seu lugar em todas as economias" (2004, p. 88).

A noção de Estado como empreendedor abre as portas para justificar a condução ativa de políticas industriais, comerciais e tecnológicas, bem como de políticas macroeconômicas, na condução estatal do processo de desenvolvimento, em marcado contraste com a visão segundo a qual este processo decorreria naturalmente da livre operação das "forças de mercado".

A partir destes contornos, é possível observar que as recomendações de Chang entram em choque com a visão ortodoxa. Esta última encontra abrigo nas instituições da cooperação econômica internacional, refletindo-se em pacotes de ajuste estrutural e empréstimos condicionais do Banco Mundial e do FMI e na regulamentação multilateral do comércio, 
incluindo regras sobre propriedade intelectual (TRIPS) e investimentos (TRIMS). Os diferentes regimes que ainda compõem a ordem econômica internacional contemporânea representam obstáculos a muitas das sugestões heterodoxas de Ha-Joon Chang. No entanto, como o autor afirma em conjunto com Illene Grabel, “é imperativo que os defensores de políticas econômicas alternativas não encarem as regras atuais do ambiente global como fixas. Sempre é possível, e certamente é necessário, reescrever as regras globais.” (2004, p. 203) Suas contribuições fornecem, portanto, insumos à formação de uma agenda de reforma das instituições da cooperação econômica internacional.

\subsubsection{Dani Rodrik: globalização econômica com policy space}

As visões de Ha-Joon Chang e Dani Rodrik compartilham diversos elementos. Entre eles, a concepção de que as instituições importam para o desenvolvimento, mas que não podem ser replicadas de modo simples a partir de um pacote comum de reformas (one-sizefits-all). Embora os autores defendam soluções contextualmente específicas, não deixam de apresentar certos princípios gerais para instituições e políticas voltadas ao desenvolvimento. Dentre estes, figura a presença do Estado na atividade econômica, não como substituto da iniciativa privada, mas como elemento de ativação ou impulso das "forças de mercado". Outro importante ponto compartilhado por Chang e Rodrik é a proposta de reforma das instituições da cooperação econômica internacional para desfazer obstáculos aos formatos de instituições e políticas pretendidos por países em desenvolvimento.

Quanto a este último aspecto, pode-se considerar que as contribuições de Chang são mais gerais do que as de Rodrik, que alcança maior nível de detalhe. Este será o foco da caracterização das ideias de Rodrik a seguir, ou seja, elementos que conduzem a propostas de reforma de padrões de cooperação econômica internacional.

Como já se observou, a perspectiva econômica ortodoxa desenvolveu agenda de reformas conducentes à liberalização ou desregulamentação máxima dos mercados. Rodrik se refere a esta agenda como hiperglobalização. Para ele, no entanto, os países que obtiveram crescimento econômico destacado nas últimas décadas não foram aqueles que aderiram à hiperglobalização, mas sim os que souberam aproveitar a globalização econômica a seus próprios termos. Embora outras experiências do Sudeste e do Leste Asiáticos sejam mencionadas com frequência em The globalization paradox (2011), maior atenção é atribuída à experiência chinesa, descrita como a "maior história de sucesso da globalização durante o último quarto de século" (2011, p. 273). 
No caso chinês, o desenvolvimento recente é explicado não pela atuação desempedida das "forças de mercado", mas pela participação deliberada do governo chinês no impulso e reestruturação da economia. Entre as políticas adotadas para tanto estiveram elementos rejeitados pela ortodoxia econômica. Não se adotou o regime "forte" de proteção da propriedade privada, mas uma variante híbrida. Teve lugar uma política de transferência de tecnologia que requeria de investidores estrangeiros a formação de joint ventures com firmas locais e o atendimento a metas de uso de conteúdo chinês na produção. Em paralelo, a aplicação deliberadamente fraca das normas de proteção à propriedade intelectual permitiu que "produtores domésticos fizessem engenharia reversa e imitassem tecnologias estrangeiras com pouco receio de serem processados." (2011, p. 153)

Políticas comerciais e industriais seletivas também estavam na base de um programa de crescimento que "combinava exportações com uma estratégia domesticamente elaborada de diversificação econômica e inovação institucional.” (2011, p. 274) Rodrik destaca que a China esteve ao largo das restrições que a regulamentação da OMC significou para as políticas comerciais e industriais de muitos países, como pela proibição de subsídios à exportação e da adoção de práticas discriminatórias favoráveis a empresas locais. Quando a China acedeu à OMC, em 2001, o país já contava com uma "forte base industrial" (2011, p. 154). Ainda assim, a acessão não significou abandono da proteção à indústria local. "Políticas industriais explícitas deram lugar a uma política industrial implícita conduzida por meio da política cambial", via depreciação sustentada do renmibi (2011, p. 155). "Uma moeda local barata tem o mesmo efeito econômico de um subsídio à exportação combinado com uma tarifa à importação." (2011, p. 276) Todos estes elementos suportam a avaliação de que, se a China foi a maior história de sucesso da globalização dos últimos 25 anos, muito disso se deve ao fato de que " moldou as regras da globalização a suas próprias necessidades." (2011, p. 155)

Para Rodrik, o exemplo da China (e de outros países que souberam valer-se da globalização segundo suas próprias regras) relaciona-se a duas ideias fundamentais a respeito de instituições e desenvolvimento. Essas ideias estão na base das reformas que o autor sugere para que a cooperação econômica internacional abrigue os projetos de desenvolvimento de países variados.

A primeira ideia sustenta que mercados e governos não são substitutos, mas complementares. A noção contraria o discurso econômico comum que descreve o desenvolvimento como favorecido pela livre atuação da iniciativa privada e "distorcido" pela interferência estatal, que tende a ser caracterizada como indevida. "Mercados necessariamente 
requerem instituições que não são de mercado para que possam funcionar.” (2011, p. 10) Há uma correlação, no sentido de que os governos são maiores e mais fortes justamente nas economias mais avançadas (2011, p. 16). A expansão econômica precisa ser acompanhada da expansão governamental porque os mercados não são entidades "autocriadas, autorreguladas, autoestabilizantes ou autolegitimantes":

Toda economia de mercado com bom funcionamento mistura Estado e mercado, laissez-faire e intervenção. A mistura precisa depende das preferências de cada nação, sua posição internacional e sua trajetória histórica. Mas nenhum país descobriu como se desenvolver sem atribuir responsabilidades substanciais ao setor público. (Rodrik, 2011, p. 22)

De acordo com a segunda ideia fundamental apresentada por Rodrik, o capitalismo não está associado a nenhum modelo único. Afinal, as experiências econômicas bemsucedidas em diversos pontos da Ásia "violam estereótipos" (2011, p. 146). O autor enxerga com bons olhos a "experimentação pragmática" em instituições e políticas de que se valeram estes países, conformando projetos próprios de desenvolvimento associados à globalização econômica. Afinal, das sete economias do Leste e Sudeste asiáticos que fizeram parte do chamado "milagre asiático", apenas Hong Kong "chegou perto de ser uma economia de livre mercado" (as demais foram Coreia do Sul, Taiwan, Cingapura, Malásia, Tailândia e Indonésia). (Rodrik, 2011, p. 144-5) Ao contrário, portanto, do que a ortodoxia econômica sugere, há múltiplos caminhos para o desenvolvimento econômico. Rodrik não descarta que a liberdade dos mercados possa ser um desses caminhos, mas rejeita que este possa ser sustentado como o mais adequado independentemente das características da realidade local.

As duas ideias fundamentais acima apresentadas têm pontos de contato. São, de fato, convergentes, no sentido de que a interação entre governos e mercados é contextualmente específica e resulta em projetos variados de desenvolvimento econômico:

O crescimento econômico requer um governo pragmático disposto a fazer o
necessário para energizar o setor privado. Requer empregar os mercados e a
globalização estrategicamente para diversificar a economia doméstica para além dos
recursos naturais. As ferramentas específicas e os instrumentos necessários para
atingi-lo podem variar e dependerão pesadamente do contexto. Receitas específicas
para o sucesso não viajam bem. É a visão geral por trás delas que precisa ser
emulada. (Rodrik, 2011, p. 148-9)

Valorização do Estado e do contexto. Estes dois elementos estão na base do ponto teórico principal da obra de Rodrik (2011), que se refere ao trilema que caracteriza o “paradoxo da globalização". O trilema (vide Quadro 3.7, abaixo) consiste na afirmação de que não é possível ter ao mesmo tempo política democrática, determinação nacional e (hiper)globalização econômica: 
Temos três opções. Podemos restringir a democracia com o interesse de minimizar custos internacionais de transação, quaisquer que sejam as repercussões sociais e econômicas que a economia global eventualmente venha a produzir. Podemos limitar a globalização, na esperança de construir a legitimidade democrática domesticamente. Ou podemos globalizar a democracia, sacrificando a soberania nacional. [Mas...] não podemos ter hiperglobalização, democracia e autodeterminação nacional simultaneamente. Podemos ter no máximo duas das três. Se queremos hiperglobalização e democracia, temos que abrir mão do Estado-nação. Se precisamos preservar o Estado-nação e também a hiperglobalização, então precisamos esquecer a democracia. E se queremos combinar democracia e o Estadonação, precisamos dizer adeus à globalização. (Rodrik, 2011, p. 200)

São, portanto, três configurações possíveis para a estrutura da cooperação econômica internacional:

Quadro 3.7 - "O trilema político da economia mundial”

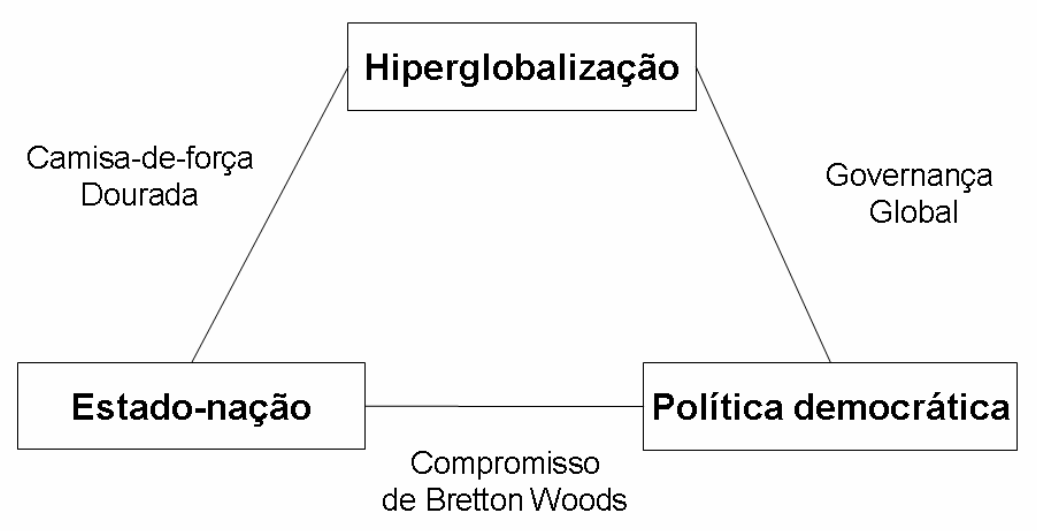

Fonte: Rodrik, 2011,p. 201

Ao optar por preservar Estado-nação e hiperglobalização, tem-se algo que se aproxima dos contornos das reformas propostas pela perspectiva econômica ortodoxa, e que Rodrik, fazendo alusão a uma expressão empregada por Thomas Friedman, chama de "camisa-deforça dourada" (golden straitjacket). Esta tem aproximações com a configuração política favorecida durante o POI (que se erodiu justamente com a emergência da política democrática), e é sintetizada da seguinte forma:

Neste mundo, os governos perseguem as políticas que acreditam ser favoráveis a ganhar a confiança dos mercados e a atrair fluxos de comércio e capital: aperto monetário, governo reduzido, tributação baixa, mercados de trabalho flexíveis, desregulamentação, privatização e abertura generalizada. (Rodrik, 2011, p. 201)

Uma segunda opção consiste em conciliar hiperglobalização e política democrática, com menor importância do Estado-nação. O resultado, de caráter utópico, é uma "forma de federalismo global” (2011, p. 202), em que a fonte privilegiada de regulação migra das soberanias nacionais a entes supranacionais. Esta é a situação a que Rodrik se refere como "governança global": 
Um deslocamento expressivo em direção à governança global, em qualquer modalidade, necessariamente demandaria diminuição significativa da soberania nacional. Os governos nacionais não desapareceriam, mas seus poderes seriam severamente circunscritos por entidades supranacionais de criação e aplicação de regras, empoderados (e refreados) pela legitimidade democrática. A União Europeia é um exemplo regional disto. (Rodrik, 2011, p. 203)

Rodrik, porém, descarta quaisquer das opções que proponham a hiperglobalização. Para ele, a opção de configuração para a cooperação econômica internacional mais favorável à coexistência de projetos variados de desenvolvimento (em linha com suas duas ideias fundamentais) é a que concilia política democrática e Estado-nação. Não se trata de descartar a globalização econômica, mas de tê-la de forma atenuada, uma versão "fina", tênue, ou pouco profunda, que permita aos Estados o espaço suficiente para que cada um adote políticas e instituições segundo as preferências localmente deliberadas. Esta configuração é referida por Rodrik como “compromisso de Bretton Woods" (2011, p. 205).

Não se trata, porém, de simplesmente realizar o transplante das abordagens dos anos 1950 e 1960, retornando à configuração institucional da época. “O que precisamos [...] é de uma atualização do compromisso de Bretton Woods para o século XXI.” (2011, p. 236) A partir da caracterização feita por Rodrik, é possível interpretar que sua preferência por um arranjo inspirado em Bretton Woods decorre do fato de que, sob esta configuração, os diferentes países tinham seu "policy space" preservado. Nesse sentido, países em desenvolvimento puderam conciliar a abertura ao comércio exterior com as políticas de welfare state demandadas pelas populações locais, ao passo que os países em desenvolvimento tiveram espaço para perseguir estratégias próprias de crescimento econômico, variando da estratégia de substituição de importações a modelos baseados na promoção de exportações.

O que Rodrik emula na configuração de Bretton Woods é expresso pela metáfora da janela telada. A abertura ao exterior é favorável como o "ar fresco", mas pela janela podem entrar também os insetos indesejados. A instalação da tela não impede que o ar fresco entre, mas mantém fora os insetos (2011, p. 138). A metáfora ilustra um argumento favorável à configuração de uma globalização tênue, em que a interação econômica internacional conte com mecanismos para evitar repercussões sociais, políticas e econômicas danosas aos contextos locais. "A globalização é uma força tremendamente positiva, mas somente se você é capaz de domesticá-la para trabalhar a seu favor, e não contra você.” (2011, p. 146) 
Sete princípios para uma nova globalização

A solução de Rodrik ao trilema em termos de Estado nação com politica democrática é aquela que se situa no nível mais geral de abstração. Rodrik expressa esta opção em nível intermediário por meio da apresentação de sete princípios para uma "nova globalização". Alcançando maior grau de especificidade, esses princípios são em seguida convertidos em propostas mais concretas para reforma de elementos da cooperação econômica internacional.

De acordo com o primeiro princípio apresentado por Rodrik, "os mercados devem ser profundamente incrustados nos sistemas de governança.” (2011, p. 237) Esta é uma decorrência da afirmação de que mercados e governos são complementares, não substitutos um do outro. Neste sentido, os mercados não podem escapar às estruturas de governança capazes de discipliná-lo. E, para Rodrik, o âmbito adequado para tanto é o Estado. Portanto, a recomendação contida neste princípio é a de que o espaço mais apropriado para regulamentação dos mercados é a esfera nacional (2011, p. 250). A globalização não deve ser promovida para além do ponto em que suas forças deixem de poder ser disciplinadas. Valendo-se da metáfora proposta por Rodrik, trata-se de manter a possibilidade de filtrar a passagem de elementos indesejados através da janela, por meio de uma tela.

Pelo segundo princípio, "a governança democrática e as comunidades políticas são organizadas em Estados-nação e devem permanecer assim no futuro imediato.” (2011, p. 237) A globalização não deve se tornar um objetivo autônomo, capaz de ganhar proeminência sobre os valores e preferências determinados localmente. "Podemos melhorar tanto a eficiência quanto a legitimidade da globalização se empoderarmos ao invés de prejudicarmos os procedimentos democráticos domésticos.” (2011, p. 237) Este princípio é expressão direta da opção que Rodrik faz por Estado-nação e política democrática em detrimento de hiperglobalização.

O terceiro princípio afirma não haver "caminho único para a prosperidade" (2011, p. 239). Rodrik almeja uma "economia mundial que deixe espaço para que as democracias determinem seus próprios futuros.” (2011, p. 280) Em linha com essa proposta, é necessário reconhecer o valor e garantir o espaço da diversidade e da experimentação institucionais (2011, p. 240). A afirmação seguinte ressalta estes elementos, concatenados com os princípios anteriores:

Ao reconhecermos que o núcleo da infraestrutura institucional da economia global deve ser construído no âmbito nacional, liberamos espaço para que os países desenvolvam as instituições que melhor lhes sirvam. Mesmo as supostas sociedades 
industriais de hoje contemplam uma ampla variedade de arranjos institucionais ${ }^{203}$. (Rodrik, 2011, p. 239)

O quarto princípio confere aos países o "direito de proteger seus próprios arranjos sociais, regulações e instituições” (2011, p. 240). Trata-se de uma opção por "policy space ao invés de acesso a mercados" (2011, p. 253), que reflete a proposta de que a globalização e o comércio internacional sejam encarados como meios para outros fins, ao invés de fins em si mesmos. "A globalização deve ser um instrumento para atingir os objetivos que as sociedades buscam: prosperidade, estabilidade, liberdade e qualidade de vida." (2011, p. 240) Para tanto, é necessário deixar espaço para que padrões nacionais para as atividades econômicas sejam estabelecidos, "erguendo-se barreiras nas fronteiras se necessário, quando o comércio demonstravelmente ameaçar práticas domésticas que contem com suporte popular amplo." (2011, p. 241) Mais uma vez, a metáfora da tela é ilustrativa. O princípio, mais adiante, reflete-se na ênfase que Rodrik dá a que as estruturas da cooperação econômica internacional contenham "válvulas de escape" para preservar as preferências locais democraticamente deliberadas. Apesar das ressalvas de Rodrik aos resultados das deliberações democráticas, ele enfatiza preferir estas às soluções tecnocráticas, encaradas como supressoras do policy space:

A política democrática é bagunçada e nem sempre faz o "certo". Mas quando temos que escolher entre diferentes valores e interesses, não há nada mais em que possamos nos apoiar. Remover estas questões do âmbito da deliberação democrática e passá-las a tecnocratas ou órgãos internacionais é a pior solução. (Rodrik, 2011, p. 242)

Pelo quinto princípio, os "países não têm o direito de impor suas instituições aos demais" (2011, p. 242). Trata-se da outra face do quarto princípio, configurando cláusula que busca salvaguardar a proposta de adequação institucional segundo o contexto local, a deliberação democrática etc., inclusive com espaço para a experimentação. Assim como Chang, Rodrik é defensor da coexistência de países com opções institucionais diversas, caracterizável como pluralismo econômico institucional.

Consoante o sexto princípio, o "propósito dos arranjos econômicos internacionais deve ser estabelecer as regras de trânsito para gerenciar a interface entre as instituições nacionais" (2011, p. 243). Rodrik pretende que a substância das normas a reger as atividades econômicas seja nacionalmente definida, cabendo às estruturas de cooperação econômica internacional estabelecer como se dará o contato entre os diferentes modelos domésticos. A regulamentação multilateral da globalização econômica assumiu o sentido de propiciar as condições para que

\footnotetext{
${ }^{203}$ Este ponto é enfatizado pela literatura de variedades de capitalismo, que identifica na diversidade institucional a fonte de vantagens comparativas institucionais, baseadas no favorecimento de diferentes tipos de investimento nas economias de mercado, segundo as características dos contextos variados (Hall; Soskice, 2001).
} 
haja mais globalização, o que equivale a torná-la um fim em si mesma. Rodrik, porém, não objetiva regulamentação para globalização mais intensa. Afinal, sua proposta é conciliar política democrática e Estado-nação com uma globalização econômica de tipo tênue:

Ao invés de perguntarmos, "que tipo de regime multilateral maximizaria o fluxo de
bens e capital pelo mundo?", deveríamos perguntar, "que tipo de regime multilateral
melhor capacitaria as nações em todo o mundo a buscar seus próprios valores e
objetivos de desenvolvimento e a prosperar com seus próprios arranjos sociais?"
(Rodrik, 2011, p. 244)

Para Rodrik, a chave para tornar regimes multilaterais compatíveis com as aspirações nacionais é a introdução de cláusulas de escape (escape clauses). "As cláusulas de escape seriam vistas não como 'derrogações' ou violações das regras, mas como componente inerente aos arranjos econômicos internacionais sustentáveis.” (2011, p. 244)

Por fim, o sétimo princípio reflete a preferência explícita de Rodrik por arranjos democráticos. Nesse sentido, os países autoritários "não poderiam contar com os mesmos direitos e privilégios na ordem econômica internacional que as democracias" (2011, p. 244). Configura-se, assim, um princípio de "discriminação contra não-democracias" (2011, p. 246). Rodrik não chega a definir quais seriam os critérios para geração das listas de países democráticos e não democráticos. A eleição da democracia como valor ou formato institucional digno de convergência global parece destoar de sua postura geral contrária a harmonizações institucionais universais. Ainda assim, parece ser implicitamente justificada por sua opção manifesta pela política democrática como componente obrigatório para solução do "trilema", e pela caracterização da democracia como uma metainstituição desejável (Rodrik, 2007, p. 51, 94, 170), isto é, uma instituição percebida como adequada para que cada país defina as outras instituições e políticas apropriadas ao desenvolvimento, cada qual em seu contexto. Outra metainstituição na moldura intelectual elaborada por Rodrik parece ser o próprio Estado.

\section{Aplicações na reforma de elementos da cooperação econômica internacional}

Os sete princípios acima descritos são aplicados de maneira mais concreta por Rodrik para gerar propostas de reformas em regimes da cooperação econômica internacional. Três deles serão aqui destacados: comércio, finanças e trabalho.

Em sua concepção, o regime de comércio internacional precisa ser reformado para compatibilizar a abertura existente com "objetivos sociais mais amplos". As regras comerciais deveriam ser reformuladas para propiciar o "espaço doméstico necessário para proteger 
programas e normas sociais, renovar pactos sociais domésticos, e buscar políticas de desenvolvimento localmente elaboradas." (2011, p. 253) O foco do regime de comércio deveria deixar de ser a ampliação do acesso a mercados, e passar a ser a ampliação do policy space de países variados.

O principal alvo da reforma pretendida por Rodrik é o Acordo sobre Salvaguardas da OMC. Atualmente, as normas do Acordo constituem válvula de escape para que os países protejam firmas locais ameaçadas pelo aumento súbito de importações. O critério para aplicar salvaguardas - e com isso excepcionar a liberdade de comércio internacional em prol da sobrevivência de um setor econômico - é o teste de "dano grave" às empresas domésticas a partir do surto de importações. Rodrik propõe que este esquema básico seja expandido. A começar pelo nome, que passaria a ser "Acordo sobre Salvaguardas de Desenvolvimento e Sociais" (Agreement on Developmental and Social Safeguards):

\footnotetext{
Uma interpretação mais ampla das salvaguardas reconheceria que os países podem desejar restringir o comércio ou suspender suas obrigações com a OMC - exercer "opt-outs" - por razões outras que não as ameaças competitivas às suas indústrias. Preocupações distributivas, conflitos com normas e arranjos sociais domésticos, prevenção contra a erosão de regulações domésticas ou prioridades de desenvolvimento estariam entre os fundamentos legítimos. (Rodrik, 2011, p. 253)
}

A aplicação das salvaguardas sociais e de desenvolvimento estaria sujeita a um teste procedimental, não mais substancial ou de mérito, como o teste de "dano grave" do atual regime. O país que invocasse salvaguardas precisaria demonstrar que seguiu procedimentos democráticos para determinar que estas refletem o interesse público, e que todas as partes relevantes foram ouvidas (2011, p. 254). O regime mais fácil para a aplicação de salvaguardas contaria com "válvulas de escape" para que os países buscassem atender objetivos domésticos ainda que em detrimento do motivo da liberalização comercial.

Outro item de reforma, de caráter mais geral, incide sobre as restrições da regulamentação da OMC a subsídios e a outros mecanismos de política industrial. Para Rodrik, tais restrições deveriam ser ou suspensas, ou incluídas em "exceção geral a países em desenvolvimento". O novo regime reconheceria a cada país o direito de seguir sua própria estratégia de crescimento, com a ressalva de que estes não poderiam valer-se de seus regimes excepcionais para "produzir efeitos negativos de grande monta para o restante do mundo na forma de superávits comerciais.” (2011, p. 277)

Quanto ao regime internacional das finanças, Rodrik propõe a quebra do foco excessivo na harmonização internacional, percebida como desfavorável aos "interesses específicos de países em desenvolvimento" (2011, p. 265). Para ele, o regime internacional 
precisa reconhecer explicitamente o "direito dos governos de limitar as transações financeiras transfronteiriças" (2011, p. 254). Para evitar a chamada "arbitragem regulatória", que estimula a desregulamentação financeira competitiva, o novo regime também reconheceria o direito à aplicação de controles prudenciais de fluxos de capital (2011, p. 265). O objetivo de redução da volatilidade transfronteiriça do capital - que viabiliza a arbitragem regulatória - seria ainda auxiliado pela criação de uma "pequena taxa global sobre as transações financeiras", na ordem de $0,1 \%$ sobre o valor de cada transação (2011, p. 264).

A ordem financeira global seria construída com base em um "conjunto mínimo de diretivas internacionais e coordenação internacional limitada” (2011, p. 264), preservando o policy space de cada país para buscar as regulamentações de finanças mais adequadas a seus projetos específicos de desenvolvimento. Para Rodrik, as diferenças nas regulamentações deveriam passar a ser encaradas não como "aberrações da norma de harmonização internacional, mas como consequências naturais das circunstâncias nacionais variadas." (2011, p. 262)

O princípio que devemos aplicar aqui é o mesmo que aplicamos no caso da segurança do consumidor. Se outro país quer exportar-nos brinquedos, deve assegurar-se de que tais brinquedos atendem nossos padrões [...] de segurança. Semelhantemente, quando uma instituição financeira faz negócios em nossa economia, ela deve atender às nossas regulamentações financeiras, qualquer que seja seu lugar de origem. Isso significa que ela tem de manter os mesmos níveis de reserva de capital que as firmas domésticas, atender aos mesmos requisitos de transparência, e pautar-se pelas mesmas regras para transações. É um princípio simples: se quer fazer parte de nosso jogo, tem que jogar pelas nossas regras. (Rodrik, 2011, p. 262)

O resultado é a afirmação da liberdade de introduzir regulamentações financeiras pautadas por prioridades localmente definidas (2011, p. 263). A liberdade de movimentação transfronteiriça do capital é colocada em segundo plano diante dessas prioridades. $\mathrm{Na}$ concepção de Rodrik, estes projetos poderiam coexistir com os de outros países com afinidades econômicas mútuas e que desejassem harmonizar suas regulamentações (2011, p. 266), como no caso de blocos econômicos regionais. A reforma do regime financeiro internacional suprimiria, no entanto, os elementos que criam constrangimentos para a harmonização global em torno de mercados desregulados.

As reformas pretendidas por Rodrik na área do trabalho jogam com as contradições da globalização econômica. O sentido de reformas para os regimes de comércio e finanças reflete a percepção de que estas áreas estariam sobreglobalizadas. Já o trabalho seria um fator de produção que a globalização não liberou, no sentido de que esta impulsionou a mobilidade de bens e de capital, mas não de fluxos internacionais de trabalhadores. Rodrik chama a atenção 
para o fato de que esta característica da globalização contemporânea não repetiu o ocorrido durante a primeira globalização de finais do século XIX e início do século XX. Afinal, naquele momento, havia grau relativamente elevado de liberdade para fluxos laborais transfronteiriços. Para o autor, os mercados de trabalho contemporâneos não se encontram suficientemente globalizados, e sua abertura poderia trazer "enormes benefícios" para países mais pobres (2011, p. 266).

Em termos mais concretos, a proposta para a mobilidade internacional do trabalho consistiria na criação, por países desenvolvidos, de programas de pequena escala para receber mistos de trabalhadores migrantes qualificados e não qualificados de países pobres. Os países avançados concederiam vistos de trabalho temporário, por até cinco anos, numa quantidade que chegaria a $3 \%$ da força de trabalho local. Segundo este esquema, cada país pobre teria quotas de trabalhadores emigrantes em determinado país avançado, e os trabalhadores seriam substituídos dentro das quotas conforme regressassem aos países de origem (2011, p. 268).

Trabalhadores que acumularam know-how, habilidades, redes de relações (networks) e poupança em países ricos poderiam ser verdadeiros agentes de transformação de suas sociedades ao regressar. Sua experiência e investimentos poderiam dar início a dinâmicas econômicas e sociais positivas. (Rodrik, 2011, p. 269)

Rodrik destaca que sua proposta não é de "liberalização total", "completa" ou mesmo "significativa" dos fluxos internacionais de trabalhadores, mas a de criação de programas de "pequena escala". Ainda assim, cogita que estas reformas possam "gerar ganhos econômicos bastante amplos para os trabalhadores migrantes e as economias de seus países." (2011, p. 268) Em outra obra, Rodrik relata que a proposta de liberalização internacional do trabalho começou em tom jocoso (tongue-in-cheek) quando inicialmente formulada, mas, com o tempo, passou a ser tratada mais seriamente pelo próprio autor (Rodrik, 2007, p. 9).

Pode-se notar que as contribuições de Rodrik se singularizam do corpo das perspectivas econômicas heterodoxas por avançar nas propostas sobre como tornar a globalização econômica receptiva às necessidades e pretensões de países em desenvolvimento. Neste esquema, a globalização deixa de ser encarada como fim em si, e passa a ser o meio para realização de aspirações nacionais diversas. Os princípios e propostas específicas de reforma que Rodrik endereça à estruturação da cooperação econômica internacional têm objetivos que convergem com outras propostas heterodoxas, como a de HaJoon Chang, no sentido de abrigar a diversidade institucional e, como parte desta, a possibilidade de projetos de desenvolvimento que atribuem ao Estado papel ampliado no impulso e disciplina das forças de mercado. Uma das principais características do pensamento 
econômico heterodoxo sobre desenvolvimento e instituições parece ser, afinal, a formulação de argumentos conducentes ao que se poderia chamar de pluralismo institucional global. 


\section{CAPÍTULO 4 - EXPERTISES E INTERDISCIPLINARIDADE A SERVIÇO DE REFORMAS}

As reformas propostas por instituições da cooperação econômica internacional com vistas à promoção do desenvolvimento passaram por três fases ou momentos distintos. Primeiramente, ao longo das décadas de 1950-60, a aposta foi em "obras de infraestrutura e programas públicos de investimento", e o mecanismo privilegiado, a concessão de assistência oficial ao desenvolvimento, ou ajuda externa. Num segundo momento, correspondente às décadas de 1970-80, as chamadas reformas de "segunda geração" passaram a ter foco no "ajuste macroeconômico" e a pautar-se pela divisa "getting the prices right", em linha com a noção neoliberal de que a remoção de distorções estatais às sinalizações de preços seria fundamental para desencadear o dinamismo do setor privado (vide seção 3.3). Por sua vez, as reformas de "terceira geração" voltaram sua atenção ao "aprimoramento institucional" como chave para o desenvolvimento, adotando o mote "getting the institutions right". Após um período em que o funcionamento das instituições, inclusive jurídicas, foi ignorado nas análises do mainstream, em meados da década de 1990, refletindo desdobramentos intelectuais que caracterizaram uma "virada institucional", elas passam a ser consideradas variáveis relevantes para o desenvolvimento econômico (cf. Schapiro, 2010, p. 216; Trubek, 2006; Trubek; Santos, 2006).

Esse terceiro momento corresponde à ascensão do mote da boa governança nas relações internacionais, abordado anteriormente. Corresponde, ainda, à centralidade da preocupação com instituições jurídicas no discurso e prática do desenvolvimento (Santos, 2006, p. 253). Institutions matter, getting institutions right, good governance etc.: a virada institucional, no que diz respeito aos países em desenvolvimento e também aos recém-saídos do bloco soviético, na década de 1990, refletiu-se em programas de reforma inspirados no paradigma rule of law, promovidos por organizações como o Banco Mundial ${ }^{204}$, o FMI, entre

\footnotetext{
${ }^{204}$ Segundo Alvaro Santos, nos anos 1990, o Banco Mundial apoiou 330 projetos de reforma jurídica e judicial, baseados no mote de "rule of law", em 100 países (2006, p. 253). Mariana Mota Prado ressalta, ao observar esses dados, que a noção de que as instituições importam para o desenvolvimento (institutions matter) tornou-se "uma das ideias mais influentes no pensamento sobre direito e desenvolvimento nos dias de hoje." (Prado, 2010, p. 13; cf. Trebilcock; Prado, 2014) Dentro do Banco Mundial, há dois grupos que se destacam na incorporação da noção de rule of law de modo mais instrumental. Um deles é o World Bank Institute, com o projeto de Governance Indicators, inaugurada em 1996, que estabelece correlações entre componentes institucionais dos países e renda per capita. A abordagem permite colocar os países ao longo de um ranking de qualidade de governança, a partir do qual propostas de reforma são sugeridas e fundamentadas (Santos, 2006, p. 293). Essa visão tem larga inspiração nos materiais fornecidos pela Nova Economia Institucional (NEI), dando expressão numérica à noção de que países com instituições "ruins", que criam custos às transações nos mercados, são
} 
outras (vide seção 2.3). Esse paradigma aposta "na promoção do desenvolvimento a partir da promoção de boas regras do jogo, capazes de amparar um ambiente econômico estável e seguro para as transações privadas.” (Schapiro, 2010, p. 214) O ambiente institucional "correto" é aquele que privilegia transações privadas nos mercados, percebendo-as como principal elemento dinâmico, indutor do crescimento e do bem-estar (cf. 2010, p. 217). Juridicamente, a concepção de que o dinamismo reside no setor privado se traduz na "primazia do direito privado sobre o direito público":

A noção de direito subjacente ao paradigma Rule of law é a de um veículo promotor
de garantia, previsibilidade e calculabilidade para as transações privadas. A
existência de regras claras, a proteção adequada da propriedade privada, a certeza do
cumprimento dos ajustes contratuais e a confiança no funcionamento célere e
independente do Poder Judiciário passaram a ser consideradas como itens
necessários a serem atendidos pelos ambientes jurídico-institucionais. (Schapiro,
2010, p. 219)

Quais foram os quadros de referência para as reformas conduzidas sob o paradigma rule of law? Em termos de ideias provenientes da economia, a principal fonte consistiu nos estudos da chamada Nova Escola Institucional (NEI), cujos expoentes são Douglass North e Oliver Williamson ${ }^{205}$. Em termos de ideias jurídicas (ou interdisciplinares, de direito $e$ economia), vertentes de maior notoriedade internacional, como a Análise Econômica do Direito (AED) e o movimento Law \& Finance (Castro, 2011, p. 8) contribuíram com materiais intelectuais para crítica às instituições jurídicas ligadas a políticas públicas e à política econômica, e elaboração de propostas de reforma. Elas compartilham (entre si e com a NEI) a noção de que o ambiente institucional correto, favorável ao funcionamento desimpedido dos mercados, seja a chave para a eficiência econômica e, por conseguinte, do desenvolvimento, entendido primariamente como crescimento econômico.

Apesar de ter se tornado, na prática, a moldura mais influente para a condução de reformas ao longo do globo na década de 1990, o paradigma rule of law tem contestações tanto na economia quanto no direito. Desde a economia, há contribuições da chamada "Nova Economia do Desenvolvimento", como as de Ha-Joon Chang e Dani Rodrik (cf. seção 3.4), além de autores como Alice Amsden, Peter Evans e Erik Reinert. Desde o direito, há movimentações como o Novo Direito e Desenvolvimento (NDD) e a Análise Jurídica da

menos aptos ao crescimento econômico. Outro projeto consiste nos relatórios Doing Business e nos indicadores Ease of Doing Business, da Rapid Response Unit, e que se iniciou em 2003. Embora igualmente convergente com as formulações da NEI, a fonte mais direta de materiais intelectuais para estruturá-lo é o movimento Law \& Finance (Santos, 2006, p. 280), abordado na seção 4.2.

${ }^{205}$ Vide subseção 4.1.4. 
Política Econômica (AJPE). Configura-se um novo e rico debate entre expertises interdisciplinares que disputam o sentido de reformas institucionais.

Esse debate é o foco do presente capítulo. Como será possível notar, há significativas modulações nos usos de referenciais do direito e da economia na composição de cada vertente, resultando em convergências e divergências entre os movimentos. É possível perceber, de plano, a existência de dois agrupamentos, a dividir as quatro correntes. Os dois primeiros projetos (AED e Law \& Finance) são perspectivas de suporte ao paradigma rule of law. Guardam afinidades com a sensibilidade econômica do neoliberalismo (vide seção 3.3) e com o mote da "boa governança" (vide seção 2.3). Os dois últimos projetos questionam as recomendações do paradigma prevalente. Suas afinidades com o pensamento econômico residem na heterodoxia (vide seção 3.4), e assim também ocorre com o pensamento jurídico a respeito das relações internacionais, (vide, por exemplo, na subseção 2.3.5, o item "pluralismo jurídico global"). Buscam, nesse sentido, a construção de uma ordem alternativa.

Este é um debate conectado a elementos das trajetórias descritas nos capítulos 2 e 3 , ou seja, às instituições e sensibilidades jurídicas e econômicas a respeito das relações internacionais. Trata-se do pano de fundo que confere sentido à caracterização dos aspectos principais, nas seções seguintes, de expertises interdisciplinares a serviço de reformas, como a AED (4.1); Law \& Finance (4.2); NDD (4.3) e AJPE (4.4).

\subsection{Análise Econômica do Direito}

“[E]scolhi ignorar por completo questões de justiça ao proceder à análise.” Tal afirmação poderia parecer ter sido retirada da Teoria Pura do Direito de Hans Kelsen (2011), em seu esforço de autonomização do direito como objeto de conhecimento, inclusive em relação à moral. A citação, porém, pertence ao livro Law's Order, de David Director Friedman, que objetiva compreender sistemas jurídicos por meio das "consequências que produzem em um mundo no qual indivíduos racionais ajustam suas ações às regras jurídicas com que se deparam" (Friedman, 2000, p. 4). Não é exatamente um projeto de autonomia do direito em relação a conceitos morais como justiça, mas sim de uso de categorias econômicas para a compreensão de fenômenos jurídicos. Assim, a análise da "justiça" é afastada porque uma categoria econômica é apresentada como tendo maior poder explicativo: "ocorre que as regras que pensávamos apoiar por serem justas são, na verdade, eficientes.” (2000, p. 4) A principal característica da Análise Econômica do Direito (AED), também conhecida como "Direito e Economia", é precisamente o emprego de ferramentais típicos da economia para 
compreender, criticar e projetar regras jurídicas. “As regras jurídicas devem ser julgadas pela estrutura de incentivos que estabelecem e as consequências de alterações de comportamentos das pessoas em resposta a tais incentivos." (Friedman, 2000, p. 11)

Essas características enquadram a AED como uma visão instrumental do direito, já que este é orientado à promoção da eficiência econômica (cf. Tamanaha, 2006). Valendo-se de metodologia que "evoca a precisão matemática e a objetividade" (2006, p. 119), a AED tem pretensões descritivas e prescritivas a respeito das instituições jurídicas. No aspecto descritivo (ou positivo), há a afirmação de que as regras do common law tendem a incorporar a eficiência, entendida sobretudo como maximização de riqueza. O common law opera sobretudo como uma moldura para a condução de transações privadas, "facilitando a transferência de atividades, bens e serviços para aqueles que os valorizam mais" (2006, p. 118-9). No aspecto prescritivo (ou normativo), há a proposição de que o direito - todo o direito, não só o common law - "deva ser orientado para a maximização da riqueza" (2006, p. 119). A promoção da eficiência como critério balizador da eficiência desloca, na prática, questões de redistribuição (ou o aspecto da equidade econômica) para "fora dos domínios" da $\operatorname{AED}^{206}$ (2006, p. 120).

A tradição de julgar instituições jurídicas com base em categorias econômicas - e em especial microeconômicas - teve a publicação de dois artigos, no início da década de 1960, como expressão de um momento fundacional (cf. Salama, 2008, p. 12; Posner, 1998, p. 1). Um deles foi The problem of Social Cost, em 1960, de Ronald Coase. Outro foi Some thoughts on risk distributions and the law of torts, de Guido Calabresi, em 1961. Optou-se, aqui, por abordar as origens da AED (subseção 4.1.1, a seguir) de forma delimitada a Ronald Coase, por três motivos. Primeiramente, a publicação de Coase antecede a de Calabresi. Em segundo, uma categoria de base em The problem of Social Cost (Coase, 1960), "custos de transação", já havia sido explorada em uma de suas publicações décadas antes, The nature of the firm, de $1937^{207}$. Por fim, Coase permaneceu no mainstream da AED, ou seja, associado à "Escola de Chicago", ao passo que Calabresi viria a ser um dos nomes de uma linhagem

\footnotetext{
${ }^{206}$ Brian Tamanaha esclarece que a maximização de riqueza, na AED, é medida pela disposição de pagar por bens e serviços. Essa disposição, evidentemente, se encontra em função da habilidade de pagar, que por sua vez "levanta questões de distribuição justa", mas que são marginalizadas nos estudos desta vertente (2006, p. 118$20)$.

207 "Embora Posner seja um escritor prolixo e tenha ficado conhecido como o grande expoente da AED, realizada nos moldes propagados por professores da Universidade de Chicago, as ideias que realmente estruturaram os referenciais analíticos dessa abordagem vieram de Ronald Coase, um economista cujas concepções a respeito das relações entre direito e economia remontam à década de 1930, mas ficaram marginalizadas por várias décadas dos debates acadêmicos mais prestigiados.” (Castro, 2012, p. 207)
} 
alternativa - a "Escola de New Haven"208, cujos argumentos tendem a favorecer maior medida de intervencionismo estatal na economia (Salama, 2008, p. 28; Mackaay, 2000, p. 410). A abordagem aqui feita permanece, porém, com foco na AED de Chicago, não só por ter sido a vertente com maior visibilidade e influência acadêmica e prática, como também o tronco principal do qual emergiram variantes: "a história oficial e interna do campo começa em Chicago.” (Harris, 2003, p. 662)

Como reflexo disso, a caracterização de aspectos da AED encontra-se estruturada da seguinte maneira. A subseção 4.1.1 propõe que as contribuições de Coase possam ser encaradas como principais bases intelectuais imediatas da AED. Diz-se, aqui, "imediatas", porque o objetivo não é fazer referência a outras movimentações intelectuais mais "remotas", e que também envolveram, em alguma medida, a avaliação de instituições jurídicas com base em critérios econômicos, como o realismo jurídico norte-americano, o marxismo ou mesmo o utilitarismo de Jeremy Bentham. Em seguida, a subseção 4.1.2 volta-se à consolidação da AED a partir do projeto antitruste da Faculdade de Direito da Universidade de Chicago. De um projeto focado em uma área do direito de tonalidades econômicas bastante marcantes, a AED, após Coase, Becker e sobretudo Posner, projetou-se sobre as mais diversas áreas do direito. A subseção destaca, ainda, a importância que fundações de fomento à divulgação de ideias conservadoras tiveram para o crescimento e aquisição de relevância política da AED. Um elemento de destaque, nessa descrição, são as conexões entre a AED e o projeto caracterizado como "neoliberal" na seção 3.3 do capítulo anterior. A subseção 4.1.3, por sua vez, aponta as principais características do mainstream da AED, pautado por Posner. Ao fazêlo, atribui importância ao lugar de destaque que a eficiência assume, bem como à tese da eficiência do common law. A subseção conta, ainda, com exemplos de raciocínios pautados pela AED e dirigidos a instituições jurídicas no Brasil. Por fim, a subseção 4.1.4 relaciona a AED ao paradigma rule of law, e menciona, ainda que brevemente, certas reformas de instituições jurídicas no Brasil que foram apoiadas com base nesse referencial.

\footnotetext{
${ }^{208}$ Nesse sentido, "alguns fazem referência ao artigo Some Thoughts on Risk Distribution and the law of Torts de Guido Calabresi, de 1961, como equivalente à contribuição de Coase para a fundação da análise econômica do direito (law and economics). Outros entendem que Calabresi foi o fundador da escola da análise econômica do direito de New Haven, como algo distinto da escola da análise econômica do direito de Chicago.” (Harris, 2003, p. 662)
} 


\subsubsection{Bases intelectuais imediatas da AED: as contribuições de Ronald Coase}

Em The nature of the firm, Coase critica uma presunção fundamental da teoria econômica: a de que "a direção dos recursos depende diretamente do mecanismo de preços." (Coase, 1937, p. 387) Há instituições, como a firma, que também coordenam atividades de produção e troca, de modo alternativo às sinalizações de preços. Assim, Coase exemplifica que um funcionário é alocado "do departamento Y para o departamento X" não por causa de uma "mudança nos preços relativos, mas porque ele é ordenado a fazê-lo." (1937, p. 387) Dentro da firma, são as ordens do empreendedor, e não as sinalizações de preços de mercado, que alocam os fatores de produção (1937, p. 388).

Para Coase, o que determina a existência desse sistema alternativo para a alocação de recursos - a firma - é a existência de custos de transação. A teoria econômica convencional presume que todos os preços nos mercados sejam conhecidos pelos indivíduos, mas "isso claramente não é verdade no mundo real.” (Coase, 1937, p. 390) Há custos para descobrir preços, para negociar e concluir contratos ${ }^{209}$ (1937, p. 390-1). Diante da existência de tais custos, no mundo real, torna-se mais viável reunir os diferentes fatores de produção sob uma estrutura unificada de direção e comando por um indivíduo ou grupo de indivíduos, do que pela celebração de uma miríade de contratos em transações de mercado determinadas pelas sinalizações de preços. A firma é vista, nesse sentido, como um feixe ou nexo de contratos:

Um fator de produção (ou seu dono) não tem que realizar uma série de contratos
com os fatores com os quais está cooperando dentro de uma firma, como seria
necessário, é claro, se essa cooperação se desse como resultado do funcionamento
do mecanismos de preços. Um só contrato substitui uma série de outros (Coase,
1937, p. 391).

Pode-se perceber que a noção de custos de transação está na base da explicação que Coase oferece para a firma como meio alternativo às sinalizações de preço para coordenar atividades econômicas. Até aqui, não se está no campo da AED. Porém, a mesma noção custos de transação - também está na base do que viria a ficar conhecido como teorema de Coase $^{210}$, a partir de formulações em The problem of social cost, publicado em 1960, e que é

\footnotetext{
${ }^{209}$ Uma explicação mais detalhada e exemplificada dos custos de transação é dada por Coase em The problem of social cost: "Para realizar transações de mercado é necessário descobrir com quem se quer negociar, informar pessoas de que se quer negociar e em que termos, conduzir negociações que levem a um acordo, redigir o contrato, fazer a inspeção necessária para assegurar-se de que os termos do contrato estão sendo observados, e assim por diante. Essas operações são frequentemente bastante custosas, custosas o suficiente para impedir a ocorrência de muitas transações que seriam conduzidas num mundo em que o sistema de preços funcionasse sem custos." (Coase, 1960, p. 15)

${ }^{210}$ Segundo o próprio Ronald Coase, a expressão "teorema de Coase" não foi cunhada por ele, mas por George Stigler (cf. Coase, 1993, p. 249).
} 
dedicado "às ações de empresas que têm efeitos danosos sobre terceiros" (Coase, 1960, p. 1), ou seja, ao tema das externalidades, advindo da economia do bem-estar (welfare economics). Este, sim - isto é, o teorema de Coase - passaria a estar na base das formulações da AED.

As externalidades são efeitos benéficos ou prejudiciais que a realização de uma atividade econômica origina para terceiros. Coase aborda uma série de exemplos (alguns dos quais são mencionados a seguir), com ênfase em externalidades de tipo negativo. $\mathrm{O}$ modo como trabalha esses exemplos implica a rejeição de duas pressuposições comuns a respeito de situações em que a atividade econômica de um gera dano sobre outros.

A primeira das pressuposições rejeitadas é a de que as externalidades devam ser lidadas por meio da regulamentação governamental. Coase critica economistas e formuladores de políticas da época por apresentarem essa tendência (1960, p. 18), que se reverte na recomendação de que subsídios sejam utilizados para fomentar externalidades positivas, e a tributação ou mesmo proibição de determinadas atividades em locais delimitados ocorra para as externalidades negativas. As soluções de subsidiar ou tributar, especificamente, se encaixariam na tradição "pigouviana", assim referida em razão das ideias de Arthur Pigou, que sugeriu tais medidas como formas de internalizar as externalidades. Ou seja, como meio para que os efeitos de uma atividade econômica sobre terceiros passassem a integrar o preço do que é produzido e comercializado.

A segunda pressuposição rejeitada por Coase é a noção comum de que o agente econômico que causa dano a terceiros deva ser monetariamente responsabilizado por isso. Essa seria uma visão simplificada, ou mesmo equivocada, do sentido de "dano". Para Coase, esta noção deve ser abandonada e substituída por outra, que reflita a "natureza recíproca" do dano no que diz respeito a atividades econômicas. Assim, interromper a atividade do "causador" ocasiona-lhe dano, da mesma forma que sua continuidade causa danos a terceiros. E o problema torna-se, assim, "evitar o dano mais sério" (Coase, 1960, p. 2), o que se faz por uma análise de custos.

Um dos exemplos é a situação de emissão de fumaça gerada na produção de sulfato de amônia, que escurece tecidos produzidos em propriedade vizinha ao interagir com o alvejante ali empregado (1960, p. 10-1). Em uma tal situação, a análise comum identificaria a fábrica química como causadora do dano, derivando disto um dever de indenizar. Coase ressalta, porém, a natureza recíproca do dano: tanto o escurecimento é um "custo" para a atividade de tingir tecidos, como também a presença da produção têxtil, vizinha à fábrica química, é um "custo" para esta última. Dada a reciprocidade do dano, ou seja, da imposição de custos às atividades de terceiros, a resposta a ser dada "não é clara, a não ser que saibamos o valor do 
que é obtido bem como o valor do que é sacrificado para obtê-lo.” (1960, p. 2) Ou seja, a questão de quem deverá indenizar dependerá de uma análise de custo-beneficio. É antes necessário responder: qual das atividades maximiza o valor da produção?

Para Coase, a concepção econômica dos fatores de produção é falha porque os considera como entidades físicas ou materiais - terra, capital, trabalho... - ao passo que seria mais adequado considerá-los como direitos. "Podemos falar que uma pessoa possui terra e a emprega como fator de produção, mas o que proprietário da terra de fato possui é um direito de conduzir uma lista limitada de ações." 211 (Coase, 1960, p. 44) Quando a análise dos fatores de produção passa a encará-los em termos de direitos, "torna-se mais fácil compreender que o direito a fazer algo que tenha um efeito danoso (como a geração de fumaça, barulho, cheiros etc.) também é um fator de produção.” (Coase, 1960, p. 44) A partir disso, Coase destaca que o exercício de tais direitos têm custos de oportunidade:

O custo de exercer um direito (de usar um fator de produção) é sempre a perda ocasionada em outro lugar como consequência do uso desse direito - a impossibilidade de atravessar uma propriedade, estacionar um carro, construir uma casa, desfrutar de uma paisagem, ter paz e sossego ou respirar ar puro. (Coase, 1960, p. 44)

O ponto fica mais claro quando o exemplo tomado é contaminação de um córrego (e morte de peixes) por efluentes despejados por uma fábrica. Novamente, pela visão convencional, o dano ambiental é responsabilidade da fábrica, que deve assim indenizar. $\mathrm{Na}$ visão de Coase, porém, a questão ambiental representa um "custo" para a atividade da fábrica. Assim, "a questão a ser decidida é: o valor dos peixes perdidos é maior ou menor do que o valor da produção que a contaminação do córrego torna possível"? (Coase, 1960, p. 2) Essa deve ser a base para atribuir ou não, à fábrica, um "direito de poluir" (como fator de produção): o teste da relação custo-benefício.

Como se pode notar, não há espaço, nesse tipo de análise, para valores intrínsecos (como a preservação ambiental), somente para valores que possam ser expressos monetariamente, ou seja, para coisas passíveis de transação nos $\operatorname{mercados}^{212}$. Isso leva a

\footnotetext{
${ }^{211}$ A mesma ideia é espelhada de forma didática por David Friedman: "o que você possui não é um pedaço de terra, mas um feixe de direitos [a bundle of rights] relacionados a um pedaço de terra." (Friedman, 2000, p. 14)

${ }^{212} \mathrm{Em}$ sentido contrário, Ivo Gico Jr. sustenta: "são plenamente passíveis de análise econômica situações em que o comportamento humano tenha como motivação central elementos imateriais ou psicológicos, como prestígio (e.g. academia), poder (e.g., política) ou mesmo altruísmo (e.g. família)." (Gico Jr., 2012, p. 23) No entanto, como a AED procede a partir da teoria dos preços, a análise econômica, nesse caso, precisará estimar valores para tais elementos imateriais ou psicológicos, ou seja, precificá-los. De fato, esse expediente chega a ser feito pelos autores da AED ao estilo de Chicago, como o próprio Posner, que em certa passagem voltada à análise de atropelamentos e custos de medidas de segurança ligadas a ferrovias, emprega raciocínios que se valem de expressões do tipo: "[s]uponha que a vida de uma criança valha tanto quanto a de quem fez o seu resgate, digase, \$X" (Posner, 1998, p. 6). O mesmo ocorre com a abordagem de crimes como o estupro, em que Posner supõe
} 
argumentação de Coase à afirmação de um direito de poluir que está em função da maximização da produção ou da riqueza, quer dizer, de resultados economicamente ótimos. Essa mesma lógica é aplicada na situação de uma população afetada pela fumaça emitida por uma fábrica vizinha. Partindo de uma suposição aritmética em que os custos para continuar poluindo são menores do que os de medidas destinadas a evitá-la, o autor considera que "haveria ganho no valor da produção [...] se a fábrica continuasse a emitir fumaça e os habitantes do distrito se mudassem para outro lugar ou fizessem outros ajustes para evitar o dano." (1960, p. 41) Nesse contexto, o objetivo da regulação não deve ser o de "eliminar a poluição gerada pela fumaça, mas o de assegurar a quantidade ótima de poluição pela fumaça, que é a quantidade que maximizará o valor da produção." (1960, p. 42)

A lógica econômica de maximização do valor da produção, que permite falar em um "nível ótimo" de poluição, é o elemento que Coase pretende aplicar para pautar o olhar jurídico dos problemas que envolvam a geração de danos para terceiros. "Tudo é uma questão de comparar os ganhos que adviriam da eliminação desses efeitos danosos com os ganhos que são obtidos ao permitir sua continuidade.” (1960, p. 26) A partir disso, a solução que Coase oferece é tratar os problemas de danos a terceiros não como situações de responsabilidade civil (como normalmente faria um jurista), mas como situações em que direitos de causar dano - por assim dizer - tornam-se passíveis de transação.

Aqui, está-se adentrando propriamente o caminho que leva à afirmação do "teorema de Coase". Esse teorema envolve duas situações. Uma é hipotética: refere-se a um mundo imaginário em que não há custos de transação, uma situação que Coase já havia rejeitado como irrealista em The nature of the firm (Coase, 1937). Noutra, os custos de transação são significativos. Como resultado dessa modulação, há diferentes efeitos a partir da definição inicial de quem é ou não responsável juridicamente pela existência de um dano ou custo a terceiros.

Não havendo custos de transação, a definição jurídica das responsabilidades por danos causados a terceiros simplesmente não será relevante $(1960$, p. 8). Isso porque o direito de causar dano será objeto de transação entre as partes. As negociações levarão necessariamente a um mesmo resultado: o prosseguimento da atividade de maior valor econômico, que resulte

valores a partir de preferências estimadas tanto para o autor quanto para a vítima, conforme relata Buchanan: "se os benefícios alcançados pelo potencial estuprador excederem as perdas sofridas pela vítima potencial, ganhos mútuos da transação [no sentido de Kaldor-Hicks] devem existir, e tais transações devem ocorrer."[!] (Buchanan, 1974, p. 485) Esse tipo de raciocínio habilita quem usa a AED a falar em "nível eficiente" ou "ótimo" para a ocorrência de crimes em uma sociedade. Raciocínios baseados em "níveis ótimos" são usados para validar, como se pôde observar, a permanência de situações injustas e indesejadas pelos indivíduos e grupos adversamente afetados. 
numa alocação mais eficiente, ou ótima, de recursos (1960, p. 6). Assim, não importa se a fábrica será ou não considerada responsável pela poluição que atinge a vizinhança. Se a atividade da fábrica resultar em maior valor econômico, ela negociará com os vizinhos e comprará deles o que se pode considerar um direito de poluir, prosseguindo com suas atividades. Caso a fábrica não seja inicialmente responsabilizada, "a alocação de recursos será a mesma nessa situação, tal como seria se o negócio causador de dano fosse considerado responsável pelos danos causados." (Coase, 1960, p. 6) Ou seja, juridicamente responsabilizada ou não, a fábrica poderia "contornar" as restrições jurídicas por meio de negociações com as outras partes afetadas, neste cenário em que os custos de transação são presumidos nulos. "Sempre é possível modificar a delimitação inicial de direitos por transações de mercado. E, é claro, se tais transações de mercado forem sem custos, tal rearranjo de direitos sempre ocorrerá se for conducente ao aumento no valor da produção." (1960, p. 15)

Havendo custos de transação, como no mundo real, a situação muda de figura. Os direitos inicialmente atribuídos só passarão por rearranjos se os custos para que as partes os negociem forem inferiores ao benefício que decorreria da negociação. "Em tais condições a delimitação inicial de direitos tem efeito sobre a eficiência com que o sistema econômico opera." (1960, p. 15-6) Por isso, as decisões de juízes sobre quem será responsabilizado por danos a terceiros têm influência direta sobre a eficiência econômica. Sabendo que essa atribuição de direitos, na prática, pode não ser modificada por livre negociação das partes em razão de custos de transação -, os juízes devem procurar pautar suas decisões pelo critério de maximização do valor da produção: "Parece desejável que as cortes devam compreender as consequências econômicas de suas decisões e devam, tanto quanto é possível sem criar muita incerteza sobre a posição jurídica em si, levar essas consequências em conta para a tomada de suas decisões.” (Coase, 1960, p. 19)

Em outros termos, Coase está afirmando que os juízes devem decidir de forma a maximizar a eficiência econômica, fazendo uma atribuição inicial de direitos que corresponda ao que hipoteticamente seria a alocação "ótima" a partir da livre negociação das partes num cenário de ausência de custos de transação. A esse respeito, Coase observa que os juízes no common law, embora nem sempre versem suas decisões em raciocínios explicitamente econômicos, tendiam a incorporar racionalidades econômicas implicitamente ao decidir sobre casos de danos a terceiros. Ou seja, há uma tendência a que as decisões judiciais sejam eficientes. 
Em síntese, o "teorema de Coase" reúne dois enunciados sobre as consequências das instituições jurídicas nos cenários de existência e inexistência de custos de transação:

É necessário saber se a atividade econômica danosa é ou não responsável pelos danos causados porque, sem essa delimitação inicial de direitos estabelecidas, pode não haver transações de mercado para transferir e recombinar estes direitos. Mas o resultado final (que maximiza o valor da produção) é independente da posição jurídica quando o mecanismo de preços tem funcionamento presumido sem custos. (Coase, 1960, p. 8)

As análises feitas por Coase estão carregadas de implicações normativas. A mais evidente é a eleição da eficiência econômica como critério para julgar a adequação das instituições jurídicas. Isso implica que as consequências econômicas das instituições jurídicas devam ser tomadas como relevantes para sua validação. Nesse sentido, Coase afirma: "Ao projetar ou escolher entre arranjos sociais, devemos considerar os efeitos totais. Esta é, sobretudo, a mudança de abordagem que proponho." (Coase, 1960, p. 44) Outra consequência normativa diz respeito à hipótese de funcionamento dos mercados sem custos de transação: como os mercados são tomados como capazes de resolver automaticamente problemas envolvendo a delimitação inicial de direitos, "o tipo de ação governamental que os economistas pensavam ser necessária" - como tributação e outras formas de regulação restritiva - "é completamente desnecessário, dadas as presunções de seu sistema analítico." (Coase, 1993, p. 252)

Mesmo quando os custos de transação voltam à análise, a "eficiência dos mercados" continua sendo o critério para pautar as decisões jurídicas ideais: a implicação normativa que Coase retira da presença de custos de transação não é a de que o Estado deva buscar regular as atividades dos causadores de danos. É, ao contrário, uma solução que busca "simular" o que ocorreria caso não houvesse custos de transação. Quer quando custos de transação são levados em conta, quer quando não, o teorema de Coase continua sendo uma defesa do laissez-faire (cf. Friedman, 2000, p. 39). Os juízes devem procurar atribuir direitos - ou seja, definir quem deve ser responsabilizado e quem deve receber reparações por danos sofridos - como se estes pudessem ser livremente negociados na ausência de custos de transação. É curioso, nesse sentido, que Coase aponte a existência de custos de transação como um elemento que torna irrealistas as análises tradicionais dos economistas, que tendem a excluir (ou pressupor) a relevância das instituições jurídicas. Da constatação de que existem impedimentos ao funcionamento adequados dos mercados não deriva, porém, uma receita de maior abertura para a participação da regulação estatal. Pelo contrário, a receita sugerida consiste em buscar 
imitar os mecanismos de alocação dos mercados por exercícios hipotéticos de subtração dos custos de transação e por análises de custo-benefício.

Ainda outra implicação do raciocínio de Coase é a noção de que os problemas das externalidades sejam melhor resolvidos segundo os moldes das negociações privadas. Quando não há custos de transação, os direitos migram espontaneamente para a parte que os valoriza mais. Quando há custos de transação, as cortes devem atribuir responsabilidades e direitos de acordo com o que seria o resultado da livre negociação privada na ausência de tais custos. O local privilegiado da eficiência é a esfera privada. As cortes - como mãos do Estado - entram "no jogo" apenas como remédios contra custos elevados de transação que interferem na habilidade privada de negociar.

Um exemplo adicional pode ajudar a aclarar o emprego do teorema e algumas de suas implicações. Coase toma o caso da ferrovia cujas faíscas geram incêndios nas matas das propriedades vizinhas. "Não é necessariamente desejável que a ferrovia deva ser obrigada a compensar aqueles que sofram danos causados pelas locomotivas." (Coase, 1960, p. 31) Na ausência de custos de transação, mesmo que a atividade da ferrovia fosse mais valiosa e juízes decidissem pelo dever desta de indenizar proprietários vizinhos, a ferrovia poderia negociar com estes e comprar-lhes o "direito de incendiar". Como se disse anteriormente, a alocação inicial de direitos não importa para o cenário de ausência de custos de transação: a livre barganha entre as partes conduzirá ao resultado economicamente mais eficiente. "O problema consiste em ser ou não desejável tornar a ferrovia responsável por danos em condições nas quais seja muito caro para que tais barganhas ocorram.” (1960, p. 31) Nessa situação, Coase sugere que os juízes devam decidir pelo direito de a ferrovia causar danos aos proprietários vizinhos: "do ponto de vista econômico, a situação em que exista 'danos não compensados às matas vizinhas de faíscas oriundas de locomotivas' não é necessariamente indesejável.” (1960, p. 34) O critério empregado é a análise de custo-benefício. A decisão judicial deve validar as atividades econômicas em que "o que é ganho vale mais do que aquilo que é perdido" (Coase, 1960, p. 44) - já que este seria o resultado atingido, afinal, pela ocorrência desimpedida de transações nos mercados.

Portanto, para Coase, havendo alguma ação econômica que cause malefícios a alguém, ela pode permanecer defensável sob o argumento de que os recursos "usados" pela mesma ação devem passar a ser considerados como parte de seus "custos" econômicos - sem que à ação seja atribuída qualquer conotação de ilicitude. Uma consequência disso é que as condutas percebidas por alguns como causadoras de inaceitáveis malefícios, e que podem ser caracterizadas juridicamente como "ofensa a um direito subjetivo", passam a ser justificáveis economicamente. E, sendo aplicadas genericamente à análise jurídica, como defendem os adeptos da AED ao estilo de Chicago, as condutas vistas como injuriosas sob o prisma jurídico 
convencional passam a ser consideradas como juridicamente válidas, se forem economicamente justificáveis. (Castro, 2012, p. 208-9)

\subsubsection{AED em expansão: do nicho antitruste em Chicago à AED abrangente e influente}

As contribuições de Coase demonstraram ser possível empregar critérios econômicos para avaliar instituições nos mais variados domínios do direito. Antes, o procedimento de avaliar instituições jurídicas com base na economia já era aplicado a áreas do direito com tonalidades econômicas mais evidentes, como o direito antitruste. Era o que ocorria na Faculdade de Direito da Universidade de Chicago que, em decorrência da existência do projeto interdisciplinar de direito antitruste, passou a contar com economistas como integrantes de seu corpo docente.

O primeiro economista contratado pela Faculdade de Direito foi Henry Simons. Sua inserção é sugestiva da influência de Hayek e da Mont-Pèlerin Society (MPS, vide seção 3.3) dentro da Escola de Chicago $^{213}$, uma marca inicial de sua orientação pró-mercados. São várias as ligações: Simons (i) havia participado do encontro fundacional da MPS, apesar de não ter se tornado um membro; (ii) havia ajudado a publicar nos Estados Unidos, em 1944, uma edição do The road to serfdom, de Hayek, pela Universidade de Chicago; (Coase, 1993, p. 245; Teles, 2008, p. 91) e (iii) recebeu apoio financeiro do Volker Fund ${ }^{214}$, que impulsionou sua carreira na Faculdade de Direito da Universidade de Chicago, contribuindo para que saísse de uma "posição marginal" rumo ao "centro de gravidade" (van Horn; Mirowski, 2009, p. 143). Curiosamente, quando a MPS foi formalmente constituída como entidade sem fins lucrativos, sua sede foi "formalmente registrada como situada na Faculdade de Direito da Universidade de Chicago." (2009, p. 159) Para além de Simons, as conexões entre o que viria a ser a AED ao estilo de Chicago e o projeto da MPS (neoliberalismo) são fortalecidas pelo fato de que muitos dos expoentes da primeira foram também membros da segunda - e alguns, até mesmo seus presidentes (cf. Plehwe, 2009, p. 8) -, como Ronald Coase, Richard Posner, James Buchanan e Gary Becker.

\footnotetext{
${ }^{213}$ Coase avalia que Hayek não só desempenhou papel crucial na formação da Mont-Pèlerin Society mas também "nos eventos que conduziriam à formação do programa de Análise Econômica do Direito [Law and Economics] na Faculdade de Direito da Univrsidade de Chicago." (Coase, 1993, p. 246)

${ }^{214} \mathrm{O}$ Volker Fund era uma fundação presidida por Harold Lunhow, membro da MPS e "estridente conservador anti-New Deal". A fundação era voltada ao financiamento de projetos que promovessem o "repensamento da política liberal na América" (van Horn; Mirowski, 2009, p. 141). Entre as contribuições do Volker Fund estão o pagamento de passagens áreas para que acadêmicos norte-americanos atendessem aos encontros da MPS; o financiamento do tour de Hayek pelos Estados Unidos em 1946; o apoio financeiro a Henry Simons e a Aaron Director na Faculdade de Direito da Universidade de Chicago, concessão de bolsas de estudos, entre outros (cf. van Horn; Mirowski, 2009, p. 150-9; Teles, 2008, p. 93-5; Coase, 1993, p. 243).
} 
Hayek e Simons articularam, juntos, a contratação de Aaron Director pela Faculdade de Direito de Chicago, e obtiveram do Volker Fund o apoio financeiro para concretizá-la. O Volker Fund, nesse sentido, arcou com parte da remuneração de Director durante sua carreira em Chicago. Além de assumir o lugar de Simons nas aulas de direito antitruste, Director recebeu de Hayek a incumbência de conduzir projeto intitulado A free market study, "um estudo da moldura jurídica e institucional para um sistema competitivo efetivo" (Coase, 1993, p. 246; cf. van Horn, 2009). O estudo não chegou a ser concluído (van Horn, 2009, p. 213), mas Director deixou ao menos dois legados significativos para a trajetória da AED. O primeiro deles foi o envolvimento na criação do Journal of Law and Economics ${ }^{215}$ (Mercuro; Medema, 1997, p. 53). O segundo foi a persuasão de diversos estudantes de direito a respeito dos méritos do uso do instrumental econômico para analisar instituições jurídicas, como narra Ronald Coase:

\begin{abstract}
Inicialmente, Director lecionou o curso de Análise Econômica e Políticas Públicas, essencialmente um curso de teoria dos preços, mas depois ele foi convidado por Edward Levi para colaborar no curso de antitruste. Depois de uma tentativa de lecionarem conjuntamente, decidiram dividir as lições em quatro dias para Levi e um para Director. O que ocorreu foi descrito por alguns que fizeram o curso. Wesley Leiberler disse isso: "Por quatro dias a cada semana, Ed Levi abordaria o direito e utilizaria técnicas tradicionais do raciocínio jurídico para relacionar os casos uns com os outros, e criar uma síntese do tipo com que juristas estão acostumados para explicar e racionalizar os casos. Era um feito considerável. Por quatro dias, Ed faria isso, e por um dia a cada semana, Aaron Director nos diria que tudo o que Levi havia nos falado nos quatro dias precedentes era bobagem. Ele usava análise econômica para mostrar-nos que a análise jurídica simplesmente não se sustentava." [...] Dali em diante, a superioridade da análise econômica do direito, ao menos na área de antitruste, tornou-se firmemente estabelecida na Faculdade de Direito da Universidade de Chicago. (Coase, 1993, p. 247 - adicionou-se ênfase)
\end{abstract}

Outros importantes economistas contratados pela Faculdade de Direito foram o próprio Ronald Coase, em 1964, e Gary Becker, em 1968 (cf. Teles, 2008, p. 96-8). Coase assumiu a editoria do Journal of Law and Economics conjuntamente com Director. Como se viu, a importância fundamental de Coase residiu na expansão inovadora da análise econômica - para além do antitruste - a áreas do direito que até então não eram percebidas como tendo interdisciplinaridade evidente com a economia, tal como a responsabilidade civil. A importância de Gary Becker reside no aprofundamento desse projeto a áreas inexploradas, como a análise econômica da discriminação racial, das relações de família e do crime (Harris, 2003, p. 663; cf. Mercuro; Medema, 1997, p. 56).

$\mathrm{O}$ projeto de expansão da análise econômica às mais diversas áreas do direito consolidou-se com a publicação de The economic analysis of law, de Richard Posner, em

\footnotetext{
${ }^{215}$ Até a publicação do artigo de Coase em 1960, o Journal of Law and Economics havia focalizado questões de direito antitruste (cf. Posner, 1998, p. 1).
} 
1973, livro que atualmente se encontra em sua nona edição. Esta foi a "obra que, por assim dizer, 'codificou' esse estilo da análise jurídica, desenvolvido com a intenção de adotar pressupostos microeconômicos para o processo de determinação das 'formas' da jurisprudentia." (Castro, 2012, p. 207) “Ao passo que o trabalho de Director e Coase ajudou a estabelecer a análise econômica do direito (law and economics) como um campo respeitável, foi a ascensão de Richard Posner que a tornou um fenômeno acadêmico de primeira grandeza.” (Teles, 2008, p. 96; cf. Coase, 1993, p. 254)

Posner - contratado pela Faculdade de Direito de Chicago em 1969 (Teles, 2008, p. 98) - encarava a AED como fonte de "ferramentas analíticas muito mais afiadas para lidar com o direito do que o vocabulário jurídico padrão". A nova aplicação desse ferramental era orientada por certa inclinação político-econômica específica. Nas palavras de Posner, "nos anos 1970 eu era bastante conservador, então certamente parte do meu interesse na [AED] era um esforço de reformar o direito e tornar o direito antitruste mais econômico e menos político". O mesmo se pode dizer em relação às outras áreas do direito. Mais à frente, Posner complementa: "era, é claro, uma reação à regulação excessiva (overregulation)" (Posner apud Teles, 2008, p. 98). Certos aspectos do pensamento de Posner serão destacados adiante (subseção 4.1.3).

Mesmo as contribuições intelectuais mais visíveis da Escola de Chicago, tais como a de Posner, não respondem sozinhas pelo crescimento e influência da AED. Em The rise of the conservative legal movement, Stephen Teles (2008) vincula a ascensão da AED às suas convergências com o projeto político de grupos conservadores. Nos anos 1970, apesar de sua proeminência política, grupos conservadores (isto é, favoráveis ao livre mercado, autonomia privada e governo limitado, contra medidas de redistribuição de renda etc.), "sentiam-se como estrangeiros nas divisões de elite da academia jurídica" (2008, p. 278), bem como no judiciário e no meio advocatício. A orientação da AED para a eficiência econômica e os desdobramentos intelectuais do teorema de Coase resultavam na promoção de "soluções de mercado" para problemas de políticas públicas, o que tornava a AED

atraente para corporações que reconheciam que o crescimento da regulação federal
não era um mito. Quer o apelo fosse ao antitruste, que atingia em cheio os interesses
de grandes corporações, ou à nova "regulação social" do início dos anos 1970, a
regulação era inescapável, crescente, e conectada a uma estrutura poderosa de
suporte nas universidades. (Teles, 2008, p. 116)

Como decorrência dessas afinidades, o movimento da AED recebeu "suporte financeiro substancial de corporações e fundações, de uma maneira que nenhum outro movimento jurídico conservador o foi.” (Teles, 2008, p. 218) Uma dessas fundações de apoio 
à difusão de ideias pró-mercado já foi mencionada anteriormente: o Volker Fund (2008, p. 93). Outras relevantes fontes de recursos foram o Liberty Fund e a Olin Foundation.

O Liberty Fund apoiou o projeto de Henry Manne de expandir a "audiência para a produção acadêmica da análise econômica do direito tanto na academia quanto no judiciário." (Teles, 2008, p. 101) Da década de 1970 em diante, Manne iniciou a realização de cursos intensivos de introdução à microeconomia, inicialmente voltados a professores de direito (2008, p. 105). Num segundo momento, o curso contou com uma versão dirigida a magistrados do judiciário federal norte-americano. "Os atrativos do programa, especialmente antes de ter obtido uma reputação entre juízes federais, eram seu preço (gratuito), acomodações de luxo [...] e instrutores de alta qualidade, como Milton Friedman, Paul Samuelson [etc.]" (2008, p. 112) Nos anos 1990, os cursos de Manne haviam coberto 40\% dos juízes federais e $67 \%$ dos membros de cortes federais de apelação nos Estados Unidos (2008, p. 113). O Liberty Fund também apoiou projetos de Manne para realização de conferências e a criação de institutos de AED em pontos variados dos Estados Unidos, bem como a concessão de bolsas a economistas que buscassem titulação adicional em direito (2008, p. 109).

\begin{abstract}
Os institutos de Manne para professores de direito equiparam um número considerável de acadêmicos jurídicos com as técnicas necessárias para aplicar a análise econômica do direito ao campo, e aumentaram a receptividade da profissão aos insights desses acadêmicos. Ao mesmo tempo, os programas de Manne para juízes federais garantiram que muitos membros da associação federal de advogados e juízes [members of the federal bar] pudessem entender os conceitos que esses professores estavam desenvolvendo, o que significava que as cortes não teriam que esperar por uma geração completamente nova de juizes para absorver essas novas teorias. (Teles, 2008, p. 133)
\end{abstract}

Por sua vez, a Olin Foundation orientou seus investimentos ao posicionamento estratégico da AED em escolas jurídicas de elite nos Estados Unidos e, em certos casos como o da Universidade de Toronto - também no exterior, com base na noção de que o restante da academia pautaria sua produção pelo que ocorre nas grandes faculdades, inclusive em termos de configuração do currículo acadêmico (cf. Teles, 2008, p. 202). Dessa forma, dirigiu seus investimentos para a realização de conferências, concessão de bolsas e apoio a projetos de pesquisa em instituições como Harvard, Yale, Chicago, Stanford, Columbia e outras (2008, p. 200-3). “Ao apoiar a análise econômica do direito, a fundação esperava estabelecer uma 'posição firme' (foothold) para conservadores em escolas de direito, e 
fornecer um 'contrapeso' contra os liberais." ${ }^{216}$ (Teles, 2008, p. 206) O ocorrido em Harvard exemplifica essa orientação estratégica de apoio a AED como parte de um projeto de

redirecionamento ideológico da escola de direito e derrota de sua faç̧ão mais dinâmica, o critical legal studies (CLS). [...] Na mente desses conservadores, a análise econômica do direito era o único movimento capaz de prover uma alternativa intelectualmente respeitável, e a fundação aplicou milhões de dólares em seu apoio. (Teles, 2008, p. 191)

Os elementos levantados ao longo desta subseção permitem perceber que a AED ao estilo de Chicago tem com a sensibilidade econômica do neoliberalismo não só afinidades intelectuais, como também conexões práticas. Algumas conexões são de ordem organizacional ou mesmo pessoal, como contatos e sobreposições entre partidários da Escola de Chicago e o espaço intelectual transnacional da MPS, encabeçada por Hayek. Outras conexões são de ordem financeira. O Volker Fund é um elo entre a MPS e Chicago. Outras fundações de orientação conservadora, como o Liberty Fund e a Olin Foundation, operaram "em sinergia" com esse projeto.

Por mais que esses elementos "práticos" revelem a força das conexões, as sobreposições intelectuais não devem ser desprezadas. Tanto a AED como os economistas alinhados ao paradigma neoliberal compartilham o viés pró-mercados e a aversão à intervenção estatal e em particular às medidas de redistribuição de renda. Além disso, ambos privilegiam o uso da microeconomia neoclássica como método de análise. Como resultado, não é surpreendente que as recomendações feitas pelos dois grupos sejam convergentes, dado que as ferramentas analíticas de base e suas orientações políticas são essencialmente as mesmas. Uma diferença, porém, reside no fato de que, na década de 1970, os economistas ainda encaravam "instituições" como pressupostos de sua análise, ao passo que a AED já as havia "internalizado", considerando os formatos assumidos pelas instituições jurídicas como relevantes para a eficiência econômica e, portanto, para o crescimento econômico.

\subsubsection{Principais características e teses da AED ao estilo de Chicago}

As formulações da AED encontram-se permeadas pelo raciocínio de que instituições jurídicas guardam relação com o desempenho econômico. Nesse sentido, modulações nas normas e procedimentos jurídicos afetam a estrutura de incentivos dos indivíduos,

\footnotetext{
${ }^{216}$ O sentido da expressão "liberais", aqui, deve ser entendido no contexto da política dos Estados Unidos, ou seja, como referência à inclinação política que favorece maior presença do Estado na economia, maior preocupação com welfare social e medidas redistributivas etc.
} 
ocasionando mudanças de comportamento e, em última análise, trazendo impactos para as atividades econômicas (Mercuro; Medema, 1997, p. 22).

Valendo-se dessa lógica, praticantes da AED conseguem identificar "uma 'estrutura profunda' do direito que exibe considerável coerência” (Posner, 1998, p. 5-6). Essa coerência é dada por um elemento de ligação específico, capaz de conectar normas nos mais diferentes campos do direito. Trata-se do emprego da teoria dos preços, derivada da microeconomia neoclássica. A AED analisa instituições jurídicas em função das sinalizações de preços que emitem, e que se refletem no comportamento dos indivíduos. Na base desse uso encontram-se os pressupostos de que "o homem é um maximizador racional ${ }^{217}$ de utilidade em todas as áreas da vida, não só em assuntos "econômicos"” e de que "as pessoas respondem a incentivos" (Posner, 2003, p. 4). Em outros termos, diferentes áreas do direito tornam-se intercambiáveis sob o olhar da AED em razão de sua adoção dos seguintes pressupostos ${ }^{218}$ :

(1) os indivíduos são maximizadores racionais de suas satisfações em seu comportamento fora e dentro dos mercados; (2) os indivíduos respondem aos incentivos de preços em seu comportamento fora e dentro dos mercados; e (3) regras jurídicas e resultados jurídicos podem ser avaliados com base em suas propriedades de eficiência, junto com a qual vem a prescrição normativa de que as decisões jurídicas devam promover a eficiência. (Mercuro; Medema, 1997, p. 57)

Apesar de partir do indivíduo como unidade de análise, a AED, ao menos na tradição de Posner, não se ocupa de estudar o comportamento empírico dos indivíduos, ou seja, ele é "presumido ao invés de estudado."219(Harris, 2003, p. 665) Os "preços", outro elemento central para a análise proposta nessa tradição (afinal, são as sinalizações de preços que representam incentivos ao comportamento individual), são também frequentemente supostos ao invés de empiricamente aferidos. É comum, nesse sentido, encontrar, nas publicações que aplicam a AED, preços hipoteticamente "lançados", a partir dos quais argumentos são ilustrados. O emprego de suposições aritméticas é um procedimento de que Ronald Coase se valeu bastante, não sendo surpreendente que Posner, assim como os praticantes da AED ao estilo de Chicago em geral, tenham acompanhado essa tradição de emprego de modelos abstratos para versar a análise sobre instituições jurídicas.

\footnotetext{
217 "Racionalidade significa [...] a disposição de escolher, consciente ou inconscientemente, um meio apto a atingir quaisquer objetivos que o formulador da escolha tenha em vista. [...] Ela não pressupõe consciência, e certamente não pressupõe onisciência.” (Posner, 2003, p. 17)

${ }^{218}$ Numa descrição alternativa, mas convergente, Ejan Mackaay desmembra esses mesmos pressupostos em quatro premissas fundamentais: (i) individualismo metodológico; (ii) escolha racional; (iii) preferências estáveis e (iv) o emprego da noção de equilíbrio de mercado (Mackaay, 2000, p. 408-9).

219 Evidentemente, há exceções, como a "análise econômica do crime" realizada por Shikida e Amaral (2012), cuja conclusão, no sentido de que "os criminosos migraram para as atividades ilegais na esperança de que os ganhos esperados superassem os riscos da atividade" (2012, p. 316), é escorada em dados levantados por meio de questionários aplicados a mais de 500 indivíduos encarcerados no Paraná entre 2000 e 2009.
} 
Exemplos de aplicação da AED

Valendo-se da teoria dos preços, a AED consegue unir as diferentes áreas do direito sob uma só racionalidade econômica, abrangendo mesmo áreas que comumente não eram associadas ao sentido comum dos negócios. Esse é o caso do direito penal, que, "apesar de geralmente considerado o domínio par excellence da moral ao invés do pensamento econômico em direito, tem uma lógica econômica impressionante.” (Posner, 1985, p. 1230) As sanções penais são encaradas como "custos" para os autores de crimes e contravenções, vistos como indivíduos que procedem a análises de custo-benefício realizando ponderação entre, de um lado, a utilidade a obter com o crime em caso de sucesso e, de outro, as chances de detecção e punição, a severidade das penas aplicáveis, e os custos para condução do ilícito (que podem ir desde os custos associados à obtenção de uma arma até os custos de oportunidade envolvidos no tempo investido na prática criminosa, e que poderia ser empregado em outra atividade lícita ou ilícita).

Esse tipo de visão produz concepções do criminoso “como um 'empresário’ [...], um agente que irá organizar a sua produção, reunindo os fatores de produção disponíveis, assumindo os riscos inerentes à atividade criminal" (Shikida; Amaral, 2012, p. 297); e permite a afirmação do "setor criminal como o empregador, de fato, de última instância" (Posner, 2003, p. 476). Produz, também, consequências em termos de política criminal, balizadas pela ideia de um nível ótimo de crime.

Este é identificado como o ponto de equilíbrio que minimiza as perdas sociais decorrentes de atividades criminosas. As "perdas sociais" existem não só em função dos danos provocados pelo crime, como também dos custos de detecção, apreensão, condenação e execução das penas (Becker, 1974, p. 43). Decorre dessa ideia a noção de que investimentos adicionais na repressão do crime, mas que superem em custos o valor dos danos causados pela atividade criminosa, serão ineficientes. Portanto, "as políticas ótimas de combate ao comportamento ilícito são parte da alocação ótima de recursos.” (Becker, 1974, p. 45)

A mesma lógica fundamental de modulação das sinalizações de preços em busca da eficiência econômica - maximização de riqueza ou "alocação ótima de recursos" - pode ser encontrada em análises que abrangem outras áreas do direito.

Numa “análise econômica dos contratos", por exemplo, Timm e Guarisse (2012) caracterizam como eficientes os contratos cujo excedente econômico - correspondente ao aumento na riqueza total da sociedade - é maior do que zero (2012, p. 161). A partir dessa base, os autores avaliam instituições do direito contratual. Encontram uma racionalidade 
econômica para o "princípio da autonomia da vontade": "já que os contratos criarão riqueza, atingindo situações de ótimo de Pareto, o direito contratual deve deixar as partes livres para buscarem o que é melhor para si." O mesmo ocorre com o "princípio da liberdade de forma", que "serve à diminuição dos custos de transação." (2102, p. 172) Quando o assunto é a sobreposição judicial à vontade das partes, a condução de políticas resdistributivas via direito privado é desaconselhada, em razão dos chamados efeitos de segunda ordem: "a alteração judicial de juros em contratos bancários com consumidores pode ter, por efeito, a diminuição da oferta desse tipo de contrato, gerando, provavelmente, uma situação socialmente ineficiente. ${ }^{220}(2012$, p. 174) No fundo, todas estas recomendações estão alinhadas à aplicação do teorema de Coase ao direito dos contratos:

\begin{abstract}
É fácil ver por que a regra, no direito contratual, é pela não intervenção na liberdade das partes. De acordo com o Teorema de Coase, o acordo das partes tende, de fato, a soluções socialmente eficientes. Assim, a intervenção estatal somente fará sentido quando ela levar a soluções melhores e mais eficientes do que o acordo das partes sozinho conseguiria atingir. (Timm; Guarisse, 2012, p. 174)
\end{abstract}

Outro estudo, que realiza uma "análise econômica da propriedade" (Vera, 2012), contém o mesmo sentido contrário à intervenção estatal com intenções redistributivas. Segundo a autora,

qualquer área do direito privado, incluindo a de propriedade e contratos, não é reconhecida como ferramenta eficiente para políticas redistributivas por frequentemente acarretar quatro grupos de falhas indesejáveis: (1) riscos de alvos imprecisos (atingir pessoas ou instituições erradas); (2) efeitos imprevisíveis (o resultado não corresponde ao objetivo inicial); (3) altos custos de transação; e (4) distorções nos incentivos. (Vera, 2012, p. 211)

A existência de definição clara e proteção forte da propriedade é fundamental para "lubrificar transações e diminuir custos de transação", porque os "indivíduos que compõem os mercados precisam de segurança para operar bem, para transacionar.” (2012, p. 208-9) Intervenções estatais na propriedade privada são encaradas como economicamente perversas, mesmo que precedidas de compensação: “[q]ualquer que seja a forma de indenização ou justificativa para a desapropriação, a intervenção do Estado na propriedade sempre acarretará distorções no mercado.” (2012, p. 211) Por sua vez, a noção de efeitos de segunda ordem é evocada contra os usos da "função social da propriedade":

\footnotetext{
${ }^{220}$ Outro exemplo de efeitos adversos de segunda ordem a partir da interferência estatal na vontade das partes é fornecido pelos autores: "Em muitos casos as intervenções do legislador parecem favorecer um certo grupo, mas uma análise mais profunda mostra que esse alegado benefício traz consigo um custo. Um exemplo é a aplicação, na Alemanha, da Diretiva europeia que [...] determina a responsabilidade do vendedor por defeitos em carros usados pelo período de um ano após a compra. Isso resultou num aumento sensível no preço de carros usados na Alemanha, visto que os vendedores de carro agora precisariam contratar seguros para se proteger de eventuais demandas." (Timm; Guarisse, 2012, p. 177-8)
} 
Quando um magistrado num processo de despejo resolve proteger o idoso que não paga há algum tempo o aluguel (parte pretensamente mais fraca) em detrimento dos proprietários (parte pretensamente mais forte), mesmo com a boa intenção de fazer justiça social, ele sinaliza para todos os outros proprietários de imóveis para não alugarem para idosos. Ele acaba prejudicando os idosos. O mercado é implacável e responde a intervenções como esta em detrimento do grupo que justamente o magistrado pretendia proteger. (Vera, 2012, p. 218)

A propriedade privada chega a ser apresentada como solução para problemas ambientais, como o desmatamento na Amazônia. "Transformar as terras comunais ou públicas em propriedades privadas, cuja responsabilização é internalizada e cada dono protege e cuida do que é seu, poderia resolver o problema em certos casos.” (Vera, 2012, p. 221-2)

No campo da responsabilidade civil, a AED não parte do critério preponderante de atribuir o dever de reparação ao indivíduo culpado por um dano. Deve pautar as regras de responsabilização, ao invés, a promoção de incentivos para comportamentos que conduzam a resultados eficientes, ou seja, que levem ao "nível ótimo de precaução":

em determinadas circunstâncias, adotar mais precaução pode não ser eficiente.
Medidas de prevenção excessivamente custosas que não reduzam significativamente
as chances de ocorrência de danos tendem a ser ineficientes. Da mesma forma que
deixar de adotar medidas razoáveis de precaução pode levar a resultados
indesejáveis, a adoção de medidas excessivamente onerosas e injustificadas gera
perdas sociais. (Porto, 2012, p. 181)

As análises da responsabilidade civil produzem, como resultado, a afirmação de que a responsabilização por danos deva incidir sobre o cheapest cost avoider, aquele capaz de reduzir as externalidades negativas ao menor custo. Essa atribuição depende de uma análise dos custos envolvidos em cada situação hipotética, não havendo "regra de responsabilidade civil que atinja o resultado ótimo em todos os casos." (Porto, 2012, p. 199) Vale lembrar que, em termos de implicações para políticas públicas, a AED sugere que modulações na responsabilidade civil são preferíveis a medidas "pigouvianas" para lidar com externalidades, como subsídios e tributação, em linha com o raciocínio de Coase (1960). Trata-se, mais uma vez, de preferências por soluções que incorporem mecanismos de mercado ao invés de transações não voluntárias, que guardam relação com a identificação da iniciativa privada como fator de dinamismo econômico a ser protegido da interferência estatal, percebida como indutora de ineficiências.

O mesmo viés é percebido quando a AED se projeta sobre áreas do direito público, como processo, tributação e (apesar de sua classificação controvertida) trabalho.

A abordagem da AED tende a enxergar o judiciário como protetor da inviolabilidade da esfera privada frente às tentativas de incursão do Estado. A segurança da propriedade e dos contratos é percebida como fundamental para preservar os incentivos individuais para 
engajamento em transações de mercados, conduzindo ao crescimento econômico. Esta segurança encontra-se vinculada ao comportamento judicial, uma vez que ausência de previsibilidade e constância - bem como de celeridade - nas decisões é fator de aumento dos custos de transação. Para além de reformas que induzam comportamentos judiciais alinhados com as preocupações acima, a AED privilegia formatos privatizados de processo e solução de controvérsias, como a arbitragem, que deve existir como alternativa ao judiciário por duas principais razões:

Em primeiro lugar, a arbitragem poderá reduzir os custos de transação diretamente relacionados à resolução de disputas. Em segundo lugar, a arbitragem pode favorecer o estabelecimento de um sistema de incentivos mais adequado para o cumprimento de contratos, maximizando os ganhos na relação contratual entre as partes. (Salama, 2012, p. 383)

Um ponto interessante na argumentação pró-arbitragem é a lógica de competição de mercado introduzida em dois níveis: intramodelo e intermodelos. No primeiro aspecto, há incentivos para que a arbitragem forneça bons resultados porque "árbitros e câmaras competem entre si pelos serviços de resolução de controvérsias". O segundo aspecto é o mais curioso, porque a existência da arbitragem promove uma competição que "opõe, de um lado, o modelo público (cortes estatais) e, de outro, o modelo privado (árbitros e câmaras arbitrais)." (Salama, 2012, p. 387) A existência desses dois níveis de competição faz com que as organizações envolvidas nestes modelos estejam sujeitas às leis da oferta e da procura:

A hipótese básica que trago aqui é a de que a dinâmica da relação de oferta e procura
pelos serviços de resolução de disputas tenha contornos semelhantes àqueles da
oferta e procura por produtos e serviços nos mercados. A teoria microeconômica
sugere que, nos mercados, a competição geralmente induz à redução dos preços. Da
mesma forma, argumentarei que a competição entre o modelo estatal e o modelo
privado pode reduzir os custos de transação na prestação do serviço de resolução de
disputas. (Salama, 2012, p. 388)

A competição interinstitucional afeta, por sua vez, o comportamento dos indivíduos pela mesma lógica de oferta e demanda. Como o comportamento individual é, para a AED, a unidade básica para compreender a operação da economia, as sinalizações emitidas pela existência da arbitragem aos indivíduos podem afetar o nível da atividade econômica:

nos casos em que o indivíduo não possui incentivos para utilizar a arbitragem na solução de controvérsias, sua escolha pela jurisdição estatal dependerá da eficiência das instituições judiciais. A ineficiência das cortes estatais será um incentivo para que o indivíduo resolva suas disputas alterando seus padrões negociais, de forma a evitar ou tornar desnecessária a disputa judicial. Potencialmente, esse processo envolve, inclusive, a redução da atividade econômica como um todo [para evitar os custos de solução de disputas]. (Salama, 2012, p. 388) 
A “análise econômica da tributação" (Carvalho, 2012) parte dos incentivos que os tributos sinalizam para o comportamento humano, capazes de "alterar escolhas e ações dos cidadãos.” (2012, p. 246) Assim como em outras análises, a tributação é aproximada desde uma preocupação centrada na autonomia individual, na esfera privada. Apesar de reconhecer a necessidade da tributação para o funcionamento da máquina estatal, que em última medida fornece "bens públicos" essenciais ao funcionamento dos mercados - tais como proteção dos contratos e da propriedade, além de provimento de segurança e solução de controvérsias -, o foco recai na tendência da tributação de induzir ineficiências econômicas (2012, p. 259-60). "Não se pode esquecer que os recursos sempre são mais bem geridos pela esfera privada." (2012, p. 60) Sendo este o viés de fundo, não causa surpresa a afirmação de que, “[q]uando o Estado institui algum tributo incidente sobre as trocas econômicas, o sistema de preços do mercado sofre ruído, causando desequilíbrio na oferta e demanda.” (2012, p. 259) Esta noção é capturada pela categoria de "peso morto" gerado pela tributação: "é quase um axioma na Economia Neoclássica que a tributação frequentemente causa distorção no sistema de preços do mercado e também gera custo social negativo.” (2012, p. 258) Para conciliar sua necessidade com os efeitos nocivos sobre a iniciativa privada, a análise se vale da noção de "ponto ótimo" da tributação: “[o] que se deseja, do ponto de vista de eficiência econômica, é a limitação da tributação em um ponto que não seja inviabilizador da atividade privada, única geradora de riqueza para a sociedade.” (2012, p. 260)

Um último exemplo de estudos brasileiros instruídos pela AED no estilo de Chicago pode ser encontrado na "análise econômica do direito do trabalho" (Yeung, 2012). Parece certo que, para os proponentes da AED, o direito do trabalho devesse ser encarado como ramo do direito privado, e não do direito público. Caso assim fosse, este ramo estaria sujeito a maior margem de liberdade para a definição privada dos conteúdos contratuais, e seria menos vinculado a conteúdos não livremente negociáveis e derivados de políticas públicas, como o adicional remuneratório de um terço durante as férias, o Fundo de Garantia por Tempo de Serviço (FGTS), o décimo-terceiro salário, entre outros ${ }^{221}$. A análise econômica do direito do

\footnotetext{
${ }^{221} \mathrm{Na}$ concepção de Yeung, trata-se de três instituições indutoras de ineficiências econômicas. A análise não admite espaço para implicações redistributivas das normas de direito do trabalho. Assim, o terço de férias, "aos olhos dos estrangeiros, constitui uma das mais peculiares regras da legislação trabalhista brasileira: o direito a um salário mais um terço durante o período de férias, quando o trabalhador não está ativo." (2012, p. 328) Quanto ao FGTS, "nada mais é do que uma poupança forçada para usos específicos e sua existência é mais uma evidência de que o Estado brasileiro olha para seus cidadãos (no caso, os trabalhadores) como seres irracionais, incapazes de tomar decisões adequadas para si próprios, que precisam que a lei os proteja e diga a eles quando e quanto poupar e quando gastar.” (2012, p. 329) Por sua vez, a existência conjunta destas duas instituições, somada ao décimo-terceiro, produz a seguinte análise: "pode-se acreditar que sejam parte da explicação dos baixos índices de poupança doméstica no país. Ora, em qualquer lugar, em qualquer momento da história, festas de fim de ano, férias, aposentadoria e aquisição da casa própria são as principais razões para que os
} 
trabalho também parte do teorema de Coase, e sugere a existência de "algumas situações nas relações trabalhistas onde os custos de transação podem ser menores. Nestes casos, uma intervenção legal não somente é desnecessária como é inútil, dado que o resultado será determinado pelas partes que negociam entre si." (Yeung, 2012, p. 321) Sendo, porém, que "a lei continua excessivamente regulada e excessivamente detalhada" (2012, p. 318); cria "um peso financeiro excessivo aos empregadores", fomenta "um ambiente propício ao litígio judicial no local do trabalho" (2012, p. 320), e induz "desincentivos para a criação de empregos" (2012, p. 322) entre outros fatores, a conclusão sugere que "o Direito do Trabalho brasileiro não é uma instituição de boa qualidade", o que decorre do juízo de que "as leis trabalhistas não são eficientes." (2012, p. 330) Ao invés disso, o direito do trabalho deveria, segundo essa visão, "criar um ambiente mais propício à barganha cooperativa" (2012, p. 321), e "seguir uma regra de correção de ineficiências, ou seja, de redução das perdas da sociedade como um todo." (2012, p. 322)

A partir desses exemplos de aplicação da AED, nota-se forte viés pró-mercado, no sentido de que as instituições jurídicas devam ser formuladas segundo o objetivo de fomentar a ocorrência de livres transações. Elementos recorrentes nessas análises são a aplicação da teoria dos preços, do teorema de Coase, e o emprego de ponderações do tipo "custobenefício", que geralmente conduzem à afirmação da existência de um "ponto ótimo" além do qual o comportamento estatal não deve passar. Além destes, desponta a preocupação marcada com o aspecto da eficiência econômica, ao mesmo tempo em que considerações redistributivas são marginalizadas ou explicitamente rechaçadas como indutoras de ineficiências.

\subsubsection{Propostas e teses da AED e suas convergências com o paradigma "rule of law"}

Como anteriormente apontado, o paradigma rule of law embalou intervenções de reforma institucional por instituições financeiras multilaterais e outras organizações internacionais, a partir da década de 1990. Certamente, o referencial que mais próxima e diretamente contribuiu para a consolidação desse paradigma foi a Nova Economia Institucional (NEI), cujos expoentes são Douglass North e Oliver Williamson. No entanto, a NEI e a AED guardam convergências notáveis em suas elaborações intelectuais (pontos de

trabalhadores poupem parte de suas rendas regulares." (2012, p. 329) Como se pode perceber, a análise deixa de lado o aspecto de que, como grande parte dos trabalhadores tem baixa renda, a maior parte de sua remuneração tende a ser destinada às necessidades imediatas de consumo. $\mathrm{Na}$ ausência de tais "mecanismos de poupança forçada", é duvidoso que o planejamento individual, dado este quadro, poderia supri-los. 
partida e de chegada), vinculações históricas, pessoais e organizacionais. Essas convergências permitem afirmar que as contribuições da AED foram instrumentais mediatos para a conformação do paradigma rule of law ${ }^{222}$. Nesse sentido, a AED promove uma agenda de reformas que a NEI, subsequentemente, contribuiu - como também o fez o Law \& Finance para projetar internacionalmente (cf. Castro, 2011, p. 8). Uma diferença essencial parece ser, no entanto, a de que a NEI incorpora um componente comparativo de instituições entre países, aspecto que não tem centralidade nas elaborações da AED.

Embora relações pessoais e sobreposições organizacionais devam ser abordadas com cuidado, sua utilidade não pode ser descartada na avaliação de convergências entre movimentações intelectuais. Nesse sentido, de plano, é valido lembrar que a Heritage Foundation - think tank conservador fundado em 1973 - tinha como membros Ronald Coase e Douglass North, além de outros pensadores de inclinação neoliberal, como Milton Friedman e Friedrich Hayek (vide seção 3.3). Além disso, já no mérito “intelectual” dessa convergência, deve-se levar em conta o fato de que a NEI desenvolve suas formulações com base no teorema de Coase, que também ocupa - como observado anteriormente - posição nuclear para os estudos instruídos pela AED (cf. Williamson, 2015). A NEI chega a ser encarada, por Ronaldo Fiani, como

uma versão do assim chamado "Teorema de Coase", como instrumento de análise do desenvolvimento econômico: se os direitos de propriedade forem bem definidos e garantidos, não haverá externalidades, os investimentos terão o nível adequado e o desenvolvimento acontecerá. (Fiani, 2011, p. 175)

Em virtude disso, é comum encontrar abordagens acadêmicas que consideram a NEI como "refinamento" da teoria básica da AED (Newton, 2006, p. 192) ou como abordagem integrada à sua moldura (Mercuro; Medema, 1997), e que ressaltam convergências entre as duas vertentes a partir de semelhanças de visão de autores como Coase, Posner e Williamson (Nicita; Pagano, 2008, p. 417).

$\mathrm{O}$ que a NEI faz é vincular mais explicitamente o problema do desenvolvimento à existência de ambientes institucionais adequados, o que passa por instituições jurídicas e políticas. Nesse sentido, diversas afirmações de Douglass North, após o conhecimento dos contornos da AED, não se mostram propriamente "novas". Assim, North afirma que as instituições interferem nos incentivos para o comportamento individual e são capazes de

222 O paradigma rule of law conforma o "segundo momento" dos estudos de direito e desenvolvimento, na perspectiva de autores inseridos no NDD (vide seção 4.3). Um desses autores é Diogo Coutinho, que considera, a respeito desse segundo momento e sua agenda de reformas: "Argumentos derivados da análise econômica do direito (law and economics), tanto em seu viés descritivo-empírico quanto em sua versão normativa, que sugerem que o direito deve mimetizar mercados desempenhando a função de maximizar a riqueza social agregada [...], tornam-se cada vez mais comuns." (Coutinho, 2013, p. 88) 
induzir a economia a crescer, estagnar ou mesmo contrair (North, 1991, p. 97). A chave para saber o resultado remete a Coase: custos de transação baixos representam estímulos à troca, à especialização e à produtividade do trabalho (1991, p. 33), ao passo que altos custos de transação tendem a provocar recessões econômicas. Assim, o objetivo do desenvolvimento, em North, passa por reformas institucionais destinadas à redução dos custos de transação.

Como o teorema de Coase está na base tanto da AED como da NEI, não surpreende que as recomendações de reforma para redução dos custos de transação passem pelos mesmos tópicos. Para North, como para os praticantes da AED ao estilo de Chicago, a definição imprecisa e a proteção fraca da propriedade privada e dos contratos, bem como a existência de um judiciário que não forneça constância e previsibilidade, são fatores indutores de altos custos de transação. O mesmo traço está presente em Williamson, que faz referência à sua abordagem como "economia dos custos de transação":

A economia dos custos de transação sustenta que as instituições microeconômicas
desempenham um papel crucial, sutil e relativamente negligenciado na explicação de
performances econômicas diferenciadas - ao longo do tempo, dentro e entre
indústrias, dentro e entre Estados e sistemas sociopolíticos (Williamson, 1985, p.
408).

O papel do Estado, em ambas, é o de prover o ambiente institucional propício às transações privadas. Ambas posicionam-se contrariamente à interferência estatal no domínio econômico, para além do necessário a assegurar o próprio funcionamento adequado dos mercados. Tanto a AED quanto a NEI podem ser enquadradas naquilo que Ronaldo Fiani (2011) descreve como "abordagem dos ambientes institucionais", segundo a qual, dado o ambiente institucional "correto", custos de transação serão reduzidos, o mercado funcionará de maneira "ótima", e se encarregará de operar o desenvolvimento.

No fundo, o referencial de "rule of law", assim instruído pelas contribuições convergentes da AED e da NEI, contém a receita do que Rodrik qualificou como "markets as a magic bullet". Afinal, deposita-se a crença de que, uma vez que as instituições jurídicas (e políticas) sejam reformadas para reduzir custos de transação, a livre operação dos mercados ocasionará o desenvolvimento, entendido prioritariamente, nesse paradigma, como crescimento econômico.

A aplicação desse paradigma instruiu reformas apoiadas pelo Banco Mundial em países em desenvolvimento. Assim, "países como o Brasil e Argentina inauguraram, na década de 1990, um audacioso programa de reformas econômicas, orientadas para a promoção do ambiente de mercado, semelhante ao que já havia sido realizado no Chile." (Schapiro, 2010, p. 222) No caso do Brasil, diversas reformas mostram-se convergentes com 
o receituário da AED, como: (i) emendas constitucionais que alteraram a presença do Estado na economia (ECs 5, 8, 9 e 19); (ii) "novos marcos reguladores em setores privatizados" (como a Lei de Concessões, de Telecomunicações, do Petróleo e da Energia Elétrica); (iii) programas de desestatização/privatização de empresas públicas; (iv) "alterações legislativas dedicadas a amparar o elenco da proteção jurídica a investidores e credores", como a Lei de Falências, a Lei das S.A (2012, p. 222) e, pode-se acrescentar, a Lei de Arbitragem; e (v) a introdução de mercados autorregulados na Bovespa ${ }^{223}$ (2012, p. 222).

A compreensão de certas propostas, teses e contornos da AED, sobretudo a partir de Posner, contribuirá para explicitar outros pontos de convergência com a NEI e que foram incorporados no paradigma rule of law. Quatro aspectos serão ressaltados com esse fim: (i) o lugar da eficiência em relação ao direito (item 4.1.4.1); (ii) a tese da eficiência do common law (4.1.4.2); (iii) o emprego da "hipótese dos mercados eficientes" (4.1.4.3) e (iv) a marginalização ou exclusão de propósitos redistributivos para políticas públicas (4.1.4.4).

\subsubsection{O lugar da eficiência em relação às instituições jurídicas}

Uma das propostas mais significativas da AED é a de que as instituições jurídicas devam ser configuradas de modo a favorecer a eficiência econômica. Para Posner, eficiência significa maximização de riqueza, ou "aquela alocação de recursos em que o valor é maximizado" (Posner, 2003, p. 11).

Essa proposta incorpora a tese de que as normas jurídicas conduzem à eficiência econômica quando induzem trocas voluntárias, desimpedidas, porque estas levam ao uso mais apreciado dos recursos econômicos escassos: "[q]uando os recursos estão sendo empregados onde seu valor é maior, ou de modo equivalente, quando nenhuma realocação aumentaria seu valor, dizemos que estão sendo empregados eficientemente.” (Posner, 2003, p. 10) Pode-se perceber que a noção de eficiência está ligada à alocação "ótima” de recursos, na qual nenhuma realocação superior é possível.

Por trás dessa noção há a discussão dos critérios de eficiência de Pareto e de KaldorHicks. Pelo critério de Pareto, uma situação ou equilíbrio ${ }^{224}$ é eficiente quando não for

\footnotetext{
${ }^{223}$ A esse respeito, Marcus Faro de Castro afirma que "a defesa da adoção da AED responde ao interesse em alinhar o direito brasileiro com uma agenda de reformas de políticas públicas semelhante à que esteve associada a objetivos de grupos conservadores (contrários ao ativismo estatal, programas de redistribuição de renda etc.) nos Estados Unidos, especialmente a partir do governo de Richard Nixon, na década de 1970.” (Castro, 2011, p. 8)

224 “'Equilíbrio’ significa o ponto estável, ou seja, o ponto em que, a não ser que as condições de demanda ou oferta mudem, não há incentivo para que os vendedores alterem preços ou quantidades produzidas." (Posner,
} 
possível promover uma realocação de recursos sem prejudicar ao menos um indivíduo. Ou seja, qualquer melhoria para uns implicaria perda para outros. Dessa forma, ainda que a mudança econômica aumentasse o bem-estar total da sociedade, ela não seria considerada eficiente caso representasse perda para um indivíduo. Trata-se de concepção essencialmente protetora do status quo. Posner considera que o critério de superioridade de Pareto tem pouca aplicabilidade no mundo real, porque a maior parte das transações têm efeitos sobre terceiros (2003, p. 13).

O critério de eficiência de Kaldor-Hicks contorna o problema da exigência de que ninguém fique em situação pior a partir de certa mudança de equilíbrio. É um conceito "menos austero de eficiência", segundo o qual a eficiência econômica ainda existe quando a realocação de recursos promove o aumento de riqueza e os "ganhadores podem compensar os perdedores, quer o façam mesmo ou não." (Posner, 2003, p. 13) Em outros termos, as normas jurídicas devem criar uma estrutura de incentivos que favoreçam a maximização de riqueza. Ainda que alguns grupos sejam adversamente afetados, uma tal estrutura permanece validável pela comparação dos custos ou perdas sofridas por esses grupos com os benefícios ou ganhos obtidos por outros, ou seja, por uma análise de custo-benefício ${ }^{225}$.

A AED privilegia, como já foi possível observar, a noção de que a eficiência (como maximização de riqueza) é melhor promovida pela esfera privada, não pela iniciativa pública. Nesse sentido, o emprego desta noção é a chave para "desmontar" instituições jurídicas que confiram ao Estado papéis ativos no cenário econômico, quer no formato de sua participação como "empresário" (em setores como energia, recursos naturais, transportes, comunicações etc.), quer segundo propósitos redistributivos (ponto abordado adiante). O Estado é encarado como provedor do ambiente institucional que favoreça baixos custos de transação, e sua atuação, quando necessária (como ocorre com a tributação), não deve ultrapassar pontos “ótimos" de equilíbrio.

Posner trabalhou a eficiência como critério ético para "distinguir regras justas de injustas" (cf. Salama, 2008, p. 28), o que equivale a dizer que a equiparou - ao menos em uma primeira fase, que Bruno Salama (2008) apelida de "fundacional" - à própria justiça. Este traço remete à citação empregada na abertura desta seção, de David Director Friedman, que

2003, p. 8) Ivo Gico Jr. relaciona a noção de equilíbrio à autonomia da vontade e à eficiência: "Equilíbrio é um conceito técnico utilizado para explicar qual será o resultado provável de uma alteração na estrutura de incentivos dos agentes. [...] Como o equilíbrio decorre da livre interação dos agentes até que todas as possibilidades de trocas benéficas se esgotem, diz-se que um mercado em equilíbrio tem uma propriedade socialmente valiosa: o seu resultado eliminou todos os desperdícios, ou seja, é eficiente.” (Gico Jr., 2012, p. 21)

${ }^{225}$ A esse respeito, Marcus Faro de Castro observa que "a AED, ao proceder por meio da chamada 'análise de custo-benefício', não leva em conta as relações entre interesses materiais e valores não econômicos, que são relevantes para a promoção da justiça econômica.” (Castro, 2009, p. 21) 
afirmava o propósito de ignorar, deliberadamente, questões de justiça ao longo de seu livro. Isto porque, para ele, "há uma surpreendente correspondência entre justiça e eficiência." (Friedman, 2000, p. 22) O mesmo parece poder ser dito de Posner.

Numa segunda fase, após sofrer pesadas críticas, Posner passou a apresentar o argumento de eficiência numa versão que Salama (2008, p. 31-2) chama de "pragmática". Nesse sentido, Posner haveria descartado tanto o emprego da eficiência como "critério operativo suficiente para avaliar as questões postas ao Direito, quanto a noção de que a eficiência deveria se sobrepor aos demais valores da sociedade." (Salama, 2008, p. 32) O direito - como a eficiência - passaram a ser apresentados como meios para fins sociais apreciados. A seguinte fala de Posner, na sexta edição de seu tratado, exemplifica o novo uso da eficiência como maximização de riqueza:

o que a riqueza torna possível - não somente ou principalmente bens voluptuários,
mas também lazer, conforto, medicina moderna, e oportunidades de autoexpressão e
autorrealização - são componentes importantes da felicidade da maior parte das
pessoas, então a maximização da riqueza é instrumental à maximização da utilidade.
(Posner, 2003, p. 16)

A conversão da versão "fundacional" à versão "pragmática" a respeito da posição da eficiência parece, no entanto, ter sido muito mais uma concessão ressentida à crítica do que uma reorientação concreta na produção da AED. Isso porque Posner e os praticantes da AED ao estilo de Chicago, ainda que tenham aceitado limitações à equiparação entre eficiência e justiça, continuaram, na prática, a empregar a eficiência como critério de validação ou rejeição das normas jurídicas. Assim, por exemplo, Salama observa que o "desperdício de recursos é, no mínimo, indesejável. Há, portanto, algo de intuitivo no emparelhamento entre eficiência (que corresponde à ausência de desperdício) e justiça." ${ }^{226}$ Da mesma forma, Ivo Gico Jr. afirma que:

toda definição de justiça deveria ter como condição necessária, ainda que não suficiente, a eliminação de desperdícios (i.e., eficiência). Não sabemos o que é justo, mas sabemos que a ineficiência é sempre injusta, por isso, não consigo vislumbrar qualquer conflito entre eficiência e justiça, muito pelo contrário, uma é condição de existência da outra. (Gico Jr, 2012, p. 28)

\footnotetext{
${ }^{226}$ Salama questiona-se, no entanto: "Mas até que ponto a maximização da riqueza se relaciona com a justiça? Até que ponto o Direito, enquanto 'ciência normativa', deve integrar cálculos de custo e benefício?" (Salama, 2008 , p. 26) Tal questionamento decorre da proposta do autor de que "a análise dos incentivos postos pela legislação é onde começa a discussão do justo; não onde ela acaba. A questão não é substituir a discussão da justiça pela discussão da eficiência, mas sim enriquecer a gramática jurídica integrando a discussão da eficiência na discussão do justo." (Salama, 2008, p. 7) Apesar de tais ressalvas, aplicações práticas da AED, como ilustradas adiante, permanecem no emprego da eficiência como ponto central para a crítica das instituições jurídicas e para a elaboração das propostas de reforma.
} 
Extrai-se a conclusão de que, em Posner, a eficiência (maximização de riqueza) foi inicialmente apresentada como critério igualável à própria noção de justiça, posição subsequentemente atenuada pela afirmação de que a eficiência poderia ser considera um meio para outros fins, ao invés de fim em si mesma. Quer igualada à justiça, quer não, a eficiência permanece, para a AED, como crivo para a avaliação das instituições jurídicas. Essa visão instrumental - segundo a qual o direito está em função da eficiência - também está presente no paradigma rule of law, que sustenta a "necessidade de tornar os sistemas jurídicos mais efetivos e eficientes, de promover o pensamento instrumental e maior sensibilidade às preocupações de políticas públicas (policy concerns).” (Trubek, 2006, p. 86) Vale recordar, ainda, que a promoção da eficiência encontra-se vinculada, nas duas propostas, ao direito "entendido como fundação para relações de mercado e como limite ao Estado" (Trubek; Santos, 2006, p. 2), um “instrumento para abrigar transações privadas.” (2006, p. 5)

Em suma, na AED as instituições jurídicas são julgadas pelo crivo da eficiência econômica, excluindo outros critérios. Na NEI, a existência de instituições (inclusive jurídicas) indutoras de maiores custos de transação é correlacionada a menores graus de desenvolvimento, ao passo que instituições redutoras de custos de transação - como proteção forte de propriedade, contratos e judiciário célere e independente - são encaradas como promotoras do crescimento econômico. No fundo, a noção de que a eficiência ou o crescimento econômico é favorecido pela existência de instituições que reduzam custos de transação é ponto de convergência entre as duas abordagens.

\subsubsection{A tese da eficiência do common law}

Outro ponto de convergência entre a AED e a NEI é a percepção do common law como matriz de instituições tendentes à eficiência ou ao crescimento econômico. Na AED, há a afirmação de que as instituições do common law são mais tendentes à eficiência do que aquelas do civil law. Na NEI, um forte componente de comparação internacional de modelos institucionais se reflete no posicionamento de instituições do modelo anglo-americano, e mais especificamente dos Estados Unidos, como mais favorecedoras do crescimento econômico. Num caso como no outro, é fácil derivar desse receituário propostas de reforma institucional que passem pela sugestão de "transplantes" de instituições do common law para países em desenvolvimento.

Em The problem of social cost, Ronald Coase, a partir da análise de diversos julgados britânicos e norte-americanos do século XIX, havia proposto que os juízes do common law 
decidiam segundo a racionalidade econômica da eficiência ainda que não se valessem explicitamente de critérios econômicos para balizar suas decisões. Essa é a tese de que o common law, sobretudo por ser uma moldura jurídica favorecedora de transações voluntárias - e são justamente estas que o teorema de Coase aprecia -, é mais propenso a promover a eficiência econômica do que o direito estatutário ou legislado, como é o caso dos sistemas de civil law ${ }^{227}$ (cf. Friedman, 2000, p. 110). Posner, assim como os partidários da AED ao estilo de Chicago, acompanha essa tese:

A teoria é de que o common law é melhor (mas não perfeitamente) explicado como um sistema para a maximização da riqueza na sociedade. $\mathrm{O}$ direito estatutário ou constitucional, como campos distintos do common law, são menos propensos a promover a eficiência. (Posner, 2003, p. 25)

Uma das implicações dessa tese - na qual é possível notar a presença de matizes antirredistributivos ${ }^{228}-\mathrm{é}^{-}$

servir como barreira ideológica à promoção geral do direito estatutário - mais especificamente, como barreira à aprovação de leis. [...] Sempre que o mercado falhar em prover uma alocação eficiente de recursos em razão de externalidades ou outra falha de mercado qualquer, pode-se contar com o common law e atribuição de medidas reparatórias [damage measures] [...] para dar ao mercado um ligeiro empurrão [a gentle nudge] na direção do bem-estar social máximo. (Mercuro; Medema, 1997, p. 66)

A tese também está presente nas propostas de reforma instruídas pelo paradigma rule of law. Afinal, elas são pautadas por "transplantes institucionais" conduzidos "de cima para baixo", a partir de um só modelo jurídico (inspirado no common law) que "faria sentido para todos os países" (Trubek, 2006, p. 86). Ou seja, a promoção do rule of law, como parte do projeto de difusão internacional da "boa governança" (vide seção 2.3.3), contém o sentido de universalização de instituições derivadas do common law, que confere tonalidades etnocêntricas a esse projeto. Além da AED e da NEI, outra expertise interdisciplinar que fomentou convergências institucionais globais em torno de instituições do common law foi o movimento Law and Finance, abordado na seção 4.2.

\footnotetext{
${ }^{227}$ Na leitura de James Buchanan, o livro fundamental de Posner contém uma "teoria normativa", qual seja, a sugestão de que "o common law, do modo como se desenvolveu, tem sido ao menos indiretamente guiado pelo critério de eficiência dos economistas ortodoxos." Essa tese normativa contém a implicação de que "o common law feito por juizes é superior à legislação, às decisões que emergem das atividades de representantes políticos." (Buchanan, 1974, p. 488)

${ }^{228}$ Para Posner, o common law subordina considerações distributivas às considerações de eficiência (Posner, 2003, p. 532).
} 
4.1.4.3 AED e a "hipótese dos mercados eficientes"

O emprego da "hipótese dos mercados eficientes" pela AED guarda coerência com a tese da eficiência do common law quando se considera que ambas privilegiam instituições jurídicas de desestímulo à intervenção e à regulação direta do Estado em relação aos mercados. Em linha com a aplicação abrangente que a AED faz da teoria dos preços, pode-se dizer: no fundo, a recomendação de ambas é a de que o Estado evite influenciar a operação do mecanismo de preços, ou seja, "contaminar" suas sinalizações.

De acordo com Posner, a livre operação dos mercados é o modo mais eficiente de fazer com que os recursos sejam empregados no seu uso mais valorizado. De modo diferente, quando o Estado se propõe a intervir ou regular além do "ponto ótimo", os resultados são negativos. Assim, por exemplo, "controles de preços levam a filas, mercados negros e desabastecimento; a competição e o livre comércio promovem a produtividade, e a propriedade privada encoraja o investimento." (Posner, 2003, p. 18)

A “hipótese dos mercados eficientes" (Posner, 2003, p. 451) parece, porém, ter sido concebida especificamente para lidar com mercados financeiros ${ }^{229}$. A partir dela, a AED deriva recomendações antirregulação.

Para Posner, a regulação dos ativos financeiros "teve suas origens, em parte, numa concepção equivocada a respeito da grande depressão dos anos 1930.” Assim, a quebra da Bolsa de Nova Iorque em 1929 teria sido "menos o resultado de abusos nos mercados de ativos financeiros do que uma antecipação da depressão" (2003, p. 457). Há, aqui, a sugestão de que os mercados se antecipam à regulação, frustrando-a. "Se isso é correto, tem-se o direito de ser cético sobre aspectos da regulação de ativos financeiros que são concebidos para prevenir outra crise ao estilo de 1929." No fundo, a base para sustentar a desnecessidade de regulação estatal dos mercados financeiros - ou seja, para dizer que esta é uma área que não deve ser atingida por instituições jurídicas que tragam conteúdos oriundos de políticas públicas - é a crença de que a informação gerada pelos mercados traduz-se em sinalizações de preços, e que isso é o suficiente para pautar o comportamento dos agentes envolvidos: “[o]s mercados de capital são competitivos, e mercados competitivos geram informação sobre os produtos vendidos.” (Posner, 2003, p. 457)

\footnotetext{
${ }^{229}$ Para compreender o papel de apoio à desregulamentação financeira que a hipótese dos mercados eficientes representou no campo jurídico, bem como seu contraponto, representado pela caracterização dos mercados financeiros como inerentemente instáveis, de Hyman Minsky, vejam-se os trabalhos de Pistor (2012) e Valadares (2015).
} 
Mais uma vez, as formulações da AED (que nesse ponto convergem acentuadamente com a perspectiva do Law \& Finance) mostram-se replicadas no paradigma rule of law, que concebe o investimento estrangeiro (sobretudo privado) como fator de elevada importância na promoção do crescimento em países em desenvolvimento e, em linha com isso, define como objetivo primário das reformas institucionais

tornar as economias nacionais mais atrativas aos investidores estrangeiros. Para esse
fim, a propriedade e outros direitos econômicos devem ser protegidos, e a
intervenção governamental limitada. Ao mesmo tempo, esta visão enfatiza a
importância de medidas de harmonização jurídica e de eliminação de qualquer
discriminação contra estrangeiros para que as economias nacionais tornem-se mais
facilmente ligadas a entidades econômicas ou globais mais amplas. (Trubek, 2006,
p. 89)

Cabe ressalvar que, como reação à crise de 2008, Posner publicou o livro A failure of capitalism: the crisis of '08 and the descent into depression. Nesta obra, Posner atribuiu a ocorrência da nova depressão econômica à "confluência de dois perigosos fatores: baixas taxas de juros no início dos anos 2000 e o movimento de desregulamentação, que começou em 1970." No que diz respeito a esse último aspecto, considerou que "a desregulamentação financeira acabou por fazer com que os bancos assumissem riscos excessivos e o grande entrelaçamento da indústria financeira fez com que, quando um banco faliu, todo o sistema financeiro também veio abaixo." (Heinen, 2013, p. 366) Nesse sentido, deve-se considerar que Posner acabou por rejeitar a "hipótese dos mercados eficientes", favorecida por seus escritos desde a década de 1970.

\subsubsection{A AED e as políticas públicas de caráter redistributivo}

A noção de eficiência como justiça, empregada na AED quer em sua versão fundacional (eficiência como justiça), quer na versão pragmática (eficiência como meio para fins sociais diversos), permanece tendo marcado viés de marginalização do aspecto da equidade econômica. Nesse sentido, a AED privilegia noções de igualdade formal, que também se projetam sobre o paradigma rule of law, e não de igualdade substancial. Essa noção concebe que os indivíduos desfrutam de condições econômicas condizentes com suas escolhas e comportamentos. É uma visão essencialmente liberal, traduzida pelo mote segundo o qual "o homem se faz por si mesmo".

A presença desse elemento - o outro lado da moeda da aversão a políticas redistributivas - é ilustrado na seguinte passagem de Posner, em que o autor considera a desigualdade de renda de um ponto de vista essencialmente privado, que presume livre mobilidade (livre escolha) dos indivíduos em relação às posições econômicas que ocupam: 
Considere uma distribuição simples de quatro rendas: um carpinteiro de 20 anos, que ganha \$20,000; um estudante de 20 anos, que nada ganha; um carpinteiro de 30 anos, que ganha $\$ 30,000$, e uma pessoa com ensino superior, que ganha $\$ 40,000$. O quadro é de desigualdade substancial, mas pode não haver nenhuma na realidade. A renda zero do estudante representa investimento na educação, que ele recupera ao longo de sua vida de trabalho com salário mais alto. Os $\$ 10,0000$ extras que ele recebe aos 30 anos, na comparação com o carpinteiro, que trabalhava enquanto o estudante ainda estava na faculdade, pode representar simplesmente o retorno [repayment] com juros de parte da contribuição em capital na forma das taxas escolares pagas [tuition] e na renda de que ele ou sua família abriram mão em seus anos anteriores de estudante. (Posner, 2003, p. 469)

No cenário imaginado por Posner (note-se o emprego de suposições aritméticas na base do raciocínio), os indivíduos obtêm os resultados econômicos de suas decisões privadas. Assim, a menor renda do carpinteiro é justificada como fruto de uma escolha por não investir mais em educação: ausência de oportunidades, outros constrangimentos sobre a renda que impeçam a poupança necessária a investimentos etc. não entram na conta. Como resultado, emerge a sugestão da desnecessidade de políticas públicas desenhadas para corrigir desigualdades de renda.

O pensamento econômico de Posner é essencialmente supply-side - rejeitando preocupações keynesianas com a necessidade de incentivar a demanda para manter o nível de atividade econômica -, o que se reflete em sua crítica às instituições jurídicas redistributivas. $\mathrm{Na}$ seção 3.3 do capítulo anterior, mencionou-se a preferência do pensamento econômico neoliberal pela noção de trickle down economics, ao invés de welfare state ou medidas diretas de redistribuição de renda, para lidar com questões de bem-estar das pessoas que se encontram em situação de baixa renda. Posner também reflete essa linhagem: "[s]e a renda média estiver aumentando, $[\ldots]$ as rendas dos pobres podem estar aumentando mesmo que a distribuição de renda esteja se tornando mais desigual.” (Posner, 2003, p. 473) Essa é uma forte conexão com o paradigma rule of law impulsionado pela NEI, que

aceita o alívio da pobreza como objetivo, mas na versão robusta deste credo, não há necessidade de ação direta para o alívio da pobreza porque este resultaria do crescimento econômico em si - mais uma ideia de "gotejamento" em um campo infestado (plagued) por tais noções. (Trubek, 2006, p. 89)

O paradigma rule of law enfatiza o "papel do direito em tornar a economia mais eficiente, [...] uma moldura para a alocação eficiente de recursos", deixando de lado as “consequências distributivas." (Trubek, 2006, p. 89) Na mesma linha, para a AED de Posner, a desigualdade de renda não é um problema a ser endereçado diretamente pelo direito. O foco deve residir na maximização da riqueza, ou no "crescimento do bolo" em geral, e não na forma como a riqueza é alocada entre os grupos que compõem o todo social. Posner traz, além da justificativa econômica do trickle down (redistribuição de renda por gotejamento, ou 
efeitos indiretos - cf. seção 3.3) para a permanência da desigualdade, também considerações políticas a seu respeito: "[a] desigualdade de renda pode ser muito menos importante do que a renda total na manutenção da paz social e da estabilidade política." ${ }^{230}$ (2003, p. 472)

As críticas da AED a políticas de caráter redistributivo são amplas. Três delas serão ressaltadas, e dizem respeito (i) à divisão de tarefas entre o judiciário e os parlamentos; (ii) à tributação; e (iii) a outras medidas de redistribuição de renda.

\section{Divisão de tarefas entre o judiciário e os parlamentos}

Partidários da AED frequentemente descrevem o common law produzido por juízes como eficiente, em linha com as teses de Coase e Posner, e salientam não haver lugar para políticas redistributivas que envolvam o direito privado. Nesse sentido, um autor desta vertente afirma, por exemplo, ser "prudente que juízes, mesmo os juízes igualitários, concentrem-se na maximização do tamanho da torta social [size of the social pie] [...] e que deixem às legislaturas a disputa sobre como ela deve ser dividida.” (Friedman, 2000, p. 298) Essa linhagem sustenta que a intenção de fazer redistribuição pelas cortes é frequentemente ineficiente ao ser frustrada pelos chamados "efeitos de segunda ordem":

Se as cortes persistentemente interpretarem contratos em favor de uma classe
específica de litigantes, como locatários em disputa com locadores, por exemplo, ou
empregados em disputa com seus patrões, outras características das transações se
ajustarão; aluguéis subirão ou salários cairão para acompanhar os termos alterados.
É pouco provável que o resultado final beneficie a classe favorecida [pelas decisões
judiciais] e pode muito bem prejudicar ambos os lados ao forçá-los a adotar
cláusulas menos eficientes do que aquelas que eles teriam pactuado por si sós.
(Friedman, 2000, p. 298)

Políticas redistributivas não devem ser conduzidas, portanto, pela via judicial. No entanto, como visto anteriormente, a tese da eficiência do common law tem como implicação o viés contrário à adoção do direito legislado. Assim, a aparente abertura à condução de políticas redistributivas pelo legislativo é, de certo modo, "fechada" quando conjugada com implicação normativa de que se deva evitar modular instituições jurídicas pela via da legislação ou dos estatutos, já que o judiciário é percebido como mais favorável a resguardar a autonomia da vontade privada contra as incursões estatais.

\footnotetext{
${ }^{230}$ Em contaste, para a corrente da AED da escola de New Haven - que não é o mainstream -, associada aos nomes de Calabresi e Susan Rose-Ackerman, "questões distributivas permanecem centrais. Falhas de mercado são vistas como mais prevalentes do que na análise econômica do direito de Chicago, e espera-se que a intervenção governamental seja capaz de corrigi-las, embora possa não ser bem-sucedida em todas as circunstâncias." (Mackaay, 2000, p. 412) A AED de New Haven e de Chicago, apesar de orientações políticas distintas, compartilham o uso da teoria microeconômica dos preços para escrutinar instituições jurídicas.
} 


\section{Redistribuição por tributação}

Um caminho possível para realizar políticas de redistribuição de renda é a tributação. A esse respeito, Posner considera que a tributação fortemente progressiva "reduz a eficiência econômica" (2003, p. 473) ao retirar os incentivos para a acumulação da propriedade, numa manifestação de sua orientação econômica de supply-side. O que Posner defende é, de certo modo, o caráter regressivo da tributação: "de fato, os pobres, embora paguem mais tributos (a maior parte indiretos) do que se possa pensar, recebem ainda mais em transferências do que eles pagam em tributos, embora talvez apenas pouco mais." (2003, p. 469) Assim, faz o argumento de ser coerente que os mais pobres, por serem os usuários mais frequentes de serviços públicos, arquem com carga tributária maior.

\section{Outras formas de redistribuição}

A redistribuição não deve ser feita nem pelo judiciário, nem pela via da tributação, dado que ambos os caminhos comprometem a eficiência econômica. Também outras modalidades de políticas de redistribuição de renda estão sujeitas ao veto da eficiência. A educação gratuita, como direito social, é uma das formas de redistribuição indireta de renda. $\mathrm{Na}$ passagem abaixo, Posner submete o direito à educação de criança portadora de necessidades especiais à análise de custo-benefício:

Considere a exigência da legislação federal [...] de que toda criança deficiente receba
"apropriada educação pública gratuita." A ideia é dar à criança, às expensas
públicas, a educação necessária para maximizar seu aprendizado, qualquer que seja
o custo. Se a criança tem severas limitações físicas ou mentais, o custo pode ser
astronômico. E o programa não é limitado aos [economicamente] necessitados.
Embora se possa argumentar que alguma medida de assistência à educação dos
deficientes seja um método de seguro social contra um infortúnio terrível, [...] é
obvio que o ponto ótimo dos gastos com a educação de crianças deficientes nem de
perto chega ao infinito, embora gastos infinitos possam ser necessários para fazer
com que algumas dessas crianças cheguem ao nível das crianças sem deficiências.
Questão: qual seria o critério maximizador de eficiência para decidir o quanto gastar
com a educação de uma criança deficiente? (Posner, 2003, p. 485)

Posner não traz a resposta de modo explícito (o livro é recheado de questões posicionadas como provocações ao pensamento). A julgar pelo ponto central da obra, uma possível resposta seria a seguinte: os gastos com educação dessas crianças devem ir até o ponto em que igualem, mas não superem, a contribuição (na margem) destas crianças para a riqueza social. Em outros termos, a proposta seria a de que os custos econômicos da medida não ultrapassassem o benefício para o todo social. 
As considerações acima permitem posicionar a AED como fonte de materiais intelectuais de apoio à agenda de reformas institucionais promovidas segundo o paradigma rule of law. Esse paradigma, como se viu, consolidou-se na década de 1990 de modo mais próximo das contribuições da NEI, com componentes internacionais e comparativos mais expressivos que a AED. Os diversos pontos de convergência permitem, no entanto, a caracterização da AED e da NEI como duas afluentes de um mesmo paradigma, que incorporou traços como (i) análises institucionais baseadas em custos de transação; (ii) uso da eficiência para validar instituições jurídicas; (iii) afirmação de que as instituições típicas do common law são mais propensas à promoção da eficiência ou do crescimento econômico do que as do civil law; (iv) adoção da "hipótese dos mercados eficientes" para incentivar a desregulamentação financeira; e (v) um viés de supply-side que se reverte em afastamento de políticas de caráter redistributivo. No fundo, todos esses pontos convergem, ainda, com a sensibilidade econômica tipicamente pró-mercados do neoliberalismo, ganhando expressão adicional na ênfase que estas análises atribuem a mecanismos típicos do direito privado, e não do direito público.

Ao lado da AED, outra fonte de análises jurídicas - dessa vez com maior teor comparativo internacional - a embalar as propostas de reforma inspiradas pelo paradigma rule of law (e por isso também convergentes com os receituários da NEI) consistiu no movimento Law \& Finance, abordado na seção seguinte.

\subsection{Law \& Finance ou Teoria das Origens Jurídicas}

Outra literatura jurídica de apoio ao paradigma do rule of law, porém com ligação a instituições como o Banco Mundial ${ }^{231}$, é o movimento Law \& Finance, também conhecido como Teoria das Origens Jurídicas (Legal Origins Theory). Os principais expoentes dessa vertente são Rafael La Porta, Florencio Lopes-de-Silanez, Andrei Shleifer e Robert Vishny, com diversas publicações conjuntas (em razão das quais ficaram conhecidos como "LLSV"). O ponto principal dessa linhagem consiste na vinculação entre o bom desempenho dos mercados financeiros a dotações jurídicas (legal endowments) consideradas "corretas", resultando em ambientes institucionais eficientes na atração de investidores. Há afinidades com a empreitada intelectual da NEI, dado que as duas correntes vinculam o desenvolvimento

\footnotetext{
${ }^{231}$ Considera-se, aqui, que a influência das contribuições intelectuais da AED sobre as propostas de reforma institucional de organizações da cooperação econômica internacional foram mais indiretas, tendo sido mediatizadas pela NEI, que por sua vez é diretamente empregada no embasamento de parte das propostas de reforma do Banco.
} 
- entendido primariamente como crescimento econômico - à existência de ambientes institucionais "corretos", isto é, propícios aos negócios, pró-mercados ${ }^{232}$.

Os estudos de Law \& Finance se conformaram no final da década de 1990 e são marcados por comparações institucionais entre países, feitas com base em levantamentos empíricos de dados, e que relacionam instituições jurídicas a mercados financeiros e a variáveis de desempenho econômico. Em termos gerais, os estudos de La Porta e colaboradores $(1997 ; 1998 ; 2008)$ fazem duas afirmações fundamentais. Primeiramente, suas análises comparativas conduzem à afirmação de que países com "dotação jurídica" do common law são mais propícios a ter mercados financeiros melhores e maiores do que aqueles cujo direito tem raízes no civil law. Em segundo lugar, associam a existência de mercados financeiros amplos e dinâmicos ao próprio desenvolvimento. Essa associação - ou melhor, correlação - assume o sentido de causalidade: finanças promovem o crescimento econômico. Além disso, há a incorporação do pressuposto de que quanto maiores os mercados financeiros, melhor para a economia: algo que a ocorrência da crise do subprime, de 2008, coloca em questão. De todo modo, as formulações acima compõem o alicerce intelectual das receitas do Law \& Finance para reformas institucionais destinadas a promover o desenvolvimento em pontos variados no mundo; receitas que consistem, essencialmente, na universalização de instituições do common law.

A apresentação de argumentos baseados em linguagem numérica e correlações estatísticas certamente contribuiu para que as elaborações de LLSV se tornassem "altamente influentes" tanto na academia como entre formuladores de políticas públicas (cf. Milhaupt; Pistor, 2008, p. 20; Santos, 2006). Tais contribuições estão na base do projeto Doing Business, do Banco Mundial, que "afirma ter descoberto quais regras jurídicas promovem o crescimento e recomenda sua adoção a países em desenvolvimento como melhores práticas para os negócios.” (Santos, 2006, p. 280) Desde 2003, o Doing Business produz relatórios anuais que atualmente abrangem 189 países. As instituições jurídicas associadas a maiores níveis de desempenho econômico no mundo são apresentadas como benchmarks, ou melhores práticas, para as instituições jurídicas de países em desenvolvimento (2006, p. 294). Além de informar esses relatórios, o movimento Law \& Finance esteve na base da elaboração do

\footnotetext{
${ }^{232}$ Douglas Arner esclarece essa ligação ao afirmar: "Partindo da base teórica desenvolvida por North, uma literatura empírica desenvolveu-se rapidamente no final dos anos 1990 conforme as teorias de North eram modeladas e testadas. A mais influente consistiu numa série de estudos por La Porta, Lopez-de-Silanes, Shleifer e Robert Vishny, aos quais é comum se referir coletivamente como 'LLSV'." (Arner, 2007, p. 48) Também Emerso Fabiani destaca as afinidades entre a NEI e a literatura do Law \& Finance: "Essas contribuições podem ser agrupadas dentro da perspectiva da dotação institucional, que vê o direito como um investimento primeiro sem o qual não se pode dar início ao processo de desenvolvimento." (Fabiani, 2011, p. 38)
} 
indicador "Ease of Doing Business", que estabelece ranking de países segundo o grau em que suas instituições são julgadas favoráveis ao ambiente de negócios ${ }^{233}$.

Com a ajuda de La Porta e colaboradores, o Banco Mundial estabeleceu uma base de dados que atribui um indicador numérico a cada país para uma gama de instituições que vão desde direitos de acionistas e credores à proteção do trabalho, ao funcionamento dos tribunais, e assim por diante. [...] Mais concretamente, a perspectiva da dotação jurídica [endowment perspective], com apoio da literatura de law and finance, tem guiado as políticas de reforma jurídica do Banco Mundial e de outras organizações internacionais. (Milhaupt; Pistor, 2008, p. 20)

Os expedientes de quantificação e tratamento estatístico de dados, dos quais derivam os argumentos do Law \& Finance, permitem que os autores nessa tradição - e o Banco Mundial, ao empregar esse referencial - consigam revestir suas recomendações de reforma jurídica de uma qualidade de "necessidade técnica" (Milhaupt; Pistor, 2008, p. 20), de modo desentranhado de - ou impermeável a - outras considerações políticas ${ }^{234}$. Na prática, a afirmação de que as propostas de reforma são derivadas de considerações tecnocráticas - não políticas - permite contornar a vedação de interferência na política doméstica dos países, que recai sobre o Banco como decorrência dos Acordos de Bretton Woods ${ }^{235}$.

Os métodos do Law \& Finance são diversos daqueles empregados pela AED. Ao passo que é comum encontrar nos estudos da AED - a começar por Coase (cf. 1960), mas sobretudo em Posner (1973) e seguidores - argumentos embasados em suposições aritméticas (cenários hipotéticos em que preços são estimados para refletir preferências de indivíduos nos

\footnotetext{
233 "Desde a criação do projeto Doing Business pelo Grupo de Desenvolvimento do Setor Privado do Banco Mundial (BM), a literatura da Law and Finance passou a desempenhar papel de destaque no campo prático das reformas jurídicas, já que seus métodos de mensuração da qualidade do direito foram adotados para embasar pesquisas comparativas sobre o ambiente de negócios nos países membros do Banco Mundial. Eles passaram a influenciar, assim, decisões de investimentos de atores privados e do próprio BM. Com isso, as regras valorizadas como indutoras do desenvolvimento financeiro passaram a ser tomadas como referência por reformadores nacionais que pretendiam criar melhores condições para o investimento privado, especialmente por aqueles que demandavam recursos do Banco Mundial para a implementação dessas reformas. Recentemente, isso vem sendo reforçado pelo fato de que outras áreas do BM passaram a adotar os indicadores do projeto Doing Business para avaliar o impacto de reformas financiadas pelo Banco Mundial." (Fabiani, 2011, p. 53-4)

${ }^{234}$ Embora não se refira especificamente à influência do movimento Law \& Finance, a tese de João Márcio Mendes Pereira sobre o Banco Mundial ressalta o papel instrumental que bandeiras como a da "boa governança" tiveram para o Banco, no sentido de "prover uma referência aparentemente técnica para [...] transformação dos países do Leste europeu e da ex-URSS em "economias de mercado", bem como de promover reformas em países em desenvolvimento (cf. Pereira, 2009, p. 208 e passim). A pretensão da apresentação dos modos tecnocráticos como ferramentas despolitizadas de organização de relações econômicas e sociais remete à função política que ela no fundo desempenha, e que está sugerida no título da obra: $O$ Banco Mundial como ator político, intelectual e financeiro (Pereira, 2009).

${ }^{235}$ A proibição de engajamento em atividades políticas é encontrada na seção 10 do artigo IV do Acordo Constitutivo do Banco Mundial: "O Banco e seus funcionários não interferirão nos assuntos políticos de quaisquer de seus membros, nem se deixarão influenciar, em suas decisões, pelas características políticas do membro ou dos membros em questão. Somente considerações econômicas serão relevantes para suas decisões, e essas considerações deverão ser sopesadas imparcialmente para que se possam atingir os propósitos afirmados no Artigo I [reconstrução e desenvolvimento; promoção de investimentos privados externos e do desenvolvimento equilibrado, entre outros]."
} 
mercados), as análises de Law \& Finance são assentadas sobre correlações estatísticas entre variáveis construídas a partir de levantamentos empíricos. Além disso, o movimento Law \& Finance traz o elemento "internacional" e "comparativo" para o centro de suas análises, e estes não são focos especiais da AED. Apesar dessas diferenças, o paradigma que as duas vertentes apoiam (rule of law) e o sentido de reformas que buscam promover (instituições pró-mercado, moldadas segundo o common law) são essencialmente os mesmos, permitindo que as duas sejam posicionadas no mesmo lado do debate contemporâneo sobre direito e desenvolvimento, e em oposição a movimentos como o NDD e a AJPE.

A seguir, aspectos das principais teses do Law \& Finance são apresentados (4.2.1), ao passo que a subseção subsequente (4.2.2) expõe algumas das principais críticas ${ }^{236}$ dirigidas a suas elaborações. Ao final, a subseção 4.2.3 aborda exemplos de reformas em instituições jurídicas brasileiras conduzidas com base neste referencial.

\subsubsection{Aspectos das principais teses do Law \& Finance}

Os estudos inaugurais de Law \& Finance compararam dotações jurídicas e variáveis de desempenho econômico de 49 países (La Porta et al, 1997; 1998). A amostra foi dividida em dois grandes grupos, segundo a linhagem histórica dos ordenamentos jurídicos dos países, abordados como dotações ou legados jurídicos (legal endowments). Disso deriva, aliás, o nome alternativo do Law \& Finance: "teoria das origens jurídicas" (cf. La Porta et al., 2008, p. 286). De um lado, 18 países foram identificados com a tradição do common law angloamericano. De outro, os 31 países restantes foram classificados em três subgrupos correspondentes a três origens do civil law: 21 no civil law francês, 6 no alemão, e 3 no escandinavo. Apesar de procederem a três categorizações do civil law, os autores afirmam que seu foco recai sobretudo na comparação entre "o common law e o civil law francês." (La Porta et al, 2008, p. 290)

Partindo dessa divisão de origens, LLSV delineiam e quantificam variáveis jurídicas relativas à proteção de investidores e acionistas - ou, de modo geral, credores - em mercados financeiros. Assim, a proteção aos acionistas é avaliada em termos de seus "poderes de voto, facilidade de participação em deliberações corporativas, e proteções jurídicas contra expropriações pelos administradores” de empresas (La Porta et al, 1998, p. 1115). A proteção

\footnotetext{
236 Também os movimentos abordados nas seções 4.3 e 4.4 devem ser encarados como críticas ao Law \& Finance, bem como à AED.
} 
a credores em geral é abordada por mensurações que compreendem "o respeito pela garantia dos empréstimos, a facilidade de penhorar ativos em caso de inadimplência, e a restrição à possibilidade de administradores buscarem proteção contra seus credores unilateralmente" (1998, p. 1115-6). Outra variável compreendida nas análises é a efetividade na aplicação das normas (enforcement). No fundo - e de modo a simplificar o sentido dessa gama ampla de variáveis - pode-se interpretar que LLSV buscam avaliar o rule of law nas relações entre investidores, acionistas, administradores de empresas e - não se pode deixar de fora - o Estado. De fato, rule of law é uma expressão que aparece expressa e repetidamente nesses estudos (La Porta et al, 1997; 1998).

Essa etapa das análises de Law \& Finance já produz conclusões estatísticas. LLSV concluem, assim, que "países do common law oferecem aos credores proteção jurídica mais forte contra administradores", ao passo que "países do civil law francês oferecem as proteções mais fracas.” (1998, p. 1138) Por sua vez, a variação no grau do rule of law relativo ao ambiente financeiro é correlacionada a outros fatores institucionais e de desempenho econômico. Entre eles, o grau de concentração ou diversificação de acionistas numa sociedade (doravante referido como "concentração societária"), a facilidade de atração de capital externo, o tamanho e o dinamismo de mercados financeiros, renda per capita do país etc. $\mathrm{O}$ cruzamento entre os dados relativos a instituições jurídicas com esse segundo grupo de variáveis produz múltiplas e concatenadas conclusões a respeito do impacto das origens jurídicas sobre o tamanho e o desempenho dos mercados financeiros. Por sua vez, os autores vinculam o crescimento econômico geral ao dinamismo das finanças (vide Quadro 4.1, abaixo, para uma representação esquemática das vinculações apontadas nesse parágrafo).

Uma das conclusões derivadas do cruzamento de dados sugere que nos países em que a qualidade de proteção aos investidores é pior, há maior grau de concentração societária. Os países do civil law francês apresentam os piores índices de proteção a acionistas e os maiores índices de concentração societária ${ }^{237}$ (1998, p. 1146). Apenas grandes acionistas, com controle sobre a administração da empresa, tendem a poder assegurar retornos a seus investimentos nesses cenários de baixa proteção jurídica (1998, p. 1145). Segundo LLSV, essa configuração produz efeitos adversos para o crescimento dos mercados financeiros,

\footnotetext{
${ }^{237}$ Os menores índices de concentração societária são atribuídos aos países do civil law germânico, ao passo que os países do common law são posicionados em situação intermediária. LLSV ressalvam, porém, que muitos dos países enquadrados como pertencentes ao civil law germânico são do Leste Asiático, onde "o direito societário foi significativamente influenciado pelos Estados Unidos, ao invés de pela Alemanha, Áustria ou Suíça." (1998, p. 1146) A partir dessa modulação nas origens do sistema jurídico desses países, LLSV mantêm a conclusão geral de que as instituições do common law são mais propícias ao desenvolvimento adequado dos mercados financeiros, ao invés de tomar os casos dos países do Leste Asiático como fonte de dúvidas para essa conclusão.
} 
sobretudo por afastar pequenos investidores, inclusive estrangeiros. Estes - que não podem adquirir um interesse controlador - perdem incentivos para investir diante da possibilidade de expropriação por parte dos administradores de empresas. Por sua vez, com bases menos diversificadas de acionistas, empresas nesses países têm canais mais restritos de financiamento para suas atividades empresariais, o que afeta o desempenho econômico geral, já que "a proteção que os investidores recebem determina sua disposição para financiar firmas." (1998, p. 1114)

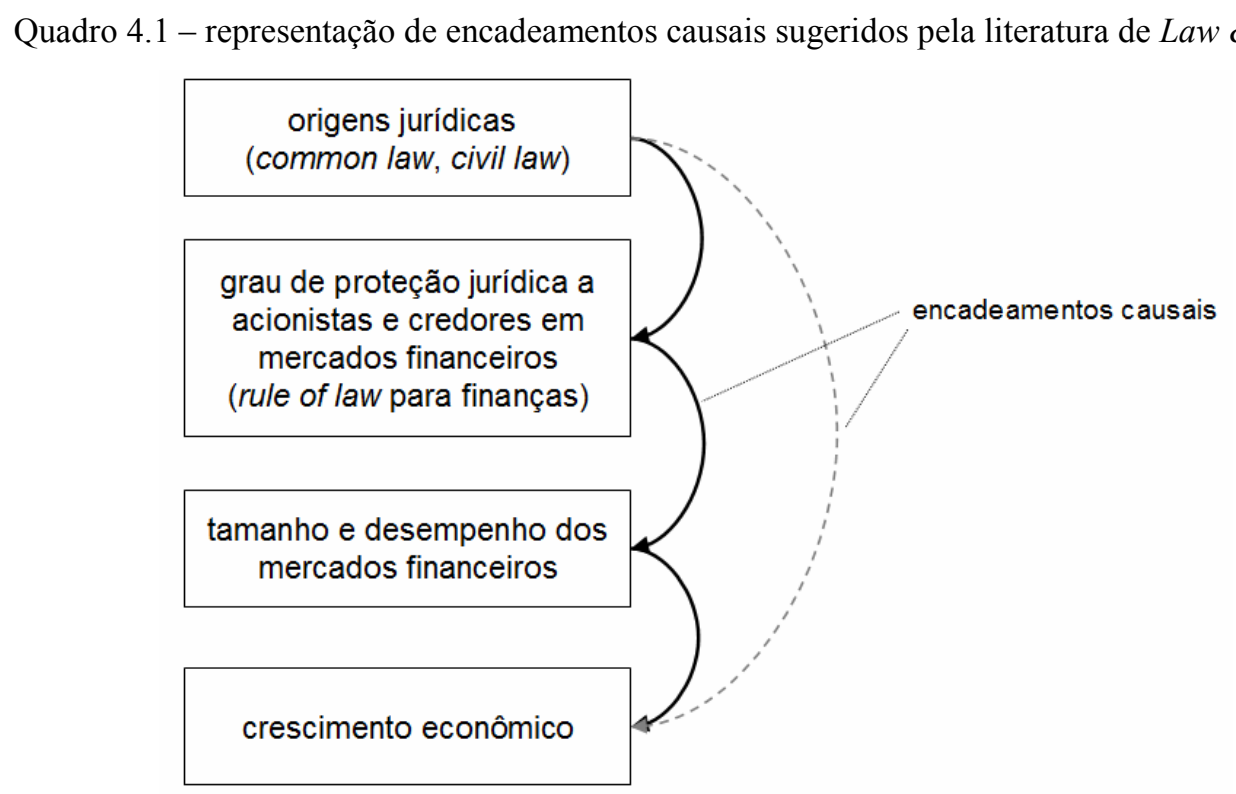

Fonte: elaborado com base em La Porta et al., 1997; 1998; 2008; Pistor, 2009, p. 1648.

No que diz respeito à proteção a credores em geral - e não somente a acionistas -, LLSV concluem que os países com melhores mecanismos de garantia de dívidas demonstram "crescimento superior em setores intensivos em capitais que se apoiam de modo particularmente intensivo em financiamentos externos.” (1998, p. 1152) A forte proteção jurídica a credores é correlacionada à atratividade da economia local a investimentos externos. Mais uma vez, as análises produzidas pelos autores apontam que as normas do common law são mais protetivas de investidores externos do que as do civil law, em "em especial do que os países do civil law francês" (2008, p. 286). Ou ainda: "[n]ossos resultados demonstram que o civil law, e em particular o civil law francês, tem tanto os menores níveis de proteção a investidores quanto os mercados de capital menos desenvolvidos, especialmente quando comparados a países do common law" (1997, p. 1149).

As diferenças entre sistemas, até aqui relatadas, são reunidas em considerações mais amplas sobre as tendências dos ambientes jurídicos em função de suas origens: "sustentamos 
que o common law promove a estratégia de controle social que procura apoiar o funcionamento dos mercados privados, ao passo que o civil law busca substituir esse funcionamento por alocações determinadas pelo Estado.” (2008, p. 286)

Aqui, há forte aproximação com a tese da eficiência do common law, capitaneada pela AED, mas também presente na NEI. Diferentemente, porém, o Law \& Finance não precisa basear seus argumentos explicitamente em termos de custos de transação. No lugar de raciocínios hipotéticos fundamentados no teorema de Coase, a afirmação de superioridade do common law é resultante de correlações entre as variáveis trabalhadas na análise, em bases empíricas. Ainda que versadas em linguagens diferentes, as conclusões convergem, a exemplo dos trechos seguintes, comparáveis às aplicações (e aos vieses nelas incorporados) da AED narradas na seção anterior (cf. 4.1.3):

[...] a ênfase do common law na solução judicial de disputas privadas, ao invés de na legislação, como solução para problemas sociais, sugere ser mais provável encontrar maior ênfase em contratos e ordenações privadas, e menor ênfase na regulamentação governamental, nos países do common law. (2008, p. 305)

Essa consideração é complementada por outra: "no ferramental dos países de civil law figuram mais proeminentemente políticas como nacionalização e controle estatal direto; no ferramental de países do common law figuram mais a litigância e a regulação em apoio aos mercados.” (2008, p. 308) Essas diferenças de estilo, propostas como intrínsecas às diferentes origens jurídicas, estariam na base das explicações para variações no grau de prosperidade financeira: “[p]aíses do common law são bem sucedidos nas finanças porque suas estratégias regulatórias procuram apoiar os mercados ao invés de substituí-los.” (2008, p. 310) Por fim, o tamanho e o dinamismo dos mercados financeiros é correlacionado ao próprio crescimento econômico dos países (1998, p. 1152; 2008, p. 294). Os autores sugerem, nesse sentido, que os níveis de renda per capita estão associados ao grau de desenvolvimento dos mercados financeiros, ao passo que este se encontra em função do grau de proteção a investidores (2008, p. 294). E o rule of law para finanças, por sua vez, tem variações a partir das origens jurídicas. O encadeamento nas variáveis leva à conclusão de que, no fundo, as instituições do common law são mais propícias ao crescimento econômico do que as do civil law, estabelecendo uma "ligação que vai do sistema jurídico ao desenvolvimento econômico." (1998, p. 1152)

A afirmação da superioridade do common law pelo Law \& Finance - correlata da tese da eficiência do common law, na AED - é a base para a produção de propostas de reforma. Nesse sentido, as reformas buscam introduzir, nos países em desenvolvimento, instituições jurídicas de apoio ao funcionamento dos mercados financeiros, o que se traduz em maiores 
graus de proteção a acionistas, investidores e credores em geral, bem como em outras medidas destinadas a incrementar o rule of law nas finanças, como reformas judiciais. A receita para o crescimento passa a consistir em "transplantes" institucionais derivados de países do common law e, em particular, do sistema jurídico dos Estados Unidos (cf. Woo, 2007, p. 172; Milhaupt; Pistor, 2008, p. 219-21).

Assim, por exemplo, a existência de "frequentes recursos interlocutórios nos procedimentos falimentares" de países do civil law é criticada. A morosidade implicada na existência de ampla possibilidade recursal é vinculada a resultados de "massiva destruição de valor nas falências" (2008, p. 323), dado que a protelação dos processos abre espaço para que devedores dissipem seu capital. Para favorecer o desenvolvimento, esses países devem reformar o processo falimentar para torná-lo mais célere. Outra crítica é dirigida à ordem de preferência dos créditos nas falências. A prioridade absoluta atribuída a créditos trabalhistas e tributários sobre demais credores com garantias reais é apontada como tendo o efeito de afastar novos investimentos (1998, p. 1135). Tal como o ocorrido na legislação falimentar brasileira (vide seção 4.2.3), o movimento Law \& Finance favorece reformas na ordem de preferência para aumentar a prioridade conferida a investidores. Esses são apenas alguns exemplos da ampla gama de recomendações de reformas jurídicas destinadas a dinamizar mercados financeiros e ocasionar crescimento, como: facilitar a penhora de bens, diminuir as etapas envolvidas na abertura de empresas, reduzir a participação do Estado na economia em geral, mediante privatizações, menor participação no sistema bancário e desregulamentação das finanças. Há, ainda, formulações destinadas a tornar o poder judiciário mais independente, menos formalizado, e mais capaz de conferir segurança aos contratos e aos direitos de propriedade $^{238}$ (cf. 2008, p. 298).

\subsubsection{Algumas críticas ao Law \& Finance}

O Law \& Finance tem recebido críticas que vão desde a metodologia empregada nas análises até o sentido de reformas propostas, passando por suas conclusões ou teses, dentre as quais a da superioridade do common law e a ligação entre o tamanho e o dinamismo dos mercados financeiros com o próprio crescimento econômico dos países. Muitas dessas críticas antecedem a ocorrência da crise de 2008, após a qual a relação entre desregulamentação das finanças - que o Law \& Finance promove ativamente - e instabilidade econômica veio à tona.

\footnotetext{
${ }^{238}$ Inclusive por meio de programas de treinamento direcionados a juízes, com apoio do Banco Mundial (cf. Santos, 2006, p. 282; Castro, 2005a, p. 128-9; 2014, p. 40).
} 
Várias das críticas abordadas abaixo apresentam proximidades com formulações da nova economia do desenvolvimento, abordada na seção 3.4. Há, ainda, pontos de contato com a literatura de "variedades de capitalismo". Todas, afinal, podem ser lidas como contribuições de contestação à promoção de convergências institucionais globais, ou adoção de pacotes padronizados de reformas que, no caso do Law \& Finance, replicam receitas do common law. Cumpre lembrar, ainda, que as perspectivas abordadas nas seções 4.3 e 4.4 também são críticas às teses e sentidos de reformas do Law \& Finance.

4.2.2.1 Aproximações entre civil law e common law e efeitos da Segunda Guerra Mundial sobre finanças

Mark Roe (2006) é um dos autores que atacam a metodologia do Law \& Finance, contribuindo para lançar dúvidas sobre a consistência do tratamento estatístico dos dados empíricos por LLSV. Um primeiro ataque diz respeito ao pressuposto mais essencial do Law \& Finance: a existência de diferenças significativas entre o common law e o civil law quanto às instituições jurídicas que incidem sobre finanças. Outro ataque é feito mediante a apresentação de variável que se correlaciona fortemente ao desenvolvimento de mercados financeiros robustos, mas que está ligada à política, e não a “dotações jurídicas": a ocupação por potência estrangeira durante a Segunda Guerra Mundial.

No primeiro aspecto, Roe aponta que o common law e o civil law já não são mais tão diferentes entre si. Convencionalmente, o common law é descrito como sistema de produção normativa centrado no precedente e na prudência judiciais, ao passo que o civil law tem centralidade na legislação. No entanto, ao menos no que diz respeito à regulação financeira, os dois sistemas têm se aproximado, erodindo a distinção (2006, p. 475-8). Ao passo que ambos passaram a "regular e codificar" - até mesmo os Estados Unidos, via Securities and Exchange Commission (2006, p. 473) -, projetando uma feição típica do civil law, também os países dessa linhagem "adotaram modos do common law” (2006, p. 476), e expressão disso é a maior importância prática que os precedentes passaram a ter em seus ordenamentos jurídicos. Parafraseando Milton Friedman ${ }^{239}$, Roe afirma: "somos todos codificadores agora" (2006, p. 479), e sintetiza esse primeiro argumento:

As diferenças nas origens jurídicas provavelmente nunca foram fortes o suficiente para explicar bem as diferenças no desenvolvimento financeiro. Quaisquer diferenças gerais que tenham existido passaram por muita erosão. Os sistemas de common law regulamentam e legislam, assim como fazem as nações do civil law.

239 "We're all Keynesians now." 
Além do mais, a função procurada - proteção ao investidor especificamente, e aos direitos de propriedade em geral - pode ser atingida por múltiplos meios. (Roe, 2006, p. 516)

Assim, haveria um erro de construção na teoria das origens jurídicas, já que, não sendo tais origens significativamente diferentes, elas não poderiam ser empregadas como variáveis independentes para explicar efeitos sobre o formato das instituições jurídicas, o grau de proteção a investidores, o formato e tamanho de mercados financeiros e, em última análise, o grau de desenvolvimento econômico. Roe propõe que outra variável seja correlacionada a essas últimas, a partir da constatação de que quase todas as nações centrais do civil law sofreram invasão militar e devastação durante o século XX, e em especial durante a Segunda Guerra Mundial. O autor afirma que o conflito produziu efeitos diferentes sobre as instituições dos dois grupos de países: ao passo que os principais países do common law não sofreram invasão - como Estados Unidos e Grã-Bretanha -, resultando em uma sobrevivência "mais ou menos intacta" de suas instituições, o mesmo não aconteceu com os países do civil law, cujas "instituições foram destruídas e então reconstruídas no ambiente político do póssegunda guerra.” (2006, p. 482) Nesse ambiente, a reconstrução institucional de países devastados tendeu a privilegiar a proteção aos mercados de trabalho e a alocação pública do capital, refletindo preferências de um eleitorado cuja riqueza havia sido afetada pelo conflito. Roe apresenta a hipótese de que tais eleitores "se importariam pouco com a proteção do capital financeiro porque tinham pouco dele e porque seu bem-estar encontrava-se mais vinculado a seu capital humano." (2006, p. 498) Como resultado, nos países de civil law afetados pelo conflito, o cenário político não era favorável aos mercados (market-friendly) (2006, p. 502).

Em contraste, os principais países do common law foram relativamente menos afetados pela destruição, o que Roe associa a instituições mais favoráveis aos mercados financeiros (2006, p. 495). Roe emprega o caso da Suíça - país com mercados financeiros "sólidos" (2006, p. 508) -, para reforçar essa tese:

Suspeito não ser acidente que a Suíça - uma nação do civil law - tenha mercados de
valores mobiliários e índices de desconcentração societária (ownership separation
numbers) mais próximos aos dos Estados Unidos e da Grã-Bretanha do que aqueles
da França ou da Alemanha: a Suíça é um dos poucos países principais (core) do civil
law que não foram destruídos durante o século XX. (2006, p. 498-9)

Outro elemento apontado por Roe para lançar dúvidas sobre a teoria das origens, e para reforçar a explicação baseada nos efeitos do conflito militar, reside na constatação de que as "[d]iferenças financeiras entre nações ocupadas e não ocupadas, e entre nações do civil e 
do common law, esvaeceram-se no Ocidente rico conforme o ano de 1945 se tornou mais distante." (2006, p. 510)

A dissipação, na última década, dos principais efeitos financeiros do pós-segunda guerra no Ocidente rico nos diz que as diferenças nas finanças foram provavelmente locais e temporárias, não decorrentes de características persistentes incrustadas nas origens jurídicas, mas de variações do pós-guerra na política, nas políticas públicas, e nas tarefas econômicas. (2006, p. 517)

Para Roe, portanto, os elementos que explicam as diferenças institucionais ligadas às finanças são afeitos a conflitos, à economia política, a circunstâncias localizadas e temporárias. Os dois ataques de Roe podem ser sintetizados numa só afirmação: o movimento Law \& Finance realiza correlações espúrias entre, de um lado, o tamanho e dinamismo de mercados financeiros na atualidade e, de outro, as origens medievais, bastante remotas, dos ordenamentos jurídicos.

\subsubsection{Estendendo as críticas ao Law \& Finance}

Outra série de críticas ${ }^{240}$ desfere ataques ainda mais abrangentes ao Law \& Finance, levantando aspectos e embasamentos diferentes daqueles abordados por Mark Roe (2006). Tais críticas se voltam a quatro pontos principais, que dizem respeito (i) à tese da superioridade do common law (que contém questionamentos mais abrangentes sobre o papel do rule of law) para a promoção do crescimento econômico; (ii) à concepção estática de "dotação jurídica" como possível determinante de desfechos econômicos; (iii) a abordagem de reformas como assunto formal, tecnocrático e politicamente neutro e (iv) à abordagem do direito com foco reduzido à sua função "protetiva". Esses aspectos são abordados a seguir.

"Rule of law" e superioridade do "common law"

$\mathrm{Na}$ abordagem de Law \& Finance, a existência do rule of law é o elemento que ampara o crescimento econômico, via mercados financeiros. Assume-se uma relação causal que "corre em uma direção: do direito às instituições econômicas e ao crescimento." (Milhaupt; Pistor, 2008, p. 21) Uma vez configurada essa relação, há a afirmação adicional de que o sistema do common law - em especial aquele incorporado nas instituições jurídicas dos Estados Unidos - provê o modelo mais próximo do que seria o ideal de rule of law. Esse

\footnotetext{
${ }^{240}$ Tais críticas foram levantadas com base, sobretudo, em Milhaupt e Pistor (2008) e Pistor (2009). Certos aspectos de Woo (2007) e Kennedy (2011) são convergentes com essas críticas e foram utilizados de modo complementar.
} 
modelo é tomado, portanto, como o "benchmark" do qual deriva um "menu bastante padronizado de reformas jurídicas” (2008, p. 5) para outros cantos do globo.

Milhaupt e Pistor (2008, p. 5) apontam, porém, que relações como estas não servem para explicar "algumas das histórias de sucesso econômico mais importantes do século XX, como as do Japão, Coreia do $\mathrm{Sul}^{241}$ e, mais recentemente, da China." Além disso, salientam em linha com Chang (2002) em Kicking away the ladder - que o desenvolvimento precoce de muitos países precedeu o estabelecimento do "rule of law tal como esse termo é amplamente compreendido e discutido na literatura contemporânea." (Milhaupt; Pistor, 2008, p. 220) Essa inversão temporal compromete a concepção de causalidade que LLSV propõem: rule of law primeiro, crescimento econômico em seguida.

Ainda em relação com o argumento do rule of law, Milhaupt e Pistor (2008) contrariam a afirmação de superioridade das instituições moldadas segundo o common law. Esse ataque se dirige ao modo como LLSV trabalharam os dados que resultaram na associação entre common law e crescimento econômico. Esses dados se referem principalmente aos anos 1990 e, apenas no caso de alguns estudos, se estendem aos anos 1960. Em contraste, Milhaupt e Pistor (2008) repetiram as correlações de LLSV para o período compreendido entre 1870 e 2000, e constataram que “[e]m todos os períodos, países pertencentes a pelo menos alguma família do civil law cresceram mais rápido que os países do common law (2008, p. 23). Essa constatação permite, por sua vez, a afirmação de que "não há um só tipo de sistema jurídico exclusivamente associado ao sucesso econômico.” (2008, p. 220)

Como notado anteriormente, a literatura de Law \& Finance atribui a superioridade do common law a suas feições de apoio às transações privadas nos mercados e ao estímulo à

\footnotetext{
${ }^{241}$ Milhaupt e Pistor apontam que "dispositivos extrajurídicos" (extralegal devices) em operação no Japão, na Coreia do Sul e na China podem "servir como fundamento para o sucesso econômico, ao menos até certo ponto." (2009, p. 39) Entre eles, está a prática de administrative guidance, ou orientação administrativa da atividade empresarial pelo Estado (2009, p. 41). O estudo de Meredith Woo na obra de Chang (2007) aborda essa prática com maior atenção, focalizando os casos do Japão e da Coreia do Sul. Administrative guidance é ali definida como prática estatal pela qual "a política econômica é formatada e implementada por mecanismos informais, conscientemente isolados da interferência do sistema jurídico formal." (Woo, 2007, p. 162) Como resultado, há "ampla discricionariedade para que a burocracia faça, interprete e aplique regras detalhadas de comportamento econômico." (2007, p. 164) Woo argumenta, em especial, que o uso de administrative guidance foi ainda mais importante para o desenvolvimento da Coreia do Sul do que no caso do Japão, por não ter sido apenas usada para dar "empurrões" (to nudge) na economia, mas também para reformá-la por meio da "reorganização industrial de 1998, que propunha encontrar a vantagem comparativa industrial de cada conglomerado e então exigir que as firmas se ativessem a ela. O objetivo final era reduzir o sobreinvestimento pela redução do número de firmas em um mesmo setor industrial, forçando as firmas a focar sua 'competência principal' após anos de diversificação excessiva e redundante.” (2007, p. 168) Em outros termos, a orientação estatal organizou a competição entre conglomerados industriais coreanos, permitindo que estes se especializassem com segurança e adquirissem ganhos de escala na produção, o que favoreceu seu posicionamento estratégico como empresas globalmente competitivas em setores de uso intensivo em tecnologia.
} 
ampliação das finanças. Ao considerar esses fatores, Pistor afirma que o elemento normativo subjacente à abordagem de LLSV é a "amistosidade aos mercados (market friendliness)" (Pistor, 2009, p. 1659), que adota como pressuposto que mercados financeiros maiores e menos regulamentados são melhores. No entanto, a ocorrência da crise financeira global de 2008 contribuiu para colocar em questão a validade desse elemento normativo, tanto no sentido de que "políticas públicas amistosas aos mercados nem sempre estão produzindo crescimento sustentado" (2009, p. 1660), quanto de ser dubitável que "maiores mercados de ações ou de crédito sejam necessariamente o melhor" (2009, p. 1652).

\section{Perspectiva "estática” da dotação jurídica}

As produções de Law \& Finance encaram as instituições jurídicas como resultados de “dotações” ou legados históricos. Há um elemento estático nessa concepção, segundo a qual as origens medievais dos ordenamentos jurídicos mantêm seus efeitos determinativos de desfechos econômicos através dos tempos. Além disso, o direito é tomado como a variável exógena e independente, e não como elemento que interaja com seu contexto e que responda a mudanças econômicas: “a posição do sistema jurídico em relação aos mercados é encarada como exógena e fixa." (Milhaupt; Pistor, 2008, p. 21) Em contraste com essa noção, Milhaupt e Pistor propõem uma concepção dinâmica, de "relação rolante" (rolling relation) entre direito e mercados: "o direito não deveria ser visto como fixo, mas fluido: uma relação rolante, não uma dotação.” (2008, p. 219) Essa mudança de visão implica atribuir menor importância às origens remotas de um ordenamento jurídico e suas características formais, e mais a "como os sistemas jurídicos" mudam na prática, resultando num ataque à literatura de Law \& Finance que Pistor (2009) formula da seguinte maneira:

\footnotetext{
se - como sugerimos - sistemas jurídicos e econômicos engajam-se em uma relação rolante, tentativas de encontrar os determinantes últimos para resultados observados quer no direito ou na economia (ou na política, para esse propósito) devem ser fúteis, já que isso sugere que a relação entre esses diferentes fatores é altamente endógena. (Pistor, 2009, p. 1664)
}

Esse ponto engloba a importância das instituições informais para desfechos econômicos, e não apenas das instituições "no papel" - ponto que converge com críticas da linhagem de Ha-Joon Chang (cf. 2007a; 2007b) às abordagens institucionais convencionais. Este aspecto, por sua vez, guarda relação com o tópico dos transplantes de instituições formais como estratégia de mudança jurídica favorecida pelo Law \& Finance. 
Transplantes como empreitada formal, tecnocrática e apolítica

As reformas propostas pelos estudos de Law \& Finance enfatizam mudanças nas instituições jurídicas formais por meio de "transplantes" a partir do common law, deixando de lado considerações de que "a natureza da demanda pelo direito transplantado e processo pelo qual ele é incorporado à estrutura institucional do país que o recebe significativamente afetam se e como o transplante irá funcionar.” (Milhaupt; Pistor, 2008, p. 208) Parte da desatenção ao contexto local deriva de uma abordagem com foco na oferta (supply-side) sobre as instituições jurídicas. Nesta concepção, o provimento das instituições jurídicas “corretas”, nos moldes do benchmark do direito anglo-americano, resultará no ambiente institucional favorável à expansão dos mercados financeiros e, por conseguinte, em desenvolvimento. Para a abordagem de supply-side, as reformas são imperativos de ordem técnica, politicamente neutros, refletindo uma concepção do direito e dos mercados "desentranhada" (disembedded) da sociedade (cf. Milhaupt; Pistor, 2008, p. 20).

Milhaupt \& Pistor propõem encarar o problema em termos de uma "economia política" das instituições jurídicas. As instituições jurídicas não são independentes do sistema político e da demanda existente para que elas existam. Há necessidade de demanda local por instituições ofertadas por instituições como o Banco Mundial para que elas possam de fato funcionar. $\mathrm{Na}$ ausência de demanda, o transplante pode ser rechaçado na prática por mecanismos de contestação, ou "o processo pelo qual as estruturas de governança existentes podem ser desafiadas e adaptadas ao ambiente socioeconômico cambiante em resposta à demanda." (Milhaupt; Pistor, 2008, p. 206) Sem que haja demanda por relevantes atores locais, as instituições formais permanecerão no papel:

\begin{abstract}
o desempenho de um transplante jurídico depende da extensão na qual as mudanças estão alinhadas com a conduta de advogados, juízes e burocratas na aplicação (applying and enforcing) da lei. E tal como ocorre com uma lei feita domesticamente, a conduta de aplicação é profundamente afetada pela demanda pelo transplante jurídico dentre os atores relevantes (relevant constituencies) que dão sustentação ao sistema de governança existente. Nossa teoria é que o transplante jurídico se encaixará na jurisdição que $\mathrm{o}$ recebe se for suficientemente correspondente à demanda para que a comunidade jurídica integre o direito transplantado ao sistema jurídico que o circunda. (Milhaupt; Pistor, 2008, p. 210)
\end{abstract}

Em outros termos, Milhaupt e Pistor criticam a abordagem de supply-side de reformas do Law \& Finance e sua concepção de instituições jurídicas e de mercados "desentranhada" de instituições sociais. Ao invés disso, propõem a abordagem de demand-side para compreender a adesão local às reformas pretendidas, favorecendo a visão de instituições 
jurídicas "incrustadas em uma gama de outras regras e instituições complementares" (2009, p. 20), que interagem com elas e afetam seu funcionamento prático.

\title{
A função exclusivamente protetiva do direito
}

As análises de Law \& Finance atribuem ao direito uma função protetiva, dirigida sobretudo aos direitos de propriedade e contratos, mas também a direitos individuais correlatos ao dinamismo da esfera privada e em particular dos mercados financeiros (Milhaupt; Pistor, 2008, p. 21, 31; Pistor, 2009, p. 1666-7). "Nenhuma consideração séria é feita quanto à possibilidade de que o direito possa desempenhar outras funções em suporte à atividade econômica." (Milhaupt; Pistor, 2008, p. 21) Esta concepção reflete "prescrições econômicas neoliberais" - em particular avançadas pela NEI - de que "direitos de propriedade 'fortes e claros' são pré-requisito para o funcionamento de uma economia de mercado, e de que provê-los promoverá eficiência e crescimento.” (Kennedy, 2011, p. 2) A limitação do direito à função exclusivamente protetiva concilia-se, no fundo, com um tema transversal a diversas literaturas: a noção de que as instituições devem ser moldadas de modo a apoiar as atividades dos mercados, estes sendo o núcleo da concepção de organização da sociedade:

\begin{abstract}
o mercado no estado de natureza permanece sendo o tipo ideal em relação ao qual os mercados do mundo real são avaliados (benchmarked). Os elementos institucionais são complementos, não constitutivos dos mercados. Sua função é tornar os mercados mais próximos de sua suposta verdadeira natureza. A implicação é que há apenas um modelo ótimo (eficiente) de mercado e apenas um conjunto ótimo de regras que podem conduzir a ele. (Pistor, 2009, p. 1652)
\end{abstract}

Milhaupt e Pistor enfatizam, porém, múltiplas funcionalidades do direito ${ }^{242}$. Há duas funções básicas e duas suplementares. Entre as funções básicas encontram-se, além da proteção, a coordenação de relações econômicas. Afinal, o "desenho de sistemas jurídicos pode ser utilizado para refletir preferências sociais e políticas pela barganha coletiva e pela coordenação em contraste à garantia (enforcement) individualizada de direitos." (Milhaupt; Pistor, 2008, p. 34) São exemplos do emprego da função coordenativa do direito em relação à economia as práticas de administrative guidance, já mencionadas, além do exemplo bastante enfatizado na literatura de variedades de capitalismo a respeito da determinação jurídica, existente na Alemanha, de que metade dos membros de conselhos diretivos de companhias sejam eleitos por empregados (cf. Milhaupt; Pistor, 2008, p. 181). Para saber se um sistema

\footnotetext{
${ }^{242}$ Para outra concepção de papéis e funções do direito, com pontos de contato com a caracterização de Milhaupt e Pistor (2008) aqui abordada, cf. Coutinho (2013, p. 95-101).
} 
jurídico pende mais à proteção ou à coordenação, os autores propõem que se avalie "como ele propõe resolver interesses conflitantes":

Alguns sistemas optam pela litigância entre demandantes contrapostos, cada qual sustentando ter um direito exclusivo [...]. Contraste isso com sistemas que abertamente desencorajam mecanismos formais de solução de disputas e, ao invés, encorajam ou constrangem demandantes contrapostos a usar canais menos formais de barganha e coordenação. (Milhaupt; Pistor, 2008, p. 181) ${ }^{243}$

Apesar de introduzirem esse critério de diferenciação, as funções do direito não são encaradas como mutuamente excludentes, mas complementares (2008, p. 36). É até mesmo possível fazer uma leitura no sentido de que a própria escolha dos direitos de propriedade a proteger já envolve uma função coordenativa do direito, ao menos em sentido ampliado. Essa interpretação encontra elementos de sustentação em aspectos levantados por David Kennedy, que enfatiza a variedade dos regimes de propriedade envolvidos em diferentes estratégias de desenvolvimento e o elemento de escolha entre titularidades nelas imbricado:

as economias avançadas do Ocidente moderno experimentaram períodos de
industrialização agressiva e crescimento econômico com uma ampla gama de
diferentes regimes de propriedade em operação. Regimes de propriedade se
diferenciam, por vezes dramaticamente, entre sociedades industrializadas, e todas
estas sociedades abrigam uma variedade de diferentes regimes formais e informais.
O crescimento econômico com frequência dependeu da erosão ou eliminação de
titularidades tradicionais, assim como gerou novos direitos e novas formas de
propriedade. [...] Usar a propriedade como instrumento para estratégia de
desenvolvimento requer escolher - entre interesses econômicos variados e entre
modos de titularidades. O instrumento estratégico pode muito bem ser a força ou
clareza relativa de um, ao invés de outro, interesse jurídico. Em qualquer regime de
propriedade algumas titularidades serão fracas e vagas, outras fortes ou claras. A
configuração estratégica de um regime de propriedade requer análise cuidadosa do
impacto econômico de tornar alguns direitos fortes ou algumas titularidades claras
em detrimento de outras. (Kennedy, 2011, p. 6 )

A abordagem de desenvolvimento versada em termos de incrementos de proteção e clareza dos direitos de propriedade mostra-se, a partir dessas considerações, inadequada por obscurecer as escolhas subjacentes à definição de um regime de propriedade: sobretudo quais titularidades serão resguardas, e em detrimento de que outras. Mesmo a definição dos elementos envolvidos na função protetiva do direito acaba por abranger aspectos de coordenação - não tanto em termos de estabelecimento de mecanismos de barganha coletiva

\footnotetext{
${ }^{243}$ David Kennedy complementa esse ponto ao afirmar: "A atividade econômica, nesta visão, acontece fora do poder estatal e prospera mais quando deixada só. Atualmente, pode parecer que a modernização e o crescimento nas regiões menos desenvolvidas do mundo requer que este domínio econômico seja libertado do controle do Estado desenvolvimentista assim como uma vez ele foi libertado do feudalismo e do mercantilismo. [...] Não é incomum associar direitos de propriedade fortes e claros a um Estado fortemente contido e concomitantemente com um mercado privado robusto, capaz de funcionar como motor de crescimento e garantidor de eficiência." (Kennedy, 2011, p. 7)
} 
no lugar de vias para litigância individual (sentido mais estrito), mas de uma escolha estatal com implicações econômicas coletivas e estratégicas (sentido mais amplo) ${ }^{244}$.

Além das funções básicas (protetiva, coordenativa) do direito, Milhaupt e Pistor (2008) relacionam a sinalização e provimento de credibilidade como papéis suplementares do direito. A sinalização está ligada à transmissão de informações, que nos mercados tende a se incorporar ao mecanismo de preços. Diante disso, as sinalizações do direito podem revestir-se de caráter estratégico:

O direito não apenas ajuda a estabelecer as regras pelas quais as atividades de mercado acontecem, mas também a fazer afirmações mais amplas sobre prioridades governamentais, a direção futura das políticas públicas, a força relativa de grupos de interesse quanto a um assunto específico, e outras informações que podem ser úteis para atores nos mercados. (Milhaupt; Pistor, 2008, p. 34)

Por fim, o direito exerce a função de prover credibilidade "às estruturas de governança fornecidas pelo Estado.” (Milhaupt; Pistor, 2008, p. 35) O direito dá condições para que os agentes acreditem nas sinalizações do Estado e atuem de modo correspondente. "Na ausência de tais estruturas de governança, cada desfecho precisa ser barganhado e implementado do zero." (Milhaupt; Pistor, 2008, p. 35)

Ao ressaltar essa variedade de funções do direito em relação à atividade econômica, Milhaupt e Pistor criticam a abordagem de Law \& Finance em seu enfoque exclusivo na função protetiva dos sistemas jurídicos. No fundo, porém, o foco dessa literatura nessa função restrita corresponde à visão "amistosa aos mercados" e que vê com desconfiança a atuação estatal na economia, ao passo que a ampliação das funcionalidades do direito de Milhaupt e Pistor corresponde a papéis mais ativos do Estado nos mercados. De certo modo, esse elemento é reflexo da formação de um novo momento nas discussões sobre direito e desenvolvimento que, entre outras feições, resgata a importância de funções mais destacadas para as instituições jurídicas e o Estado na economia, sem menosprezar a atuação privada. Neste novo momento, a própria noção de desenvolvimento - antes versada de modo praticamente exclusivo em termos de crescimento econômico - passa a incorporar objetivos jurídicos. Essa nova configuração intelectual, crítica às abordagens jurídicas sobre desenvolvimento fundadas no paradigma rule of law (e de suas recomendações de reformas para políticas públicas), é o tema da seção 4.3 , mais adiante.

\footnotetext{
${ }^{244}$ Essas considerações remetem ao papel do Estado como "gestor de conflitos" em Ha-Joon Chang (1994). Vide, no capítulo anterior, o item 3.4.2.1.
} 
A seguir, a subseção 4.2.3 oferece exemplos de reformas que ocorreram no direito brasileiro segundo as orientações do Law \& Finance, criticamente relatadas na obra Direito e crédito bancário no Brasil, de Emerson Fabiani ${ }^{245}$ (2011).

4.2.3 Algumas aplicações do Law \& Finance em reformas no setor de crédito bancário no $\underline{\text { Brasil }}$

Certas reformas em políticas públicas relacionadas a crédito bancário no Brasil antecederam a influência do Law \& Finance sobre as orientações no Banco Mundial. Entre elas está a decisão de ampliar o "grau de abertura do setor bancário ao capital estrangeiro", em 1995 (Fabiani, 2011, p. 30). Mudanças como essas foram instruídas por análises "de ordem econômica e, quando microeconômicas, de viés concorrencial." Algo diferente ocorreria a partir de 1999, quando hipóteses do Law \& Finance começaram a integrar explicações informadoras de reformas:

\begin{abstract}
falhas institucionais também seriam fatores explicativos fundamentais para o parco desenvolvimento do mercado de crédito. Essa conjectura, cada vez mais difundida, aponta a debilidade do regime de proteção do investidor e a incapacidade do sistema judiciário de fazer valer contratos (falta de enforcement) como principais responsáveis pelo baixo volume e pelos altos custos do crédito em circulação. (Fabiani, 2011, p. 32)
\end{abstract}

A primeira das reformas analisadas por Fabiani é a criação da cédula de crédito bancário pela Medida Provisória 1925/1999. Antes, credores - inclusive instituições financeiras - normalmente precisavam percorrer duas modalidades processuais distintas para a obtenção judicial do pagamento de dívidas: o processo de conhecimento e o de execução. Nesse contexto, o contrato de abertura de crédito em instituições financeiras não era considerado um título executivo extrajudicial. O ponto era sumulado pelo Superior Tribunal de Justiça (STJ), impedindo que credores "pulassem" a etapa do processo de conhecimento e partissem diretamente para o processo de execução. Com a reforma que introduziu a cédula de crédito bancário, não só os contratos de abertura de crédito, como também "toda promessa de pagamento em dinheiro feita a instituição financeira em operações de crédito", passaram a contar com uma forma jurídica que lhes conferia força executiva (Fabiani, 2011, p. 61-2). A inovação jurídica favoreceu a previsibilidade e a celeridade "na constituição de garantias e na cobrança judicial dos débitos", havendo "correspondências exatas entre a medida implementada e as regras valorizadas pela Law and Finance." (2011, p. 64)

\footnotetext{
${ }^{245}$ Autor que se enquadra na moldura do NDD (vide seção 4.3 a seguir; cf. Castro, 2014a).
} 
Outra reforma que reflete recomendações dessa perspectiva foi o aumento do alcance da alienação e cessão fiduciárias. Na década de 1960, a introdução da instituição jurídica da alienação fiduciária significava a "transferência da propriedade resolúvel e da posse indireta de um bem móvel para o credor, como garantia do cumprimento de uma obrigação pelo devedor, que se tornava possuidor direto do bem em questão.” (Fabiani, 2011, p. 66) Essa restrição a bens móveis foi alterada ao longo do tempo. Modificações anteriores a 1999 permitiram a "alienação fiduciária de ações das sociedades anônimas" e de bens imóveis. A Medida Provisória 2160/2001 expandiu ainda mais esse rol, permitindo a incidência sobre "coisas fungíveis nas operações no âmbito do mercado financeiro e de capitais." (Fabiani, 2011, p. 66) As mudanças não só ampliaram a "gama de objetos passíveis de servir como garantia fiduciária" em transações financeiras, como também dispensaram "formalidades ou o envolvimento do Poder Judiciário na realização da garantia" ao estipular que, na ausência de disposição contratual em contrário, os bens objetos de alienação ou cessão fiduciária "ficarão na posse direta e indireta do credor." (2011, p. 66) Fabiani considera que

a medida de extensão do alcance da alienação fiduciária aumenta o nível de proteção
dos credores nas dimensões da previsibilidade e da celeridade, vez que prevê
mecanismos para minorar os riscos de comportamento oportunista do devedor, dá
soluções inequívocas para temas que eram objeto de discussões judiciais e confere
mais agilidade para os processos de constituição e realização de garantias. (Fabiani,
2011, p. 69)

A terceira modificação foi o reconhecimento do acordo para compensação de pagamentos. No mercado financeiro é comum que duas partes sejam simultaneamente credora e devedora uma da outra em razão de celebrarem diversos contratos paralelamente. Nessas circunstâncias, "presume-se que as obrigações são cumpridas à medida que vencem os prazos contratuais." Há, porém, margem para que o administrador de uma empresa em processo de falência escolha "quais contratos devem ser cumpridos e quais não devem", de modo que a parte solvente se veja "obrigada a saldar débitos presentes, independentemente da existência de créditos futuros com a mesma empresa falida." (Fabiani, 2011, p. 70-1) A Medida Provisória 2192/2001 introduziu a compensação de pagamentos nos processos falimentares, retirando "a decisão sobre cumprir ou não cumprir o contrato da esfera de controle do administrador da massa, em nome da regularidade dos comportamentos e da higidez do sistema financeiro.” (Fabiani, 2011, p. 73) 
A quarta alteração alinhada ao Law \& Finance foi a previsão legal do crédito consignado em folha de pagamento, introduzia pela Lei $10820 / 2003^{246}$, e que estabeleceu a possibilidade de empregados celetistas, aposentados e pensionistas do Instituto Nacional de Seguro Social (INSS) “autorizarem o desconto, diretamente na folha de pagamento, de débitos correntes de contratos de empréstimo, de financiamento e de arrendamento mercantil." (Fabiani, 2011, p. 74-5) Na prática, criou "novo instrumento de crédito, marcado por baixo risco de inadimplência e, por isso, mais atrativo para as instituições financeiras e mais barato para o tomador de recursos." (Fabiani, 2011, p. 75)

A quinta medida analisada por Fabiani foi a reforma da lei de falências. A legislação falimentar brasileira que vigorou até 2005 , entre outros aspectos, dava prioridade ilimitada a créditos trabalhistas e fiscais, além de tornar o adquirente de ativos da massa falida o sucessor em seus débitos fiscais (Fabiani, 2011, p. 78). Essa configuração correspondia a diagnósticos de desvalorização dos ativos em processos falimentares, em prejuízo dos credores (Fabiani, 2011, p. 80). Passava, além disso, uma mensagem de risco adicional para os investimentos em empresas brasileiras. A lógica de intervenção consistiu em incrementar a posição dos credores com garantias reais em contextos falimentares, com suspensão temporária de execuções e "limitação quantitativa dos créditos trabalhistas a serem satisfeitos prioritariamente" e decréscimo na ordem de preferência dos créditos tributários (Fabiani, 2011, p. 81-2). Além disso, os adquirentes de filiais, unidades produtivas isoladas ou ativos deixaram de tornar-se sucessores das obrigações tributárias das empresas em processo de recuperação judicial ou falência (Fabiani, 2011, p. 82).

Por fim, Fabiani agrupa uma série de alterações correspondentes à racionalização dos processos judiciais, ou seja, a "remoção de obstáculos procedimentais que provocam congestionamento no Poder Judiciário.” (Fabiani, 2011, p. 88) Entre as medidas introduzidas estão (i) o poder conferido ao Supremo Tribunal Federal (STF) para editar súmulas vinculantes, de aplicação obrigatória por todos os juízes e pela Administração Pública; (ii) modificações no processo civil destinadas a simplificar a intimação e penhora de bens de devedores; (iii) remoção de possibilidades recursais, a exemplo da limitação das hipóteses de cabimento do agravo de instrumento no processo civil e a introdução de tratamento diferenciado - com decisão por amostragem - para recursos repetitivos etc. (cf. Fabiani, 2011, p. 87-92). As alterações foram destinadas a conferir celeridade aos meios de execução e a “diminuir as possibilidades de comportamento oportunista do devedor" (Fabiani, 2011, p. 93),

\footnotetext{
${ }^{246}$ Recentemente, a Medida Provisória 681/2015 estendeu de 30\% para o 35\% o montante da remuneração consignável como garantia de pagamento em contratos creditícios.
} 
via redução dos mecanismos que tornavam o judiciário um meio para protelação do pagamento de dívidas.

Fabiani analisa documentos elaborados pelo Banco Central do Brasil e a Secretaria de Política Econômica do Ministério da Fazenda entre os anos de 1999 e 2006, e que instruíram as alterações legislativas caracterizadas acima, constatando correspondência entre as medidas propostas e o receituário da "perspectiva da dotação institucional" - o amálgama entre a literatura do Law \& Finance e da NEI, que exerce influência sobre o Banco Mundial. Nesse sentido, chega a duas principais conclusões:

(a) para embasar a proposição de algumas medidas, os documentos oficiais citam referências teóricas da perspectiva da dotação institucional; e (b) as medidas analisadas encontram-se, todas elas, mencionadas em relatórios do Banco Mundial como atividades preparatórias para a obtenção de financiamento ou como resultado de projetos financiados. (Fabiani, 2011, p. 122)

Especificamente, as transformações em instituições jurídicas ligadas ao crédito bancário assumiram os sentidos comuns de incrementar a "previsibilidade de comportamentos" e a "celeridade procedimental" do direito brasileiro (Fabiani, 2011, p. 122), atributos dos ambientes institucionais considerados propícios ao desenvolvimento dos mercados financeiros.

A pesquisa de Fabiani evidencia a relevância prática dos estudos de Law \& Finance para a conformação de instituições jurídicas ligadas à política econômica e políticas públicas no Brasil. Exemplifica, ainda, a permeabilidade dos processos de gênese normativa do ordenamento jurídico nacional a desdobramentos transfronteiriços, que correspondem ao momento da ordenação jurídica das relações internacionais abordado na seção 2.3.

\subsection{Novo Direito e Desenvolvimento}

Embora o paradigma rule of law tenha instruído o mainstream da literatura sobre direito e desenvolvimento e orientado o sentido de reformas institucionais em pontos variados do globo, certas perspectivas críticas, em anos recentes, têm emergido e questionando sua prevalência. As novas contribuições têm matizes variados, havendo dúvidas sobre se chegam a conformar um "campo" a título próprio. No entanto, as críticas agrupadas contêm elementos em comum o suficiente para que se possa falar em um novo momento no debate sobre direito e desenvolvimento. Vários termos são empregados para rotular essas contribuições e as novas práticas institucionais a que fazem referência: "Novo Direito e Desenvolvimento" 
(NDD), "novo desenvolvimentismo", "novo Estado desenvolvimentista", "novo ativismo estatal", "direito e desenvolvimento no século XXI" etc.

Um momento marcante para as formulações do NDD foi a publicação da obra The new law and economic development: a critical appraisal, organizada por David Trubek e Alvaro Santos, em 2006. O livro se mostrou importante referência para estudos posteriores. Na esteira de sua publicação, o projeto LANDS - Law and the New Developmental State - foi iniciado por David Trubek em 2007, com abrangência transnacional (Universidade de Wisconsin, Direito GV - São Paulo, Centro Brasileiro de Análise e Planejamento - CEBRAP, e Faculdade de Direito da Universidade de Los Andes - Colômbia) e apoio da Fundação Ford (cf. LANDS, 2015). No Brasil, o projeto Conference on Global Law and Development encontra-se ligado às articulações do LANDS (cf. CGLAD, 2015). Esses projetos têm resultado, em anos recentes, na publicação de obras pertinentes ao NDD, dentre as quais destacam-se Direito e desenvolvimento: um diálogo entre os BRICS (Schapiro; Trubek, 2012) e Law and the new developmental State: the Brazilian experience in Latin American context (Trubek; Alviar Garcia; Coutinho; Santos, 2013), com contribuições de autores variados e enfoque em aspectos diversos de políticas públicas.

Ao passo que a subseção 4.3.1 busca contextualizar essas novas contribuições diante de seus precedentes históricos, seus contornos são melhor especificados na subseção 4.3.2. Por fim, alguns exemplos selecionados de análises jurídicas de políticas públicas no Brasil que se encaixam na moldura do NDD são trazidos na subseção 4.3.3.

\subsubsection{Momentos antecedentes ao Novo Direito e Desenvolvimento}

O Novo Direito e Desenvolvimento (NDD) foi precedido por dois outros momentos. O primeiro deles começou a tomar forma na década de 1960 e entrou em crise na década de 1970. Foi o direito do Estado desenvolvimentista ${ }^{247}$. O segundo, por sua vez, dominou as décadas de 1980 e 1990, marcado por ideias associadas ao neoliberalismo e, como manifestação destas no campo institucional, pelo paradigma rule of law - cujos apoios, desde o direito, foram abordados nas seções 4.1 e 4.2. Os itens a seguir buscam caracterizar, ainda que brevemente, o contexto que serve de contraponto às ideias do NDD.

\footnotetext{
${ }^{247}$ A respeito dessa delimitação temporal, vide ressalva adiante, no item 4.3.1.1.
} 


\subsubsection{Primeiro momento: direito e Estado desenvolvimentista}

Parte da assistência ao desenvolvimento no pós-Segunda Guerra Mundial assumiu a forma de programas de reformas nas instituições jurídicas. Na década de 1960, certas agências de desenvolvimento e fundações mostraram algum interesse por articulações do direito que o concebiam como instrumento para políticas estatais voltadas ao crescimento econômico. Esse momento ficou conhecido como direito e Estado desenvolvimentista, ou ainda como antigo direito e desenvolvimento. É importante ressalvar, porém, que no plano mais abrangente das discussões sobre desenvolvimento, o aspecto jurídico teve interesse reduzido frente a outras ações associadas à sua promoção, num cenário em que os debates sobre desenvolvimento econômico encontravam-se dominados por economistas, com inserção tardia dos juristas (Trubek; Galanter, 2007 [1974], p. 264).

Apesar da existência de algum interesse e de iniciativas práticas de reforma jurídica, esse primeiro momento do debate sobre direito e desenvolvimento perdeu força antes de ter se consolidado em um "campo ou disciplina." (Trubek; Galanter, 2007, p. 265) Segundo Trubek, o interesse pelo estilo de reformas jurídicas proposto pelo primeiro momento declinou na década de 1970 e "perdeu o apoio das agências de desenvolvimento antes que pudesse construir uma base sustentável na academia." (Trubek, 2014, p. 7) Apesar disso, tanto no meio acadêmico quanto no das agências de desenvolvimento, algumas ideias fundamentais "sobre a natureza do direito e sobre as características do desenvolvimento" foram compartilhadas (Trubek; Galanter, 2007, p. 265).

Enquanto durou, a visão de "direito do Estado desenvolvimentista" privilegiou certa noção de desenvolvimento atrelada à modernização e mensurada em termos de crescimento econômico. Qualquer que fosse a vertente de teoria do desenvolvimento empregada desenvolvimento equilibrado, desequilibrado ou mesmo a teoria da dependência -, todas elas encaravam a acumulação de riqueza e a industrialização como "pontos-chave para a superação da defasagem econômica" e apontavam para o Estado como lugar privilegiado para solução dos problemas de ação coletiva (Schapiro; Trubek, 2012, p. 31).

Diferentemente de concepções alinhadas com o segundo momento - como as descritas nas seções 4.1 e 4.2 -, no primeiro momento, o setor privado não era visto como fonte de dinamismo. Era percebido como fraco demais para promover a decolagem rumo ao desenvolvimento sustentado. A presença de setores sociais tradicionais representava resistências a mudanças que, embora destinadas a promover o crescimento econômico, atentassem contra seus interesses particulares. E havia as "falhas de mercado". Como 
resultado, o setor público capitaneava as estratégias para promoção do desenvolvimento. Estas, em muitos países da América Latina, consistiam em industrialização por substituição de importações, planejamento estatal dos investimentos em áreas consideradas estratégicas para o crescimento e propriedade estatal de indústrias e serviços públicos - além de, no plano externo, fluxos de assistência oficial ao desenvolvimento.

Cumpre ressalvar que muitas dessas estratégias - com exceção da assistência oficial ao desenvolvimento - não eram novidades do pós-guerra, tendo precedido as formulações de direito e desenvolvimento aqui referidas. As políticas associadas ao modelo do Estado desenvolvimentista ocorreram em um período mais amplo, que vai da década de 1930 até a de 1980 (Trubek; Coutinho; Schapiro, 2012, p. 4). Essas políticas eram apoiadas, no entanto, em outros referenciais jurídicos. No caso do Brasil, como aponta Marcus Faro de Castro, as reformas em programas de governo correspondentes ao Estado desenvolvimentista - ou seja, até o final da década de 1980 - encontraram apoio em doutrinas do direito administrativo (Castro, 2013; Castro, 2014a, p. 35). De todo modo, o primeiro momento de direito e desenvolvimento abriga as estratégias do Estado desenvolvimentista, ao postular o modelo "de uma economia de mercado regulada em que o Estado desempenhava um papel ativo, não apenas por formas variadas de planejamento e política industrial, mas também pela propriedade das principais indústrias e utilidades.” (Trubek, 2006, p. 75)

Nesse contexto, o papel do direito era essencialmente instrumental: uma ferramenta para que os Estados desenvolvimentistas interviessem na economia e promovessem as mudanças necessárias ao crescimento econômico: um "vetor de transformação da sociedade."248 (Coutinho, 2013, p. 91) Não por outra razão, o foco recaia sobre as instituições de direito público, veículos para os impulsos estatais nas políticas públicas ${ }^{249}$. Porém, nem todo direito era associado com o dinamismo transformador do Estado. Certas instituições jurídicas poderiam configurar barreiras ao desenvolvimento econômico e servir à perpetuação

\footnotetext{
248 "A esse modelo típico ideal de Estado, dedicado a uma política nacional de desenvolvimento econômico ainda dissociada da dimensão social, corresponde um tipo de arcabouço jurídico que tem a incumbência primordial de institucionalizar e operacionalizar o impulso modernizante e industrializante. $\mathrm{O}$ direito possibilita a estruturação de uma tecnocracia voltada para a administração do aparato público, incluindo o gerenciamento de órgãos, empresas e interfaces institucionais, bem como a regulação setorial, o que acarreta uma abundante produção normativa. Regras jurídicas são utilizadas tanto para estruturar o próprio Estado como para estimular setores específicos como siderurgia, construção civil, mineração, petroquímica, gás e petróleo, por exemplo. No limite, o direito é empregado para criar mercados inexistentes, estimulando fluxos e transações que de outra forma não existiriam." (Coutinho, 2013, p. 87)

249 "Diversas ferramentas jurídicas são utilizadas nesse contexto: controle de preços, subsídios, tarifas, quotas, linhas de crédito, licitações e compras públicas, incentivos e renúncias fiscais, monopólios e bancos públicos. Os campos do direito econômico, administrativo, financeiro, tributário, comercial e corporativo são mobilizados pragmaticamente para pôr de pé um projeto de desenvolvimento industrial capitaneado por um Estado conhecedor de meios adequados para chegar a fins legítimos, dentre os quais o aumento da renda da população." (Coutinho, 2013, p. 87)
} 
de setores tradicionais considerados retrógrados, já que "o tipo errado de regras e práticas jurídicas poderia reduzir os incentivos ao investimento e aumentar os custos da inovação" (Trubek, 2014, p. 4). Portanto, o direito poderia tanto facilitar o desenvolvimento canalizando a ação estatal transformadora - quanto colocar-lhe obstáculos (cf. Trubek; Galanter, 2007, p. 265).

Diante dessas possibilidades, parte das reformas articuladas com base nesse primeiro direito e desenvolvimento buscavam "modernizar" o direito de países do "terceiro mundo" a partir de transplantes: "acadêmicos e agências pressupunham que as leis dos Estados Unidos e da Europa representavam uma forma 'moderna' avançada de direito." Outra parte enfatizava a necessidade de mudanças na cultura jurídica e considerava as faculdades de direito "agentes primários da modernização jurídica”, razão pela qual um dos principais focos dos projetos de reforma desse período consistiu na educação jurídica (Trubek, 2014, p. 5; cf. Trubek; Galanter, 2006). A cultura jurídica dos países da América Latina era vista como demasiadamente formalista e carente de "atenção a objetivos de políticas públicas", e portanto como fonte de obstáculos a políticas desenvolvimentistas (Trubek, 2006, p. 76). Os propositores desse estilo de reformas argumentavam que, "ao treinar juristas que pensassem de maneira mais instrumental, as faculdades poderiam iniciar uma mudança que diminuiria a distância entre o desempenho atual das profissões jurídicas e suas possibilidades, relacionadas ao desenvolvimento." (Trubek; Galanter, 2006, p. 271-2) Presumiam, porém, que as "profissões jurídicas eram, ou se tornariam, representantes do interesse público (interesses de 'desenvolvimento') e não agentes que defenderiam interesses de segmentos relativamente pequenos da sociedade." (Trubek; Galanter, 2006, p. 275) Ou seja, favoreciam uma concepção do direito como algo neutro, no sentido de ser mais forte do que as inclinações particulares, ao mesmo tempo que o enxergavam como bom e poderoso, no sentido de que o direito seria de fato capaz de ocasionar as transformações sociais intencionadas (Trubek; Galanter, 2006, p. 290). Segundo Trubek e Galanter, esse modo de pensar o direito e desenvolvimento

\footnotetext{
levou os esforços de assistência a se concentrar na reforma de normas formais; a trabalhar com profissões estabelecidas, a acreditar que mudanças nos ensino dos profissionais produziriam, finalmente, as mudanças sociais desejadas e, acima de tudo, a presumir, quase que automaticamente, que qualquer atividade destinada a transformar as instituições jurídicas dos países do Terceiro Mundo com o fim de torná-las mais próximas àquelas dos Estados Unidos teria valor efetivo e moral. (Trubek; Galanter, 2006, p. 275)
}

Os programas de reforma jurídica orientados por essa concepção falharam em promover as mudanças esperadas. "Investimentos no ensino do direito destinados a 
transformar a orientação e o papel dos juristas resultaram em poucas mudanças, tanto no desempenho do direito quanto nas relações sociais." (Trubek; Galanter, 2006, p. 278, cf. Trubek, 2014, p. 9) O fracasso do primeiro momento do direito e desenvolvimento também foi reflexo do esgotamento do modelo de estado desenvolvimentista em razão de condições econômicas adversas nas décadas de 1970 e 1980, já abordadas no capítulo 3. Em seu momento de crise, o aspecto etnocêntrico ${ }^{250}$ das reformas propostas também foi criticado (Trubek; Galanter, 2006, p. 275-6; Trubek, 2006, p. 80). No entanto, influência da tese da superioridade do common law sobre o paradigma do rule of law, característico do segundo momento do direito e desenvolvimento, demonstra que essa crítica não foi suficiente para que o aspecto etnocêntrico das reformas institucionais fosse abandonado.

4.3.1.2 Segundo momento: direito e desenvolvimento neoliberal ou do paradigma rule of law

A passagem do primeiro ao segundo momento do direito e desenvolvimento, consolidada na década de 1980, foi marcada por três grandes mudanças gerais de ênfase: do Estado ao mercado; de estratégias de crescimento voltadas ao mercado interno para aquelas voltadas ao mercado externo; e de fluxos públicos para fluxos privados de capital (Trubek, 2006, p. 83).

A concepção de desenvolvimento prevalente nesse cenário alterado já não enxerga o Estado como impulsionador das transformações socioeconômicas ligadas ao crescimento. Seu novo papel é o de "fiador institucional", garantidor da "estabilidade das regras do jogo" (Schapiro; Trubek, 2012, p. 36). "A teoria do desenvolvimento deu ensejo às proposições do propalado Consenso de Washington. A identificação do Estado como setor de liderança econômica foi solapada pelas análises de falhas de governo e abriu espaço para o protagonismo do mercado." (Schapiro; Trubek, 2012, p. 34)

O segundo momento de direito e desenvolvimento, assim como o primeiro, também atribuiu papel instrumental para as instituições jurídicas. No entanto, essa instrumentalidade assume direção diferente. Não é mais um veículo para canalizar impulsos transformadores do

\footnotetext{
250 "Tornou-se claro que muitos projetistas haviam empregado um modelo linear de desenvolvimento. Nesse modelo, presumia-se que todas as nações passavam por estágios similares para alcançar um fim comum, representado, nesse tipo de pensamento, pelas estruturas jurídicas, econômicas e sociais dos Estados Unidos e da Europa Ocidental.” (Trubek, 2006, p. 80) A concepção de estágios de desenvolvimento em uma sequência linear remete às formulações de Walt Rostow (1964 [1960]), em Etapas do desenvolvimento econômico. Segundo este autor, seria "possível enquadrar todas as sociedades, em suas dimensões econômicas, dentro de uma das cinco seguintes categorias: a sociedade tradicional; as precondições para o arranco, o arranco, a marcha para a maturidade e a era do consumo em massa.” (Rostow, 1964, p. 14)
} 
Estado na sociedade, mas sim uma moldura para as atividades de mercado $^{251}$ e uma ferramenta de contenção do poder do Estado frente à esfera privada. Como resultado, o direito passou a ser articulado em apoio à "desestatização das economias" e para "reforçar os direitos privados dos agentes econômicos", ou seja, "para garantir as bases de sustentação para um modelo de desenvolvimento menos ancorado na coordenação pública e mais confiante nas transações privadas e espontâneas de mercado." (Schapiro; Trubek, 2012, p. 35) Em contraste com a ênfase no direito público do primeiro momento, o direito privado é o veículo privilegiado de governança ${ }^{252}$ (Schapiro; Trubek, 2012, p. 28).

A partir desses aspectos, é possível notar que a caracterização do segundo momento do direito e desenvolvimento se casa com o paradigma institucionalista do rule of law e suas formulações jurídicas de suporte, abordadas nas seções 4.1 e 4.2. Em outros termos, a AED e o Law \& Finance integram as articulações do "direito e desenvolvimento neoliberal" - que no campo econômico, encontram guarida na NEI de North e Williamson -, impulsionando a agenda de reformas pró-mercados já delineada nas seções mencionadas. Curiosamente, foram estas concepções - refratárias a papéis ativos do Estado na promoção do desenvolvimento que se tornaram o mainstream do direito e desenvolvimento, e não o desenvolvimentismo que o antecedeu. Com o auxílio de seus influxos, o campo de direito e desenvolvimento ganhou espaço acadêmico e consolidou sua influência junto a agências internacionais de desenvolvimento, tornando-se "big business" na década de 1990 (Trubek; Santos, 2006, p. $11)$.

\subsubsection{Contornos do Novo Direito e Desenvolvimento}

O terceiro momento do debate sobre direito e desenvolvimento - o NDD - formou-se no século XXI num cenário de "novas ideias na economia do desenvolvimento, novas formas de ativismo estatal, e novas questões para o campo de direito e desenvolvimento." (Trubek, 2014, p. 17) Esses três aspectos remetem aos três elementos levantados por Schapiro e Trubek

\footnotetext{
251 "Em termos de ferramentas jurídicas, o Momento 2 corresponde, sinteticamente, à utilização do aparato jurídico para 'liberalizar' mercados. Rejeita-se uma intervenção estatal considerada intrusiva por meio da introdução de estímulos à competição e à rivalidade entre agentes econômicos, da desregulação de setores até então subordinados a normas que previam padrões técnicos, tecnológicos, metas de desempenho, bem como controlavam o ingresso e a saída de agentes nos mercados." (Coutinho, 2013, p. 88)

${ }^{252}$ As reformas no direito público correspondentes a esse segundo momento buscaram a contenção do papel do Estado na economia. "O direito econômico e administrativo em vários países é utilizado para, por meio de processos de privatização, retirar o Estado da economia, vender ativos públicos, atribuindo ao Poder Público o papel de regulador em um jogo em que os jogadores são atores privados. A definição clara e a efetivação (enforcement) segura de direito de propriedade e a função de reduzir custos de transação em prol da fluidez das trocas de mercado sintetizam as funções essenciais de uma ordem jurídica eficiente.” (Coutinho, 2013, p. 88)
} 
(2012, p. 28) para distinguir momentos do direito e desenvolvimento: (i) a concepção de desenvolvimento utilizada; (ii) o setor apontado como protagonista para sua promoção e (iii) o veículo de governança enfatizado. Os itens 4.3.2.1 a 4.3.2.3 empregam esses elementos para caracterizar os principais aspectos do NDD. Subsequentemente, a subseção 4.3.3 retrata alguns exemplos de abordagens correspondentes a esse terceiro momento de direito e desenvolvimento.

\subsubsection{NDD e novas concepções sobre desenvolvimento}

No que diz respeito a novas ideias sobre desenvolvimento, o NDD dialoga proximamente com autores de contribuições econômicas heterodoxas, como Ha-Joon Chang, Dani Rodrik, Erik Reinert, Peter Evans e Alice Amsden, entre outros (vide seção 3.4). As elaborações desses autores atribuem ao Estado papéis mais ativos do que o de provedor das "regras do jogo", ao mesmo tempo em que enfatizam a necessidade de sua parceria ou sinergia com o setor privado. Há rejeição, ainda, de soluções que sigam receitas prefixadas para o desenvolvimento. Ao invés de intervenções tecnocráticas, top-down, segundo modelos one-size-fits all, essa linha de pensamento enfatiza a pluralidade de caminhos possíveis para o desenvolvimento, a partir de experimentação, descoberta, diálogo democrático na elaboração de políticas públicas e diálogo horizontal (observação e troca de experiências institucionais entre países). Em suma, ao invés de pregarem que o melhor caminho consiste em seguir um script, estes autores tornam central o contexto de cada país na descoberta de suas próprias alternativas de desenvolvimento (cf. Schapiro; Trubek, 2012, p. 53).

Bastante importante, ainda no que diz respeito à incorporação de novas formulações econômicas pelo NDD, é a concepção expandida do próprio desenvolvimento, que absorve ideias de Amartya Sen (Schapiro; Trubek, 2012, p. 42; Trubek, 2014, p. 17). Esta visão quebra a associação praticamente exclusiva entre desenvolvimento e crescimento econômico, passando a incluir elementos jurídicos, sociais e políticos em sua definição, que em Sen aparecem sob o nome de "liberdades" (vide seção 1.2). O primeiro e segundo momentos narrados acima atribuíam ao direito função instrumental em relação ao desenvolvimento. As reformas jurídicas tinham o objetivo de promover o crescimento econômico. No NDD, a "proteção jurídica de valores constitucionais e de direitos humanos, incluindo direitos econômicos e sociais", passa a ser incorporada como objetivo a título próprio do desenvolvimento. Ou seja, mais do que uma função instrumental, o direito recebe papel 
constitutivo em relação ao desenvolvimento, passando a integrar sua definição (Trubek, 2014, p. 17, 19; Trubek; Santos, 2006, p. 9).

Como resultado, "diferentemente das proposições anteriores, ora voltadas à industrialização, ora ao fundamentalismo de mercado, os trabalhos recentes sugerem uma noção menos absoluta e fechada de desenvolvimento." (Schapiro; Trubek, 2012, p. 42) Há aproximações com a visão de "desenvolvimento como discurso baseado em valores, culturalmente particular", de Balakrishnan Rajagopal (2003, p. 138), que diverge de noções unívocas de desenvolvimento, concebidas e aplicadas top-down. A abertura aqui aludida nas concepções de desenvolvimento também remete ao maior espaço atribuído a políticas redistributivas, à redução de desigualdades, na moldura intelectual oferecida pelo NDD aspecto retomado mais adiante (4.3.2.3).

\subsubsection{NDD e novas formas de ativismo estatal}

Outra marca do terceiro momento de direito e desenvolvimento é o reconhecimento do papel expandido para o Estado na promoção do desenvolvimento. A "intervenção estatal é necessária em razão de obstáculos estruturais ao crescimento", como "baixa propensão ao investimento, sistemas fracos de inovação, e baixos níveis de investimento privado em pesquisa e desenvolvimento (P\&D)" (Trubek, 2013, p. 8). Não se trata, porém, de retorno à proposta do Estado desenvolvimentista do primeiro momento, que não conferia maior importância às iniciativas dos agentes privados nos mercados. Essa nova forma de ativismo estatal procura "estimular, não substituir, o setor privado." (Trubek; Coutinho; Schapiro, 2012, p. 3) A abordagem procura embasar configurações institucionais que favoreçam "mercados fortes e Estados fortes", enfatizando a "importância da colaboração públicoprivada" (Trubek, 2013, p. 8). Diferentemente dos momentos anteriores, "não há um protagonismo único, nem para os dispositivos de intervenção estatal, nem para os mecanismos de proteção privada." (Schapiro; Trubek, 2012, p. 49)

A diferença de enfoque correspondente ao novo ativismo estatal reverte-se no uso de políticas de intervenção econômica - a exemplo da política industrial, mas não só - como "mecanismo orientado para a indução da descoberta empresarial e não para a programação de resultados a serem alcançados pelos agentes privados." Nesse sentido, a "política industrial não é tomada como uma ferramenta de direção pública, por meio da qual o Estado estabeleceria os meios e metas." (Schapiro; Trubek, 2012, p. 46) Esta concepção afirma que “políticas públicas efetivas de desenvolvimento requerem coordenação próxima entre atores 
públicos e privados, experimentação conjunta e busca por novas oportunidades de investimento, e a formatação cuidadosa da ação pública para lidar com necessidades e contextos específicos." (Trubek, 2013, p. 10) Esse novo sentido de ativismo estatal - em que o estatal não suprime o privado - é identificado com o ocorrido no Brasil ${ }^{253}$ :

\begin{abstract}
quando o Brasil começou a desenvolver novas formas de ativismo estatal, ele não renacionalizou empresas estatais que haviam sido privatizadas, impôs controles de preços, criou um plano de desenvolvimento de cima para baixo, desencorajou o investimento estrangeiro, declarou moratória às suas obrigações internacionais, realizou gastos deficitários, ou fechou seus mercados para indústrias estrangeiras. Os esforços focalizaram a construção de novas formas de política industrial que enfatizavam a inovação e parceria com a indústria. Ao mesmo tempo, deu ênfase substancial a políticas sociais e à redistribuição e tem almejado combinar suas estratégias de política social e de crescimento industrial. (Trubek; Coutinho; Schapiro, 2012, p. 13)
\end{abstract}

Outra distinção entre o novo e o antigo ativismo estatal consiste no modo como o mercado interno se relaciona com o externo. No antigo desenvolvimentismo, a industrialização era buscada, em muitos países da América Latina, segundo o modelo de substituição de importações, que implicava certo grau de isolamento da indústria nacional em relação a competidores externos. Em contraste, o NDD não fomenta estratégias de isolamento, mas de integração aos mercados internacionais (Trubek, 2013, p. 9; Trubek; Coutinho; Schapiro, 2012, p. 2). Ou seja, a política industrial passa a assumir sentidos de fomentar condições de competição global para setores econômicos locais, via parcerias estratégicas entre Estado e agentes privados.

\title{
4.3.2.3 NDD e novas concepções sobre direito como veículo de governança
}

O modo como o direito, em sua relação com o desenvolvimento, é abordado pelo NDD contrasta em muitos aspectos com o ocorrido em momentos anteriores. Os itens abaixo

\footnotetext{
${ }^{253} \mathrm{O}$ novo ativismo estatal no Brasil corresponde à retomada de instrumentos de política industrial no século XXI, que havia sido abandonada na década de $1990 \mathrm{em}$ favor de abordagens centradas no mercado. O novo estilo de política econômica não suprimiu completamente o modelo anterior, mas resultou num "híbrido" (Trubek, 2013, p. 12), dada a preservação de políticas anteriores como controle de inflação, abertura ao investimento estrangeiro e da política macroeconômica em geral (Trubek; Coutinho; Schapiro, 2012, p. 8). A retomada ocorreu em 2004, com a Política Industrial, Tecnológica e de Comércio Exterior (PITCE), que focalizou o suporte financeiro e a promoção da inovação em quatro setores: semicondutores, software, bens de capital e medicamentos. Parte da estratégia da PITCE consistiu em "facilitar parcerias e sinergia entre universidades, empresas e institutos de pesquisa", bem como de prover "apoio governamental à pesquisa universitária." (Trubek; Coutinho; Schapiro, 2012, p. 9, cf. Schapiro; Trubek, 2012, p. 48) Em 2008, a Política de Desenvolvimento Produtivo (PDP) substituiu a PITCE como uma política industrial "muito mais ambiciosa e complexa" e que "colocou ênfase especial na colaboração entre os setores público e privado" em uma gama mais variada de indústrias (Trubek; Coutinho; Schapiro, 2012, p. 9-10; cf. Schapiro; Trubek, 2012, p. 50). Essa linhagem de política industrial baseada na coordenação público-privada teve continuidade com o programa "Brasil Maior", iniciado em 2011, e que identificou 20 setores prioritários para o desenvolvimento econômico (Trubek; Coutinho; Schapiro, 2012, p. 11).
} 
destacam diferenças no ramo privilegiado como veículo de governança, nas funções e dimensões atribuídas ao direito, no lugar para políticas sociais ou redistributivas, bem como em outros aspectos da abordagem jurídica.

Veículo de governança: direito público ou privado?

No primeiro momento, o veículo privilegiado de governança era o direito público. No segundo, o direito privado. No momento correspondente ao novo ativismo estatal, porém, o “direito não pode ser simplesmente uma ferramenta para a intervenção estatal direta, nem meramente uma moldura neutra para decisões privadas.” (Trubek, 2014, p. 18) Entre os papéis atribuídos ao direito, está o de promover "parcerias entre os setores público e privado e de institucionalizar um processo de busca mútua por soluções inovadoras e melhores percursos de desenvolvimento." (Trubek, 2014, p. 18) Como resultado, a concepção do terceiro momento promove a abertura de um leque de possibilidades para arranjos institucionais, cuja adequação deve ser julgada em função do contexto, permitindo diferentes combinações de elementos de direito público e privado. Não há um só ferramental jurídico adequado à promoção do desenvolvimento, mas uma pluralidade de conformações possíveis, uma maior "seletividade de meios de intervenção." (Schapiro; Trubek, 2012, p. 49) O NDD, afinal, desloca receitas institucionais prontas (instituições de padrão global, transplantes de "melhores práticas" institucionais) e privilegia elaborações baseadas no "experimentalismo democrático", na descoberta, no aprendizado (cf. Trubek, 2014, p. 13).

\section{Múltiplas funções e dimensões do direito}

Além da abertura desse leque de combinações de instituições jurídicas, outras contribuições que se encaixam no NDD enfatizam diferentes papéis e funções do direito e desenvolvimento e que, embora tenham alguns pontos de contato com aquelas descritas por Milhaupt e Pistor (2008), narradas na seção 4.2, focalizam outros aspectos. Para Diogo Coutinho, o direito "não apenas define e cristaliza, a seu modo, fins substantivos, como ainda molda e forja instituições encarregadas de persegui-los, influenciando, ainda, as ações e processos destinados a implementar políticas públicas.” (Coutinho, 2013, p. 96) Essa caracterização engloba quatro papéis correspondentes a quatro dimensões jurídicas.

O direito pode ser encarado "como objetivo" ao "formalizar metas e indicar os "pontos de chegada"” das políticas públicas (2013, p. 99). Essa função corresponde à dimensão 
substantiva (2013, p. 102), de definição de conteúdos desejados para ação governamental, a exemplo do que ocorre com normas programáticas presentes na Constituição de 1988 (cf. Coutinho, 2013, p. 99).

O direito também exerce papel de "ferramenta", porque a "seleção e a formatação dos meios a serem empregados para perseguir os objetivos predefinidos são um trabalho jurídico." (Coutinho, 2013, p. 99) Essa dimensão instrumental (2013, p. 102) envolve "a escolha dos instrumentos de direito administrativo mais adequados", o "desenho de mecanismos de indução ou recompensa", bem como de sanções, para estimular ou desencorajar comportamentos, e a "seleção do tipo de norma a ser utilizada" na implementação de uma política pública. Em função dos meios jurídicos escolhidos, a política pública pode ser dotada de maior ou menor flexibilidade ${ }^{254}$ e revisibilidade ${ }^{255}$, o que tem relações com o grau em que ela pode favorecer a experimentação e as interações entre os setores público e privado, como o NDD incentiva.

Em sua terceira função, o direito atua como "arranjo institucional", partilhando "responsabilidades entre atores públicos e privados" na condução de uma política e definindo “estruturas jurídicas capazes de fazer com que os objetivos se convertam em ações baseadas na escolha de ferramentas, de modo que não haja, do ponto de vista da divisão de tarefas, sobreposições, lacunas ou rivalidades em políticas públicas.” (Coutinho, 2013, p. 100) Esta é a dimensão estruturante do direito, segundo Coutinho (2013, p. 102).

Por fim, o direito exerce a função de "vocalizador de demandas", podendo "prover (ou desprover) as políticas de mecanismos de deliberação, participação, consulta, colaboração e decisão conjunta" (Coutinho, 2013, p. 101). Essa dimensão legitimadora do direito se relaciona com a criação de mecanismos propícios ao "experimentalismo democrático" defendidas pelo NDD, bem como com a existência do policy space (em contraste com a tomada tecnocrática de decisões) na definição das políticas públicas e da política econômica. Nesse sentido, Coutinho reforça que as

normas jurídicas podem levar políticas públicas a serem mais democráticas uma vez
que, por meio de regras procedimentais que disciplinem consultas e audiências
públicas e a publicidade dos atos administrativos, as obriguem a estar abertas aos
inputs de uma pluralidade de atores. (Coutinho, 2013, p. 101)

Essa expansão de funcionalidades rompe com a tendência existente, em momentos anteriores, de considerar o direito como tendo papel meramente instrumental. No primeiro e

\footnotetext{
${ }^{254}$ A flexibilidade é definida como "a possibilidade do arcabouço jurídico que estrutura a política pública servir a mais de uma finalidade." (Coutinho, 2013, p. 100)

${ }^{255}$ Coutinho define revisibilidade como "a característica de a política pública conter em seu próprio corpo jurídico mecanismos de ajuste e de adaptação.” (2013, p. 100)
} 
segundo momentos, o direito é um meio para o crescimento econômico, mas com estratégias que assumem sentidos opostos. No primeiro caso, o direito é uma ferramenta para transformação social e econômica modernizadora. No segundo, funciona como moldura para dar a segurança e previsibilidade necessárias para resguardar o dinamismo da iniciativa privada nos mercados. Além disso, é possível interpretar que a definição do direito "como objetivo" permite abrigar a concepção expandida de desenvolvimento para incluir, para além dos aspectos econômicos relativos a industrialização e crescimento, também aspectos políticos, sociais e jurídicos. Ou seja, para que direitos sejam incorporados como ponto de chegada do processo de desenvolvimento das sociedades.

\section{Direito e políticas sociais ou redistributivas}

O segundo momento de direito e desenvolvimento, ao refletir a sensibilidade econômica do neoliberalismo, favoreceu a subordinação de gastos públicos "a objetivos macroeconômicos de estabilização e austeridade fiscal", diminuindo o espaço para a condução de políticas sociais e redistributivas (Coutinho, 2013, p. 89). Este era, afinal, o momento de ênfase na eficiência do direito, não na distribuição equitativa dos ganhos econômicos. Questões distributivas eram endereçadas pela concepção de trickle-down economics (vide seção 3.3), que foi incorporada pelo paradigma rule of law.

Em contraste, no NDD, uma das faces no novo ativismo estatal é a condução de políticas sociais com caráter redistributivo (cf. Trubek; Coutinho; Schapiro, 2012, p. 2, 11-2; Coutinho, 2013). A preocupação com a eficiência é ressignificada e conciliada com o aspecto da equidade econômica. $\mathrm{O}$ uso da eficiência subsumida ao propósito redistributivo aparece, por exemplo, em Coutinho: "o arcabouço jurídico pode desempenhar a importante tarefa de ajudar a reduzir as ineficiências de políticas públicas redistributivas, contribuindo para os esforços de redução de desigualdade e erradicação da pobreza.” (2013, p. 91) Em sentido mais amplo, o NDD "atribui grande ênfase à necessidade de políticas sociais ativas para superar a exclusão social, reduzir a pobreza, manter a demanda, e contribuir para o objetivo de aumento da competitividade ao promover treinamento e reduzir os custos sociais da mudança estrutural." (Trubek, 2013, p. 8) 
Quadro 4.2 - Três momentos do debate sobre direito e desenvolvimento

\begin{tabular}{|c|c|c|c|}
\hline Momentos & $1^{\circ}$ & $2^{\circ}$ & $3^{\circ}$ \\
\hline Rótulos & $\begin{array}{c}\text { Direito e Estado } \\
\text { desenvolvimentista }\end{array}$ & $\begin{array}{c}\text { Direito e mercado } \\
\text { neoliberal }\end{array}$ & $\begin{array}{c}\text { NDD, novo ativismo } \\
\text { estatal, direito e } \\
\text { desenvolvimento no } \\
\text { século XXI } \\
\end{array}$ \\
\hline $\begin{array}{l}\text { Caracterização } \\
\text { temporal } \\
\text { aproximada } \\
\end{array}$ & $1965-80$ & anos $1980-90$ & anos 2000 em diante \\
\hline $\begin{array}{l}\text { Concepção de } \\
\text { desenvolvimento }\end{array}$ & \multicolumn{2}{|c|}{ Crescimento econômico. } & $\begin{array}{l}\text { Concepção expandida de } \\
\text { desenvolvimento como } \\
\text { liberdade, com } \\
\text { componentes } \\
\text { econômicos, políticos, } \\
\text { sociais e jurídicos }\end{array}$ \\
\hline $\begin{array}{c}\text { Setor } \\
\text { protagonista }\end{array}$ & Estado & $\begin{array}{c}\text { Agentes privados nos } \\
\text { mercados }\end{array}$ & $\begin{array}{l}\text { Erosão da divisão rígida } \\
\text { entre Estado e mercados. } \\
\text { Busca de parcerias entre } \\
\text { setores público e privado }\end{array}$ \\
\hline $\begin{array}{c}\text { Principais } \\
\text { estratégias de } \\
\text { desenvolvimento }\end{array}$ & $\begin{array}{l}\text { Industrialização por } \\
\text { substituição de importações; } \\
\text { condução de atividades } \\
\text { econômicas estratégicas via } \\
\text { empresas públicas; } \\
\text { direcionamento público dos } \\
\text { investimentos a setores } \\
\text { estratégicos; AOD }\end{array}$ & $\begin{array}{l}\text { Remoção de distorções } \\
\text { econômicas provocadas } \\
\text { pela intervenção estatal } \\
\text { (getting prices right), } \\
\text { liberdade de comércio e } \\
\text { finanças, disciplina fiscal, } \\
\text { reformas destinadas a } \\
\text { encorajar o investimento } \\
\text { estrangeiro }\end{array}$ & $\begin{array}{c}\text { Mistura de diferentes } \\
\text { ideias para políticas de } \\
\text { desenvolvimento. Foco } \\
\text { na descoberta, na } \\
\text { experimentação, em } \\
\text { estratégias adequadas ao } \\
\text { contexto }\end{array}$ \\
\hline Papel do direito & $\begin{array}{l}\text { Instrumental: ferramenta de } \\
\text { intervenção do Estado e vetor } \\
\text { de transformações na } \\
\text { economia e na sociedade }\end{array}$ & $\begin{array}{l}\text { Instrumental: ferramenta } \\
\text { para a configuração de } \\
\text { moldura para a atividade } \\
\text { privada nos mercados e } \\
\text { para limitar o poder do } \\
\text { Estado }\end{array}$ & $\begin{array}{l}\text { Múltiplos papéis para o } \\
\text { direito. Além de } \\
\text { dimensões instrumentais, } \\
\text { estruturantes e } \\
\text { legitimadoras, o direito é } \\
\text { também tomado em sua } \\
\text { função substancial, } \\
\text { configurando um objetivo } \\
\text { de desenvolvimento a } \\
\text { título próprio } \\
\end{array}$ \\
\hline $\begin{array}{l}\text { Ramo } \\
\text { privilegiado da } \\
\text { atuação jurídica } \\
\text { e de sua reforma }\end{array}$ & $\begin{array}{l}\text { Direito público; transplantes } \\
\text { de modelos normativos de } \\
\text { Estados avançados; reformas } \\
\text { na educação jurídica do } \\
\text { "Terceiro Mundo" }\end{array}$ & $\begin{array}{l}\text { Direito privado. Ênfase } \\
\text { no rule of law e } \\
\text { sobretudo na proteção } \\
\text { forte e clara dos direitos } \\
\text { de propriedade e dos } \\
\text { contratos, bem como na } \\
\text { existência de judiciário } \\
\text { previsível, célere e } \\
\text { independente. Reformas } \\
\text { promovidas a partir de } \\
\text { transplantes com origem } \\
\text { no common law }\end{array}$ & $\begin{array}{l}\text { Leque de possibilidades } \\
\text { de construção de arranjos } \\
\text { institucionais adequados } \\
\text { a cada contexto. Rejeição } \\
\text { a modelos one-size-fits } \\
\text { all e a transplantes } \\
\text { institucionais. Abertura } \\
\text { ao experimentalismo, } \\
\text { descoberta e diálogo } \\
\text { horizontal para troca de } \\
\text { experiências } \\
\text { institucionais. }\end{array}$ \\
\hline
\end{tabular}

Fonte: elaborado com base em Trubek; Santos, 2006; Trubek, 2006; 2014; Schapiro; Trubek, 2012; Coutinho, 2013. 
Outras características da abordagem jurídica no NDD

Além dos aspectos já levantados, a abordagem do NDD é marcada por seu foco empírico, pelo consequencialismo e também pela atenção à relação entre direito e fluxos financeiros.

$\mathrm{O}$ primeiro desses aspectos reflete a crítica, geralmente dirigida às perspectivas do segundo momento, de tender a tomar em conta apenas as instituições jurídicas formais (law in the books) e deixar em plano secundário sua operação prática (law in action), inclusive pela interação com instituições informais. Nesse sentido, Trubek afirma que os partidários do NDD “aprenderam que para compreender a relação entre direito e políticas de desenvolvimento na atualidade, é necessário ir além do estudo das regras jurídicas e aplicar uma abordagem de 'law in action'." (Trubek, 2013, p. 15) Essa preocupação com o aspecto empírico das instituições jurídicas (Trubek, 2014, p. 20) se projeta, nos estudos inseridos na moldura do NDD, na forma de estudos de caso, a exemplo das contribuições caracterizadas na subseção 4.3.3.

Um segundo aspecto é a tomada de uma perspectiva consequencialista nas abordagens de NDD: "é muito visível nessa abordagem uma preocupação vital com os resultados." (Castro, 2014a, p. 38) Nesse sentido, o raciocínio jurídico do NDD não procede a recomendações de formatos ou caminhos para políticas públicas em abstrato, como ocorre com o modo de proceder tipicamente formalista da "ponderação de valores" (cf. Castro, 2009, p. 20-1). A propósito, apesar de contrapostas em muitos aspectos, as abordagens da AED e do NDD têm no consequencialismo um ponto de convergência (assim como a AJPE - vide seção 4.4).

Por fim, outra característica saliente do NDD é a centralidade da preocupação dos fluxos financeiros. Este aspecto é salientado por Marcus Faro de Castro, que intitula estudos inseridos na linhagem de NDD como "abordagem de Gestão Pública do Capital" (Castro, 2014a, p. 37). O nome deriva da ênfase no novo ativismo do Estado em política econômica e na "importância da estrutura de fluxos financeiros para a realização de fins jurídicos por grupos e indivíduos, promovendo assim tanto a liberdade como o desenvolvimento." (2014a, p. 37)

Os contornos acima expostos permitem a caracterização do NDD como um referencial para políticas públicas alternativo ao mainstream do debate sobre direito e desenvolvimento. A caracterização aqui feita corre o risco de sugerir, no entanto, um grau de coesão intelectual 
que na realidade não se configura ${ }^{256}$. O terceiro momento de direito e desenvolvimento é "fragmentado", sem que haja uma só abordagem dominante ou consenso sobre as políticas desejáveis (Trubek, 2014, p. 21). Essa fragmentação também se refere aos diferentes tópicos enfatizados nos estudos, embora sejam dimensões interdependentes (Trubek, 2014, p. 26): "comércio e desenvolvimento, finanças e desenvolvimento, direitos humanos e desenvolvimento, direitos das mulheres e desenvolvimento, meio ambiente e desenvolvimento, e assim por diante." (Trubek, 2014, p. 23) Nesse sentido, o NDD pode ser mais apropriadamente considerado uma moldura intelectual que abriga contribuições com certas características fundamentais comuns do que um paradigma para políticas públicas - o que exigiria maiores graus de autonomia, coesão e consenso - inclusive em questões metodológicas - entre seus integrantes.

\subsubsection{Novo ativismo estatal e análises jurídicas de políticas públicas no Brasil}

O propósito da presente subseção é trazer exemplos de análises jurídicas de políticas públicas no Brasil que sugerem a ocorrência de um novo ativismo estatal, conformando estudos que podem ser considerados pertinentes à moldura do NDD. Diferentes dimensões são enfatizadas nesses exemplos. O primeiro deles, abordado no item 4.3.3.1, aborda aspectos de novas políticas sociais no Brasil a partir da década de 2000, marcadas por caráter redistributivo acentuado e novas elaborações jurídicas de apoio. A participação estatal incrementada nesse setor guarda correspondência com a concepção ampliada de desenvolvimento, que transcende o foco na eficiência e crescimento econômicos para abranger, também, aspectos equitativos, de distribuição de renda. O relato é feito com base no estudo de Diogo Coutinho (2013).

O segundo exemplo (4.3.3.2) focaliza, de modo resumido, três momentos de políticas públicas referentes ao etanol combustível no Brasil, a abranger aspectos de política agrícola, industrial, tecnológica e comercial. Em particular, há a sugestão de que os formatos assumidos por essas políticas guardam forte correspondência com os três momentos do próprio debate sobre direito e desenvolvimento. Este item baseia-se na análise de Michelle Ratton Sanchez Badin e Daniela Helena Godoy (2012).

Por fim, o item 4.3.3.3 volta-se a aspectos dos arranjos institucionais para o mercado de crédito corporativo no Brasil, com base na perspectiva de Mario Gomes Schapiro (2010).

\footnotetext{
${ }^{256}$ Nesse sentido, ao contrário do que é sugerido pela divisão entre as seções 4.1 e 4.3 neste capítulo, há formulações que propõem sobreposição entre as contribuições da AED e do NDD (cf. Prado, 2014). Nesta visão, a AED comporia o quadro de abordagens do terceiro momento do debate sobre direito e desenvolvimento.
} 
De modo análogo ao que o item 4.3.3.2 significa para políticas agrícolas, industriais, tecnológicas e comerciais, a caracterização feita por Schapiro serve para ilustrar três momentos da política de crédito no Brasil, correspondentes a orientações distintas de direito e desenvolvimento. Em particular, sugere-se o traçado de trajetória institucional peculiar ao Brasil e resistente às tentativas de reforma inspiradas no rule of law, com persistência de arranjo jurídico de apoio ao que Marcus Faro de Castro (2014a) denomina “Gestão Pública do Capital”.

\subsubsection{Programa Bolsa Família e dimensão redistributiva do desenvolvimento}

Na obra Direito, desigualdade e desenvolvimento, Diogo Coutinho (2013) considera que o aparato jurídico que estrutura políticas públicas no Brasil, embora tenha historicamente favorecido "resultados regressivos" em termos de distribuição de renda - a exemplo da estruturação desigual da tributação, aposentadorias e pensões -, nos últimos anos contribuiu para que "ganhos de equidade" fossem alcançados (2013, p. 110, 130). Coutinho, como já se mencionou adiante, encara o direito como uma "tecnologia de desenvolvimento" - uma “espécie de correia de transmissão que liga normas gerais e abstratas [...] a resultados concretos" - capaz tanto de obstá-lo quanto de promovê-lo (2013, p. 131). Para o autor, o aspecto da igualdade compõe a definição de desenvolvimento não só por razões instrumentais - já que "níveis elevados de desigualdade de renda [...] produzem resultados negativos para as economias capitalistas" (2013, p. 129), mas também intrínsecas: "a desigualdade é discutível e questionável desde o ponto de vista ético, moral, filosófico e jurídico" (2013, p. 50). Nesse sentido, o aparato jurídico relacionado à estruturação do Programa Bolsa Família (PBF) é tomado como exemplo de uso da tecnologia jurídica para favorecer a "dimensão da igualdade" do desenvolvimento.

O PBF é um programa de transferência de renda condicionada, iniciado em 2013, que concede benefícios pecuniários a "famílias pobres com renda mensal por pessoa entre $\mathrm{R} \$ 70 \mathrm{e}$ R\$ 140”, mediante o cumprimento de condicionalidades (Coutinho, 2013, p. 112-3). Os recursos dirigidos ao programa representam $0,35 \%$ do PIB $(2013$, p. 118) e uma cobertura de 12,5 milhões de famílias (2013, p. 117).

A análise que Coutinho faz do PBF salienta as quatro funcionalidades do aparato jurídico em sua relação com políticas públicas, anteriormente mencionadas. No primeiro aspecto - o direito como objetivo - o autor aponta que o programa promoveu a "juridificação" 
de objetivos de política pública que, embora distintos, foram agrupados sob um guarda-chuva comum, dentre os quais:

promover o acesso à rede de serviços públicos, em especial, de saúde, educação e assistência social, combater a fome e promover a segurança alimentar e nutricional, estimular a emancipação sustentada das famílias que vivem em situação de pobreza e extrema pobreza, combater a pobreza e promover a intersetorialidade, a complementaridade e a sinergia das ações sociais do Poder Público. (Coutinho, 2013, p. 114)

A juridificação desses objetivos é encarada como meio de redução da "chamada 'política de balcão', por meio da qual lideranças políticas disputam recursos do governo federal (transferências voluntárias) para atender a necessidades emergenciais de populações sob sua influência." (2013, p. 114) Dessa forma, um objetivo "macro" do programa consistiria em mudar o modo pelo qual a alocação de recursos públicos é feita nesse setor de assistência social. Os beneficiários não seriam mais "clientes" de seus benfeitores políticos em relações personalizadas. A transferência de renda passa a ser impessoal ao ser tratada como direito de famílias que, inscritas num "cadastro único", atendam as condicionalidades do programa.

$\mathrm{O}$ cadastro insere-se entre as ferramentas jurídicas de direito administrativo voltadas à operacionalização dos objetivos do programa (2013, p. 116). É o meio para identificação dos beneficiários do programa, e a responsabilidade por sua operação é dividida entre diversos entes. Municípios fazem a coleta de informações que, repassadas à Caixa Econômica Federal (CEF), são consolidadas para decisão dos beneficiários elegíveis por parte do Ministério do Desenvolvimento Social e Combate à Fome (MDS) que, por sua vez, autoriza a realização de pagamentos pela CEF. O PBF conta, ainda, com cotas municipais que "limitam a quantidade de beneficiários que cada cidade pode ter", funcionando como mecanismo de "focalização" da política pública. Nesse sentido, as cotas seriam importantes para impedir "que prefeitos e outras autoridades públicas, por razões políticas, registrem pessoas indiscriminada ou fraudulentamente", representando incentivos para cadastramento apenas das famílias que "realmente necessitam do benefício." (Coutinho, 2013, p. 117)

Outro uso do aparato jurídico como ferramenta na condução de política pública consiste no emprego das mencionadas condicionalidades como instrumento de indução comportamental e de alerta. No primeiro aspecto, elas incorporam um mecanismo de incentivos e sanções. A concessão do benefício encontra-se vinculada ao cumprimento de uma série de condições, que por sua vez dizem respeito a outros direitos na área de educação e saúde, dentre os quais: matrícula e frequência escolar mínima para crianças e adolescentes, cumprimento do cronograma de vacinação e acompanhamento nutricional de crianças 
menores de 7 anos, acompanhamento médico pré-natal para gestantes, manutenção de crianças fora do trabalho infantil etc. (Coutinho, 2013, p. 118)

Em caso de descumprimento, há imposição gradativa de sanções, que começam com a advertência, passam pelo bloqueio do benefício por um mês em caso de reincidência, progridem para a suspensão do benefício por dois meses na terceira e quarta violações, e só então, na quinta violação, dão ensejo ao cancelamento do benefício (2013, p. 119). O desenho desse mecanismo de condicionalidades e sanções progressivas revela-se voltado ao reforço de direitos e não de cerceamento do acesso aos benefícios de transferência de renda (2013, p. 118).

As condicionalidades operam, ainda, como provedoras de alerta e sinalizadoras da necessidade de investimentos públicos, já que seu "descumprimento poderia revelar a ausência de serviços públicos essenciais, o que, por sua vez, motivaria o Ministério da Saúde ou da Educação a suprir a carência de forma mais célere do que de outra forma ocorreria." (Coutinho, 2013, p. 120) Nesse sentido, as condicionalidades incorporam um mecanismo de transmissão de informações que podem ser usadas na reorientação da política pública.

Ainda quanto à função instrumental do aparato jurídico, Coutinho destaca a criação do “Índice de Gestão Descentralizada" (IGD) para medir o desempenho dos municípios na gestão do programa e de seu cadastro único. O indicador é calculado a partir de quatro variáveis: "taxa de cobertura de cadastros, taxa de atualização de cadastros, taxa de crianças com informações de frequência escolar e taxa de famílias com acompanhamento das condicionalidades de saúde." (2013, p. 12) Esses dados compõem uma nota, que varia de 0 a 1, com base no qual é avaliado o desempenho de cada município, que por sua vez orienta a destinação de novos recursos. Essa é uma "inovação jurídico-institucional" na forma de estruturar relações entre entes federativos:

\footnotetext{
Sua racionalidade, baseada no estímulo comportamental dos municípios (e não na possibilidade de imposição de sanção punitiva), não é familiar ao tipo de direito e de configuração de norma jurídica que marca as relações federativas no Brasil, historicamente centralizadas. (Coutinho, 2013, p. 122)
}

No aspecto do direito como arranjo institucional, Coutinho destaca que o PBF envolve uma teia de articulação de políticas públicas com dimensão vertical (entre entes federativos distintos) e horizontal (entre órgãos e entidades distintas), marcada pela “descentralização, pela intersetorialidade e pela cooperação em meio a uma pluralidade de atores de todos os níveis de governo", bancos públicos, "ministérios, governos estaduais e os órgãos de controle, como Ministério Público, Controladoria Geral da União e Tribunal de Contas da União.” (Coutinho, 2013, p. 122-3) 
Por fim, o PBF incorpora a dimensão do direito como vocalizador de demandas, dada a exigência jurídica da existência de Instâncias de Controle Social (ICS) como parte da gestão do programa. Segundo Coutinho, parte dos municípios criou novos conselhos para lidar com o PBF, ao passo que outra parte promoveu a adaptação de conselhos já existentes (2013, p. 126). Aliás, embora as sinalizações da ausência de cumprimento de condicionalidades do PBF sejam tratadas por Coutinho como reflexos do uso do direito como ferramenta, pode-se considerar que esse "mecanismo de alerta" também seja uma forma de vocalização de demandas.

A abordagem de Coutinho acerca dos quatro papéis ou funções do direito na condução do PBF aponta para o potencial de uso do direito para "privilegiar resultados progressivos, isto é, em favor dos mais pobres, desempenhando, assim, um papel-chave na superação do subdesenvolvimento", em contraste com o papel conservador, "no sentido de fossilizar desigualdades", que o arcabouço jurídico também pode cumprir (Coutinho, 2013, p. 129). É, ainda, uma ilustração prática da incorporação de objetivos redistributivos (e de postura estatal ativa em sua realização) como parte dos papéis do direito no desenvolvimento, em marcado contraste com a concepção anterior - do segundo momento -, que relegava questões distributivas a noções de trickle-down e pregava a retração do welfare state.

\subsubsection{Três momentos da política brasileira quanto à produção e comércio de etanol}

A experiência brasileira com o etanol é marcada por três conformações que, em linhas gerais, correspondem às três concepções sobre direito e desenvolvimento que conformaram os “momentos" referidos nessa seção 4.3.

Segundo Michelle Ratton Sanchez Badin e Daniela Helena Godoy (2012), até meados da década de 1970 a produção brasileira de etanol era irrisória, só tendo assumido relevância após a crise do petróleo e a queda do preço do açúcar no mercado internacional. Em meio a essas turbulências, o Programa Nacional do Álcool (Proálcool) foi criado, e sua implementação contou com instrumentos como:

políticas econômicas (fixação de preços, subsídios, transferências); mandato de mistura obrigatório; equalização de custos; isenções fiscais; garantia de pagamentos e de compra aos produtores; financiamento para produção agrícola, indústria, logística e criação de veículos movidos a álcool. (Sanchez Badin; Godoy, 2012, p. 2004)

O Proálcool foi baseado em forte ativismo estatal para a criação de um mercado doméstico para o etanol, sobretudo como alternativa energética para o transporte automotivo. 
Um de seus principais elementos foi a introdução de automóveis movidos a álcool, que de uma fatia inexpressiva em finais da década de 1970, alcançou 66\% da frota em 1986, correspondendo a um salto de $1 \%$ para $55 \%$ da participação do etanol no consumo de combustíveis (Sanchez Badin; Godoy, 2012, p. 204). A política foi marcada pela "dependência do setor privado em relação ao setor público, sobretudo na frente de financiamento das atividades privadas." Além disso, a relação do Estado com o setor privado assumiu o sentido de "fechamento da economia e a proteção da indústria doméstica das atividades do comércio internacional.” (2012, p. 205) Esse primeiro momento da política brasileira de etanol, na década de 1970, foi marcado por forte gerenciamento estatal e foco no mercado interno, em linha com as concepções do Estado desenvolvimentista.

Os fundamentos do Proálcool foram abalados na década de 1980 e o programa foi abandonado na década seguinte. A crise da dívida externa nos anos 1980, além de comprometer a capacidade governamental de arcar com os custos da promoção do etanol, levou a acordos de renegociação da dívida com o FMI, que incluíram condicionalidades de "revisão das políticas de subsídios do governo". Além disso, o período contou com crises de abastecimento que abalaram a confiança dos consumidores e fizeram cair as vendas de veículos movidos a etanol (Sanchez Badin; Godoy, 2012, p. 206). Ao longo da década de 1990, o Proálcool foi "desmontado" gradativamente, com sucessivas etapas de liberalização da produção e comercialização, extinção de quotas de produção, liberalização de preços e supressão de subsídios e garantias de compra (2012, p. 208). Como reflexo da dependência do setor privado em relação aos estímulos e controles governamentais, a retirada do Estado implicou o fechamento de significativa parcela das unidades produtivas de etanol. $\mathrm{O}$ combustível "restou como um produto complementar à produção do açúcar, sem nenhuma projeção estratégica” (2012, p. 209). Nesse segundo momento, correspondente à desregulamentação e retirada do Estado apregoadas pelo "Consenso de Washington”, já na década de 1990, há o abandono do ativismo estatal no setor e da pretensão de relevância do etanol na matriz energética brasileira.

$\mathrm{Na}$ virada do século, o posicionamento do etanol como produto estratégico para o Brasil correspondeu a novas estratégias multifacetadas de atuação público-privada, ao resgate da relevância do produto para o mercado doméstico e ao novo ímpeto de alcançar projeção internacional no setor, num estilo de política que se pode considerar mais próximo às formulações do NDD. Em parte, a mudança de posição se deu em razão de um ambiente internacional mais propício, que incluiu "o aumento contínuo da demanda mundial por energia", "repetidas elevações no preço internacional do petróleo" e "a força adquirida pelas 
questões ambientais" (2012, p. 218). Noutra parte, o novo ativismo estatal no setor de etanol foi reflexo de opção política pela atribuição de papel estratégico ao etanol no plano de desenvolvimento brasileiro, ocorrido com o governo Lula, baseado em preocupações de segurança energética (redução da dependência do petróleo), com a questão ambiental (apresentação do etanol como "energia limpa”) e de geração de emprego (2012, p. 219).

Um importante eixo dessa política foi a "introdução dos veículos flex-fuel, em 2003, com estímulos de isenção fiscal pelo governo." A medida resultou na expansão de 4\% para 90\% dos veículos flex entre 2003 e 2008, com a correspondente criação de expressivo mercado consumidor doméstico para o etanol, cujas vendas quintuplicaram e ultrapassaram as de gasolina (2012, p. 219). Diferentemente do ocorrido na década de 1970, porém, a nova política de etanol não restringe seu foco ao mercado doméstico. O Brasil tem "participação de $48 \%$ nas exportações globais de etanol." (2012, p. 224) No entanto, a criação e expansão de mercados internacionais conta com entraves. O primeiro deles refere-se à ausência de classificação única pelo sistema harmonizado de comércio internacional. O etanol "não se encaixa a uma nomenclatura aduaneira padrão", havendo confusões burocráticas entre o etanol combustível e o álcool utilizado na fabricação de bebidas (2012, p. 215). Além disso, há expressivas barreiras tarifárias e não tarifárias. Diante desse cenário, “o governo brasileiro tem investido em disposições e concessões especiais em acordos e memorandos bilaterais, além da estratégia padrão na OMC e demais para a liberalização do setor agrícola.” (2012, p. 237) Ainda no eixo internacional, outra iniciativa governamental consiste na "ampliação da base de países produtores" de etanol, sobretudo na América Central e na África, com vistas ao "fortalecimento do Brasil nesses mercados como referência em tecnologia associada à produção (como máquinas e fertilizantes) e a expansão dos espaços de investimento para os produtores nacionais." (2012, p. 229)

Neste último aspecto, a participação do setor privado torna-se particularmente relevante. O objetivo de inserção internacional do etanol brasileiro e de expansão das bases de produção no mundo concilia-se com o propósito de "fortalecimento do processo de internacionalização de empresas brasileiras” (2012, p. 238). Além disso, esse novo momento conta com "mobilização do setor privado em torno de iniciativas próprias para enfrentar limites no acesso ao mercado internacional" (2012, p. 236) - inclusive por meio de estratégias de marketing e lobbying internacionais destinadas a promover o uso do etanol como energia limpa e o acesso a mercados (2012, p. 234). Pode-se observar a existência de esforços públicos e privados de abertura de mercados internacionais tanto para a exportação de etanol quanto para novas oportunidades de investimento em sua produção no exterior. 
Após uma fase de ativismo estatal e foco no mercado doméstico, ao estilo desenvolvimentista do "primeiro momento", outra de retirada do Estado e abandono de políticas estratégias para o etanol, correspondentes ao segundo momento de direito e desenvolvimento, o terceiro momento dessa política pública correspondeu ao ativismo estatal ressignificado no setor, com parecerias público-privadas e nova frente de atenção aos entraves jurídicos internacionais à criação e expansão de mercados no exterior. Essa caracterização é sugestiva de que os sentidos assumidos pelo tratamento brasileiro do etanol, da década de 1970 aos dias presentes, servem como ilustração prática dos três momentos de concepções sobre direito e desenvolvimento referidos nesta seção.

\subsubsection{Alternativas institucionais para o financiamento corporativo}

A política do etanol no Brasil não foi a única a passar pela trajetória de forte ativismo estatal inicial, retração deste e abertura à maior atuação das forças de mercado, e terceiro momento de resgate ressignificado dos papéis do Estado. O relato de Mario Gomes Schapiro (2010) a respeito da trajetória brasileira de financiamento corporativo permite consideração semelhante. Configura, além disso, outro exemplo de estudos que se encaixam na moldura do NDD.

Schapiro (2010) parte de retrospectiva histórica, remetendo ao período do primeiro direito e desenvolvimento. Na década de 1950, a criação do Banco Nacional de Desenvolvimento Econômico (a cujo nome seria acrescida a expressão "e Social”, resultando no atual acrônimo "BNDES") marcou a construção de um modelo baseado na alocação pública de capital, com forte atuação de bancos públicos. Os bancos privados atuavam na “intermediação financeira de curto prazo e baixo risco", trabalhando com altos spreads bancários que resultavam em empréstimos encarecidos. Sua atuação não era voltada a financiamentos mais arriscados e de longo prazo, como os envolvidos na industrialização. De modo semelhante, tampouco o mercado de ações, nesse contexto brasileiro, atuou como principal fonte de capitais para o desenvolvimento nacional. Esse papel foi desempenhado por bancos públicos, como expressão de um modelo de finanças "baseado na regulação institucional do sistema bancário" ${ }^{257}$ :

\footnotetext{
${ }^{257}$ A esse respeito, Schapiro destaca que o BNDES "não só foi o principal provedor nacional de recursos para os empreendimentos corporativos (públicos e privados), como também o fez de modo a vincular a sua intervenção às prioridades governamentais, favorecendo os segmentos identificados como estratégicos para o programa de transformação industrial do país" (Schapiro, 2010, p. 230).
} 
Assim como ocorrido em outros países em desenvolvimento, como Coreia do Sul, Taiwan e México, foram os agentes estatais que supriram, no Brasil, ambas as ausências, a do mercado de capitais e a do segmento bancário, encarregando-se de disponibilizar os recursos necessários para os investimentos de maior risco e com prazo longo de retorno. Nessa medida, o papel desempenhado pelo direito extrapolou a função de meramente garantir os interesses de acionistas e credores privados. A sua efetiva função foi a de constituir um sistema de financiamento de longo prazo, para o que foi necessário o estabelecimento de um regime de propriedade estatal no segmento bancário, suprindo, assim, a carência do investidor privado. Desde então, o modelo brasileiro de financiamento tem sido baseado nestes dois elementos: (i) a poupança compulsória, formada por meio do poder de arrecadação do Estado e (ii) o direcionamento dos recursos pelos agentes estatais (pelos bancos públicos). (Schapiro, 2010, p. 229)

No contexto da década de 1990, reformas inspiradas no paradigma rule of law - e em particular no Law \& Finance - promoveram mudanças no ambiente financeiro nacional. Em linhas gerais, as alterações tentaram fazer a migração de um modelo baseado na alocação pública de capital para outro, baseado em bancos privados e na importância acrescida do mercado de ações para o financiamento das atividades empresariais. Foram três os principais eixos de reformas.

Primeiramente, a "reorganização do segmento financeiro público", que resultou na privatização de bancos estaduais (que passaram de 32 em 1995 para 14 em 2003) e na reestruturação de bancos federais, que "passaram a adotar padrões de atuação e regras de governança corporativa semelhantes às das demais instituições financeiras.” (2010, p. 233-4) Correspondentemente, a participação dos bancos públicos federais e estaduais declinou de “50,91\%, em 1996, para 29,64\%, em 2006” (2010, p. 236).

O segundo eixo consistiu na "abertura do segmento bancário à concorrência internacional", voltada a "responder, via ampliação da competição, a um problema crônico do setor de crédito brasileiro: o alto custo dos spreads nas operações de crédito." A medida resultou na expansão da participação do capital estrangeiro na composição dos ativos bancários no Brasil, de 10,51\% em 1996 para 21,70\% em 2006 (Schapiro, 2010, p. 234).

Por fim, houve "alterações legislativas e iniciativas de autorregulação no mercado de capitais". Em 2000, a Bovespa estabeleceu três outros níveis de mercados (além do mercado tradicional) de ações com regras de adesão voluntária e padrões progressivamente mais exigentes pelas empresas listadas: Nível 1, Nível 2 e Novo Mercado ${ }^{258}$. Em 2001, a reforma

\footnotetext{
258 “As regras do Nível 1 são particularmente voltadas à garantia de um patamar mais elevado de transparência; as regras do Nível 2, para além da transparência, apresentam exigências relativas ao padrão de demonstração financeira e a possibilidade de voto para os preferencialistas em algumas situações, tais como fusões e aquisições. Já o Novo Mercado reúne um conjunto mais abrangente e incisivo de regras de governança" (Schapiro, 2010, p. 235).
} 
na Lei das Sociedades Anônimas conferiu novos direitos a acionistas minoritários ${ }^{259}$. Ao longo da década de 2000, ao lado do incremento da participação de bancos privados e estrangeiros no mercado financeiro, o "volume de operações no mercado de capitais também foi incrementado" (Schapiro, 2010, p. 236).

Apesar de as reformas inspiradas no paradigma rule of law terem conseguido aumentar a participação dos recursos privados no financiamento corporativo brasileiro, elas "não foram suficientes para alterar a característica central do modelo brasileiro de financiamento", no qual as "operações de longo prazo e alto risco ainda dependem dos agentes estatais." (2010, p. 236) A aposta de que a concorrência estrangeira reduziria os altos spreads bancários praticados no Brasil não conduziu ao resultado esperado: ao invés, estes bancos viram no acesso ao mercado brasileiro uma oportunidade de maior rentabilidade em suas atuações, aproximando seus preços aos que já eram praticados por aqui. Quanto à tentativa de expandir as fontes de financiamento para além do setor bancário, por meio do mercado de ações, também nisso o modelo brasileiro mostrou-se singular, com forte presença do BNDES, "detentor da maior carteira de ações do país" (Schapiro, 2010, p. 239). Ou seja, mesmo o financiamento das atividades empresariais via mercado de ações no Brasil conta com forte presença do setor público. Além disso, a captação de recursos no mercado de ações no Brasil mostra-se inferior aos volumes de empréstimos bancários desembolsados pelo BNDES (2010, p. 238).

Como resultado, apesar das reformas, o modelo brasileiro, num terceiro e mais atual momento, permanece centrado na relevância de bancos públicos, e em especial do BNDES, para financiamentos de longo prazo, maior risco e a menor custo. Em parte, a posição estratégica de bancos públicos como agentes de intermediação financeira no Brasil é composta pelo acesso juridicamente estabelecido a taxas de juros preferenciais e mecanismos de poupança forçada, como o Fundo de Amparo ao Trabalhador (FAT) e o Fundo de Garantia por Tempo de Serviço (FGTS), resultando em menores custos de captação. A base jurídicoinstitucional desse modelo contraria as receitas de organização do sistema financeiro fundadas na noção de "instituições corretas" e na função protetiva do direito quanto a direitos de credores e investidores. Essa concepção não encara a presença dos bancos públicos “como resultado de um arranjo nacional, mas sim como uma patologia, um produto das falhas

\footnotetext{
259 "Além de firmar uma nova proporção entre ações com e sem direito a voto, fixando o limite de preferenciais em $50 \%$ do capital, a nova lei restabeleceu a proteção ao acionista minoritário nos casos de alienação do controle da companhia pelo majoritário (tag along). A redação original da Lei das S.A. autorizava as sociedades anônimas a emitir até dois terços das ações sem direito a voto, o que se entendia como prejudicial ao equilíbrio de forças intracompanhia. Já o tag along, embora fosse previsto na Lei 6.404/76, havia sido suprimido, em 1997, pela Lei 9.457." (Schapiro, 2010, p. 235)
} 
existentes na proteção jurídica dos investidores privados” (Schapiro, 2010, p. 242). Mas a trajetória brasileira releva que o direito pode ter outro papel, qual seja, "o de construir um sistema financeiro público no qual os agentes estatais é que estabelecem as mediações entre poupadores e investidores, valendo-se para tanto dos dispositivos de poupança compulsória e do direcionamento estatal dos recursos." (Schapiro, 2010, p. 241) Para Schapiro, a abordagem do NDD - que em seu texto aparece como "paradigma das alternativas institucionais" -, embora compartilhe com o rule of law "o pressuposto de que há uma correlação positiva entre o desenho de arranjos jurídico-institucionais e o alcance de bons indicadores de produtividade, crescimento e renda - ou seja, a análise consequencialista -, tem como contraste o uso "da premissa de que esses desenhos devem ter como ponto de partida a trama social dada, concentrando-se em uma reprogramação da trajetória institucional existente" (2010, p. 243). O contraste representado por esse último ponto implica descartar soluções baseadas em modelos únicos e transplantes de instituições jurídicas formais.

A valorização do contexto, da "trama social dada", da "trajetória institucional existente", resulta na produção de argumentos jurídicos que, diferentemente do que ocorre com o paradigma rule of law, validam a configuração do mercado financeiro nacional em que o setor público corresponde a importante parcela de participação tanto no setor bancário quanto no mercado de ações, com destaque para atuação do BNDES: No panorama brasileiro, a trajetória do BNDES, para além de desafiar as
expectativas das reformas econômicas conduzidas aos moldes do Rule of Law, tem
sido também um exemplo significativo do que pode ser um exercício de
reprogramação institucional. Embora o Banco tenha sido constituído como um
agente de apoio aos programas desenvolvimentistas, adequado ao padrão de
desenvolvimento Estado-centrado e às estratégias substitutivas de importação, sua
intervenção tem sido redesenhada nos últimos vinte anos. De um ator encarregado
das metas inscritas nos planos governamentais de desenvolvimento, o BNDES
passou a ser um agente relevante para o mercado de capitais e para as estratégias
corporativas afinadas com uma economia internacionalizada. (Schapiro, 2010, p.
244)

Observa-se que essa abordagem, ao invés de tratar o modelo de financiamento baseado em bancos públicos como um "desvio" em relação ao formato "correto" de instituições como fazem as análises estruturadas segundo o paradigma rule of law, encara-o como singularidade do arranjo institucional brasileiro. Este traço corresponde, por sua vez, à valorização de arranjos institucionais que favoreçam estratégias de desenvolvimento adequadas ao contexto, ao invés de derivadas de receituários-padrão, "melhores práticas" ou global standard institutions, em linha com as características gerais do NDD. 


\subsection{Análise Jurídica da Política Econômica}

As vertentes do debate sobre direito e desenvolvimento até agora descritas têm em comum características como a abertura interdisciplinar entre o direito e ao menos outra área de conhecimento, a adoção do pressuposto de que as instituições importam para o desenvolvimento, e a valorização das consequências na análise das instituições jurídicas. A Análise Jurídica da Política Econômica (AJPE) partilha destas características. Esta contribuição mais recente ao debate desenvolveu-se com base em publicações de Marcus Faro de Castro $(2009 ; 2010$; 2011) e tem sido objeto de discussão e aplicação na análise de políticas públicas no grupo de pesquisa Direito, Economia e Sociedade, da Universidade de Brasília.

Nem tudo, porém, são semelhanças com as demais vertentes. Na realidade, certas características da AJPE aproximam-na do NDD, estabelecendo contraste com os referenciais que instruem o paradigma rule of law, como a AED e o Law \& Finance. Diferentemente destes últimos, a AJPE, tal qual o NDD, rejeita o pressuposto da superioridade de soluções institucionais baseadas na promoção da liberdade irrestrita dos mercados (financeiros ou não) e em modelos one-size-fits all; adota graus maiores de abertura interdisciplinar, que não se restringe a categorias da microeconomia ou à análise estatística comparativa internacional de fundo histórico; abriga maior espaço para justificar o ativismo econômico estatal e arranjos institucionais inovadores e contextualmente específicos, entre outros traços. Apesar de afinidades e convergências com o NDD, a AJPE trabalha com categorias e métodos novos e próprios, que a singularizam. Esta seção busca identificá-los e apresentar seus principais aspectos.

A principal característica da AJPE consiste no emprego de novas categorias e métodos para a análise crítica de instituições jurídicas ligadas à política econômica ${ }^{260}$ e a políticas públicas $^{261}$, dada a carência de "opções disponíveis para os operadores do direito ${ }^{262}$, diante de situações que se apresentam prima facie como injustas" (Castro, 2009, p. 20). Ao contrário do caráter formalista de abordagens jurídicas convencionais ${ }^{263}$ (cf. Castro, 2012), na AJPE, o

\footnotetext{
${ }^{260}$ Entendida como "conjunto de regras e princípios juridicamente instituídos que organizam muitos aspectos cruciais das práticas de produção, troca e consumo na vida social.” (Castro, 2009, p. 22)

${ }^{261}$ Doravante, a expressão "políticas públicas" será usada de modo a abranger medidas de política econômica.

${ }^{262}$ A referência às "opções disponíveis" inclui: (i) interpretação formal e (ii) substantiva da lei e da constituição; (iii) "cálculo prudencial de caráter abstrato e genérico" (ponderação de valores) e (iv) a AED, que, "ao proceder por meio da chamada 'análise de custo-benefício', não leva em conta as relações entre interesses materiais e valores não econômicos, que são relevantes para a promoção de justiça econômica.” (Castro, 2009, p. 21)

${ }^{263}$ Em Formas jurídicas e mudança social, fica sugerido que o formalismo, o fechamento conceitual e a incapacidade para lidar adequadamente com transformações empíricas, característicos de abordagens jurídicas
} 
engajamento do jurista com tais instituições e situações não se dá em abstrato. Ao invés disso, há forte ênfase na "fruição empírica" dos direitos subjetivos ligados a políticas públicas ${ }^{264}$, o que lhe confere outro traço distintivo.

Nesse sentido, de acordo com a abordagem da AJPE, o "trabalho do jurista deve se concentrar na pesquisa dos efeitos concretos das políticas públicas - que têm sempre representações tanto tecnocráticas quanto jurídicas - sobre a fruição empírica dos direitos fundamentais e direitos humanos." (Castro, 2011, p. 18) Por sua vez, o foco na fruição empírica está ligado a outra característica importante da abordagem da AJPE: sua proposta de "abertura interdisciplinar do estudo do direito, para o fim de reforçar e organizar a capacidade do jurista de engajar-se criticamente com os fatos empíricos da realidade." (Castro, 2011, p. 4) No caso da AJPE, esta abertura é ampla, não se restringindo à economia e, de especial interesse para a presente tese, confere importância jurídica a elementos das relações internacionais. Neste aspecto, em particular, há forte conexão com a proposta de reconhecimento de processos de ordenação jurídica transnacional (vide, na seção 2.3, o item sobre teoria das ordenações jurídicas transnacionais). A aspiração da AJPE de fortalecer o engajamento jurídico crítico com os fatos da realidade tem o objetivo último de fomentar reformas institucionais que promovam a justiça econômica.

A seguir, a subseção 4.4.1 apresenta as principais categorias de trabalho da AJPE, assim como as relações estabelecidas entre elas e com os métodos analíticos. Estes novos métodos, por sua vez, são caracterizados na subseção 4.4.2, na qual o item 4.4.2.1 é dedicado à Análise Posicional, e o item 4.4.2.2, à Nova Análise Contratual, também conhecida como Análise de Portfólio. A subseção 4.4.2 também procede de modo a ilustrar o emprego desses métodos em pesquisas que aplicaram a AJPE. Por fim, a subseção 4.4.3 ressalta conexões e contrastes entre a AJPE e as demais vertentes do debate sobre direito e desenvolvimento, abordadas nesse capítulo.

\footnotetext{
convencionais, estiveram na base da perda de espaço do direito como quadro de referência para políticas públicas. Ao longo do século XX, esta perda correspondeu à habilitação de saberes econômicos e tecnocráticos como linguagens mais afeitas ao embasamento e orientação do exercício da autoridade, o que guarda correspondência com a justificação da permanência de situações sociais e econômicas injustas. A obra sugere, ainda, que o resgate do potencial orientador do direito está vinculado à sua reinvenção (cf. Castro, 2012). Para uma aplicação específica desta crítica ao direito constitucional brasileiro, vide Globalização, democracia e direito constitucional: legados recebidos e possibilidades de mudança (Castro, 2014b). Estes textos abrigam críticas a modos convencionais de conceber e trabalhar o direito, em relação aos quais a AJPE apresenta-se como alternativa.

${ }^{264}$ A fruição empírica é entendida como o "gozo de direitos enquanto experiência social que ocorre em um contexto específico." (Castro, 2013, p. 12)
} 


\subsubsection{Principais categorias e relações da AJPE}

As categorias que conformam a base conceitual da AJPE têm como característica o estabelecimento de "pontes" entre elementos jurídicos e econômicos. No fundo, elas podem ser lidas, em seu conjunto, como um empreendimento de "tradução interdisciplinar", no sentido de fazer o discurso jurídico alcançar - sobretudo, mas não só - elementos da economia. Esse traço reflete a adoção, pela AJPE, do pressuposto de que as práticas econômicas, as atividades nos mercados - ou seja, as relações de produção, troca e consumo encontram-se permeadas por instituições jurídicas. Assim, as instituições jurídicas não são meramente auxiliares ao funcionamento dos mercados, mas estão na própria base de sua formação, ou seja, exercem papel constitutivo para a atividade econômica. Esse ponto de partida - que guarda associação com as contribuições de Karl Polanyi (2001[1944]) e converge com a perspectiva do NDD - reforça a importância das instituições jurídicas para o funcionamento da economia.

A própria definição de política econômica, expressão presente no próprio acrônimo "AJPE", é versada em termos jurídicos. Trata-se do conjunto de regras e princípios juridicamente instituídos que organizam práticas de produção, troca e consumo na vida social (Castro, 2014a, p. 43; cf. 2009, p. 22; 2006, p. 42). Ao definir política econômica deste modo, a AJPE acaba por relacioná-la, em múltiplas frentes, com outra categoria: a de direitos subjetivos.

Em primeiro lugar, esta relação existe em função dos impactos variados que decisões de política econômica e políticas públicas têm sobre direitos de indivíduos e grupos. Há, nesse sentido, "reflexos sobre a formação de suas concepções sobre o que são (em termos de fruição presente), ou devam ser, os seus direitos." (2009, p. 24) Em segundo lugar, em razão da própria sobreposição entre linguagens de "políticas públicas" e de "direitos". Medidas de política econômica que envolvam taxas de juros preferenciais no financiamento de novas moradias, bem como o acesso de bancos públicos mecanismos de poupança forçada como principal fonte de recursos para este fim, podem ser tanto lidas como aspectos da "política de habitação" (linguagem de políticas públicas) ou como medidas destinadas a dar efetividade ao “direito à moradia" (linguagem jurídica). No fundo, o conjunto de fenômenos e instituições a que se referem é o mesmo. O mesmo ocorre com "pares" como: política de saúde/direito à saúde; política de emprego/direito ao trabalho; política de mobilidade urbana/direito ao transporte, etc. A correspondência entre estes pares aponta para a ausência de "critérios definitivos para a separação cabal entre o que o jurista, de seu ângulo, vê como 'direito' e o 
administrador caracteriza, desde seu ponto de vista, ao menos em parte como sendo o campo de uma ou mais políticas públicas.” (2009, p. 36) Em conexão com a sobreposição aqui apontada, a AJPE objetiva compreender

qual o sistema montado de política econômica, quais as suas transformações, quais
os seus efeitos práticos, incluindo especialmente sua influência sobre a fruição
empírica de direitos subjetivos considerados fundamentais, e entender, também, de
que modo o "direito vigente" contribui para tornar tudo isso inteligível, ou - ao
contrário - obscuro (Castro, 2011, p. 16).

Ligar direitos à política econômica e políticas públicas implica reconhecer que estes não têm conteúdos fixos ou imutáveis. O sentido assumido por direitos subjetivos está atrelado a conteúdos prestacionais correspondentes a políticas públicas, a mudanças no "estilo de atuação das autoridades e nos processos institucionais determinativos das possibilidades pragmáticas de consumo e investimento.” (2006, p. 52) Estão conectados, ainda, a flutuações em variáveis econômicas, a impactos monetários que se transmitem de contrato a contrato, e de rede contratual a rede contratual, e alcançam as relações internacionais (cf. Castro, 2006; 2011, p. 17). Por considerar que esses elementos são relevantes para a experiência jurídica, a AJPE concebe que os direitos subjetivos se configuram em fluxo.

Por um lado, esta concepção fluida de direitos subjetivos implica reconhecer que seus conteúdos não podem ser isolados de modo absoluto de fatores econômicos, políticos e daqueles pertinentes às relações internacionais. Por outro, o desprendimento em relação a formas fixas - derivadas de um sistema conceitual abstrato ou do texto positivado - acaba por atribuir interessante aspecto de liberdade na definição do que sejam os direitos subjetivos, condizente com possibilidades de inovação e experimentação institucional. Abre-se, afinal, a possibilidade de que as instituições que organizam a produção, troca e consumo (inclusive no âmbito da cooperação econômica internacional) sejam reformadas com vistas à expansão da fruição empírica de direitos subjetivos, moldados segundo as aspirações de indivíduos e grupos em cada contexto.

A fluidez de sua definição permite, assim, que novos conteúdos, correspondentes a "interesses emergentes" na sociedade, venham a ser juridicamente reconhecidos e tratados como direitos subjetivos (2010, p. 162). A esse respeito, a AJPE considera que, nas democracias, a opinião dos indivíduos e grupos "sobre o que são e devem ser os seus direitos" deve balizar políticas econômicas e políticas públicas para dar-lhes concretude, em termos de fruição empírica (cf. Castro, 2009, p. 26). Ou seja, a AJPE concebe que as políticas públicas devam estar em função da expansão da fruição de direitos (o que envolve a necessidade de 
que o jurista se habilite para apreciá-las criticamente e indicar reformas, aspecto retomado adiante) em consonância com expectativas de indivíduos e grupos:

A AJPE pressupõe que as instituições e políticas devem servir a ordens compatíveis com a equânime fruição dos direitos humanos e fundamentais e que os indivíduos e grupos não devem ser escravizados a instituições cuja estrutura oponha obstáculos a tal fruição. Sendo plenamente convencionais, são as instituições (políticas públicas, políticas econômicas, mecanismos de cooperação internacional) que devem ser mudadas para se adaptarem ao exercício da fruição de direitos humanos e fundamentais, não o inverso. (Castro, 2009, p. 46)

Não só política econômica é definida em termos jurídicos, mas também a categoria de justiça econômica, que pode ser entendida como fruição ampla e efetiva de direitos de produção e, simultaneamente, de direitos de consumo (cf. 2009, p. 41, 49). Novamente, esta é uma tradução jurídica de justiça (igualmente versada em direitos subjetivos) que realiza pontes com aspectos econômicos. De um lado, a preocupação com a fruição de direitos de produção remete ao aspecto econômico da competitividade, que inclui considerações sobre crescimento econômico, produtividade, lucratividade, eficiência etc. De outro, a preocupação com direitos de consumo reflete o aspecto econômico da equidade, da distribuição de renda, fruição equânime dos ganhos econômicos etc ${ }^{265}$. A justiça econômica é alcançada quando esses dois aspectos, correspondentes a duas esferas de direitos, são atingidos conjuntamente: "não deve ser considerado aceitável, do ponto de vista jurídico, que uma economia cresça, sem que ao mesmo tempo esteja assegurada a efetiva fruição de direitos fundamentais e direitos humanos pelos membros da sociedade como um todo." (2011, p. 16) Em outros termos, “a arquitetura contratual da economia nacional deve 'equilibrar' a proteção dos direitos de consumo com a capacidade dos detentores de propriedade comercial de manter condições de competir na economia global.” (2013, p. 22)

Mas o que são direitos de produção e de consumo, na base da definição acima indicada? Direitos de produção são relacionados a práticas "orientadas para a obtenção de lucro" (Castro, 2011, p. 20), encontrando-se "centralmente implicados nas esferas da produção e da troca econômica." São exemplos "o direito de propriedade ${ }^{266}$ e a liberdade de

\footnotetext{
${ }^{265}$ Nesse sentido, para Marcus Faro de Castro, justiça econômica implica "conciliar a funcionalidade e a produtividade da economia, de um lado e, de outro, a equânime proteção aos direitos fundamentais dos indivíduos e grupos" (Castro, 2009, p. 21).

${ }^{266}$ Em conexão com a diferenciação entre direitos de produção e de consumo, a AJPE distingue o direito de propriedade em três modalidades (sendo que uma delas ocupa posição intermediária). Além da propriedade comercial, que é o sentido referido no trecho acima, há também civil e a híbrida. A propriedade comercial é encarada como direito de produção, encontrando-se direcionada a "fins precipuamente comerciais e para a obtenção de lucro.” (2009, p. 50) Tem como característica forte ligação com a economia monetária, porque sua própria existência depende da comparação entre sua lucratividade e a rentabilidade do investimento especulativo (cf. 2009, p. 52). Ou seja, o investimento na propriedade comercial está sujeito à constante comparação entre as perspectivas de lucro e as taxas de juros obteníveis em mercados financeiros. Por isso, a estrutura da propriedade
} 
contratar" (2009, p. 50). Direitos de consumo, por sua vez, são ligados a práticas de consumo e incluem os chamados "direitos sociais, econômicos e culturais", a exemplo dos direitos a “alimentação, moradia, transporte, saúde, educação e outros compatíveis." (Castro, 2009, p. 49-50)

A fruição destes dois grupos de direitos encontra-se vinculada a "ações institucionais e sociais" que podem promovê-la ou bloqueá-la (2013, p. 13). Em linha - mais uma vez - com a concepção de direitos subjetivos em fluxo, a AJPE articula a fruição de direitos em termos de posições em que se encontram indivíduos e grupos. Estas correspondem a graus diferenciados de inserção ou habilitação econômica (2010, p. 160-1). A habilitação econômica corresponde ao aumento da fruição de direitos de produção e consumo, com melhoria na posição de indivíduos e grupos. Já a inabilitação econômica refere-se à piora ou bloqueio desta fruição, implicando a permanência ou “"congelamento' de indivíduos ou grupos em posições por eles indesejadas" (2013, p. 16). A AJPE propõe um método para mensuração e crítica da posição ou habilitação econômica de indivíduos e grupos: a Análise Posicional, abordada no item 4.4.2.1.

As traduções de aspectos econômicos em termos jurídicos, que permeiam a AJPE, são uma "chave" para promover (por meio de novos métodos de análise) a capacidade jurídica de criticar e (re)orientar medidas de política econômica e políticas públicas correlatas à fruição de direitos subjetivos. Outra categoria representativa dessa estratégia de configuração jurídica de aspectos econômicos consiste na visão da economia de mercado como sendo estruturada em contratos. Mais precisamente, em agregados contratuais, que são a categoria analítica da AJPE para expressar "padrões de ações sociais e institucionais que têm impactos sobre a fruição de direitos” (2013, p. 13). Tais contratos entrecruzados trazem componentes tanto privada quanto publicamente pactuados, que incidem sobre a organização da produção, da troca e do consumo (cf. 2009, p. 32, 34). Para a estruturação do raciocínio e da crítica jurídica

comercial apresenta maior fluidez. Já a propriedade civil está ligada a práticas de consumo. Sua ligação com a economia monetária é propositadamente mais indireta e limitada (2009, p. 53), o que reflete a atribuição de importância além do aspecto econômico às práticas de consumo a que se refere, a exemplo das instituições jurídicas de "reserva de indisponibilidade" (cf. 2010, p. 161), como nos casos do bem de família e de limitações à penhora que incidem sobre alguns imóveis e salários. Como exemplo dessa distinção, um "pacote de arroz na prateleira de um supermercado ou na despensa de um restaurante" é trabalhado como propriedade comercial, ao passo que o mesmo pacote, no armário de uma cozinha doméstica, representa a propriedade civil (2009, p. 50). Por fim, no caso da propriedade híbrida, "as práticas de consumo produtivo são muito próximas das de consumo final", como ocorre com indústrias caseiras ou "de quintal", pequenas propriedades de agricultura familiar e práticas de economia informal $(2009$, p. 51). 
a respeito de uma economia contratualmente organizada ${ }^{267}$ (nos quais as medidas de política econômica e as ações de políticas públicas são compreendidas como conteúdos de interesse público dos agregados contratuais), a AJPE propõe procedimentos de análise que reconfiguram categorias do direito dos contratos, consubstanciados na Nova Análise Contratual ou Análise de Portfólio, abordada no item 4.4.2.2.

A partir das considerações feitas nesta subseção, é possível notar que as categorias da AJPE procedem de modo a construir pontes para que o discurso jurídico abarque elementos de esferas relacionadas à fruição empírica de direitos subjetivos, dentre os quais aqueles correspondentes a conteúdos de políticas públicas e medidas de política econômica. Além de guardarem relações entre si, as categorias refletem-se nos novos métodos propostos, objeto da subseção seguinte, a exemplo das conexões entre posição ou habilitação econômica e a Análise Posicional, e entre agregados contratuais e a Nova Análise Contratual.

\subsubsection{Novas metodologias de análise jurídica e exemplos de sua aplicação}

A AJPE propõe dois novos métodos para crítica jurídica e proposição de reformas de políticas públicas. Um deles, a Análise Posicional, (abordada no item 4.4.2.1) é um instrumental para avaliação do grau de fruição empírica de direitos subjetivos em contextos específicos. Destaca-se, neste método, a possibilidade de estruturar a argumentação jurídica na forma de índices que reflitam o contraste entre a fruição empírica de um direito subjetivo e o grau que corresponderia à habilitação econômica desejável para indivíduos ou grupos ${ }^{268}$.

\footnotetext{
${ }^{267}$ A visão da economia como sendo organizada em contratos guarda proximidade com os escritos de Ronald Coase em The nature of the firm (1937), em que instituições como as "firmas" são vistas como "nexos de contratos". Vide seção 4.1 .

268 Os índices ocupam posição central no procedimento da Análise Posicional. Esta forma de dotar a argumentação jurídica de expressão numérica reflete o reconhecimento, pela AJPE, de que a articulação do conhecimento na forma de indicadores matemáticos assume grande relevância para a orientação do comportamento de atores diversos, incluindo autoridades públicas e agentes privados. Globalmente, uma variedade de indicadores (inclusive aqueles provenientes de fontes privadas, cf. seção 2.3) têm sido empregados como guias para a elaboração de políticas públicas e também como ferramentas para sua avaliação, nas mais variadas áreas e temas. As implicações normativas dos indicadores já são reconhecidas em literatura jurídica recente, a exemplo da obra Governance by indicators: global power through quantification and rankings, de Davis et al (2012). Além de suas implicações normativas, outro aspecto relevante do emprego de indicadores ou da argumentação em forma estatística consiste em seu uso para a crítica social. Como Alain Desrosières salienta, índices foram historicamente empregados para tornar visíveis - e trazer à pauta de discussões públicas sobre fenômenos econômicos e sociais que antes permaneciam escondidos, a partir da mensuração, por exemplo, do desemprego, da pobreza e da criação de índices de desigualdade de renda, entre outros (cf. Desrosières, 2014). Nesse sentido, índices podem ser usados para construir novas realidades cognitivas, ou seja, para que novos fenômenos - ou fenômenos que permaneciam obscuros - passem a ser reconhecidos como fatos sociais e por conseguinte tornem-se objeto de atuação. Este aspecto também é incorporado pela AJPE.
} 
Por sua vez, a Nova Análise Contratual, também referida como Análise de Portfólio (item 4.4.2.2), envolve, como mencionado anteriormente, a reconfiguração de categorias do direito contratual para dar conta dos efeitos da incidência de políticas públicas sobre os agregados contratuais que conformam as economias de mercado. Nela, assume particular importância a noção de deflexão monetária interportfólio. Ela também contribui para caracterizar diferentes configurações possíveis de ambientes monetários institucionais, conformadores da moeda civil, comercial ou estratégica. A característica central do método consiste no uso de uma matriz analítica para identificar e posicionar conteúdos dos agregados contratuais, de modo a facilitar a estruturação de propostas de reforma condizentes com a expansão conciliada da fruição de direitos de produção e de consumo, que por sua vez corresponde à definição de justiça econômica na AJPE.

Alguns exemplos de uso desses novos métodos são apontados ao longo dos itens a seguir, com foco em pesquisas que aplicaram a AJPE a políticas públicas como o Programa Microempreendedor Individual (Lima, 2014; Castro; Lima, 2015) e o Programa Nacional de Banda Larga (Fontes, 2014; Castro; Fontes, 2014).

\subsubsection{Análise Posicional}

A Análise Posicional é o método proposto pela AJPE para avaliar a posição de indivíduos e grupos quanto à fruição empírica de direitos subjetivos de produção ou consumo. O método tem como núcleo a construção de, e comparação entre, dois índices: um para representar o grau de fruição de direito correlato a certa política pública, e outro para expressar o patamar de fruição correspondente à sua validação jurídica. O resultado dessa comparação permite avaliar se determinada política pública "atende a requisitos de ‘concretização' ou 'efetividade' de direitos fundamentais e direitos humanos.” (Castro, 2009, p. 40) Caso a fruição empírica verificada se mostre insatisfatória, o jurista deverá proceder à indicação de "possíveis reformas corretivas" (2011, p. 20; cf. 2013, p. 12), o que pode ser feito com auxílio da Nova Análise Contratual (cf. item 4.4.2.2). Essas são as linhas gerais de um procedimento que consiste em cinco etapas.

A primeira consiste na identificação de política pública sujeita a controvérsias, que deve ser traduzida em termos jurídicos. Ou seja, nesta etapa, o jurista identifica também o direito subjetivo que com ela se correlaciona, que pode ser encarado sob a ótica dos direitos de produção ou de consumo. Trata-se, em termos simplificados, da identificação do objeto da análise. 
O Quadro 4.3, abaixo, reúne exemplos de caracterizações dessa primeira etapa em aplicações da AJPE em dissertações recentes ${ }^{269}$.

Quadro 4.3 - Primeira etapa da Análise Posicional e exemplos de sua aplicação

\begin{tabular}{|c|c|c|c|}
\hline $\begin{array}{c}\text { Etapa da Análise } \\
\text { Posicional }\end{array}$ & \multicolumn{2}{|c|}{1 - Identificação de política pública controversa e de direito subjetivo correlato } \\
\hline $\begin{array}{c}\text { desmembramento da } \\
\text { etapa }\end{array}$ & política pública analisada & $\begin{array}{c}\text { direito subjetivo } \\
\text { correlato }\end{array}$ & aspecto enfatizado \\
\hline $\begin{array}{c}\text { Aplicação por Lima, } \\
2014\end{array}$ & $\begin{array}{c}\text { Programa } \\
\text { Microempreendedor } \\
\text { Individual }\end{array}$ & propriedade comercial & direitos de produção \\
\hline $\begin{array}{c}\text { Aplicação por } \\
\text { Fontes, 2014 }\end{array}$ & $\begin{array}{c}\text { Programa Nacional de Banda } \\
\text { Larga }\end{array}$ & $\begin{array}{c}\text { liberdade de expressão; } \\
\text { acesso à informação }\end{array}$ & direitos de consumo \\
\hline
\end{tabular}

Fonte: elaborado com base em Lima, 2014; Fontes, 2014

A segunda etapa corresponde à decomposição analítica do conteúdo relacional dos direitos subjetivos envolvidos na política pública. Para a AJPE, "políticas públicas adquirem as formas de conteúdos de interesse público inseridos em contratos organizados em redes ou agregados contratuais". Esta etapa corresponde, portanto, ao delineamento dos "componentes prestacionais" da política pública, que se ligam à fruição empírica do direito analisado. (Castro, 2009, p. 41)

Quadro 4.4 - Segunda etapa da Análise Posicional e exemplos de sua aplicação

\begin{tabular}{|c|c|c|}
\hline $\begin{array}{l}\text { Etapa da Análise } \\
\text { Posicional }\end{array}$ & \multicolumn{2}{|r|}{2 - Decomposição analítica do direito subjetivo } \\
\hline $\begin{array}{l}\text { desmembramento da } \\
\text { etapa }\end{array}$ & Política Pública & Variáveis decompostas (indicadores) \\
\hline $\begin{array}{c}\text { Aplicação por Lima, } \\
2014\end{array}$ & $\begin{array}{c}\text { Programa } \\
\text { Microempreendedor } \\
\text { Individual }\end{array}$ & $\begin{array}{l}\text { 1 Facilidade de obtenção do crédito } \\
2 \text { Facilidade na contratação de empregado } \\
3 \text { Melhoria nas condições de negociação } \\
4 \text { Nível de dificuldade na gestão dos negócios } \\
5 \text { Apoio na formalização } \\
6 \text { Facilidade no pagamento do Documento de Arrecadação Simplificada }\end{array}$ \\
\hline $\begin{array}{l}\text { Aplicação por } \\
\text { Fontes, } 2014\end{array}$ & $\begin{array}{l}\text { Programa Nacional } \\
\text { de Banda Larga }\end{array}$ & $\begin{array}{l}\text { 1 Preço do acesso à internet banda larga (em dólares dos EUA) } \\
2 \text { Velocidade (em Mbps) } \\
3 \text { Cobertura ou penetração populacional (em percentuais de domicílios) }\end{array}$ \\
\hline
\end{tabular}
Fonte: elaborado com base em Lima, 2014; Fontes, 2014

Em outros termos, nesta etapa o jurista faz o levantamento ou construção das variáveis ou indicadores que comporão sua análise. Um critério fundamental para a eleição ou

\footnotetext{
${ }^{269}$ A Análise Posicional também foi empregada por Paulo Soares Sampaio em dissertação que avaliou a fruição de direitos a oportunidades sociais, entendidos como um agrupamento de direitos diversos, de participantes do Programa Nacional de Microcrédito Produtivo Orientado. A análise contou com levantamento de dados em pesquisa de campo, a partir de entrevistas realizadas em pontos diversos do território brasileiro. A maior complexidade do procedimento de análise empregado - com índices compostos por grande número de variáveis (13 variáveis que incluem frequência escolar, alfabetização, aspectos ligados a nutrição e saúde, qualidade de moradias e saneamento básico, acesso à energia elétrica, entre outras) - gera dificuldades em sua exposição sintética, motivo pelo qual, ao invés de ser abordado nesta seção, sugere-se a consulta à pesquisa original (Sampaio, 2014).
} 
formulação dessas variáveis é a viabilidade de sua quantificação, visto que elas comporão o contraste entre os índices que formam o núcleo da Análise Posicional. Em outros termos, a etapa da decomposição analítica precisa levar em conta a possibilidade de levantamento empírico - e traduzível em expressão numérica - dos conteúdos prestacionais identificados com a política pública objeto da pesquisa. Na quantificação das variáveis decompostas, o jurista

pode optar por utilizar dados e informações já produzidos por autoridades ou especialistas, ou pode produzir dados e informações novos. Há, evidentemente, também a possibilidade de utilização de dados já prontos, mas de maneira combinada com dados produzidos pelo próprio jurista pesquisador. De qualquer modo, o objetivo da quantificação é produzir índices quantitativos que possam dar precisão à caracterização da experiência empírica da fruição. (Castro, 2009, p. 41-2)

A terceira etapa consiste na formação do Índice de Fruição Empírica (IFE) a partir da quantificação das variáveis decompostas. O IFE é obtido pela organização dos indicadores analiticamente decompostos - as variáveis identificadas - em uma fórmula matemática, que dá expressão quantitativa à fruição empírica do direito em questão (Castro, 2009, p. 43). Na composição da fórmula, o jurista pode atribuir pesos diferenciados às variáveis ou conteúdos prestacionais da política pública analisada, procedimento que se reveste de caráter prudencial. Em outros termos, não há uma composição específica ou necessária para o IFE correspondente a um direito subjetivo correlato a certa política pública. Sua elaboração é aberta à pluralidade de interpretações sobre os meios para a realização da justiça econômica. Ou seja, ao invés de um instrumento de "revelação" de uma realidade inquestionável, o IFE pode ser mais apropriadamente encarado como componente de estratégia de argumentação jurídica que, embora matematizada, admite, tal como ocorre com os raciocínios baseados em estatística, múltiplas interpretações e contestações. Diferentemente, porém, de procedimentos formais de "ponderação de valores" (que também estão abertos a múltiplos desfechos), a análise baseada na elaboração do IFE tem por característica o engajamento necessário com o aspecto empírico da fruição de direitos, não podendo, por definição, ser feito em abstrato.

Uma vez elaborado o IFE, o jurista insere em sua fórmula os dados quantitativos correspondentes às variáveis que a integram, obtendo um resultado numérico. As aplicações da AJPE em dissertações recentes contaram com elaborações de IFEs com graus variados de complexidade. Nos exemplos aqui abordados, a construção do IFE foi feita com 3 e 6 variáveis.

O primeiro é o caso da pesquisa sobre o Programa Nacional de Banda Larga (PNBL), em que Daniele Fontes (2014) compôs um IFE do acesso à internet banda larga no Brasil que 
envolveu preço em dólares dos Estados Unidos (representado, na fórmula abaixo, por "X"), a velocidade em Mbps ("Y”) e a cobertura populacional (“Z”). $\mathrm{Na}$ fórmula, os indicadores foram divididos por três, de modo a obter uma média para representar a qualidade do gozo à banda larga no Brasil:

Quadro 4.5 - Estrutura do IFE empregado na pesquisa de Fontes (2014)

$$
\begin{gathered}
\text { IF E }=\frac{X+Y+Z}{3} \\
\text { Onde: } \\
\mathrm{X}=\text { Preço do acesso à banda larga, em dólares dos EUA. } \\
\mathrm{Y}=\text { Velocidade, em Mbps } \\
\mathrm{Z}=\text { Cobertura populacional (\% dos domicílios) } \\
\text { Fonte: Fontes, 2014, p. 106-7 }
\end{gathered}
$$

No passo seguinte, a fórmula do IFE foi "alimentada" com os dados quantitativos relativos às variáveis que o compõem. No caso da pesquisa de Fontes (2014, p. 107), as quantificações refletem as metas do PNBL, aprovadas pelo Decreto 7175/2010, e que foram tomadas como proxies da fruição empírica do acesso à banda larga. A política pública objetiva atingir cobertura de $70 \%$ dos domicílios, com velocidade de banda larga de $1 \mathrm{Mbps}$, ao preço de R 30 (valor convertido em dólares de fevereiro de 2014):

Quadro 4.6 - Fórmula do IFE alimentada com dados quantitativos, em Fontes (2014)

$$
I F E=\frac{15,2+1+70}{3}
$$

Fonte: Fontes, 2014, p. 107

Como resultado, Fontes obteve IFE com valor “28,73”, que é a expressão do nível de fruição do acesso à banda larga no Brasil a partir das metas do PNBL. Esse índice é o primeiro passo da avaliação jurídica dessa política pública, que ainda depende de seu contraste com o "Padrão de Validação Jurídica" (PVJ), etapa abordada mais adiante.

Antes de passar a ela, cabe apresentar outro exemplo, relativo à pesquisa sobre o Programa Microempreendedor Individual. Albério Lima (2014) compôs um IFE com seis indicadores obtidos em sua decomposição analítica, já referida acima. Alguns desses indicadores (facilidade de contratação de empregado e melhoria das condições de negociação) tiveram seu peso diminuído na fórmula, refletindo a avaliação prudencial do autor de que 
estes aspectos são menos importantes para a fruição do direito em questão do que as demais variáveis que integram sua fórmula:

Quadro 4.7 - Estrutura do IFE empregado na pesquisa de Lima (2014)

$$
\begin{aligned}
& I F E=\frac{C+\frac{C e}{2}+\frac{M m}{2}-D G+A p F+F p}{5} \\
& C=\text { Facilidade na obtenção do crédito } \\
& C e=\text { Contratação de empregado } \\
& M m=\text { Melhoria de acesso ao mercado (condições de negociação) } \\
& D G=\text { Dificuldade na gestão dos negócios } \\
& A p F=\text { Apoio na formalização } \\
& F p=\text { Facilidade no pagamento do carnê de Microempreendedor Individual }
\end{aligned}
$$$$
\text { Fonte: Lima, 2014, p. } 101
$$

Em seguida, Lima inseriu os dados quantitativos referentes às variáveis da fórmula. No caso de sua pesquisa, os números foram obtidos a partir de levantamentos publicados pelo Sebrae, referentes aos anos de 2012 e 2013, e com abrangência nacional:

Quadro 4.8 - Fórmula do IFE alimentada com dados quantitativos, em Lima (2014)

$$
I F E=\frac{55,31+\frac{36,07}{2}+\frac{77,90}{2}-66,88+100+53}{5}
$$

Fonte: Lima, 2014, p. 102

Como resultado das operações aritméticas, Lima (2014, p. 102) obtém o "IFE=39,683" como expressão numérica da fruição empírica do direito à propriedade comercial por microempreendedores individuais no Brasil entre os anos de 2012 e 2013. Assim como no caso de Fontes (2014), esse número é a base para o contraste com o "Padrão de Validação Jurídica” (PVJ) na quarta etapa da Análise Posicional, exposta a seguir.

O PVJ é um “padrão’ ou benchmark utilizado para caracterizar o que corresponderia, em termos quantitativos, à efetividade empírica juridicamente validada do direito considerado." (2009, p. 44) A fórmula do PVJ, na realidade, assume o mesmo aspecto daquela do IFE. Ao passo, porém, que os dados que alimentam a fórmula do IFE devem referir-se à fruição empírica, o PVJ é composto por valores ideais, correspondentes ao que o jurista avalia como o grau de fruição desejável para o direito em questão. Em outros termos, o IFE é concebido como uma imagem numérica da esfera do ser (tem função descritiva), ao passo que 
o PVJ reflete o dever ser (tem função normativa) ${ }^{270}$. O PVJ, no entanto, não se presta como crivo para validação universal da fruição de um direito, independentemente do local ou grupo social a que se refere. Em sua formulação, o jurista deve evitar "exercícios abstratos, imprecisos e genéricos de "ponderação de valores"” (Castro, 2009, p. 48), atendo-se, ao invés, ao que expressa a validação jurídica em um determinado contexto. Assim, por exemplo:

as características de fruição consideradas "padrão de validação jurídica" em uma
cultura podem ser diferentes em outra. O PVJ relativo ao "direito à alimentação" em
uma sociedade ou população regional pode corresponder a uma dieta diária distinta
daquela representada no PVJ de outras sociedades ou populações regionais. (Castro,
2009 , p. 45)

Outro aspecto do caráter contextual - e mesmo contingente - dessa validação é temporal. O PVJ elaborado para um momento pode deixar de refletir o que seria fruição ideal de um direito subjetivo em momento subsequente. Nesse sentido, PVJs:

remetem diretamente a contextos concretos e necessitam ser tão continuamente atualizados quanto as políticas públicas necessitam ser reformadas, dadas as novas invenções, mudanças institucionais, realizações tecnológicas e oscilações nas percepções de pessoas sobre a ordem social desejável. (Castro, 2009, p. 48)

Na elaboração do PVJ, o jurista pode adotar, como referenciais, "as recomendações ou metas contidas em lei ou regulamentos normativos de autoridades governamentais, ou estipuladas por organizações internacionais.” (Castro, 2009, p. 45) Não há, porém, limitação à adoção de referenciais normativos prontos: “[o]s índices produzidos por essas entidades podem ser adaptados, como também criticados, tendo em vista especificidades dos contextos em que a fruição é pesquisada." (Castro, 2009, p. 45) Esta abertura na elaboração do PVJ reflete o pressuposto adotado pela AJPE, mencionado anteriormente, no sentido de que a opinião dos indivíduos sobre qual deva ser a fruição presente e futura de seus direitos deve balizar políticas públicas e a política econômica nas democracias. Neste ponto, a Análise Posicional revela sua afinidade com as propostas de experimentalismo democrático, descoberta e inovação institucional, de modo a convergir com o NDD.

Um exemplo prático de elaboração do PVJ a partir de critérios mistos pode ser encontrado na pesquisa de Albério Lima (2014). Para avaliar se o Programa Microempreendedor Individual resulta em uma taxa de sobrevivência empresarial juridicamente válida de seus participantes, Lima adotou o índice de mortandade das empresas em geral, de $24,4 \%$, como critério para o período pesquisado. Ou seja, ao proceder dessa maneira, a política dirigida aos microempreendedores individuais terá sido juridicamente

\footnotetext{
${ }^{270}$ A presença do PVJ na Análise Posicional parece refletir, na classificação empregada por Coutinho (2013), o papel do direito como objetivo, visto que o PVJ se presta a apontar quais seriam os "pontos de chegada" das políticas públicas, em termos da fruição de direitos.
} 
validada, nesse aspecto, se a mortalidade empresarial destes for equiparável ou inferior ao das sociedades empresariais comuns. Para outras variáveis, critérios de validação distintos foram empregados. Assim, a fruição considerada ideal foi determinada em 100\% para todos os outros indicadores, com exceção da facilidade de obtenção de crédito (representada por "C") - que manteve uma margem de $2 \%$ de margem de rejeição de empréstimos ao microempreendedor individual (cf. Lima, 2014, p. 103-7).

Quadro 4.9 - PVJ, como projeção de valores ideais de indicadores que compõem o IFE, em Lima (2014)

$$
\begin{aligned}
& P V J=\frac{98+\frac{100}{2}+\frac{100}{2}-24,40+100+100}{5} \\
& I F E=\frac{C+\frac{C e}{2}+\frac{M m}{2}-D G+A p F+F p}{5}
\end{aligned}
$$

Fonte: Lima, 2014, p. 106

Como resultado, Albério Lima obteve "PVJ = 74,72" (2014, p. 106), o que significou contraste com o IFE anteriormente obtido, no valor de "39,683". Esta situação, de IFE menor que o PVJ, traduz-se na avaliação de que a fruição empírica do direito de microempreendedores individuais à propriedade comercial está aquém do critério estabelecido para sua validação jurídica, sinalizando a necessidade de reformas na política pública correlata a esse direito. Este quinto e último passo será abordado mais adiante.

Procedimento diferente de composição do PVJ foi adotado na pesquisa de Daniele Fontes (2014) sobre o PNBL. Neste caso, os critérios para avaliação da validade jurídica da política pública foram compostos a partir de uma "cesta" de referenciais, que agregou expectativas da sociedade civil brasileira e as metas de planos de banda larga de outros países (cf. Fontes, 2014, p. 108-19). Como resultado da agregação destas expectativas e metas, Fontes considerou que o critério para validação da política pública seria a cobertura de $83,3 \%$ dos domicílios (Z), com velocidade de banda larga de 19,15 Mbps (Y), ao preço de 3,95 dólares (X) - ver Quadro 4.10, a seguir.

A aplicação da fórmula do PVJ gera o referencial numérico de " 35,5 ” para validação jurídica da política pública. Em contraste com o IFE de “28,73”, a comparação sugere a existência de deficiências nas metas do PNBL, indicando a necessidade de reformas. 
Quadro 4.10 - PVJ, como projeção de valores ideais de indicadores que compõem o IFE, em Fontes (2014)

$$
\begin{gathered}
P V J=\frac{3,95+19,15+83,3}{3} \\
I F E=\frac{X+Y+Z}{3}
\end{gathered}
$$

Fonte: Fontes, 2014, p. 119

A quinta e última etapa da Análise Posicional - a recomendação de reformas - só se justifica caso a fruição empírica do direito analisado seja discrepante de seu padrão de validação jurídica, representando efetividade insuficiente ou inexistente (cf. Castro, 2009, p. 45-6). A comparação entre os valores atribuídos às variáveis que compõem o IFE e o PVJ serve de guia para que o jurista identifique os conteúdos prestacionais da política pública que se mostram mais problemáticos. O objetivo último é o de que a política seja reformada de acordo com as necessidades identificadas por meio da comparação de índices, o que se enquadra, mais uma vez, na proposta mais ampla de experimentalismo democrático, aprendizado e descoberta. Em outros termos, o grau de proximidade ou distância entre os valores assumidos pelo IFE e o PVJ é apontado como instrumento para mensurar o que funciona para cada contexto, e o que precisa ser mudado. Uma consequência desse mecanismo, na Análise Posicional, é não haver lugar para receituários institucionais prontos, derivados de recomendações padronizadas (reformas do tipo one-size-fits all). Este aspecto sugere proximidade da AJPE com outros referenciais abordados anteriormente: desde o direito internacional, com a vertente do pluralismo jurídico global; desde a economia, com contribuições heterodoxas da economia do desenvolvimento, e desde as correntes interdisciplinares de direito e economia, mais uma vez, com o NDD.

Ao proceder à recomendação de reformas, a AJPE, por considerar que as instituições não são "dadas", mas “convencionais", sugere que o jurista não se detenha diante de instituições existentes e que funcionem como obstáculos à fruição adequada dos direitos de produção e de consumo: "são as instituições (políticas públicas, políticas econômicas, mecanismos de cooperação internacional) que devem ser mudadas para se adaptarem ao exercício da fruição de direitos humanos e fundamentais, não o inverso.” (Castro, 2009, p. 46) Partindo do objetivo de ampliação da fruição empírica de direitos, o jurista "deve estar preparado para recomendar reformas 'de baixo para cima", e "a sequência de reformas recomendadas pode progredir até recomendações de reformas nas políticas objeto de 
cooperação internacional.” (Castro, 2009, p. 46) Como exemplo, se restrições legais à despesa deficitária do Estado forem apontadas como obstáculo à fruição apropriada do direito à propriedade comercial (a exemplo de aumentos da taxa de mortandade de empresas em razão da contração de gastos governamentais) ou de direitos de consumo (em razão de cortes em políticas sociais), o jurista deve ter a liberdade para recomendar reformas nestes dispositivos legais constritores. Se, no mesmo contexto, for identificado que outra barreira à despesa deficitária consiste na ausência de suporte internacional ao endividamento estatal, o jurista poderá recomendar a reformulação das instituições da cooperação econômica internacional para corresponder, por exemplo, à migração de um modelo baseado em fluxos transfronteiriços privados para outro, com maior presença de fluxos de capital publicamente geridos.

Se, por um lado, o incentivo a reformas "de baixo para cima" representa grande liberdade para a imaginação institucional do jurista, por outro, a própria concepção de justiça econômica, como categoria de base da AJPE, introduz certas limitações. Isto porque o conceito propõe a ampliação conciliada da fruição empírica de direitos de produção e consumo, ou seja, a conjugação entre o aspecto da eficiência e da equidade econômicas. Dessa forma, desde a ótica dos direitos de produção, reformas que busquem, por exemplo, o aumento da fruição do direito à propriedade comercial (lucratividade, sobrevivência de empresas), mas impliquem a diminuição da fruição de direitos de consumo, mostram-se problemáticas. O contrário também é verdadeiro: não será conforme à proposta da AJPE a indicação de reformas destinadas a maximizar conteúdos prestacionais correspondentes a direitos sociais sem que haja atenção aos impactos sobre direitos de produção. Não se deve perder de vista, nesse sentido, que a AJPE valoriza a análise das consequências das modificações nas instituições jurídicas.

A aplicação da Análise Posicional em pesquisas conduzidas com uso da AJPE resultou em recomendações de reformas que ilustram esta quinta etapa. Assim, por exemplo, Daniele Fontes (2014) identificou como principal obstáculo para explicar a distância entre o IFE e PVJ quanto ao PNBL a condução da política pública sob um modelo "concorrencial" de telecomunicações, que não resultou na universalização do acesso à banda larga. Como medidas de reforma para superação desse obstáculo, a autora sugeriu maior espaço para o ativismo estatal, com um regime regulatório público como frente principal de expansão da banda larga, complementado pelo modelo concorrencial (2014, p. 131-2, 136). Em consonância com esta proposição principal de reforma, sugeriu que o incremento do acesso à banda larga no Brasil poderia ser favorecido pela expansão da infraestrutura com recursos 
parcialmente públicos (2014, p. 133), inclusive pela utilização de verbas provenientes do Fundo de Universalização de Telecomunicações como subsídio direto aos usuários contratantes do serviço (2014, p. 140).

Já a pesquisa de Albério Lima (2014) identificou diversos obstáculos à fruição do direito à propriedade comercial por microempreendedores individuais no Brasil, dois dos quais serão aqui mencionados para ilustrar as correspondentes propostas de reforma. Um deles foi a existência de restrições no acesso ao crédito em razão de dificuldades no oferecimento de garantias para contratação de empréstimos bancários. Como possível reforma, o autor indica a adoção do "aval solidário" como modalidades para garantia das dívidas bancárias contraídas por microempreendedores individuais (2014, p. 109). Outro ponto problemático apontado foi o grau de densidade burocrática envolvido no recolhimento de tributos. Albério Lima sugeriu, a esse respeito, a inclusão do recolhimento previdenciário, ISS e ICMS no regime do "Simples" (2014, p. 119).

Como foi possível observar, no centro da Análise Posicional está uma proposta de crítica jurídica de políticas públicas que se vale de linguagem numérica. A comparação entre índices - um para a fruição verificada, outro para sua validação jurídica - é a base para a argumentação jurídica que pode levar à confirmação da efetividade de certa política pública ou a propostas de reforma. Nesse sentido, por meio da Análise Posicional, a AJPE a incorpora índices ou indicadores ao discurso jurídico, valendo-se deles para validar, rejeitar ou reformar políticas públicas. O método também se presta a dar visibilidade a realidades "escondidas" de "congelamento" de indivíduos e grupos, correspondentes a graus de fruição empírica inadequada de direitos subjetivos. Este último aspecto torna a Análise Posicional, de certo modo, afeita à função do direito como vocalizador de demandas, levantada por Coutinho (2013).

\subsubsection{Nova Análise Contratual ou Análise de Portfólio}

Em muitos aspectos, a Nova Análise Contratual complementa e auxilia as avaliações procedidas por meio da Análise Posicional. A AJPE concebe a economia de mercado como sendo estruturada por pluralidades de contratos que, ao invés de se situarem de modo isolado ou atomizado, formam redes ou agregados (Castro, 2011, p. 19). Tanto no interior dessas redes - como de uma rede para outra - há impactos mútuos, sobretudo por meio da deflexão monetária, retomada adiante. A Nova Análise Contratual é a ferramenta para representar a arquitetura dos agregados contratuais e fenômenos a ela correlatos. 
Para tanto, ela se vale de redefinições de categorias do direito contratual, voltadas a permitir a "inclusão de políticas públicas como elemento abrangido pela análise jurídica." (Castro, 2009, p. 36) O meio para tanto é uma matriz que separa analiticamente, num eixo, conteúdos contratuais em cláusulas de utilidade e monetárias, e noutro eixo, de interesse privado e público. A matriz permite desempenhar funções de análise diversas. Primeiramente, é um meio para obter clareza a respeito de quais aspectos das relações de produção, troca e consumo sofrem a incidência de conteúdos atrelados a políticas públicas. Em segundo, permite explicitar relações intercontratuais, sobretudo de caráter monetário, acompanhando transmissões de efeitos em cadeia na economia (deflexão monetária). Além disso, facilita a decomposição analítica de políticas públicas em componentes prestacionais e, por decorrência, a identificação de pontos passíveis de reforma. O quadro abaixo ilustra a estrutura da referida matriz:

Quadro 4.11 - Matriz da Nova Análise Contratual

\begin{tabular}{|c|c|c|}
\hline & $\begin{array}{c}\text { Cláusula de } \\
\text { Utilidade }\end{array}$ & $\begin{array}{c}\text { Cláusula } \\
\text { Monetária }\end{array}$ \\
\hline Interesse Privado & $\mathrm{U}$ & $\mathrm{M}$ \\
\hline Interesse Público & $\mathrm{U}$, & $\mathrm{M}$ \\
\hline
\end{tabular}

Fonte: Castro, 2013, p. 17; 2011, p. 42.

Os conteúdos de utilidade e monetários dos contratos são analiticamente decompostos ao longo do eixo horizontal da matriz. Cláusulas de utilidade (U) são objetos dos contratos que refletem "interesses materiais da economia real" (2011, p. 21; cf. 2013, p. 17), ou seja, o objeto principal do que está sendo negociado. Assim, por exemplo, ilustram cláusulas de utilidade: (i) “[a] obrigação das indústrias de alimentos de incluírem, nos rótulos de seus produtos, a declaração sobre nutrientes" (Castro, 2009, p. 36); (ii) especificações de tarefas, horários e intervalos, no caso dos contratos individuais de trabalho e (iii) a construção de um posto de saúde e o prazo para entrega da obra, no caso de licitação realizada pelo poder público. Há um gênero de contratos em que a cláusula de utilidade, no entanto, não se refere a interesses da economia real, mas monetária. É o caso dos contratos financeiros, em que o objeto principal negociado é um ativo monetário (Castro, 2011, p. 21). No caso de um 
contrato de empréstimo bancário, por exemplo, o capital emprestado integra a casa "U" da matriz, ao passo que os juros contratados são sua contrapartida monetária (M).

As cláusulas monetárias (M) incorporam "interesses materiais que adquirem forma monetária." (Castro, 2011, p. 21) Correspondem a uma prestação pecuniária ou obrigação financeira (Castro, 2009, p. 32), que incluem contrapartidas da cláusula de utilidade - a exemplos do preço pago para aquisição de um alimento, o salário do empregado e a remuneração da empreiteira -, mas também tributos e outras prestações pecuniárias, como taxas de juros e de câmbio.

Ao longo do eixo vertical, a matriz da Nova Análise Contratual organiza conteúdos de de interesse privado e público. O que os diferencia é o caráter da negociação de que eles derivam. Os conteúdos de interesse privado têm como principal característica serem, em princípio, livremente negociados e não sujeitos a exigências de ampla publicidade (Castro, 2009, p. 34; cf. 2011, p. 21). Um exemplo extremo de contratos formados de modo praticamente exclusivo por conteúdos de interesse privado consiste nos derivativos financeiros negociados nos chamados "mercados de balcão", ou seja, no shadow banking system (cf. 2009, p. 59), já abordados no capítulo 3.

Já os conteúdos de interesse público são determinados por procedimentos sujeitos a publicidade ampla, como pela via legislativa, administrativa ou judicial (Castro, 2009, p. 34; cf. 2011, p. 21). A estas vias, podem ser acrescidas as negociações internacionais, decisões e resoluções vinculantes de organizações internacionais, decisões de mecanismos internacionais de soluções de controvérsias etc. Assim, como exemplo da incidência de conteúdos de interesse público sobre agregados contratuais, a negociação de contratos de trabalho sofre a incidência de normas constitucionais, como a que determina que a remuneração não seja inferior ao salário-mínimo, bem como de outras normas legais e as provenientes de convenções coletivas de trabalho. Também as decisões judiciais, como mencionado, participam da definição destes conteúdos de interesse público. É o caso da proibição de que o salário-mínimo seja utilizado como indexador para o cálculo de vantagem remuneratória de servidor público ou empregado, estabelecida por súmula vinculante do Supremo Tribunal Federal em 2008. Além destes, os contratos de trabalho contam com a incidência de conteúdos derivados de convenções da OIT ratificadas pelo Brasil. Conteúdos de interesse público dos agregados contratuais, como os exemplificados acima, são simbolizados, na matriz da Nova Análise Contratual, pela adição de um apóstrofo às clausulas de utilidade e monetárias (U' e M'). Analiticamente, quando políticas públicas incidem sobre os agregados contratuais, elas o fazem pela adição de conteúdos U' e M'. 
Quadro 4.12 - Exemplo de aplicação da Matriz da Nova Análise Contratual

\begin{tabular}{|c|c|c|}
\hline & Cláusula de Utilidade & Cláusula Monetária \\
\hline $\begin{array}{l}\text { Interesse } \\
\text { Privado }\end{array}$ & \begin{tabular}{ll} 
& \multicolumn{1}{c}{$(\mathrm{U})$} \\
- & o pneu comercializado; \\
eventual serviço de \\
instalação; \\
- eventual garantia adicional \\
fornecida pela empresa;
\end{tabular} & \begin{tabular}{l}
\multicolumn{1}{c}{$(\mathrm{M})$} \\
- o preço cobrado do \\
consumidor;
\end{tabular} \\
\hline $\begin{array}{l}\text { Interesse } \\
\text { Público }\end{array}$ & \begin{tabular}{ll} 
& \multicolumn{1}{c}{$\left(\mathrm{U}^{\prime}\right)$} \\
- & padrões da ABNT de \\
medidas e segurança; \\
obrigações de destino \\
ambiental adequado de \\
pneus inservíveis por pneus \\
novos ou remoldados \\
introduzidos no mercado.
\end{tabular} & $\begin{array}{l}\quad\left(\mathrm{M}^{\prime}\right) \\
\text { - } \quad \text { tributos incidentes sobre a } \\
\text { transação, inclusive tarifas } \\
\text { aplicáveis ao comércio } \\
\text { exterior; } \\
\text { taxa básica de juros da } \\
\text { economia. }\end{array}$ \\
\hline
\end{tabular}

Fonte: Castro; Pena, 2015, p. 16.

O quadro acima (4.12) traz uma ilustração de aplicação. Os contratos usados no exemplo são de compra e venda de pneus entre empresas e consumidor final no Brasil. Por ser de caráter meramente ilustrativo, o delineamento das cláusulas não tem caráter exaustivo.

Dentre os diversos conteúdos que não estão sujeitos à livre negociação privada, vale chamar a atenção para a presença do elemento "taxa básica de juros da economia" (em M'). No fundo, ela funciona como crivo para a decisão sobre investimentos na economia real ou monetária. $\mathrm{Na}$ perspectiva do produtor e revendedor de pneus, que detêm ou tomam de empréstimo o capital para a produção e comercialização desse bem, há sempre a possibilidade de destinação alternativa de seu capital. Caso a lucratividade de seu investimento na economia real seja inferior à rentabilidade oferecida por investimentos financeiros, estes empresários podem optar pelo "desinvestimento" na produção ou comércio. Do ponto de vista dos incentivos privados, não compensará investir na compra de um estoque de pneus para revenda, ou no pagamento dos fatores para produzi-lo, se a taxa básica de juros for alta o suficiente para tornar as aplicações financeiras mais atrativas. Como efeito, contratos da economia real deixam de existir, para dar lugar a contratações correspondentes à economia monetária (cf. Castro, 2011, p. 23-4). Este é um efeito pervasivo e importante das taxas básicas de juros praticadas.

A AJPE emprega a noção de deflexão monetária interportfólio - ou transmissão intercontratual de valores monetários - para fazer referência a fenômenos como o mencionado acima: nexos ou engastes monetários entre contratos distintos (Castro, 2010, p. 162). As sinalizações de preços, nesse sentido, “viajam” pelas redes contratuais. São variados 
os tipos de interconexão capturados por essa categoria. Como o exemplo acima sugere, uma delas acontece entre a economia real e monetária. Mas há, também, transmissões ou reflexos monetários entre contratos posicionados ao longo de uma mesma cadeia ou agregado contratual. O principal exemplo é o da inflação. Notando aumentos em seus custos de produção, empresários reajustam seus preços, que são transmitidos em cadeia até o consumidor final. O mesmo ocorre com aumentos nas taxas de juros: o encarecimento do acesso ao capital tende a fazer com que empresas incorporem esse aumento nos preços praticados para a venda de seus produtos. Reajustes como estes podem espalhar-se de modo rápido e abrangente pelos agregados contratuais que formam a economia (cf. Castro, 2014a, p. 29).

A deflexão monetária pode dizer respeito, ainda, a sinalizações de preços que viajam transnacionalmente. Afinal, os agregados contratuais abrigam "interconectividades contratuais que estabelecem múltiplos vínculos entre a economia real e a economia monetária, tanto em sua dimensão local quanto na internacional" (Castro, 2006, p. 60). Diferenciais internacionais nas taxas de câmbio, de juros e nos custos locais de produção são fatores relevantes para a sobrevivência de uma empresa diante de seus competidores. Assim, a depreciação do Real pode impulsionar exportações de produtos brasileiros em detrimento de competidores estrangeiros, ao passo que a apreciação da moeda brasileira frente ao dólar corresponde ao acesso facilitado das mercadorias importadas ao mercado nacional, comprometendo a competitividade de empresas locais (cf. Castro, 2014c). Algo semelhante ocorre com as taxas de juros, diretamente ligadas aos custos de acesso ao capital para financiamento das atividades empresariais (bem como do consumo e de novos investimentos). A existência de taxas de juros mais elevadas no Brasil do que em outros pontos do globo, como Europa, Japão e Estados Unidos, representa um obstáculo à inserção competitiva de empresas brasileiras, dado que seus competidores, nesses outros mercados, podem ter acesso ao fator "capital" a menores custos. O mesmo ocorre com custos de outros fatores de produção, como o trabalho. Os diferenciais internacionais no preço da mão de obra estão ligados a decisões de investimento das indústrias, e estimulam fenômenos de "migração empresarial" e internacionalização de cadeias produtivas.

Vale lembrar que, tal qual sugerido quanto a outras modalidades de deflexão monetária, também as decorrentes de diferenciais internacionais (de câmbio, juros e outros preços) espalham-se pelas redes contratuais que compõem a economia. Assim, o fechamento de uma indústria local em razão destes diferenciais corresponde a menos trabalhadores empregados, menor renda em circulação, menos tributos arrecadados etc. Por sua vez, a 
instalação da fabrica que "migrou" para onde juros são menores, mão de obra mais barata, ou as relações de câmbio mais favoráveis, tende a corresponder a impactos opostos. O Quadro 4.13 procura ilustrar esses encadeamentos monetários intercontratuais.

Quadro 4.13 - Representação da deflexão monetária interportfólio

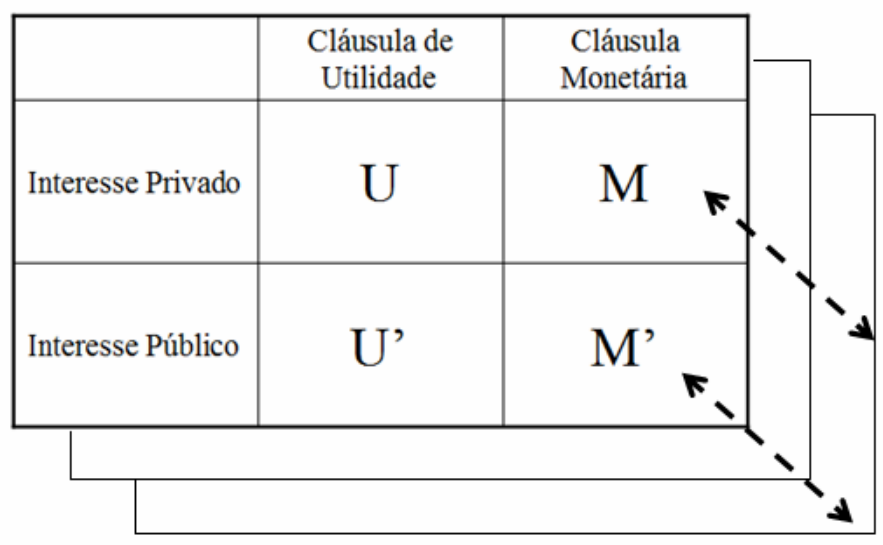

Fonte: Castro; Pena, 2015, p. 17

A importância que a AJPE atribui à deflexão monetária interportfólio em seu procedimento de análise contratual reflete o componente consequencialista de sua abordagem. O jurista, tanto para criticar quanto para apresentar propostas de reforma a políticas públicas, não pode deixar de levar em conta o fato de que as sinalizações de preços viajam pelos contratos que integram a economia. Outro aspecto que reflete essa importância é a consideração da moeda tanto como instituição ordenadora de relações econômicas e sociais, quanto como habilitadora de mudanças. A moeda "possibilita a mobilização e a coordenação de interesses para fins produtivos e de comércio", ao lado dos "complementos contratuais" (Castro, 2009, p. 27) capturados pela matriz da Nova Análise Contratual. Ao mesmo tempo, é indutora e habilitadora de mudanças, um meio para o exercício do "poder prático de transformação social", correspondente a "mudanças nas hierarquias sociais herdadas, não negociadas no presente, e que definem a ordem corrente da sociedade.” (Castro, 2009, p. 30) Esse leque de possibilidades é capturado, na AJPE, pela categorização de três "ambientes monetários institucionais", também referidos simplesmente como "moedas".

O primeiro deles é o ambiente institucional monetário civil ou social, ou, simplesmente, "moeda civil". Ele é composto por "instrumentos e políticas que incorporam o interesse público na proteção a práticas de consumo”. Guarda relação, portanto, com direitos de consumo e com a propriedade civil. Em termos da Nova Análise Contratual, o ambiente monetário civil ou social corresponde à presença de conteúdos $\mathrm{M}^{\prime}$ orientados para a proteção 
de (ou fomento a) práticas de consumo que podem se revestir (inclusive) de caráter extraeconômico. Assim, por exemplo, contratos de financiamento da casa própria contam com conteúdos monetários diferenciados, que guardam relação com o direito à moradia (cf. Castro 2009, p. 59). Da mesma forma, a instituição do "bem de família" confere imunidade jurídica a um imóvel em relação a execuções, protegendo a prática de consumo de um bem considerado especial (o lar). Outra prática de uso de bem imóvel revestida de caráter extraeconômico e a que o direito brasileiro confere proteção especial refere-se aos "templos de qualquer culto", que são imunes da incidência de impostos em função de norma constitucional.

O segundo ambiente monetário institucional é o comercial, ou moeda comercial, correspondente a "instrumentos monetários e financeiros da livre criatividade contratual de atores privados dos mercados bancário e financeiros", cujas "regras procedimentais de negociação e prestações podem não ter o requisito de ampla publicidade." (Castro, 2009, p. 59) Os "mercados de diversos ativos transacionais em balcão" exemplificam esse tipo de ambiente monetário institucional (Castro, 2009, p. 59). Mas nem todos os ambientes monetários institucionais são tão isolados da incidência de políticas públicas quanto os "mercados de balcão". Muitos deles são permeados por instrumentos monetários estratégicos.

Finalmente, a "moeda estratégica" refere-se a "instrumentos e políticas que se traduzem em conteúdos de 'estratégia' do Estado" e que podem ser dirigidos a "ampliar a competitividade de investimentos", "proteger práticas de consumo" ou "adquirir posições estratégicas nas relações econômicas e internacionais." No fundo, os três ambientes monetários institucionais se interligam, porque os instrumentos da "moeda estratégica" podem ser "enxertados" na moeda civil e comercial (Castro, 2009, p. 59). Essa categoria abriga, como componentes $\mathrm{M}^{\prime}$, as estratégias variadas de intervenção estatal que correspondem a políticas comerciais, industriais e de tecnologia, dentre os quais subsídios à exportação (inclusive por abertura de linhas de crédito com taxas de juros preferenciais), imposição de barreiras tarifárias, concessão de benefícios tributários, modulações estratégicas da taxa de câmbio, compras governamentais etc.

A partir do delineamento acima, é possível perceber que a Nova Análise Contratual oferece uma linguagem para situar, em termos jurídicos (ressignificados e expandidos) o que usualmente é referido como políticas comerciais, industriais e de tecnologia, bem como medidas de política econômica. Ao traduzir esses elementos para categorias como cláusulas de utilidade e monetárias, de interesse público e privado, a AJPE contribui para torná-los mais próximos do discurso e de preocupações jurídicas, e em particular para sua orientação para emprego em análises utilizadas em reformas que propiciem graus mais amplos de fruição 
empírica conciliada de direitos de produção e consumo, ou justiça econômica. Nesse sentido, temas que normalmente encontram-se "mistificados", ou envolvidos (e isolados) pela noção de serem passíveis de discussão e decisão apenas se versados em termos tecnocráticos, tornam-se sujeitos à crítica jurídica.

Além de cumprir esse objetivo mais amplo, o uso da matriz da Nova Análise Contratual serve como complemento à Análise Posicional, em particular no que diz respeito à etapa de decomposição analítica da política pública ou direito subjetivo em componentes prestacionais passíveis de quantificação. A identificação dos elementos de "interesse público" (U' e M') nos agregados contratuais eleitos para análise facilita o delineamento dos componentes prestacionais que contam com a incidência de políticas públicas, bem como a imaginação do jurista a respeito de novos componentes possíveis, e seu âmbito de incidência. Em outros termos, a matriz presta-se também para situar, analiticamente, a proposição de reformas institucionais. Vale ressaltar, ainda, que a Nova Análise Contratual favorece a percepção de que a economia não é estruturada nem a partir de conteúdos contratuais exclusivamente privados, nem de conteúdos exclusivamente atinentes a políticas públicas: mas de combinações variadas entre ambos. Este é um ponto de abertura para novas concepções institucionais de atuação conjunta entre o setor público e o privado, feição que também caracteriza as formulações do NDD.

Quadro 4.14 - Análise de portfólio do direito à propriedade comercial por participantes do Programa

Microempreendedor Individual

\begin{tabular}{|c|c|c|}
\hline & Cláusula de Utilidade & Cláusula Monetária \\
\hline $\begin{array}{l}\text { Interesse } \\
\text { Privado }\end{array}$ & $\begin{array}{l}(\mathrm{U}) \\
\text { Características técnicas privadamente negociadas } \\
\text { de bens e serviços }\end{array}$ & $\begin{array}{l}(\mathrm{M}) \\
\text { Preços de bens e serviços } \\
\text { (com exclusão analítica de } \\
\text { conteúdos M') }\end{array}$ \\
\hline $\begin{array}{l}\text { Interesse } \\
\text { Público }\end{array}$ & $\begin{array}{l}\text { - Assistência à pré-abertura, abertura e } \\
\text { desenvolvimento de negócios, incluindo } \\
\text { condições institucionais especificadas pela } \\
\text { Análise Posicional (facilidade de acesso ao } \\
\text { crédito, facilidade de contratação de empregado, } \\
\text { acesso ao mercado, dificuldades no } \\
\text { gerenciamento do negócio, facilidade de lidar } \\
\text { com documentação tributária) } \\
\text { - Mais conteúdos adicionados de documentos } \\
\text { jurídicos (por exemplo, recomendações da OIT) e } \\
\text { de pesquisas de opinião de participantes do } \\
\text { Programa Microempreendedor Individual. }\end{array}$ & $\begin{array}{c}\text { (M') } \\
\text { Incentivos tributários } \\
+ \\
\text { Acesso adequado ao capital } \\
\text { (com ajustes em formas de } \\
\text { crédito que razoavelmente } \\
\text { compensem os diferenciais } \\
\text { internacionais em taxas de } \\
\text { juros) }\end{array}$ \\
\hline
\end{tabular}

Fonte: traduzido de Castro; Lima, 2015, p. 25 
Dois trabalhos recentes servem de exemplos de aplicação da matriz da Nova Análise Contratual, de modo relacionado às pesquisas já mencionadas no item anterior. Assim, Castro e Lima (2015) analisam agregados contratuais envolvendo microempreendedores individuais, apontando para elementos de políticas públicas relacionados à fruição de seu direito à propriedade comercial, bem como para possibilidades de reformas direcionadas a ampliá-la (vide Quadro 4.14, acima). No exemplo acima, o adensamento de conteúdos U' e M' conteúdos de interesse público - reflete a percepção dos autores de que o distanciamento entre o IFE e o PVJ na fruição do direito à propriedade comercial de microempresários individuais brasileiros, apurado por meio da Análise Posicional, precisa ter reconfigurados os componentes correspondentes a políticas públicas.

A recomendação de acesso facilitado ao crédito é uma indicação de mudança institucional compartilhada com outro exemplo, referente ao acesso à internet banda larga no Brasil:

Quadro 4.15 - Análise de portfólio de investimentos em serviços de banda larga no Brasil

\begin{tabular}{|c|c|c|}
\hline & Cláusula de Utilidade & Cláusula Monetária \\
\hline $\begin{array}{c}\text { Interesse } \\
\text { Privado }\end{array}$ & $\begin{array}{c}\text { (U) } \\
\text { Características privadamente negociadas } \\
\text { do serviço de banda larga }\end{array}$ & $\begin{array}{l}\text { (M) } \\
\text { Preço adicional por velocidade igual } \\
\text { ou superior a } 1 \text { Mbps e por outros } \\
\text { serviços adicionais. }\end{array}$ \\
\hline $\begin{array}{l}\text { Interesse } \\
\text { Público }\end{array}$ & $\begin{array}{c}\text { (U') } \\
\text { Velocidade maior ou igual a } 1 \text { Mbps } \\
+ \\
\begin{array}{c}\text { Diversas outras regulações de qualidade } \\
\text { do serviço }\end{array}\end{array}$ & $\begin{array}{c}\left(\mathrm{M}^{\prime}\right) \\
\text { Preço de até USD 7,00 por Mb } \\
+ \\
\text { Linhas especiais de crédito } \\
+ \\
\text { Incentivos tributários }\end{array}$ \\
\hline
\end{tabular}

Fonte: traduzido de Castro; Fontes, 2014, p. 26.

4.4.3 AJPE: conexões e contrastes com outras vertentes do debate sobre direito e desenvolvimento

Como anteriormente apontado nesta seção, a AED, o Law \& Finance, o NDD e a AJPE têm em comum o uso de abordagens interdisciplinares, a adoção do pressuposto de que instituições são importantes para o desenvolvimento, e o consequencialismo como integrante das análises de instituições jurídicas. Apesar de partilharem certas características comuns, os referenciais abordados neste capítulo conformam um rico debate. Uma das maneiras de 
compreendê-lo é partir de uma divisão entre perspectivas que instruem o paradigma rule of law e as recomendações dele derivadas, e as que se colocam em posição crítica em relação a estes.

No primeiro grupo, como se viu, situam-se a AED e o Law \& Finance. Apesar de suas diferenças metodológicas (a primeira é baseada em análises custo-benefício, a segunda, em correlações de variáveis a partir de séries estatísticas), estas vertentes de análise propõem, em esseência, que o melhor formato para as instituições jurídicas é aquele que fomente a liberdade privada de transação. As instituições jurídicas são colocadas como fiadoras de um dinamismo situado essencialmente na esfera privada. Em termos da Nova Análise Contratual da AJPE, essa recomendação corresponde ao esvaziamento de conteúdos U' e M' nos agregados contratuais que compõem a economia. A estratégia favorecida pela AED e o Law \& Finance para reforma nas instituições jurídicas consiste em transplantes de modelos derivados do common law. Em particular, suas argumentações levam à conclusão de que as instituições jurídicas do common law são superiores às do civil law para ocasionar o desenvolvimento, justamente por serem percebidas como mais propensas a criar o ambiente institucional de estímulo às transações privadas. Ambas (AED e Law \& Finance) empregam em comum, ainda, uma noção de desenvolvimento atrelada ao crescimento econômico via "mercado", permanecendo avessas à aceitação de políticas redistributivas ou outros elementos jurídicos (exceto no que diz respeito ao rule of law necessário ao funcionamento adequado dos mercados). São abordagens que propõem, em síntese, reformas pró-mercado. Em termos de projeto global, a visão ideal seria a homogeneização/harmonização institucional dos países de modo a convergir para o modelo do common law, com mínima regulação pública do comércio e das finanças, e com predominância dos mecanismos de alocação privada de recursos econômicos. Fica sugerido que as instituições jurídicas que ofereçam obstáculos à eficiência econômica (ou, especificamente, dos mercados financeiros) devem ser removidas. Na AED como no Law \& Finance, o direito está em função da economia.

Conjuntamente, o NDD e a AJPE oferecem contribuições de reforma institucional que não compartilham do paradigma rule of law. Nestas vertentes de análise, o direito não é concebido apenas em sua função instrumental em relação aos mercados. Mais do que isso, instituições jurídicas são vistas como constitutivas dos mercados. Este novo posicionamento do direito reflete-se, inclusive, na adoção de concepções de desenvolvimento que não se restringem ao crescimento econômico - embora, evidentemente, não o excluam como objetivo -, mas que incorporam explicitamente aspectos redistributivos e jurídicos. Na AJPE, a ênfase no aspecto redistributivo aparece não só na definição de justiça econômica como 
situação de fruição ampla e conciliada de direitos de produção e de consumo, mas também na adoção de procedimentos analíticos destinados a avaliar mudanças na posição de indivíduos e grupos, ou seja, de seu grau de habilitação ou inabilitação econômica. A categoria de "justiça econômica" exerce, na AJPE, papel equivalente ao da categoria ampliada de “desenvolvimento" no NDD, ambas abrigando tanto preocupações redistributivas quanto definições de "bem" que incluem objetivos jurídicos. Ao invés da ênfase exclusiva em formatos institucionais que favoreçam o dinamismo da esfera privada, o NDD e a AJPE podem ser vistos como contribuições que buscam superar as divisões entre mercado e Estado, favorecendo a concepção de que as melhores estratégias para o desenvolvimento ou justiça econômica envolvem conteúdos correspondentes a atuações dos dois setores. Em outros termos, ambas abrem espaço para a construção de argumentações de apoio ao novo ativismo estatal. As estratégias de reforma institucional privilegiadas são a experimentação democrática, a descoberta e a inovação. Há abertura para diálogos horizontais entre países, mas rejeição de global standard institutions. O "projeto global" implicado no NDD e na AJPE é essencialmente pluralista: a abertura de espaço para a adoção de soluções institucionais contextualmente adequadas, específicas, e que dialoguem com as aspirações de seus respectivos povos.

Porém, apesar de suas afinidades e convergências, o NDD e a AJPE - tal qual a AED e o Law \& Finance no agrupamento das visões de apoio ao paradigma rule of law - têm diferenças relevantes. O NDD reúne ideias sobre instituições jurídicas que estabelecem diálogo próximo com contribuições heterodoxas da economia do desenvolvimento, mas não há a adoção de ferramentas metodológicas próprias, que permitam definições precisas de seus contornos. Como mencionado na seção 4.3, sua própria caracterização como "campo" integra um debate corrente. Nesse sentido, o NDD se distingue de todas as outras correntes analisadas até aqui, pela ausência de um método analítico característico. A AJPE, apesar de também trabalhar de modo afim a contribuições econômicas heterodoxas, procede de modo a subsumir aspectos econômicos por meio da geração de novas categorias e métodos jurídicos, destinados a abarcá-los. Assim, a AJPE é marcada pela adoção de categorias e métodos próprios de análise jurídica, como apontado no trecho a seguir:

Enquanto a abordagem do NDD estabelece diversas ligações entre a análise jurídica e argumentos derivados da literatura sobre desenvolvimento econômico e também de buscas por "novas funcionalidades" do direito, a perspectiva da AJPE atribui ênfase significativa à reconstrução de categorias jurídicas e à abordagem de fatos com o auxílio do engajamento interdisciplinar variado do discurso jurídico com a análise sociopolítica de projetos de políticas públicas e sua implementação. (Castro; Lima, 2015, p. 5) 
Além disso, no que diz respeito a noção de "bem" que instrui as análises, enquanto o NDD adota a categoria ampliada de "desenvolvimento", absorvendo uma tendência relativamente recente na economia heterodoxa, a preocupação com esse aspecto, na AJPE, também é traduzida em termos jurídicos, capturados a partir da definição de "justiça econômica". Ou seja, a AJPE conta com uma definição própria para sua concepção do "bom" e do "desejável", que recebe uma interpretação versada diretamente na linguagem de direitos subjetivos.

O quadro 4.16, na página seguinte, procura reunir as principais características que permitem aproximações e contrastes entre as expertises interdisciplinares a serviço de reformas, abordadas neste capítulo. 
Quadro 4.16 - Aproximações e contrastes entre expertises interdisciplinares a serviço de reformas

\begin{tabular}{|c|c|c|c|c|}
\hline Expertise / aspecto & AED & Law \& Finance & NDD & AJPE \\
\hline $\begin{array}{l}\text { Momento do debate } \\
\text { sobre direito e } \\
\text { desenvolvimento }\end{array}$ & \multicolumn{2}{|c|}{$2^{\circ}$ - rule of law } & \multicolumn{2}{|c|}{$3^{\circ}$ - novo ativismo estatal } \\
\hline $\begin{array}{c}\text { Principais } \\
\text { características } \\
\text { metodológicas das } \\
\text { análises }\end{array}$ & $\begin{array}{l}\text { Análise custo- } \\
\text { benefício de } \\
\text { instituições } \\
\text { jurídicas; } \\
\text { emprego do } \\
\text { Teorema de } \\
\text { Coase; uso de } \\
\text { suposições } \\
\text { aritméticas }\end{array}$ & $\begin{array}{l}\text { Emprego de séries } \\
\text { estatísticas } \\
\text { históricas para } \\
\text { correlacionar } \\
\text { origens de } \\
\text { instituições } \\
\text { jurídicas a } \\
\text { variáveis relativas } \\
\text { a mercados } \\
\text { financeiros }\end{array}$ & $\begin{array}{l}\text { Amálgama de } \\
\text { diferentes e } \\
\text { amplas } \\
\text { possibilidades } \\
\text { metodológicas, } \\
\text { tendência à } \\
\text { condução de } \\
\text { estudos de caso }\end{array}$ & $\begin{array}{l}\text { Nova Análise } \\
\text { Contratual; } \\
\text { Análise } \\
\text { Posicional; foco } \\
\text { na fruição } \\
\text { empírica de } \\
\text { direitos subjetivos }\end{array}$ \\
\hline Papel do direito & $\begin{array}{l}\text { Instrumental, com } \\
\text { destaque para } \\
\text { função protetiva. } \\
\text { Direito é meio } \\
\text { para a eficiência } \\
\text { econômica }\end{array}$ & $\begin{array}{l}\text { Instrumental, com } \\
\text { destaque para } \\
\text { função protetiva. } \\
\text { Direito é meio } \\
\text { para expansão e } \\
\text { dinamismo dos } \\
\text { mercados } \\
\text { financeiros }\end{array}$ & $\begin{array}{c}\text { Múltiplos papéis, } \\
\text { inclusive como } \\
\text { "ponto de } \\
\text { chegada". } \\
\text { Instituições } \\
\text { jurídicas são } \\
\text { constitutivas de } \\
\text { mercados }\end{array}$ & $\begin{array}{l}\text { Múltiplos papéis. } \\
\text { Direito usado } \\
\text { como referencial } \\
\text { para crítica e } \\
\text { reforma de } \\
\text { políticas públicas } \\
\text { e da política } \\
\text { econômica }\end{array}$ \\
\hline $\begin{array}{c}\text { Ênfase em } \\
\text { instituiçõos jurídicas } \\
\text { de }\end{array}$ & \multicolumn{2}{|c|}{ Direito privado } & \multicolumn{2}{|c|}{$\begin{array}{c}\text { Acoplamento de conteúdos de direito } \\
\text { público e privado em arranjos } \\
\text { institucionais contextualmente } \\
\text { específicos }\end{array}$} \\
\hline Desenvolvimento & $\begin{array}{l}\text { Crescimento } \\
\text { econômico via } \\
\text { desenhos } \\
\text { institucionais de } \\
\text { estímulo à } \\
\text { eficiência }\end{array}$ & $\begin{array}{l}\text { Crescimento } \\
\text { econômico via } \\
\text { mercados } \\
\text { financeiros }\end{array}$ & $\begin{array}{c}\text { Concepção } \\
\text { multifacetada de } \\
\text { desenvolvimento } \\
\text { como liberdade, } \\
\text { com componentes } \\
\text { econômicos, } \\
\text { políticos, sociais e } \\
\text { jurídicos }\end{array}$ & $\begin{array}{l}\text { Justiça econômica } \\
\text { como ampliação } \\
\text { conciliada da } \\
\text { fruição de direitos } \\
\text { de produção e } \\
\text { consumo }\end{array}$ \\
\hline $\begin{array}{l}\text { Principal setor } \\
\text { protagonista }\end{array}$ & \multicolumn{2}{|c|}{ Iniciativa privada } & \multicolumn{2}{|c|}{$\begin{array}{l}\text { Valorização de potenciais de atuação } \\
\text { pública e privada }\end{array}$} \\
\hline $\begin{array}{l}\text { Estratégia de } \\
\text { redistribuição } \\
\text { privilegiada }\end{array}$ & \multicolumn{2}{|c|}{$\begin{array}{l}\text { Trickle down; spillover: políticas de } \\
\text { redistribuição deliberada tendem a ser } \\
\text { encaradas como distorções }\end{array}$} & \multicolumn{2}{|c|}{ Políticas públicas } \\
\hline $\begin{array}{l}\text { Tendência de sentido } \\
\text { de reformas }\end{array}$ & \multicolumn{2}{|c|}{$\begin{array}{l}\text { Configurar ambientes institucionais } \\
\text { pró-mercados; fortalecer direitos de } \\
\text { propriedade e de contrato; buscar } \\
\text { independência e celeridade do } \\
\text { judiciário; desregular finanças }\end{array}$} & \multicolumn{2}{|c|}{$\begin{array}{l}\text { Configurar arranjos institucionais } \\
\text { contextualmente específicos e com } \\
\text { espaço para participação do setor } \\
\text { público sem supressão do potencial } \\
\text { dinâmico da iniciativa privada }\end{array}$} \\
\hline $\begin{array}{l}\text { Estratégias } \\
\text { favorecidas de } \\
\text { reforma }\end{array}$ & \multicolumn{2}{|c|}{$\begin{array}{l}\text { Transplantes institucionais inspiradas } \\
\text { no common law, convergência ou } \\
\text { harmonização institucional global, } \\
\text { adoção de global strandard institutions }\end{array}$} & \multicolumn{2}{|c|}{$\begin{array}{l}\text { Ênfase em soluções contextualmente } \\
\text { adequadas; experimentalismo } \\
\text { democrático, imaginação e descoberta } \\
\text { institucional, aprendizado, diálogo } \\
\text { horizontal, pluralismo institucional } \\
\text { global. }\end{array}$} \\
\hline
\end{tabular}

Fonte: elaborado pelo autor a partir das caracterizações feitas neste capítulo. 


\section{CONCLUSÃO}

A análise do processo de cooperação econômica internacional no período compreendido entre o final do século XIX e o início do século XXI sugere, em primeiro lugar, que tal processo sofreu mudanças.

A trajetória de mudanças foi permeada por diferentes "momentos", aqui entendidos como conformações temporárias de ideias, práticas institucionais e articulações de interesses a que se vinculam. O principal objetivo da tese consistiu em caracterizar as perspectivas jurídicas e econômicas - bem como perspectivas interdisciplinares do debate sobre as relações entre direito e desenvolvimento - cujos materiais intelectuais produzidos foram (ou têm sido) articulados na estruturação, perpetuação ou contestação das configurações de ideias e práticas a que correspondem esses "momentos".

Ao longo da tese, o núcleo de ideias mais importantes e gerais em cada "momento" foi abordado como langue, de acordo com o uso crítico que Duncan Kennedy faz desta noção, ao passo que as manifestações práticas ou particulares (na forma de posições de autores, emanações de direito positivo, adoção de medidas de política econômica etc.) das ideias desse núcleo foram lidas como parole (vide capítulo 1). Tal estratégia de abordagem permitiu atribuir relevância aos elementos jurídicos, econômicos e interdisciplinares - bem como de concepções de desenvolvimento - que predominaram no vocabulário de políticas públicas em cada "momento", ou seja, que integraram a "estrutura" discursiva ou, ainda, a "moldura cognitiva" prevalente. Esta tese propõe que a sucessão destes momentos e destas langues é reveladora.

Primeiramente, as mudanças descritas revelam, como elemento "de fundo", a presença de "projetos institucionais globais" implicados nos vocabulários jurídicos, econômicos e interdisciplinares abordados neste estudo. De um lado, certas langues, do século XIX até a primeira década do século XXI, participaram do fomento a um projeto que pode ser caracterizado como "universalismo institucional global". Tal "universalismo" apareceu nas ideias e práticas (i) jurídicas correspondentes ao direito internacional clássico e a certas perspectivas sobre a governança global - como o direito administrativo global - (ver seções 2.1 e 2.3.5.2); (ii) econômicas, correspondentes ao liberalismo econômico e ao neoliberalismo (ver seções 3.1 e 3.3) e (iii) interdisciplinares, correspondentes à AED e ao Law \& Finance (ver seções 4.1 e 4.2). De outro lado, concepções recentes têm fornecido vocabulários para a estruturação do que se pode designar "pluralismo institucional global", que se manifestou, em 
termos de ideias e práticas (i) jurídicas, na vertente do pluralismo jurídico global (ver seção 2.3.5.3); (ii) econômicas, nas novas contribuições heterodoxas da economia do desenvolvimento (ver seção 3.4) e (iii) interdisciplinares, no NDD e na AJPE (ver seções 4.3 e 4.4).

Sobre a formação dos "projetos institucionais globais", a tese mostrou que, na porção final do século XIX e inicial do século XX, o direito internacional clássico e o liberalismo econômico eram, na delimitação empregada na pesquisa, os quadros de referência para a estruturação da cooperação econômica internacional. Ambos foram permeados pela influente concepção de "civilização" (e progresso), que permitia não só a distinção entre povos (com tonalidades culturais e raciais), senão também sua hierarquização, com a correspondente afirmação da superioridade dos povos "civilizados" sobre os demais. Embutida nesta hierarquização estava um projeto de assimilação destes outros povos às instituições jurídicopolíticas e econômicas europeias. Este sentido de assimilação foi persistente, atravessando o sistema de mandatos e alcançando o pós-Segunda Guerra, quando a divisão de mundo em torno de desenvolvidos e subdesenvolvidos foi acompanhada de hierarquias entre modelos institucionais. Foi também discutido como a multiplicação de Estados recém-independentes gerou uma maioria terceiro-mundista que ventilou pretensões de nova ordem econômica internacional. Suas tentativas de articular doutrinas na esfera do direito internacional público em prol de seu projeto (soberania permanente dos recursos naturais e, de modo geral, a própria categoria de soberania) foram contrabalançadas por rearticulações de outras doutrinas, como sucessão de Estados, responsabilidade internacional, fontes do direito internacional e, ainda, pela emergência de novos campos (o direito dos contratos internacionais, ou direito internacional dos investimentos estrangeiros, international standards e favorecimento da arbitragem internacional), cujos vocabulários jurídicos destinavam-se a isolar o investidor estrangeiro da incidência do direito local de países em desenvolvimento. O resultado parece ter sido próximo ao obtido com as jurisdições consulares do século XIX e início do século XX: o isolamento do (investimento) estrangeiro em relação ao direito local.

A tese também discutiu, ainda relativamente à sucessão dos "projetos institucionais globais", como a partir da década de 1970, a perspectiva neoliberal alcançou prestígio político e promoveu a noção de mercados autorregulados como fundamento para organização das instituições econômicas domésticas e da cooperação econômica internacional. Com a ascensão desta perspectiva, o projeto de universalismo institucional global tornou-se ainda mais saliente, visto que foram explicitadas, como estratégias conducentes ao desenvolvimento, a harmonização ou convergência global em torno de instituições pró- 
mercados, que no fundo representam uma receita de projeção global do modelo do common law. Estas noções foram, em especial, fomentadas pela NEI e por expertises interdisciplinares como a AED ao estilo de Chicago e o Law \& Finance. A busca de instituições eficientes ou conducentes ao dinamismo dos mercados financeiros, que estas vertentes promovem, conciliou-se com a desconfiança neoliberal em relação ao Estado e a identificação da iniciativa privada como motor do crescimento econômico.

A tese também ofereceu uma análise de como foi articulado o projeto alternativo, de "pluralismo institucional global". Conforme discutido, no direito, este projeto esteve (e continua, no presente) fortemente implicado na vertente de teoria jurídica denominada pluralismo jurídico global (item 2.3.5). As formulações aí contidas, afinal, provêm vocabulários para a coexistência de diferenças institucionais internacionais (a exemplo da noção de "hibridismo jurídico global") e, além disso, defendem a superação da compartimentação entre direito público e privado (o que se casa com a proposta de transcender analiticamente a divisão "Estado x mercados", divisão esta que serviu de base ao mote de "liberalização de mercados", abrigado pelo neoliberalismo).

$\mathrm{Na}$ economia, contribuições heterodoxas promoveram releituras das trajetórias institucionais e estratégias de desenvolvimento de países variados, de modo a lançar dúvidas sobre as receitas do "momento" anterior, ou seja, sobre receitas institucionais inspiradas no paradigma rule of law e conducentes a reformas pró-mercados. Autores como Ha-Joon Chang e Dani Rodrik, entre outros, passaram a enfatizar a necessidade de adequar arranjos institucionais às peculiaridades de cada contexto e às aspirações locais. As estratégias de desenvolvimento que autores nesta linha favorecem incluem maior espaço para a participação estatal, sem que a importância da iniciativa privada seja posta de lado. Em outros termos, esta nova vertente propõe superar a divisão "Estado x mercados" pela ênfase na busca do que funciona em cada caso, sem modelos pré-fixados. Em sintonia com este sentido, trabalham com concepções multifacetadas de desenvolvimento, não o restringindo ao crescimento econômico. Sugerem, além disso, reformas para tornar as estruturas da cooperação econômica internacional mais propícias a abrigar variedades de configurações institucionais locais. A convergência institucional não é um objetivo a ser perseguido, nesta visão.

Duas das expertises interdisciplinares do debate abordado no capítulo 4 têm forte aproximação com estas ideias: NDD e AJPE. As duas correntes trabalham com concepções ampliadas de desenvolvimento, com atenção a componentes jurídicos e a aspirações locais para sua compreensão. Novamente em contraste com a AED e o Law \& Finance, as estratégias privilegiadas de reforma institucional não consistem em transplantes ou na busca 
de convergências institucionais globais, nem se baseiam na afirmação de superioridade do common law, mas na ênfase na descoberta, inovação e experimentação institucional. O projeto normativo global implicado nestas visões tem feições pluralistas.

Em segundo lugar, ao examinar de outro ângulo o processo de mudanças dos padrões de cooperação internacional, a tese mostrou como elementos jurídicos e econômicos receberam pesos variáveis na formação de perspectivas interdisciplinares sobre direito e desenvolvimento. Inicialmente, as elaborações deste debate favoreceram o posicionamento "instrumental" do direito em relação a objetivos definidos a partir de referenciais econômicos, como fizeram a AED e a literatura de Law \& Finance. Mais recentemente, porém, perspectivas alternativas passaram a encarar o direito para além de suas funcionalidades instrumentais tradicionais, identificando-o como fonte de referenciais para estruturação da ordem econômica e para a própria definição de desenvolvimento. Os vocabulários de vertentes como o NDD e a AJPE abriram espaço, com maior ou menor ênfase, para que políticas públicas e padrões regulatórios da cooperação econômica institucional sejam pautados por objetivos precipuamente jurídicos.

Como visto, na conformação das sucessivas ordens econômicas internacionais, instituições e ideias jurídicas tenderam a cumprir papéis instrumentais na estruturação de padrões regulatórios ligados à cooperação econômica internacional, quando comparadas aos referenciais econômicos. O direito internacional clássico proveu formas que embalaram a expansão comercial europeia, mas não resultou na elaboração de nenhum projeto jurídico de ordenação das relações econômicas internacionais - tampouco de orientação desta para finalidades propriamente jurídicas. Foi o POI, um regime internacional informal, que proveu padrões regulatórios para as relações monetárias e financeiras da porção final do século XIX e inicial do século XX, e não uma ordem multilateralmente negociada.

Esta lógica perdurou no entreguerras. Apesar da existência da ação estatal em políticas redistributivas e de pleno emprego, positivadas em termos de direitos sociais, não foi a racionalidade jurídica, mas sim a macroeconômica, que proveu as formas para embasar e orientar este comportamento "desviante" em relação ao liberalismo econômico clássico.

No pós-Segunda Guerra, similarmente, instituições jurídicas continuaram a ser vistas como ferramentas - apesar da existência uma ordem econômica internacional multilateralmente negociada e expressa em termos de direito positivo -, desta vez para a coordenação estatal econômica e social, e com ênfase no direito público, aspectos característicos do primeiro momento do debate sobre direito e desenvolvimento, conhecido como direito e Estado desenvolvimentista. No segundo momento desde mesmo debate, ou 
direito e desenvolvimento neoliberal, o direito é tomado como provedor do ambiente institucional favorável às livres transações nos mercados, com destaque para sua função de garantir a autonomia privada, via proteção de direitos como propriedade e contratos - feições que se projetaram na AED e no Law \& Finance. Nestes últimos casos, reformas em instituições jurídicas são explicitamente orientadas por racionalidades econômicas. O direito é posto em função da economia, quer na versão da eficiência, quer na versão da expansão dos mercados financeiros (que no fundo se sobrepõem).

Mais recentemente, porém, a concepção multifacetada de desenvolvimento contou com a inclusão de aspectos jurídicos como objetivos a título próprio, e não só como caminhos para o crescimento econômico. O NDD, dentre as vertentes analisadas, enfatiza mais explicitamente os múltiplos papéis ou funcionalidades do direito, dentre as quais o de estabelecer pontos de chegada para políticas públicas e medidas de política econômica. $\mathrm{Na}$ AJPE, a seu turno, a própria definição de "justiça econômica" empregada - análoga à de "desenvolvimento" no NDD - reflete o novo posicionamento do direito como objetivo último das análises, já que a categoria é versada em termos de ampla fruição conciliada de direitos de produção e de consumo. Visões como estas não situam o direito em função da economia, mas sugerem, em sentido contrário, que políticas públicas e padrões de cooperação econômica internacional devam ser pautados por finalidades jurídicas. Em outros termos, abrem possibilidades de balizamento destas por referenciais jurídicos. A este respeito, a AJPE se singulariza por apresentar ferramentas metodológicas próprias e categorias jurídicas ressignificadas como meios para habilitação do jurista para criticar e sugerir reformas em políticas públicas e medidas de política econômica, embasadas nos impactos destas sobre a fruição empírica de direitos subjetivos.

Estas novas movimentações do debate sobre direito e desenvolvimento apresentam contribuições no sentido de que o olhar jurídico não descarte como externos a seu âmbito de incidência e pretensão de ordenação elementos da economia e das relações internacionais. Correspondem, ainda, a possibilidades de ganho de relevância do discurso jurídico para seu balizamento, em contraste com a tendência verificada, ao longo do século XX, de retraimento a posições "instrumentais" em relação ao domínio econômico e à estruturação da cooperação econômica internacional. 
O processo de mudanças relatado neste ensaio não sugere que cada momento da cooperação econômica internacional seja lido como a continuidade melhorada, ou seja, como "adição" ao legado ou "evolução" das práticas institucionais e elementos ideacionais precedentes. O percurso é permeado por rupturas, embates, quadros de referência em choque, ideias que ganham e perdem prestígio político e traduções em termos de prática e influência sobre padrões regulatórios. E este ponto também é relevante para o cenário hoje vivido, de conjuntura crítica na cooperação econômica internacional, pós-crise de 2008.

Por décadas, o predomínio de certa visão de cooperação econômica internacional baseada no motivo da liberalização dos mercados conseguiu "naturalizar-se", fixando a noção de que a desregulamentação financeira, a autocontenção estatal no domínio econômico e a adoção de instituições jurídicas de apoio à atuação dos agentes privados (entre outros elementos) seriam componentes indispensáveis ao desenvolvimento. Mas perceber as descontinuidades históricas da cooperação econômica internacional e dos vocabulários existentes para articulá-la é importante para "desnaturalizar" a conformação (ainda hoje) existente como "necessária", “inevitável” ou, ainda, como "a melhor possível”, e fomentar a busca por concepções alternativas, inclusive as versadas em termos do "pluralismo institucional global" e orientadas por objetivos jurídicos.

Os apontamentos acima consistem em contribuições que o estudo apresenta à compreensão do debate sobre direito e desenvolvimento. Considera-se, ainda, que o próprio acompanhamento contextualizado deste debate seja uma contribuição relevante. Afinal, ao fazê-lo, a tese apontou para interações entre estruturas da cooperação econômica internacional e formatos de instituições jurídicas domésticas, entre o econômico e o jurídico, o externo e o interno. A sinalização destas interações traz, por sua vez, a provocação sobre o lugar pretendido para o direito: permanecer como fonte de instrumentos ou reinventar-se como balizador de políticas públicas, de medidas de política econômica e mesmo como referencial para crítica e reforma de estruturas da cooperação econômica internacional? A existência das interconexões apontadas, bem como a provocação a elas relacionada, implica repensar a postura jurídica convencional de definir o que é relevante para sua análise apenas com referência a elementos incorporados ao ordenamento doméstico ou a categorias abstratas do edifício conceitual jurídico convencional. 


\section{REFERÊNCIAS}

A CORPORAÇÃO. Direção de Mark Achbar; Jennifer Abbott. Roteiro: Joel Bakan; Harold Crooks; Mark Achbar. Toronto: Big Picture Media Corporation, 2003. (145 min.), son., color. Legendado. Documentário (1 DVD).

ACCIOLY, Hildebrando. Manual de direito internacional público. 11. ed. São Paulo: Saraiva, 1991.

ACEMOGLU, Daron; ROBINSON, James A. Why nations fail: the origins of power, prosperity, and poverty. New York: Crown Business, 2012.

ANGHIE, Anthony. Imperialism, sovereignty and the making of international law. Cambridge: Cambridge University Press, 2004.

ARNER, Douglas W. Financial stability, economic growth and the role of law. Cambridge: Cambridge University Press, 2007.

AVANT, Deborah D; FINNEMORE, Martha; SELL, Susan K.; Who Governs the Globe? In: AVANT, Deborah D; FINNEMORE, Martha; SELL, Susan K.; (eds.) Who Governs the Globe? Cambridge: Cambridge University Press, 2010, p. 1-31.

BAITZ, Rafael. O saber histórico na pesquisa jurídica: as teses acadêmicas e suas introduções históricas. In: BOUCAULT, C. E. A. (org.) História e Método em Pesquisa Jurídica. São Paulo: Quartier Latin, 2006. p. 35-55.

BALASSA, Bela. Towards a theory of economic integration. Kyklos, Vol. 14, No. 1, 1961, p. $1-17$.

BANNISTER, Geoffrey J.; THUGGE, Kamau. International trade and poverty alleviation. Finance \& Development. Vol. 38, n. 4, 2001.

BARRAL, Welber de Oliveira. O comércio internacional. Belo Horizonte: Del Rey, 2007a.

BARRAL, Welber de Oliveira. Solução de controvérsias na Organização Mundial do Comércio. Brasília: Fundação Alexandre de Gusmão, 2007b.

BATEMAN, Bradley W. Keynes and keynesianism. In: BACKHOUSE, Roger E.; BATEMAN, Bradley W. (eds). The Cambridge companion to Keynes. Cambridge: Cambridge University Press, 2006, p. 271-90.

BBC BRASIL. Copa pode provocar despejo de 250 mil pessoas, afirmam ONGs. 14. jun. 2013. Disponível em:

$<$ http://www.bbc.co.uk/portuguese/noticias/2013/06/130614_futebol_despejos_cm_bg.shtml. Acesso em: 7 abr. 2014.

BECKER, Gary S. Crime and punishment: an economic approach. NBER Essays in the economics of crime and punishment, 1974. Disponível em:

$<$ http://www.nber.org/books/beck74-1>. Acesso em: 29 jul. 2015. 
BERMAN, Paul Schiff. From international law to law and globalization. Columbia Journal of Transnational Law, Vol. 43, 2005, p. 485-556.

BERMAN, Paul Schiff. Global legal pluralism. Southern California Law Review, Vol. 80, 2007, p. 1155-238.

BESLEY, Tim et al. The global financial crisis: why didn't anybody notice? British Academy Review, v. 1, n. 14, 2009, p. 8-10.

BHAGWATI, Jagdish. Protectionism. Cambridge: MIT Press, 1995 [1988].

BHAGWATI, Jagdish. In defense of globalization. New York: Oxford University Press, 2004.

BIRCH, Kean; MYKHNENKO, Vlad. Introduction: a world turned right way up. In: BIRCH, Kean; MYKHNENKO, Vlad (eds.). The rise and fall of neoliberalism: the collapse of an economic order? London: Zed Books, 2010, p. 1-20.

BLACK, Lloyd D. A estratégia da ajuda externa. Rio de Janeiro: O Cruzeiro, 1968.

BLYTH, Mark. The transformation of the Swedish model: economic ideas, distributional conflict, and institutional change. World Politics, Vol. 54, No. 1, 2001, p. 1-26.

BOYLE, Francis Anthony. World politics and international law. Durham: Duke University Press, 1985.

BRASIL. CÂMARA DOS DEPUTADOS. Câmara aprova acordo de reconhecimento mútuo de CNH com Moçambique. 2012. Disponível em:

$<$ http://www2.camara.leg.br/camaranoticias/noticias/RELACOES-EXTERIORES/429159CAMARA-APROVA-ACORDO-DE-RECONHECIMENTO-MUTUO-DE-CNH-COMMOCAMBIQUE.html>. Acesso em: 20 abr. 2014.

BRESSER-PEREIRA, Luiz Carlos. A crise financeira global e depois: um novo capitalismo? Novos Estudos (CEBRAP), n. ${ }^{\circ}$ 86, 2010. p. 51-72.

BROWN, Andrew G. Reluctant partners: a history of multilateral trade cooperation, 18502000. Ann Arbor: The University of Michigan Press, 2003.

BROZ, Lawrence. The domestic politics of international monetary order: the gold standard. In: FRIEDEN, Jeffry A.; LAKE, David A (ed.). International political economy: perspectives on global power and wealth. 4. ed. London: Routledge, 2003. p. 199-219.

BRUM, Algemiro Luís; HECK, Cláudia Regina. Economia internacional: uma síntese da análise teórica. Ijuí: Unijuí, 2005.

BUCHANAN, James M. Good economics - bad law. Virginia Law Review, Vol. 60, No. 3. 1974. p. 483-92.

CALIXTO, Vinícius Machado. A afirmação da lex sportiva como uma ordem jurídica transnacional autônoma. 2013. 77 f. TCC (Graduação) - Curso de Curso de Graduação em Direito, Departamento de Faculdade de Direito, Universidade de Brasília, Brasília, 2013. Disponível em: < http://bdm.bce.unb.br/bitstream/10483/6788/1/2013_ViniciusMachado Calixto.pdf>. Acesso em: 7 abr. 2014. 
CARR, Edward Hallett. The twenty years' crisis 1919-1939: an introduction to the study of international relations. London: Macmillan \& Co, 1946.

CARVALHO, Cristiano. Análise econômica da tributação. In: TIMM, Luciano Benetti (org.). Direito e economia no Brasil. São Paulo: Atlas, 2012, p. 246-65.

CASSESE, Antonio. International law. New York: Oxford University Press, 2001.

CASTRO, Marcus Faro de (org). A sociedade civil e o monitoramento das instituições financeiras multilaterais. Brasília: Rede Brasil, 2005a.

CASTRO, Marcus Faro de. Política e relações internacionais: fundamentos clássicos. Brasília: Editora UnB, 2005b.

CASTRO, Marcus Faro de. Instituições econômicas: evolução de seus elementos constitucionais na sociedade de mercado. Revista de Direito Empresarial. Curitiba, n. 6. jul./dez. 2006, p.41-62.

CASTRO, Marcus Faro de. Análise Jurídica da Política Econômica. Revista da ProcuradoriaGeral do Banco Central, v. 3, 2009, p. 17-71.

CASTRO, Marcus Faro de. Jurisdição, Economia e Mudança Social. In: KOERNER, Andrei; DUARTE, Fernanda (orgs.). Justiça Constitucional no Brasil: Política e Direito. Rio de Janeiro, Revista do TRF da Segunda Região, 2010, p. 143-74.

CASTRO, Marcus Faro de. Direito, tributação e economia no Brasil: aportes da Análise Jurídica da Política Econômica. Revista da Procuradoria-Geral da Fazenda Nacional, v.1, n.2, (jul.-dez.), 2011, p. 23-51.

CASTRO, Marcus Faro de. Formas jurídicas e mudança social: interações entre o direito, a filosofia, a política e a economia. São Paulo: Saraiva, 2012.

CASTRO, Marcus Faro de. Economic development and the legal foundations of regulation in Brazil. De Gruyter - Law and Development Review, Vol. 6, No. 1, 2013, p. 61-115.

CASTRO, Marcus Faro de. New legal approaches to policy reform in Brazil. University of Brasília Law Journal, Vol. 1, No.1, 2014a, p. 32-64.

CASTRO, Marcus Faro de. Globalização, democracia e direito constitucional: legados recebidos e possibilidades de mudança. In: CLÈVE, Clèmerson Merlin; FREIRE, Alexandre (org.) Direitos fundamentais e jurisdição constitucional: análise, crítica e contribuições. São Paulo: Revista dos Tribunais, 2014b, p. 697-719.

CASTRO, Marcus Faro de. Monetary impacts and currency wars: a blind spot in the discourse about transnational legal orders? Paper presented at the Law and Society Association (LSA) 2014 Annual Meeting, Minneapolis, May 29-Jun 1, 2014c.

CASTRO, Marcus Faro de; FONTES, Daniele Kleiner. Regulating broadband services and digital development in Brazil: some new ideas on the role of legal analysis. Paper presented at the 5th Biennial ECPR Standing Group for Regulatory Governance Conference, Barcelona, 25-7 June, 2014, p. 1-32. Disponível em: <http://reggov2014.ibei.org/bcn-14-papers/55187.pdf>. Acesso em: 29 set. 2015. 
CASTRO, Marcus Faro de; LIMA, Albério Júnio Rodrigues de. Confronting policy reform needs of democracy with new legal tools: the example of the legal analysis of the individual microentrepreneur program of Brazil. Paper presented at the Law and Society Association (LSA) 2015 Annual Meeting, Seattle, May 28-31, 2015, p. 1-30.

CASTRO, Marcus Faro de; PENA, Hugo. Relevância jurídica dos encadeamentos decisórios e outros processos transfronteiriços: o exemplo de seu impacto sobre barreiras comerciais

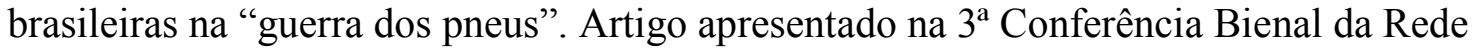
Latinoamericana de Direito Econômico Internacional, Porto Alegre, 22-4 out. 2015.

CATO INSTITUTE. About Cato. 2015. Disponível em: $<$ http://www.cato.org/about $>$. Acesso em: 11. mar. 2015.

CHANG, Ha-Joon. State, institutions and structural change. Structural Change and Economic Dynamics, vol. 5, no. 2, 1994, p. 293-313.

CHANG, Ha-Joon. Kicking away the ladder: development strategy in historical perspective. London: Anthem Press, 2002.

CHANG, Ha-Joon. Theories of state intervention in historical perspective. In: CHANG, HaJoon. Globalisation, economic development and the role of the state. London: Zed Books, 2003.

CHANG, Ha-Joon. Institutional change and economic development: an introduction; In: CHANG, Ha-Joon (ed.) Institutional change and development. New York: United Nations University Press, 2007a, p. 1-16.

CHANG, Ha-Joon. Understanding the relationship between institutions and economic development: some key theoretical issues.In: CHANG, Ha-Joon (ed.) Institutional change and development. New York: United Nations University Press, 2007b, p. 17-33.

CHANG, Ha-Joon; GRABEL, Illene. Reclaiming development: an alternative economic policy manual. London: Zed Books, 2004.

CINTRA, Marcos Antonio; FARHI, Maryse. A crise financeira e o global shadow banking system. Novos Estudos (CEBRAP), n. ${ }^{\circ} 82,2008$, p. 35-55.

CNN (Cable News Network). G-20 to supplant G-8 as international economic council. 25. set. 2009. Disponível em: <http://edition.cnn.com/2009/US/09/24/us.g.twenty.summit/ index.html>. Acesso em: 31 mar. 2015.

COASE, Ronald H. The nature of the firm. Economica, New Series, Vol. 4, No. 16, 1937, p. 386-405.

COASE, Ronald H. The problem of social cost. The Journal of Law and Economics, Vol. 3, 1960, p. 1-44.

COASE, Ronald H. Law and Economics at Chicago. The Journal of Law and Economics, Vol. 36, No. 1, 1993, p. 239-54.

CONFERENCE on Global Law and Development (CGLAD). 2015. Disponível em: $<$ http://cglad.com.br/>. Acesso em: 22 set. 2015. 
CONFLITO das águas. Direção de Icíar Bollaín. Roteiro: Paul Laverty. S.l.: Morena Films, 2010. (103 min.), son., color. Legendado. Drama (1 DVD).

CONFORTI, Benedetto. The law and practice of the United Nations. 3. ed. Leiden/Boston: Martinus Nijhoff Publishers, 2005.

COUTINHO, Diogo Rosenthal. Direito, desigualdade e desenvolvimento. São Paulo: Saraiva, 2013.

DAVIDSON, Paul. Post keynesian economics: solving the crisis in economic theory. In: BELL, Daniel; KRISTOL; Irving (eds). The crisis in economic theory. New York: Basic Books, 1981, p. 151-73.

DAVIS, Kevin; FISHER, Angelina; KINGSBURY, Benedict; MERRY, Sally Engle (eds.). Governance by indicators: global power through quantification and rankings. Oxford: Oxford University Press, 2012.

DELREAL, Jose A. Students Walk Out of Ec 10 in Solidarity with 'Occupy'. The Harvard Crimson. Cambridge, 3 nov. 2011. Disponível em: $<$ http://www.thecrimson.com/article/2011 /11/2/mankiw-walkout-economics-10/>. Acesso em: 27 mar. 2015.

DESROSIÈRES, Alain. Statistics and social critique. Partecipazione e Conflitto: the open journal of sociopolitical studies, Vol. 7, No. 2, 2014, p. 348-59.

DITTMER, Lowell. The strategic triangle: an elementary game-theoretical analysis. World Politics, v. 33, n. 4,1981, p. 485-515.

DUMONT, Louis. Homo aequalis: gênese e plenitude da ideologia econômica. Bauru: EDUSC, 2000.

EASTERLY, William. The white man's burden: why the West's efforts to aid the rest have done so much ill and so little good. New York: Penguin Books, 2006.

EICHENGREEN, Barry. Hegemonic stability theories of the international monetary system. FRIEDEN, Jeffry A.; LAKE, David A (ed.). International political economy: perspectives on global power and wealth. 4. ed. London: Routledge, 2003. p. 220-44.

EICHENGREEN, Barry. Globalizing capital: a history of the international monetary system. 2. ed. Princeton: Princeton University Press, 2008.

ESTEVA, Gustavo. Development. In: SACHS, Wolfgang (ed.) The development dictionary: a guide to knowledge as power. 2. ed. London, New York: Zed Books, 2010. p. 1-23.

FABIANI, Emerson Ribeiro. Direito e crédito bancário no Brasil. São Paulo: Saraiva, 2011.

FERGUSON, Niall. The ascent of money: a financial history of the world. New York:

Penguin Press, 2008.

FIANI, Ronaldo. Cooperação e conflito: instituições e desenvolvimento econômico. Rio de Janeiro: Elsevier, 2011. 
FINKELSTEIN, Lawrence S. What is global governance? Global Governance, Vol. 1, No. 3, 1995, p. 367-72.

FONTES, Daniele Kleiner. Universalização da internet banda larga no Brasil: o Plano Nacional de Banda Larga sob a perspectiva da Análise Jurídica da Política Econômica. Universidade de Brasília. Faculdade de Direito. Programa de Pós-Graduação em Direito. Brasília: UnB, 2014 (Dissertação de mestrado).

FRIEDMAN, David Director. Law's order: what economics has to do with law and why it matters. Princeton: Princeton University Press, 2000.

GALBRAITH, John Kenneth. O pensamento econômico em perspectiva: uma história crítica. São Paulo: Pioneira, 1989.

GALBRAITH, John Kenneth. Moeda: de onde veio, para onde foi. 2. ed. São Paulo: Pioneira, 1997.

GALINDO, George Rodrigo Bandeira. Quando o direito internacional é humanizado: algumas reflexões sobre a fragmentação do sistema jurídico internacional e seu impacto no direito constitucional brasileiro. In: GALINDO, George Rodrigo Bandeira (org). Direitos humanos e democracia: algumas abordagens críticas. Curitiba: CRV, 2013, p. 73-102.

GAZIER, Bernard. A crise de 1929. Porto Alegre: L\&PM, 2009.

GAZIER, Bernard. John Maynard Keynes. Porto Alegre: L\&PM, 2011.

GICO JR., Ivo. Introdução ao direito e economia.In: TIMM, Luciano Benetti (org.). Direito e economia no Brasil. São Paulo: Atlas, 2012, p. 1-33.

GINNEKEN, Anique H. M. van. Historical dictionary of the league of nations. Lanham: The Scarecrow Press, 2006.

GLOBALISATION is good. Direção de Charlotte Metcalf. Roteiro: Johan Norberg. Londres: Freeform Productions, 2003 (49 min.), Documentário. Disponível em: <https://youtu.be/ 12YDLZq8rT4>. Acesso em: 11. mar. 2015 (Streaming de vídeo online).

GUIMARÃES, Samuel Pinheiro. Quinhentos anos de periferia. Porto Alegre: Contraponto, 1999.

GUTTMANN, Robert. Uma introdução ao capitalismo dirigido pelas finanças. Novos Estudos (CEBRAP), n. ${ }^{\circ}$ 82, 2008, p. 11-33.

HALL, Peter A.; TAYLOR, Rosemary C. As três versões do neo-institucionalismo. Lua Nova, Vol. 58, 2003, p. 193-223.

HALL, Peter. The movement from keynesianism to monetarism: institutional analysis and British economic policy in the 1970s. In: STEINMO, Sven; THELEN, Kathleen;

LONGSTREETH, Frank (eds.) Structuring politics: historical institutionalism in comparative analysis. Cambridge: Cambridge University Press, 1992, p. 90-113. 
HALL, Peter; SOSKICE, David. An introduction to varieties of capitalism. In: HALL, Peter; SOSKICE, David (eds.). Varieties of capitalism: the institutional foundations of comparative advantage. Oxford: Oxford University Press, 2001, p. 1-68.

HALL, Rodney Bruce; BIERSTEKER, Thomas J. The emergence of private authority in the international system. In: HALL, Rodney Bruce; BIERSTEKER, Thomas J. (org.) The emergence of private authority in global governance. Cambridge: Cambridge University Press, 2004. p. 3-22.

HARLOW, Carol. Global administrative law: the quest for principles and values. European Journal of International Law, Vol. 17, No. 1, 2006, p. 187-214.

HARRIS, Ron. The uses of history in law and economics. Theoretical Inquiries in Law, Vo.1 4, No. 2, 2003, p. 659-96.

HAY, Colin. Constructive institutionalism. In: RHODES, R. A. W.; BINDER, Sarah A.; ROCKMAN, Bert A. The Oxford handbook of political institutions. Oxford: Oxford University Press, 2006, p. 56-74.

HEINEN, Luana Renostro. Reflexões pós-assombro: efeitos da crise financeira sobre Richard Posner e os limites de sua posição keynesiana. Economic Analysis of Law Review, Vol. 4, No. 2, 2013, p. 360-76.

HELLEINER, Eric. From Bretton Woods to global finance: a world turned upside down. In: STUBBS; Richard; UNDERHILL, Geoffrey R. D (eds.). Political economy and the changing global order. London: Macmillan Press, 1994a, p. 163-75.

HELLEINER, Eric. States and the reemergence of global finance: from Bretton Woods to the 1990s. Ithaca: Cornell University Press, 1994b.

HILLIER, Tim. Sourcebook on public international law. London: Cavendish Publishing, 1998.

HIRSCHMAN, Albert O. The passions and the interests: political arguments for capitalism before its triumph. Princeton: Princeton University Press, 1997.

IKENBERRY, G. John. After victory: institutions, strategic restraint, and the rebuilding of order after major wars. Princeton: Princeton University Press, 2001.

JACKSON, John H. The world trading system: law and policy of international economic relations. 2. ed. Cambridge: MIT Press, 2000.

JACKSON, John H. The jurisprudence of GATT and the WTO. Cambridge: Cambridge University Press, 2002.

JACKSON, Scott. Prologue to the Marshall Plan: the origins of the American commitment for a European recovery program. The Journal of American History, v. 65, n. 4, 1979, p. 1043-68.

JESSUP, Philip C. Transnational law. New Haven: Yale University Press, 1956. 
JORNAL DO BRASIL. Corrupção: caso Siemens e as propinas do metrô paulista. 2014. Disponível em: $<$ http://www.jb.com.br/pais/noticias/2014/03/17/corrupcao-caso-siemens-eas-propinas-do-metro-paulista/>. Acesso em: 7 abr. 2014.

KAPLAN, Morton A.; KATZENBACH, Nicholas de B. Fundamentos políticos do direito internacional. Rio de Janeiro: Zahar, 1964 [1961].

KELSEN, Hans. Teoria pura do direito: introdução à problemática científica do direito. 7. ed. São Paulo: Revista dos Tribunais, 2011.

KENNAN, George. Review of Current Trends, U.S. Foreign Policy: Report by the Policy Planning Staff PPS23, February 28, 1948. In: U.S. DEPARTMENT OF STATE. Foreign Relations of the United States: 1948. Vol. 1, Part 2. Washington D.C.: Government Printing Office, 1976, p. 509-29. Disponível em: <https://history.state.gov/historicaldocuments/ frus1948v01p2/d4>. Acesso em: 15 jan. 2016.

KENNEDY, David. Challenging expert rule: the politics of global governance. Sidney Law Review, Vol. 27, 2005, p. 1-24.

KENNEDY, David. Some caution about property rights as a recipe for economic development. Accounting, Economics and Law, Vol. 1, No. 1, 2011, p. 11-62.

KENNEDY, David. Law and the political economy of the world. Leiden Journal of International Law, vol. 26, 2013, p. 7-48.

KENNEDY, Duncan. A semiotics of legal argument. Syracuse Law Review, Vol. 42, 1991, p. 75.

KENNEDY, Duncan. A critique of adjudication (fin de siècle). Cambridge: Harvard University Press, 1997.

KENNEDY, Duncan. A semiotics of critique. Cardozo Law Review, Vol. 22, 2001, p. 114775.

KENNEDY, Duncan. Three globalizations of law and legal thought: 1850-2000. In: TRUBEK, David M; SANTOS, Alvaro (eds.). The new law and economic development: a critical appraisal. Cambridge: Cambridge University Press, 2006, p. 19-73.

KENWOOD, George; LOUGHEED, Alan. The growth of the international economy 18202000: an introductory text. 4. ed. London: Routledge, 1999.

KEOHANE, Robert O.; NYE, Joseph S. Poder e interdependencia: la política mundial en transición. Buenos Aires: Grupo Editorial Latinoamericano, 1988 [1977].

KEOHANE, Robert O; NYE, Joseph S. Introduction. In: NYE, Joseph S.; DONAHUE, John D. (eds.) Governance in a globalizing world. Washington, D.C.: Bookings Institution Press, 2000, p. 1-44.

KETTELL, Steven. The political economy of exchange rate policy-making: from the gold standard to the Euro. London: Palgrave Macmillan, 2004. 
KEYNES, John Maynard. A teoria geral do emprego, do juro e da moeda. São Paulo: Nova Cultural, 1996 [1936].

KEYNES, John Maynard. As consequências econômicas da paz. São Paulo/Brasília: Imprensa Oficial do Estado/Universidade de Brasília, 2002 [1919].

KINDLEBERGER, Charles P. The rise of free trade in Western Europe. In: FRIEDEN, Jeffry A.; LAKE, David A (eds.). International political economy: perspectives on global power and wealth. 4. ed. London: Routledge, 2003. p. 73-89.

KINGSBURY, Benedict; KRISCH, Nico; STEWART, Richard. The emergence of global administrative law. Law and Contemporary Problems, Vol. 68, No. 15, 2005, p. 15-61.

KOSKENNIEMI, Martti. The gentle civilizer of nations: the rise and fall of international law 1870-1960. 2. ed. Cambridge: Cambridge University Press, 2004.

KOSKENNIEMI, Martti. The fate of public international law: between technique and politics. The Modern Law Review, v. 70, n. ${ }^{\circ}$ 1, 2007a, p. 1-30.

KOSKENNIEMI, Martti. International law: constitutionalism, managerialism and the ethos of legal education. European Journal of Legal Studies, Vol. 1, No. 1, 2007b, p. 1-18.

KOSKENNIEMI, Martti; LEINO, Päivi. Fragmentation of International Law? Postmodern anxieties. Leiden Journal of International Law. Leiden. Vol. 15. n. ${ }^{\circ}$ 3, 2002, p. 553-79.

KRASNER, Stephen D. Structural causes and regime consequences: regimes as intervening variables. In: KRASNER, Stephen D. (ed.) International regimes. Ithaca/London: Cornell University Press, 1983, p. 1-22.

KRISCH, Nico. The pluralism of global administrative law. European Journal of International Law, Vol. 17, No. 1, 2006, p. 247-78.

KRUGMAN, Paul. The return of depression economics and the crisis of 2008. New York: W.W. Norton \& Company, 2009.

LA PORTA, Rafael; LOPEZ-DE-SILANES, Florencio; SHLEIFER, Andrei. The economic consequences of legal origins. Journal of Economic Literature, Vol. 46, No. 1, 2008, p. 285332.

LA PORTA, Rafael; LOPEZ-DE-SILANES, Florencio; SHLEIFER, Andrei; VISHNY, Robert. Legal determinants of external finance. The Journal of Finance, Vol 52, No. 3, 1997, p. 1131-50.

LA PORTA, Rafael; LOPEZ-DE-SILANEZ, Florencio; SHLEIFER, Andrei; VISHNY, Robert W. Law and finance. The Journal of Political Economy, Vol. 106, No. 6, 1998, p. 1113-55.

LAFER, Celso. A OMC e a regulamentação do comércio internacional: uma visão brasileira. Porto Alegre: Livraria do Advogado, 1998.

LAKE, David A. Rightful rules: authority, order, and the foundations of global governance. International Studies Quarterly, n. 54, 2010, p. 587-613. 
LANKES, Hans Peter. Market access for developing countries. Finance \& Development, Vol. 39, n. 2, 2002.

LAW and The New Developmental State (LANDS). 2015. Disponível em:

$<$ http://www.law.wisc.edu/gls/lands.html >. Acesso em: 22 set. 2015.

LIMA, Albério Júnio Rodrigues de. A efetividade do Programa Microempreendedor Individual, com base na Análise Jurídica da Política Econômica, em relação ao direito de produção. Universidade de Brasília. Faculdade de Direito. Programa de Pós-Graduação em Direito. Brasília: UnB, 2014 (Dissertação de mestrado).

LUMSDAINE, David Halloran. Moral vision in international politics: the foreign aid regime, 1949-89. Princeton: Princeton University Press, 1993.

MACKAAY, Ejan. Schools: general. In: BOUCKAERT, Boudewijn; DE GEEST, Gerrit (eds.). Encyclopedia of Law and Economics, Vol. I: The History and Methodology of Law and Economics , Cheltenham, Edward Elgar, 2000. Disponível em:

$<$ http://encyclo.findlaw.com/tablebib.html $>$. Acesso em: 13 jul. 2015.

MAHONEY, James; THELEN, Kathleen. A theory of gradual institutional change. In:

MAHONEY, James; THELEN, Kathleen (eds.). Explaining institutional change: ambiguity, agency and power. Cambridge, Cambridge University Press, 2010, p. 1-37.

MANDEVILLE, Bernard. The fable of the bees or private vices, publick benefits. Vol. 1. Indianapolis: Liberty Fund, 1988 [1714].

MANKIW, Nicholas Gregory. Introdução à economia. São Paulo: Cengage Learning, 2008.

MAQUIAVEL, Nicolau. O Príncipe. 3. ed. São Paulo: Martins Fontes, 2004.

MARTINEAU, Anne-Charlotte. The Rhetoric of Fragmentation: Fear and Faith in International Law. Leiden Journal of International Law, Vol. 22. n. ${ }^{\circ}$ 1, 2009, p. 1-28.

MAZOWER, Mark. No enchanted palace: the end of empire and the ideological origins of the United Nations. Princeton: Princeton University Press, 2008.

MENEZES, Wagner. Ordem global e transnormatividade. Ijuí: Unijuí, 2005.

MERCURO, Nicholas; MEDEMA, Steven G. Economics and the law: from Posner to PostModernism. Princeton: Princeton University Press, 1997.

MERCURO, Nicholas; MEDEMA, Steven G. Chicago Law and Economics. In: MERCURO, Nicholas; MEDEMA, Steven G. Economics and the law: from Posner to post-modernism and beyond. 2. ed. Princeton: Princeton University Press, 2006, p. 94-155.

MILHAUPT, Curtis J.; PISTOR, Katharina. Law and capitalism: what corporate crises reveal about legal systems and economic developments around the world. Chicago: University of Chicago Press, 2008.

MILLER, David. How neoliberalism got where it is: elite planning, corporate lobbying and the release of the free market. In: BIRCH, Kean; MYKHNENKO, Vlad (eds.).The rise and fall of neoliberalism: the collapse of an economic order? London: Zed Books, 2010, p. 23-41. 
MONEY, Power \& Wall Street. Roteiro: Marcela Gaviria; Doug Hamilton; Tom Jennings; Martin Smith. Arlington: PBS, 2012. (240 min.), son., color. Documentário, 4 episódios. Disponível em: < http://www.pbs.org/wgbh/pages/frontline/money-power-wall-street/>. Acesso em: 16 mar. 2015 (Streaming de vídeo online).

NASSER, Salem Hikmat. Fontes e normas do direito internacional: um estudo sobre a soft law. 2. ed. São Paulo: Atlas, 2006.

NICITA, Antonio ; PAGANO, Ugo. Law and economics in retrospect. In : BROUSSEAU, Éric; GLACHANT, Jean-Michel (eds.). New institutional economics: a guidebook. Cambridge: Cambridge University Press, 2008, p. 409-24.

NISBET, Robert. História da ideia de progresso. Brasília: Editora Universidade de Brasília, 1985 .

NORBERG, Johan. In defense of global capitalism. Washington D.C.: Cato Institute, 2003.

NORTH, Douglass C. Institutions, institutional change and economic performance. Cambridge: Cambridge University Press, 1991.

O DIA que durou 21 anos. Direção e roteiro de Camilo Tavares. São Paulo: Pequi Filmes, 2012. (77 min.). (1 DVD).

PAHUJA, Sundhya. Decolonizing international law: development, economic growth and the politics of universality. Legal Studies Research Paper No. 520, Melbourne Law School, 2009. Disponível em: $<$ http://papers.ssrn.com/sol3/papers.cfm?abstract_id=1743269>. Acesso em: 7 out. 2015.

PECK, Jamie; THEODORE, Nik; BRENNER, Neil. Mal-estar no pós-neoliberalismo. Novos Estudos (CEBRAP), n. ${ }^{\circ}$ 92, 2012, p. 59-78.

PELLET, Alain. "Human rightism" and international law. Italian Yearbook of International Law, Vol. 10, 2000, p. 3-16.

PEREIRA, João Márcio Mendes. O Banco Mundial como ator político, intelectual e financeiro (1944-2008). Universidade Federal Fluminense. Instituto de Ciências Humanas e Filosofia. Programa de Pós-Graduação em História. Niterói: UFF, 2009. (Tese de doutorado)

PERES, Paulo Sérgio. Comportamento ou instituições? A evolução histórica do neoinstitucionalismo na ciência política. Revista Brasileira de Ciências Sociais, Vol. 23, No. 68,2008 , p. 53-71.

PERMANENT COURT OF INTERNATIONAL JUSTICE [PCIJ]. S.S. Wimbledon. (GreatBritain, France, Italy, Japan v. Germany) Judgment of 17 August 1923. PCIJ Ser. A. Disponível em: $<$ http://www.icj-cij.org/pcij/series-a.php?p1=9\&p2=1>. Acesso em: 23. jan. 2014.

PERMANENT COURT OF INTERNATIONAL JUSTICE [PCIJ].. S.S. Lotus. (France v. Turkey). Judgment of 17 September 1927. PCIJ Ser. A. Disponível em: < http://www.icjcij.org/pcij/series-a.php?p1=9\&p2=1>. Acesso em: 27. jan. 2014. 
PIERSON, Paul. Positive feedback and path dependence. In: PIERSON, Paul. Politics in time: history, institutions and social analysis. Princeton: Princeton University Press, 2004, p. $15-53$.

PIKETTY, Thomas. Introduction. In: PIKETTY, Thomas. Capital in the twenty-first century. Cambridge: Harvard University Press, 2014, p. 1-35.

PINHEIRO, Patrícia Peck. Direito Digital. 3. ed. São Paulo: Saraiva, 2009.

PISTOR, Katharina. Rethinking the "law and finance" paradigm. Brigham Young University Law Review, Vol. 6, 2009, p. 1647-70.

PISTOR, Katharina. On the theoretical foundations for regulating financial markets. Columbia Public Law Research Paper No 12-304, 2012, p. 1-66. Disponível em: $<$ http://ssrn.com/abstract=2113675>. Acesso em: 19 ago. 2015.

PLEHWE, Dieter. Introduction. In: MIROWSKI, Philip; PLEHWE, Dieter (eds.). The road from Mont-Pèlerin: the making of the neoliberal thought collective. Cambridge: Harvard University Press, 2009, p. 1-44.

POLANYI, Karl. The great transformation: the political and economic origins of our time. 2.ed. Boston: Beacon Press, 2001 [1944].

POLLARD, Sidney. The international economy since 1945. London: Routledge, 1997.

POPPER, Karl. A lógica da pesquisa científica. São Paulo: Cultrix, 1972.

PORTO, Antônio José Maristrello. Análise econômica da responsabilidade civil. In: TIMM, Luciano Benetti (org.). Direito e economia no Brasil. São Paulo: Atlas, 2012, p. 180-200.

POSNER, Richard A. An economic theory of the criminal law. Columbia Law Review, Vol. 85 , No. 6, 1985, p. 1193-231.

POSNER, Richard A. Values and consequences: an introduction to economic analysis of law. John M. Olin Law \& Economics Working Paper No. 53. 1998. Disponível em: $<$ http//www.law.uchicago.edu/Lawecon/index.html $>$. Acesso em: 8 jul. 2015.

POSNER, Richard A. Economic analysis of law. 6. ed. New York: Aspen Publishers, 2003.

PRADO, Mariana Mota. What is law \& development? Revista Argentina de Teoria Jurídica, Vol 11, 2010, p. 1-20.

PRADO, Mariana Mota. Ensino jurídico e pesquisa em direito nas Américas: ideias fora do lugar. Cadernos FGV Direito Rio: globalização e ensino jurídico, Vol. 9, 2014, p. 119-28.

QUESNAY, François. Tableau économique. In: MEDEMA, Steven G.; SAMUELS, Warren J. (ed) The history of economic thought: a reader. London: Routledge, 2003, p. 97-102.

RAJAGOPAL, Balakrishnan. International law from below: development, social movements and third world resistance. Cambridge: Cambridge University Press, 2003. 
REZEK, José Francisco. Direito internacional público: curso elementar. 9. ed. São Paulo: Saraiva, 2002.

RIBEIRO, Jomara de Carvalho. A responsabilidade do Estado perante a Corte Internacional de Justiça. Porto Alegre: Sérgio Antonio Fabris Ed., 2012.

RICARDO, David. Princípios de Economia Política e de Tributação. 4. ed. Lisboa: Fundação Calouste Gulbenkian, 2001 [1817].

RIST, Gilbert. The history of development: from Western origins to global faith. London, New York: Zed Books, 2002.

RODRIK, Dani. One economics, many recipes: globalization, institutions and economic growth. Princeton: Princeton University Press, 2007.

RODRIK, Dani. The globalization paradox: democracy and the future of the world economy. New York: W.W. Norton \& Company, 2011.

ROE, Mark J. Legal origins, politics and modern stock markets. Harvard Law Review, Vol. 120,2006, p. $460-527$.

ROSTOW, Walt Whitman. Etapas do desenvolvimento econômico. 2. ed. Rio de Janeiro: Zahar, 1964 [1960].

RUGGIE, John Gerard. International regimes, transactions, and change: embedded liberalism in the postwar economic order. International Organization, Vol. 36, no. 2, 1982, p. 379-415.

SACHS, Jeffrey. O fim da pobreza: como acabar com a miséria mundial nos próximos vinte anos. São Paulo: Companhia das Letras, 2005.

SACHS, Wolfgang. Introduction. In: SACHS, Wolfgang (ed.) The development dictionary: a guide to knowledge as power. 2. ed. London, New York: Zed Books, 2010, p. xv-xx.

SACRISTE, Guilhaume; VAUCHEZ, Antoine. The force of international law: lawyers' diplomacy on the international scene in the 1920s. Law \& Social Inquiry, Vol. 32, n 1, 2007, p. 83-107.

SALAMA, Bruno Meyerhof. O que é pesquisa em direito e economia? Cadernos Direito GV, v.5, n. 2, 2008, p. 1-58.

SALAMA, Bruno Meyherhof. Análise Econômica da Arbitragem. In: TIMM, Luciano Benetti (org.). Direito e economia no Brasil. São Paulo: Atlas, 2012, p. 382-90.

SALIBA, Aziz Tuffi. Conselho de segurança da ONU: sanções e limites jurídicos. Curitiba: Juruá, 2008.

SALIBA, Aziz Tuffi; PENA, Hugo. Retórica jurídica e poder: uma análise da campanha do Itamaraty por assento permanente no Conselho de Segurança da ONU. Revista Sequência, Vol. 29, No. 57, 2008, p. 195-212.

SALLY, Razeen. Classical liberalism and international economic order: studies in theory and intellectual history. London: Routledge, 1998. 
SAMPAIO, Paulo Soares. Microcrédito, desenvolvimento e superação da pobreza: uma análise jurídica do Programa Nacional de Microcrédito Produtivo Orientado. Universidade de Brasília. Faculdade de Direito. Programa de Pós-Graduação em Direito. Brasília: UnB, 2014 (Dissertação de mestrado).

SANCHEZ BADIN, Michelle Ratton; GODOY, Daniela Helena. Desafios regulatórios do comércio internacional para o Brasil e algumas lições da promoção do etanol. In:

SCHAPIRO, Mario Gomes; TRUBEK, David M. Direito e desenvolvimento: um diálogo entre os BRICS. São Paulo: Saraiva, 2012, p. 193-245

SANDRONI, Paulo. Novíssimo dicionário de economia. São Paulo: Editora Best Seller, 1999.

SANTOS, Alvaro. The world bank's uses of the 'rule of law' promise in economic development. In: TRUBEK; David M; SANTOS, Alvaro (eds). The new law and economic development: a critical appraisal. Cambridge: Cambridge University Press, 2006, p. 253-300.

SANTOS, Claire Gomes dos; CARRION, Rosinha da Silva Machado. Sobre a governança da cooperação internacional para o desenvolvimento: atores, propósitos e perspectivas. Revista de Administração Pública, vol. 45, n. 6, 2011, p. 1847-68.

SATO, Eiiti. Economia e política das relações internacionais. Belo Horizonte: Fino Traço, 2012.

SBERT, José Maria. Progress. In: SACHS, Wolfgang (ed.) The development dictionary: a guide to knowledge as power. 2. ed. London, New York: Zed Books, 2010, p. 212-27.

SCAHILL, Jeremy. Blackwater: the rise of the world's most powerful mercenary army. New York: Nation Books, 2007.

SCHAPIRO, Mario Gomes. Repensando a relação entre estado, direito e desenvolvimento: os limites do paradigma rule of law e a relevância das alternativas institucionais. Revista Direito $G V$, Vol. 6, No. 1, 2010, p. 213-52

SCHAPIRO, Mario Gomes.; TRUBEK, David M. Redescobrindo o direito e desenvolvimento: experimentalismo, pragmatismo democrático e diálogo horizontal. In: SCHAPIRO, Mario G.; TRUBEK, David M. (org.) Direito e desenvolvimento: um diálogo entre os BRICS. São Paulo: Saraiva, 2012. p. 27-72.

SCHMIDT, Vivien A. The explanatory power of ideas and discourse. Annual Review of Political Science, Vol. 11, 2008, p. 303-26.

SEMMEL, Bernard. Classical political economy, the empire of free trade, and imperialism. In: SEMMEL, Bernard. The rise of free trade imperialism: classical political economy, the empire of free trade and imperialism, 1750-1850. Cambridge: Cambridge University Press, 1970 , p. 203-30.

SEN, Amartya. O desenvolvimento como expansão de capacidades. Lua Nova, Vol. 28-29, 1993, p. 313-34.

SEN, Amartya. Desenvolvimento como liberdade. São Paulo: Companhia das Letras, 2000. 
SHAFFER, Gregory. Transnational legal ordering and state change. In: SHAFFER, Gregory (ed.) Transnational legal ordering and state change. Cambridge: Cambridge University Press, 2013, p. 1-22.

SHEEHAN, Michael. The balance of power: history \& theory. London/New York: Routledge, 2005.

SHIKIDA, Pery Francisco Assis; AMARAL, Thiago Bottino do. Análise econômica do crime. In: TIMM, Luciano Benetti (org.). Direito e economia no Brasil. São Paulo: Atlas, 2012, p. 296-317.

SMITH, Adam. A riqueza das nações: investigação sobre sua natureza e suas causas. Vol I. São Paulo: Nova Cultural, 1996a [1776].

SMITH, Adam. A riqueza das nações: investigação sobre sua natureza e suas causas. Vol II. São Paulo: Nova Cultural, 1996b [1776].

SMITH, Gordon G. G7 to G8 to G20: evolution in global governance. Centre for International Governance Innovation Papers (CIGI papers), No. 6, 2011. Disponível em: $<$ https://www.cigionline.org/sites/default/files/g20no6.pdf>. Acesso em: 30 mar. 2015.

SÖDERSTEN, Bo; REED, Geoffrey. International economics. 3. ed. London: Macmillan Press, 1994.

SOLINGEN, Etel. Of dominoes and firewalls: the domestic, regional, and global politics of international diffusion. International Studies Quarterly, n 56, 2012, p. 631-644.

STELZER, Joana. União Europeia e supranacionalidade: desafio ou realidade? 2. ed. Curitiba: Juruá, 2004.

STIGLITZ, Joseph E. Globalization and its discontents. New York: W.W. Norton \& Company, 2002.

STREECK, Wolfgang; THELEN, Kathleen. Introduction: institutional change in advanced political economies. In: STREECK, Wolfgang; THELEN, Kathleen (eds.). Beyond continuity: institutional change in advanced political economies. Oxford: Oxford University Press, 2005, p. $1-40$.

TAMANAHA, Brian Z. Instrumentalism in theories of law. In: TAMANAHA, Brian Z. Law as a means to an end: threat to the rule of law. Cambridge: Cambridge University Press, 2006, p. 118-32.

TEIXEIRA, Ernani. Economia monetária: a macroeconomia no contexto monetário. São Paulo: Saraiva, 2002.

TEUBNER, Gunther; FISCHER-LESCANO, Andreas. Regime-collisions: the vain search for legal unity in the fragmentation of global law. Michigan Journal of International Law, Vol. 25, 2004, p. 998-1046.

THE ECONOMIST. Bitcoin: new money. 2014. Disponível em: $<$ http://www.economist.com/blogs/freeexchange/2014/03/bitcoin>. Acesso em: 7 abr. 2014. 
TIMM, Luciano Benetti; GUARISSE, João Francisco Menegol. Análise Econômica dos contratos. In: TIMM, Luciano Benetti (org.). Direito e economia no Brasil. São Paulo: Atlas, 2012, p. 158-79.

TRABALHO interno. Direção de Charles Ferguson. S.1.: Sony Pictures Classics, 2010. (105 min.), son., color. Legendado. Documentário (1 DVD).

TREBILCOCK, Michael J.; PRADO, Mariana Mota. Advanced introduction to law and development. Cheltenham: Edward Elgar Publishing, 2014.

TRUBEK; David M. The "rule of law" in development assistance: past, present and future. In: TRUBEK; David M; SANTOS, Alvaro (eds). The new law and economic development: a critical appraisal. Cambridge: Cambridge University Press, 2006, p. 74-94.

TRUBEK, David M. Law, state and the new developmentalism: an introduction. In: TRUBEK, David M.; ALVIAR GARCIA, Helena; COUTINHO, Diogo R.; SANTOS, Alvaro (eds.). Law and the new developmental state: the Brazilian experience in Latin American context. Cambridge: Cambridge University Press, 2013, p. 3-27.

TRUBEK, David M. Law and development: 40 years after Scholars in self-estrangement - a preliminary review. University of Wisconsin Law School Legal Studies Research Paper Series, No. 1255, 2014. Disponível em: <http://ssrn.com/abstract=2435190>. Acesso em: 28 ago. 2015.

TRUBEK, David M.; ALVIAR GARCIA, Helena; COUTINHO, Diogo R; SANTOS, Alvaro (eds.). Law and the new developmental State: the Brazilian experience in Latin American context. Cambridge: Cambridge University Press, 2013.

TRUBEK, David M.; COUTINHO, Diogo R.; SCHAPIRO, Mario G. Towards a new law and development: new state activism in Brazil and the challenge for legal institutions. University of Wisconsin Law School Legal Studies Research Paper Series, No. 1207, 2012. Disponível em: <http://ssrn.com/abstract=2144939>. Acesso em: 28 ago. 2015.

TRUBEK, David M.; GALANTER, Marc. Acadêmicos auto-alienados: reflexões sobre a crise norte-americana da disciplina "direito e desenvolvimento" (1974). Revista Direito GV, Vol. 4, No. 2, 2007, p. 261-304.

TRUBEK; David M; SANTOS, Alvaro. Introduction: the third movement in law and development theory and the emergence of a new critical practice. In: TRUBEK; David M; SANTOS, Alvaro (eds). The new law and economic development: a critical appraisal. Cambridge: Cambridge University Press, 2006, p. 1-18.

TURNER, Rachel S. Neo-liberal ideology: history, concepts and policies. Edinburgh: Edinburgh University Press, 2008.

VALADARES, Marcio Vidal de Campos. Direito e economia da regulação financeira: debates recentes. Universidade de Brasília. Faculdade de Direito. Programa de Pós-Graduação em Direito. Brasília: UnB, 2015 (Dissertação de mestrado).

VAN HORN, Rob. Reinventing monopoly and the role of corporations: the roots of Chicago law and economics. In: MIROWSKI, Philip; PLEHWE, Dieter (eds.). The road from Mont- 
Pèlerin: the making of the neoliberal thought collective. Cambridge: Harvard University Press, 2009, p. 204-37.

VAN HORN, Rob; MIROWSKI, Philip. The rise of the Chicago School of Economics and the birth of neoliberalism. In: MIROWSKI, Philip; PLEHWE, Dieter (eds.). The road from Mont-Pèlerin: the making of the neoliberal thought collective. Cambridge: Harvard University Press, 2009, p. 139-80.

VERA, Flávia Santinoni. Análise econômica da propriedade. In: TIMM, Luciano Benetti (org.). Direito e economia no Brasil. São Paulo: Atlas, 2012, p. 201-24.

WEBB, Michael C. Understanding patterns of macroeconomic policy co-ordination in the post-war period. In: STUBBS, Richard; UNDERHILL, Geoffrey R.D. (eds.) Political economy and the changing global order. London: Macmillan Press, 1994, p. 176-89.

WEIL, Prosper. Towards relative normativity in international law? American Journal of International Law, v. 77, 1983, p. 413-27.

WEIR, Margaret; SKOCPOL, Theda. State structures and the possibilities for "keynesian" responses to the great depression in Sweden, Britain and the United Sates. In: EVANS, Peter B.; RUESCHEMEYER, Dietrich; SKOCPOL, Theda (eds). Bringing the state back in. Cambridge: Cambridge University Press, 1985, p. 107-64.

WHITMAN, Jim. The development of the 'governance' concept. In: WHITMAN, Jim. The limits of global governance. London/New York: Routledge, 2005, p. 16-31.

WHITMAN, Jim. The fundamentals of global governance. London: Palgrave Macmillan, 2009.

WILLIAMSON, Oliver E. The economic institutions of capitalism: firms, markets, relational contracting. New York: The Free Press, 1985.

WILLIAMSON, Oliver E. Ronald Harry Coase: institutional economist and institutional builder. Journal of Institutional Economics, Vol. 11, No. 2, 2015, p. 221-6.

WOLF, Martin. A reconstrução do sistema financeiro global. Rio de Janeiro: Elsevier, 2009.

WOLF, Martin. From imbalances to the subprime crisis. In: WOLF, Martin. Fixing global finance. 2. ed. Baltimore: Johns Hopkins University Press, 2010, p. 193-214.

WOLKMER, Antonio Carlos. Síntese de uma história das idéias jurídicas: da antiguidade clássica à modernidade. Florianópolis: Boiteux, 2006.

WOO, Meredith Jung-En. The rule of law, legal traditions, and economic growth: the east asian example. In: CHANG, Ha-Joon (ed.). Institutional change and economic development. New York: United Nations University Press, 2007, p. 157-76.

YEUNG, Luciana Luk-Tai. Análise econômica do direito do trabalho. In: TIMM, Luciano Benetti. (org.) Direito e economia no Brasil. São Paulo: Atlas, 2012, p. 318-49. 